\author{
UNIVERSIDADE DE SÃO PAULO \\ FACULDADE DE FILOSOFIA, LETRAS E CIÊNCIAS HUMANAS \\ Departamento de Letras Clássicas e Vernáculas \\ Programa de Pós-Graduação em Filologia e Língua Portuguesa
}

WINOLA WEISS PIRES CUNHA

Movimentação Epistêmico-Axiológica em canais de ativismo digital feminista: uma perspectiva multidisciplinar

versão corrigida 


\author{
UNIVERSIDADE DE SÃO PAULO \\ FACULDADE DE FILOSOFIA, LETRAS E CIÊNCIAS HUMANAS \\ Departamento de Letras Clássicas e Vernáculas \\ Programa de Pós-Graduação em Filologia e Língua Portuguesa
}

WINOLA WEISS PIRES CUNHA

\title{
Movimentação Epistêmico-Axiológica em canais de ativismo digital feminista: uma perspectiva multidisciplinar
}

\author{
versão corrigida
}

Dissertação apresentada ao Programa de Pós-Graduação em Filologia e Língua Portuguesa do Departamento de Letras Clássicas e Vernáculas da Faculdade de Filosofia, Letras e Ciências Humanas da Universidade de São Paulo, como parte dos requisitos para a obtenção do título de Mestre em Letras

Área de concentração: Filologia e Língua Portuguesa

Linha de Pesquisa: Linguística Textual e Teorias do Discurso no Português

Orientador: Paulo Roberto Gonçalves-Segundo

São Paulo 
Autorizo a reprodução e divulgação total ou parcial deste trabalho, por qualquer meio convencional ou eletrônico, para fins de estudo e pesquisa, desde que citada a fonte.

Catalogação na Publicação

Serviço de Biblioteca e Documentação

Faculdade de Filosofia, Letras e Ciências Humanas da Universidade de São Paulo

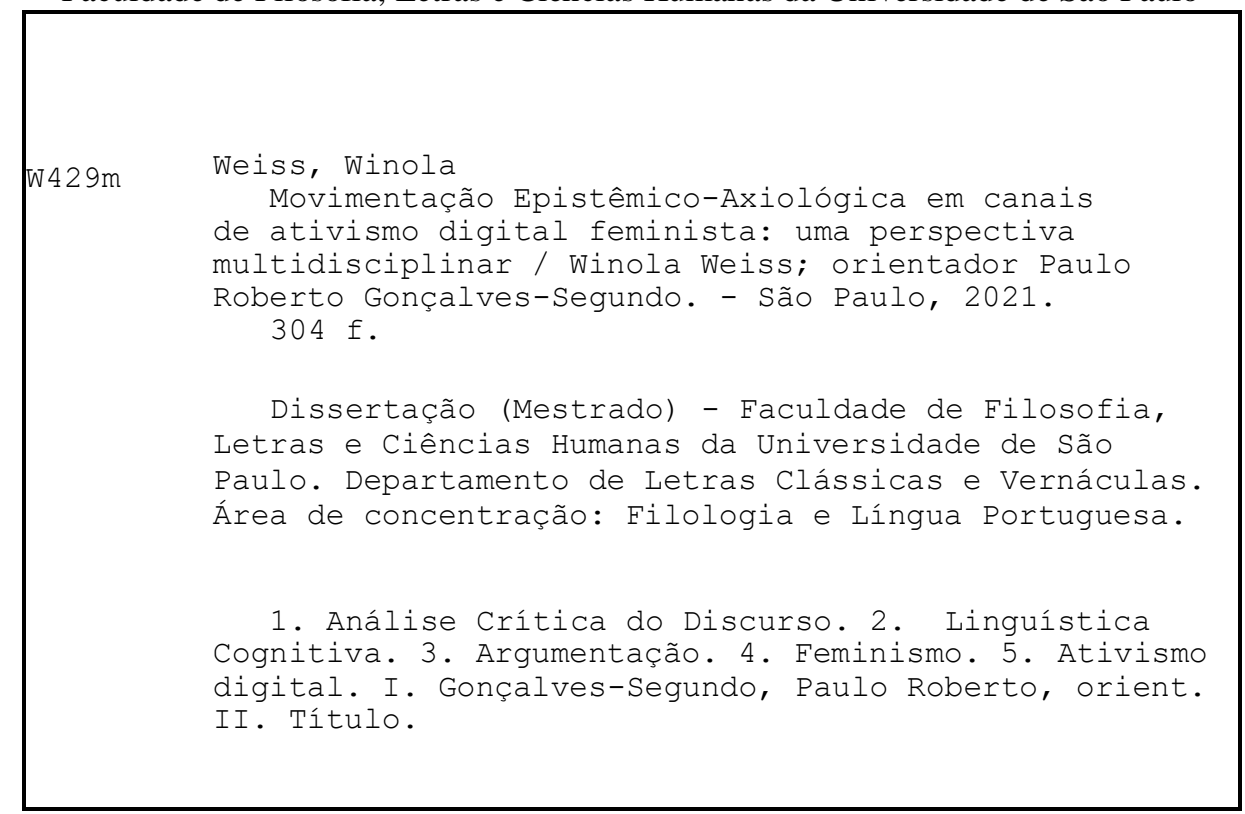




\section{ENTREGA DO EXEMPLAR CORRIGIDO DA DISSERTACÃO/TESE}

\section{Termo de Ciência e Concordância do (a) orientador (a)}

\section{Nome do (a) aluno (a): Winola Weiss Pires Cunha}

Data da defesa: 15/12/2020

Nome do Prof. (a) orientador (a): Paulo Roberto Gonçalves Segundo

Nos termos da legislação vigente, declaro ESTAR CIENTE do conteúdo deste EXEMPLAR CORRIGIDO elaborado em atenção às sugestões dos membros da comissão Julgadora na sessão de defesa do trabalho, manifestando-me plenamente favorável ao seu encaminhamento e publicação no Portal Digital de Teses da USP.

São Paulo, 12/02/2021

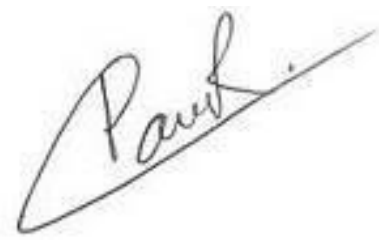

(Assinatura do (a) orientador (a) 
WEISS, Winola. Movimentação Epistêmico-Axiológica em canais de ativismo digital feminista: uma perspectiva multidisciplinar. 304f. Dissertação (Mestrado) - Faculdade de Filosofia, Letras e Ciências Humanas. Universidade de São Paulo. São Paulo. 2021.

Banca examinadora

Prof. Dr. Alexandre Marques Silva

Instituição: Externo

Assinatura:

Julgamento: Aprovado

$\operatorname{Prof}^{\mathrm{a}} \mathrm{Dr}^{\mathrm{a}}$ Solange Coelho Vereza

Instituição: UFF

Assinatura:

Julgamento: Aprovado

Prof $^{\mathrm{a}} \mathrm{Dr}^{\mathrm{a}}$ Viviane Gonçalves Freitas

Instituição: UFMG

Assinatura:

Julgamento: Aprovado 


\section{AGRADECIMENTOS}

A dissertação, na forma que ela assume no depósito, na forma pela qual ela é apresentada à banca, falha em representar o que é de fato uma pesquisa de mestrado. Aprendi ao longo dos últimos anos é que a pesquisa é muito mais um processo de reflexão, discussão, análise e revisão, muito mais indas e vindas, erros e acertos, do que apenas o texto apresentado aqui. É um processo que se faz a algumas mãos e olhos, e muitos, muitos ouvidos. Nesse sentido, queria incluir aqui nesses agradecimentos algumas das pessoas que foram essenciais para o desenvolvimento das discussões que realizo, seja com perguntas, discussões, conselhos, problematizações, divagações, ou ainda abraços apertados, sorrisos compreensivos e gostosas gargalhadas. Com o isolamento social, destaco também as chamadas telefônicas e de vídeo, jogatinas pelo Zoom e conversas pelo WhatsApp tarde da noite como fontes de carinho, escuta, compreensão e força para seguir nesse processo. Enfim, reservo os próximos parágrafos para agradecer e pontuar a importância da presença de algumas pessoas neste projeto, na minha trajetória acadêmica e pessoal. Poder contar com o apoio de professores, familiares, amigas e colegas ao longo da minha formação e, especialmente, durante os anos da pós-graduação, foi, com certeza, essencial para a conclusão dessa pesquisa.

A começar pelo Paulo, a quem agradeço imensamente pelos anos de orientação e amizade, pelas muitas (muitas!) horas de conversa sobre a pesquisa, a pós-graduação e os inesperados enredos da política brasileira, pela paciência e pelas discussões sempre estimulantes. A sua capacidade de criar espaços seguros e de nos incentivar a desenvolver as nossas próprias vozes é inspiradora. Obrigada por acreditar em mim!

Agradeço à professora Solange Vereza e ao professor Alexandre Marques Silva pelas leituras atentas e generosas do relatório de qualificação, que renderam reflexões importantíssimas para o desenvolvimento da dissertação. Fico muito feliz em ter a oportunidade de dialogar com vocês novamente. Agradeço também à professora Viviane Gonçalves Freitas pelo aceite em participar banca de defesa e pelos comentários generosos sobre o capítulo 1. Foi uma alegria muito grande poder contar com o seu olhar!

Não poderia faltar um agradecimento às funcionárias, funcionários e docentes do Programa de Pós-Graduação em Filologia e Língua Portuguesa pelo apoio acadêmico e pelos diversos incentivos à formação dos alunos, em especial à Vera Mendes, à Daniela Teixeira e ao Gabriel Carra, e às professoras Maria Clara Paixão de Sousa e Vanessa Martins do Monte.

Aos meus pais, Ricardo e Nina, que apoiam e incentivam meus estudos desde as primeiras letras, agradeço por seu carinho, amor e sinceridade de sempre. E à minha irmã, 
Fernanda, que me ensina todos os dias a ser gentil, paciente e a celebrar quem somos, agradeço pela honestidade e pelo companheirismo inabaláveis. Estamos perto mesmo longe.

Fernanda e Lenise, o carinho, o ombro amigo e as conversas instigantes não são de hoje, mas me fizeram especialmente felizes nessa quarentena. Com vocês eu me sinto sempre em casa. Pepe, companheiro querido da pós, parceiro de aventuras e papos de madrugada. Dani, que carrega meu coração consigo do outro lado do estado. Laura, das gargalhadas sinceras e das conversas mais sinceras ainda. Lara, pelo abraço e pela escuta que só você sabe dar. Otávio, pela companhia em muitos meses de quarentena, pelas conversas de madrugada, invenções na cozinha e compromisso em fazer as pessoas felizes. Bianca, minha amiga-prima, obrigada pela amizade ao longo desses anos e pela leitura atentíssima do Capítulo 1, que esquentou meu coração durante o isolamento. Obrigada, galera, por serem minha família estendida, no interior e na cidade grande.

Às amizades da pós-graduação, em especial as companheiras de orientação, membros do NEAC e do Midigita, amigas e amigos da Comissão de Ações Afirmativas do PPG-FLP e da Frente Pró-Cotas, um gigantesco obrigada pelas conversas, problematizações e planos, reuniões, idas e vindas de projetos, editais, relatórios, traduções... Um abraço virtual com saudades pra Adriana, Felipe, Estefânia, Lis, Lucas, Clau, Natália, Álvaro, Antônio, Célia e Sandra. Queria estar topando com vocês pelos corredores da faculdade e descendo pra tomar um café no Italiano, na Tia Bia ou no trailer da Educação. Cresço muito com vocês como pesquisadora e como pessoa!

Um agradecimento mais que especial vai para o Gabs, com quem tive o prazer de não só construir organizações de eventos, aulas e o desafio de ser representante discente, como também uma amizade que nasceu nos tempos da graduação e só cresceu nos últimos anos. É um prazer gigante partilhar espaços e projetos contigo.

Além disso, queria mandar um salve para Kate Bush, Beyoncé, The Weeknd e as grandes mentes musicais por trás das versões forró dos sucessos do pop internacional, trilha sonora para muitas madrugadas de escrita quando eu só tinha o gato como companhia. Também mando beijos pra Alexandra Asanovna Elbakyan e à política de publicação gratuita dos periódicos acadêmicos brasileiros, fundamentais para a difusão do conhecimento acadêmico.

Por fim, mas não menos importante, ressalto que o presente trabalho foi realizado com apoio da Coordenação de Aperfeiçoamento de Pessoal de Nível Superior Brasil (CAPES) - Código de Financiamento 1794845, processo $\mathrm{n}^{\circ}$ 88882.377630/2019-01, aspecto fundamental para que eu pudesse me dedicar a este processo. 


\section{RESUMO}

WEISS, Winola. Movimentação Epistêmico-Axiológica em canais de ativismo digital feminista: uma perspectiva multidisciplinar. 304f. Dissertação (Mestrado) - Faculdade de Filosofia, Letras e Ciências Humanas. Universidade de São Paulo. São Paulo. 2021.

Ao longo dos últimos anos, mobilizações feministas, antirracistas e pró-LGBTTQIAPN+ têm ocupado as redes e as ruas ao redor do Brasil. Considerando o atual cenário, defendemos que investigar as estratégias discursivas contra-hegemônicas, voltadas para a (des)construção da diferença, presentes no ativismo digital feminista, possa auxiliar a entender o seu papel na formação de uma nova geração política. Para tanto, nesta dissertação voltamos o nosso olhar para vídeos de duas youtubers ativistas (Nátaly Neri e LouiePonto), publicados no primeiro semestre de 2017. São eles: "HETEROFOBIA E RACISMO REVERSO EXISTEM? | Louie Ponto e Nátaly Neri"; "POR QUE VOCÊ É TÃO AGRESSIVA, NÁTALY" e "YOUTUBER SÓ FALA MERDA NA INTERNET? Feat. Louie Ponto"; "RÓTULOS ME LIMITAM OU ME DEFINEM? | Especial Dia do Orgulho LGBT | Louie Ponto". Nosso objetivo foi investigar o papel da (des)construção das diferenças a partir do dissenso em suas estratégias argumentativas em vídeos de formação política. Para tanto, desenvolvemos o conceito de Movimentação Epistêmico-Axiológica, uma contribuição teórica de aprimoramento da noção de Posicionamento enquanto estratégia discursiva, conforme definida por Hart (2014) em sua proposta cognitivamente orientada de Análise Crítica do Discurso cognitivamente orientada. Partimos da hipótese de que tal aparato teórico-metodológico multidimensional permitiria aprimorar a visão sobre os mecanismos utilizados na construção de Espaços Discursivos em textos de visada argumentativa (epistêmica ou prática) e compreender de que forma são construídas relações de solidariedade, neutralidade e antagonismo entre comunidades discursivas a partir da disputa entre Alegações e Propostas de Ação. Propomos um modelo de análise centrado em tal processo que nos permitiu investigar a representação do $\mathrm{Eu}$, do Nós e do Outro enquanto objetos do discurso (entidades discursivas) com o apoio de layouts de configuração funcional dos argumentos (TOULMIN, 2006; FAIRCLOUGH; FAIRCLOUGH, 2012; GONÇALVES-SEGUNDO, 2020a). Dessa forma, pudemos reconhecer uma maior variedade de formas de mapear as diferenças tanto entre as entidades discursivas, quanto entre tais entidades e $o$ endo/exogrupo. A partir desse mapeamento, analisamos de que forma as vozes autorais se articulavam ou se opunham a outras vozes ao longo dos textos. Mais especificamente, por meio das análises da Avaliatividade, verificamos o grau de abertura dialógica das vozes autorais em relação à perspectiva do Outro nos pontos de tensão entre os movimentos argumentativos. Com isso, determinamos as mudanças efetuadas na distância relativa entre as entidades e, consequentemente, os tipos de relação sugerida entre as comunidades discursivas às quais elas faziam referência. Em quase todos os vídeos analisados depreendemos instâncias de movimentos de aproximação e afastamento epistêmico-axiológico, exceto naqueles cujos debates se configuraram como instâncias de desacordo profundo (FOGELIN, 2005). Os movimentos foram mobilizados para, respectivamente, amenizar e reforçar, respectivamente, as tensões dialógicas entre os elementos argumentativos considerados como critérios inegociáveis para determinar a filiação ideológica ao endo/exogrupo. Com isso, depreendemos os papéis dos movimentos epistêmico-axiológicos para as práticas de formação política no âmbito do ativismo digital e comprovamos a produtividade do modelo.

Palavras-chave: Análise Crítica do Discurso. Linguística Cognitiva. Argumentação. Feminismo. Ativismo digital. 


\begin{abstract}
WEISS, Winola. Epistemic-Axiological Movement in feminist digital activism: a multidisciplinary approach. 304f. Dissertação (Mestrado) - Faculdade de Filosofia, Letras e Ciências Humanas. Universidade de São Paulo. São Paulo. 2021.
\end{abstract}

Over the past few years, feminist, anti-racist and pro-LGBTTIAPN + mobilizations have occupied the networks and streets around Brazil. Considering the current scenario, we argue that investigating counter-hegemonic discursive strategies, aimed at the (de)construction of difference, present in digital feminist digital activism can help understand its role in the formation of a new political generation. To this end, we analyze the following videos, published by two young activists, Nátaly Neri and LouiePonto, during the first semester of 2017: "HETEROFOBIA E RACISMO REVERSO EXISTEM? | Louie Ponto e Nátaly Neri"; "POR QUE VOCÊ É TÃO AGRESSIVA, NÁTALY" e "YOUTUBER SÓ FALA MERDA NA INTERNET? Feat. Louie Ponto"; "RÓTULOS ME LIMITAM OU ME DEFINEM? | Especial Dia do Orgulho LGBT | Louie Ponto". Thus we developed the concept of Epistemic-Axiological Movement, a theoretical-methodological contribution meant to improve the notion of Positioning as a discursive strategy, as defined by Hart (2014) in his cognitive linguistic approach to Critical Discourse Analysis. We present the hypothesis that such an apparatus would improve the understanding of the mechanisms used in the construction of Discursive Spaces in texts of (epistemic or practical) argumentative aim and how relations of solidarity, neutrality and antagonism between communities are construed regarding the dispute between Claims and Claims for Action. Furthermore, we display a methodological model centered in this notion. Accordingly, in our analysis, we investigate the representation of the Self, the Us and the Other as objects of discourse (discursive entities) with the support of layouts of arguments (TOULMIN, 2006; FAIRCLOUGH; FAIRCLOUGH, 2012; GONÇALVESSEGUNDO, 2020a), which allowed us to recognize a greater variety of ways of to map differences both between discursive entities, and between such entities and the in/out-groups. Thereby, we were able to analyze how authorial voices engaged with other voices throughout the texts. Furthermore, through the analysis of APPRAISAL (MARTIN; WHITE, 2005), we determined how open the authorial voices were in relation to the dialogic alternatives regarding the most controversial argumentative movements. This allowed us to trace the changes of the relative distance between the entities and, consequently, the types of relationships construed between the discursive communities to which they referred. We perceived instances of epistemic-axiological convergence and divergence movements in almost all videos, except those whose debates were instances of deep disagreement (FOGELIN, 2005). These movements were used, respectively, to soften and reinforce the dialogical tensions between the argumentative elements considered as non-negotiable criteria to determine the ideological affiliation to the in/out-group. Therewith, we pinpointed the roles of the epistemic-axiological movements of convergence and divergence for the practices of political formation in the field of digital activism and therefore substantiated the productivity of the model.

Key-words: Critical Discourse Analysis. Cognitive Linguistics. Argumentation. Feminism. Digital Activism. 


\section{LISTA DE FIGURAS}

Figura 1 - Playlists do Canal Nátaly Neri

Figura 2 - Playlists do canal LouiePonto

Figura 3 - Indicações do canal Nátaly Neri

Figura 4 - Visualização padrão do vídeo "HETEROFOBIA E RACISMO REVERSO EXISTEM? | Louie Ponto e Nátaly Neri”

Figura 5 - Layout de Argumentação Epistêmica

Figura 6 - Layout de argumentação prática

Figura 7 - O subsistema de ENGAJAMENTO

Figura 8 - Layout da Configuração Funcional Epistêmica do campo epistêmico-axiológico do Outro no vídeo "POR QUE VOCÊ É TÃO AGRESSIVA, NÁTALY?" 162

Figura 9 - Layout da Configuração Funcional Epistêmica do campo epistêmico-axiológico do Eu-Nós no vídeo "POR QUE VOCÊ É TÃO AGRESSIVA, NÁTALY?" 164

Figura 10 - Layout da Configuração Funcional Prática do campo epistêmico-axiológico do Outro no vídeo "POR QUE VOCÊ É TÃO AGRESSIVA, NÁTALY?" 168

Figura 11 - Layout da Configuração Funcional Prática do campo epistêmico-axiológico do Eu no vídeo "POR QUE VOCÊ É TÃO AGRESSIVA, NÁTALY?"

Figura 12 - Layout da Configuração Funcional Prática do vídeo "YOUTUBER SÓ FALA MERDA NA INTERNET? Feat. Louie Ponto 174

Figura 13 - Layout da Configuração Funcional Epistêmica das Circunstâncias Motivadoras do Outro no vídeo "YOUTUBER SÓ FALA MERDA NA INTERNET? Feat. Louie Ponto".. 177 Figura 14 - Layout da Configuração Funcional Epistêmica das Circunstâncias Viabilizadoras do Eu-Nós no vídeo "YOUTUBER SÓ FALA MERDA NA INTERNET? Feat. Louie Ponto" 
Figura 15 - Layout da Configuração Funcional Epistêmica do Outro e do movimento de refutação interna efetuado pelo Eu-Nós no vídeo "HETEROFOBIA E RACISMO REVERSO EXISTEM? | LouiePonto feat. Nátaly Neri"

Figura 16 - Layout da Configuração Funcional Epistêmica do Eu no vídeo "HETEROFOBIA E RACISMO REVERSO EXISTEM? | LouiePonto feat. Nátaly Neri”

Figura 17 - Layout da Configuração Funcional Epistêmica do Eu no vídeo "HETEROFOBIA

E RACISMO REVERSO EXISTEM? | LouiePonto feat. Nátaly Neri”

Figura 18 - Layout da Configuração Funcional Epistêmica do vídeo "RÓTULOS ME LIMITAM OU ME DEFINEM? | Especial Dia do Orgulho LGBT | Louie Ponto" 193

Figura 19 - Layout da Configuração Funcional Prática do vídeo "RÓTULOS ME LIMITAM OU ME DEFINEM? | Especial Dia do Orgulho LGBT | Louie Ponto” 197 


\section{LISTA DE QUADROS}

Quadro 1 - 10 principais categorias temáticas encontradas nas publicações Nzinga Informativo, Cadernos Geledés e Blogueiras Negras ....................................................................... 46

Quadro 2 - Gestos de empatia, de dispatia e de antagonismo........................................ 100

Quadro 3 - Realização da AvALIATIVIDADE de acordo com os estratos linguísticos............ 143

Quadro 4 - Tipos de JULGAMENTO e exemplos de realizações canônicas ............................ 146

Quadro 5 - Revisão das categorias de JULGAMENTO .................................................... 147

Quadro 6 - A metáfora Ativismo digital é ponte/porta de entrada .................................... 243

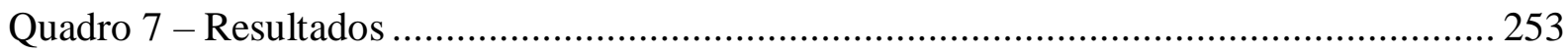




\section{SUMÁRIO}

Considerações Iniciais

Capítulo 1 - Feminismos brasileiros e ativismo nas redes sociais: uma leitura críticodiscursiva

Introdução

1.1 Feministas brasileiras no campo da comunicação: estratégias e debates do período pós-redemocratização à ascensão da direita conservadora

1.1.1 Assumindo o risco de "falar com todas as implicações": Movimentos de Mulheres Negras e Feminismo Negro 41

1.1.2 Entendidas: Movimentos de Mulheres Lésbicas e Feminismo Lésbico 53

1.2 Práticas sociais e práticas discursivas no YouTube 62

Capítulo 2 -A Movimentação Epistêmico-Axiológica: discussões teórico-metodológicas 86

Introdução 86

2.1 Movimentação Epistêmico-Axiológica: embasamento teórico 87

2.1.1 O combate a políticas de silenciamento: contribuições dos estudos sobre a empatia e do feminismo negro

2.1.2 A Teoria da Proximização

2.2 Movimentação Epistêmico-Axiológica: teoria e método

2.2.1 Movimentação Epistêmico-Axiológica como estratégia discursiva multidimensional121

2.2.2 Movimentação Epistêmico-Axiológica: Metodologia de análise 132

2.2.2.1 Mapeamento das entidades no Espaço Discursivo: Eu, Nós e Outro 133

2.2.2.2 Mapeamento dos movimentos de aproximação/afastamento epistêmicoaxiológico

2.2.2.3 Análise dos efeitos da Movimentação Epistêmico-Axiológica na constituição de estratégias discursivas

Capítulo 3 - A Movimentação Epistêmico-Axiológica como estratégia discursiva no ativismo digital feminista no YouTube

Introdução

3.1 Mapeamento das entidades no Espaço Discursivo e delimitação dos respectivos campos epistêmico-axiológicos

"POR QUE VOCÊ É TÃO AGRESSIVA, NÁTALY?" __ 157

"YOUTUBER SÓ FALA MERDA NA INTERNET? Feat. Louie Ponto" __ 172

“HETEROFOBIA E RACISMO REVERSO EXISTEM? | LouiePonto feat. Nátaly Neri”_ 181 
"RÓTULOS ME LIMITAM OU ME DEFINEM? | Especial Dia do Orgulho LGBT | Louie Ponto"

3.2 Análise dos movimentos de afastamento e aproximação epistêmico-axiológicos198

3.2.1 Movimentos de afastamento epistêmico-axiológico 199

3.2.2 Movimentos de aproximação epistêmico-axiológica 232

3.2.3 Articulações entre aproximação e afastamento epistêmicos e axiológicos 246

3.3 Os usos da Movimentação Epistêmico-Axiológica no discurso do ativismo digital 251

Considerações Finais 257

Referências bibliográficas 264

Fontes 279

Glossário 282

Anexos 287 
com as feministas que lutavam contra a ditadura aprendemos

mas fazer pacto suicida com o companheiro é pouco feminista daí fomos morar juntas e o pessoal de casa finalmente ficou político

- Bianca Gonçalves, Como se pesassem mil atlânticos 


\section{Considerações Iniciais}

Você não precisa ter medo de mim, você precisa ter medo de você e do que você acha que eu devo ser - Nátaly Neri

Ao longo dos últimos anos, uma série de mobilizações feministas, antirracistas e próLGBTTIAPN $+{ }^{1}$ tem ocupado as redes e as ruas ao redor do Brasil. Para fazer frente aos ataques vindos de diversas instâncias governamentais e de uma crescente mobilização da extrema direita (PENTEADO; SANTOS; ARAÚJO, 2014; Claudio L. PENTEADO; Celina LERNER, 2015), com um discurso abertamente racista ${ }^{2}$, misógino e LGBTfóbico, vemos o fortalecimento de articulações entre movimentos sociais, organizações da sociedade civil, comunidades tradicionais, militantes, ativistas e veículos da imprensa alternativa nas redes e fora delas.

São exemplos dessas articulações as campanhas da Coalizão Negra por Direitos ${ }^{3}$, a plataforma Mulheres Negras Decidem ${ }^{4}$, o Mapa das Delegacias da Mulher ${ }^{5}$ a criação de diversas casa de acolhimento e centros culturais ${ }^{6}$ para a população LGBTTIAPN+, além das redes de apoio "invisíveis" que se formam e se transformam entre militantes e ativistas individuais nas redes sociais, nos protestos, nas articulações políticas. Neste panorama, vemos também o reflexo dessas articulações fora das redes, no aumento de candidaturas e bancadas feministas, antirracistas e pró-LGBTTIAPN+ eleitas ao redor do Brasil no ciclo eleitoral municipal de 2020 .

Considerando o cenário atual, já bastante diverso do que contextualiza a publicação original dos vídeos que compõem nosso corpus (postados em 2017), vemos mudanças significativas no papel e na legitimidade do ativismo digital entre os movimentos sociais progressistas e de esquerda no Brasil.

No ano de 2020, em meio à pandemia do coronavírus, as manifestações de rua e nas redes foram ressignificadas. Neste cenário, tais mobilizações tomam uma proporção "nova", promovendo também o reconhecimento de lideranças já existentes e dando visibilidade para

\footnotetext{
${ }^{1}$ Utilizaremos ao longo da dissertação a abreviatura LGBTTIAPN+ em referência aos movimentos de lésbicas, gays, bissexuais, travestis, transexuais e transgêneros, pessoais intersexo, assexuais, pansexuais e não-bináries. Em algumas situações, utilizaremos outras siglas quando estivermos fazendo referência a textos/autoras específicas e, no capítulo 3, adotaremos a forma reduzida LGBT por ser esta a utilizada nos vídeos do corpus.

${ }^{2}$ Debateremos nesta dissertação apenas o racismo contra a população negra, mas ressaltamos que esses discursos (e ações) afetam também as populações indígenas, imigrantes de origem latino-americana, africana e asiática, assim como seus descendentes no Brasil.

${ }^{3}$ Para saber mais, visite: <https://coalizaonegrapordireitos.org.br/>.

${ }^{4}$ Mais informações em: 〈https://mulheresnegrasdecidem.org/> .

${ }^{5}$ Saiba mais em: <https://azmina.com.br/projetos/delegacia-da-mulher/>.

${ }^{6}$ São exemplos a Casa Nem (RJ), a Casa 1 (SP) e a Casa Miga de Acolhimento LGBT+ (AM).
} 
novas/os ativistas. Essas articulações têm gerado pressão sobre diversos setores para denunciar o racismo, o machismo e a cisheteronormatividade como fatores estruturantes da sociedade brasileira, incluindo a raça, o gênero e a sexualidade como eixos de análise e debates fundamentais para além da academia. Essas questões se mostram hoje presentes em diversos níveis e esferas, como a disputa política institucional, as organizações privadas e as relações sociais cotidianas.

Quando olhamos para o Brasil em específico, ao longo do ano de 2020 (contexto de escrita desta dissertação), cresceram também a proporção dos protestos na internet e nas ruas no Brasil em relação ao genocídio da população negra, pelo direito ao aborto e contra a violência sexual.

Não é de hoje, evidentemente, que o assassinato de pessoas negras gera indignação e mobilização dentre a população organizada nos Movimentos Negros. Ao longo dos últimos anos, no entanto, o trabalho de denúncia do racismo estrutural existente no Brasil vem trazendo a discussão e as ações contra o genocídio da população (em especial, da juventude) negra para a esfera pública de forma decisiva. Destacamos, nesse sentido, as manifestações em resposta ao assassinato da vereadora Marielle Franco, em 2018, que continuam exigindo respostas a respeito dos mandantes do crime com a realização de atos periódicos em memória da vereadora sob a palavra de ordem/hashtag \#QuemMandouMatarMarielle.

Aqui, em 2020, as manifestações no luto pela morte de jovens negras/os tomaram as ruas para denunciar o genocídio da população negra e para velar a memória de meninos como João Pedro Matos Pinto, de 14 anos (vítima de violência policial em São Gonçalo, levado pela Polícia Militar sem acompanhamento da família após ser alvejado numa operação policial, enquanto estava em casa) e Miguel Otávio Santana, de 5 anos (que estava aos cuidados da patroa de sua mãe, de Sari Côrtes Real - à época primeira-dama da cidade de Tamandaré (PE) -, quando esta o abandonou sozinho no elevador de seu prédio) em Recife.

Outro caso que ganho noticiários e obteve manifestações pelo Brasil inteiro como resposta ocorreu no final do ano, na madrugada do dia 20 de novembro (Dia Nacional de Zumbi e da Consciência Negra). Em uma unidade do Carrefour em Porto Alegre (RS), ocorreu o espancamento de José Alberto "Beto" Freitas (40 anos) por Geovane Gaspar da Silva, Magno Braz Borges, Paulo Francisco da Silva, Kleiton Silva Santos e Rafael Rezendo, que o levou à morte. Nos dias que se seguiram, ocorreram uma série de manifestações, sobretudo na cidade de Porto Alegre, em repúdio ao ocorrido e em denúncia à negligência da rede de supermercados. 
Tudo isso no ano em que os protestos Black Lives Matter, contra a violência policial nos Estados Unidos, tomaram uma proporção global. Com uma longa e intensa trajetória marcada por protestos de rua e ações nas redes durante a década de 2010, o movimento ganhou nova projeção após o assassinato de George Floyd (46 anos) pelo policial branco Derek Chauvin (44) em Minneapolis, em uma abordagem no dia 25 de maio de 2020. O vídeo registrando o tratamento brutal conferido a Floyd, que resultou em sua morte, foi divulgado no dia seguinte ao ocorrido. O caso agiu como catalisador para impulsionar as mobilizações que já vinham ocorrendo para denunciar e cobrar justiça em relação a uma série de outros casos de violência.

Além dos protestos de rua que ocorreram em diversos estados dos EUA e em vários países do mundo, aconteceram também uma série de ações de denúncia e debate sobre a questão da violência policial racializada nas redes sociais, promovidas por grupos, coletivos e atores individuais, o que também contribui para o nosso contexto nacional. As hashtags \#BlackLivesMatter e as variantes \#SayHisName, \#SayHerName e \#SayTheirName ${ }^{7}$, traduzidas em diversas línguas, congregaram uma série de postagens e ações coordenadas em redes sociais. No Brasil, as traduções \#VidasNegrasImportam e \#VidasPretasImportam foram utilizadas em diversas ações, entre elas o Movimento AR, da Universidade Zumbi dos Palmares ${ }^{8}$ e a intervenção do Coletivo Arte 1 na Avenida Paulista.

Simultaneamente, destacaram-se ações no campo da Saúde e no Judiciário que apresentaram sérios retrocessos no que se refere à autonomia de nós, mulheres, sobre nossos próprios corpos. Em agosto de 2020, grupos de fundamentalistas religiosos se articularam para tentar impedir que uma menina capixaba de apenas 10 anos tivesse acesso ao seu direito de interromper a gravidez. A demora na liberação do procedimento, a recusa de profissionais do Hospital Universitário Cassiano Antônio Moraes (Hucam), o vazamento de seus dados pessoais na internet pela ativista da nova direita conservadora Sara Giromini e os assédios cometidos contra ela no hospital em Recife onde finalmente teve seu direito atendido. Em novembro do mesmo ano, a estratégia jurídica utilizada pela defesa do empresário André de Camargo Aranha contra a promotora de eventos Mari Ferrer ameaçou criar um precedente perigoso para o devido litígio de casos de violência sexual. À época, Schirlei Alves (Intercept Brasil) definiu a estratégia por meio do termo "estupro culposo"".

Em ambos os momentos, ocorreram articulações dos movimentos feministas em apoio e defesa dessas mulheres, como manifestação de ruas e nas redes, e mobilizações para a garantia

\footnotetext{
${ }^{7}$ Para saber mais, acesse: 〈https://sayevery.name/>.

${ }^{8}$ Saiba mais em: 〈http://movimentoar.com.br/>.

${ }^{9}$ Originalmente cunhado aqui: 〈https://theintercept.com/2020/11/03/influencer-mariana-ferrer-estupro-culposo/>.
} 
da realização do aborto em segurança. Nesse sentido, as articulações feministas se mostram fundamentais para fazer frente às forças que visam à subjugação das mulheres sob a égide da "ideologia de gênero" vigente, do heteropatriarcado branco. Como coloca Helena Bertho (2020), em matéria da revista AzMina, "Não minimizemos. Grupo rezando na porta de hospital e agredindo menina vítima de estupro é parte de um projeto de poder em marcha há anos no Brasil".

Em meio a tudo isso, a pandemia. Ao longo do ano, foram criadas uma série de ações propositivas sendo realizadas em um ano marcado pela negligente ação estatal para garantir direitos básicos às populações mais vulneráveis. São exemplos marcantes as redes de pressão e de apoio constituídas para divulgação de informações e cuidados contra a COVID-19 nas regiões mais afetadas e menos amparadas pelo Estado, como periferias, favelas, quilombos e aldeias, assim como a atenção ao aumento dos casos de violência doméstica e feminicídio. Destacamos a criação do Mapa Corona nas Periferias (do Instituto Marielle Franco em parceria com o Favela em Pauta) ${ }^{10}$, as diversas campanhas e vaquinhas online para a distribuição de EPIs e cestas básicas, as ações da Pastoral do Povo da Rua na cidade de São Paulo ${ }^{11}$ e as pressões dos movimentos sociais para a criação de programas de renda mínima nos níveis federal, estadual e municipal, como o Auxílio Emergencial ${ }^{12}$.

Dessa forma, tendo em vista a crescente importância que o compartilhamento de informações e denúncias por meio das redes sociais assume no cenário atual, considerando o isolamento social imposto pela pandemia do coronavírus, aumenta também a relevância das/os atoras/es sociais engajados na produção de conteúdo em ambientes de sociabilidade online, como Twitter, Facebook, Tik Tok e Instagram. Esses perfis e páginas não apenas veiculam denúncias, como também conceitos, pautas, agendas e debates dos movimentos aos quais estão articulados, agindo também de forma conectada com novos veículos de imprensa alternativa (tais como Ponte, Mídia Ninja, AzMina, Notícia Preta, Alma Preta, Geledés, entre vários outros), assim como páginas e perfis de coletivos, movimentos e ONGs (como Criola, Teia dos Povos, MST, MTSTS, entre outros ), ao propagar notícias que não obtêm espaço na mídia hegemônica, assumindo perspectivas críticas para debater questões sociais.

Dessa forma, vão constituindo também uma espécie de arquivo, posto que os textos e vídeos publicados nas redes se mantêm disponíveis posteriormente e podem ser acessados e

\footnotetext{
${ }^{10}$ Saiba mais em <https://www.institutomariellefranco.org/mapacoronanasperiferias $>$.

${ }^{11}$ Para saber mais, acesse: <https://brasil.elpais.com/brasil/2020-09-20/padre-julio-lancellotti-nao-se-humaniza-avida-numa-sociedade-como-a-nossa-sem-conflito.html $>$.

12 Mais informações em: <https://observatorio3setor.org.br/noticias/renda-basica-emergencial-e-resultado-dauniao-da-sociedade/>.
} 
revisitados ao longo dos anos. Chamamos atenção para isso pelo fato de que, embora os vídeos analisados aqui precisem ser contextualizados em relação a sua data de publicação e discutidos em referência a isto, enquanto constituintes de um "arquivo digital", podem ser ressignificados.

Em contrapartida, é importante ressaltar que a disseminação do discurso de ódio nas redes vem tomando corpo nos últimos anos, devido, em parte, à articulação de certas forças no contexto brasileiro e internacional e a uma certa leniência de plataformas, mesmo que elas alardeiem um posicionamento pró-diversidade. Assim, analisar a construção discursiva das diferenças e as estratégias argumentativas envolvidas na gestão das relações intersubjetivas sob um viés crítico se mostra crucial. Afinal, os mecanismos discursivos de produção das diferenças que estruturam as sociedades racistas e machistas em territórios colonizados têm propósitos ideológicos, econômicos e políticos, e se baseiam na construção de imagens distorcidas que naturalizam práticas de silenciamento, violência, marginalização e genocídio de certos grupos, e de beneficiamento, supremacia e autoritarismo de outros.

Atenta ao papel que o ativismo digital exerceu na constituição do meu olhar enquanto pesquisadora, percebo-o como um espaço de divulgação de pautas e ideias, em que se encontra desde apresentações didáticas de conceitos acadêmicos, até a polemização estratégica e discussões densas a respeito da estruturação das raízes de dominação. Nesse processo, vemos uma interlocução muito grande entre as dimensões privadas e públicas, em meio a uma reorganização geral desses conceitos que parece estar acontecendo na sociedade, sobretudo quando olhamos para práticas sociais e discursivas mediadas pelas tecnologias digitais, cada vez mais comuns e rotineiras.

Essa pesquisa nasce do interesse em compreender como as estratégias discursivas de ativistas digitais lidam com o cenário de polarização política e escalada da extrema direita. Considerando o atual cenário da esfera pública no Brasil, acredito que pesquisas que se dedicam à investigação de estratégias discursivas hegemônicas e contra-hegemônicas, voltadas para a (des)construção da diferença, exerçam um papel crucial no sentido de auxiliar a compreensão do acelerado processo de polarização política e de radicalização de setores da extrema direita no Brasil.

Nessa concepção, enxergo o ativismo digital feminista como a apropriação de tecnologias digitais por atores sociais engajados ${ }^{13} \mathrm{com}$ o propósito de disputar narrativas, divulgar pautas e agendas, realizar denúncias por meio de uma variada gama de práticas

\footnotetext{
${ }^{13}$ Ressaltamos aqui a diferença na estruturação do que consideramos ativismo (protagonizado por um indivíduo) e militância (protagonizado por um coletivo).
} 
discursivas; desenvolver espaços de interação com seguidores e outros produtores de conteúdo, estabelecendo redes de solidariedade e mobilizar grupos em defesa de direitos e em prol de campanhas a partir de uma filiação ideológica marcada (BARROS, s/d; MORAES, 2001). Devido à persistência dos conteúdos publicados em plataformas online, muitos dos canais, blogs e perfis ligados aos movimentos sociais consistem em um repositório, que permite repertoriar outras atoras sociais interessadas nesses temas e debates. Assim, contribuem para capilarizar a formação política em novos territórios.

Localizo-me neste cenário enquanto mulher branca, bissexual, de classe média e de esquerda. Enquanto analista crítica do discurso e feminista, busco estabelecer em minha abordagem um diálogo com autoras feministas negras e lésbicas, com o horizonte de contribuir para o desenvolvimento de posicionamentos analíticos comprometido com a crítica à branquitude numa perspectiva antirracista. Resenhando discussões realizadas a respeito das políticas de silenciamento e as estratégias de combate formuladas por feministas brasileiras ao longo das últimas décadas, espero também contribuir para a discussão a respeito de estratégias de enfrentamento aos ataques a direitos adquiridos que ocorrem dentro e fora das redes, refletindo sobre os ataques racistas, machistas e LGBTfóbicos a ativistas e militantes que têm ocorrido com cada vez mais frequência nos últimos anos.

Nesse sentido, vale a pena nos debruçarmos sobre os discursos que circulam nessas esferas, considerando práticas discursivas diversas ligadas à politização de certas pautas, já que os textos produzidos nesse contexto podem nos oferecer pistas relevantes a respeito das correlações de forças e da (re)construção de imaginários coletivos. Sendo assim, ao longo desta dissertação, vamos nos deter sobre o manejo do dissenso e, mais do que isso, sobre a sua operacionalização em estratégias discursivas no âmbito do ativismo feminista digital.

Para uma geração que trabalha, muitas vezes, na chave do deboche e da ironia para tratar problemas sociais e, assim, demonstrar uma postura de resistência e enfrentamento, a quebra de expectativa e o riso são marcas discursivas fortes e características. Dessa forma, trabalhamos medos e ansiedades, contradições e horizontes políticos. Como coloca Bianca Gonçalves, "fazer pacto suicida com o companheiro é pouco feminista". A partir dos aprendizados com outras gerações, que articulações podemos criar a partir de uma nova percepção da sociedade? Nesse sentido, pensemos nas criações de redes de ativismo e militância feministas (no meio digital ou fora dele), como uma forma de "morar juntas", e levar a política para o pessoal de casa. 
Essas questões serão investigadas em um corpus composto por dois vídeos postados pelo canal Nátaly Neri e outros dois postados pelo canal Louie Ponto ao longo do primeiro semestre de 2017. Trata-se de dois canais feministas, alocados na plataforma YouTube, que debatem, além de questões de gênero, pautas e conceitos provenientes de outros movimentos sociais aos quais as youtubers estão articuladas, nomeadamente os movimentos negros e LGBTTIAPN+.

O canal Nátaly Neri (anteriormente conhecido como Afros e Afins) debate uma série de temas ligados à vida universitária e à intelectualidade negra, além de produzir conteúdos sobre consumo consciente, beleza, sexualidades e saúde mental. É embaixadora da iniciativa Creators For Change, do YouTube, por meio da qual realizou o documentário Negritudes Brasileiras (2018). Nátaly é uma mulher negra, cis, panromântica e, em 2017, época de publicação dos vídeos analisados, era graduanda em Ciências Sociais pela Universidade Federal de São Paulo. Ela também atua no Twitter e no Instagram. Tem uma extensa produção, tendo publicado mais de 200 vídeos até 2020, muitos deles em parceria com ativistas e militantes dos movimentos negros e de outros movimentos sociais.

O canal Louie Ponto trabalha temas ligados à comunidade LGBT (termo utilizado no canal), sobretudo visibilidade lésbica e saúde mental por meio de vlogs e em colaborações com outros youtubers. A youtuber também posta vídeos sobre vegetarianismo e veganismo, assim como covers e músicas. Louie é uma mulher branca, cis, lésbica e, em 2017, época de publicação dos vídeos analisados, era mestranda em Literatura pela Universidade Federal de Santa Catarina. Ela também está presente em outras plataformas, como Instagram e Twitter, mas é seu canal no YouTube que reúne a maior parte de seus seguidores.

Durante o processo de pesquisa que deu origem a esta dissertação, uma das inquietações fundamentais que orientou as leituras e discussões se relacionava com a (des)construção da(s) diferença(s) por meio do discurso a partir de perspectivas contra-hegemônicas. Dessa forma, a seleção de vídeos nos quais se elaboram estratégias discursivas contra-hegemônicas a partir de lugares de fala específicos e com articulações diversas, enquanto foco de investigação primordial, se mostrou produtivo não apenas para a compreensão do ativismo digital feminista em si, como também para a reflexão e para a elaboração de propostas teórico-metodológicas capazes de atender a tal complexidade.

Encontramos em nossas análises algumas características discursivas e materiais do ativismo digital que impuseram desafios para a aplicação dos modelos analíticos previamente selecionados, o que nos motivou a propor um novo modelo de análise, centrado no conceito de 
Movimentação Epistêmico-Axiológica (MEA) - uma abordagem multidisciplinar que articula conceitos e métodos da Análise Crítica do Discurso, da Linguística Cognitiva, das teorias da Argumentação, da Linguística Sistêmico-Funcional, dos estudos sobre a empatia e perspectivas feministas negras para propor um novo olhar sobre o uso do rearranjo simbólico do Espaço Discursivo enquanto estratégia discursiva.

Em suma, objetivamos, nesta dissertação, desenvolver uma discussão sobre o atual cenário dos ativismos digitais feministas, com uma atenção especial para a questão da (des)construção das diferenças a partir do dissenso. Por causa disso, desenvolvemos problematizamos alguns critérios, conceitos e metodologias estabelecidos na área das Teorias do Texto e do Discurso, considerando as especificidades dos ativismos digitais. Isso nos leva à proposta da Movimentação Epistêmico-Axiológica, que se pretende uma contribuição teórica de aprimoramento da noção de Posicionamento enquanto estratégia discursiva, conforme definida por Hart (2014) em sua proposta de Análise Crítica do Discurso cognitivamente orientada.

Mais especificamente, entendemos que o avanço apresentado por esta pesquisa consista numa revisão acerca das dinâmicas de estabelecimento de objetos do discurso em uma perspectiva discursiva e multidisciplinar. Partindo, sobretudo, da Teoria da Proximização e dos estudos sobre a empatia, defenderemos que as noções de comunidades e entidades discursivas permitem aprofundar as reflexões sobre a dinâmica das estratégias discursivas baseadas na distinção entre endogrupo e exogrupo (nós vs. eles), já discutidas por van Dijk (2013) no âmbito da Análise Crítica do Discurso.

Essa distinção surgiu da percepção da necessidade de considerar, sob um viés críticodiscursivo, em textos de visada argumentativa, a relevância das respostas pré-legitimadas a determinadas questões argumentativas para a definição das diferenças e semelhanças entre atoras/es e grupos sociais. Acreditamos que essas respostas sejam índices importantes para analisar o processo de polarização discursiva que, de alguma forma, perpassa os discursos ativistas na contemporaneidade.

A princípio, optamos por analisar os vídeos a partir das metodologias encontradas na Teoria da Proximização (CAP, 2013; HART, 2014) e dos estudos da empatia, sobretudo no projeto Living With Uncertainty (CAMERON, 2012, 2013), por considerar que a articulação entre essas abordagens traria avanços positivos em termos da complexidade da teorização a respeito da construção discursiva da alteridade e dos mecanismos envolvidos no rearranjo simbólico do Espaço Discursivo. No entanto, no decorrer as análises iniciais, percebemos 
indícios de que a variedade funcional de usos do manejo do dissenso como estratégia discursiva extrapolava as tipologias e categorias de análise encontradas na literatura consultada.

Quando olhamos para o ativismo digital em específico, percebemos que o colapso do contexto e o advento dos públicos em rede colocam uma série de desafios para a compreensão do estabelecimento das relações entre as instâncias de produção textual e os consumidores textuais. A definição do interlocutor prototípico de um canal do YouTube se mostra, então, uma tarefa complexa a ser realizada a partir da análise da materialidade textual. Nesse sentido, a mobilização das teorias da argumentação parece mostrar uma saída por meio do conceito de auditório, que nos dá pistas de como realizar essa distinção. Novamente, mostra-se essencial o estabelecimento de uma abordagem multidisciplinar para encarar essas questões.

No caso da empatia, encontramos como vantagem a teorização aprofundada sobre os aspectos discursivos envolvidos na construção discursiva do Outro, especialmente no que se refere à compreensão de que, nesse processo, são decisivos o imaginário coletivo de uma dada sociedade ou comunidade, bem como as experiências pessoas, crenças e valores daquela/e que realiza essa representação. Encontramos, no entanto, sérios obstáculos para aplicar os níveis de análise e as categorias de gestos empáticos elaboradas por Cameron $(2012,2013)$ ao nosso corpus, o que se justificava pelas diferenças da natureza dos textos selecionados. No projeto Living With Uncertainty, o Outro consiste em um/a co-enunciador/a, ator/a ou grupo social específico, que se encontra em situação de vulnerabilidade ou em conflito com o Eu. O objetivo das situações comunicativas analisadas no estudo é promover a compreensão através da alteridade, e não há uma visada argumentativa unidirecional, como é o caso dos vídeos analisados aqui.

No caso da Proximização, ressaltamos o desenvolvimento do eixo avaliativo ou axiológico para a construção do Espaço Discursivo, o que se mostrou uma ferramenta analítica importante para a análise do manejo do dissenso. Ademais, com as noções de entidades internas e externas ao centro dêitico, percebemos um ganho analítico para a compreensão do nosso corpus, tendo em vista que elas complexificam a construção da diferença entre endogrupo e exogrupo nos textos. Além disso, a consideração do propósito retórico dos textos por meio da concepção de um deslocamento de natureza avaliativa no Espaço Discursivo - isto é, a mudança de percepção sobre a relação entre as entidades internas e externas do centro dêitico - se mostrou especialmente instigante para a consideração de uma análise mais aprofundada da dimensão retórica dos vídeos que compõem o corpus. 
O propósito retórico dos textos e a posição ocupada pelas youtubers em relação a sua audiência também se mostrou relevante para as análises, posto que, enquanto os vídeos das youtubers consistem em práticas de formação política para o combate do racismo, do machismo e da LGBTfobia no cotidiano, os discursos analisados pela perspectiva da Proximização configuram-se, em geral, em práticas de legitimação de ações intervencionistas, ligadas ao âmbito da guerra e de políticas anti-imigração ${ }^{14}$. Entretanto, apesar dos avanços na construção dos objetos do discurso representados pela concepção de entidades, estas ainda se mostravam bilaterais, isto é, completamente identificadas com o campo avaliativo/axiológico do endogrupo ou do exogrupo, o que impedia a consideração das particularidades das práticas de formação política, que precisam lidar com dissidências dentro do endogrupo.

Assim, se o Eu e o Outro são entidades discursivas que se articulam a grupos sociais e a comunidades discursivas, como faremos sua delimitação?

Não encontramos na literatura solução clara para este problema. Discernimos, portanto, a necessidade de elaborarmos um aporte teórico-metodológico multidisciplinar capaz de analisar estratégias discursivas baseadas no sistema cognitivo da Perspectiva (HART, 2014) de forma a refinar a tipologia de funções dos mecanismos de projeção e rearranjo simbólico no Espaço Discursivo. Essa ferramenta deveria apresentar ainda categorias de análise pertinentes para investigar a representação das comunidades de crenças e valores e de sua relação com a voz autoral dos textos.

Chegamos, com isso, à problemática do estabelecimento da alteridade em situações em que não há referência direta entre o Outro e o exogrupo nem entre o Outro e um ator social ou co-enunciador. Percebemos, portanto, a necessidade de uma abordagem multidisciplinar que desse conta das dimensões cognitiva, retórico-argumentativa e dialógico-atitudinal de tal processo. Nossa hipótese é a de que a de Movimentação Epistêmico-Axiológica consiste em uma estratégia discursiva multidimensional que articula essas três dimensões e permite compreender de que forma ela participa da construção de relações de solidariedade, neutralidade e antagonismo entre comunidades discursivas a partir da disputa entre Alegações e Propostas de Ação. Com isso, refinamos a compreensão da construção do Outro enquanto objeto do discurso em face do colapso do contexto, dos públicos em rede e do propósito da formação política.

\footnotetext{
${ }^{14}$ Há pesquisas mais recentes que aplicam a Proximização sobre outros corpora também, como o discurso médico, ambientalista e humanitário. No entanto, os textos e práticas analisados estão, também, voltados para legitimação de certos tipos de intervenção envolvendo polarizações endo e exogrupais.
} 
Logo, a MEA deverá ser capaz de (i) considerar o Outro enquanto objeto do discurso (entidade discursiva), valorizando a análise de sua representação; (ii) reconhecer uma maior variedade de formas de mapear as diferenças tanto entre as entidades discursivas, quanto entre tais entidades e o endo/exogrupo; (iii) considerar a articulação de vozes na construção das relações com outras comunidades discursivas em textos monologais com duas vozes autorais.

Concebemos, assim, como objetivo desta dissertação elaborar um modelo de análise para a investigação da Movimentação Epistêmico-Axiológica. Para tanto, iremos (i) defender a definição da MEA como estratégia discursiva multidimensional (cognitiva, retóricoargumentativa e dialógico-atitudinal); (ii) construir um modelo analítico centrado na MEA, delimitando os procedimentos metodológicos relevantes, o que inclui a seleção de categorias de análise e o estabelecimento de etapas de trabalho; (iii) verificar a produtividade do modelo para a análise de práticas discursivas do ativismo digital; (iv) depreender papéis da MEA no âmbito do ativismo digital, considerando o funcionamento dessa prática na sociedade contemporânea.

Em primeiro plano, a Movimentação Epistêmico-Axiológica é definida como uma estratégia discursiva que opera nas dimensões cognitiva, retórico-argumentativa e dialógicoatitudinal, voltada para o estabelecimento de comunidades de crenças e valores (doravante comunidades discursivas) como objetos de discurso e para a construção de relações entre as mesmas ao longo de um determinado texto. Para além disso, ela pode ser utilizada, por meio do contraste entre discursividades distintas, como forma de explorar o dissenso em determinadas práticas sociais e esferas de atividade.

Na dimensão cognitiva, a Movimentação Epistêmico-Axiológica se ancora no sistema cognitivo de Perspectiva (HART, 2014; CHILTON, 2013) e está relacionada à construção de Espaços Discursivos, assim como à delimitação das entidades discursivas. Este processo é realizado em diálogo com a dimensão retórico-argumentativa. Para abarcamos tal dimensão, mobilizamos categorias de análise e metodologia embasadas na configuração funcional dos argumentos (GONÇALVES-SEGUNDO, 2020a; Isabela FAIRCLOUGH; Norman FAIRCLOUGH, 2012; TOULMIN, 2006) para delimitar as comunidades discursivas referenciadas nos textos. Isso é realizado a partir da depreensão do problema epistêmico/prático central em cada vídeo e como as vozes autorais apresentam os posicionamentos em disputa.

Por meio do diálogo entre essas dimensões, procuramos aprimorar a noção de entidades proposta pela Proximização, definindo três entidades básicas (Eu, Nós e Outro) para analisar a 
construção dessas comunidades nos textos. Isso decorre, como já mencionamos acima, do propósito retórico dos vídeos de ativismo digital analisados: a formação política.

A partir da dimensão retórico-argumentativa, depreendemos também os pontos de tensão dialógica nos textos, o que orientou a seleção de trechos a serem analisados pela dimensão dialógico-atitudinal, que verifica as variações do grau de abertura das vozes autorais em relação aos posicionamentos contrários e aos elementos argumentativos que os compõem. Tal estudo será realizado por meio da mobilização do sistema de AVALIATIVIDADE (MARTIN; WHITE, 2005) e dos gestos de empatia propostos por Gonçalves-Segundo (2019b), categorias produtivas para compreender os efeitos discursivos gerados a partir da relação entre os posicionamentos e, consequentemente, entre as comunidades discursivas em pauta em cada um dos vídeos.

Para considerar essas três dimensões nos textos, estabelecemos uma metodologia de análise realizada em três etapas, a saber: (i) Mapeamento das entidades no Espaço Discursivo; (ii) Mapeamento dos movimentos de aproximação/afastamento epistêmico-axiológico; (iii) Interpretação das funções da Movimentação Epistêmico-Axiológica na constituição de estratégias discursivas. Tal metodologia será aplicada a cada um dos vídeos que compõem o corpus e permitirá depreender a produtividade do modelo que propusemos para compreender o uso da construção da alteridade e do manejo do dissenso no âmbito do ativismo digital na composição de estratégias discursivas para a formação política.

A dissertação está organizada em três capítulos. No primeiro, Feminismos brasileiros e ativismo nas redes sociais: uma leitura crítico-discursiva, contextualizaremos a atuação das duas youtubers cujos vídeos compõem o corpus, Nátaly Neri e Louie Ponto. Para tanto, discutiremos práticas dos feminismos e movimentos de mulheres negras e lésbicas que se dedicaram à divulgação de temas, debates e práticas de combate ao heteropatriarcado branco desde a década de 1990 até os anos 2010, com atenção especial às práticas discursivas do campo do ativismo digital. Isso incluirá ainda a reflexão sobre seus vídeos como instâncias de práticas sociais e discursivas específicas do YouTube brasileiro hoje, considerando, por um lado, a sujeição dessa produção à arquitetura da plataforma (BURGESS; GREEN, 2009), e, por outro, o YouTube enquanto rede social, caracterizado pela relação das instâncias de produção com públicos em rede (boyd, 2011, 2014). Para tanto, vamos resenhar alguns conceitos dos Estudos Críticos do Discurso na perspectiva faircloughiana e da Antropologia Digital. A partir dessa discussão, refletiremos sobre os canais ativistas, seus limites e potenciais enquanto espaços de discussão e divulgação de temas, debates e pautas feministas. 
No segundo capítulo, A Movimentação Epistêmico-Axiológica: discussões teóricometodológicas, apresentaremos, em detalhe, o embasamento teórico da noção de Movimentação Epistêmico-Axiológica, dialogando com os estudos sobre a empatia, o Feminismo Negro e a Teoria da Proximização. A partir das problematizações levantadas a respeito e com o apoio dessas três perspectivas, desenvolveremos a noção de Movimentação Epistêmico-Axiológica e sua metodologia, resenhando também as categorias de análise recrutadas: configuração funcional dos argumentos (epistêmica e prática) e AVALIATIVIDADE.

As etapas da metodologia organizam o terceiro capítulo, A Movimentação EpistêmicoAxiológica como estratégia discursiva do ativismo digital feminista, no qual apresentaremos as análises realizadas por meio da realização da descrição macroargumentativa e microlinguística dos textos, da interpretação discursiva e da explicação sócio-histórica de cada um dos vídeos, conforme preconiza a Análise Crítica do Discurso.

Por fim, encerrraremos a dissertação, refletindo sobre os resultados das análises e o que eles indicam a respeito das práticas discursivas feministas no ativismo digital. Também debateremos os potenciais e limites da Movimentação Epistêmico-Axiológica enquanto ferramenta de análise para investigar as formas pelas quais é possível estabelecer, manter e subverter relações entre visões de mundo e comportamentos, bem como entre comunidades discursivas ao longo de um texto de forma estratégica. 


\section{Capítulo 1 - Feminismos brasileiros e ativismo nas redes sociais: uma leitura crítico-discursiva ${ }^{15}$}

\section{Introdução}

Embora diversas pautas, conceitos e modos de ação feministas tenham ganhado um espaço considerável na mídia hegemônica nos últimos anos, a atuação das feministas no campo da comunicação consiste em um esforço contínuo que se processa há décadas. Neste capítulo, pretendemos contextualizar a atuação de duas youtubers feministas, Nátaly Neri e Louie Ponto, apresentando um breve histórico sobre os feminismos no Brasil da década de 1990 aos anos 2010, com foco sobre a atuação de organizações feministas, assim como movimentos de mulheres negras e de mulheres lésbicas ${ }^{16}$.

Para tanto, discutimos práticas que se dedicaram à divulgação de temas, debates e práticas ligadas aos feminismos e à emancipação das mulheres, de forma a refletir sobre as (des)continuidades na atuação das youtubers citadas. Consideraremos, especialmente, as mudanças, transformações e continuidades entre esses momentos no que se refere às práticas discursivas do campo do ativismo digital. Para tanto, vamos resenhar alguns conceitos dos Estudos Críticos do Discurso, na perspectiva faircloughiana, e da Antropologia Digital.

Isso incluirá ainda a reflexão sobre os vídeos como instâncias de práticas sociais e discursivas específicas do YouTube brasileiro hoje, considerando, por um lado, a sujeição dessa produção à arquitetura da plataforma (BURGESS; GREEN, 2009), e, por outro, o YouTube enquanto rede social, caracterizado pela relação das instâncias de produção com públicos em rede (boyd, 2011, 2014). A partir dessa discussão, refletiremos sobre os canais ativistas e seus potenciais enquanto espaços de discussão e divulgação de temas, debates e pautas feministas.

Em suma, nosso objetivo neste capítulo é discutir as formas como as estratégias de comunicação feministas no ativismo digital podem constituir um "nexo de empoderamento" para as mulheres, como coloca Sueli Carneiro (2019a). Com isso, localizaremos a atuação das youtubers ativistas Nátaly Neri e Louie Ponto em um contexto mais amplo de lutas e reivindicações.

\footnotetext{
${ }^{15}$ Agradecemos imensamente os comentários da Professora Doutora Viviane Gonçalves Freitas na defesa dessa Dissertação, que contribuíram sobremaneira para as discussões realizadas neste capítulo.

${ }^{16}$ Para um resumo detalhado dos marcos dos feminismos brasileiros nesse período, sugerimos a leitura da "Breve cronologia do movimento feminista no Brasil" (Eva BLAY; Lúcia AVELAR, 2015). Trata-se de uma linha do tempo que data desde o lançamento de periódicos e a criação de grupos de pesquisa feministas, até as apresentações de reivindicações, congressos e conquistas de direitos políticos e trabalhistas para as mulheres, de 1832 até 2015.
} 
Nosso interesse nos vídeos de youtubers ativistas como objeto de pesquisa para o desenvolvimento da noção de Movimentação Epistêmico-Axiológica, que apresentaremos em detalhe no capítulo seguinte, se justifica pelo fato de que essas produções são marcadas pelo propósito de divulgação de visões contra-hegemônicas a respeito do papel das mulheres na sociedade brasileira. No caso dos vídeos selecionados, isso se mostra especialmente marcado, posto que as discussões realizadas complexificam a questão de gênero, articulando-a a questões de raça e/ou de sexualidade, a partir de perspectivas "interseccionais" 17.

Dessa forma, passamos a enxergar a atuação dos canais analisados como forma de divulgar conceitos e debates dos feminismos e movimentos de mulheres negras e mulheres lésbicas e, em última análise, possa assumir uma função na formação política de suas seguidoras.

Hipotetizamos que a projeção de um Outro com que se estabelece um diálogo fictício (em desacordo com o Eu-Nós, entidade textual correspondente à comunidade epistêmica da qual participam as youtubers) possa concorrer de duas formas (pelo menos) para a formação política de um campo progressista: (i) provocar o processo de revisão de crenças, e (ii) fornecer arcabouço teórico e prático para o processamento de outras práticas discursivas também embasadas pela discursividade progressista. Tais objetivos se assemelham bastante aos de outras iniciativas feministas no campo comunicacional, nomeadamente as publicações da imprensa alternativa durante o período de redemocratização e de sites e portais feministas, antirracistas e LGBTTIAPN+ criados nos últimos anos. Esse debate será aprofundado também no capítulo seguinte, quando debateremos as políticas de silenciamento e as estratégias discursivas para combatê-las a partir de perspectivas feministas negras ${ }^{18}$.

\footnotetext{
17 Utilizamos o termo aqui de forma ateórica, posto que nem todas as referências teóricas recrutadas pelas youtubers de fato são filiadas ao conceito de interseccionalidade da feminista negra estadunidense Kimberlé Crenshaw (2002). Nessa proposição, afirma-se que gênero e raça sejam marcadores sociais indissociáveis. Outras perspectivas também produziram análises multidimensionais, como é o caso da produção de Lélia Gonzalez, por exemplo, que adiciona ainda o eixo da classe. Outras características também podem ser integradas, como sexualidade, territorialidade, geração, religião etc. A respeito da utilização do termo a partir de sua formulação feminista negra estadunidense e no contexto brasileiro, sugerimos a leitura do livro de Carla Akotirene (2018), e dos artigos de Rodrigues (2013), Regina Facchini, Íris Nery do Carmo e Stephanie Pereira Lima (2020), assim como o capítulo de Marlise Matos e Solange Simões (2018).

${ }^{18}$ Optamos por esse embasamento por entendermos que as perspectivas feministas negras brasileiras, e o diálogo que estabelecem com algumas produções estadunidenses, apresentam ganhos analíticos cruciais para a compreensão do funcionamento do discurso conservador, bem como das estratégias discursivas para combatê-lo. Destacamos, conforme Alvarez (2014), a distinta capacidade de articulação dos feminismos e movimentos de mulheres negras em sua diversidade, o que se reflete também nos aprendizados que outros movimentos têm demonstrado em termos de estabelecimento de diálogos e definição de linhas de ação.
} 


\subsection{Feministas brasileiras no campo da comunicação: estratégias e debates do período pós-redemocratização à ascensão da direita conservadora}

Os movimentos feministas e de mulheres ${ }^{19}$ em atuação no Brasil contemporâneo são vários e complexos, com aportes teóricos, estratégias políticas e agendas bastante diversas entre si. Sendo assim, os aspectos que caracterizam os modos de atuação atuais dos feminismos são: a ampliação da força de vozes não hegemônicas no espaço público (Heloisa Buarque de HOLLANDA, 2018) e a disseminação de valores feministas para novas esferas sociais (Sônia ALVAREZ, 2014; Fabiana MARTINEZ, 2019).

Hollanda (2018, p. 12-13) compreende esse momento como a quarta onda feminista: os “feminismos da diferença”, cujo pano de fundo seria uma nova geração política que apresenta estratégias e formas de organização próprias, autônomas e horizontais, baseadas em narrativas de si e em éticas insurgentes. A autora reconhece uma pluralidade de contextos de atuação política feminista, o que envolve desde as manifestações de rua, os ativismos na internet e as novas linguagens e fazeres poéticos, artísticos e acadêmicos.

Alvarez (2014), por sua vez, posiciona-se de forma contrária à delimitação de "ondas" feministas, defendendo que o termo não seria capaz de explicar a atuação dos movimentos de mulheres e dos movimentos feministas na América Latina e, mais especificamente, no Brasil. Ela sugere que pensemos os nossos feminismos em três movimentos: o "centramento" da década de 1970, durante o qual o movimento foi estabelecido de forma monolítica (MARTINEZ, 2019, p. 6); o "descentramento" dos anos 1980 e 1990, quando ocorreu um processo de "pluralização"; e o "sidestreaming", que vem ocorrendo desde os anos 2000 e consiste na propagação dos discursos feministas em diversos campos de ação.

Assim, o que caracterizaria o presente momento seria, por um lado, a atuação do “feminismo jovem". Essa atuação corresponderia a "expressões feministas que se desenvolveram para além das intersecções", constituídas por "uma proliferação geométrica de atoras/es que se identificam com o campo feminista e nele disputam espaço e poder; também testemunhamos processos de descentramento no interior desses feminismos plurais" (ALVAREZ, 2014, p. 41).

\footnotetext{
${ }^{19}$ Ressaltamos que, muitas vezes, esses dois movimentos não se confundem. Há, por exemplo, reconhecidas militantes nos movimentos de mulheres negras, como Jurema Werneck, que não se reivindicam feministas. Entre essas militantes, há ainda aquelas que se reivindicam mulheristas. Isso não implica, evidentemente, que não haja articulações entre esses movimentos e suas respectivas ativistas e militantes. Por isso, ao longo desta dissertação, vamos nos referir a movimentos feministas e de mulheres quando discutirmos as mobilizações de mulheres em termos amplos. Utilizaremos o termo 'feministas' para nos referirmos a autoras, pautas, teorias e agendas abertamente vinculadas aos feminismos.
} 
Neste cenário, a autora destaca o movimento de mulheres negras como "exemplo quintessencial", posto que se constitui como um campo discursivo de ação próprio devido a sua variedade de vertentes e às articulações criadas em seu interior e entorno, envolvendo atoras diversas como "as domésticas, as quilombolas, as lésbicas, as mulheres de comunidades tradicionais de matriz africana, e as jovens/hip-hopeiras/grafiteiras" (ALVAREZ, 2014, p. 41).

Segundo Valdecir Nascimento, reconhecida liderança feminista e articuladora da Marcha de $2015^{20}$, a pluralidade no interior dos movimentos de mulheres negras deixa claro que "elas não querem as mesmas coisas, e elas não são iguais". "Agora, são todas grandes lideranças", continua, "A estratégia é você estabelecer um diálogo horizontal e você falar das expertises de cada uma e trazer cada uma para a cena em cada momento" [para ir] "consolidando um pouco as alianças na nossa própria diversidade". Esse processo de pluralização talvez seja ilustrativo de como um determinado campo pode desembocar em novos e distintos campos discursivos de ação (ALVAREZ, 2014, p. 42)

Apesar de Hollanda e Alvarez apresentarem divergências teóricas importantes, utilizaremos ambas as perspectivas de forma complementar nesta dissertação. Nesse sentido, levaremos em conta, por um lado, o volume de estudos feministas que, como Hollanda (2018), encaram o movimento no Brasil a partir da divisão entre ondas e, por outro, as contribuições analíticas que demarcam as especificidades do contexto brasileiro, tais quais elaboradas por Alvarez (2014) e Martinez (2019). Em comum, elas apontam para a ampliação dos espaços de ação dos feminismos.

Interessa-nos, pois, nesta dissertação, discutir esse espraiamento em termos de novas práticas sociais e discursivas que se constituem com/por meio das redes sociais. Afinal, de acordo com Fabiana Martinez (2019, p. 6),

É nesse terceiro momento que a internet emerge como ponto referencial e constitutivo de redes e pontos de contato entre grupos e organizações feministas, criando "outras redes de comunicação a partir das apropriações da atividade prosumer como instrumento de ação política e recurso de identificação" (Ferreira, 2015: 208). Os fenômenos aqui analisados são pontos de contato e nós constitutivos desse campo discursivo de ação: blogs, páginas e grupos de discussão do Facebook, vídeos do youtube, sites de notícias, postagens de influenciadores digitais, todos se articulam em uma dinâmica reticular muito especifica desse "ciberfeminismo social” (Boix; Miguel, 2013) através da troca e da discussão de conteúdos.

\footnotetext{
${ }^{20}$ A autora se refere aqui à "Marcha das Mulheres Negras 2015 contra o Racismo e a Violência e pelo Bem Viver". Destacamos a respeito desse evento ainda o papel que o ativismo digital ocupou em sua elaboração. De acordo com Laila Thaíse Batista de Oliveira (2016, p. 819) "A Marcha ganhou grande repercussão durante o período de construção através das redes sociais o que contribuiu para reunir milhares de militantes dos mais diversos estados. Além disso, as informações eram difundidas por meio das páginas do facebook o que facilitou a comunicação entre a comissão organizadora e as militantes."
} 
Nesse processo, vemos também a ampliação do alcance de iniciativas e vozes de mulheres negras e/ou lésbicas. Historicamente marginalizados na historiografia do feminismo hegemônico (notadamente branco, heterossexual e de classe média), feminismos e movimentos de mulheres lésbicas, negras, indígenas e trans apresentam, alguns há décadas, críticas ao desenvolvimento da categoria universal mulher encampada até hoje no discurso e nas práticas de grande parte das feministas brancas, cis e heterossexuais. Na atualidade, esses grupos atuam também por meio de blogs, grupos de discussão, portais de notícias e canais do YouTube, para articular projetos políticos e identitários próprios, em articulação com outras demandas interseccionais $^{21}$ (Érica SARMET, 2018; Zelinda Barros, s/d; Thiane Neves BARROS, 2020). Esse processo se relaciona também com o que Martinez (2019) denomina segmentação em vertentes, as quais disputam narrativas, práxis e a ontologia do gênero.

No YouTube, vemos como sintomas desse processo o progressivo aumento do número e da visibilidade de canais protagonizados por atoras/es sociais alinhadas/os aos movimentos feministas, negros ${ }^{22}$ e LGBTTIAPN+, tais como Muro Pequeno, Gabi Oliveira, Neggata, PH Cortes, Spartakus Santiago, Põe na Roda, Canal das Bee, Maíra Medeiros, Luci Gonçalves, Gorda de Boa, Papo de Pretas, Barraco da Rosa, Nath Finanças, Aza Njeri, Camilla de Lucas, Jacy July, para citar apenas alguns ${ }^{23}$.

Nesse processo, a articulação entre ativistas, organizações e movimentos sociais é potencializada, criando redes de apoio e de debate com capilaridade cada vez maior. Entretanto, embora as mudanças e as novas dinâmicas criadas a partir do advento da internet sejam essenciais para a compreensão desse momento, ressaltamos que essas articulações dão continuidade aos processos de articulação regional, nacional e internacional dos feminismos que vêm ocorrendo nas últimas décadas.

\footnotetext{
${ }^{21}$ Discutiremos essas questões com um pouco mais de detalhe nas seções Movimentos de Mulheres Negras e Feminismo Negro e Movimentos de Mulheres Lésbicas e Feminismo Lésbico ainda neste capítulo.

${ }^{22}$ Para mais referências de youtubers negras/os/es, ver a lista publicada por @Dende_e_pimenta (à época, @ gritodairene): https://twitter.com/gritodairene/status/1204776130391220225.

${ }^{23}$ Esse crescimento vem sendo articulado também pela plataforma, que tem programas de treinamento e apoio institucional em campanhas como \#YouTubeBlackBrasil, Mulheres na Comédia, \#FalaMiga, \#VisibilidadeLésbica, e, mais especificamente, por meio da iniciativa Creators For Change, da qual são embaixadores no Brasil os canais Nátaly Neri e Muro Pequeno. Esses programas não são, entretanto, ponto pacífico. Não iremos nos aprofundar neste debate aqui, mas consideramos que as críticas apontadas ao processo de pinkwashing de empresas e plataformas como o próprio YouTube são essenciais para a compreensão mais aprofundada do cenário político. A esse respeito, sugerimos a leitura do texto "Pinkwashing à brasileira": do racismo cordial à LGBTTTfobia cordial, de Berenice Bento (2015), do artigo Homonacionalismo como mosaico: viagens virais, sexualidades afetivas, de Jasbir K. Puar (2015) e dos vídeos Homonacionalismo e pinkwashing: o mal liberal (Exemplo EUA e Israel), do canal Doutora Drag - Dimitra Vulcana (2019), Pink money e a diversidade de mercado feat. Dimitra Vulcana | feat 010, do canal Tese Onze (2019) e Pinkwashing, Harassment, and the YouTube Hate Machine, do canal rantasmo (2019).
} 
A seguir, realizaremos uma brevíssima retomada sobre o histórico dos feminismos no período da redemocratização a partir do recorte do diálogo com o Estado e dos ganhos em termos de construção de sujeitos políticos e jurídicos, para posteriormente discutirmos de forma mais detida os campos de atuação das feministas nos anos 2010 - especialmente o da comunicação.

De modo geral, após duas décadas de Ditadura Militar, temos, no final dos anos 80 e no início dos anos 90, um momento de inflexão para os movimentos sociais brasileiros. Sua relação com o Estado, antes puramente antagonista, passava, pouco a pouco, a ser pautada por certa permeabilidade e diálogo. Desse modo, o aprendizado da linguagem estatal para a pressão democrática e para a elaboração de políticas públicas se tornou paulatinamente mais relevante para ativistas e militantes feministas, dos movimentos de mulheres negras e mulheres lésbicas (Sérgio CARRARA; Adriana VIANNA, 2008) - o campo da saúde, em especial, é paradigmático.

Nos anos 80, ao fim da Década Internacional da Mulher (1975-1985), de grande impacto nas agendas dos Estado e dos movimentos, e em meio aos eventos sobre o centenário da abolição da escravatura no Brasil, era criada uma série de instituições organizadas pela sociedade civil e na estrutura do Estado que pressionavam por políticas públicas para as mulheres brasileiras. São exemplos dessas organização a SOS Mulher, o Conselho Nacional de Direitos da Mulher, os Conselhos Estaduais da Condição Feminina, a primeira Delegacia Especial de Atendimento à Mulher em São Paulo e o Programa de Assistência Integral à Saúde da Mulher (Paism), além de ONGs e organizações relevantes até hoje no cenário brasileiro, como o Geledés - Instituto da Mulher Negra, SOS Corpo, Centro das Mulheres do Cabo, CFEMEA e Criola, em um processo que se estendeu pelos anos 1990 (Sueli CARNEIRO, 2018; CARRARA; VIANA, 2008; Maria Salet Ferreira NOVELLINO, 2006).

Foi também esse o momento dos primeiros encontros feministas nacionais, da criação dos primeiros centros de estudos sobre a mulher e de frentes sobre mulheres nos sindicatos e associações profissionais, de acordo com Jaqueline Pitanguy (2018). Paralelamente, outros grupos e coletivos de mulheres continuavam seus trabalhos, articulando-se como movimento de mulheres ou autoproclamando-se feministas.

Sueli Carneiro (2018) destaca também a primeira desagregação dos dados de mulheres negras e brancas do Censo realizado na história do país, assim como o Tribunal Winnie Mandela, o "julgamento simbólico" da Lei Áurea no ano do Centenário da Abolição (1988). No âmbito dos movimentos negros, criavam-se "estratégias de positivação da história, memória 
e identidade negra no país e então muitos nomes de mulheres foram fortalecidos ou destacados" (Thiane Neves BARROS, 2020).

É nesse período também que as mulheres lésbicas começam a se autonomizar em relação às mulheres heterossexuais do movimento feminista e dos homens gays. É simbólica desse momento a criação do Dia da Visibilidade Lésbica (29 de agosto) durante o Senale - Seminário Nacional de Lésbicas (hoje Senalesbi - Seminário Nacional de Lésbicas e Bissexuais, desde 2014), que discutia as pautas de mulheres lésbicas e bissexuais.

Acerca desse período, Larissa Martins (2019) destaca o papel da imprensa alternativa e sua importância para o processo de redemocratização. Segundo a autora, esses veículos consistiam em espaços de resistência nos quais novas identidades eram construídas. Sobre a atuação da imprensa alternativa e feminista em particular, Elizabeth Cardoso (2004 apud MARTINS, 2019, p. 2) divide essas publicações em duas gerações. Enquanto a primeira era caracterizada pelas "questões de classe e as diferenças sociais no cotidiano da mulher, que em geral eram ligadas a partidos políticos", a segunda era mais voltada para o exame das relações de gênero, com base nas "individualidades das mulheres", pautando questões como sexualidade, planejamento familiar e violência contra a mulher, "desvinculadas de partidos políticos e produzidas por organizações não governamentais, coletivos e associações" (MARTINS, 2019, p. 2).

Já nos anos 2000, as relações entre movimentos sociais e Estado passa por uma nova transformação. Durante os governos petistas, vemos a entrada de alguns quadros dos movimentos sociais na estrutura do governo, com a criação de secretarias com status ministerial, como a SEPPIR (Secretaria de Políticas de Promoção da Igualdade Racial) e a SPM (Secretaria de Políticas para as Mulheres), ambas em 2003, no primeiro mandato do Governo Lula.

Além disso, entre os anos 2000 e 2010, uma série de políticas públicas foi implementada a partir da pressão dos movimentos sociais organizados sobre o poder legislativo, com a consequente conquista de direitos, no contexto da "onda rosa", momento em que diversos partidos progressistas latino-americanos ascenderam à presidência de sesus países, tais como: a obrigatoriedade do ensino de história e cultura afro-brasileira, africana (Lei 10.639/03) e indígena nas escolas (Lei 11.465/08); a Lei de Cotas para o Ensino Superior ${ }^{24}$ (Lei 12.711/2012); a Lei Maria da Penha (Lei 11.340/2006); a PEC das Domésticas (Lei

\footnotetext{
${ }^{24}$ Políticas de cotas já tinham sido implementadas em diversas universidades públicas brasileiras. As pioneiras foram a UERJ, em 2003, e a UnB, em 2004.
} 
Complementar $\mathrm{n}^{\mathrm{o}} 150 / 2015$ ); a Lei do Feminicídio (Lei $\mathrm{n}^{\circ}$ 13.104/15); o reconhecimento da União Estável Homoafetiva (2015) e a criminalização da LGBTfobia ${ }^{25}$ (2019) pelo STF. Em relação ao ingresso de novos atores na política institucional, vemos a eleição de congressistas abertamente LGBTTIAPN+ e a eleição da primeira presidenta brasileira, Dilma Rousseff.

Destacamos, entre essas conquistas, a Lei de Cotas para o Ensino Superior, posto que, segundo Cypriano (2019, p. 102),

Com o amplo processo de ampliação de vagas e democratização do acesso ao ensino superior público, a presença de estudantes negros e oriundos de escola pública cresceu exponencialmente. Um dos reflexos dessa maior participação de negras e negros no ensino superior pode ser observada em temáticas emergentes de pesquisa e de ativismo.

Salientamos essa questão porque vemos o reflexo dela na atuação de Nátaly Neri em seu canal, que se dedica, em grande parte, à discussão e divulgação de textos e conceitos de intelectuais negras do campo das Ciências Sociais.

Por outro lado, embora os anos 2000 e 2010 tenham sido palco para grandes conquistas, ao mesmo tempo, vemos a permanência da violência contra as mulheres, em especial as mulheres negras e/ou LGBTTIAPN+, além de um grande retrocesso em termos de políticas públicas de proteção às mulheres e das populações negras e LGBTTIAPN+ em geral nos últimos quatro anos.

De acordo com o Atlas da Violência de 2019, no período entre 2007 e 2017, 66\% das mulheres vítimas de homicídios no país foram mulheres negras. Em relação à população em geral, o número de pessoas negras vítimas de homicídio no país cresceu $33 \%$ em dez anos, e o estudos apontam também um crescimento da violência contra a população LGBTI+ (termo utilizado no ATLAS DA VIOLÊNCIA, 2019). Simultaneamente, vemos um descréscimo do feminicídio de mulheres brancas. Essa desigualdade nas estatísticas do feminicídio se explica, de acordo com Natália Pereira da Silva (2019),

[...] tendo em vista os fatores sociais que ensejam a desigualdade social, racial e cultural, e sendo a violência que as atinge subproduto de uma sociedade machista e preconceituosa. Assim, não há dúvidas da influência dos fatores sociais acerca da violência contra as mulheres negras no Brasil, tendo em vista que ainda persiste uma cultura enraizada de discriminação e de estereótipos preconceituosos que permeiam e se fazem presentes neste cenário de violência que leva a morte da mulher negra.

\footnotetext{
${ }^{25}$ Essa não é, entretanto, uma mudança entendida como conquista pela totalidade do movimento. Sobre o assunto, ver Firmiano, Rodrigues e Pinheiro (2019).
} 
Esses índices reforçam as denúncias realizadas pelos movimentos negros há décadas no país, que apontam para uma abolição inconclusa e, consequentemente, para uma democracia que não atende a todas e a todos igualmente no país.

De forma análoga, vemos a condição da população LGBTTIAPN+ brasileira. De acordo com levantamento realizado anualmente pelo GGB - Grupo Gay da Bahia ${ }^{26}$, em 2016 foi registrado o maior número de assassinatos de pessoas LGBTTIAPN+ das últimas quatro décadas. De acordo com o Relatório 2016, os índices registrados no Brasil ultrapassam aqueles de países onde a homossexualidade é criminalizada (GGB, 2017). Esses dados apontam para um problema que vem sendo discutido e denunciado há anos pelo movimento e que, nos últimos anos, tem se inserido no debate público (sobretudo em referência aos assassinatos de pessoas trans).

O Grupo de Pesquisa Lesbocídio - As histórias que ninguém conta tem atuado, de forma mais direcionada, na pesquisa e divulgação de dados a respeito dos assassinatos e suicídios de mulheres lésbicas no Brasil. De acordo com o Dossiê sobre lesbocídio no Brasil: de 2014 até 2017 (Milena Cristina Carneiro PERES; Suane Felippe SOARES; Maria Clara DIAS, 2017), foram registrados 180 homicídios de lésbicas entre 2000 e 2017 - só entre 2014 e 2017 teriam ocorrido ao menos 126 casos.

Quando nos debruçamos sobre os anos 2010, vemos um aumento exponencial no alcance dos discursos dos movimentos sociais antiopressão que denunciam essas e outras violências ${ }^{27}$, como os feminismos, os movimentos negros e os movimentos LGBTTIAPN+, que se opera tanto pela conquista de espaço nas mídias hegemônicas (emissoras de rádio, jornais e redes de televisão), quanto pelo trabalho de construção de espaços auto-organizados voltados para a socialização, reflexão, debate, organização, reivindicação, luta e formação política fora e dentro das redes sociais (Heloisa Buarque de HOLLANDA; Cristiane COSTA, 2018; Érica SARMET, 2018). Em ambientes digitais, salientamos a criação de grupos de discussão no Facebook e em outras redes sociais, canais no YouTube, perfis no Instagram e, mais

\footnotetext{
${ }^{26}$ O relatório organizado pelo GGB é desenvolvido a partir da coleta de informações sobre assassinatos, suicídios e violências contra pessoas LGBT (termo utilizado pelo grupo) publicadas na imprensa e na internet (GGB, 2017). Sua metodologia envolve a análise do perfil das vítimas com base em orientação sexual, faixa etária, cor e profissão, entre outras questões. Trata-se de uma iniciativa pioneira e quase solitária no que diz respeito ao levantamento de dados sobre esse tipo de homicídio. 2019 foi o primeiro ano em que o Atlas da Violência incluiu uma seção sobre a população LGBTI+, realizada a partir de denúncias feitas no Disque 100 e do Sinan. Entretanto, para a aferição dos dados publicados e para a elaboração de políticas públicas mais eficazes para o combate dessas violências, fazem-se necessários estudos mais aprofundados sobre a população LGBTTIAPN+ em geral.

${ }^{27}$ Por outro lado, os índices de violência física continuam crescendo e soma-se a isso os ataques às ativistas que agora ocorre também online, por meio de ataques coordenados a perfis e páginas em redes sociais, contando também com a ação de bots e trolls para massificar as mensagens.
} 
recentemente, no TikTok, além de blogs e portais de notícias (alguns existentes desde o final dos anos 1990).

No entanto, apesar de haver alguns diferenciais importantes entre os modos de organização previamente existentes, como os números de audiência e a velocidade de disseminação de ideias, Castells (2013) enfatiza a importância atemporal da comunicação e do estabelecimento de relações interpessoais para os movimentos sociais. Assim, aquilo que ele chama de "redes de comunicação interativas" (CASTELLS, 2013, p. 134) ocupa, em nosso tempo, também as redes sociais e as diversas plataformas de comunicação digital. Vemos, dessa forma, um certa continuidade no que se refere à relevância das práticas do campo da comunicação enquanto ferramenta dos movimentos sociais.

Angela Alonso (2009, p. 51) indica algumas particularidades dos movimentos sociais dos anos 1960 que podem nos ajudar a compreender as transformações pelas quais essas mobilizações têm passado. Sobre os movimentos de contracultura ${ }^{28}$, ela afirma que
A ruptura está no próprio nome que o fenômeno ganhou. Tratava-se seguramente de "movimentos", no sentido de ações coordenadas de mesmo sentido acontecendo fora das instituições políticas, mas não eram, de modo algum, protagonizadas por mobs, tampouco por "proletários". Eram jovens, mulheres, estudantes, profissionais liberais, sobretudo de classe média, empunhando bandeiras em princípio também novas: não mais voltadas para as condições de vida, ou para a redistribuição de recursos, mas para a qualidade de vida, e para afirmação da diversidade de estilos de vivê-la. Essas demandas "pós-materiais", como as chamou Inglehart (1971), se completavam com a opção por formas diretas de ação política e pela demanda por mudanças paulatinas na sociabilidade e na cultura, a serem logradas pela persuasão, isto é, léguas longe da ideia de tomada do poder de Estado por revolução armada. Então eram, sim, movimentos, mas movimentos sociais.

A partir das discussões no âmbito das teorias dos movimentos sociais estadunidenses e europeias, a autora destaca que "uma convergência mínima entre os enfoques "objetivista" e "subjetivista" se estabeleceu em torno da tese de que movimentos sociais não surgem pela simples presença de desigualdade, nem resultam diretamente de cálculos de interesses ou de valores" (ALONSO, 2009, p. 72). Em outras palavras, há uma série de fatores a serem considerados nas análises dessas mobilizações, a saber: “a ação estratégica, crucial para o controle sobre bens e recursos que sustentam a ação coletiva, [...] a formação de solidariedades e identidades coletivas" (ALONSO, 2009, p. 72). De todo modo, esses se articulavam com um horizonte de atuação restrita, de âmbito nacional.

\footnotetext{
${ }^{28}$ A autora, realizando uma resenha crítica de perspectivas estadunidenses e europeias, refere-se a movimentos de contracultura nesses territórios, e no trecho citado não necessariamente discute aspectos dos movimentos que ocorriam no Brasil no mesmo período.
} 
Os ativismos contemporâneos, por sua vez, marcados por articulações internacionais e pelo uso das Tecnoloigas da Informação e Comunicação (TICs), apresentam novos desafios para a sua compreensão. De acordo com Alonso (2009, p. 74)

A virada para o século XXI trouxe problemas novos. Houve uma mudança de escala do ativismo, de nacional a global. Os protestos contemporâneos envolvem ativistas e temas que atravessam fronteiras e se dirigem, muitas vezes, a instituições multilaterais ou a uma opinião pública transnacional. $\mathrm{O}$ Estado nacional deixa, assim, de ser o antagonista prioritário, desafiando todas as teorias dos movimentos sociais, que definiam o fenômeno em escala nacional. Além disso, o ativismo se profissionalizou. Em vários países do Ocidente, movimentos sociais se burocratizaram, se converteram em partido, se empresariaram ou assumiram a prestação de serviços estatais (Rootes, 2003). Assim se esmaeceu a auréola de inovação política que traziam desde os anos 1970. A associação entre novos movimentos e pautas "pós-materiais" também se esgarçou com a leva de mobilizações étnicas, religiosas, comunitárias e conservadoras. Nelas, a cultura, sobretudo a questão da identidade, ganhou saliência, mas amalgamada a outras pautas, dando aos movimentos uma feição multi-issue (Tarrow, 2005).

Hollanda, Costa e suas colaboradoras de pesquisa (2018) salientam a relevância das redes sociais para a potencialização das táticas e da militância feminista de modo geral nas ruas e na esfera pública na última década. As autoras atribuem aos espaços de sociabilidade online como Facebook, Twitter e blogs a responsabilidade por impactar a esfera pública e produzir alianças locais, regionais, nacionais e mesmo internacionais. Elas definem o impacto dos movimentos nas redes tanto como "mecanismo de pressão diante de instituições estabelecidas" (HOLLANDA; COSTA, 2018, p. 43), quanto como um movimento cultural que permite a um ator social "tornar-se sujeito ao definir sua ação segundo seus próprios valores e interesses, independentemente das instituições" (HOLLANDA; COSTA, 2018, p. 44). Essa segunda visão está diretamente ligada ao entendimento desses movimentos como parte da cultura da autonomia e é considerada em parte como consequência da descentralização das redes, cujo modo de funcionamento altera padrões organizacionais, permitindo a criação de novas estratégias comunicativas para a mobilização política (HOLLANDA; COSTA, 2018, p. 44).

Desse processo decorre também a possibilidade de entender a igualdade por meio da diferença (HOLLANDA; COSTA, 2018, p. 47). Trata-se, de acordo com as autoras, de um modelo de comunicação pautado pela articulação de vozes individuais enunciadas a partir de variadas posições identitárias, o que possibilitaria um comprometimento político com a criação de laços que visam à produção de uma “expressiva percepção comum” (HOLLANDA; COSTA, 2018, p. 47). Quando nos voltamos para a análise de espaços de sociabilidade online, vemos algo bastante semelhante. Os grupos no Facebook, as campanhas feministas e as seções de comentários e de mensagens privadas em várias redes sociais parecem ter se tornado espaços 
possíveis para grupos de reflexão online. Além disso, parecem ter o potencial para agregar diversos tipos de ações, tais como o acolhimento, a pressão democrática, a denúncia de violências, a organização de manifestações etc. Martinez (2019, p. 11) associa esses modos de funcionamento aos grupos de consciência, símbolos dos feminismos dos anos 1970 e 1980, constituindo-se como "espaço facilitador de trocas, onde as mulheres (mesmo as que não reivindicam para si uma identidade feminista) identificam, compartilham e nomeiam experiências comuns". Esses espaços contribuem, portanto, para a elaboração de estratégias de atuação feministas em diversos âmbitos.

Quando olhamos para as mobilizações feministas em específico, Gilberta Santos Soares e Jussara Carneiro Costa (2011/2012, p. 10) indicam as seguintes particularidades ao discutirem as aproximações do movimento com os ativismos de mulheres lésbicas:

\begin{abstract}
A junção entre prática política e produção de conhecimento, ações internas com grupos de mulheres e externas, escuta das subjetividades das mulheres nos espaços formativos e demandas objetivas por marcos legais e políticas públicas habilitaram ao movimento explicitar as discriminações vivenciadas pelas mulheres no ambiente doméstico e, no mundo público, nos mais diversos contextos e áreas sociais.
\end{abstract}

Veremos que essas práticas políticas de articulação entre o pessoal e o político, entre as dimensões subjetiva e social, transformam-se consideravelmente com o advento da internet e, em especial, das redes sociais. Hollanda, Costa e suas colaboradoras indicam uma abertura de possibilidades para experimentações entre o pessoal e o público, possivelmente oriunda do caráter algo descentralizador das interações online (HOLLANDA; COSTA, 2018, p. 46).

Assim, os relatos pessoais, tornados públicos por meio do compartilhamento nas redes sociais - de forma anônima ou não - são utilizados estrategicamente devido ao potencial tanto afetivo quanto epistêmico. Em outras palavras, a forma como narrativas pessoais são organizadas e apresentadas em campanhas, blogagens, vídeos e ilustrações, entre outras práticas discursivas salienta as relações entre as estruturas das opressões de gênero, raça, classe e sexualidade e as experiências individuais cotidianas. Dessa forma, se mostram essenciais para as estratégias de conscientização sobre a dimensão política da vida pessoal, atualizando um dos principais motes feministas (o pessoal é político) das últimas décadas.

Discutindo as interações entre o movimento feminista e o movimento estudantil chileno na internet, Valentina Errázuriz (2019, p. 2) descreve a atuação das feministas em grupos comunitários no Facebook da seguinte forma

Grupos comunitários feministas no Facebook são espaços nos quais as estudantes assumem posições de poder para controlar discursos sobre elas mesmas, suas questões e as condições que permitem às estudantes ter uma voz 
política. Por meio desses grupos, essas jovens se organizam politicamente e produzem suas subjetividades de gênero e políticas de forma coletiva como protagonistas das narrativas de um movimento social de estudantes feministas. Esses grupos também permitem que seus visitantes coconstruam esses processos. $^{29}$

Nesse sentido, entendemos que a criação de conteúdo audiovisual que dialoga tanto com experiências pessoais quanto com teorias sociais elaboradas com vistas à reflexividade e ao empoderamento individual e coletivo (Joice BERTH, 2019) constitua um dos modos pelos quais os movimentos sociais se articulam hoje.

Como plataforma, o YouTube se mostra interessante para esses grupos sociais porque permite que a informação, em um de seus meios mais acessíveis, a modalidade oral da língua ${ }^{30}$, seja gravada e disponibilizada para uma audiência de milhões. Além disso, há vários anos, o YouTube conta com a possibilidade de incorporar seus vídeos em outras redes sociais de grande popularidade, como o Facebook, o Twitter e o Tumblr ${ }^{31}$, além de blogs e sites, o que potencializa o alcance dos vídeos. Isso aponta, inclusive, para a possibilidade de romper, em certa medida, com as câmaras de eco da plataforma, uma vez que outras redes sociais são pautadas não apenas pelo conteúdo das publicações, mas também por ligações estabelecidas entre usuárias em espaços offline - relações familiares, de amizade, de trabalho, regionais e de interesses comuns, por exemplo.

As transformações nas interações entre atoras/es sociais propiciadas pelas redes sociais causaram grande impacto em diversas esferas da vida social, e, dentre elas, incluem-se os ativismos e movimentos sociais. Assim, concordamos com Castells (2013) no que se refere ao impacto da participação política no meio digital sobre as dinâmicas dos movimentos sociais e que isso se deva (em parte) ao caráter interativo das plataformas e ao grande alcance das redes sociais, que permitem a expansão dos espaços de sociabilidade previamente existentes e novas

\footnotetext{
${ }^{29}$ No original, "Feminist communitarian Facebook websites are spaces where students hold powerful positions to control discourses about themselves, their issues, and the conditions which allow students to have a political voice. Through these websites, these youth politically organize and produce their collective gender/political subjectivities as the protagonists of feminist student social movement narratives. The websites also allow their visitors to coconstruct these processes" (ERRÁZURIZ, 2019, p. 2)

${ }^{30}$ Destacamos que, embora a modalidade oral seja bastante acessível para a parcela ouvinte da população brasileira, o conteúdo do YouTube não é, em sua maioria, adequadamente produzido para garantir o acesso a pessoas cegas (sem ferramentas de audiodescrição) e surdas (sem tradução em Libras ou legendagem), por exemplo.

31 Mais recentemente, tornou-se possível assistir a vídeos do YouTube também por meio do WhatsApp, o aplicativo de mensagens instantâneas mais utilizado no Brasil. Isso se relaciona ao processo que Silva (2020, p. 122) define como a "plataformização da web", isto é, "gradualmente, ambientes digitais como Facebook estenderam-se para toda a web em uma espécie de integração que priorizou a concentração de dados e valor inclusive financeiro - em poucas empresas. A plataformização transformou sites de redes sociais em plataformas de mídias sociais, nos termos de Helmond, que adiciona que, como "modelo de infraestrutura, plataformas de mídias sociais fornecem um framework tecnológico para que outros construam sobre [...] direcionado a sua expansão sobre o resto da web" (Helmond, 2015, p. 3).”
} 
formas de acesso a eles. A esse respeito, salientamos o caráter eminentemente didático de grande parte dos canais, páginas, perfis e grupos militantes que atuam nas redes. Esses conteúdos costumam ter um tom mais informal do que o usual em debates acadêmicos, muitas vezes simulando diálogos com as/os seguidoras/es ou assemelhando-se a vídeos de divulgação científica, outra categoria de vídeos de grande relevância no YouTube.

Acreditamos que essas características textual-interativas se devam ao projeto político no qual as youtubers se encontram envolvidas. Lília Dias Mariano (2018, p. 416), ao discutir as mobilizações de mulheres protestantes, descreve os feminismos latino-americanos como originais e pioneiros, "nutrido[s] pela luta autóctone das mulheres do continente" e envolvidos em militâncias libertárias e de esquerda, fortemente inspirados pelo trabalho de Paulo Freire. Logo, entendemos que os canais ativistas e militantes, muito embora nem sempre estejam abertamente vinculados a ou mesmo representem um coletivo, uma organização nem um partido político, são descendentes de outras gerações políticas, de suas estratégias e objetivos políticos $^{32}$.

Ademais, é importante ressaltar que existia - e ainda existe - um ceticismo bastante grande em relação à atuação de ativistas e militantes de movimentos sociais nas redes sociais para além da organização de manifestações de rua, o que é comumente descrito de forma pejorativa como "ativismo de sofá" 33 . Nessa perspectiva, o ativismo digital e considerado como incapaz de intervir de forma contundente na vida social. Entretanto, após as eleições presidenciais de 2018, na qual a atuação da campanha do candidato de extrema-direita, Jair Bolsonaro, se deu primariamente por meio de redes sociais, a percepção do campo progressista de esquerda parece estar sendo transformada.

Inclusive, durante o ano de 2018, diversos canais progressistas (dentre os quais os das youtubers estudadas nesta pesquisa) se colocaram contra essa candidatura, publicando vídeos como parte da campanha \#EleNão e, após o resultado final, continuaram se articulando, discutindo estratégias de oposição, questões de saúde mental e de sobrevivência. Essa postura,

\footnotetext{
${ }^{32}$ Embora não exploremos essa hipótese em detalhe na presente dissertação, acreditamos que o trabalho de atoras/es sociais pertencentes a grupos historicamente marginalizados articulados a projetos de mudança social em espaços de sociabilidade online, como o YouTube, apresente uma série de semelhanças em relação aos trabalhos de veículos de comunicação engajados da imprensa alternativa no período de redemocratização do país, voltados para a conscientização e divulgação de estudos e dados sobre a condição das mulheres brasileiras em suas especificidades.

33 Sobre essa polêmica, sugerimos a leitura de dois artigos: "O "ativismo de sofá" pode ser eficaz?", de Gabriela Rousani Pinto (disponível em: <https://cepedi.org/2016/10/01/o-ativismo-de-sofa-pode-ser-eficaz/>) e "Feminsitas comentam importância da ação \#PrecisamosFalarSobreAborto24h", de Thaís Campolina (disponível em: https://revistaforum.com.br/blogs/ativismodesofa/precisamosfalarsobreaborto/). O primeiro fala sobre os limites e potenciais do ativismo online, e o segundo discute as suas relações com formas de agir pré-existentes.
} 
no entanto, não é novidade. Em 2016 e 2017, diversos youtubers ativistas se posicionaram contra a Intervenção Militar no Rio de Janeiro, por exemplo ${ }^{34}$. Além disso, canais voltados especificamente para formação política, ligados a movimentos sociais e a partidos políticos de esquerda estão sendo criados e vêm ganhando espaço (citamos, a título de exemplo, os canais Doutora Drag - Dimitra Vulcana, Tese Onze, Chavoso da USP, Debora Baldin, Jones Manoel e Tempero Drag). Ao que parece, o momento presente exige uma reflexão sobre as maneiras pelas quais a atuação nesses lugares pode ser instrumentalizada para a construção de movimentos massificados, que de fato se traduzam em ações coordenadas.

Argumentamos aqui que a produção e distribuição de conteúdo audiovisual engajado no YouTube seja parte desse processo, sobretudo quando esse conteúdo é realizado por e para grupos sociais historicamente marginalizados articulados a projetos de mudança social. Considerando a relevância dessa plataforma no Brasil hoje, tanto em termos de entretenimento, quanto de divulgação científica e de difusão de notícias ${ }^{35}$, a ocupação desses espaços com conteúdos contra-hegemônicos cuja produção seja pautada por esforços de mudança social se mostra estratégica. Em termos textuais, isso envolve, por exemplo, questões de protagonismo tanto da instância de produção textual, quanto do público-alvo: trata-se de endereçar os vídeos a grupos historicamente invisibilizados, excluídos ou estereotipados nos discursos hegemônicos. No entanto, o caráter contra-hegemônico dos discursos deve envolver não apenas a representatividade, que já é relevante, mas sobretudo o enfrentamento, o questionamento e a transformação de modos de agir nessas esferas.

Assumir a posição de produtoras textuais em espaços de sociabilidade online cuja hegemonia é dos grupos dominantes possibilita mudanças não apenas no conteúdo do que circula nas redes, mas também tem impactos nas formas de distribuição, consumo (quais perfis serão retuitados, que perfis os compartilharão, em que grupos do Facebook e do WhatsApp serão postados) e interpretação (identificação e grau de resistência a uma alegação ou proposta de ação, por exemplo), possivelmente alterando padrões de engajamento das/os usuárias/os.

\footnotetext{
${ }^{34}$ Destacamos os vídeos “POR QUE ESTAMOS PREOCUPADOS?”, publicado no canal JoutJout Prazer em 22 de fevereiro de 2018, e "Como sobreviver a uma abordagem indevida? Spartakus feat. AD Junior e Edu Carvalho", publicado no canal spartakus em 17 de fevereiro de 2018. O segundo vídeo é descrito como "Dicas para que a população negra das comunidades do Rio de Janeiro sobreviva a possíveis abordagens indevidas durante a intervenção que acontecerá até o fim de 2018”. Os vídeos estão disponíveis em: 〈https://www.youtube.com/watch?v=tk5IitUj2Bk> e 〈https://www.youtube.com/watch?v=eBdSBmTFR5g $>$ respectivamente.

${ }^{35}$ De acordo com Melo e Abibe (2019), do Think With Google, a plataforma é o principal destino dos brasileiros que buscam vídeos na Internet.
} 
As alterações no padrão de consumo envolvem o engajamento com o canal ou com certos comunicadores, mas esse processo pode também se estender para além do YouTube e mudar os padrões de consumo de textos de mais pessoas - em outras palavras, quem assiste a vídeos no YouTube pode divulgar o ideário do canal para seus amigos, colegas e familiares, que, por sua vez, podem buscar se informar mais sobre esses tópicos em práticas discursivas e sociais diversas. Dessa forma, a alteração no padrão de consumo se relaciona com a busca por novos conhecimentos e valores, mudanças nas atitudes pessoais etc.

No Brasil, hoje, muitos dos que denominamos canais ativistas estão articulados com coletivos on e offline, redes de ativistas (que, muitas vezes, participam dos vídeos como convidados), grupos de discussão em outras redes sociais, como o Facebook, e outras plataformas de publicação como blogs, Medium etc. Nesses espaços, discutem-se os projetos políticos dos movimentos, deliberam-se propostas de ação, organizam-se manifestações, e seus participantes não raro criam redes de apoio e acolhimento dentro e fora das redes.

Entretanto, há que se salientar que as redes sociais não são espaços à parte das estruturas sociais. Pelo contrário, elas se constituem como lócus de tensões sociais assim como os ambientes de sociabilidade offline. Um exemplo da continuidade das relações de poder em termos de raça e classe nas mobilizações realizadas via redes sociais é apresentado por Hollanda e Costa (2018, p. 52) ao discutirem as campanhas feministas na Internet. Mais especificamente, a disparidade entre a propulsão e a visibilidade da hashtag criada por Preta Rara, \#EuEmpregadaDoméstica, e outras campanhas, encampadas por feministas brancas e/ou de classe média.

No que se refere aos ativismos de mulheres negras em específico, de acordo com Zelinda Barros (s/d, p. 4), a internet constitui uma arena complementar. Para a autora, o ativismo digital é multidirecional e permite ampliar o alcance de iniciativas (sejam elas novas, próprias do meio digital, ou pré-existentes). Ao definir o ativismo feminista digital em contraste com o cyberfeminismo, a autora (BARROS, s/d, p. 7 -8) caracteriza aquele da seguinte forma:

Denis de Moraes (2001) define o ativismo digital como um fenômeno que se caracteriza pela utilização da Internet por organizações não-governamentais e demais entidades civis com o propósito de “...divulgar suas reivindicações e desenvolver espaços de interação e de mobilização pelos direitos da cidadania." Nesta definição, a tecnologia torna-se aliada na busca por novas formas de convívio social e na luta pela garantia e preservação de direitos realizada por grupos de distintas tendências e orientações político-ideológicas. Aqui, aparece a principal diferença do cyberfeminismo em relação ao ativismo digital: enquanto o primeiro não defende bandeiras ou se orienta por ideologias (apesar da insinuação no nome), o ativismo digital marca sua posição no cyberespaço através de sua filiação ideológica, que pode não ser 
necessariamente de caráter partidário, mas refere-se à defesa de uma causa em torno da qual pessoas e instituições são intencionalmente mobilizadas.

Além disso, ela chama a atenção para as tensões ideológicas e socioeconômicas que subjazem a esse processo de atuação/apropriação das tecnologias e das plataformas e que, em maior ou menor medida, coloca obstáculos para a atuação de certos grupos e, ao mesmo tempo, privilegia outros:

A apropriação das tecnologias digitais, segundo Samuel Wilson e Leighton Peterson (2002), não deve ser orientada pela visão demasiadamente otimista de que a Internet informaria e empoderaria mundialmente os indivíduos ("utopia online") enquanto subverteriam estruturas de poder, porque tende a subestimar o poder do Estado de controlar o acesso à informação. Os autores citam os exemplos dos zapatistas e dos sobreviventes de Belgrado, que utilizam a Internet como forma de articulação internacional, mas enfatizam que em alguns Estados há esforços intensivos no sentido de regular e controlar o acesso às informações. Questões de gênero, raça e classe ainda impedem a igualdade de acesso.

Fica evidente, portanto, que o ativismo digital precisa ser considerado em sua dimensão econômica também, posto que, como o domínio e a posse dessas tecnologias não é democratizada no país, o acesso e a atuação online envolvem uma série de questões, como renda e letramento digital (BARROS, s/d).

De forma análoga, os processos políticos são igualmente relevantes para a compreensão o cenário da produção, distribuição e consumo desses textos. Pensando no que discutimos no início desta seção a respeito da inserção de quadros dos movimentos feministas, negros e LGBTTIAPN+ na estrutura do Estado, vemos recentemente uma série de mudanças que sinalizam um fechamento dos canais de diálogo construídos nas últimas décadas.

No momento em que os vídeos analisados nesta pesquisa foram publicados, o clima político no Brasil se mostrava desfavorável para as pautas feministas. Após o golpe jurídicoparlamentar que derrubou a presidenta Dilma Rousseff em 2016, as reformas ministeriais efetivadas pelo então presidente em exercício, Michel Temer (PMDB), fizeram retroceder uma série de conquistas dos movimentos de mulheres no âmbito institucional. Destacamos a transformação da Secretaria de Políticas para Mulheres (SPM) e o Conselho Nacional dos Direitos da Mulher em pasta do Ministério dos Direitos Humanos (como era chamado à época), desassociando-os da estrutura administrativa da Secretaria de Governo da Presidência da República ${ }^{36}$.

${ }^{36}$ Noticiado em: <https://www.gov.br/mdh/pt-br/assuntos/noticias/2018/junho/decreto-transfere-secretaria-depolitica-para-mulheres-para-o-ministerio-dos-direitos-humanos $>$. Acesso em 06/02/2021. 
Nesse mesmo ano, ocorriam no Brasil protestos contra a Reforma Trabalhista e contra a Reforma da Previdência, ambas de cunho neoliberal, que acarretaram significativas perdas para as/os trabalhadoras/es. No plano internacional, o movimento \#MeToo, criado em 2006 por Tarana Burke, ganhou os holofotes da imprensa mundial a partir de um tuíte da atriz Alyssa Milano e das acusações contra Harvey Weinstein. Com o intuito de denunciar casos de assédio e violência sexual, assim como oferecer apoio às sobreviventes, o movimento se alastrou para várias partes do mundo. Além disso, incentivou outras denúncias contra grandes figuras públicas, como foi o caso do médium João de Deus, acusado em 2018 por dezenas de mulheres, brasileiras e estrangeiras, que visitaram Casa de Dom Inácio de Loyola (Abadiânia - GO). Em ambos os casos, destacamos a função que as redes sociais tiveram nas estratégias de comunicação desses movimentos e articulações, utilizadas como forma de coordenar denúncias e discussões na esfera pública.

Desenvolveremos, a seguir, algumas estratégias de enfrentamento que têm sido utilizadas no campo dos movimentos de mulheres e dos ativismos feministas negros e lésbicos nos últimos anos para contextualizarmos a atuação das youtubers no cenário descrito acima.

A seguir, discutiremos com maior detalhe algumas questões sobre os Movimentos de Mulheres Negras e o Feminismo Negro em termos de sua atuação na imprensa alternativa e na internet, bem algumas das críticas colocadas por essas perspectivas para o feminismo branco e heterossexual. Ao final da seção, apresentaremos brevemente o canal Nátaly Neri. Faremos o mesmo na seção Movimentos de Mulheres Lésbicas e Feminismo Lésbico, ao final da qual apresentaremos o canal LouiePonto.

\subsubsection{Assumindo o risco de "falar com todas as implicações": Movimentos de Mulheres Negras e Feminismo Negro}

Podemos aprender a agir e falar quando temos medo da mesma maneira como aprendemos a agir e falar quando estamos cansadas. Fomos socializadas a respeitar mais o medo do que nossas necessidades de linguagem e significação, e enquanto esperarmos em silêncio pelo luxo supremo do destemor, o peso desse silêncio nos sufocará. (Audre LORDE, 2019a, p. 55)

Como coloca Érica Malunguinho (2018), primeira deputa estadual trans e negra, ao se discutir Brasil, raça não deve ser recorte, mais sim fundamento. Tal afirmação nos instiga a refletir sobre as origens coloniais das noções de sexo/gênero e seus ecos sobre as proposições e críticas realizadas pelas feministas, ativistas e militantes de movimentos de mulheres no 
último século. É nesse sentido, entre tantos outros, que se dá a contribuição do Feminismo Negro e dos movimentos de mulheres negras para as lutas de emancipação das mulheres.

Feministas negras chamam a atenção para o fato de que não é apenas o gênero que define a posição social das mulheres, mas que esta será sempre condicionada por uma série de fatores, dentre os quais se destacam também a raça, a classe e a sexualidade (Luiza BAIRROS, 2020 [1995]; COLLINS, 2019; GONZALEZ, 1980, 1984, 2019; LORDE, 2019).

Para bell hooks (1989 apud BAIRROS, 2020), o que une as feministas não deve ser a identidade da condição feminina universal, nem o compartilhamento de uma forma de opressão à qual todas as mulheres estão sujeitas. $\mathrm{O}$ fator que deve ser considerado relevante é antes a luta comum contra as "relações baseadas em diferenças de gênero socialmente construídas" (BAIRROS, 2020, p. 212), que afetam as mulheres de formas distintas a depender de sua posição social. Dessa forma, a solidariedade - sororidade, ou ainda dororidade, como sugere Vilma Piedade (2017) - feminista não deve se basear no compartilhamento de uma identidade, mas sim em um entendimento comum sobre a vida social que dê conta das semelhanças e das diferenças entre suas experiências pessoais e de grupo para a constituição teórica e para a prática política.

Quando Piedade (2017) expõe o conceito de Dororidade, ela enfatiza a importância desses princípios para um feminismo que se pretenda antirracista. Trata-se do reconhecimento da atuação de mulheres negras nos diversos campos de luta na sociedade brasileira e a incorporação de seus valores civilizatórios nas orientações, práticas e ações de um feminismo que se pretende interseccional. Como exemplos de outras possibilidades de relações de gênero, ela cita o Culto das Gelede e a lenda-itan na qual Oiá-Iansã se apropria dos "poderes ditos masculinos" (PIEDADE, 2017, p. 33) para propor que, da mesma forma, o Feminismo Preto se aproprie do que é posto pelo feminismo eurocêntrico que possa informar e fortalecer a sua luta.

É esta postura que nos permitirá estabelecer interlocução entre as análises das diversas matrizes de dominação, para utilizar o termo de Patricia Hill Collins (2019), que estruturam a nossa sociedade. Daí a proposta de um Feminismo Dialógico Interseccional (PIEDADE, 2017), baseado no Diálogo e na Escuta, na palavra e no acolhimento. Trata-se de reconhecer e dialogar com as presenças e ausências de mulheres, sobretudo negras, nos espaços de poder institucional, apostando nas possibilidades de transformação por meio da disposição para a escuta, o diálogo, o acolhimento e a inclusão.

"Pegou pra uma... pegou pra geral" (PIEDADE, 2017, p. 45). Isso significa, entre outras coisas, encarar os fatores raciais que separam mulheres brancas e negras nas estatísticas de 
feminicídio, combater as violências do Racismo Religioso e do genocídio da juventude negra e lutar pelos direitos das empregadas domésticas como questões e práticas feministas como um todo - e não como questões que são de responsabilidade apenas de mulheres negras.

Quando eu argumentei que Dororidade carrega, no seu significado, a Dor provocada em todas as Mulheres pelo Machismo, destaquei que quando se trata de Nós, Mulheres Pretas, tem um agravo nessa Dor, agravo provocado pelo Racismo. Racismo que vem da criação Branca para manutenção de Poder... E o Machismo é Racista. Aí entra a Raça. E entra Gênero. Entra Classe. Sai a Sororidade e entra Dororidade. (PIEDADE, 2017, p. 46-47)

Como coloca Piedade (2017, p. 47), "No nosso caso, a história é diferente. O buraco é mais embaixo. Ou, parafraseando Lélia Gonzalez... Cumé qui é?. Porque é o Racismo que nos dilacera. É assim que entendo o Racismo. Dororidade.”. Os desafios que se colocam para mulheres negras precisam ser abordados, portanto, por meio de um prisma que considere as articulações do sexismo e do racismo. Trata-se de uma perspectiva interseccional que analisa a sociedade enquanto mosaico e recusa-se a priorizar um tipo de luta, entendendo que as estruturas de opressão se articulam mutuamente. A esse respeito, Ribeiro (2017, p. 73) afirma o seguinte

não posso dizer que luto contra o racismo e amanhã, às 14h5, se der tempo, luto contra o machismo, pois essas opressões agem de forma combinada. Sendo eu mulher e negra, essas opressões me colocam em um lugar maior de vulnerabilidade. Portanto, é preciso combatê-las de forma indissociável.

Se as colocações das autoras apresentam suas perspectivas para a construção de uma sujeita política do Feminismo Negro, nossa interpretação é a de que, em contrapartida, elas também sugerem um novo espaço/modo de ação para a participação de mulheres brancas. Assim, mulheres brancas que nos engajamos com um feminismo antirracista não devemos entender nossas ações como "abrir espaço" ou "dar voz" para mulheres negras, mas antes devemos nos envolver numa escuta ativa e desenvolver uma fala que realize a integração de epistemologias negras/pretas para a análise política e social da luta feminista pela emancipação das mulheres.

Nesta seção, abordaremos brevemente duas perspectivas a respeito dos mecanismos de silenciamento que agem sobre mulheres negras: a metáfora da máscara, abordada por Grada Kilomba (2019), e a noção de epistemicídio, discutida por Sueli Carneiro (2005). Essas questões serão posteriormente relacionadas aos ativismos de mulheres negras no campo da comunicação.

Grada Kilomba (2019) aponta que a naturalização da assimetria de posições entre pessoas negras e brancas na sociedade é gerada e sustentada pelo racismo como lógica da organização social, gerando consequências psíquicas tanto para pessoas negras quanto para 
pessoas brancas ${ }^{37}$. Retomando a imagem da máscara, instrumento utilizado como ferramenta de tortura e de silenciamento de pessoas negras no período das escravaturas, a autora define essa assimetria como a pressuposição da existência de dois lugares, ambos racializados: aquele de quem é forçado a calar-se e aquele que faz calar. Para a autora (KILOMBA, 2019, p. 41),

\begin{abstract}
A máscara, portanto, levanta muitas questões: por que deve a boca do sujeito negro ser amarrada? Por que ela ou ele tem de ficar calada/o? O que poderia o sujeito negro dizer se ela ou ele não tivesse sua boca tapada? E o que o sujeito branco teria de ouvir? Existe um medo apreensivo de que, se o sujeito colonial falar, a/o colonizadora/r terá de ouvir. Seria forçada/o a entrar em uma confrontação desconfortável com as verdades da/o "Outra/o". Verdades que têm sido negadas, reprimidas, mantidas e guardadas como segredos. [...] Segredos como a escravização. Segredos como o colonialismo. Segredos como o racismo.
\end{abstract}

A máscara pode ser compreendida, então, não apenas como um mecanismo de silenciamento, como um mecanismo essencial para a produção das "verdades" coloniais, na medida em que as representações de mundo racistas só se mantêm hegemônicas na medida em que se age em prol da repressão das verdades do "Outro" em favor das verdades do "Eu". Nesse processo, constrói-se, simultaneamente, uma representação negativa de pessoas negras como alteridade, em contraste com o Eu hegemônico, e uma imagem positiva deste Eu. Dessa forma,

O medo branco de ouvir o que poderia ser revelado pelo sujeito negro pode ser articulado com a noção de repressão de Sigmund Freud, uma vez que a "essência da repressão", segundo o mesmo: "Encontra-se simplesmente em afastar-se de algo e mantê-lo à distância do consciente" (Freud, 1923, p. 17). Esse é o processo pelo qual ideias - e verdades - desagradáveis se tornam inconscientes, vão para fora da consciência devido à extrema ansiedade, culpa ou vergonha que causam. Contudo, enquanto enterradas no inconsciente como segredos, permanecem latentes e capazes de ser reveladas a qualquer momento. A máscara vedando a boca do sujeito negro impede-a/o de revelar tais verdades, das quais o senhor branco quer "se desviar", "manter à distância" nas margens, invisíveis e "quietas". Por assim dizer, esse método protege o sujeito branco de reconhecer o conhecimento da/o "Outra/o". (KILOMBA, 2019 , p. 41-42, grifos do original)

Vemos, ademais, que, sendo uma dinâmica estruturante da sociedade brasileira, o racismo tem efeitos importantes sobre o acesso de atoras/es sociais racializadas/os a posições de poder dentro das práticas e estruturas sociais. Consequentemente, a legitimação dessa posição muitas vezes se torna uma questão a ser defendida. Isso se relaciona com as considerações de Carneiro (2005) a respeito do epistemicídio, posto que

não é possível desqualificar as formas de conhecimento dos povos dominados sem desqualificá-los também, individual e coletivamente, como sujeitos cognoscentes. E, ao fazê-lo, destitui-lhe a razão, a condição para alcançar o conhecimento "legítimo"

\footnotetext{
${ }^{37}$ Esses tensionamentos nos remetem ainda à noção de branquitude e das discussões sobre a racialização de pessoas brancas. Embora não tenhamos nos debruçado sobre essa questão na dissertação, consideramos que ela aponte para questões cruciais a respeito das relações étnico-raciais na sociedade brasileira. Sugerimos, a esse respeito, a leitura dos trabalhos de Maria Aparecida da Silva Bento (2002), Lia Vainer Schucman (2012, 2014), Lourenço Cardoso (2010, 2014) e Julia Kumpera (2019).
} 
ou legitimado. Por isso o epistemicídio fere de morte a racionalidade do subjugado ou a seqüestra, mutila a capacidade de aprender etc. (CARNEIRO, 2005, p. 97)

Esse não-lugar ao qual são confinadas as pessoas negras pelo discurso hegemônico da branquitude gera consequências para todas as pessoas envolvidas em uma sociedade estruturalmente racista.

Quintão (1999 apud CARNEIRO, 2019a) define a "exclusão simbólica" e a "distorção da imagem da mulher negra" como violências a serem tratadas como violação aos direitos humanos, tendo em vista os danos simbólicos e psicológicos da representação minoritária e da fixação de sua presença em determinadas posições sociais (a empregada doméstica e a mulata). A respeito das percepções da branquitude sobre as pessoas negras, Mills (1997 p. 18 apud CARNEIRO, 2005, p. 101) aponta que

[...] na verdade, nas questões relativas à raça, o Contrato Racial prescreve para seus signatários uma epistemologia invertida, uma epistemologia da ignorância, uma tendência particular de disfunções cognitivas localizadas e globais (que são psicológica e socialmente funcionais), produzindo o resultado irônico de que, em geral, os brancos serão incapazes de compreender o mundo que eles próprios criaram (...) Poderíamos dizer, portanto, como regra geral, que a interpretação errada, a representação errada, a evasão e o auto-engano nas questões relativas à raça estão entre os mais generalizados fenômenos mentais dos últimos séculos, uma economia cognitiva e moral psiquicamente necessária para a conquista, civilização e escravização. E esses fenômenos não têm nada de acidental: são prescritos pelos termos do Contrato Racial, que requer uma certa medida de cegueira e obtusidade estruturadas a fim de estabelecer e manter a sociedade organizada branca.

Por esses motivos, e sobretudo a partir dos processos de globalização, a comunicação como "nexo de empoderamento" (CARNEIRO, 2019a) tem se mostrado especialmente relevante para a construção de um novo imaginário sobre a mulher negra. Isso inclui a capacitação de lideranças para trabalhar com tecnologias de informação e de comunicação, assim como a construção de representações positivas e a visibilização do processo de mobilização e das lutas (CARNEIRO, 2019a).

Como coloca Lélia Gonzalez, para combater a ideologia do branqueamento, isto é, a “dominação da negrada mediante a internalização e a reprodução dos valores brancos ocidentais" (GONZALEZ, 2019, p. 251), é necessário assumir o risco do "ato de falar com todas as implicações" (GONZALEZ, 2019, p. 239), o que inclui, entre outras coisas, pensar estratégias de comunicação para divulgação dos debates, princípios e valores do Feminismo Negro e dos movimentos de mulheres negras. Discutindo a representação das mulheres negras nos meios de comunicação brasileiros, Carneiro (2019a, p. 281) coloca que

Os meios de comunicação vêm se constituindo em um espaço de interferência e agendamento de políticas do movimento de mulheres negras, pois a naturalização do racismo e do sexismo na mídia reproduz e cristaliza, sistematicamente, estereótipos e 
estigmas que prejudicam, em larga escala, a afirmação da identidade racial e o valor social desse grupo.

Fica evidente, portanto, a centralidade da atuação de mulheres negras no campo da comunicação como estratégia de combate às políticas de silenciamento e ao epistemicídio da população negra. Discutindo essa atuação, Cristiano Rodrigues e Viviane Gonçalves Freitas (2019) realizam uma historiografia sobre as estratégias comunicacionais e temas mais tratados por três veículos de comunicação de mulheres negras organizadas nos últimos 35 anos. São eles: Nzinga Informativo (organizado pelo Nzinga - Coletivo de Mulheres Negras), que circulou durante a década de 1980 no Rio de Janeiro; os Cadernos Geledés (organizado pelo Geledés - Instituto da Mulher Negra), publicado nos anos 1990 em São Paulo; e o Blogueiras Negras, blog criado em 2012 a partir do Blogagem Coletiva Mulher Negra e ativo até o presente ano de 2021.

Segundo os autores, esses periódicos consistem em veículos da imprensa alternativa, espaço que diversos movimentos sociais encontraram para ampliar a articulação e a visibilidade política de suas agendas (RODRIGUES; FREITAS, 2019, p. 76) durante a Ditadura Militar e o período de redemocratização. Nesses espaços, as autoras pautavam/pautam raça, gênero, desigualdade social, empoderamento, estética, arte e educação financeira, entre outros assuntos. Elas criam redes de conhecimento, citando os trabalhos uma das outras, realizando resgate da memória de mulheres negras históricas e outras figuras importantes dos movimentos negro e feminista do Brasil e da diáspora africana.

De acordo com Barros (2020, p. 185-186)

\begin{abstract}
Antes, essa circularidade acontecia nos jornalecos, boletins, rádios piratas, assembleias, congressos, artigos e livros. Nos recentes 15/20 anos, com a potencialização da internet, essa comunicação ficou mais robusta e entre as várias frentes de construção e reconstrução dessas narrativas, o movimento de mulheres negras feministas também ficou mais visível. O feminismo negro tem sido uma das principais estratégias de comunicação lançadas pelo ativismo de mulheres negras na internet há alguns anos no Brasil no combate ao racismo e no fortalecimento de seus protagonismos.
\end{abstract}

Assim, um estudo dos temas mais tratados por cada um desses veículos permite uma reconstrução das agendas desses coletivos em particular e a elaboração de algumas suposições acerca dos movimentos de mulheres negras em geral em cada período. Por esse motivo, reproduzimos o levantamento a seguir.

\title{
Quadro 1 - 10 principais categorias temáticas encontradas nas publicações Nzinga Informativo, Cadernos Geledés e Blogueiras Negras
}

\begin{tabular}{|c|c|c|}
\hline $\begin{array}{c}\text { Nzinga Informativo } \\
(1985-1989)\end{array}$ & $\begin{array}{c}\text { Cadernos Geledés } \\
(1991-1993)\end{array}$ & $\begin{array}{c}\text { Blogueiras Negras } \\
\text { (2012-presente) }\end{array}$ \\
\hline
\end{tabular}




\begin{tabular}{|c|c|c|}
\hline Categoria temática & Categoria temática & Categoria temática \\
\hline $1^{\text {a) }}$ Comunidade negra & $\begin{array}{l}1^{\text {a) }} \text { Direitos sexuais e } \\
\text { Reprodutivos }\end{array}$ & $1^{\text {a })}$ Lugar de fala \\
\hline $\begin{array}{l}\left.2^{a}\right) \text { Organizações de } \\
\text { mulheres }\end{array}$ & $\begin{array}{l}2^{\text {a })} \text { Organizações de } \\
\text { Mulheres }\end{array}$ & $2^{\mathrm{a}}$ ) Representatividade \\
\hline $\left.3^{a}\right)$ Política institucional & 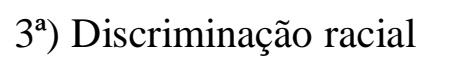 & $3^{\text {a }}$ ) Interseccionalidade \\
\hline $\left.4^{\mathrm{a}}\right)$ Histórias de mulheres & $\left.4^{a}\right)$ Saúde & $\left.4^{a}\right)$ Empoderamento \\
\hline $5^{\mathrm{a}}$ ) Educação & $\begin{array}{l}\left.5^{\mathrm{a}}\right) \text { Encarceramento da } \\
\text { população negra }\end{array}$ & $\left.5^{a}\right)$ Solidão da Mulher Negra \\
\hline $\begin{array}{l}\left.6^{a}\right) \text { Direitos sexuais } \\
\text { Reprodutivos }\end{array}$ & $\left.6^{a}\right)$ Pena de morte & 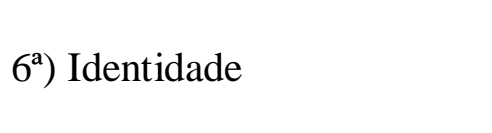 \\
\hline $\begin{array}{l}7^{a} \text { ) Violências contra } \\
\text { Mulheres }\end{array}$ & $\left.7^{a}\right)$ Movimento negro & $\begin{array}{l}\left.7^{\text {a }}\right) \text { Estética, autoestima e } \\
\text { Autocuidado }\end{array}$ \\
\hline $8^{\text {a) }}$ Trabalho & $\begin{array}{l}\left.8^{a}\right) \text { Violências contra } \\
\text { Mulheres }\end{array}$ & $\begin{array}{l}\left.8^{a}\right) \text { Genocídio da Juventude } \\
\text { Negra }\end{array}$ \\
\hline $9^{\text {a) }}$ Saúde & $\begin{array}{l}\left.9^{a}\right) \text { Religiões de matriz } \\
\text { Africana }\end{array}$ & $\begin{array}{l}\left.9^{a}\right) \text { Saúde Mental da } \\
\text { População Negra }\end{array}$ \\
\hline $10^{\mathrm{a}}$ ) Pobreza & $\left.10^{\mathrm{a}}\right)$ Histórias de mulheres & $10^{\mathrm{a}}$ ) Sexualidade \\
\hline
\end{tabular}

Fonte: Rodrigues e Freitas (2019, p. 75).

Nzinga Informativo foi atuante ao longo dos anos 1980, anterior ao processo de onguização. Já os Caderno Geledés, datam do início do processo de autonomização do movimento de mulheres negras em relação ao movimento negro e também em relação ao movimento feminista (RODRIGUES; FREITAS, 2019, p. 76), que culminaria na criação de diversas ONGs voltadas especificamente para a condição das mulheres negras. Tratava-se de um processo de afirmação das mulheres negras enquanto sujeitas protagonistas das mobilizações e nãos mais "sujeitos implícitos" dos movimentos feminista e negro, como aponta Matilde Ribeiro (1995 apud RODRIGUES; FREITAS, 2019, p. 78).

Além disso, essas publicações estavam envolvidas com a denúncia do racismo na sociedade brasileira, questão que fora duramente reprimida durante a Ditadura Militar por meio da propagação do mito da democracia racial, contribuindo de forma decisiva para a retomada do fortalecimento da cultura e da articulação de organizações políticas negras (RODRIGUES; FREITAS, 2019, p. 77). 
No caso do Nzinga Informativo, anterior aos Cadernos, tratava-se também de organizarse para disputar espaços e posições de poder dentro dos outros movimentos nos quais essas mulheres atuavam (RODRIGUES; FREITAS, 2019, p. 78). Sua linguagem era "simples e acessível" e tinha como público-alvo "mulheres e homens, negros(as) e brancos(as)", preocupados(as) com as questões que embasavam a agenda do grupo e, consequentemente do veículo (APRESENTAÇÃO, 1985, p. 1)” (RODRIGUES; FREITAS, 2019, p. 80). O tema da valorização da comunidade negra como um todo era predominante, o que envolvia a divulgação e a apreciação dos ritos e costumes dessa comunidade, bem como a denúncia da segregação em termos de raça, classe e gênero no Brasil (RODRIGUES; FREITAS, 2019, p. 81).

Os Cadernos Geledés, por sua vez, tinham como foco o trabalho com a saúde reprodutiva, a prevenção à AIDS e a denúncia da política de esterilização de mulheres negras em São Paulo, enquadrado como um mecanismo do genocídio da população negra. Esse foco sobre a saúde das mulheres negras estava bastante relacionado ao trabalho do Geledés enquanto ONG, realizado inclusive no âmbito da política institucional, junto ao Conselho da Condição Feminina de São Paulo e ao Coletivo de Mulheres Negras de São Paulo.

Com a reconfiguração do espaço público que a internet e as redes sociais proporcionam, questões que costumavam ser trabalhadas dentro dos coletivos, como os grupos de reflexão, hoje são publicadas em diversas plataformas de forma mais ou menos pública. A esse respeito, salientamos as considerações de Francis Musa Boakari e Emanuella Geovana Magalhães de Souza (2019) sobre o uso dos espaços de sociabilidade online enquanto espaços educativos que abarcam uma certa diversidade epistêmica, muitas vezes não encontradas em espaços educativos tradicionais, como as escolas e universidades, tendo em vista que muitos canais se constituem como

[...] possibilidades de ensinamentos e aprendizagens que podem ser oferecidas e/ou despertadas no intuito de incentivar e fortalecer os diálogos, compartilhamento de experiência e, além disso, ecoar, validar e ampliar a diversidade epistêmica do "outro lado da linha. (BOAKARI; SOUZA, 2019, p. 235)

Martinez (2019, p. 25-26), a partir da análise de conteúdo de grupos no Facebook, resume os objetivos das feministas negras na internet da seguinte forma:

$\mathrm{Na}$ internet, o feminismo negro tem colocado em debate pautas que supostamente não seriam priorizadas em outros feminismos, como: genocídio da juventude negra e seus impactos sobre as mulheres negras, a intolerância religiosa e a valorização das religiões de matriz africana, relacionamentos inter-raciais e relações afetivo-amorosas de mulheres negras, mercado de trabalho, padrões estéticos femininos e a representatividade dos negros na mídia, impacto da violência cotidiana na população negra, etc. 
Vemos, portanto, uma continuidade das discussões realizadas nos anos 1980 e 1990 em relação aos debates contemporâneos, ao mesmo tempo em que novos temas são trazidos à baila ou revisitados. Quanto às principais referências, Martinez (2019, p. 26) cita Angela Davis, Audre Lorde, bell hooks, Lélia Gonzalez e Sueli Carneiro, ativistas que iniciaram sua atuação a partir dos anos 1970 - e muitas das quais ocupam hoje destacadas posições de liderança.

As pautas do Blogueiras Negras (http://www.blogueirasnegras.org/) apontam para essas mudanças, trabalhando com profundidade questões teóricas do Feminismo Negro - sobretudo estadunidense - que se mostram relevantes para a militância de mulheres negras no cenário contemporâneo. Rodrigues e Freitas salientam a interseccionalidade como abordagem que contribui para a "gramática política sobre hierarquias e formas de opressão" (RODRIGUES; FREITAS, 2019, p. 89) e para a assunção da raça como categoria essencial para compreender o patriarcalismo, o sexismo e o próprio feminismo no Brasil.

De acordo com as autoras, essas mudanças se devem a alguns fatores, entre eles:

[...] o aumento das disputas internas no feminismo, o processo de ressignificação do papel desempenhado por mulheres não brancas como sujeitos do feminismo, o aumento de estudos sobre a permanência de padrões históricos de desigualdade entre mulheres brancas e não brancas e a democratização do acesso ao ensino superior na primeira década do século XXI. (RODRIGUES; FREITAS, 2019, p. 89).

Essa determinação por priorizar as pautas de mulheres se mostra decisiva para a transformação do Blogueiras Negras - e também de alguns grupos e outros espaços de sociabilidade online - em espaços de acolhimento e reflexão, nos quais ocorre a criação de comunidades e de redes de apoio, nas quais mulheres negras têm voz e vez no compartilhamento de sentimentos e visões de mundo (Inaldete Pinheiro de ANDRADE, 2012 apud RODRIGUES; FREITAS, 2019, p. 87). O Geledés também participa desse momento, por meio da criação de um portal de notícias (https://www.geledes.org.br/) em 1997.

Simultaneamente, a criação de laços e de redes de mulheres negras online dão origem a novas frentes de atuação e fortalecem espaços e grupos pré-existentes. São exemplos a WinnieTeca, fundada pela feminista negra Winnie Bueno, no Twitter (https://twitter.com/WinnieTeca), que promove a doação de livros para pessoas negras; o PretaLab (https://www.pretalab.com/), estudo da ONG Olabi a respeito de raça e gênero na tecnologia, e a Rede de Ciberativistas Negras (https://alyne.org.br/category/rede-ciberativistasnegras/), ligada à ONG Criola.

É nesse contexto que foi criado o canal Afros e Afins por Nátaly Neri (hoje Nátaly Neri). A autora do canal é uma jovem mulher negra estudante de Ciências Sociais da Universidade 
Federal de São Paulo. Inscrita no YouTube desde 22 de julho de 2015, publica seu primeiro vídeo em 28 de julho de 2015. Hoje com mais de 580 mil inscritos e 245 vídeos, tem um total de 25.244 .841 visualizações no canal (em 17/02/2020).

Em seu canal, ela trata de "processos de autonomia" no âmbito intelectual, mental e de consumo, relacionados a uma série de temas, como "raça, gênero, sociedade, sustentabilidade, slow living, amores, beleza, e tudo o que uma jovem interessada em melhorar sua vida e a realidade ao seu redor poderia se interessar". Seu objetivo é discutir estética, sobretudo moda, maquiagem e cabelo (NERI, 2015b) a partir de uma perspectiva racializada (NERI, 2015a).

Para tanto, ela parte de "narrativas pessoais compartilhadas", isto é, narrativas sobre a sua vida pessoal, experiências na infância e na adolescência que são identificadas com experiências de outras crianças e adolescentes negras (mais especificamente mulheres e meninas). Essas narrativas são bastante pautadas por ela em seus vídeos, que não raro consistem em entrevistas com outras/os youtubers para discutir questões específicas, filiando-se ao Feminismo Negro abertamente.

Embora esteja presente também no Twitter e no Instagram, é reconhecida principalmente pela sua atuação no YouTube. Nessa plataforma, ela também é embaixadora do Creators For Change, uma iniciativa voltada para jovens "criadores de conteúdos inspiradores" para "desenvolver projetos de impacto em vídeo, aproximar as pessoas e aumentar a tolerância e a compreensão" (YOUTUBE, s/d). Por meio desses projetos, ela recebeu verba para a realização do documentário "Negritudes Brasileiras" (NERI, 2018), que discute os efeitos e origens do colorismo no contexto nacional.

Seu canal está organizado por meio de playlists ${ }^{38}$ - listas de vídeos relacionadas por uma usuária ou produtora de conteúdo a partir de alguma característica comum - com uma variedade de critérios de organização:

- Participação em \#tags - campanhas, muitas vezes impulsionadas por marcas ou pelo próprio YouTube, que incentivam os canais a discutirem um determinado tópico -, como \#YouTubeNegro e \#VivaSuaBelezaViva;

\footnotetext{
${ }^{38}$ Ressaltamos que nem todos os vídeos presentes nessas playlists foram publicados no canal ou contam com a participação de Nátaly. Muitas vezes, trata-se de uma playlist organizada pela youtuber e que conta com vídeos de outros canais. No entanto, tomamos as playlists como mecanismos estruturantes do canal, quer encaremo-lo como texto, quer como arquivo, tendo em vista que facilitam a navegação entre seus temas, suas publicações e as redes de youtubers conectadas a ele.
} 
- Gênero discursivo - VLOGS, Arrume-se Comigo \#sallve, \#7DiasDeEscolha, COLABORAÇÕES e EntreVistas Negras, VARIEDADES - Coisas que quis fazer, \#ReuniãoDeQuinta;

- Temas, como \#AutonomiaMental, \#AutonomiaIntelectual, \#AutonomiaDeConsumo e AUTONOMIA ESTÉTICA - Cabelo e Maquiagem.

Figura 1 - Playlists do Canal Nátaly Neri

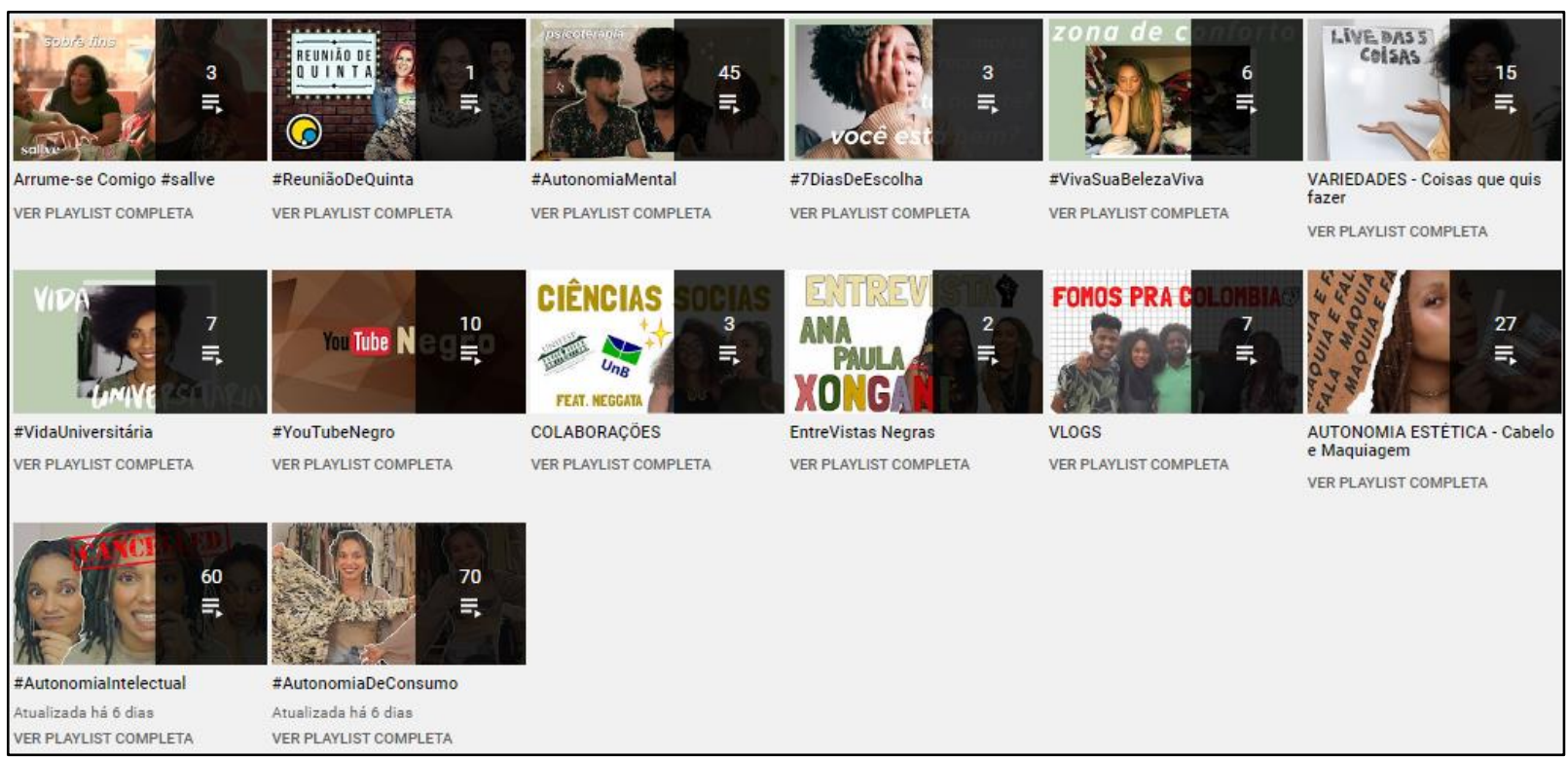

Fonte: Canal Nátaly Neri ${ }^{39}$. Acesso em 15/02/2020.

Os vídeos desse canal analisados nesta dissertação são "POR QUE VOCÊ É TÃO AGRESSIVA, NÁTALY?", publicado em 5 de maio de 2017 e alocado na playlist \#AutonomiaIntelectual ${ }^{40}$, e "YOUTUBER SÓ FALA MERDA NA INTERNET? Feat. Louie Ponto", publicado em 15 de maio de 2017 e não alocado em nenhuma playlist até o momento ${ }^{41}$. Na descrição da playlist \#AutonomiaIntelectual, Nátaly define o termo autonomia como "a capacidade de tomar decisões não forçadas baseadas em informações disponíveis". Mais especificamente,

Autonomia intelectual, no contexto desse canal e dessa playlist, é quando você consegue fazer a junção entre conhecimento adquirido e experiências vividas,

\footnotetext{
${ }^{39}$ Disponível em:

<https://www.youtube.com/channel/UCjivwB8MrrGCMlIuoSdkrQg/playlists?view=1\&sort=dd\&flow=grid $>$.

${ }^{40}$ Para acessar a playlist \#AutonomiaIntelectual:

https://www.youtube.com/playlist?list=PL7TPlcav5cfby8Jm8rQTRRS8r6Ws-wz1t.

${ }^{41}$ No entanto, em 12 de abril de 2018, Nátaly publicou outro vídeo com temática semelhante, “ATIVISMO DE INTERNET É ATIVISMO?", também alocado na playlist \#AutonomiaIntelectual. Neste vídeo, ela aprofunda as questões já apresentadas no vídeo com LouiePonto, apontando para desdobramentos e impasses dos ativismos de internet, salientando as tensões entre individualismo e coletividade.
} 
transformando-os em sua própria forma de ver o mundo para ponderar sobre a sua realidade subjetiva e a realidade social, objetiva.

Acessar conhecimentos múltiplos é um caminho para a possibilidade de tomar escolhas conscientes com uma abordagem crítica.

Nessa playlist vocês vão encontrar algumas das coisas que venho pensando e aprendendo há alguns anos e que mudaram completamente a minha forma de ver o mundo e de encarar a minha existência enquanto mulher e negra entre várias outras coisas. Espero que essas discussões sirvam como ferramentas para que também possam refletir sobre suas realidades.

Façam bom proveito! (NERI, 2020)

Essa definição nos auxilia a compreender os objetivos da produção de conteúdo do canal: auxiliar processos de compreensão de si e do mundo com o apoio das Ciências Sociais e dos feminismos negros, entre outras perspectivas. Seus vídeos são pensados para consumidoras individuais, interessadas nos tópicos discutidos pela youtuber e interessadas por ou comprometidas com projetos de transformação social. Podemos, portanto, definir como seu auditório primário pessoas politicamente engajadas e, mais especificamente, jovens mulheres conforme aponta na descrição do canal ${ }^{42}$ : "uma jovem interessada em melhorar sua vida e a realidade ao seu redor".

Ambos os vídeos analisados tratam sobre assuntos específicos dos ativismos feministas, LGBTTIAPN+ e negros. O primeiro vídeo visa à desconstrução de estereótipos sobre a mulher negra e consiste em uma resposta a ataques sofridos por Nátaly em suas redes sociais, que a acusavam de ser "agressiva demais" $"$. O segundo afirma a legitimidade dos próprios ativismos de internet, tendo em vista que, à época de sua publicação, a atuação dos movimentos sociais na internet - sobretudo no YouTube - ainda era vista com bastante ceticismo e desconfiança por seus integrantes e também pela academia.

\footnotetext{
${ }^{42}$ De fato, no vídeo mencionado na nota de rodapé, ela fala sobre contatos que tem com adolescentes que estão organizando coletivos feministas e coletivos negros em suas escolas e entram em contato com ela para pedir indicações de leitura.

${ }^{43}$ Essas ataques parecem relacionados aos ataques racistas sofridos por mulheres negras de classe média estudados por Trindade (2020).
} 


\title{
1.1.2 Entendidas: Movimentos de Mulheres Lésbicas e Feminismo Lésbico
}

\author{
l_sb_c_ \\ $s \_p \_t$ \\ $s \_p \_t \_n \_$ \\ $f_{-} n c h \_$ \\ $v_{-} r_{-} g_{-}$ \\ _nv_rt_d_ \\ [texto censurado \\ pela república do brazil]
}

- Luana Claro, Construção

Assim como a atuação das mulheres negras discutida na seção anterior, o feminismo e os movimentos de mulheres lésbicas também tensionam as discussões de gênero e o fazem também nas articulações com o movimento negro e o movimento LGBTTIAPN+.

Em sua atuação no campo da comunicação, um dos principais eixos de crítica e denúncia dos movimentos de mulheres lésbicas e dos feminismos lésbicos é a (in)visibilidade. Não à toa, no calendário nacional de mobilizações figura o Dia da Visibilidade Lésbica (29 de agosto), que reúne ações no sentido de publicizar pautas lésbicas em diversas áreas, como o acesso à saúde, o combate à violência sexual (na forma de assédio ou estupro corretivo) e a representação nas artes e no entretenimento.

Quando pensamos a afirmação da sexualidade lésbica no contexto brasileiro, nos deparamos não apenas com a invisibilidade, mas com a marginalização de corpos femininos que fogem à regra da heteronormatividade. Afirma Pocahy (2017, p. 50) que "a diferença dos sexos é também a marca do ferro em brasa de um regime arbitrário sobre os desejos - expressa em uma linha de inteligibilidade amalgamada sobre corpo-gênero-sexualidade-prazer-desejo". Comparada ao leito de Procusto - que espicha e corta os membros daquelas/es que se deitam em sua cama para adequá-las/los às suas próprias medidas -, a heterossexualidade compulsória é uma das dimensões responsáveis pela regulação social das populações, na medida em que produz uma divisão entre "nós" e "eles", "eu/outro" que se articula para a definição da abjeção, isto é, da representação de determinados corpos como repulsivos, desprezíveis e ignóbeis, estabelecendo práticas em esferas diversas, como a saúde e a educação, que legitimam regimes de apartheid social (POCAHY, 2017). 
Ferrari (2016, p. 119-120), discutindo novas estéticas das homossexualidades masculinas, constituídas nas/por meio das redes, afirma que estas, enquanto "resultado do discurso médico, surgem como doença, como algo que deveria ser tratado, curado, expulso das pessoas". Trata-se de algo a ser oculto, escondido, censurado.

Essa pauta se articula também com o processo de afirmação identitária das mulheres lésbicas. Érica Sarmet (2018) distingue quatro momentos do feminismo lésbico brasileiro, estruturados em torno dos seguintes eixos:

1. Afirmação da identidade lésbica e afastamento em relação aos movimentos feministas e homossexual - final da década de 1970 e início da década de 1980.

2. "Onguização" do movimento, profissionalizado em organizações voltadas para a elaboração de políticas públicas para mulheres no âmbito dos direitos reprodutivos, da saúde do trabalho e da violência de gênero com apoio de programas governamentais e de agências de cooperação internacionais - final da década de 1980 e anos 1990.

3. Difusão de imagens e representações na mídia e na internet, com a criação de diversos grupos lesbofeministas em cidades brasileiras e associação à política institucional - anos 2000 e início dos anos 2010.

4. A política do "Fervo também é luta" (SARMET, 2018, p. 388), fortalecimento e celebração da cultura lésbica, atuação em coletivos, discussão de pautas que, embora presentes, costumavam ser silenciadas dentro do movimento, como a gordofobia, o racismo e a transfobia. Participa também desse momento o uso das redes sociais para distribuição de textos, discussão e articulação política - a partir de 2015.

De acordo com Gláucia Almeida e Maria Luiza Heilborn, esse primeiro processo, de autonomização, envolveu a elaboração de repertórios e princípios articulatórios internos e progressivamente diferenciados em relação a outros movimentos e organizações. Conforme as autoras (ALMEIDA; HEILBORN, 2008, p. 226)

No início da década de 1980 e nos primeiros anos da década de 1990, as lésbicas realizaram vários esforços de afirmação identitária no interior de organizações mistas do movimento homossexual brasileiro (formadas por gays e travestis, principalmente), de organizações feministas e do movimento negro. Os grupos lésbicos contemporâneos surgiram em decorrência desse movimento de afirmação.

As autoras relacionam duas grandes vertentes teóricas especificamente lésbicas no cenário internacional ao movimento lésbico brasileiro. Essas vertentes estariam ligadas a duas destacadas intelectuais lésbicas: Adrienne Rich, poeta estadunidense, e Monique Wittig, francesa radicada nos Estados Unidos. A primeira estaria mais ligada ao feminismo, à defesa 
da solidariedade entre mulheres, bem como à denúncia da heterossexualidade compulsória e à invisibilidade do lesbianismo, enquanto a segunda entende o "pensamento straight" como mais fundamental do que o patriarcado para a organização da sociedade (ALMEIDA; HEILBORN, 2008, p. 227-228).

No cenário nacional, em específico,

[...] as três correntes internacionais [do lesbianismo político] ${ }^{44}$ são representadas por diferentes sujeitos que vocalizam suas propostas, demandas e divergências, seja pela militância partidária, de grupos com baixo grau de formalidade, seja por ONGs. Estes sujeitos se articularam mais recentemente também em torno de grandes entidades agregadoras nacionais, como a LBL (Liga Brasileira de Lésbicas), ABGLT (Associação Brasileira de Gays, Lésbicas e Transgêneros) e a ABL (Articulação Brasileira de Lésbicas). Estas entidades, por sua vez, divergem por diferentes motivos: desde disputas de poder e de espaço de representação governamental entre lideranças, até desavenças quanto à demarcação de fronteiras identitárias. Há posições entre as francamente favoráveis à articulação com os gays, bissexuais e travestis pela potencialização da ação política -, e as que consideram prejudicial ao reconhecimento público das demandas especificamente lésbicas tal articulação. (ALMEIDA; HEILBORN, 2008, p. 229)

Conforme afirmado pelas autoras, as relações entre os movimentos feministas e os movimentos lésbicos também são marcadas por tensões e distanciamentos. Há décadas a "acusação" de o feminismo ser um movimento de mulheres lésbicas "que odeiam homens" tem sido usada para "desqualificá-lo". De acordo com Gilberta Santos Soares e Jussara Carneiro Costa (2012, p. 2-3)

A associação entre feministas e lésbicas cumpre a função política e pedagógica de alertar as mulheres para o perigo da perda da feminilidade representada pelo feminismo, produzindo abjeção para ambas, pela associação que se faz entre essas e a mulher masculinizada.

Com isso, as relações entre mulheres heterossexuais e lésbicas foram/são tensionadas, o que muitas vezes leva ao apagamento da existência de mulheres não heterossexuais tanto dentro do movimento quando no seu desenvolvimento epistemológico. Em contrapartida, as feministas lésbicas criticam o caráter heteronormativo de teorias e grupos feministas (SOARES; COSTA, p. 4, 2012) que, embora ecoem o repúdio à lesbofobia, tendem a centrar suas reflexões

\footnotetext{
44 As autoras resumem as correntes da seguinte forma: o lesbianismo feminista critica o heterofeminismo e denuncia a lesbofobia, enfatizando a importância da solidariedade política das mulheres (como "classe de sexo") contra o heteropatriarcado; o lesbianismo radical - relacionada a pensadoras francesas como Monique Wittig e Colette Guillaumin -, entende que "as lésbicas certamente escapam à apropriação privada por parte dos homens, mas não conseguem se livrar da apropriação coletiva, o que as vincula à classe das mulheres, e implica lutas conjuntas (FALQUET, 2004, p. 31)" (ALMEIDA; HEILBORN, 2008, p. 228); o lesbianismo separatista, por sua vez, é caracterizado como bastante diverso regionalmente, mas sintetizado como "a criação ou tomada de espaços físicos ou simbólicos unicamente por e para lésbicas. Tal posicionamento acarreta a criação de comunidades ou comunas em casas ocupadas, ou no campo, a organização de festivais de cinema ou de música, revistas, casas editoriais ou espaços de sociabilidade e de luta política" (ALMEIDA; HEILBORN, 2008, p. 228-229).
} 
teóricas e práticas políticas em relações heterossexuais, a não desenvolver reflexões sobre a heterossexualidade obrigatória (elaboradas por Adrienne RICH, 1980) e nem a se envolver em ações de enfretamento aberto a essas questões.

Além disso, as feministas lésbicas também pressionavam pela desconstrução discursiva do termo "mulher" de forma a abarcar maior número de experiências reais, bem como combater a representação de corpos que fogem à heteronormatividade e a outros padrões como corpos abjetos, passíveis de exclusão, marginalização e outras violências.

Soares e Costa (2012, p. 28) creditam esse olhar ao Combahee River Collective (um dos primeiros coletivos feministas negros estadunidenses, criado em Boston em 1974), a articulação entre a crítica ao heterossexismo e ao racismo, assim como as questões de classe:

[...] o movimento critica o sexismo do movimento negro; o racismo e as perspectivas classistas do movimento feminista e lésbico; o caráter reformista da National Black Feminist Organization - primeira organização nacional norte-americana feminista negra - e a invisibilidade das questões de raça e orientação sexual entre as feministas socialistas.

Essas posições teriam gerado consequências irreversíveis para o paradigma feminista em termos da compreensão da inseparabilidade das lutas. Uma das intelectuais feministas influenciada por essa perspectiva é Monique Wittig, cujas ideias são apropriadas pelo lesbofeminismo radical latino-americano e caribenho (SOARES; COSTA, p. 31, 2012). Nessa abordagem, incorpora-se a "crítica à heterossexualidade obrigatória, a perspectiva teórica da práxis do feminismo materialista francês e as contribuições de feministas negras, mestiças, 'de cor' e pós-colonialistas". De acordo com as autoras, essa perspectiva apresenta um posicionamento bastante assertivo no que se refere à articulação das lésbicas com outros grupos, movimentos e modos de atuação (SOARES; COSTA, 2012, p. 31-32),

No lesbofeminismo latino-americano e caribenho, as tensões estão associadas à ausência de crítica ao heterossexismo e a perda da autonomia do movimento lésbico, advinda da institucionalização do feminismo. Para as integrantes do lesbofeminismo radical, a partir do momento em que lésbicas feministas integram organizações financiadas com recursos governamentais ou oriundos de agências de cooperação internacional, sucumbem as pressões heterossexistas e deixam de se identificar como lésbicas. Observam ainda que a construção das agendas feministas internacionais não contemplou o enfrentamento ao heterossexismo e tentam recompor o espaço perdido pelo feminismo. As lesbianas se engajam no movimento LGBT, mas, de acordo com Miñoso (2007), logo percebem a inviabilidade de empreender uma luta política lesbiana e feminista nesse espaço, que abandonou posturas mais radicais em prol de um discurso que enfatiza a diversidade, que ficou empobrecido politicamente, especialmente, por não questionar a heterossexualidade obrigatória. 
Nesse contexto, os Encontros Lésbicos Latino-Americanos e Caribenhos se mostram importantes para resistência, acolhimento e desenvolvimento de estratégias políticas, bem como para o fortalecimento e desenvolvimento de uma cultura lesbiana (SOARES; COSTA, 2012, p. 32,). Das reflexões sobre a atuação junto ao movimento feminista e LGBTTIAPN+, deriva-se a decisão (mais ou menos consensual) de focar os esforços no desenvolvimento do conceito da heterossexualidade compulsória e no combate ao heterossexualismo como sistema político, o que envolveria o lesbianismo político ${ }^{45}$.

No que se refere à atuação do movimento no campo da comunicação, Paula SilveiraBarbosa (2019, p. 144) salienta que "[e]mbora oprimidas pela violência da heterossexualidade compulsória (RICH, 2010), as lésbicas desenvolveram estratégias de resistência a partir de mídias criadas e gestadas por elas mesmas". Em sua pesquisa de mestrado, a autora destaca algumas diferenças editoriais entre os periódicos do período ditatorial e aqueles produzidos após o processo de redemocratização.

De acordo com ela, no caso dos veículos dos grupos de lésbicas e gays, o "escracho" e o "deboche" se constituíram em estratégias de resistência na busca de visibilidade política para suas pautas, tendo em vista o clima de vigilância moral e da recusa dos movimentos feministas e das organizações ortodoxas de esquerda em ouvir e apoiar suas pautas, muitas vezes motivados por lesbofobia/homofobia (SILVEIRA-BARBOSA, 2019, p. 150). Nesse sentido, uma das estratégias adotadas neste período foi a denúncia das consequências da heterossexualidade compulsória tanto para mulheres lésbicas quanto para mulheres não lésbicas com o objetivo de salientar as contribuições dos estudos sobre sexualidade para os estudos feministas, bem como afirmar a posição das ativistas lésbicas no âmbito dos movimentos sociais (SILVEIRA-BARBOSA, 2019, p. 153).

Um exemplo de atuação da Imprensa Lésbica é a experiência do boletim ChanacomChana (1982-1987), produzido e distribuído pelo Grupo de Ação Lésbica-Feminina (GALF) ao redor do Brasil ${ }^{46}$. Entre os objetivos do boletim, salienta-se a busca por visibilidade e representatividade lésbica, isto é, a representação daquilo que "está na vivência de tal grupo através de pequenos traços identitários" (MARTINS, 2019, p. 3), combatendo estereótipos e normalizando a lesbiandade. Esse processo se dava por meio da produção, pela distribuição e

\footnotetext{
${ }^{45}$ Mongrovejo (2010, p. 163 apud SOARES; COSTA, p. 33, 2014) define o lesbianismo político da seguinte maneira: "o lesbianismo é mais que uma preferência sexual, é uma opção política porque desafia o sistema político estabelecido que obriga que as relações entre homens e mulheres sejam relações de domínio".

${ }^{46}$ Este periódico e o próprio GALF inclusive estiveram envolvido no levante do Ferro's Bar, que tem sido comparado à revolta de Stonewall. A esse respeito, sugerimos a leitura do verbete Ferro's Bar no site do OUTROS - Laboratório para Outros Urbanismos da FAUUSP e da bibliografia relacionada.
} 
pelo consumo do periódico, tendo em vista que assiná-lo contribuía para a afirmação da identidade das leitoras - as quais, não raro, passavam a contribuir elas mesmas com textos e sugestões para o ChanacomChana (MARTINS, 2019, p. 3).

Além disso, o corpo editorial assumia como objetivo a difusão de debates da comunidade lésbica nacional e internacional, bem como a criação de uma rede de contatos que promovesse o contato entre as assinantes por meio de troca de cartas.

O segundo momento, no pós-Ditadura, consiste na reconfiguração do movimento lésbico de origem universitária ligado à Imprensa Lésbica, tendo em vista a mudança das condições de vida das ativistas. Os objetivos neste momento consistiam em "romper a bolha" das organizações políticas, criando grupos em mais regiões do país e pluralizar os debates realizados nos veículos, que passaram a discutir questões de cultura, saúde, sexualidade e amenidades (SILVEIRA-BARBOSA, 2019, p. 150).

São exemplos desse período o Deusa Terra, que era voltado para cultura e autoaceitação lésbicas, compartilhando relatos de vivências e de discriminação, enquanto o Grupo Estação Mulher tinha como objetivo romper o isolamento social das lésbicas, estimulando encontros e organização política (SILVEIRA-BARBOSA, 2019, p. 156). Os periódicos Lesbertária e Femme, por sua vez, chegaram a fazer matérias sobre destinos de viagens "LGBTfriendly" e entrevistas com celebridades LGBT.

Entre as semelhanças encontradas entre os dois períodos, conforme descrição realizada por Silveira-Barbosa (2019, p. 157), destacamos a prática de assinar os textos apenas com o primeiro nome ou mesmo com pseudônimos, atitude que se estendeu nos anos 1990. Nesse período, o pânico e o estigma em relação à AIDS ainda impediam que pessoas não heterossexuais assumissem sua sexualidade na vida pública.

De acordo com Sarmet (2018), nos anos 2010 ocorre uma reinvenção do movimento lésbico, em um processo que envolve uma mudança nos modos de organização. A autora salienta a articulação entre o ativismo de internet e a militância mais "tradicional", voltada para as políticas públicas e para a atuação local.

Nesse momento, destacamos dois tópicos de atenção para as publicações online, sobretudo aquelas voltadas para um público mais jovem: a visibilidade lésbica e o processo de "sair do armário".

Seguimos Camila L. Sant'Anaa e Cristian F. Guimarães (2019, p. 10-11) na compreensão da invisibilidade lésbica apresentada abaixo

O ser invisível aqui é o não se revelar como lésbica, é o manter-se 'dentro armário' e não expor sua sexualidade, deixando assim de manter conversas de 
cunho mais íntimo com colegas, mesmo que tendo necessidades de troca de confidências, forçando-as assim, a guardar angústias para si quando em permanência por longos períodos no local. Já o ser visível é claramente o oposto. É adotar uma postura direta, 'fora de seu armário', muitas vezes demonstrando estigmas masculinos, lidando com outros atravessamentos e situações. Nas duas formas, as garotas passam por situações cotidianas de aprovação ou desaprovação.

No ativismo digital, destacamos que a experiência de "sair do armário" continua sendo um aspecto formador importante na vida de pessoas LGBTTIAPN+. De acordo com Eve K. Sedgwick (2007, p. 22), "O armário é a estrutura definidora da opressão gay no século XX” (SEDGWICK, 2007, p. 26). Na internet, é possível encontrar uma série de textos (vídeos, threads, textões de Facebook, postagens em blogs, entre outros) comentando - e mesmo retratando - formas de "sair do armário" para amigos e familiares.

Em sua análise sobre a questão da homossexualidade na Europa e nos EUA durante os séculos XIX e XX, Sedgwick (2007, p. 26), argumenta que

[...] grande parte da energia de atenção e demarcação que girou em torno de questões relativas à homossexualidade [...] foi impulsionada pela relação distintivamente indicativa entre homossexualidade e mapeamentos mais amplos do segredo e da revelação, do privado e do público, que eram e são criticamente problemáticos para as estruturas econômicas, sexuais e de gênero da cultura heterossexista como um todo; mapeamentos cuja incoerência capacitadora, mas perigosa, foi condensada de maneira opressiva e duradoura em certas figuras da homossexualidade. "O armário" e "a saída do armário", ou "assumir-se", agora expressões quase comuns para o potente cruzamento e recruzamento de quase todas as linhas de representação politicamente carregadas, têm sido as mais magnéticas e ameaçadoras dessas figuras.

Assim, a diferença entre a homofobia (para utilizar o termo da autora) e outras opressões, como o racismo e o machismo, por exemplo, estaria justamente no caráter de sigilo que é imposto à(s) sexualidade(s) não heteronormativas. Por isso, a opção por romper o sigilo ao sair do armário assume uma importância tão grande. De acordo com Pedro Frazão e Renata Rosário (2008, p. 30), que analisam o processo de saída do armário no contexto português,

[...] o processo de coming out encerra em si uma componente pessoal, mas que é integrada numa dimensão social mais vasta. De grande relevância também, é a ideia de que este processo não é algo que se inicia na idade adulta, mas sim no processo global da formação da identidade iniciado na adolescência. Em consonância com esta ideia, verificamos hoje que a idade média do coming out é cada vez mais precoce.

A partir desse ponto de vista, os autores reafirmam a relevância que esse processo assume na formação das subjetividades não heterossexuais. Atuando na área da Psicologia, eles fazem referência a uma série de modelos que objetivam descrever e analisar esse processo para discutir seu impacto nas relações pessoais de pessoas gays e lésbicas, sobretudo no que se refere às relações familiares. Entre as gerações mais novas, em algumas localidades e contextos, no 
Brasil, assumir a sexualidade se tornou mais comum.Por outro lado, os autores também afirmam que existe uma parcela considerável dessa população (sobretudo adolescentes) que ou recusa o processo de saída do armário como um todo (com um posicionamento semelhante ao discutido por Louie no vídeo "RÓTULOS ME LIMITAM OU ME DEFINEM? | Especial Dia do Orgulho LGBT | Louie Ponto") ou afirma sexualidades não monossexuais e/ou fluidas. Esses aspectos motivam, inclusive, críticas aos modelos atuais por desconsiderarem mudanças sociais e as novas identidades sexuais.

De acordo com Frazão e Rosário (2008, p. 33),

Em primeiro lugar, os modelos desenvolvimentistas clássicos foram concebidos num contexto histórico em que o coming out era visto como o desfecho natural e imperativo do percurso de qualquer gay ou lésbica (Rasmussen, 2004). Alguns estudos contemporâneos (e.g., Savin-Williams, 2001a, 2005) demonstram que os adolescentes recusam de forma, muitas vezes, veemente a ideia do coming out, no sentido em que este rotula e restringe a sua sexualidade. De facto, verifica-se que os adolescentes preferem cada vez mais identidades fluidas, tais como ambissexual, atraído por uma pessoa, bi-lésbica, bi-queer, heterossexual com tendências lésbicas, etc. (Savin-Williams, 2005).

Nesse contexto, encontramos LouiePonto, cujo canal hoje contabiliza 19.518.021 visualizações e um total de 587 mil inscritas (em 17/02/2020). Inscrita no YouTube desde 21 de abril de 2008, já publicou 149 vídeos. Louie discute principalmente feminismos, saúde mental, vegetarianismo, veganismo, vivência e visibilidade lésbica. Além disso, publica de tempos em tempos músicas autorais e covers - seu objetivo inicial com o canal. Graduada em Letras e mestre em Literatura pela UFSC, uma das formas que utiliza para trabalhar questões de sexualidade é a análise de livros e filmes ficcionais sobre pessoas LGBTTIAPN+.

Assim como Nátaly, LouiePonto organiza seu canal por meio de playlists ${ }^{47}$ :

\footnotetext{
${ }^{47}$ Assim como no canal Nátaly Neri, nem todos os vídeos presentes nessas playlists foram publicados no canal ou contam com a participação de Louie. Muitas vezes, trata-se de uma playlist organizada pela youtuber e que conta com vídeos de outros canais. Nesse sentido, as considerações realizadas sobre o primeiro canal também se aplicam a este.
} 
Figura 2 - Playlists do canal LouiePonto

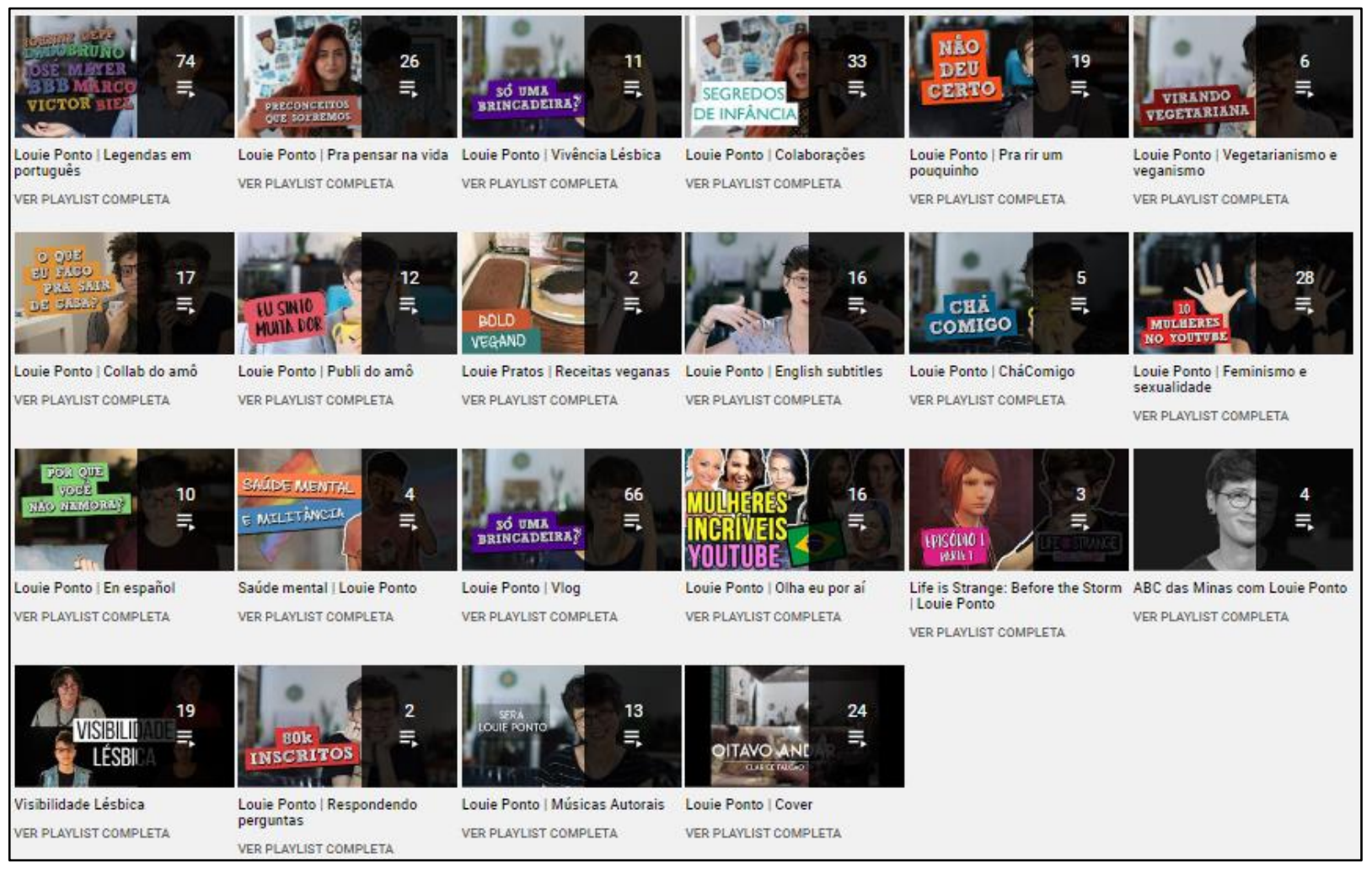

Fonte: canal LouiePonto ${ }^{48}$. Acesso em: 17/02/2020

As playlists estão organizadas por:

- Tema - Pra pensar na vida, Vivência Lésbica, Pra rir um pouquinho, Vegetarianismo e veganismo, Receitas veganas, Feminismo e sexualidade, Saúde mental, Life is Strange: Before the Storm, Visibilidade Lésbica.

- Gênero discursivo - Colaborações, Collab do amô, Publi do amô, CháComigo, ABC das Minas, Respondendo perguntas, Músicas Autorais, Cover.

- Grau de acessibilidade - Legendas em Português, En español, English subtitles. Além disso, há uma playlist Vlog, que parece alocar todos os vídeos exceto músicas autorais, gameplay e cover.

Entre os títulos das playlists, percebemos sua disposição em discutir feminismos e sexualidades de forma direta e aberta. Ambos os vídeos analisados nesta dissertação, "RÓTULOS ME LIMITAM OU ME DEFINEM? | Especial Dia do Orgulho LGBT | Louie Ponto" e "HETEROFOBIA E RACISMO REVERSO EXISTEM? | Louie Ponto e Nátaly Neri” estão alocados na playlist Louie Ponto | Vlog, que contém tanto vídeos individuais quanto

\footnotetext{
${ }^{48}$ Disponível em: 〈https://www.youtube.com/user/loouieee/playlists>.
} 
colaborativos.Os vídeos que compõem o corpus discutem questões relevantes entre as militâncias feministas, LGBTTIAPN+ e negras com atuação na internet: a recusa em afirmar a sexualidade, bem como as noções de racismo reverso e heterofobia. As acusações de racismo reverso e de heterofobia, embora estejam bastante presentes no discurso conservador, não raro aparecem também no campo progressista ${ }^{49}$.

Até a postagem do vídeo sobre "rótulos", Louie já havia postado pelo menos três outros vídeos sobre a "saída do armário": "COMO REAGIR QUANDO UMA MULHER SAI DO ARMÁRIO | Louie Ponto"50, "TROLLEI MINHA MÃE DIZENDO QUE SOU LÉSBICA | Louie Ponto" 51 e "COMO SE ASSUMIR PRA FAMÍLIA? | CháComigo \#1| Louie Ponto"52. Desde 2019, ela publicou também “COMO EU SAÍ DO ARMÁRIO: minha história | Louie Ponto" ${ }^{\circ 3}$.

\subsection{Práticas sociais e práticas discursivas no YouTube}

Nesta seção, efetuaremos uma sucinta resenha de alguns conceitos dos Estudos Críticos do Discurso na perspectiva faircloughiana - doravante Teoria Social do Discurso (TSD) centrais para as nossas discussões: os conceitos de Discurso, texto, práticas sociais e práticas discursivas no que se refere à sua utilização no embasamento de análises linguísticas. Utilizaremos, em especial, a concepção dialético-relacional do discurso para dialogar com questões oriundas da Antropologia Digital.

Partindo de Burgess e Green (2009, p. 21), entendemos que se mostra proveitoso investigar práticas discursivas no YouTube - e, especialmente, em canais ativistas - porque elas podem nos fornecer insights sobre alguns dos variados modos de interação online e também sobre os modos como esses textos incitam a reflexão, a consciência ética e o estabelecimento do que Castells (2013) denomina "redes de indignação e esperança". Essa análise não pode ser, no entanto, realizada sem que consideremos a sujeição dessa produção à arquitetura da plataforma $^{54}$ (BURGESS; GREEN, 2009; SILVA, 2020).

\footnotetext{
${ }^{49}$ Essas questões serão trabalhadas em detalhe no capítulo de análise.

${ }^{50}$ Disponível em: 〈https://www.youtube.com/watch?v=aVIlphCDyGg\&ab_channel=LouiePonto>. Publicado em 13/10/2016.

${ }^{51}$ Disponível em: 〈https://www.youtube.com/watch?v= Tzee8tHa0Y\&ab_channel=LouiePonto $>$. Publicado em 09/11/2016.

52 Disponível em: 〈https://www.youtube.com/watch?v=eZ_y518NUr4\&ab_channel=LouiePonto>. Publicado em 22/02/2017.

${ }^{53}$ Disponível em: 〈https://www.youtube.com/watch?v=INjUD-gZgs4\&ab channel=LouiePonto >. Publicado em $11 / 03 / 2019$.

54 Embora não trabalhemos essa questão aqui, acreditamos que essa análise contribuiria bastante para o entendimento dos modos de atuação de youtubers e influenciadores digitais nos ativismos, considerando os
} 
Nos parágrafos seguintes, procederemos à apresentação do YouTube enquanto rede social, valendo-nos dos estudos de Burgess e Green (2009) sobre o site e do conceito de públicos em rede proposto por boyd $(2011,2014)$. A seguir, consideraremos o YouTube em sua faceta comercial, no sentido de que sua construção se baseia, sobretudo, no objetivo de criar uma audiência para conteúdo publicitário. A partir dessa discussão, refletiremos sobre os canais ativistas, seus potenciais e seus limites transformadores em termos das redes de indignação e de esperança (CASTELLS, 2013). Para tanto, apoiamo-nos sobre as discussões acerca da Internet e das redes sociais como espaços de sociabilidade (MILLER; SLATER, 2004; Daniel MILLER; Heather HORST, 2012; RAMOS, 2015; boyd, 2014), as noções de "interfaces culturais" (MANOVICH, 2002), bem como sobre os desdobramentos da produção de conteúdo na web 2.0 (MANOVICH, 2009).

Em tempo, utilizaremos essas discussões para fazer algumas considerações a respeito dos canais e das práticas discursivas em que se envolvem as youtubers Nátaly Neri e LouiePonto nessa plataforma.

A Análise Crítica do Discurso busca integrar as orientações sociais e linguístico-textuais sobre o estudo da linguagem a partir do entendimento de que esta é parte irredutível dos processos que compõem a vida social, já que, por meio da linguagem, atribuímos sentido ao mundo e o fazemos sempre de modo contextualizado. Definindo-se crítica, está atenta às relações e assimetrias de poder e olha para o texto com o entendimento de que o discurso participa de forma decisiva na construção dessas relações. A Teoria Social do Discurso, em específico, busca entender o poder da linguagem e a sua operacionalização no processo social de um determinado campo ou prática.

Assim, nos termos de Luciane Cristina Eneas Lira e Regysane Botelho Cutrim Alves (2018, p. 106), a TSD encara o discurso como “"uso da linguagem” como prática social, para além das atividades individuais ou do resultado das variáveis da situação", isto é,

[...] como elemento de produção de significado no processo social; como linguagem associada a determinado campo ou prática (como o discurso publicitário e o discurso educacional, por exemplo) e como modo de construção de aspectos do mundo, associado a uma perspectiva social

desafios colocados pela plataforma em termos da coerção dos algoritmos sobre os modos de produção dos vídeos, assim como das questões de liberdade de expressão x discurso de ódio das quais muitas plataformas se furtam de enfrentar. Um exemplo recente foi a discussão a respeito da "preferência" do algoritmo do Instagram por publicações retratando pessoas brancas no Instagram, denunciado por influenciadores negras/os/es em outubro de 2020. Para uma discussão aprofundada, sugerimos a leitura do artigo de Silva (2020) Racismo algorítmico em plataformas digitais: microagressões e discriminação em código. 
particular (o discurso tradicional de constituição da família, por exemplo) (Fairclough, 2009).

A análise orientada pela ACD é constituída pela articulação entre três dimensões sociais e três dimensões semióticas: evento social e o texto; prática social (que inclui as práticas discursivas) e as ordens do discurso; a estrutura social e a semiose ${ }^{55}$. Assim, parte do trabalho da analista crítica do discurso consiste em discutir de que maneira os textos analisados participam de práticas sociais e discursivas. Outra dimensão deste trabalho é investigar o processo de materialização do texto, que se dá no nível dos eventos sociais, mas é, simultaneamente, possibilitado e constrangido pela organização das práticas sociais e pela articulação destas com a rede de práticas que constitui esferas particulares (a educação, a publicidade, a política, por exemplo) e a vida social como um todo.

Nessa perspectiva, a organização textual, as estratégias argumentativas, as ações executadas, as identidades construídas, as representações de mundo articuladas, as relações entre locutor e interlocutor simuladas/construídas no/por meio do texto são fruto da relativa liberdade criativa da instância produtora - relativa porque, para a $\mathrm{ACD}$, toda ação é constrangida pelos potenciais e limites disponibilizados pelas coerções estruturais (ordens do discurso) e materiais (como tecnologias e técnicas disponíveis).

Por ess e motivo, a análise textual é indissociável da análise da prática social na qual se insere. Em outras palavras, a ACD considera que a análise linguístico-discursiva de um texto esteja atrelada à investigação de seus contextos de produção, distribuição, consumo e interpretação, o que envolve a descrição das dimensões textual, semântico-discursiva, léxicogramatical e argumentativa.

No nível de análise do texto e dos eventos sociais, realiza-se uma descrição necessariamente seletiva e limitada (GONÇALVES-SEGUNDO, 2018c, p. 108) - dos textos, estruturada de modo a focalizar o objeto da investigação em curso. Nesse momento, verificamos de que maneira o evento-texto tensiona, subverte ou mantém os padrões de uso de linguagem correntes.

Fairclough (2003) propõe quatro eixos básicos para a descrição textual: vocabulário, gramática, coesão e estrutura textual. A depender do objeto e do enfoque da pesquisa, outras categorias de análise podem ser recrutadas. Nesta pesquisa, ao propormos a metodologia de

\footnotetext{
${ }^{55}$ A Teoria Social do Discurso desenvolve a análise textual em três níveis de abstração: nível dos eventos sociais; nível das práticas discursivas; nível das práticas sociais. No nível dos eventos discursivos, os textos são analisados como realização de uma determinada prática discursiva. No nível das práticas discursivas, por sua vez, investigase o seu encaixamento dentro de uma determinada prática social. Por fim, as práticas são discutidas em termos de sua inserção numa determinada esfera da vida social, ou, mais amplamente, dentro das estruturas sociais vigentes numa dada sociedade.
} 
análise da Movimentação Epistêmico-Axiológica, recrutamos, em especial, o sistema da AVALIATIVIDADE (MARTIN; WHITE, 2005; WHITE, 2004; GONÇALVES-SEGUNDO, 2011) e modelos de Configuração Funcional dos argumentos (TOULMIN, 1958; GONÇALVES-SEGUNDO, 2016, 2018a, 2018b; HARADA, 2009; FAIRCLOUGH, FAIRCLOUGH, 2012). Neste modelo, trabalhamos a descrição, a interpretação e a explicação sócio-histórica dos textos.

A partir da descrição, realizamos a interpretação do uso desses recursos como estratégia discursiva voltada para a construção da diferença entre posicionamentos políticos e comunidades discursivas (a partir da Teoria do Espaço Discursivo - CHILTON, 2004 - e dos desenvolvimentos propostos em relação à Teoria da Proximização - CAP, 2013, 2014a, 2014b; HART, 2014).

Por fim, a explicação sócio-histórica recruta a literatura feminista historiográfica e teórica para compreender o contexto de produção dos vídeos e a relação das youtubers e de seus públicos em rede com as comunidades discursivas referenciadas nos textos.

Como afirmamos acima, o olhar da ACD sobre os textos enquanto instâncias de linguagem em uso considera o seu encaixamento em práticas sociais específicas e a sua materialização derivada de práticas discursivas. Desenvolvida a partir do diálogo entre a Ciência Social Crítica e a Linguística Crítica, a Análise Crítica do Discurso tem um apreço especial pelo exame linguístico e textual dos corpora, sejam eles verbais, visuais ou, ainda, multimodais, por entender que eles apontam, simultaneamente, para a manutenção e para a transformação da configuração das práticas e das estruturas sociais. Isso se justifica porque, na visão da $\mathrm{ACD}$, a Semiose é entendida como parte constitutiva das práticas sociais, capaz de afetar os outros elementos da mesma (FAIRCLOUGH, 2012, p. 308). Esses outros elementos são:
a. Atividade produtiva;
b. Meios de produção;
c. Relações sociais;
d. Identidades sociais;
e. Valores culturais;
f. Consciência.

Sob esta perspectiva, a linguagem (e, de modo mais geral, a semiose) é entendida como um elemento irredutível do processo social material (WILLIAMS, 1977 apud FAIRCLOUGH, 
2012, p. 308), posto que o Discurso ${ }^{56}$ se mostra responsável por grande parte da mediação historicamente situada entre o ator social e o mundo. Por esse motivo, o foco da ACD recai sobre a relação entre a semiose e os demais elementos da prática, sobretudo os efeitos que as mudanças na vida social têm sobre a semiose de modo geral e sobre outros elementos das redes de práticas $^{57}$ - e vice-versa.

Os textos são processados pela prática discursiva (GONÇALVES-SEGUNDO, 2018, p. 81), o que envolve não apenas sua produção (o processo de construção de sentido que se processa nas etapas de roteirizar, gravar, editar e publicar um vídeo, por exemplo), como também sua distribuição (em que plataformas e de que forma ele será divulgado pelas youtubers e sua rede de parceiras e seguidoras), consumo (de que forma ele será assistido: via celular, computador, por meio de áudio e/ou legenda, etc.) e interpretação (os processos de significação que serão realizados pelas espectadoras). Como toda ação social, esses processos também se realizam no âmbito de práticas sociais específicas e, consequentemente, estão sujeitos a coerções no que se refere às condições materiais e instituições participantes das práticas (no caso, da plataforma, de eventuais estúdios ou produtoras, por exemplo), bem como aos valores, identidades e posições ocupadas pelos atoras/es sociais envolvidas/os.

As práticas sociais são analisadas em relação às estruturas; questiona-se se a prática social na qual o texto sob análise está encaixado oferece indícios sobre transformações sociais e culturais, ou se, por outro lado, reforçam as estruturas vigentes (VIEIRA; MACEDO, 2018, p. 67). Nesse sentido, deter o olhar sobre textos e discursos, buscando entender seu posicionamento numa prática social ou discursiva específica, permite entrever de que forma sua instância produtora se coloca frente a essas estruturas e se o evento discursivo pode causar algum tensionamento no processo social com vistas à mudança.

Assim, o texto pode ainda ser analisado a partir do modo como ele se insere na prática social, ou seja, em relação às ordens do discurso, a contraparte semiótica das práticas sociais: a) como parte da atividade social que se desenvolve num certo evento, i.e., no uso da linguagem, configurando o que chamamos de gêneros; b) representando o mundo, os atores, eventos,

\footnotetext{
56 A ACD de base faircloughiana estabelece uma distinção entre os termos "Discurso" e "discurso". Quando falamos em "Discurso" (ou ordens do discurso), referimo-nos às discursividades como padronizações semióticas, como coerções da (re)construção de sentido, isto é, estilos, registros, gêneros e mesmo os discursos, entre outras coisas, ao passo que quando utilizamos "discurso", trata-se de modos específicos de representar o mundo.

${ }^{57}$ Por essa dupla preocupação, a Análise Crítica do Discurso consiste em uma abordagem relacional-dialética. Relacional, pois busca entender as relações entre elementos, e dialética, porque investiga o modo como essas relações podem manter, subverter ou transformar as estruturas existentes (MATEUS; RESENDE, 2015).
} 
práticas e estruturas sociais (discursos); c) nos modos de ser que os atores desenvolvem no desempenho da prática (estilos).

As práticas sociais são, em termos gerais, as arenas de produção da vida social (FAIRCLOUGH, 2012). Nesse sentido, uma manifestação pode ser considerada uma prática social da esfera política. A $6^{a}$ Marcha das Margaridas ${ }^{58}$, que ocorreu no dia 13 de agosto de 2019 em Brasília, por outro lado, consiste em um evento social. Para sua divulgação, foram criadas diversas imagens, vídeos e textos de divulgação, compartilhados na internet e fora dela, por sua vez instâncias de práticas discursivas específicas. Durante a realização da marcha propriamente dita, as mulheres ergueram cartazes, faixas e bandeiras, que tinham como objetivo realizar denúncias, apresentar suas reivindicações, as organizações políticas às quais estavam ligadas e o mote da manifestação. Todos esses textos são também instâncias de práticas discursivas comumente vistas em manifestações e atos (cartaz, faixa, bandeira), que realizam e atualizam os potenciais das mesmas de diversas formas: nos materiais utilizados para sua produção, nas suas dimensões e na escolha lexical, por exemplo. Essas opções paradigmáticas auxiliam a análise de questões como a filiação política das manifestantes, suas reivindicações, seus modos de organização, as identidades e os discursos que constroem e mobilizam em suas práticas políticas. Além do aspecto textual, participam também da materialização do evento pessoas, recursos, crenças e valores específicos, num espaço-tempo determinado.

A prática social enquanto categoria teórica e analítica fornece à ACD um locus de investigação centrado nas tensões entre as estruturas sociais (de caráter econômico, político etc.), seus potenciais criativos e coercivos, e os eventos sociais, isto é, as atividades concretas nas quais os textos são gerados, distribuídos, consumidos, interpretados e que podem ser acessados por meio de vestígios materiais. Por exemplo, a publicação de um vídeo no YouTube integra o momento de produção da prática discursiva, enquanto compartilhá-lo no Twitter se insere na dimensão de sua distribuição. Ambos esses momentos estão, no entanto, conectados em cadeia, constituindo etapas da prática discursiva ${ }^{59}$.

\footnotetext{
58 A Marcha das Margaridas é uma mobilização que ocorre regularmente desde o ano 2000 sob organização das mulheres do campo e da floresta, promovida pela Contag, Federações e Sindicatos e consolidada na agenda do Movimento Sindical de Trabalhadores e Trabalhadoras Rurais - MSTTR e das organizações parceiras. Entre as conquistas da Marcha, destacam-se o Programa Nacional de Documentação da Trabalhadora Rural, o Plano Nacional de Enfrentamento à Violência contra as Mulheres do Campo e da Floresta e a Coordenadoria de Educação do Campo (MEC). O nome da marcha é uma homenagem a Margarida Maria Alves, uma das primeiras mulheres a ocupar cargo de liderança sindical no país, que foi assassinada em 1983 em Alagoa Grande (PB). Mais informações no livro Marcha das Margaridas de Claudia Ferreira (SILVA, 2014) e no site da Marcha (http://transformatoriomargaridas.org.br/).

${ }^{59}$ Essa ideia de etapas da prática pode ser detalhada a partir da prática discursiva da prova no contexto escolar. Embora a prova constitua uma prática discursiva só, que envolve uma diversidade de posições as quais as/os atores
} 
A prática discursiva, de forma análoga à prática social, consiste em uma cadeira de rotinização realizada por eventos sociais - textos. A cada evento de produção textual, as/os atoras/es sociais reiteram, subvertem e transformam certos aspectos da prática e outros, não.

Quando olhamos para vídeos de react a um clipe da Beyoncé, que mostram as reações dos youtubers ou de convidados em tempo real, por outro lado, vemos indícios do processo de consumo desse produto por aquela youtuber específica. De forma análoga, comentários ou textões no Facebook discutindo uma série ou filme oferecem indícios de como está ocorrendo a interpretação dos mesmos. Ainda assim, tanto os vídeos de react, quanto os comentários e textões constituem produtos, textos, em si.

Nesse sentido, entendemos que o conceito de evento social mereça ser problematizado, posto que sua definição depende da forma de "entrada" da análise, que pode se dar tanto pelo enfoque na produção, quanto pelo viés da distribuição, consumo ou interpretação. Cada uma dessas abordagens envolveria, consequentemente, categorias de análise e, possivelmente, métodos de coleta de corpus diferenciados. Análises que enfocassem consumo e interpretação de vídeos de um determinado canal no YouTube, por exemplo, poderiam trabalhar com métricas a respeito de curtidas e visualizações do canal como um todo, assim como de vídeos em específico; possivelmente envolveria uma análise quantitativa e qualitativa dos comentários, os padrões de curtidas, dislikes e compartilhamentos etc.

Para a ACD, que entende a vida social como um sistema aberto (estruturado, mas capaz de comportar mudanças), as estruturas, práticas e eventos são conectados por relações causais. Essas conexões, longe de configurarem relações mecanicistas de causa e efeito, permitem a instanciação dos poderes causais potenciais das estruturas e práticas sociais em eventos $\operatorname{concretos}^{60}$.

Em resumo, a continuidade das práticas e das estruturas sociais está dialeticamente conectada aos eventos sociais e às ações localizadas dos atores. Isso implica que os eventos sociais sejam constrangidos (e facilitados) pelos recursos materiais e semióticos disponíveis. Ao mesmo tempo, as práticas e estruturas, por sua vez, dependem de rotinas sociais que continuamente reforçam e legitimam estruturas de dominação e hegemonias (GONÇALVES-

sociais podem assumir (por exemplo, a professora, a monitora, as alunas, a corretora), ela se processa de fato ao longo do espaço-tempo de forma fragmentada, por meio de uma série de eventos sociais específicos (a elaboração da prova pela professora, a aplicação pela monitora, a resolução pelas alunas, a correção pela corretora). De forma análoga, mas um pouco mais complexa, podemos entender os processos seletivos de ingresso em programas de Pós-Graduação (PPG), que constitui uma cadeia de práticas sociais e discursivas como a prova de proficiência em língua estrangeira, a prova dissertativa, o projeto de pesquisa e a arguição do mesmo.

${ }^{60}$ Essa teorização remonta ao realismo crítico de Bhaskar, na forma do princípio epistemológico da estratificação da realidade. 
SEGUNDO, 2014, p. 1284). Em contrapartida, os tensionamentos efetuados pelos atoras/es sociais no âmbito dos eventos tanto garante essa continuidade, quanto têm o poder de ameaçála.

Assim, embora se compreenda, a partir de Fairclough (2006), que o processo de mudança social é efetuado por meio da mudança discursiva, não se pode afirmar que ele dependa unicamente da mudança de "mentalidade", derivada da inculcação de discursos - ainda que ela pareça ser essencial para iniciá-lo. Antes, questões políticas e econômicas são compreendidas como centrais para que haja mudança nas relações de poder (FAIRCLOUGH, 2006).

Dessa forma, as noções de ator/a social e de agência na Análise Crítica do Discurso se afastam tanto de concepções que assumem sujeitos socialmente determinados, quanto de noções individualistas e idealizantes de um indivíduo protagonista. Nessa perspectiva, as ações dos atoras/es sociais são parcialmente determinadas e facilitadas pela posição que se ocupa numa determinada prática. Consequentemente, a analista deve voltar especial atenção à posição ocupada pelos atores e/ou grupos sociais que são objeto de seu estudo e às relações de poder que os conectam aos demais envolvidos. Desse modo,

a abordagem [do sistema posição-prática], em casos particulares situados em práticas específicas, permite conhecer os constrangimentos e possibilidades previstos em uma determinada posição objetiva e analisar, em eventos situados, as tensões resultantes da criação de novas posições ou da ocupação subjetiva de posições preexistentes por grupos ou indivíduos historicamente localizados. (MATEUS; RESENDE, 2015, p. 458)

Isso permite considerar as tensões que envolvem tanto a instância produtora dos textos analisados, quanto as questões de distribuição, consumo e interpretação dos textos de forma sócio-historicamente situada ${ }^{61}$. Retomando o exemplo do processo seletivo que discutimos anteriormente (na nota de rodapé 46), vemos que as posições passíveis de ser ocupadas no seu processo de elaboração e em cada etapa são estruturadas a partir dos constrangimentos e possibilidades proporcionados por aspectos estruturais da instituição social em que essa cadeia de eventos é realizada.

Dessa forma, docentes, discentes e militantes interessadas/os em elaborar editais de ingresso com cotas para pessoas negras, trans, indígenas e com deficiência nos programas de Pós-Graduação (PPG) em que atuam encontrarão maior facilidade se estiverem em universidades com uma postura propositiva em relação a políticas de ações afirmativas, posto

\footnotetext{
${ }^{61}$ Essas questões serão discutidas em relação ao nosso corpus ao longo das seções e capítulos subsequentes especialmente nas análises.
} 
que existirão menos entraves burocráticos e políticos para a aprovação dessas medidas. Em contrapartida, em universidades com um histórico de engavetamento dessas propostas, esse processo possivelmente envolve a reelaboração de outros documentos, gerando um processo mais longo e disputado, envolvendo uma série de práticas sociais e discursivas, que envolvem desde a criação de comissões - responsáveis por uma cadeia de eventos sociais que envolvem o estudo de regulamentos, a revisão de regimentos, reuniões de elaboração de propostas - até a apresentação e avaliação das medidas propostas, tanto pelos membros do PPG, quanto por outras instâncias burocráticas da universidade.

A ordem social e as ordens do discurso são conceitos paralelos. Fairclough (2003, p. 3) define as ordens do discurso como "a relativamente durável estruturação da linguagem que é, ela mesma, um dos elementos da relativamente durável estruturação e articulação das práticas sociais [ordem social]" ${ }^{\prime 62}$. Assim, as ordens do discurso definem o grau de organização e controle sobre a variação da linguagem, agindo sobre os discursos, gêneros e estilos (FAIRCLOUGH, 2003, p. 24). As ordens do discurso estão ligadas a determinadas ordens sociais, tanto no âmbito global - como o neoliberalismo -, quanto em dimensões mais "locais" - como o campo da educação ou dos movimentos sociais durante os governos petistas no Brasil.

Já a ordem social é o que vai determinar os padrões de dominância entre as diversas ordens do discurso existentes numa determinada sociedade, em um determinado espaço-tempo. Assim, aspectos econômicos, políticos e ideológicos participam da definição de quais serão os discursos, gêneros e estilos hegemônicos e quais serão alternativos, ou contra-hegemônicos, em um determinado espaço-tempo. Não se trata, porém, de uma relação estática. Essas relações são constantemente reiteradas e desafiadas na dimensão dos eventos sociais, como já discutimos.

Daí vemos, por exemplo, a importância de se pautar a necessidade e a eficácia de políticas de ações afirmativas na esfera pública e de pressionar as instituições para que elas sejam adotadas de forma comprometida e responsável. Retomando, novamente, o exemplo dos editais de ingresso na pós-graduação, à medida que políticas de cotas em cursos de graduação e concursos são amplamente debatidas e aplicadas, e tanto a opinião pública quanto as instituições e o Estado se posicionam não apenas de maneira favorável, como também de forma propositiva (por meio da elaboração da Lei de Cotas e da criação de Pró-Reitorias especializadas), a conjuntura política para pautá-las nos PPG beneficia sua aprovação.

\footnotetext{
${ }^{62}$ No original, "the relatively durable social structuring of language which is itself one element of the relatively durable structuring and networking of social practices".
} 
Ademais, quando instituições reguladoras como a CAPES passam a incluir em suas Fichas de Avaliação (responsável por aferir a qualidade dos PPG a nível nacional e definir requisitos básicos para seu funcionamento, além de estabelecer critérios para a distribuição de financiamento de pesquisa) a presença de políticas de ações afirmativas como fator positivo, os PPG são instados a realizar as práticas sociais e discursivas necessárias para a elaboração dessas políticas.

Uma discussão semelhante é efetuada por Manovich (2002). Refletindo sobre os processos de significação envolvidos na produção dos textos digitais, o autor propõe que as interfaces digitais (Human-Computer Interfaces) sejam enquadradas como "interfaces culturais", lado-a-lado a códigos ${ }^{63}$ como o cinema e a língua escrita $^{64}$. Desse modo, o autor permite o estabelecimento de pontes entre as pesquisas sobre esses diferentes modos de representar a realidade, auxiliando o entendimento do advento do digital como uma inovação dentro de um continuum em vez de uma revolução desnorteadora.

Entendidas como produto de uma atividade humana, tendo sua estrutura conformada por questões econômicas e sócio-históricas, torna-se necessário investigar os códigos que alimentam as interfaces dos ambientes de sociabilidade online. Considerando que todos os códigos culturais humanos (como o cinema, as artes visuais e a língua escrita) sejam formas de linguagem, Manovich (2002) propõe que analisemos as interfaces como códigos que possibilitam a organização de dados para representar memórias e experiências humanas.

Em termos semióticos, a interface do computador age como um código que carrega mensagens culturais numa variedade de mídias. Quando se usa a Internet, tudo o que se acessa - textos, músicas, vídeos, espaços navegáveis passa pela interface do navegador e então pela interface do sistema operacional. Na comunicação cultural, um código é raramente um simples mecanismo neutro de transporte; em geral, ele afeta a mensagem transmitida por meio dele. Por exemplo, eu posso tornar algumas mensagens fáceis de entender e tornar outras impensáveis. Um código pode também prover seu próprio modelo de mundo, seu próprio sistema lógico ou ideologia; mensagens culturais subsequentes que usem esse código estarão limitadas por esse modelo, sistema ou ideologia [...]. (MANOVICH, 2002, p. 76, tradução nossa $)^{65}$

\footnotetext{
${ }^{63}$ O termo "códigos" e, mais especificamente, a noção de "código semiótico" (semiotic code) não é usualmente utilizado pela ACD, mas é largamente recrutado por Manovich (2002) para discutir vários campos de produção de sentido, desde a interface digital até o cinema, como veremos na citação reproduzida alguns parágrafos adiante.

${ }^{64}$ Numa discussão paralela, sugerimos ainda a leitura do artigo Racismo algorítmico em plataformas digitais: microagressões e discriminação em código, de Tarcízio Silva (2020).

${ }^{65}$ No original, "In semiotic terms, the computer interface acts as a code which carries cultural messages in a variety of media. When you use the Internet, everything you access — texts, music, video, navigable spaces — passes through the interface of the browser and then, in its turn, the interface of the OS. In cultural communication, a code is rarely simply a neutral transport mechanism; usually it affects the messages transmitted with its help. For
} 
Essa reflexão se faz necessária frente à passagem do status do computador de uma máquina de trabalho para uma "máquina midiática universal", que permite a visualização e interação com todo e qualquer tipo de mídia, unindo as funções de trabalho e lazer em um só objeto (FAGERJORD, 2010). Hoje, 16 anos depois, vemos o mesmo acontecer com os smartphones. Sobretudo após a invenção do push mail, as relações de trabalho foram transformadas e certas profissões vêm se tornando cada vez mais dependentes do uso de celulares e smartphones (RAMOS, 2015).

Diferentemente dos outros tipos de mídia, entretanto, a interface digital é ela mesma mediada por um metatexto: a linguagem da programação. Embora "invisível" aos olhos de grande parte dos usuários dos computadores pessoais, que não tem conhecimentos básicos de programação, ela determina todas as possibilidades de atuação, ainda que em graus variados, interferindo inclusive na representação dos eventos reportados. Por exemplo, como o YouTube gira em torno dos vídeos postados e não dos textos escritos que os descrevem ou dos comentários que se referem a eles, a própria interface estabelece uma hierarquia entre o que é mais e o que é menos importante no site - isso não impede que as/os usuárias/os criem rotas de leitura ou focos alternativos, no entanto, isso privilegia uma determinada escala de relevância.

Miller e Horst (2012) entendem que, ao contrário de modificar radicalmente a natureza das relações, o meio digital, em sua materialidade, nos auxilia a pensar sobre o caráter mediado de toda e qualquer ação social ${ }^{66}$. Se o que ocorre no mundo virtual é parte da realidade, as interações entre humanos mediadas pela internet - e mesmo entre humanos e máquinas - são práticas sociais em seu próprio direito e fazem parte da vida social assim como qualquer atividade social. Do mesmo modo, elas estão sujeitas à coerção da ordem social e das ordens do discurso e têm a capacidade de sustentar ou subverter relações de poder.

Do modo como se apresenta hoje, o YouTube permite, em termos gerais: buscar e assistir a vídeos (as únicas funções permitidas sem o cadastro), criar um canal, fazer o upload de vídeos, inscrever-se em canais, optar por receber notificações sobre novas postagens (o que alguns youtubers chamam de "ativar o sininho"), curtir ou descurtir vídeos, comentar vídeos, criar playlists e assistir aos cursos do Escola de Criadores. Grande parte dessas funcionalidades, entretanto, está disponível apenas para usuários cadastrados. Em condições de utilização comuns, sobretudo no que se refere a utilizadores não profissionais, o cadastro na plataforma

instance, it may make some messages easy to conceive and render others unthinkable. A code may also provide its own model of the world, its own logical system, or ideology [...]".

${ }^{66}$ Isso é apontado por Goffman (1985 [1956]) na Antropologia e é aceito também na linguística nas suas vertentes funcional e pragmática, que importaram as considerações do autor para sua base teórica. 
constrói uma experiência completamente personalizada. O site constantemente sugere novos vídeos para incentivar o consumo constante de conteúdo. Essas sugestões se baseiam no seu histórico de visualizações, curtidas e inscrições, além de influenciar os resultados oferecidos para as pesquisas dentro da plataforma. Em outras palavras, o YouTube sugere "mais do mesmo", isto é, vídeos alocados na mesma categoria ${ }^{67}$ ou produzidos por canais relacionados àqueles mais assistidos pelo usuário. Desse modo, o site detém o controle sobre as condições de ordenação e reapresentação do conteúdo (BURGESS; GREEN, 2009, p. 60-61).

Além disso, a interface favorece a associação entre canais, o que pode reforçar a construção de redes de canais e ativistas. Essa aplicação pode funcionar como uma lista de indicações permanente para as/os seguidoras/es do canal. Entre os dois canais analisados, apenas Nátaly Neri estava fazendo uso dessa aplicação em 2020.

Entre os canais associados, temos mulheres feministas negras e brancas, cis e trans, heterossexuais, lésbicas e bissexuais. Entre elas, Nátaly elenca dois canais grandes JoutJout Prazer (2,35 milhões de inscritos $\left.{ }^{68}\right)$ e Nunca Te Pedi Nada (1,83 milhões de inscritos) - em termos do número usual de inscritos em canais de temáticas sociais, pois, em comparação com os maiores canais do YouTube Brasil, seriam pequenos (Whindersson Nunes tem 38,4 milhões de inscritos e Felipe Neto tem 36,2 milhões de inscritos, por exemplo). Além disso, ela se associa também a canais na sua faixa, como LouiePonto (586 mil inscritos) e Tá Querida (647 mil inscritos), e também (e principalmente) canais menores. São eles: Luci Gonçalves (287 mil inscritos), Papo de Preta (113 mil inscritos), Patrícia Avelino - Beleza Negra (78,3 mil inscritos), Neggata (64,7 mil inscritos) e Canal das Travas (39,4 mil inscritos). Dentre eles, apenas JoutJout Prazer e Papo de Preta indicam o canal de Nátaly nessa coluna - os demais indicam outros canais, ou não fazem uso da aplicação.

\footnotetext{
${ }^{67}$ O Youtube hoje conta com 15 categorias de vídeos: Filmes e desenhos; Automóveis; Música; Animais; Esportes; Viagens e eventos; Jogos; Pessoas e blogs; Comédia; Entretenimento; Notícias e política; Guias e Estilo; Educação; Ciência e tecnologia; Sem fins lucrativos/Ativismo.

${ }^{68}$ Todos os dados desse parágrafo são referentes ao dia 15/02/2020. Com certeza houve crescimento de todos os canais envolvidos nos últimos 3 anos, mas em comparação uns aos outros, não houve grandes diferenças.
} 
Figura 3 - Indicações do canal Nátaly Neri

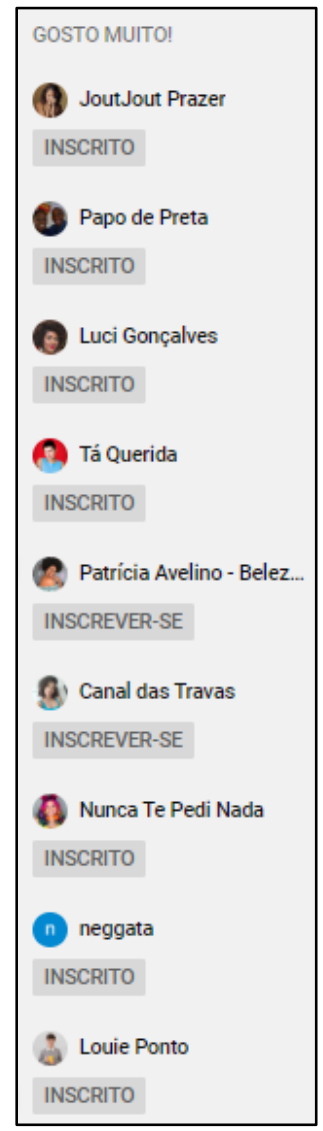

Fonte: Canal Nátaly Neri ${ }^{69}$. Acesso em 15/02/2020.

Por outro lado, outras associações (mais ou menos relevantes) podem ser realizadas com base num algoritmo padrão customizado a partir da experiência do usuário - as indicações de vídeos feitas pelo próprio YouTube em sua página inicial e na coluna vídeos relacionados, à direita das páginas de exibição de vídeos, como podemos ver na Figura 4 na página seguinte.

Consequentemente, embora as youtubers possam apontar para "caminhos de leitura" de sua própria produção e de outros (referenciando outros vídeos em seu próprio canal e em outros, sugerindo textos publicados em outras plataformas e convidando os usuários a segui-la em outros sites), essa trilha não é obrigatória nem é necessariamente a mais provável. Nesse sentido, analisar a interface é também analisar os limites e as possibilidades do site no que se refere às práticas sociais e discursivas.

${ }^{69}$ Disponível em: < Disponível em: <https://www.youtube.com/channel/UCjivwB8MrrGCMlIuoSdkrQg>. 


\section{Figura 4 - Visualização padrão do vídeo "HETEROFOBIA E RACISMO REVERSO EXISTEM? | Louie Ponto e Nátaly Neri"}

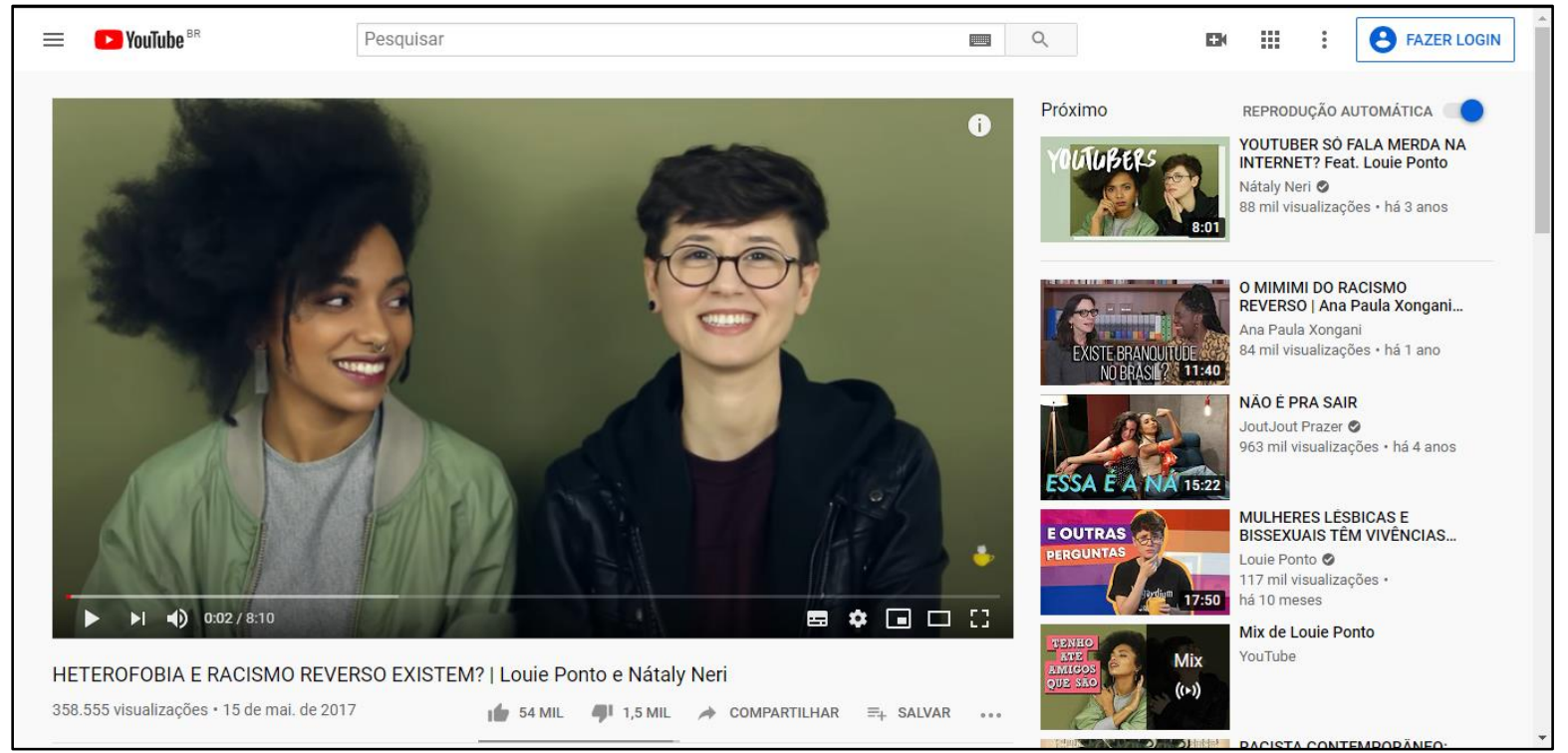

Fonte: canal Louie Ponto. Acesso em 10/11/2020 a partir do modo de navegação anônima do Google Chrome.

No que se refere aos efeitos dessas novas interfaces culturais sobre a produção artística e sobre a indústria do entretenimento, Manovich (2009) investiga também as consequências dessas mudanças no modo de funcionamento das mídias nos anos 2000 , levando em conta as facilidades para distribuição, produção e consumo de mídia e a entrada na era da mídia social. Em meados dos anos 2000, o conteúdo consumido na Internet tornava-se progressivamente mais "amador", e a rede de computadores deixava de ser um meio majoritariamente voltado para a publicação e tornava-se um meio de comunicação - o que não significava que todos os usuários consumiam conteúdo amador, ou que todos produziam algum tipo de conteúdo, mas que essa parcela de conteúdo passava a ocupar um lugar cada vez mais importante na rede de práticas digitais ${ }^{70}$.

No entanto, no que se refere às dinâmicas de produção, consumo e controle da mídia nos anos 2010, apesar da inegável criatividade e inovação inerente ao conteúdo amador, uma parcela cada vez maior do conteúdo segue certos padrões de edição e apresentação. Resta, portanto, questionarmos se, apesar de uma certa democratização da produção, essa situação não aponta para a colonização cada vez mais ferrenha das identidades e dos imaginários pela mídia

${ }^{70}$ Em termos de audiência, o que efetivamente acontecia é o que o Manovich (2009) denomina "long-tail phenomenon": as visualizações de um conteúdo amador podiam ser mínimas, mas raramente chegavam a zero. Na rede, todo conteúdo encontra uma audiência. Isso pode ser traduzido em termos econômicos no sentido de que, em muitas indústrias, o total de vendas dos itens de baixa popularidade excede a renda gerada pelos mais vendidos. 
comercial, que vende produtos previamente ou automaticamente "customizados" (como os algoritmos baseados no consumo do usuário e o caso de "subculturas", que são vendidas como estilos de vida).

Pensando no YouTube em especial, sabemos que é relevante pensar sobre a materialidade dos vídeos nele publicado: como são produzidos, gravados e editados? Quem são os atoras/es sociais envolvidas/os nesse processo? Como isso se organiza? Também se mostra necessário refletir sobre a maneira como o vídeo se apresenta para a audiência: qual é a disposição da interface, que tipos de hiperlink a página oferece, quais as diferenças na visualização causadas pela incorporação do vídeo em outras plataformas ou nos diferentes dispositivos em que pode ser reproduzido ${ }^{71}$.

As especificidades das plataformas digitais também têm consequências para as práticas discursivas e para as relações intersubjetivas. Por meio das mídias digitais, criamos redes de pessoas e de informações, participando de e construindo públicos em rede (boyd, 2011, 2014). Esses públicos, além de serem desenvolvidos por meio das tecnologias de informação e comunicação, ajudam a interligar pessoas e a formar e transformar comunidades imaginadas ${ }^{72}$. Considerar que os públicos hoje estão conectados em rede nos leva a refletir sobre as dinâmicas das interações online e offline, bem como sobre o papel das redes sociais na construção das relações sociais. Pensando nos termos da $\mathrm{ACD}$, é importante ressaltarmos que os eventos de consumo de textos publicados em plataformas digitais se processam, simultaneamente, de forma online e offline, e podem encaixar-se em uma variedade de práticas sociais.

De acordo com boyd (2014, p. 9),

O que constituiu um público nesse sentido [geral] pode variar. Ele pode ser um espaço acessível no qual as pessoas se reúnem livremente. Ou, como descreve o cientista político Benedict Anderson, um público pode ser um conjunto de pessoas que se entendem como parte de uma comunidade imaginada. As pessoas participam de uma multiplicidade de públicos delimitados enquanto audiências ou pela geografia - e, além disso, os públicos se conectam e se entremeiam. Os públicos se imiscuem entre si, o que desafia qualquer proposta de entender as fronteiras e a forma de qualquer público em particular $^{73}$

\footnotetext{
${ }^{71}$ Seria interessante investigar, ainda, quais são os hábitos de consumo de conteúdo dos usuários e os discursos circulantes na seção de comentários, por exemplo, mas isso está fora do escopo da presente pesquisa.

${ }^{72}$ A esse respeito, o propósito do público é algo a se considerar: eles podem ser de natureza política ou identitária e, ainda, construídos a partir de práticas sociais comuns (boyd, 2014, p. 9).

${ }^{73}$ No original, "What constitutes a public in this sense can vary. It can be an accessible space in which people can gather freely. Or, as political scientist Benedict Anderson describes, a public can be a collection of people who understand themselves to be part of an imagined community. People are a part of multiple publics-bounded as audiences or by geography — and yet, publics often intersect and intertwine. Publics get tangled up in one another, challenging any effort to understand the boundaries and shape of any particular public.” (boyd, 2014, p. 9)
} 
Consequentemente, embora os textos sejam escritos com um auditório em mente, na prática, podem ser consumidos por grupos sociais não previstos. Isso não impede, entretanto, que membros esses grupos consumam o texto de forma resistente, questionando, criticando e difamando as produtoras textuais.

De fato, a noção de públicos é essencial em qualquer caso para entendermos a constituição das sociedades, posto que, a partir dessas conexões individuais e coletivas, ajustamos nosso comportamento em resposta à percepção das alteridades e dos comportamentos dos outros, bem como as avaliações às quais os nossos comportamentos estão submetidos e, assim, internalizamos normas sociais. É, enfim, por meio da interação com públicos e da participação na vida pública que criamos/adquirimos/desenvolvemos conhecimento compartilhado.

Com o advento das redes sociais, os públicos previamente existentes são reestruturados pelas tecnologias conectadas (networked technologies), o que afeta tanto a sua dimensão enquanto espaço de sociabilidade quanto de comunidade imaginada (boyd, 2014, p. 8). Além disso, novos públicos são criados e as dinâmicas entre eles se modificam (boyd, 2014, p. 9-10), tendo em vistas as affordances (potenciais e coerções materiais que incentivam ou impossibilitam práticas sociais) das plataformas digitais às quais estão vinculados (boyd, 2014, p. 10-11).

A esse respeito, boyd elenca 4 tipos principais de affordances, comuns a todos os públicos, que são transformadas pelas novas tecnologias. São elas: persistência, "espalhabilidade", "buscabilidade" e visibilidade.

1. Persistência: a durabilidade das expressões e do conteúdo publicado online - algumas interações se tornam menos efêmeras, como por exemplo a troca de mensagens de texto, a publicação de fotos no Facebook e no Instagram, que ficam arquivadas indefinidamente se esse for o desejo do usuário; mesmo os gêneros que foram pensados justamente para a qualidade efêmera, como os posts de Snapchat, que podiam ser abertos apenas uma vez ou ficava publicados somente por horas foram remixados e hoje participam do Instagram, por exemplo, e ficam arquivados por default.

2. "Espalhabilidade": a facilidade para compartilhar conteúdo - o compartilhamento é encorajado por meio de numerosas ferramentas, como o encaminhamento e a repostagem de textos, bem como o encaixamento de conteúdo de outras plataformas para reprodução ou em formato resumido e o uso de hashtags. 
3. "Buscabilidade": a habilidade de encontrar conteúdo online - potencializada por meio de buscadores, o uso de hashtags e palavras-chave.

4. Visibilidade: a audiência potencial dos conteúdos - potencializada pelas características descritas acima, a visibilidade deixa de depender tão fortemente de interações de proximidade geográfica.

As dimensões da visibilidade e da persistência se mostraram especialmente relevantes para o nosso trabalho, tendo em vista que possuem consequências sérias para as práticas de consumo e de interpretação dos textos. Esse aspecto será elaborado no capítulo 2.

Por outro lado, na dimensão dos públicos em rede enquanto comunidades imaginadas, percebemos que, além de ser uma plataforma de exibição de vídeos, o YouTube se configura como uma rede de pessoas (produtores, "support workers" e audiência) baseada no conhecimento partilhado e negociado de valores estéticos, domínio de tecnologias e técnicas. A participação dos usuários nas diversas atividades permitidas na plataforma é o que move o site e a comunidade, configurando uma rede de práticas criativas (BURGESS; GREEN, 2009, p. 61 , tradução nossa).

Entretanto, longe de ter como propósito a criação de uma comunidade, o objetivo principal do YouTube sempre consistiu na criação de uma audiência para conteúdos publicitários - o que foi alcançado permitindo que os usuários publicassem e assistissem a vídeos online (BURGESS; GREEN, 2009). Isso não teria impedido, entretanto, que se construísse por meio da plataforma uma comunidade participativa ${ }^{74}$. Pelo contrário, Burgess e Green (2009) argumentam que o alvoroço comercial que se fez em torno da plataforma ajudou a alavancar essa comunidade. Para os autores, a discussão sobre a natureza da plataforma não deveria girar em torno de sua natureza mais ou menos comercial, mas antes deveria focalizar as tensões existentes entre o engajamento dos participantes na comunidade e a lógica de mercado que a governa. Com isso, torna-se possível perceber de que formas diferentes grupos sociais - por sua vez articulados em práticas sociais e discursivas concretas - colaboram para ou diminuem o potencial de diálogo intercultural dentro do YouTube

Os autores defendem que o YouTube seja uma arena em potencial para o desenvolvimento de uma cidadania cultural cosmopolita (BURGESS; GREEN, 2009, p. 81). Os desafios que essa configuração envolve são maiores do que apenas a colonização/coerção

\footnotetext{
${ }^{74}$ Ainda assim, é inegável que o propósito e a organização da plataforma tenham consequências importantes para as estratégias de produção e de distribuição do conteúdo e, consequentemente, afetem o consumo desses textos. Parece tratar-se de um contágio dos estilos da esfera publicitária.
} 
de uma lógica de mercado sobre a plataforma - sabemos que essas estruturas podem ser pelo menos tensionadas -, mas tocam em questões como o letramento digital, capital cultural, acesso a e domínio de tecnologias específicas. É o que se denomina "gap de participação", e isso significa que, apesar de uma certa ampliação no rol de produtores de conteúdo, o direito à voz ainda é um privilégio de poucos. A plataforma reconhece a potência da cultura participativa e constrói sua imagem com base no engajamento dos usuários.

De forma resumida, para ou autores (BURGESS; GREEN, 2009, p. 86-87, tradução livre),

\begin{abstract}
A impressão geral é a de que se trata de uma companhia que negocia com uma variedade de estruturas regulatórias nacionais e demandas corporativas ao mesmo tempo que mantém uma marca baseada na acessibilidade universal e ideologicamente encaixada num modelo particularmente estadunidense de "liberdade de expressão" ["free speech"]. Tensões emergem pela necessidade de controlar em quais "mercados" certos conteúdos são acessados (um problema primariamente para provedores corporativos de conteúdo como gravadoras e redes de televisão) ou para navegar pela regulação de conteúdo e pelos regimes de censura de países particulares - por exemplo, comprometer-se com a severa regulação sobre discurso de ódio e a imagética neonazista na Alemanha.
\end{abstract}

Ao longo dos últimos dez anos, no entanto, as políticas de defesa da "liberdade de expressão" expressas pela plataforma têm sido amplamente questionada por youtubers de orientação política progressista e pesquisadoras/es, que denunciam as diretrizes da comunidade e os critérios de avaliação que permitem a permanência e mesmo monetização de canais que apresentam conteúdo racista, misógino, LGBTfóbico, capacitista, entre outros. A complacência com influenciadores e grupos de trolls ${ }^{75}$ que promovem ataques de natureza semelhante a canais, figuras públicas e mesmo pessoas comuns também tem sido alvo de críticas.

Para além dessas práticas discursivas mais "visíveis", recuperamos Silva (2020) para afirmar que essas denúncias expõem a ausência de neutralidade das plataformas e o funcionamento do racismo online. Como coloca o autor (SILVA, 2020, p. 122),

Nos ambientes digitais, entretanto, temos um desafio ainda mais profundo quanto à materialidade dos modos pelos quais o racismo se imbrica nas tecnologias digitais através de processos "invisíveis" nos recursos automatizados como recomendação de conteúdo, reconhecimento facial e processamento de imagens. É preciso entender também suas manifestações "construídas e expressas na infraestrutura online ou back end (ex.: algoritmos), ou através da interface (ex: símbolos, imagens, voz, texto e representações gráficas)" (Tynes et al, 2019, p.195).

\footnotetext{
75 Trolls são, em linhas gerais, usuários que publicam "mensagens ou comentários provocadores, maldosos ou ofensivos em sítios de discussão pública on-line, com intuito desestabilizador” (TROLLAR, 2021).
} 
Considerando, entretanto, os propósitos dessa dissertação, vamos nos deter com mais atenção ao que Trindade (2018) afirma sobre o crescimento do discurso de ódio em ambientes digitais, o que desafia a pretensa noção de uma internet naturalmente democrática e "colourblind", isto é, uma internet "que não vê cor" e por isso está além do racismo estrutural como sistema político. O autor refuta essa noção com base na indissociabilidade entre os ambientes virtual e off-line, do que decorre que "raça é importante no cyber-espaço precisamente porque não podemos evitar de levar conosco nosso conhecimento, experiências de vida e valores pessoais quando nos conectamos" (KOLKO ET AL., 2000, p. 5 apud TRINDADE, 2018 , p. $30)$.

Dessa forma, se a sociedade brasileira é marcada pelo racismo estrutural, pela misoginia e pela LGBTfobia, os ambientes de sociabilidade online não estarão livres das assimetrias de poder que marcam as relações sociais no país. Ao discutir ataques racistas a mulheres negras em redes sociais, Trindade (2018) afirma que

[...] discursos depreciativos contra pessoas negras nas redes sociais (sobretudo mulheres e transmitidos através de piadas) representam articulações ideológicas que estabelecem posições racistas. Ademais, é importante ressaltar que representações raciais em discursos é essencialmente uma prática relacional (Leonardo, 2013). Isso significa dizer que discursos depreciativos exploram e amplificam diferenças percebidas entre grupos raciais a fim de ressaltar atributos de cunho negativo dos 'outros' (p. ex. perpetrador, sem escolarização, não atraente, etc.) e, em contraste, reafirmar a condição normativa e privilegiada do grupo hegemônico. Nesta dinâmica relação binária e antagônica, "negritude é sempre retratada como maligna, irracional e não-escolarizada em contraste com a branquitude" (Yoon, 2016, p. 110). Além disso, a combinação dos atributos de cunho negativo identificados nos posts analisados transmite a ideia de anomalia social no que tange as mulheres negras, seguindo reflexão desenvolvida por Guimarães (2000). Isso significa dizer que ao promover este tipo de associação por intermédio de discursos depreciativos, os usuários estabelecem espaços sociais diferenciados por meio de posições antagônicas.

Assim, com o progressivo aumento da presença e importância das relações estabelecidas com/por meio das redes sociais, assim como dos discursos que circulam nas mesmas, para a construção das subjetividades e para as dinâmicas econômicas, políticas e sociais no Brasil, torna-se extremamente relevante monitorar, avaliar e interpretar práticas discursivas racistas, misóginas e LGBTfóbicas efetuadas nas redes sociais como instâncias de políticas de silenciamento. Conforme conclui o autor (TRINDADE, 2018, p. 35-36),

Desta forma, as desigualdades sociais e raciais se perpetuam no Brasil e, por sua vez, as plataformas de redes sociais representam a arena contemporânea para a construção, disseminação e reforço de tais valores distorcidos, ou uma espécie de 'pelourinho moderno' (Trindade, 2018b). Na medida em que este crescente fenômeno social se torna um componente natural do cenário virtual 
brasileiro, conforme revelado por diferentes estudos (Safernet, 2015; Boehm, 2018; Tavares, 2018; Trindade, 2018b), corre-se o risco de a sociedade perder a capacidade de se indignar perante desigualdades raciais, já que os discursos de cunho racistas se tornam amplamente difundidos, naturalizados e reforçados.

É necessário ainda considerarmos a classe como aspecto determinante para a participação da esfera pública que se constitui nas redes. Em 2017, o Brasil ocupava o posto de segundo maior mercado mundial da plataforma, com 98 milhões de usuários (THINK WITH GOOGLE, 2017a). Entretanto, esse valor significa que menos da metade da população acessava a plataforma (cerca de $46 \%$ da população brasileira). Esses números, aliados à estrutura do algoritmo de recomendações do YouTube, reforçam nosso entendimento de que, embora a plataforma seja dotada de algum potencial para o diálogo intercultural e para o encontro com a alteridade, está sujeita às coerções materiais que restringem o acesso à Internet no Brasil.

O que era efêmero, transiente, imapeável e invisível hoje é permanente, mapeável e visível (MANOVICH, 2009, p. 324). Em parte, isso se justifica pela transformação de certas instituições/plataformas, que se tornaram, em um certo sentido, "permissivas", desenhadas para permitir hacks e remixes (em pequena escala), "encorajando" os usuários a customizá-las e a criar novas aplicações. Em contrapartida, essa permissividade também se baseou no adestramento ou abdução das táticas utilizadas pelos usuários para burlarem ou subverterem a arquitetura das plataformas.

Ainda assim, apesar da crescente homogeneização no conteúdo e na estética de muitos canais, a criatividade dos usuários sempre se baseou, em algum grau, em conteúdo préexistente, valendo-se dos processos de apropriação e/ou remix da cultura comercial. Essa contradição estruturante da plataforma é um exemplo do fenômeno da complicada convergência dos modos de produção cultural mercadológica e não mercadológica, que se baseia na incorporação de modos de produção cultural marginais, comunitários e ligados a grupos e culturas não-hegemônicos à lógica comercial de corporações midiáticas (BURGESS; GREEN, 2009, p. 75).

$\mathrm{Na}$ seção anterior, apresentamos um breve histórico acerca dos movimentos feministas no Brasil no período pós-redemocratização para localizar atuação das youtubers em meio a essas comunidades mais amplas (feminismos negros e lésbicos), que se articulam por meio de uma rede de práticas sociais e discursivas, como as blogagens, as manifestações, as rodas de conversa, os congressos etc. Interessa-nos, em especial, o modo como esses novos grupos e atoras/es sociais têm se valido das redes sociais para inserir-se na esfera pública e influenciá-la para melhor endereçarmos a análise discursivo-argumentativa. 
Havia muitas possibilidades de pesquisa nesse sentido de analisar as relações entre as youtubers e sua audiência. Optamos por nos voltar para o modo como essa relação era construída textualmente. Ainda assim, acreditamos que uma investigação etnográfica contribuiria muitíssimo para uma melhor compreensão a respeito de como essas relações se controem e se transformam por meio das interações on/offline envolvendo os vídeos e para além deles (em outras plataformas, por exemplo). Como a gestão das polêmicas e das relações de grupos se sobressaiu nas análises preliminares, quando nosso objetivo era olhar para as dinâmicas discursivas de empatia/antagonismo, optamos por seguir com essa perspectiva.

Gonçalves-Segundo (2020c), em seu modelo multidimensional de análise argumentativa, considera três possibilidades de visada argumentativa: o convencimento, a persuasão e a preservação ideológica. O autor estabelece que cada uma dessas orientações dá origem a espécies diferentes de práticas argumentativas e, consequentemente, a uma diversidade de tipos argumentativos, que estariam ligados, por sua vez, a padrões de raciocínio ou de realização multimodal, que se manifestam por meio de operações de perspectivação conceptual $^{76}$. No nosso caso, investigamos de que forma a Movimentação EpistêmicoAxiológica pode compor estratégias discursivas no campo do ativismo.

A partir das análises dos vídeos que compõem o nosso corpus, entendemos que a sua visada argumentativa consista em um tipo específico de preservação ideológica ${ }^{77}$. Com a distribuição dos discursos feministas para diversos campos de atuação, como sugere Sonia Alvarez (2014), a necessidade de diversificar as formas argumentativas parece ter crescido, e as youtubers em questão (também por se dirigirem a um público jovem, em fase de formação escolar/acadêmica) operam estratégias discursivas voltadas tanto para a sedimentação de certos acordos do endogrupo feminista, quanto para a sugestões de estratégias para o diálogo e/ou disputa de narrativas e espaços com membros do endogrupo e/ou do exogrupo.

Por esse motivo, ao longo das análises, concluímos que era necessário analisar os possíveis auditórios dos vídeos. O auditório, na perspectiva da Nova Retórica, permite a análise

\footnotetext{
76 De acordo com o autor, essas operações de perspectivação seriam responsáveis por estabelecer um posicionamento epistêmico em relação às representações e às avaliações construídas discursivamente. Essa tomada de posição pode ser realizada por meio de uma variedade de mecanismos linguístico-discursivos, responsáveis por atribuir o estatuto de realidade de uma proposição, determinar o grau de comprometimento em relação aos enunciados que produzimos, dialogar com outras vozes para (des)autorizar nossos enunciados e proposições, ou os enunciados e proposições de outros (GONÇALVES-SEGUNDO, 2020b, p. 5).

${ }^{77}$ Gonçalves-Segundo (2019, p. 112) define a preservação ideológica da seguinte forma: “o efeito perlocutório de confirmar/reforçar dada concepção de realidade, pela apresentação tanto de Dados e Alegações que já são compartilhados e acordados entre os membros do endogrupo (nós), quanto de Refutações a argumentos que já são considerados inválidos pelo mesmo grupo. Esse processo está ligado, portanto, à manutenção dos sistemas de crença dos conceptualizadores, o que pode gerar efeitos positivos na construção da identificação, mas efeitos negativos em termos de enviesamento".
} 
da representação do "conjunto daqueles que o orador quer influenciar com sua argumentação" (PERELMAN; OLBRECHTS-TYTECA, 2002, p. 22) e é entendido como uma construção da oradora, devendo estar alinhado à realidade social e psicológica daqueles que se quer influenciar. Não corresponde, entretanto, à plateia que de fato a ouve/vê. Trata-se de uma entidade que não possui existência real e apenas materializa-se no texto.

Assim, o conhecimento sobre aquelas/es que consumirão o texto é essencial para a elaboração de estratégias argumentativas eficazes, tendo em vista que, para Perelman e Olbrechts-Tyteca (2002[1958], p. 23)

Cada meio poderia ser caracterizado por suas opiniões dominantes, por suas convicções indiscutidas, pelas premissas que aceita sem hesitar; tais concepções fazem parte da sua cultura e todo orador que quer persuadir um auditório particular tem que se adaptar a ele. Por isso a cultura própria de cada auditório transparece através dos discursos que lhe são destinados [...].

Essas informações relevantes podem ser: a posição social ocupada pelos consumidores textuais em uma determinada prática ou instituição social (PERELMAN; OLBRECHTSTYTECA, 2002[1958], p. 23) ou mesmo a posição ocupada no próprio evento social de consumo do texto argumentativo (PERELMAN; OLBRECHTS-TYTECA, 2002[1958], p. 24); os valores, as crenças e os interesses dos mesmos. Isso nos leva a refletir sobre a relevância das identidades e das filiações discursivas na formação do auditório, a quem os vídeos se destinam primariamente.

Conforme mencionamos anteriormente, boyd (2014) chama a atenção para as mudanças nas dinâmicas de visibilidade dos conteúdos e para o fato de que um mesmo ator social pode participar de uma enorme variedade de públicos simultaneamente, de forma menos restrita a sua localização geográfica ou identidade social. Assim, ao discutirmos o auditório de um determinado canal no YouTube, é necessário considerar que ele é constituído a partir de/em diálogo com uma variedade de públicos, cujos interesses, gostos e orientações políticas se interseccionam. A própria variedade de temas abordados por cada canal pode dar mostras dessas intersecções.

Além disso, é importante considerar de antemão a opinião das consumidoras acerca da oradora, de seu posicionamento e do tema que será tratado. Nesses termos, é possível supor três tipos de auditório: um auditório puramente afiliado à mesma discursividade da oradora; um auditório afiliado de forma dissociativa, inserido numa discursividade contrária; e, ainda, um auditório heterogêneo, composto por um posicionamento ambíguo. Esses auditórios são formados a partir da percepção da produtora textual a respeito dos valores que embasam as diversas discursividades que participam do debate público em torno de uma certa questão. 
Novamente, para discernir o tipo de auditório focalizado pelo texto, será necessário avaliar os valores, crenças e posicionamentos que estão em discussão e quais não. No que se refere aos vídeos analisados, entendemos que o auditório focalizado é composto por jovens mulheres feministas (ou simpáticas a movimentos que lutam por igualdade de gênero) sobretudo negras, no caso do canal Nátaly Neri, e mormente lésbicas, no caso do canal LouiePonto. De forma mais ampla, estão endereçados primariamente para integrantes do campo axiológico progressista, em especial àquelas/es engajadas/os com os movimentos negro e LGBTTIAPN+. Isso não significa, entretanto, que esse seja o caso de todos os vídeos desses canais, nem que o consumo do vídeo por usuários conservadores não seja esperado. Esses diferentes auditórios estão relacionados também a possíveis modos de leitura (MARTIN; WHITE, 2005), sobre os quais levantaremos hipóteses no Capítulo 3.

Dessa forma, considerando que LouiePonto e Nátaly Neri compartilhem um certo número de seguidoras e, por outro lado, que tenham seguidoras que, mesmo participando do mesmo campo progressista, não estão completamente integradas nas discursividades dos movimentos LGBTTIAPN+, feminista e/ou negro, compreendemos que há propósitos estratégicos na definição dos temas e das estratégias argumentativas dos vídeos colaborativos entre youtubers ativistas ligados a diferentes movimentos sociais.

A partir das análises, percebemos que, muitas vezes, a construção do auditório não coincidia com a construção do Outro. Enquanto o auditório visado parece consistir, na maioria dos casos, em membros do endogrupo alinhados ao posicionamento das vozes autorais em relação ao problema em debate, o Outro costuma se estabelecer como membros do endogrupo que apresentam alguns valores ou crenças em contradição com os valores e crenças das youtubers.

Vimos, portanto, que o principal objetivo dos vídeos não se trata de resolução de conflitos sociais entre atores/grupos sociais previamente antagonizados, mas sim de um debate que visa à dissolução do dissenso dentro de um grupo mais ou menos coeso. Por esse motivo, entendemos que a visada argumentativa dos vídeos consista em um tipo específico de preservação ideológica a formação política. Trata-se, mais do que convencer aqueles que apresentam um posicionamento ambíguo em relação ao problema em pauta, de apresentar estratégias discursivas possíveis de diálogo e/ou disputa de narrativas e espaços com membros do endogrupo e/ou do exogrupo para aquelas/es que já aderiram ao posicionamento defendido pelas youtubers. Isso não significa, entretanto, que não se preze pelo convencimento/persuasão, 
mas que estes objetivos são secundários. Essas considerações serão recuperadas no capítulo 3 quando apresentarmos nossas hipóteses de leitura.

No capítulo seguinte, partiremos da discussão das políticas de silenciamento a partir de uma perspectiva feminista negra em diálogo com os estudos sobre a empatia para discutirmos as estratégias discursivas feministas de combate a ataques racistas, misóginos e LGBTfóbicos.

A partir da noção de públicos em rede resenhada neste capítulo, tomamos consciência da importância do reconhecimento dos grupos que participam da audiência dos canais analisados. No entanto, considerando a abordagem adotada por esta pesquisa, que não envolve uma metodologia etnográfica para realizar essa delimitação, partimos do conceito de auditório da Nova Retórica para darmos conta dessa problemática. Encontramos, assim, no posicionamento argumentativo frente a uma determinada questão um eixo de análise produtivo para a delimitação das comunidades discursivas representadas nos vídeos que compõem o corpus. Nisso consiste, em parte, a noção de Movimentação Epistêmico-Axiológica que será apresentada a seguir. 


\section{Capítulo 2 - A Movimentação Epistêmico-Axiológica: discussões teórico- metodológicas}

\section{Introdução}

Nesta dissertação, investigamos os usos da Movimentação Epistêmico-Axiológica como estratégia discursiva em práticas do ativismo digital em ambientes de sociabilidade online, mais especificamente em vídeos de ativistas feministas no YouTube. No corpus sob análise, refletimos sobre como as youtubers LouiePonto e Nátaly Neri utilizam recursos linguísticos, discursivos e argumentativos para discutir temas relevantes para os feminismos contemporâneos e suas intersecções com pautas dos movimentos negros e LGBTTIAPN+ em geral.

Mais especificamente, hipotetizamos que investigar como as youtubers constroem comunidades discursivas e se posicionam em relação a elas a partir de respostas a respeito de uma determinada pergunta argumentativa permitirá aprofundar a análise e a interpretação dos modos de funcionamento de estratégias discursivo-argumentativas elaboradas pelos ativismos digitais na contemporaneidade. Para tanto, concorre um esforço teórico-metodológico de base cognitivo-funcional e discursivo-argumentativa que elabora e dialoga com conceitos, teorias e metodologias de análise já existentes para considerar essa estratégia discursiva (doravante denominada Movimentação Epistêmico-Axiológica) em três dimensões: cognitiva, retóricoargumentativa e dialógico-atitudinal.

Para a análise da dimensão cognitiva, participam os conceitos de Espaço Discursivo (CHILTON, 2004) e perspectivação conceptual (HART, 2014; GONÇALVES-SEGUNDO, 2017, 2018b), assim como a Teoria da Proximização (CHILTON, 2004; CAP, 2013; HART, 2014).

Na consideração da dimensão discursivo-argumentativa, trabalhamos com estudos sobre a Configuração Funcional dos Argumentos (tanto em perspectiva epistêmica TOULMIN，2006; GONÇALVES-SEGUNDO，2016，2018a，2020a; HARADA，2009; SOUSA, 2018 -, quanto prática - Isabella FAIRCLOUGH; Norman FAIRCLOUGH, 2012; SOUSA, 2018; GONÇALVES-SEGUNDO, 2019a), e com a abordagem da Análise Crítica do Discurso, mais especificamente a concepção dialético-relacional do discurso (FAIRCLOUGH, 2003, 2006, 2012; GONÇALVES-SEGUNDO, 2018c), discutida no capítulo anterior.

Quanto à dimensão dialógico-atitudinal, consideramos o sistema de AVALIATIVIDADE (MARTIN; WHITE, 2005) e os achados de pesquisas sobre a empatia, a dispatia e o 
antagonismo a respeito da constituição da alteridade, do estabelecimento da noção de Self e dos recursos discursivos empregados nas tentativas de entendimento através da alteridade (PRESTON; DE WAAL, 2002; Lynne CAMERON, 2011, 2012, 2013; HOLLAN, 2017; Heidi MAIBOM, 2017; Shannon SPAULDING, 2017; GONÇALVES-SEGUNDO, 2019b).

Em termos da organização das seções, o capítulo está dividido da seguinte forma:

$\mathrm{Na}$ primeira seção, realizaremos a apresentação do modelo dinâmico de empatia e dispatia elaborado por Cameron $(2012,2013)$, com contribuições de discussões realizadas no âmbito da psicologia social, da filosofia e da antropologia, bem como exporemos a Teoria da Proximização, conforme exposta em Cap $(2013,2014)$ e Hart (2014). Essas discussões serão articuladas ainda à consideração das políticas de silenciamento de grupos sociais marginalizados a partir de perspectivas feministas negras para discutirmos estratégias discursivas de enfrentamento a esses mecanismos, mais especificamente o conceito de epistemicídio (Sueli CARNEIRO, 2005), os ativismos do lugar de fala (Djamila RIBEIRO, 2017), o racismo cotidiano e a postura de "calar-se e ouvir" como forma de exercer a empatia (Grade KILOMBA, 2019), eu e nós político (Mariana Jafet CESTARI, 2015, 2017), as imagens de controle, os processos de autodefinição e autoavaliação (Patricia Hill COLLINS, 2019 [2000]; Winnie BUENO, 2020). Objetivamos apresentar os potenciais de cada perspectiva para a análise discursiva, bem como discutir os impasses que encontramos na aplicação das duas primeiras teorias e de suas respectivas abordagens metodológicas sobre o corpus desta pesquisa.

Na segunda seção, justificada a necessidade de aprofundarmos algumas discussões e aprimorarmos a metodologia de análise de textos para contemplarmos a diversidade de estratégias de mapeamento do espaço discursivo presentes no corpus selecionado, apresentaremos a Movimentação Epistêmico-Axiológica (MEA) enquanto estratégia discursiva multidimensional, definindo os conceitos e metodologia de análise correlata.

Posteriormente, discutiremos sua aplicação enquanto aparato teórico-metodológico e apresentaremos brevemente as categorias de análise recrutadas, a saber: a Configuração Funcional dos Argumentos (TOULMIN, 2006; GONÇALVES-SEGUNDO, 2016, 2019a, 2020a; FAIRCLOUGH; FAIRCLOUGH, 2012; SOUSA, 2018) e o sistema de AVALIATIVIDADE. Por fim, exporemos as categorias de análises elaboradas nesta pesquisa para a depreensão dos efeitos discursivos decorrentes das estratégias discursivas instanciadas.

\subsection{Movimentação Epistêmico-Axiológica: embasamento teórico}


Ao propormos alguns diálogos entre os estudos sobre Empatia e perspectivas feministas negras a respeito das políticas de silenciamento e as estratégias de enfrentamento aos mesmos - nomeadamente as discussões e análises efetuadas por Sueli Carneiro (2005) no campo da Educação; por Mariana Jafet Cestari (2015, 2017), na Análise do Discurso; por Patricia Hill Collins (2019a,2019b; BUENO, 2020), na Ciência Política; por Grada Kilomba (2019), na Psicanálise; por bell hooks (2019), na crítica cultural, e por Djamila Ribeiro (2017), na Filosofia - acreditamos ter obtido um ganho substancial para não só para a compreensão das estratégias argumentativas das youtubers, sobretudo no que se refere aos processos de reenquadramento de questões argumentativas, como também para o entendimento dos critérios para estabelecimento de redes de solidariedade entre diversos movimentos presentes no campo dos ativismos contemporâneos.

Os estudos sobre Empatia são bastante diversos e amplos, e se mostraram relevantes para esta pesquisa, em parte, devido à relevância que os relatos pessoais assumem nas estratégias discursivas dos vídeos analisados, o que se coaduna com certas tendências do ativismo feminista digital desenvolvidas no Capítulo 1. Iniciaremos a discussão sobre os estudos da Empatia na seção seguinte com o modelo dinâmico de empatia e dispatia elaborado por Cameron $(2012,2013)$ no âmbito do projeto Living With Uncertainty, e alguns dos desdobramentos dessa perspectiva (nomeadamente, GONÇALVES-SEGUNDO, 2019b), assim como desenvolvemos algumas problematizações levantadas pela filosofia, pela antropologia e pelas ciências cognitivas a respeito do processamento desses fenômenos.

Destecamos esta perspectiva pois a sua noção de Outro e os recursos discursivos depreendidos nesse projeto se mostraram especialmente relevantes para o desenvolvimento da noção de entidade discursiva, que propomos como um dos conceitos centrais da teorização e da metodologia da Movimentação Epistêmico-Axiológica.

A teoria da Proximização, explorada na seção 1.2, por sua vez, tem como objeto de estudo a construção da legitimação de propostas de ação intervencionistas com base em metáforas de domínio-fonte espacial. Dessa forma, sugere o diálogo entre cognição, linguística, discurso e argumentação. Acreditamos que a concepção de um espaço discursivo corporeado (CHILTON, 2004), da forma como é abordado pela teoria (organizado a partir dos eixos espacial, temporal, epistêmico e avaliativo ou axiológico), apresente contribuições relevantes para os estudos discursivos em geral, em especial aqueles preocupados com questões argumentativas e, sobretudo, aqueles que se voltam para o aspecto intersubjetivo da linguagem e, mais especificamente, para a construção de efeitos perlocucionários de solidariedade, 
neutralidade e antagonismo. Destacamos, nessa teoria, as noções de entidades externas e internas ao centro dêitico, que foram também determinantes para a formulação das entidades discursivas, assim como as tipologias de Proximização, que inspiraram a nossa tipologia de movimentos de aproximação e afastamento epistêmico-axiológico.

\subsubsection{O combate a políticas de silenciamento: contribuições dos estudos sobre a empatia e do feminismo negro}

Quando discutimos o histórico de lutas de grupos sociais historicamente silenciados e marginalizados em territórios colonizados, como mulheres negras e/ou lésbicas, em específico, vemos que o combate a estereótipos e mitos sociais - as imagens de controle (COLLINS, 2019) - consistem em importantes eixos de para a discussão de políticas de silenciamento.

A relevância que esse combate assume na contemporaneidade se deve ao fato de que os estereótipos e mitos são aspectos fundamentais para a exclusão desses grupos dos debates da esfera pública. Além de fatores econômicos, esse processo de marginalização e exclusão de populações que são alocadas no espaço da alteridade em imaginários coloniais - em oposição ao Eu hegemônico branco, masculino, heterossexual e cisgênero - consiste na deslegitimação da fala e, consequentemente, das pautas e das agendas coletivas dessas populações, e se apoia em processos cognitivos de fundo relacionados ao processamento da empatia e da dispatia.

Em termos amplos, a empatia pode ser entendida como uma disposição ou capacidade mais ou menos estável de um indivíduo, que determina as possibilidades de conexão e entendimento com outra pessoa (doravante denominada Outra/ $\mathrm{o}^{78}$, alvo ou objeto da empatia/dispatia ${ }^{79}$ ) por meio do diálogo, bem como uma intenção ou atitude que ajuda a orientar e ajustar os rumos de uma conversa (CAMERON, 2013, p. 7). O termo também é utilizado para referenciar uma resposta neural automática a eventos - em geral, trata-se da percepção de algum tipo de dor ou desconforto em outra pessoa - ou o esforço imaginativo de se colocar no lugar do Outro e tentar entender suas crenças, valores e sentimentos (CAMERON, 2013, p. 7).

A empatia pode ainda corresponder à escolha moral ou ética (a priori ou circunstancial) de considerar o Outro como um ser humano complexo e particular, que merece compreensão e atenção, ainda que esta/e não compartilhe dos valores, crenças e desejos do Eu (CAMERON, 2013, p. 7).

\footnotetext{
${ }^{78}$ Este conceito de Outra/o se aplica às discussões efetuadas apenas nesta seção e não se confunde com a noção de Outra/o que utilizamos nas discussões e análises de espaços epistêmico-axiológicos.

${ }^{79}$ Cada um desses termos está ligado ao estudo da empatia em campos do saber específicos. Enquanto Outra/o se encontra filiado aos estudos do discurso e da alteridade, os termos alvo e objeto da empatia são utilizados nos estudos psicológicos.
} 
A depender da situação, o Outro pode ser um indivíduo específico ou um grupo social. Em algumas teorias psicológicas (em especial, na psicanálise), é entendido como fruto do Eu, no sentido de que é construído por meio da projeção daquilo que o Eu conhece ou imagina a respeito de um determinado indivíduo ou grupo social (CAMERON, 2012). Consequentemente, essa projeção pode ser mais ou menos "fiel" à realidade a depender do grau de conhecimento do Eu a respeito do Outro.

Nessa perspectiva, a empatia consiste no exercício do "entendimento criativo": imaginar-se no lugar do Outro com base no que se sabe sobre as suas experiências, suas crenças e valores, sua trajetória de vida, seu posicionamento no mundo, sua corporeidade etc. Entretanto, esse exercício é sempre incompleto, posto que só podemos buscar desenvolver esse entendimento a partir de nossas próprias experiências.

Uma vez que depende desse esforço imaginativo, a empatia é dinâmica, construída e desenvolvida por meio do diálogo, historicamente situada, carregada de valores e inacabável. Em geral, ela se desenvolve com base na percepção da alteridade, isto é, o entendimento de que exista algum grau de diferença entre o Eu e o Outro (CAMERON, 2011, p. 3).

Ademais, a empatia é considerada um processo cognitivo essencial para a formação e manutenção de laços sociais duradouros (ANDERSON; KELTNER, 2002, p. 21). Primeiramente, porque ela coordena as ações de diferentes indivíduos de forma eficiente, estabelecendo uma coesão intragrupal importante para aproveitar oportunidades de interação e responder a ataques contra o grupo (ANDERSON; KELTNER, 2002, p. 21). Além disso, ela ajuda a entender o que se passa na cabeça de outra pessoa, quais são seus pensamentos, sentimentos e emoções.

Esse exercício de tentar entender os pensamentos, sentimentos e emoções do Outro pode auxiliar aquela/e que empatiza a ter uma noção um pouco mais precisa do que é estar neste outro lugar, isto é, torna-se mais fácil tomar a perspectiva do Outro, perceber com mais precisão quais são suas intenções e motivações e negociar mais facilmente acordos e soluções comuns. Esse senso de solidariedade, fruto de um complexo e reiterado processo empático, fortalece o laço social que une os indivíduos e nos torna mais próximos uns dos outros (ANDERSON; KELTNER, 2002, p. 22).

Nos estudos psicológicos, a noção pode corresponder a uma variedade de processos, como o contágio emocional, a simpatia, a empatia per se, a empatia cognitiva (em suas diferentes acepções), a empatia afetiva, a preocupação simpática/empática, o comportamento pró-social e a angústia pessoal (personal distress) - para elencar apenas alguns (PRESTON; 
DE WAAL, 2002; MAIBOM, 2017b, p. 2) ${ }^{80}$. Já a literatura filosófica e psicológica europeia e estadunidense costuma, em geral, distinguir duas categorias centrais: a empatia cognitiva e a empatia afetiva (MAIBOM, 2017b).

No âmbito do projeto Living With Uncertainty ${ }^{81}$, Cameron $(2012,2013)$ cunha o termo “dispatia" (dyspathy) ${ }^{82}$ para referir-se a mecanismos cognitivos capazes de bloquear, suprimir ou desviar nossa atenção relativa a processos empáticos. Quanto à discussão que empreendemos aqui, acreditamos que compreender o imaginário colonial, racista e patriarcal, como um mecanismo de dispatia possa oferecer subsídios interessantes para compreender as dinâmicas discursivas envolvidas na reprodução de imagens de controle (COLLINS, 2019).

No modelo dinâmico e multinivelado de empatia e dispatia de Cameron (2011, 2012, 2013), esses fenômenos são vistos a partir de uma perspectiva discursiva e, sobretudo, interacional. O modelo procura entender de que forma o diálogo e a interação social podem transformar relações sociais entre indivíduos e entre grupos com o passar do tempo. Por isso, avaliamos que se mostra relevante para a construção de hipóteses sobre as dinâmicas de consumo e de interpretação dos vídeos analisados nesta dissertação

Nessa perspectiva do projeto Living With Uncertainty, a empatia é entendida como uma gama de processos cognitivos e afetivos dinâmicos que se processam através do tempo na mente de um indivíduo (Self) e podem ser bloqueados por mecanismos cognitivos abarcados pelo termo "dispatia" (dyspathy). Assim, tanto a empatia quanto a dispatia são processos que envolvem a distinção entre o Self e o Outro - aquela/e que está posicionado numa situação de alteridade em relação ao Eu.

Quando consideramos a elaboração de (novas) imagens de si (COLLINS, 2019; BUENO, 2020) por parte de mulheres negras e/ou lésbicas (que são o foco desta dissertação),

\footnotetext{
${ }^{80}$ Essa compreensão ampla da empatia está longe de ser consensual (para mais informações, ver COPLAN, 2011). Entretanto, considerando que nos preocupamos com a representação desses processos cognitivos e não com a sua ocorrência propriamente dita, não faremos essa discussão.

${ }^{81}$ O modelo do projeto Living With Uncertainty (CAMERON, 2011, 2012, 2013) se baseia em descobertas da neurociência sobre processos empáticos automáticos, em pesquisas da psicologia social sobre a influência de circunstâncias e aspectos sociais (como identidade, mitos sociais, dinâmicas entre grupos sociais etc.) sobre processos cognitivos, e em discussões dos estudos discursivos sobre a negociação intersubjetiva de crenças e valores por meio da interação social. Concorreram para o desenvolvimento do modelo ainda um conjunto de estudos de campo realizados pelo projeto Living With Uncertainty em diversos países e culturas (Reino Unido, Irlanda do Norte, Estados Unidos da América, Brasil e Quênia) entre duplas e grupos de pessoas que tinham estado previamente envolvidos em conflito, ou grupos de discussão a respeito de alguma questão social, como, por exemplo, terrorismo e violência urbana.

82 O termo dyspathy é comumente traduzido para o português como antagonismo (FELTES et al., 2015; FILLIETAZ, 2018). Nesta dissertação, optamos por traduzi-lo como dispatia para diferenciá-lo da noção de antagonismo enquanto efeito discursivo, com a qual trabalhamos na perspectiva da Movimentação EpistêmicoAxiológica.
} 
vemos que esses processos concorrem para a disputa de narrativas a respeito da formação e da estruturação da sociedade brasileira, afrontando posturas e comportamentos preconceituosos e opressores, agindo, portanto, em prol do desmantelamento dessas imagens de controle (enquanto mecanismos de dispatia e de naturalização das opressões). Simultaneamente, também colaboram para a construção de (novos) laços sociais e relações de solidariedade entre atores e grupos sociais marginalizados, mobilizando recursos voltados para a promoção da empatia. Dessa forma, podem agir no sentido de captar empatia para si (GONÇALVESSEGUNDO; RIBEIRO, 2016) por meio da autoavaliação (COLLINS, 2019; BUENO, 2020) esteja o gesto voltado àquelas/es que seriam o "Outro esperado" das mulheres negras e/ou lésbicas: homens e mulheres brancos e/ou heterossexuais, ou não. Em muitos casos, os gestos de empatia se mostram voltados para outras mulheres negras e/ou lésbicas, tendo em vista o potencial que o compartilhamento de histórias e perspectivas pessoais têm de gerar identificação e contribuir para a criação de uma identidade coletiva. Essas questões serão retomadas e aprofundadas ao final desta seção, quando discutiremos em maior detalhe os mecanismos de dispatia.

Pelos motivos acima apresentados, a compreensão da empatia e da dispatia como processos discursivo-interacionais de longo prazo, que se manifestam tanto na dimensão dos eventos sociais quanto participam da constituição das estruturas sociais (CAMERON, 2012, 2013; COLLINS, 2019), resultou no entendimento de que a negociação intersubjetiva das distâncias axiológicas e epistêmicas ${ }^{83}$ entre as youtubers e as diversas comunidades discursivas às quais elas se referem nos vídeos é uma dinâmica cuja investigação parece apontar para uma melhor compreensão dos discursos e da retórica dos movimentos sociais.

Embora este trabalho não siga a metodologia do projeto Living With Uncertainty, seus conceitos e categorias contribuem para a compreensão dos processos de consumo e de interpretação dos textos analisados. Por isso, discutiremos brevemente os cinco níveis de análise propostos na perspectiva discursivo-interacional de Cameron (2013). Eles consistem nas dimensões nas quais a empatia se processa, desde a dimensão dos eventos sociais - Níveis 0,1 e 2: encontros entre o Self e o Outro - até a dimensão das ordens do discurso - Níveis 3 e 4: padrões discursivo-interacionais de grupos sociais.

Nível 0: Condições iniciais para a Empatia - Trata-se das disposições do Self prévias à interação com o Outro. Envolve a capacidade para a empatia, afiliações sociais e

\footnotetext{
${ }^{83}$ Optamos por trabalhar apenas a dimensão axiológica e epistêmica nessa pesquisa.
} 
identitárias e a percepção Self-Outro. Em outras palavras, consiste no grau de abertura para aprender sobre o Outro, conhecer seus pontos de vista, crenças e emoções.

Nível 1: Empatia-dispatia automáticas - Em termos gerais, trata-se da empatia afetiva. Nos termos de Cameron, consistem em processos individuais e instantâneos, condicionados por um grupo heterogêneo de fatores, o que inclui crenças, conhecimento partilhado, emoções e atitudes, tais como incerteza, polarização do endogrupo, preconceito, sentido de justiça e algum conhecimento sobre o Outro.

Nível 2: Empatia-dispatia controladas - Basicamente, empatia cognitiva. Nos termos de Cameron (2013, p. 10), neste nível ocorrem "processos individuais, mais conscientes", embora ainda influenciados por questões afetivas como a polarização do endogrupo, a incerteza e o posicionamento maligno ${ }^{84}$. No entanto, aqui o Self já está mais aberto à regulação das emoções, e é possível que o raciocínio moral se sobreponha à intuição moral.

Nível 3: Padrões discursivos emergentes de empatia-dispatia - Emergem das dinâmicas discursivas locais de empatia-dispatia, criando "padrões discursivos emergentes" (CAMERON, 2013, p. 10). Estes podem ser afetados pela aprendizagem para ambos os lados. Não raro levam à dissonância moral e à ambivalência emocional do Self quando a percepção sobre o Outro está sendo modificada. Por outro lado, por meio desses padrões discursivos também se processa a desumanização de grupos e atoras/es sociais. Esse nível é especialmente relevante para o modelo porque propõe que os processos empáticos e dispáticos não sejam compreendidos apenas de forma pontual (como nos níveis 1 e 2), mas como processos que se estendem no tempo, participando tanto de interações face a face quanto de mudanças discursivas e culturais de longo prazo, cujos resultados seriam analisados no quarto nível de análise.

Nível 4: Estabilidades emergentes em empatia-dispatia - A recorrência dos padrões emergentes do nível 3 pode levar a dinâmicas culturais de empatia e de dispatia. Tratase de processos sociais de maior duração, nos quais influem decisivamente os processos

\footnotetext{
${ }^{84} \mathrm{O}$ posicionamento maligno consiste, para Cameron, em uma autoatribuição da superioridade moral ao Eu em detrimento do Outro, por meio da atribuição de traços mentais, morais e de personalidade negativos ao Outro que, em contrapartida, favorecem uma imagem positiva do Eu e validam a narrativa que este apresenta sobre uma determinada situação. Isso pode contribuir para a desumanização do Outro e para o estabelecimento de relações de poder assimétricas em que o Eu "controla" o enquadramento da narrativa a partir da qual o Outro será interpretado (CAMERON, 2012, p. 12). Embora se refira a uma dinâmica primariamente pessoal, pode ser alçada à condição de padrão discursivo ou estabelecimento de estabilidades emergentes. Nesse sentido, seria possível estabelecer um paralelo com a noção de pacto narcísico da branquitude proposta por Maria Aparecida Silva Bento (2002).
} 
de construção da identidade social, os mitos culturais e estereótipos. A diferenciação entre empatia e dispatia automáticos e controlados presente neste modelo está relacionada às definições de empatia afetiva e empatia cognitiva comumente descritas pelos estudos psicológicos e filosóficos de tradição estadunidense e europeia.

À concepção deste modelo subjazem duas noções de empatia, que se combinam nas análises: a empatia afetiva e a empatia cognitiva.

A empatia afetiva corresponderia às "diversas reações aos sentimentos de outras pessoas ou à situação em que se encontram, como a simpatia, a raiva empática e a alegria contagiante" 85 (MAIBOM, 2017a, p. 22). Diferencia-se entre duas maneiras de experienciar emoções: a direta, quando se trata de um sentimento apropriado à situação em que o experienciador se encontra, e a empática, que corresponde aos casos em que o sentimento sentido pelo experienciador é mais adequado à situação do "alvo" da empatia.

A questão da acuidade dos sentimentos produzidos pela empatia afetiva é largamente discutida tanto na psicologia quanto na filosofia (MAIBOM, 2017a). Os fatores que costumam influenciar a acuidade dos processos empáticos são: a familiaridade e a similaridade entre os indivíduos, experiências anteriores e aprendizagem (PRESTON; DE WAAL, 2002, p. 17), distinção entre o Self e o Outro, sensação de incerteza/insegurança, preconceitos, senso de justiça, estereótipos e mitos sociais (CAMERON, 2013, p. 20).

A esse respeito, Maibom (2017b) afirma que uma reação empática mais "completa" seria aquela gerada pelo mesmo evento que afetou a pessoa que é "objeto" da empatia. Sendo assim, para que minha reação seja empática à tristeza da minha amiga, seria necessário que a minha tristeza tivesse como gatilho o acontecimento que causou a tristeza dela, e não apenas o fato de ela estar triste. Ainda assim, para determinar se o processo é empático ou não, a análise deve abranger não apenas o evento, mas também a resposta emocional da pessoa afetada por ele (experienciador da empatia). Desse modo, poderíamos pensar em diferentes realizações da empatia, cada qual com um grau de complexidade, profundidade e acuidade.

Quanto à empatia cognitiva, Spaulding (2017, p. 13, tradução nossa) a define como a "capacidade de entender os estados mentais de outra pessoa a partir da perspectiva dela" $"$. A autora defende uma abordagem híbrida para a teorização desse processo, articulando a perspectiva da Model Theory Theory à Teoria Simulacionista (SPAULDING, 2017). Spaulding

\footnotetext{
${ }^{85}$ No original, "range of emotional responses we can have to what others feel or the situation they are in, which include sympathy, empathic anger, and contagious joy." (MAIBOM, 2017a, p. 22)

86 No original, "[...] the capacity to understand another person's state of mind from her perspective." (SPAULDING, 2017, p. 13)
} 
(2017) propõe que a empatia possa se processar tanto por meio de uma simulação mental a respeito da situação em que a pessoa que é "alvo" ou "objeto" da empatia se encontra, quanto por meio de uma "teoria psicológica popular" (folk psychology) que, a partir da observação e reflexão sobre a co-variância de eventos, comportamentos e estados mentais, viabilizaria a atribuição de estados mentais a outrem.

Os teóricos da Model Theory Theory defendem que as teorias psicológicas populares seriam capazes de explicar e predizer comportamentos a partir de uma teorização a respeito da covariância de eventos, comportamentos e estados mentais. Com isso, seria possível realizar uma série de inferências: a partir do comportamento observado, inferimos os estados mentais do Outro; a partir desses estados mentais hipotetizados, em conjunto com as leis psicológicas que conectam estados mentais e comportamento dentro de nossa teoria popular, fazemos previsões sobre os próximos comportamentos da pessoa observada.

Essa teorização constituiria uma "estrutura geral ou padrão esquemático que pode ter diversas instanciações específicas, e pode ser elaborado de várias maneiras para gerar sistemas hipotéticos específicos capazes de lidar com casos empíricos particulares (Godfrey-Smith, 2005, p. 2-4 )"87 (SPAULDING, 2017, p. 14, tradução nossa).

Ainda de acordo com Spaulding (2017), o uso de cada estratégia (simulação ou teoria psicológica popular) seria condicionado pela situação em questão. Em termos gerais, a simulação seria suficientemente precisa apenas nos casos em que o a pessoa que é alvo da empatia é suficientemente semelhante ao conceptualizador ${ }^{88}$ em termos de crenças, desejos e valores. De outro modo, a simulação consistiria na projeção equivocada dos próprios valores sobre o outro. Para evitar essa "pseudoempatia", seria necessário constituir uma teoria sobre a mente dessa outra pessoa - conforme descrevem os estudos da Theory Theory.

Assim, embora não faça parte do escopo desta pesquisa definir a acuidade dos sentimentos experienciados e das predições realizadas pelas youtubers em relação aos sentimentos, crenças e pensamentos dos atores e grupos sociais representados em posições de alteridade em seus vídeos, essa discussão se mostra relevante para os nossos propósitos, tendo

\footnotetext{
${ }^{87}$ No original, “[...] general structure or schematic pattern that can have many specific instantiations, and they can be elaborated in various ways to generate specific hypothetical systems to deal with particular empirical cases (Godfrey-Smith, 2005, pp. 2-4)." (SPAULDING, 2017, p. 14)

${ }^{88}$ Neste capítulo, utilizaremos os termos "conceptualizador" e "experienciador" para discutirmos as teorias aqui resenhadas. Eles não necessariamente correspondem aos termos "Proponente", "instância produtora" ou "voz autoral", posto que se referem a diferentes perspectivas teóricas, ainda que possam, em muitos casos, ser aplicados a um mesmo referente.
} 
em vista que Spaulding (2017) salienta a necessidade de conhecimento prévio sobre o Outro para o processamento da empatia de forma adequada.

Estudos no campo da etnografia também vêm alargando a definição de empatia, propondo que as ações e processos de tipo empático variam de objetivo e de natureza de acordo com povos e culturas. Segundo essas pesquisas (HOLLAN, 2017, p. 350), a empatia poderia ser entendida como uma "capacidade intersubjetiva fundacional $[. .$.$] moldada por e responsiva$ aos contextos culturais, morais e políticos nos quais sempre está encaixada" ${ }^{\text {99. }}$.

Em outras palavras, as formas de demonstrar empatia variam de cultura para cultura. Enquanto, em certas culturas, as necessidades e os desejos são demonstrados de maneira sutil, e a empatia se processa por meio da antecipação dos estados mentais do outro, em outras culturas as pessoas demonstram suas necessidades e desejos abertamente e esperam respostas apropriadas. Hollan (2017, p. 344) fala sobre um conhecimento empático e altruísta não marcado, que passa despercebido nas interações cotidianas. Este conhecimento de "insider", de "entendido" consiste em um conhecimento partilhado necessário para a convivência numa dada sociedade. Essas questões estão ligadas à construção da pessoalidade e aos conhecimentos que se pode ter do Outro, o que ela/ele pode demonstrar abertamente sobre sua vida pessoal e íntima.

Assim, apesar de ser uma capacidade cognitiva "inata", a empatia (ou consciência empática) pode se tornar "culturalmente marcada" e se desenvolver de forma a constituir um conhecimento especializado. Enquanto, em algumas sociedades, a empatia permanece "não marcada", seu desenvolvimento enquanto conhecimento especializado em geral se processa em contextos em que esse conhecimento partilhado das formas de viver, dos valores e das crenças foi limitado por sentimentos de insegurança e ignorância, não raro motivados por questões políticas (HOLLLAN, 2017, p. 350). No entanto, embora essas preferências culturais moldem e estabeleçam limites às modalidades sensoriais e formas de expressão da empatia, elas também se entrelaçam e se combinam de maneiras variadas, dinâmicas e complexas no curso das interações (HOLLAN, 2017, p. 345).

Essa contribuição se mostra relevante para as discussões empreendidas pelas youtubers a respeito das compreensões de certos seguidores de seus canais sobre suas posturas e ações como influenciadoras digitais. Nomeadamente, nos vídeos "POR QUE VOCÊ É TÃO AGRESSIVA, NÁTALY" e "YOUTUBER SÓ FALA MERDA NA INTERNET? Feat. Louie Ponto",

\footnotetext{
${ }^{89}$ No original, "[...] foundational intersubjective capacity that enables and affords many different types of human sociality, [...] shaped by and responsive to the cultural, moral, and political contexts in which it is always embedded." (HOLLAN, 2017, p. 350)
} 
discutem-se as motivações por trás de comentários que depreciam e desvalorizam o trabalho das ativistas.

Enquadrado numa perspectiva interacional, o modelo de Cameron observa três tipos de gestos de empatia (CAMERON, 2013, p. 23) que contribuiriam para o processo de desenvolver uma melhor compreensão a respeito do Outro. Esses gestos podem ser realizados verbalmente ou não, e se dividem em três tipos: aqueles que permitem a conexão, aqueles que marcam a entrada no mundo do Outro e aqueles que sinalizam mudanças na percepção sobre o Outro.

O primeiro tipo oferece ao Outro acesso a pensamentos e a sentimentos próprios, é o "primeiro passo" em direção a um entendimento empático da alteridade. Esses gestos consistem na descrição e na explicação de sentimentos, ações e posicionamentos (por vezes, violentos), autocrítica etc.

A segunda modalidade envolve um entendimento criativo sobre o Outro e a sua visão de mundo. Enlaçada pelo gesto empático, a aquela que empatiza reconhece e busca compreender melhor os sentimentos e posicionamentos do Outro, passando a antecipar os efeitos de suas próprias palavras, tentando auxiliar a explanação do Outro e experimentando falar a partir dessa nova perspectiva (CAMERON, 2013, p. 24).

O terceiro tipo de gesto empático deriva de uma reorganização conceptual da relação com o Outro, que é, por sua vez, fruto dos dois processos anteriores. Eles dependem do que Cameron denomina "posicionamento empático mútuo" (CAMERON, 2013, p. 24): a (re)avaliação da própria posição e da posição do Outro numa determinada questão. Nos processos de reconciliação por meio do diálogo, eles envolvem o reconhecimento da "distância" e o esforço para diminuí-la. Esse gesto pode se traduzir na modificação das narrativas sobre o conflito e a diferença.

No que se refere ao processamento da empatia e da dispatia entre pessoas de grupos sociais distintos, um componente-chave do modelo de Cameron se faz essencial para a nossa discussão: a disposição prévia para a empatia e o compromisso com a tentativa de entender o Outro através da alteridade (localizada no nível 0), o que pode ser posto à prova nos casos em que a conceptualizadora e a pessoa de quem ela tenta se aproximar pertencem a grupos sociais distintos e antagônicos, carregam crenças e valores opostos ou tiveram algum conflito no passado (CAMERON, 2012).

Assim, entendemos que, sobretudo nos casos em que o diálogo envolve interlocutores numa relação de assimetria de poderes, é necessário considerar a postura de "calar-se e ouvir" por parte daquela/e que ocupa uma posição social de dominância, dotada de privilégios como 
uma forma de processamento da empatia, conforme exposto por Kilomba e relatado por Ribeiro (2017).

Kilomba toca num tema essencial quando discutimos lugares de fala: é necessário escutar por parte de quem sempre foi autorizado a falar. A autora coloca essa dificuldade da pessoa branca em ouvir, por conta do incômodo que as vozes silenciadas trazem, do confronto que é gerado quando se rompe com a voz única. Necessariamente, as narrativas daquelas que foram forçadas ao lugar do Outro serão narrativas que visam trazer conflitos necessários para a mudança. O não ouvir é a tendência a permanecer num lugar cômodo e confortável daquele que se intitula poder falar sobre os Outros, enquanto esses Outros permanecem silenciados. (RIBEIRO, 2017, p. 80)

Assim, tendo em vista que o falar e o ouvir envolvem uma negociação entre interlocutores - "alguém pode falar (somente) quando sua voz é ouvida" (KILOMBA, 2019, p. 42) -, a disposição para e o compromisso em ouvir o Outro (elementos do nível 0 - Condições iniciais para a Empatia) se mostram essenciais para a dissolução de mal-entendidos e dos mecanismos psicológicos de dispatia já internalizados, que diminuem o grau de acuidade empática necessário para um diálogo bem-sucedido.

Detalhando a caracterização dos gestos empáticos desenvolvida por Cameron (2013) e por outros autores, Gonçalves-Segundo (2019b) desenvolve as noções de projeção e captação da empatia, da dispatia e do antagonismo, sugerindo uma tipologia mais abrangente. A proposta do autor é discutir a compreensão da dinâmica de captação e de projeção empática, dispática e antagônica ${ }^{90}$ "em interações que pressupõem atoras/es sociais com possibilidade de interação recíproca imediata e uma audiência visada com possibilidades restritas de interação" (GONÇALVES-SEGUNDO, 2019b, p. 314). Essa perspectiva nos interessa, portanto, considerando também a restrição da interação entre as instâncias de produção textual e sua audiência, característica marcante do corpus analisado.

Nessa proposta, a dinâmica entre a captação e a projeção da empatia, da dispatia e do antagonismo é realizada por meio de tipos distintos de operações de perspectivação conceptual, instanciadas com objetivos diversos. A captação é definida como "o processo de incitar

\footnotetext{
${ }^{90}$ A distinção entre dispatia e antagonismo proposta pelo autor consiste na concepção de um continuum entre essas duas modalidades, ambas compreendidas como modos de inibição da empatia. No caso dos gestos dispáticos, eles teriam "marcas de que os interactantes aparentemente não conseguem ou mesmo não projetam estar no lugar do outro, não constroem aproximação aos estados mentais e crenças desse outro, ou mesmo não manifestam reações afetivas esperadas diante de uma dada representação" (GONÇALVES-SEGUNDO, 2019b, p. 312). O antagonismo, por sua vez, consistiria em "perspectivações conceptuais de rejeição do outro, o que passa pela desvalorização ou mesmo pelo rechaço dos valores, das crenças e dos sentimentos desse outro até chegar ao ponto de desumanizá-lo" (GONÇALVES-SEGUNDO, 2019b, p. 312). Ratificamos tais distinções, uma vez que elas mostram que em certos processos discursivos pode não haver apenas uma inibição do processo empático (dispatia), mas a ativação de um desprezo explícito, de uma ampliação da distância axiológica entre os interactantes que pode tornar a identificação, a comoção - e, infelizmente, o respeito à dignidade e à integridade do Outro - inalcançáveis (antagonismo).
} 
reconstruções de sentido orientadas a gerar, no outro, empatia, dispatia ou antagonismo diante de algum objeto-de-discurso, que pode ou não coincidir com algum dos participantes da interação" (GONÇALVES-SEGUNDO, 2019b, p. 312-313). Em outras palavras, a captação procura instigar a empatia, dispatia ou antagonismo naquela/e que vê, ouve ou lê um determinado texto. Já a projeção consiste no processo de simular "uma disposição empática, dispática ou antagônica diante de algum objeto-de-discurso, coincidente ou não com algum interactante presente física ou virtualmente no evento discursivo" (GONÇALVES-SEGUNDO, 2019b, p. 313).

No quadro abaixo, recuperamos as diferentes tipologias resenhadas pelo autor e as suas definições para cada um desses gestos. 


\section{Quadro 2 - Gestos de empatia, de dispatia e de antagonismo}

\begin{tabular}{|c|c|c|}
\hline \multicolumn{3}{|c|}{ Gestos de empatia (parafraseados de Cameron, 2013) } \\
\hline Permitir a conexão & Entrar na perspectiva do outro & Mudar a relação percebida entre o eu e o outro \\
\hline $\begin{array}{l}\text { Inclui construções por meio das quais o self } \\
\text { compartilha com o outro acesso a seu passado, } \\
\text { presente e futuro em termos de pensamentos, } \\
\text { sentimentos e comportamentos com ofim de diminuir } \\
\text { distâncias axiológicas. }\end{array}$ & $\begin{array}{l}\text { Envolve demonstrar reconhecimento da validade da } \\
\text { perspectiva do outro, o que pode ser realizado pela } \\
\text { antecipação do efeito das palavras do outro, pela } \\
\text { mitigação, por simular estar no lugar do outro, por } \\
\text { sintetizar o que o outro disse, dentre outras } \\
\text { possibilidades. }\end{array}$ & $\begin{array}{l}\text { Abrange construções que sinalizam um } \\
\text { estreitamento da distância axiológica entre o self e o } \\
\text { outro, que resulta na modificação da maneira pela } \\
\text { qual eles se representam mutuamente. }\end{array}$ \\
\hline \multicolumn{3}{|c|}{ Gestos de dispatia (adaptados de Guidugli, 2018; Cameron \& Weatherbed, 2014; definição de Gonçalves-Segundo, 2019b) } \\
\hline Não permitir a conexão & Reduzir a credibilidade do outro & Assimilar o outro ao grupo \\
\hline $\begin{array}{l}\text { Inclui construções por meio das quais o self busca } \\
\text { impedir que o outro partilhe seus pensamentos, } \\
\text { sentimentos e comportamentos, de modo a barrar } \\
\text { processos de redução de distâncias axiológicas. }\end{array}$ & $\begin{array}{l}\text { Abarca construções por meio das quais o self } \\
\text { deslegitima a perspectiva do outro, por elaborá-lo } \\
\text { como indigno de confiança, desonesto, antiético, } \\
\text { dentre outras possibilidades. }\end{array}$ & $\begin{array}{l}\text { Abrange construções por meio das quais o outro é } \\
\text { assimilado ao grupo ao qual o self julga que ele se } \\
\text { filia, reduzindo suas particularidades à } \\
\text { caracterização estereotipada do grupo. }\end{array}$ \\
\hline \multicolumn{3}{|c|}{ Gestos de antagonismo (adaptados de Guidugli, 2018; Cameron \& Weatherbed, 2014; definição de Gonçalves-Segundo, 2019b) } \\
\hline$\underline{\text { Rejeitar a perspectiva do outro }}$ & Desumanizar o outro & Desqualificar o outro \\
\hline $\begin{array}{l}\text { Envolve construções por meio das quais o self não só } \\
\text { deslegitima a perspectiva do outro, mas também a } \\
\text { condena a partir dos valores que constituem sua } \\
\text { axiologia, perspectivando essa alternativa } \\
\text { representacional como absurda. }\end{array}$ & $\begin{array}{l}\text { Abarca construções por meio das quais o self subtrai } \\
\text { humanidade do outro, considerando-o como um } \\
\text { objeto ou um animal e, portanto, indigno de qualquer } \\
\text { forma de empatia, compaixão, simpatia, dentre } \\
\text { outras possibilidades. }\end{array}$ & $\begin{array}{l}\text { Inclui construções por meio das quais o self agride } \\
\text { verbalmente o outro, como resultado de uma } \\
\text { avaliação negativa do comportamento do outro, } \\
\text { considerando o distanciamento axiológico entre eles. }\end{array}$ \\
\hline
\end{tabular}

Fonte: extraído de Gonçalves-Segundo com algumas adaptações (2019b, p. 314). 
Dentre os mecanismos de dispatia (nos termos de Cameron, 2012) que impedem o processamento do diálogo, encontramos: estereótipos, mitos sociais, processos de desumanização e de brutalização. Enquanto a brutalização corresponde aos casos em que os indivíduos se encontram de fato incapacitados ou com dificuldades sérias de sentir e demonstrar afeto, os demais processos descrevem os mecanismos cognitivos e discursivos que podem levar a este estado.

Os estereótipos e mitos sociais impõem obstáculos à realização de processos empáticos no sentido de que oferecem e cristalizam representações superficiais e, muitas vezes, pejorativas e inadequadas de grupos sociais, que acabam se impondo na relação interpessoal, impedindo que o Outro seja compreendido em sua especificidade.

Os processos de desumanização consistem em casos em que determinados grupos sociais são categorizados como sub-humanos e, consequentemente, indignos de direitos básicos, participação política e dignidade. Cameron (2012) relata dois tipos de desumanização: a animalizada e a robótica. No primeiro caso, os grupos sociais desumanizados são aproximados de animais e entende-se que tenham capacidades cognitivas inferiores e dificuldade em controlar seus impulsos. No segundo, os grupos são retratados como frios e distantes, incapazes de sentir afeto e empatia ${ }^{91}$.

Acreditamos que a investigação dos mecanismos de desumanização próprios do discurso racista apresente contribuições consideráveis para uma compreensão mais profunda do processamento da dispatia e do antagonismo e suas funções ideológicas. Da mesma forma, encarar o racismo cotidiano (KILOMBA, 2019) como uma realização específica de mecanismo de dispatia/antagonismo, assim como localizar a função das imagens de controle (COLLINS, 2019) nesse processo, pode ajudar a compreender seu funcionamento discursivo e interacional.

A crítica feminista negra às perspectivas feministas mainstream (brancas, de classe média) visa, entre outras coisas, a complexificar a compreensão das vivências das mulheres no que se refere às opressões de gênero. Para tanto, suas autoras exploram não apenas a dor causada pela subalternização e desumanização, como também dão ênfase à potência explicativa proveniente do esforço criativo de entender a sociedade a partir de uma posição marginalizada, desenvolvendo uma postura de desafio aos discursos hegemônicos, localizando-se no campo de projetos políticos de transformação social. Ao propormos o diálogo com essas perspectivas nesta dissertação, nosso interesse está em aprofundar a compreensão das estratégias discursivas

${ }^{91}$ Em sua dimensão discursiva, esses processos podem envolver metáforas conceptuais ou situadas (VEREZA, 2013) e metáforas distribuídas ancoradas em discursos hegemônicos excludentes (GONÇALVES-SEGUNDO; Helena ZELIC, 2016; GONÇALVES-SEGUNDO, 2020ª). 
empregadas pelas youtubers como forma de combate aos referidos mecanismos de dispatia e silenciamento de grupos marginalizados.

Grada Kilomba (2019, p. 75-76) define o racismo a partir de três características: a construção da diferença, a correlação entre diferença e valores hierárquicos, e a combinação entre preconceito e poder histórico, político, social e econômico. A partir dessa tríplice definição, a autora discute a sua faceta ideológica e material (racismo estrutural e institucional), e estabelece sua relação com o racismo cotidiano, foco de sua pesquisa.

De acordo com Kilomba (2019, p. 78, marcações do original),

O racismo cotidiano refere-se a todo vocabulário, discursos, imagens, gestos, ações e olhares que colocam o sujeito negro e as Pessoas de Cor não só como "Outra/o" - a diferença contra a qual o sujeito branco é medido - mas também como Outridade, isto é, como a personificação dos aspectos reprimidos na sociedade branca. Toda vez que sou colocada como "outra" - seja a "outra" indesejada, a "outra" intrusa, a "outra" perigosa, a "outra" violenta, a "outra" passional. Seja a "outra" suja, a "outra" excitada, a "outra" selvagem, a "outra" natural, a "outra" desejável ou a "outra" exótica -, estou inevitavelmente experienciando o racismo, pois estou sendo forçada a me tornar a personificação daquilo com o que o sujeito branco não quer ser reconhecido. Eu me torno a/o "Outra/o" da branquitude, não o eu - e, portanto, a mim é negado o direito de existir como igual.

A partir dessa definição, Kilomba $(2019$, p. 79$)$ realiza uma tipologia das formas de estabelecer os sujeitos negros como "Outras/os" raciais ("incivilizadas/os", ou agressivos, e "selvagens", ou hipersexualizados), que compreende. Mais especificamente, isso pode envolver a infantilização (personificação do dependente), a primitivização (personificação do incivilizado), a incivilização (personificação do outro violento e ameaçador), a animalização (personificação do animal) e a erotização (personificação do sexualizado, com um apetite sexual violento). Vemos, portanto, que a perspectiva de Kilomba pode ampliar e aprofundar a concepção de mecanismos de dispatia apresentada por Cameron (2013).

Por outro lado, o estudo das formas de resistência e enfrentamento das diversas formas de apresentação do racismo também se mostra relevante para a compreensão desses processos, pois permite perceber os potenciais de subversão e desafio aos discursos das matrizes de dominação (COLLINS, 2019), as possibilidades do desenvolvimento da empatia e da dissolução do antagonismo.

Para compreender as experiências e processos de opressão e resistência de mulheres negras de forma multidimensional e articulada (BUENO, 2020), Collins constrói os conceitos de imagens de controle, autodefinição e autoavaliação com especial atenção para a forma como

[...] as imagens de controle criam obstáculos para suprimir os processos de subjetivação e autonomia de mulheres negras, as quais articulam mecanismos 
para a superação do controle exercido pelos grupos hegemônicos para mantêlas em situação de subordinação, o que garante sua exploração econômica, bem como a restrição do exercício de cidadania e da efetivação de direitos. A subjetivação dessas mulheres, a partir dos processos individuais que ocorrem nos espaços seguros, constitui-se um processo paradigmático para refletir sobre os caminhos emancipatórios de outros grupos. (BUENO, 2020, p. 28, grifos do original)

Nesse sentido, a autodefinição e a autovalorização assumem papeis fundamentais, posto que tratam da construção de novas imagens sobre mulheres negras, construídas a partir de uma "verdadeira consciência de si"92. Para Collins (2019, p. 206),

A ênfase na autodefinição das mulheres negras reformula todo o diálogo; de um diálogo de protesto contra a precisão técnica de uma imagem - ou seja, que refuta a tese do matriarcado negro - para um diálogo que enfatiza a dinâmica de poder subjacente ao próprio processo de definição. Ao enfatizar a autodefinição, as mulheres negras questionam não apenas o que já foi dito sobre as afro-americanas, mas a credibilidade e as intenções daqueles que têm o poder de definir. Quando nós, mulheres negras, nos autodefinimos, rejeitamos claramente o pressuposto de que aqueles em posição de autoridade para interpretar nossa realidade têm o direito de fazê-lo.

A autoavaliação, por sua vez, consiste em "enfatiza(r) o conteúdo específico das autodefinições das mulheres negras, substituindo imagens externamente definidas com imagens autênticas de mulheres negras.” (COLLINS, 2009, p. 107 apud BUENO, 2020, p. 126-127).

Nesse sentido, a reflexão a respeito dos critérios de valoração do conhecimento que (não) permitem reconhecer as mulheres negras como "agentes do conhecimento" se mostra essencial (BUENO, 2020, p.27). Isso envolve olhar, por exemplo, para as diversas possibilidades de articulação dessas ativistas, o que inclui "discursos, ensaios, registros literários, música e outros meios de linguagem que permitiram que as vozes dessas mulheres ultrapassassem as fronteiras impostas pelas opressões e articulassem estratégias de enfrentamento às imagens de controle" ${ }^{93}$ (BUENO, 2020, p.34), inclusive considerando o aspecto mutável e adaptativo que caracteriza o racismo como sistema de dominação.

Veremos, no decurso das análises, como as youtubers - Nátaly, em especial - se valem, por exemplo, do processo de reenquadramento da questão argumentativa como estratégia

\footnotetext{
92 A expressão de Du Bois é emprestada por Bueno (2019, p. 126) ao discutir as diferentes estratégias discursivas empregadas na "dupla consciência" de mulheres negras, que lhes permite valer-se da linguagem do opressor como forma de resistência e sobrevivência, ao mesmo tempo em que desenvolver um conhecimento de oposição.

${ }^{93}$ Embora a formulação dos conceitos de imagens de controle e de ponto de vista autodefinido tenham sido elaborados com base nas experiências específicas de mulheres negras, Collins e estudiosas de sua obra defendem que eles possam ser utilizados para a análise dos mecanismos de violência e dominação que agem sobre outros grupos marginalizados.
} 
discursiva voltada para o resgate dessa autonomia discursiva, e da sua autorização enquanto "agente do conhecimento".

Nesse contexto, a relevância da noção de lugar de fala ${ }^{94}$ (RIBEIRO, 2017), assim como o compartilhamento e análise de vivências pessoais se mostraram essenciais para a compreensão das estratégias discursivas voltadas para dissolução dos referidos mecanismos de dispatia nas produções dessa geração política.

Ribeiro (2017) realiza uma historiografia das noções de lugar de fala circulantes nos ativismos brasileiros contemporâneos e uma crítica a certos usos do termo. A autora sugere que, no Brasil, o conceito tenha sido cunhado de forma mais ou menos orgânica por meio dos debates realizados nas redes sociais ao longo dos anos 2010. Desenvolvido a partir da noção de feminist standpoint como "ferramenta política e com o intuito de se colocar contra uma autorização discursiva" (na perspectiva foucaultiana) (RIBEIRO, 2017, p. 60), o lugar de fala tem assumido posição central em estratégias discursivas e nas formas de organização política, cultural e intelectual.

De acordo com Collins (1997, p. 9 apud RIBEIRO, 2017, p. 62), a standpoint theory

[...] refere-se a experiências historicamente compartilhadas e baseadas em grupos. Grupos que têm um grau de continuidade ao longo do tempo de tal modo que as realidades do grupo transcendem as experiências individuais. [...] Embora minha experiência com o racismo institucional seja única, os tipos de oportunidades e constrangimentos que me atravessam diariamente serão semelhantes com o que afro-americanos confrontam-se como um grupo [...] a teoria do ponto de vista feminista enfatiza menos as experiências individuais dentro de grupos socialmente construídos do que as condições sociais que constituem esses grupos.

Em outras palavras, essa teoria trata das "condições sociais que permitem ou não que esses grupos acessem lugares de cidadania", e visa a compreender a "localização dos grupos nas relações de poder" a partir das categorias de raça, gênero, classe e sexualidade como "elementos da estrutura social que emergem como dispositivos fundamentais que favorecem desigualdades e criam grupos em vez de pensar essas categorias como descritivas da identidade aplicada aos indivíduos" (RIBEIRO, 2017, p. 63; COLLINS, 1997).

Em suma, trata-se de esforço de "tentar entender as condições sociais que constituem o grupo do qual fulana faz parte e quais são as experiências que essa pessoa compartilha ainda como grupo" (RIBEIRO, 2017, p. 69). Não se trata, portanto, de uma redução dos saberes e da prática política às experiências individuais, mas da investigação dos mecanismos que negam o

\footnotetext{
${ }^{94}$ Compreendemos essa noção aqui como um mecanismo utilizado para instigar a reflexão e estabelecer princípios para a garantia de protagonismo de atoras/es sociais historicamente marginalizadas/os nos processos de luta contra o machismo, o racismo e a LGBTfobia.
} 
direito à fala e à humanidade a certos grupos (RIBEIRO, 2017). Ao mesmo tempo, essa perspectiva participa da investigação dos mecanismos que garantem autorização e legitimidade de fala aos grupos que detêm o poder. A esse respeito, Ribeiro (2017) aponta que o termo "lugar de fala" tem uma função importante no que se refere à reconceptualização do significado das diferenças de raça, gênero, classe e sexualidade.

No que se refere às apropriações e articulações brasileiras do conceito, Ribeiro (2017) destaca a aplicação da noção de lugar de fala nas formas de organização política, cultural e intelectual que envolvem o desafio às práticas e às estruturas de silenciamento, como a hierarquização de experiências e conhecimentos, bem como o combate à desumanização a que estão sujeitos os grupos marginalizados.

Como coloca Grada Kilomba (2012, p. 56 apud RIBEIRO, 2017, p. 40), que desafia e complexifica a crítica beauvoiriana, a mulher negra é "o Outro do Outro", ocupando um "terceiro espaço", um "vácuo de apagamento e contradição" que a motiva a entender como "raça" e gênero são fatores indissociáveis.

Nesse enquadramento, o desenvolvimento de um "lugar de fala" é entendido como ferramenta política que participa da construção de uma "identidade reivindicada de mulher negra que se constitui como sujeito histórico e político" (RIBEIRO, 2017, p. 51). Trata-se de um processo de humanização com consequências pessoais e sociais, tendo em vista que seus objetivos envolvem transformar a relação de mulheres negras consigo mesmas, com outras pessoas (negras e não negras) e com o mundo.

Essa transformação das identidades se mostra presente também no conceito da mulher negra enquanto "forasteira de dentro" (outsider within) dentro dos movimentos feministas estadunidenses, proposto por Collins (2019). No momento em que define o conceito, Collins descreve a ambiguidade da situação das mulheres negras feministas que, embora construíssem o movimento juntamente com ativistas e militantes brancas, eram muitas vezes objetificadas, silenciadas, ou colocadas em segundo plano dentro das organizações. Para a autora, no entanto, reconhecer e trabalhar a dor, advinda da consciência desse "não lugar", teria um caráter emancipatório ao constituir-se como prática política, no sentido de permitir às mulheres negras, feministas ou não, "constatar, a partir de fatos de suas próprias experiências, anomalias materializadas em omissão ou observações distorcidas dos mesmos fatos sociais" (RIBEIRO, 2017, p. 47).

Trata-se de um uso criativo do lugar de marginalidade que, por meio de um olhar opositor (hooks, 2019b) e da valorização de um ponto de vista autodefinido, desafia as imagens 
de controle (COLLINS, 2019). Ao modificar a origem do eixo de observação e classificação com vistas a transcender, ou melhor, desafiar a norma colonizadora, estabelece outras possibilidades, propósitos e significados para a fala e a prática política de pessoas marginalizadas.

Conforme coloca Spivak (2010 apud RIBEIRO, 2017), esse combate consiste em uma tarefa intelectual e política para todas as mulheres, considerando que, no seu entendimento "o subalterno não pode falar". Dessa forma, integrar a noção de lugar de fala na reflexão e na ação se constitui como uma postura ética, uma vez que "pensar o lugar de onde falamos é fundamental para pensarmos as hierarquias, as questões de desigualdade, pobreza, racismo e sexismo" (Rosane BORGES ${ }^{95}$ apud Matheus MOREIRA; Tatiana DIAS, 2017, s/p). De acordo com Ribeiro (2017, p. 86), “falar a partir [desses] lugares é também romper com essa lógica de que somente os subalternos falem de suas localizações, fazendo com que aqueles inseridos na norma hegemônica nunca se pensem".

Nesse sentido, cabe a todas/os nós refletirmos sobre quem de fato pode falar e é ouvida/o dentro da lógica colonizatória, bem como (sobre) o que se pode falar e quais as consequências da nossa fala quando desafiamos o discurso hegemônico e o status quo do heteropatriarcado branco.

Quais são os estereótipos, imagens de controle e condições materiais que constrangem a fala e a escrita de mulheres brancas? E quando falam mulheres negras ou indígenas? E quando falam mulheres heterossexuais, lésbicas, assexuais? Mulheres trans ou cis? Somos taxadas de histéricas, incoerentes e/ou agressivas? E quais são as consequências que enfrentamos a partir do momento em que nos expomos no espaço público? O silenciamento, o ostracismo ou (ameaças de) morte?

Ademais, cabe questionar: há estereótipos e imagens de controle que constranjam a fala de homens brancos, cis e heterossexuais ricos sobre qualquer assunto? E quando mulheres brancas cisgêneras de classe média falamos sobre pessoas negras e/ou trans e/ou pobres, o que nos constrange?

Esse questionamento pressupõe, evidentemente, que muitas vezes assumamos uma postura introspectiva e nos questionemos a respeito dos nossos imaginários e pressupostos. Esse processo envolverá questionar, por exemplo, o que significa ser branca na sociedade brasileira, e os privilégios que estão envolvidos na minha trajetória de vida. Que direitos não me são

\footnotetext{
${ }^{95}$ Essa citação foi retirada de uma entrevista concedida a Matheus Moreira e Tatiana Dias (Nexo) em 2017. Uma vez que o artigo contempla entrevistas com outros intelectuais e ativistas, a referência completa está presente nas referências bibliográficas sob o nome dos jornalistas.
} 
negados devido a minha cor de pele e meus traços? Não se trata, no entanto, de um processo que se encerra em si mesmo. Deve estar voltado para a ação, para que reconsideremos nossos compromissos e nossas posturas nos espaços nos quais circulamos, e as posições que assumimos. Que participemos ativamente da construção de novos horizontes políticos!

Para esse processo, Ribeiro (2017) destaca como fundamental a contribuição de Audre Lorde (2019 [1984]). No entendimento de Lorde, o reconhecimento das diferenças e das diferentes formas de ser mulher - diferentes experiências e violências de gênero às quais estamos sujeitas, condicionadas por outros fatores que constituem nosso lugar no mundo, como raça, classe e sexualidade - é essencial para a construção de uma postura ética que ataque o problema das desigualdades geradas por meio de uma chave negativa para o entendimento das diferenças. De acordo com a escritora, o racismo, o machismo, a heteronormatividade e a homofobia nascm da "inabilidade de reconhecer o conceito de diferença como uma força dinâmica, que é mais enriquecedora do que ameaçadora para a definição do indivíduo quando existem objetivos em comum" (LORDE, 2019, p. 57b).

Como coloca Mombaça (2017, s/p), "não é sobre ‘quem', mas sobre 'como'”. Em outras palavras, o que o uso político da noção de lugar de fala desafia é um "modo privilegiado de enunciar verdade, uma forma particularizada pelos privilégios epistêmicos da branquitude e da cisgeneridade de se comunicar e de estabelecer regimes de inteligibilidade, falabilidade e escuta política" (MOMBAÇA, 2017, s/p). Em outras palavras, quando se discute lugar de fala, colocase em pauta as posições de poder relativa que as/os atoras/es sociais ocupam a partir de seus corpos, que invariavelmente nos inscrevem em relações de poder assimétricas e relativas.

Assim,

[...] o gesto político de convidar um homem cis eurobranco a calar-se para pensar melhor antes de falar introduz, na realidade, uma ruptura no regime de autorizações vigente. Se o conceito de lugar de fala se converte numa ferramenta de interrupção de vozes hegemônicas, é porque ele está sendo operado em favor da possibilidade de emergência de vozes historicamente interrompidas. Assim, quando os ativismos do lugar de fala desautorizam, eles estão, em última instância, desautorizando a matriz de autoridade que construiu o mundo como evento epistemicida. (MOMBAÇA, 2017)

Não há dúvidas de que as desigualdades de raça e de classe são pontos focais para essas discussões. Nesse sentido, compreendemos aqui que agir e se pronunciar a partir do nosso próprio lugar de fala não significa calar completamente a respeito de processos e estruturas das quais nos beneficiamos. Mas que pensemos nossa fala de forma estratégica. Como coloca Rosane Borges (apud MOREIRA; DIAS, 2017, s/p), 
Do ponto de vista da legitimidade do discurso e da fala, quem sofre na própria pele pode falar por si. A reivindicação do sujeito historicamente discriminado pelos dispositivos de fala passa por aí. O que se tem visto amplamente nas discussões das redes sociais é a banalização das expressões. As pessoas tendem a crer que uma pessoas (sic) branca não pode falar sobre a questão racial negra por não ser negra. Ou mesmo pessoas brancas dizem que este debate [sobre questão negra] não é seu lugar de fala. Isso é um equívoco. $\mathrm{O}$ lugar de fala pressupõe uma postura ética. Portanto, você sendo homem ou hetero e não-negro, você pode, do seu lugar de fala, falar sobre negros, mulheres, população trans, ou seja, todas as outras minorias.

Dessa forma, é importante ressaltar que se trata não apenas de uma estratégia contrahegemônica, mas também - e sobretudo - de esforços que se voltam para a construção de "outras possibilidades de existências para além das impostas pelo regime discursivo dominante" (RIBEIRO, 2017, p. 92).

A discussão de hooks (2019a) sobre o processo de transformação das dinâmicas das discussões de gênero entre mulheres negras estadunidenses no seio de suas organizações nos informa de diferentes maneiras. A partir das considerações realizadas pela autora, refletimos sobre a importância de considerarmos as estratégias e entendimentos dos movimentos feministas como processos que envolvem, simultaneamente, diversas/os atoras/ es sociais e posicionamentos na construção de subjetividades e de projetos identitários de resistência como formas de prática política. hooks (2019a, p. 105) narra uma mudança de perspectiva que muito se assemelha aos processos de humanização descritos por Cameron nos seus estudos sobre empatia, mas olhando para um caso em que o Eu e o Outro compartilham traços identitários que lhes permitem reconhecer-se como parte de um mesmo grupo:

Depois de muitos anos de movimento feminista, me parece que as mulheres negras agora podem se unir admitindo a diferença [...] Coletivamente, estávamos trabalhando para problematizar nossas ideias a respeito da subjetividade das mulheres negras. Nenhuma de nós supunha uma identidade essencial fixa. Era muito evidente que não compartilhávamos uma compreensão comum do que era ser mulher e negra, ainda que algumas das nossas experiências fossem semelhantes. Nós compartilhávamos um entendimento de que é difícil para mulheres negras construírem uma subjetividade racial dentro do patriarcado capitalista supremacista branco, de que nossa luta para sermos "sujeitos", embora semelhante, também era diferente da travada pelos homens negros, e que as políticas de gênero criam essas diferenças.

A autora salienta, a respeito do compartilhamento de experiências, vivências, informações e conhecimentos para esse processo, aquilo que, segundo ela, deve envolver discussões críticas sobre modos de pensar, mas também sobre modos de ser de mulheres negras radicais - "ao compartilhar as contradições em nossas vidas, ajudamos umas às outras a 
aprender como lidar com as contradições como parte do processo de se tornar uma pensadora crítica, uma sujeita radical" (hooks, 2019a, p.121).

Esse processo coletivo de se pensar a subjetividade comum em meio à diversidade, numa dimensão discursiva e política, está presente também nos trabalhos de Cestari (2015, 2017). A autora, ao investigar os "processos de subjetivação/identificação nos movimentos de inclusão/exclusão, diferenciação e ressignificação dos discursos feministas, dos movimentos negros, de construção da identidade nacional, da diáspora africana, entre outros" (CESTARI, 2015, p. 10), trabalha com as noções de eu político e de nós político. Trata-se de categorias oriundas da Análise do Discurso de linha francesa que se constituem de forma relacional a respeito da enunciação de si.

A autora define o eu político na produção de mulheres negras da seguinte maneira:

O eu político é também uma regularidade na enunciação de mulheres negras em luta. As análises que fiz no primeiro capítulo sobre o eu na introdução de trabalhos acadêmicos de mulheres negras sobre mulheres negras procuraram mostrar que, quando o eu diz como mulher negra (e mais outras condições atreladas, como a de universitária, professora, das classes trabalhadoras...), projeta-se como integrante de um coletivo que compartilha uma história, memórias, experiências comuns. (CESTARI, 2015, p. 152)

Vemos, portanto, que o desenvolvimento de um modo de dizer autoral que se estabelece em referência a/em diálogo com um coletivo consiste numa atitude política que, embora tenha consequências importantes no plano individual, toma corpo sobretudo enquanto posicionamento coletivo que se contrapõe aos mecanismos de dominação do poder colonial racista. Trata-se de um processo complexo e dialético, exposto pela autora (CESTARI, 2015, p. 25) da seguinte forma:

Considero que dizer $e u$ se dá como resistência às políticas de silêncio, como afirmação da condição de sujeito, em contraponto às investidas para sua objetificação - aqui tratada como o discurso do outro sobre as mulheres negras na condição de objetos sem agência e na forma de estereótipos. Trata-se de um processo contraditório, porque remete à homogeneização do comum às mulheres negras para afirmar o singular da trajetória individual, em tomadas de posição e contraidentificação aos sentidos dominantes sobre mulheres negras e em combate às políticas do silêncio (ORLANDI, 1993).

Em suma, trata-se de uma enunciação que ultrapassa o discurso do ativismo político, ou melhor, se faz presente numa miríade de campos de atuação em que o dizer em primeira pessoa se configura como resistência a uma série de violências simbólicas (CESTARI, 2015, p. 134135). Nesse sentido, o ato de dizer quem se é tem uma função política de interpelação ideológica. 
No funcionamento da reflexividade discursiva, neste lugar de enunciação, $a$ imagem de quem diz é construída também pelo o que diz de si. Também porque as projeções imaginárias em jogo na interlocução são parte das condições de produção do discurso e escapam aos sujeitos, sendo que não é necessário que o locutor fale de si para que se projete uma imagem de quem diz. Dizer quem $e ́$, apresentar explicitamente quem é e/ou defender as implicações da noção de "local de fala" - eu digo enquanto mulher negra, feminista, paulistana, historiadora -, resulta da interpelação em uma posição sujeito. Com isso, inscrevo a discussão sobre a reflexividade discursiva no quadro da interpelação ideológica, pensando a interlocução discursiva e, mais especificamente, as imagens de si, as projeções imaginárias dos interlocutores, a partir dos postulados de Pêcheux (1969, 1975). (CESTARI, 2015, p. 135)

Esse entendimento ressoou em nossa pesquisa e nos levou a refletir sobre como a articulação da voz autoral a uma voz coletiva constitui, dentro do nosso arcabouço teórico, uma estratégia discursiva relevante para a compreensão das dinâmicas dentro de/entre os ativismos contemporâneos.

Assim, embora o propósito inicial desta pesquisa fosse analisar os vídeos a partir do modelo do Projeto Living With Uncertainty, no decurso de nossas análises iniciais, percebemos que certas particularidades do corpus selecionado impunham obstáculos consideráveis para a aplicação do mesmo. Parte desses obstáculos já foi mencionada nesta seção, mas, em resumo, a dificuldade de aplicar os níveis de análise e as categorias de gestos empáticos ao nosso corpus se justificava, em parte, pelo fato de que, nos casos sob análise, a constituição do Outro não se dá da mesma forma como ocorre no projeto mencionado acima.

Enquanto este partia de um corpus constituído sobretudo por interações face-a-face entre um Self e um Outro que interagem de forma presencial, registradas em sua totalidade ao longo de um certo período de tempo, nos casos sob análise o que se poderia considerar como "Outro", nos vídeos que compõem o corpus, são, em geral, objetos de discurso (KOCH, 2014). Consequentemente, foi preciso buscar mais categorias de análise em outras referências, de forma a apurar nosso aparato analítico. Mostrou-se, enfim, necessário investigar aportes teórico-metodológicos que nos permitissem discutir a representação do Outro (enquanto “adversário argumentativo") e as formas de mapear as distâncias entre os atores e grupos sociais delimitados nos textos. Veremos na seção seguinte em que aspectos a Teoria da Proximização contribui para a resolução dessas questões - e quais os obstáculos e desafios encontrados em sua aplicação que motivaram o desenvolvimento do modelo de análise da Movimentação Epistêmico-Axiológica. 


\subsubsection{A Teoria da Proximização}

Trata-se de um instrumento metodológico cognitivo-pragmático desenvolvido para o estudo do uso de estratégias voltadas para a imposição de certas perspectivações conceptuais no debate público (CAP, 2014, p. 189), em especial para a análise de processos discursivos de legitimação de práticas estatais - seriam exemplos o discurso da Guerra ao Terror e, possivelmente, da Guerra às Drogas, que visam à hegemonia de uma perspectiva intervencionista na esfera pública.

O objetivo da Teoria da Proximização é investigar a produção de significado em termos de uma "configuração abstrata e tridimensional em um espaço 'discursivo' mental que provê a coerência conceptual para textos inteiros por meio do mapeamento de entidades e eventos em eixos que representam a 'distância' sócio-espacial, temporal e avaliativa (epistêmica e axiológica)"96 (HART, 2014, p. 163, tradução nossa).

Embora tenha sido desenvolvida a partir de corpora bastante específicos, como mencionado anteriormente, a teoria vem se mostrando útil para a análise de uma miríade de textos, o que levou a uma reformulação e expansão de seus objetos e objetivos, bem como de sua metodologia. De forma resumida, Hart (2014) a define como

[...] um modelo de conceptualização deiticamente motivado elaborado para tratar da produção de significado no discurso enquanto 'linguagem além da sentença' e para discutir formas mais pragmáticas de posicionamento que estão ancoradas no contexto mais amplo e são mais dependentes de um consenso intersubjetivo de valores ${ }^{97}$ (HART, 2014, p. 163, tradução nossa).

A teoria se baseia na noção cognitivo-linguística de Espaço Discursivo (Discourse Space), proposta por Chilton (2005) para o tratamento do discurso de forma situada e corporeada, conforme preconizam diversas linhas dentro da Linguística Cognitiva. Partindo do espaço tridimensional euclidiano (CHILTON, 2005, p. 2), o autor propõe que se pense a representação situada e corporeada da realidade em termos de uma geometria de vetores e coordenadas (CHILTON, 2005, p. 3) para analisar não apenas a localização espacial e a movimentação em termos linguísticos, como também - e especialmente - as "configurações semânticas que podem ser entendidas como derivadas de conceitos espaciais ${ }^{98 "}$ (CHILTON,

\footnotetext{
${ }^{96}$ No original, "an abstract, three-dimensional configuration in a mental 'discourse' space which provides a conceptual coherence to whole texts as entities and events are mapped out across axes representing socio-spatial, temporal and evaluative (epistemic and axiological) 'distance'." (HART, 2014, p. 163)

${ }^{97}$ No original, "a deictically motivated model of conceptualization to account for meaning construction in discourse as 'language above the sentence' and to account for more pragmatic forms of positioning which are anchored in the broader context of the text and more dependent on an intersubjective consensus of values." (HART, 2014, p.163)

${ }^{98}$ No original, "semantic configurations that can be viewed as derived from spatial concepts." (CHILTON, 2005, p. 5)
} 
2005, p. 5, grifos do original). Nesse sentido, o Espaço Discursivo consistiria em um mecanismo de perspectivação conceptual que permite o mapeamento de entidades em relação ao Self - a/o falante, a pessoa que produz o discurso, o/a produtor/a textual - nos eixos espacial, temporal e axiológico (CAP, 2013) ou avaliativo (epistêmico e axiológico - HART, 2014).

A noção de perspectivação conceptual (construal) se origina no âmbito da Linguística Cognitiva, mais especificamente em suas vertentes orientadas pelas Ciências Cognitivas Corporeadas. Gonçalves-Segundo (2017, p. 78) e Hart (2014) desenvolvem a aplicação dessa noção no âmbito dos estudos críticos do discurso. Ela está ligada a outro conceito também importante para essa área, a conceptualização. Em termos gerais, Hart (2014) descreve a relação entre essas concepções da seguinte maneira: "a mesma situação, evento, entidade ou relação pode ser conceptualizada de formas diferentes e formas linguísticas alternativas impõem à cena descrita conceptualizações alternativas"99 (HART, 2014, p. 110).

Neste trabalho, adotamos a distinção entre perspectivação conceptual e conceptualização estabelecida por Gonçalves-Segundo (2017), que refina a concepção de perspectivação conceptual para os estudos do discurso, definindo-a em termos de seu processamento na dimensão da produção e do consumo textual.

De acordo com o autor, tanto a conceptualização quanto a perspectivação conceptual se mostram intimamente ligadas a uma concepção sobre a significação que a entende em termos enciclopédicos e imagéticos. Enquanto a conceptualização é encarada como um "processo cognitivo dinâmico envolvido na construção de significado pelo produtor e em sua reconstrução pelo ouvinte", a perspectivação conceptual consiste na "estruturação semântica da experiência materializada no enunciado" (GONÇALVES-SEGUNDO, 2017, p. 74).

No nível da produção, a perspectivação conceptual abrange a

[...] estruturação semântica de uma experiência, materializada em enunciados concretos e resultado de uma atividade de conceptualização que é possibilitada e limitada pelas coerções cognitivas advindas do seu corporeamento, o que inclui tanto fatores biológicos quanto fatores sócio-histórico-culturais. (GONÇALVES-SEGUNDO, 2017, p. 78)

Nessa perspectiva, questões como o papel da ideologia na construção de certas perspectivações conceptuais e, em contrapartida, a função dos mecanismos de perspectivação conceptual na sustentação e reprodução de discursos hegemônicos e alternativos são de extrema relevância (GONÇALVES-SEGUNDO, 2017, p. 74).

Já no nível do consumo textual,

\footnotetext{
99 "The same situation, event, entity, or relation can be conceptualized in different ways and alternative linguistic forms impose upon the scene described alternative conceptualizations" (HART, 2014, p. 110).
} 
[...] a perspectivação conceptual apresenta pistas referenciais e relacionais materializadas no enunciado concreto, que representam uma alternativa de estruturação semântica da realidade, responsável por ativar nós em uma rede complexa de conceitos e categorias, que se associam a experiências multimodais corporeadas e simuladas de introspecção, ação e emoção. (GONÇALVES-SEGUNDO, 2017, p. 78)

Exemplificaremos essas noções por meio de breves descrições e exemplos da aplicação da Teoria do Espaço Discursivo e da Teoria da Proximização. Nosso objetivo é, com isso, apontar as limitações dessas perspectivas para a análise do nosso corpus e estabelecer pontos de partida para delinear os conceitos e a metodologia da Movimentação Epistêmico-Axiológica enquanto proposta teórico-metodológica para a análise discursiva.

Para a Teoria do Espaço Discursivo, o Self consiste, em termos matemáticos, na intersecção geométrica de origem - o que na teoria linguística será denominado "centro dêitico" (CHILTON, 2005, p. 8). Esse construto cognitivo é considerado responsável pela orientação, pela "situacionalidade" (situatedness) e pelo corporeamento da/o falante. É em relação a ele que todas as demais entidades serão posicionadas no Espaço Discursivo.

Entretanto, é possível estabelecer outros pontos de referência no discurso e assumir um ponto de vista projetado que corresponderia a essa outra localização dentro do espaço discursivo. Em outras palavras, "sabe-se que a linguagem nos permite codificar uma mudança de um ponto de vista egocêntrico para um ponto de vista alocêntrico, isto é, há uma mudança de centro dêitico ou de origem geométrica ${ }^{100 "}$ (CHILTON, 2005, p. 9).

Isso se deve ao fato de que a projeção de elementos dentro do espaço discursivo está sujeita, como qualquer tipo de representação da realidade, à perspectivação conceptual (HART, 2014; GONÇALVES-SEGUNDO, 2017) e, portanto, não reflete o mundo real diretamente. Pelo contrário, é o mapeamento do espaço discursivo realizado cognitivamente que propicia o processamento cognitivo de uma dada versão da realidade.

Podemos exemplificar a aplicação das noções de ponto de vista egocêntrico e alocêntrico supondo três interpretações para a seguinte oração.

1) Lélia está na frente da escola.

Em uma representação egocêntrica - que assume o ponto de vista da falante (Sueli) -, Lélia seria posicionada entre a falante e o prédio da escola. Já em uma representação alocêntrica, o ponto de referência para o mapeamento de Lélia no espaço discursivo seria a fachada da escola, não importando a localização da falante para a construção da cena. De acordo com

\footnotetext{
${ }^{100}$ No original, "It is also well known that language enables us to encode a shift from an egocentric speaker's viewpoint, to an allocentric viewpoint, i.e. there is a shift of deictic centre or geometric origin." (CHILTON, 2005, p. 9)
} 
Chilton (2005, p. 12), a opção pela primeira ou pela segunda interpretação dependeria de fatores contextuais, próprios do processamento de facto do discurso.

Ainda tratando de representação alocêntrica, podemos supor que Sueli esteja dando coordenadas sobre a localização de Lélia para uma amiga, Nilma, por telefone. Neste caso, Sueli assumiria o ponto de vista da amiga como centro dêitico. Dessa forma, a conceptualização gerada seria a de que Lélia não estaria localizada nem entre Sueli e a escola, nem em frente à fachada da escola, mas sim entre Nilma e a escola.

A partir desses dois mecanismos básicos de representação no espaço discursivo, Chilton propõe a noção de mudança de eixo (axis shift), que consiste na articulação entre diversos pontos de referência construídos discursivamente. Não entraremos em detalhes na análise deste ponto, mas ele pode ser compreendido a partir do seguinte exemplo, que orienta um ouvinte a partir da combinação de diversos pontos de referência alocêntricos.

2) Desça do ônibus na altura da padaria, entre na rua à direita e siga em frente até a esquina. $\mathrm{O}$ centro cultural está no galpão à sua esquerda.

Para chegar ao seu destino, a ouvinte precisaria processar a representação todas essas entidades em seu espaço discursivo de forma sequencial e articulada.

Vemos, portanto, que a Teoria do Espaço Discursivo está voltada para a análise microlinguística, focalizando os eixos espacial, temporal e modal. A Teoria da Proximização, por sua vez, parte dessa base teórica para estudar os efeitos retórico-pragmáticos dessas representações no nível do discurso. Enquadrada pela Análise Crítica do Discurso, ela contribui de forma decisiva para as análises das representações (discursos) de atores e grupos sociais e das relações construídas entre eles e a instância da produção textual.

Apoiada na hipótese de Chilton (2005) de que o corpo proveria uma estrutura conceptual abstrata para a linguagem, a Proximização entende que esses valores semânticos são importantes para a construção do significado no nível do discurso e podem ser conceptualizados metaforicamente em termos temporais ou de distância/proximidade axiológica ou avaliativa isto é, o compartilhamento ou embate entre crenças, comportamentos e pontos de vista.

Vemos que a noção de corporeamento se mostra presente na teoria devido às metáforas que apontam conceptualizações espaciais de conceitos temporais, como em "futuro próximo/passado distante", e, sobretudo, da avaliação em termos de crenças, valores e afetividades, como em "ficar perdido", "amigos próximos", "estar perto/longe da verdade", "até aí tudo bem" e "polarização política". 
Nos próximos parágrafos, nosso foco se voltará para os eixos da proximização axiológica ou avaliativa, sobre os quais apontaremos algumas complicações, estabelecendo pontes entre essas abordagens e aquela que proporemos na seção seguinte.

Para Hart (2014), os objetivos dos discursos que se valem da proximização são alcançados por meio estratégias referenciais e predicativas. As primeiras consistem na reprodução de representações discursivas dicotômicas que opõem o endogrupo a um exogrupo determinado (nós vs. eles) ou, ainda, antagonizam entidades internas e entidades externas ao centro dêitico (HART, 2014). As segundas consistem na reprodução de associações entre o exogrupo e entidades, elementos e eventos negativos ou de conotação ameaçadora - o que pode ser realizado por avaliações negativas e pela representação (de ações) dos membros do exogrupo como gatilhos para afetos negativos, por exemplo. Essas estratégias são capazes de criar novas representações e também podem reforçar representações antagônicas já existentes.

Cap (2014) propõe três níveis de análise para a Proximização:

1. O nível conceptual, que mapeia a organização inicial do Espaço Discursivo.

2. O nível lexical, que elenca as mudanças estratégicas da organização do Espaço Discursivo.

3. O nível coercivo, que considera os efeitos perlocutórios dos outros dois níveis do texto enquanto exemplo de discurso legitimador de intervenções na realidade.

Os dois primeiros níveis estão focados na Proximização enquanto perspectivação conceptual. Já o terceiro nível se volta para mesma considerando-a uma estratégia retóricopragmática. Enquanto estratégia retórico-pragmática, a Proximização procura legitimar uma “ação contrária" imediata (CAP, 2013, p. 49), apresentando um ator, situação ou evento construído como uma ameaça ao Self e às entidades que se localizam "dentro do centro dêitico"101 (CAP, 2013, p. 68).

Nos primeiros textos analisados por Cap (os discursos de legitimação da "Guerra ao Terror" proferidos pelos presidentes estadunidenses George Bush e Barack Obama), essa ameaça se processava sobretudo por meio do eixo espacial, representando entidades, ideologias, eventos e estados de coisas distantes como “"'negativas, estrangeiras, alienígenas e antagonísticas $^{102}$ " (CAP, 2014, p. 190), isto é, axiologicamente opostas ao centro dêitico.

${ }^{101}$ Esse centro dêitico (ou campo) pode corresponder a diferentes amplitudes espaciais, desde a casa enquanto espaço de convívio familiar, até o território nacional, englobando todos os cidadãos de um país - e distinguindoos dos "imigrantes" ou "terroristas".

102 No original, 'negative, ‘foreign', 'alien', 'antagonistic', entities.” (CAP, 2014, p. 190) 
Ao longo dos textos e ao logo do tempo, essas entidades passavam a ser representadas de forma progressivamente mais próxima e perigosa para integridade física do/a produtor/a textual e de seu auditório endogrupal, adentrando seu "campo" (ground) e potencialmente causando consequências pessoais, como violências físicas ou psicológicas.

Em suas primeiras formulações, a proximização axiológica consistia, para Cap (2010, p. 393), na perspectivação conceptual de "[...] um conflito crescente entre, de um lado, o sistema de valores ao qual o falante e sua audiência aderem, e, do outro, os valores que caracterizam as entidades ODC (cujas ações ameaçam as entidades IDC)"103.

Em publicações mais recentes (CAP, 2013, 2014ab, 2015), o autor tem definido esta dimensão como a perspectivação conceptual de um conflito ou choque ideológico iminente entre os valores próprios das entidades centrais do Espaço Discursivo, as entidades internas ao centro dêitico (doravante IDC, do original inside-the-deictic-center) e os valores "alienígenas", estrangeiros, distantes e, consequentemente, antagonistas, de entidades conceptualizadas como periféricas no mapeamento do espaço discursivo - logo, externas ao centro dêitico (doravante ODC, do original outside-the-deictic-center).

Fundamentalmente, as entidades ODC e seus valores são perspectivados de forma a revelar um "potencial de materialização de sua ameaça ideológica (isto é, a capacidade de causar um impacto físico) dentro do campo IDC, o território do falante e da audiência" (CAP, 2015 , p. 315$)^{104}$. Esse potencial serviria como legitimação da ação intervencionista proposta pelo falante, que possivelmente envolve uma ação conjunta das entidades IDC.

$\mathrm{O}$ aspecto epistêmico ${ }^{105}$ participa da proximização axiológica para Cap como forma de indicar o grau de probabilidade desse impacto, diferenciando entre os tipos de alta ou baixa probabilidade. A primeira (alta probabilidade) costuma ocorrer de forma relativamente autônoma em relação a outros tipos de proximização (temporal, espacial) e de alguma forma seu uso parece ser planejado para "compensar" a ausência dessas outras modalidades de ameaça em termos da legitimação das ações proposta; já a segunda (baixa probabilidade) atua de forma combinada com as duas outras, e por isso é menos exacerbada no discurso (CAP 2013 p. 94).

\footnotetext{
${ }^{103}$ No original, "a growing conflict between the system of values adhered to by the speaker and the addressee on the one hand, and, on the other, the values characterizing the ODCs (whose actions threaten the IDC entities)." (CAP, 2010, p. 393)

${ }^{104}$ No original, "potential to materialize (that is, prompt a physical impact) within the IDC, the speaker's and the addressee's, home territory." (CAP, 2010, p. 393)

${ }^{105}$ Epistêmico aqui assume o sentido de modalidade epistêmica, isto é, do grau de certeza ou probabilidade atribuído a uma proposição - em termos mais técnicos, sua localização em um eixo realis-irrealis. Hart, por sua vez, define o eixo epistêmico como o grau de abertura a alternativas dialógicas. Nenhuma delas se confunde, no entanto, com o nosso uso de epistêmico na conceituação da MEA, que está mais próximo da ideia de discursos, crenças e visões de mundo. Elaboraremos essa definição com mais detalhe na seção seguinte.
} 
Neste ponto a perspectiva de Hart (2014) diverge de forma substancial. O autor diferencia entre a proximização epistêmica (modalidade epistêmica) e a axiológica (avaliação moral). Embora localize ambas no eixo avaliativo (responsável pela conceptualização do 'certo' x 'errado'), a primeira modalidade se refere ao grau de abertura dialógica do PROTAGONISTA em relação à proposição apresentada - o autor (HART, 2014, p. 165) inclusive estabelece um paralelo com o subsistema de ENGAJAMENTO da AVALIATIVIDADE, que resenharemos posteriormente, já no âmbito da sua utilização como categoria de análise da MEA.

A segunda modalidade, por sua vez, é definida por Hart (2014, p. 181-182, tradução nossa) 106 como

[...] o fechamento desse vão como o sinal de que o campo axiológico do protagonista e do antagonista estão se tornando mais parecidos. A proximização axiológica contribui, portanto, para a transformação social. Isso pode envolver uma mudança no campo axiológico do PROTAGONISTA ou do ANTAGONISTA.

O autor diferencia ainda entre dois tipos de proximização axiológica: o campo estável e o campo em transformação. Ambas podem ser consideradas positivas ou negativas, a depender da perspectiva que se assume (do PROTAGONISTA ou do ANTAGONISTA).

Tomando a perspectiva do PROTAGONISTA, uma proximização axiológica positiva seria aquela que implica uma transformação do campo axiológico do ANTAGONISTA, que estaria se tornando mais próximo do PROTAGONISTA.

Em contrapartida, a proximização axiológica pode ser vista como algo ameaçador para essa perspectiva quando se trata de mudança dentro do próprio campo do conceptualizador, processo que é definido por Hart (2014) como "campo em transformação" (shifting ground). Nele a voz autoral "denuncia" supostas mudanças culturais ocorrendo entre as entidades localizadas "dentro do centro dêitico", que estariam se aproximando axiologicamente do Outro ameaçador.

A aplicação dessas categorias é exemplificada por Hart (2014, p. 182, tradução nossa) ${ }^{107}$ da seguinte maneira

\footnotetext{
106 No original, “Axiological proximization, as defined by Cap (2010: 130), consists in a "narrowing of the gap between two different and opposing ideologies'. I take the closing of this gap to represent the axiological ground of the protagonist and the antagonist becoming more alike. Axiological proximization thus amounts to social transformation. This can involve a shift in the axiological ground of the PROTAGONIST or the ANTAGONIST. From the perspective of the protagonist, we can therefore refer to stable ground or shifting ground axiological proximization. Moreover, seen again from the perspective of the protagonist, axiological proximization can be categorized as positive or negative." (HART, 2014, p. 181-182).

107 No original, "The distinction is reflected in nominalized forms like 'democratisation' (of Them) and 'radicalisation' (of Us) which represent positive, stable ground versus negative, shifting ground axiological proximization, respectively. In the discourse space, this again involves a translation from a starting set of coordinates to a target set." (HART, 2014, p. 182).
} 
A distinção está refletida em formas nominalizadas como a "democratização" (deles) e na radicalização (nossa), que representam, respectivamente, uma proximização axiológica positiva de campo estável e uma proximização axiológica negativa de campo em transformação. No espaço discursivo, isso envolve novamente uma tradução de um conjunto de coordenadas inicial para um conjunto alvo.

Utilizaremos o exemplo (3) transcrito a seguir para exemplificar a aplicação das noções de proximização axiológica propostas por Hart (2014) - campo estável, campo em transformação; estratégias referenciais e predicativas. Trata-se de uma intervenção realizada pelo à época deputado federal do Rio de Janeiro pelo Partido Progressista (PP-RJ), Jair Messias Bolsonaro, na Câmara dos Deputados em 15 de outubro de $2012^{108}$.

O então deputado denunciava uma cartilha (o "kit gay") que supostamente apresentaria orientações explícitas sobre relações sexuais e teria sido entregue para crianças e adolescentes da rede pública de ensino. Embora tenha sido repetidamente refutado por jornalistas, pesquisadores e políticos ${ }^{109}$ ao longo dos últimos anos, isso não o impediu de utilizar essa narrativa durante o ano de 2018 como estratégia de campanha ${ }^{110}$. Incluímos este exemplo aqui para mostrar um caso de campo em transformação.

3) Jair Bolsonaro: quem é que fez o kit gay? Haddad povo paulistano tá publicado no Diário Oficial da União... doze representantes do Movimento LGBT... o que é movimento LGBT? é movimento de lésbicas gays bissexuais travestis e transexuais... atenção povo católico povo evangélico de São Paulo povo paulistano... Você quer que o seu filho aprenda lições de homossexualismo no Ensino Fundamental? se quer vota no Haddad... se quer que teu filho aprenda a ser homossexual desde cedo vote no Haddad...

No trecho, Bolsonaro estabelece uma diferenciação entre o endogrupo e o exogrupo com base no contraste entre os valores de cada grupo (conforme projetados por ele). O primeiro grupo seria composto por aqueles que se filiam ao discurso conservador cristão - e que, consequentemente, estão incluídos no centro dêitico -, o povo católico, o povo evangélico. Desse discurso, o ex-deputado destaca a condenação ao "homossexualismo", pregada por esse setor.

${ }^{108} \mathrm{O}$ vídeo utilizado para a transcrição foi publicado no canal oficial do Pastor Silas Malafaia, apoiador do então candidato à presidência da República, Jair Bolsonaro (PSL), em 10 de outubro de 2018, logo após o primeiro turno das eleições. Disponível em: < https://www.youtube.com/watch?v=DfzoQ_bkRII >. Acesso em 12/03/2020.

109 A esse respeito, recomendamos a leitura das seguintes apurações: É falso que Haddad criou 'kit gay' para crianças de seis anos, da Aos Fatos (MOURA; CYPRESTE, 2018), Facebook e YouTube têm 48 h para retirar do ar vídeos com inverdades sobre livro de educação sexual (TSE, 2018) e Kit gay nunca foi distribuído em escola; veja verdades e mentiras, do Congresso em Foco (MOURA, 2020).

${ }^{110}$ A Agência Pública, especializada em checagem de notícias falsas, realizou uma série de investigações acerca do caso e publicou duas matérias a respeito da polêmica do kit gay e de sua utilização como estratégia de campanha. Haddad não criou o 'kit gay', publicada em 11 de outubro de 2018. Disponível em: < https://apublica.org/2018/10/truco-haddad-nao-criou-o-kit-gay/>. A eleição do kit gay, publicada em 17 de outubro de 2018. Disponível em: < https://apublica.org/2018/10/a-eleicao-do-kit-gay/>. Acesso em 12/03/2020. 
No vídeo, Bolsonaro endereça seu alerta contra o candidato ao "povo católico" e ao "povo evangélico" do estado de São Paulo em específico, ainda que também conclame o "povo paulistano" em geral, sugerindo que, em sua maioria, a população do estado também compartilhe seus valores.

À época, Fernando Haddad (PT) era candidato à prefeitura da Cidade de São Paulo e havia acabado de terminar seu mandato como Ministro da Educação e da Cultura do governo Dilma Rousseff. $\mathrm{O}$ então candidato é associado às entidades ameaçadoras de fora do centro dêitico: os membros do Movimento LGBT envolvidos na elaboração do suposto "kit gay" - e, de forma mais ampla, "petistas" em geral, tendo em vista o ataque à figura de Haddad e à postura de oposição que Bolsonaro sempre assumiu frente aos governos petistas. Em seu discurso, esses grupos estão intimamente ligados a valores como e práticas que competem para a dissolução da moral cristã e dos valores da família - nomeadamente, o "homossexualismo" como expressão desviante da sexualidade.

No trecho, Bolsonaro associa esses valores ao ato de votar no candidato petista. Dessa forma, infere-se que o que está em jogo na eleição não é apenas um cargo político, mas, sobretudo, a defesa dos valores endogrupo cristão conservador e a "segurança" de seus filhos na escola. Ele alerta sobre os (supostos) perigos de um mandato desse candidato sugerindo que o governo de Haddad atuaria em favor da "conversão" de crianças ao "homossexualismo", como teria feito enquanto ministro - em termos técnicos, continuaria a promover a conversão do campo axiológico de membros do endogrupo aos valores do exogrupo, agora de forma mais próxima do campo do povo paulistano, católico e evangélico. Logo, opor-se a Haddad e votar em outros candidatos, mais alinhados aos valores cristãos, seria um meio de evitar essa “inversão de valores".

Estamos diante, portanto de um caso de proximização axiológica de campo em transformação, no qual o falante denuncia uma mudança nociva dos valores do endogrupo e orienta sua audiência e tomar uma posição contrária a essa transformação como forma de manter a estabilidade do grupo.

De acordo com Cap (2014), a Proximização enquanto ferramenta analítica se mostra essencial para analistas críticas do discurso tendo em vista que, para analisar os mecanismos discursivos de reprodução, negociação, confronto e mudança de ideologias e de identidades, é necessário reconhecer qual é o seu posicionamento original, bem como qual é o seu posicionamento pretendido em termos do (re)arranjo simbólico do espaço discursivo (CAP, 2014, p. 207). 
Essa concepção vai além do que era inicialmente proposto pela teoria e permite a análise de discursos que propõem hierarquias entre diferentes etnias, gêneros e sexualidades, como é o caso da xenofobia, do racismo, do machismo, da LGBTfobia, do nacionalismo e da exclusão social, que enfocam as diferenças entre o endo e o exogrupo.

Conforme aponta Cap (2014), a Proximização é uma teoria desenvolvida a partir de noções da Linguística Cognitiva como ferramenta de análise para a Análise Crítica do Discurso. Do mesmo modo propomos a noção de Movimentação Epistêmico-Axiológica, que será apresentada na seção a seguir. Como mencionamos anteriormente, percebemos a necessidade de propor uma nova ferramenta teórico-metodológica devido a alguns obstáculos que encontramos na aplicação da teoria da Proximização em nossas análises.

Em primeiro lugar, para os estudos do corpus sob análise, a Proximização se mostrou insuficiente para dar conta dos diversos tipos de relações construídas nos textos analisados porque está focada nas representações negativas e nos embates entre o exogrupo e o endogrupo. Nos vídeos das youtubers feministas, os laços de solidariedade construídos entre elas - e também com outras atoras e grupos sociais - se mostraram tão essenciais quanto as relações de antagonismo elaboradas em relação aos comportamentos e grupos sociais denunciados.

Em segundo lugar, o objetivo dos textos é consideravelmente diferente: enquanto os textos estudados pelos autores resenhados (Cap e Hart) costumam defender uma proposta de ação intervencionista, geralmente estatal e hegemônica, que visa a neutralizar uma ameaça militar ou cultural. Embora já exista uma literatura considerável que se debruçou sobre uma série de discursos circulantes em campos distintos (discurso médico, ambientalista, humanitário, midiático, entre outros), ainda assim, percebemos particularidades no nosso corpus que parecem fugir do esquema de neutralização de ameaças que é encontrado nesses outros estudos.

Isso se justifica porque os vídeos analisados têm como proposta de ação uma mudança de comportamento. Em geral, inseridos na cena do ativismo digital de orientação política progressista, os vídeos estão voltados primariamente para a formação política do endogrupo, visando à dissolução dos resquícios dos valores do exogrupo (conservadores, racistas, machistas e homofóbicos, por exemplo) dentre os membros do endogrupo - um processo comumente descrito como "desconstruir-se".

Isso se mostrou extremamente importante porque, do ponto de vista discursivo, investigamos um discurso contra-hegemônico. Nesse sentido, não se trata de casos em que o endogrupo se apresenta como um "campo em transformação" (HART, 2014). Numa sociedade 
estruturalmente patriarcal, racista e heteronormativa, atoras/es sociais de grupos sociais marginalizados são atravessadas/os por esses discursos e estão constantemente sujeitas/os a sofrer assédio, discriminação e violências físicas ou simbólicas características das matrizes de dominação (COLLINS, 2019) às quais estão subjugadas/os.

Consequentemente, encontram-se numa condição de constante resistência à ameaça apresentada pelo Outro e parte da (re) construção de suas identidades (sobretudo quando engajada com discursos de resistência e empoderamento) envolve opor-se a e desafiar essa dominação. Nos vídeos analisados, isso se traduziu em uma estruturação do espaço discursivo constituída a partir da oposição a essas crenças, valores e pontos de vista. Seria mais adequado, portanto, falarmos em um "campo em resistência" "111, uma estratégia que busca apresentar para o seu auditório outras perspectivas possíveis, contra-hegemônicas, que inclusive lhes permitiria enxergar como ameaçadora a ideologia do exogrupo.

Na seção seguinte, apresentaremos a noção de Movimentação Epistêmico-Axiológica e sua metodologia com maior detalhamento.

\subsection{Movimentação Epistêmico-Axiológica: teoria e método}

Esta seção está dividida em duas partes. Na primeira, apresentaremos o novo conceito de Movimentação Epistêmico-Axiológica como estratégia discursiva multidimensional e discutiremos algumas especificidades em relação a sua aplicação na análise de estratégias discursivas do ativismo digital. Na segunda parte, apresentaremos nossa metodologia, elencando e resenhando as categorias de análise utilizadas em cada etapa. Ao longo dessa exposição, incluiremos alguns exemplos retirados do corpus da pesquisa.

\subsubsection{Movimentação Epistêmico-Axiológica como estratégia discursiva multidimensional}

Nesta pesquisa, desenvolvemos a noção de Movimentação Epistêmico-Axiológica (MEA) como estratégia discursiva multidimensional, que consiste na construção textual de comunidades de crenças e valores por meio do contraste entre discursividades distintas. Essa estratégia se caracteriza como uma forma de explorar o dissenso em determinadas práticas sociais e esferas de atividade para alcançar objetivos discursivos determinados.

A proposta da Movimentação Epistêmico-Axiológica nasce a partir do nosso interesse em olhar para o tratamento do dissenso como estratégia discursiva. Explicamos: consideramos

\footnotetext{
${ }^{111}$ Aproveito para agradecer meu orientador, Paulo, pela sugestão do termo.
} 
que os enunciados sejam, como propõe Bakhtin (2016), eminentemente dialógicos, compostos a partir do diálogo e de conflitos com outros enunciados pré-existentes, bem como de antecipações a outros enunciados, ainda por virem. Com a Movimentação EpistêmicoAxiológica, pretendemos analisar a opção por explicitar no discurso esses diálogos e conflitos entre diferentes discursividades, visíveis na contraposição entre Alegações e Propostas de Ação - e na atribuição destas a entidades discursivas específicas -, como forma de estratégia discursiva. Como hipótese subsidiária, afirmamos que esse uso da Movimentação EpistêmicoAxiológica possa consistir um traço constitutivo de dados discursos e esferas. Parece-nos, particularmente, uma característica dos discursos ativistas - embora, evidentemente, não se restrinja a eles.

Em nossa investigação, procuramos descrever e analisar os modos como diferentes comunidades discursivas (delimitadas a partir da adesão a uma Alegação ou Proposta de Ação) são representadas no espaço discursivo relativamente à posição central (Alegação ou Proposta de Ação) defendida pela voz autoral ${ }^{1}$. Postulamos que elas se constituem no processamento do discurso como entidades discursivas. Essa visão parte da noção de Espaço Discursivo proposta por Chilton (2005) e dos estudos de Cap (2013) e Hart (2014) a respeito da Proximização, mas sofre influência de outras perspectivas também, como apresentaremos mais à frente.

Concordamos com Cap (2014, p. 190) em suas afirmações a respeito da potencial relevância do modelo analítico Espacial-Temporal-Axiológico (Spatial-Temporal-Axiological analytic model, ou STA model) para a ACD como um todo devido ao compromisso desta com a investigação sobre as maneiras pelas quais ideologias e identidades são refletidas, engendradas, reconfiguradas, negociadas, modificadas, reproduzidas etc. no discurso. Assim, nas palavras do autor (CAP, 2014, p. 190-191) ${ }^{112}$,

[...] qualquer aplicação da ACD deve envolver, primeiramente, o estudo o posicionamento original das diferentes ideologias e identidades e, na maioria dos casos, o estudo do 'posicionamento alvo', isto é, a mudança que a analista afirma estar acontecendo por meio do uso discursivo do falante. Consequentemente, fazer ACD significa, eventualmente, lidar com questões a respeito do arranjo conceptual do Espaço Discursivo (ED) e, especialmente,

\footnotetext{
112 No original, "Since the central commitments of CDS include exploring the many ways in which ideologies and identities are reflected, enacted, re-enacted, negotiated, modified, reproduced, etc., in discourse, any 'doing' of CDS must involve, first of all, studying the original positioning of the different ideologies and identities, and, in most cases, studying also the 'target positioning', that is the change the analyst claims is taking place through the speaker's use of discourse. Thus, doing CDS means, eventually, handling issues of the conceptual arrangement of the Discourse Space (DS), and most notably, the crucial issue of the DS symbolic re-arrangement. As such, any CDS practice may need the apparatus of proximization to account for both the original and the target setup of the DS. The most relevant seem those of the CDS domains whose discourses force the distinction between the different ideologies and/or identities in a particularly clear-cut and appealing manner, to construe opposition between 'better' and 'worse' ideologies/identities." (CAP, 2014, p. 190-191)
} 
o problema crítico do rearranjo simbólico do ED. Dessa forma, qualquer prática da ACD pode precisar do aparato da proximização para dar conta tanto da organização inicial e da organização alvo do ED. Os domínios mais relevantes da ACD parecem ser aqueles cujos discursos forçam a distinção entre diferentes ideologias e/ou identidades de forma singularmente nítida e sugestiva, construindo uma oposição entre ideologias/identidades 'melhores' e 'piores'.

Diferentemente do autor, no entanto, não nos debruçamos sobre discursos estatais voltados para a legitimação de ações intervencionistas. Nosso corpus também não apresenta certas particularidades de discursos já estudados a partir do viés da Proximização, como o discurso médico (CAP, 2013), o discurso humanitário (Katarzyna MOLEK-KOZAKOWSKA, 2018), o discurso de combate à mudança climática a ameaças cibernéticas (CAP, 2014), o discurso de rechaço aos rolezinhos (GONÇALVES-SEGUNDO, 2016b) e o discurso LGBTfóbico (WEISS, 2017), no âmbito dos quais há articulações com o domínio-fonte da GUERRA.

Ademais, o fator de estudarmos discursos contra-hegemônicos voltados para a formação política do endogrupo também se mostrou um diferencial relevante para a aplicação da metodologia da Proximização, tendo em vista as diferenças nas relações de poder entre os grupos antagonistas, bem como a relação entre a voz autoral e o seu auditório. Consequentemente, notamos distinções também em relação aos casos que Hart (2014) chamaria de proximização axiológica no que se refere aos tipos de mudanças que se processam envolvendo os campos das entidades.

Para dar conta dessas problemática desenvolvemos a Movimentação EpistêmicoAxiológica com o objetivo de oferecer uma ferramenta teórico-metodológica "guarda-chuva", mais ampla do que a Proximização e, portanto, capaz de dar conta da investigação de uma maior diversidade de práticas discursivas que recrutam estratégias discursivas baseadas no rearranjo simbólico do Espaço Discursivo, como propõe Cap (2014).

Outro aspecto relevante a ser considerado em termos da especificidade da nossa proposta é o fato de consideramos que a Movimentação Epistêmico-Axiológica consista em uma estratégia discursiva multidimensional. Para dar conta dessa multidimensionalidade, a delimitação do objeto de pesquisa foi constituída de forma multidisciplinar, arrolando conceitos, abordagens e teorias da Antropologia Digital, da Análise Crítica do Discurso, da Linguística Cognitiva, da Linguística Sistêmico-Funcional, da Psicologia e dos Estudos da Argumentação

Assim, construímos nosso olhar sobre a Movimentação Epistêmico-Axiológica a partir de três dimensões: a cognitiva, a retórico-argumentativa e a dialógico-atitudinal. 
Partindo da classificação de Hart (2014), elaborada na fronteira entre a Linguística Cognitiva e a ACD, podemos entender a MEA como uma qualificação da estratégia discursiva de Posicionamento. Assim, na dimensão cognitiva, a Movimentação Epistêmico-Axiológica se ancora no sistema cognitivo de Perspectiva (HART, 2014; CHILTON, 2013) e está relacionada à construção de Espaços Discursivos.

Para o autor (HART, 2014), o Posicionamento se baseia nos mecanismos de Perspectiva, isto é, a habilidade de conceptualizar grupos, atores, situações e discussões a partir de diversas perspectivas, tanto em termos de tempo e espaço, quanto em termos avaliativos. Semanticamente, o Posicionamento é considerado primariamente espacial, mas pode ser encarado de forma pragmática, considerando um ponto de vista especificado a partir de um centro dêitico (eu, aqui, agora, real, correto).

De todo modo, ele se realiza por meio da construção de um Espaço Discursivo, recrutando uma série de operações de perspectivação conceptual ${ }^{\mathbf{1 1 3}}$ responsáveis pelo mapeamento e povoamento do espaço discursivo de forma a estabelecer parâmetros dêiticos (egocêntricos e alocêntricos) em um determinado texto ou situação comunicativa.

Nesta pesquisa, estabelecemos que a dimensão cognitiva da Movimentação EpistêmicoAxiológica se enquadraria na intersecção entre o Posicionamento e a Perspectivação, na fronteira entre o Ponto de Vista e a Dêixis ${ }^{114}$. Enquanto estratégia de Posicionamento, a Movimentação Epistêmico-Axiológica recruta mecanismos do sistema de Perspectiva para estabelecer um determinado "ponto de vista" para a conceptualização das relações entre comunidades discursivas.

Dessa forma, embora os mecanismos linguísticos utilizados para determinar o ponto de vista sejam primariamente espaciais, essa operação pode ser recrutada para realizar a ancoragem do eixo epistêmico-axiológico a partir de um determinado ponto de vista, definindo as "métricas" e as "distâncias relativas" de um dado espaço discursivo. Nos vídeos analisados, esse ponto de vista corresponde ao da voz autoral e é ele que define a posição relativa das demais comunidades discursivas representadas no texto (HART, 2014, p. 112).

\footnotetext{
113 Conforme discutimos na seção anterior, a perspectivação conceptual consiste na "estruturação semântica de uma experiência, materializada em enunciados concretos e resultado de uma atividade de conceptualização que é possibilitada e limitada pelas coerções cognitivas advindas do seu corporeamento, o que inclui tanto fatores biológicos quanto fatores sócio-histórico-culturais" (GONÇALVES-SEGUNDO, 2017, p. 78). Considera-se, na perspectiva adotada, o papel da ideologia na construção de perspectivações alternativas como essencial para a sua análise.

${ }^{114}$ Com maiúsculas, Ponto de Vista e Dêixis referem-se a estratégias discursivas.
} 
Consequentemente, para analisar a MEA, devemos considerá-la tanto em sua dimensão linguística, quanto em sua dimensão conceptual, tendo em vista que estratégias discursivas "são performadas por instanciações linguísticas, mas geram efeitos perlocucionários apenas por meio das conceptualizações que essas instanciações evocam" ${ }^{115}$ (HART, 2014, p. 110).

Em suma, a dimensão cognitiva da Movimentação Epistêmico-Axiológica, em particular, consistiria no entendimento de que se trata de uma estratégia discursiva que se processa por meio da projeção do Espaço Discursivo, isto é, da forma como ele é construído e povoado por entidades discursivas a partir dos eixos epistêmico e axiológico. Essas entidades correspondem, por sua vez, a comunidades discursivas delimitadas a partir determinados posicionamentos frente a um problema epistêmico ou prático ${ }^{116}$.

Assim, enquanto estratégia discursiva ela permite explorar o dissenso em relação a um determinado tópico ao representar comunidades discursivas em textos, de forma a sugerir relações de complementariedade, alternatividade e oposição entre as Alegações e Propostas de Ação defendidas por cada entidade. Nesse ínterim, proporciona também a geração de efeitos discursivos relacionados à inferência de relações de solidariedade, neutralidade ou antagonismo entre essas comunidades. Isso pode estar orientado a uma série de objetivos discursivos, dentre eles a legitimação de propostas de intervenção, a revisão de crenças e comportamentos, e também a formação política (nosso interesse nesta pesquisa).

Consequentemente, ao longo das análises, mostrou-se essencial, desenvolvermos um olhar mais aguçado para a construção das entidades discursivas em termos argumentativos. Para tanto, foi necessário definir qual era o problema epistêmico/prático central em cada vídeo e como as vozes autorais apresentavam não só o seu próprio posicionamento, mas também as posições diferentes das suas. Trata-se da dimensão retórico-argumentativa da Movimentação Epistêmico-Axiológica.

Para desenvolver essa dimensão, buscamos apoio na tipologia de tipos de visada argumentativa de Gonçalves-Segundo (2020b) e de algumas questões essenciais para a discussão das particularidades das estratégias discursivas do ativismo digital no YouTube: o colapso do contexto, a persistência dos conteúdos e o conceito de públicos em rede (propostas por boyd, 2011; 2014), bem como as problematizações que eles colocam para a concepção retórica do auditório (PERELMAN; OLBRECHTS-TYTECA, 2002[1958]) de textos

\footnotetext{
115 No original, "Discursive strategies are performed through linguistic instantiations but bring about perlocutionary effects only through the conceptualizations that those instantiations evoke." (HART, 2014, p. 110) ${ }^{116}$ Isso será explicado com detalhes na seção seguinte.
} 
publicados em ambientes de sociabilidade online. Essa discussão será aprofundada na seção 2.2.3 deste capítulo.

Além disso, apoiamo-nos nas metodologias de análise que se voltaram ao estudo da configuração funcional dos argumentos para delinearmos as entidades discursivas (Eu, Nós e Outro) construídas em cada texto e seus respectivos campos epistêmico-axiológicos. Essa opção metodológica também nos auxiliou a verificar os principais pontos de tensão dialógica em cada texto, o que contribuiu para a consideração da Movimentação Epistêmico-Axiológica em sua dimensão dialógico-atitudinal.

Nesta dimensão, verificamos, por meio das categorias de análise da AVALIATIVIDADE, as relações sugeridas entre as Alegações e Propostas de Ação e, a partir daí, entre as comunidades discursivas representadas no texto.

Para articularmos as dimensões acima apresentadas, desenvolvemos metodologia de análise que se processa em três etapas: o Mapeamento das entidades no Espaço Discursivo, o Mapeamento dos movimentos epistêmico-axiológicos e a Análise da Movimentação Epistêmico-Axiológica na constituição de estratégias discursivas. Para cada etapa desenvolvemos e recrutamos uma série de categorias de análise. Estabeleceremos as noções originais na presente seção e, na seguinte, apresentaremos as etapas de análise em detalhe, resenhando as categorias analíticas já existentes recrutadas para cada uma.

Para a primeira etapa, foram elaboradas as noções de comunidade discursiva, entidade discursiva (Eu, Nós e Outro) e campo epistêmico-axiológico.

Para a segunda, desenvolvemos as concepções de região de proximidade e fronteira epistêmico-axiológica, bem como de movimento de aproximação e movimento de afastamento epistêmico-axiológico.

A terceira, por sua vez, se volta para a análise dos efeitos (de alternatividade/complementariedade/disputa entre Alegações e Proposta de Ação; de solidariedade/neutralidade/antagonismo entre comunidades discursivas) gerados pela utilização da estratégia discursiva analisada.

As noções da primeira etapa foram elaboradas no diálogo entre as dimensões cognitiva e retórico-argumentativa da MEA, enquanto as concepções da segunda consistem em ferramentas de análise da dimensão dialógico-atitudinal.

A comunidade discursiva corresponde a um grupo socialmente reconhecido com base em um determinado comportamento ou posicionamento discursivo. Em outras palavras, tratase de um grupo social que se define não apenas a partir de sua visão de mundo comum, e sim, 
mais especificamente, por sua adesão a uma determinada Alegação ou Proposta de Ação a respeito de um certo problema prático ou epistêmico.

As comunidades discursivas podem ser definidas com graus diversos de especificidade, a depender do problema em pauta. Assim, podemos concluir que, embora feministas negras brasileiras possam ser encaradas como uma comunidade discursiva por apresentarem uma agenda coesa de enfrentamento ao racismo e o sexismo, ainda assim, poderíamos delinear diversas outras comunidades discursivas mais específicas em meio a elas, a depender de seus posicionamentos frente a certo problema, ou em função de uma determinada pauta. Poderíamos considerar, por exemplo, agrupamentos baseados em sexualidades (feministas negras lésbicas, feministas negras heterossexuais, feministas negras assexuais etc.) ou ideológicos (feministas negras liberais, feministas negras comunistas, feministas negras anarquistas etc.). O mesmo poderia ser hipotetizado em relação a feministas lésbicas, considerando fatores diversos. Ademais, como apontamos no capítulo anterior, a denominação "feminista" não é consenso dentro dos movimentos de mulheres negras e de mulheres lésbicas, então vemos como os recursos lexicais utilizados podem (ou não) incluir ou excluir agrupamentos, explicitar ou apagar divergências e polêmicas, com vistas a determinados objetivos.

Ressaltamos, entretanto, que as diferenças entre as comunidades discursivas não significam necessariamente antagonismo, posto que podem consistir apenas em diferentes modos de ação, como ativistas que agem prioritariamente no Twitter, divulgando e apoiando grupos de ação offline. Nesse caso, poderíamos pensar em comunidades discursivas em relação de solidariedade. Por outro lado, quando consideramos críticas feitas por feministas negras sobre feministas brancas ${ }^{117}$ a respeito de certas práticas ou posicionamentos, podemos perceber, por vezes, a construção de uma relação de antagonismo que expõe divergências políticas importantes.

A perspectivação conceptual dessas comunidades discursivas é realizada por meio do estabelecimento de entidades discursivas ${ }^{\mathbf{1 1 8}}$, mapeadas no Espaço Discursivo, em um primeiro momento, em termos da filiação ideológica (ao endogrupo ou ao exogrupo) atribuída a elas pela voz autoral, como veremos mais a frente.

117 Consideramos, neste caso, feministas brancas ou feminismo branco como aquele que, em suas análises e práticas, não considera o aspecto racial como fundamental para a discussão de gênero, não raro reproduzindo discursos e/ou comportamentos racistas, seja de forma aberta ou velada, e reforçando a ideologia da supremacia branca.

${ }^{118}$ Essa noção foi elaborada a partir dos conceitos de entidade interna ao centro dêitico e entidade externa ao centro dêitico (CAP, 2013) e inspiradas pelos conceitos de eu político e nós político da tradição francesa da Análise do Discurso (CESTARI, 2015, 2017). 
Neste trabalho, endogrupo e exogrupo ${ }^{119}$ serão considerados como categorias que referenciam divergências discursivas mais abrangentes, que não são determinados (apenas) pela questão em discussão. Trata-se de filiações ideológicas, o que inclui a questão em pauta, mas diz respeito a posicionamentos mais amplos (por exemplo, feministas e machistas, progressistas e conservadores, esquerda e direita, racistas e antirracistas, socialistas e liberais, próLGBTTIAPN+ e LGBTfóbicos).

Consequentemente, na nossa perspectiva, o endogrupo e o exogrupo são definidos "localmente" (a depender da discussão que está em jogo no texto) e determinam os valores do eixo epistêmico-axiológico a partir do qual as entidades discursivas (Eu, Nós e Outro), por sua vez, serão mapeadas no Espaço Discursivo. São eles, portanto, que definem a métrica das distâncias entre as entidades discursivas

Assim, no vídeo "HETEROFOBIA E RACISMO REVERSO EXISTEM? | LouiePonto feat. Nátaly Neri", o espaço discursivo é dividido entre racistas e LGBTfóbicos (exogrupo) e antirracistas e aliadas da causa LGBTTIAPN+ (endogrupo). No entanto, as entidades discursivas são mais determinadas e dizem respeito ao problema epistêmico colocado no vídeo. Dessa forma, consideramos o tratamento de uma comunidade discursiva bastante específica: aquelas/es que se reivindicam ou se pretendem antirracistas ou aliadas/os da causa LGBTTIAPN+ e, não obstante, aderem à tese do racismo reverso e da heterofobia.

As entidades discursivas, por sua vez, correspondem a objetos do discurso $(\mathrm{KOCH}$, 2013), manipulados ao longo do texto para construir, subverter ou manter relações de solidariedade/neutralidade/antagonismo entre as comunidades discursivas representadas no texto, bem como sugerir relações de complementariedade/alternatividade/oposição entre certas Alegações ou Propostas de Ação.

Na perspectiva aqui apresentada, entendemos o $\mathbf{E u}^{120}$ como uma projeção discursiva da instância de produção que toma forma a partir da defesa de certos posicionamentos no texto, constituindo, assim, seu campo epistêmico-aciológico no espaço discursivo. É esta a entidade que define o centro dêitico do texto e em torno da qual se constrói o Nós. O Eu não se refere a

\footnotetext{
${ }^{119}$ Nos vídeos analisados, a construção do endogrupo é constitutiva, mas a do exogrupo não. Hipotetizamos que esse resultado se deva ao fato de que os vídeos são voltados para a formação política do endogrupo. Assim, quando a gestão do dissenso não envolvia relações de oposição nem de antagonismo, o Espaço Discursivo foi mapeado apenas a partir do endogrupo. Nos demais vídeos - em que depreendemos a sugestão de relações de oposição e/ou de antagonismo -, o exogrupo se fazia presente na constituição do Espaço Discursivo.

${ }^{120}$ Essa noção é desenvolvida a partir das noções de Self trabalhadas por Cameron (2013), de centro dêitico de Chilton (2004), e entidade interna ao centro dêitico, de Cap (2013) e Hart (2014), ainda que elas não sejam plenamente correspondentes. Apoiamo-nos também na noção de voz autoral trabalhada por Martin e White (2005).
} 
uma comunidade discursiva propriamente, mas se constitui em referência a uma comunidade por meio da defesa de determinadas Alegações e Propostas de Ação.

Assim, no vídeo "RÓTULOS ME LIMITAM OU ME DEFINEM? | Especial Dia do Orgulho LGBT | Louie Ponto", o Eu corresponde à youtuber, Louie Ponto, e se constitui em referência à comunidade discursiva que defende que a saída do armário é uma ação fundamental para a construção do movimento LGBT e, em última análise, para a defesa dos direitos conquistados.

O Nós, por sua vez, se constitui como uma constante (re)articulação entre vozes com propósitos mais ou menos comuns a cada texto. Em outras palavras, não se trata de uma entidade fixa, mas uma entidade que é atualizada ao longo do texto e em diferentes textos a depender da comunidade discursiva comque a voz autoral dialogar para estabelecer o centro dêitico. Assim, em um dado texto, Nátaly Neri poderia construir um Nós composto por feministas em geral, e em outro, constitui-lo a partir de militantes dos movimentos negros ${ }^{121}$.

Em suma, essa entidade se refere ao efeito discursivo de uma voz coletivizada, à qual a voz autora vez ou outra adere ou menciona ao longo dos textos. Essa dinâmica de individualização e coletivização dos posicionamentos defendidos se mostra extremamente relevante para a consideração das estratégias discursivas dos movimentos sociais contemporâneos, sobretudo aqueles que fazem uso da noção de lugar de fala.

Em nossas análises, verificaremos quais são as comunidades discursivas e/ou os diferentes grupos sociais que constituem o Nós em cada vídeo e de que forma essa articulação contribui para a construção do campo epistêmico-axiológico do Eu naquele texto em específico. Reiteramos que essa categoria não é fixa; ela se constitui de maneiras diversas a depender do tema, da Alegação e da Proposta de Ação em foco. Ao longo do texto, conforme o Eu se articula ao Nós e estabelece sua relação de solidariedade, essas entidades passam a configurar um “complexo de vozes” (complexo Eu-Nós), responsável pelo efeito discursivo da coletivização, isto é, o efeito de que a posição argumentativa do Eu frente ao problema não é defendida por apenas um ator social, mas corresponde a um posicionamento coletivo, defendido por um movimento social.

Assim, enquanto o Nós do vídeo referido acima se constitui como pessoas LGBTTIAPN+ engajadas no movimento social, no vídeo "HETEROFOBIA E RACISMO REVERSO EXISTEM? | LouiePonto feat. Nátaly Neri”, o Nós ao qual Louie Ponto se articula

\footnotetext{
${ }^{121}$ Isso não altera, entretanto, a construção de sua imagem como feminista negra ao longo do tempo. É uma questão que se altera a depender das comunidades discursivas a que ela faz referência em cada texto.
} 
faz referência também a um posicionamento antirracista. A articulação entre o Eu, Nátaly, e o Eu, Louie, bem como à construção de um Nós antirracista e anti-LGBTfóbico, conforma uma voz coletiva que sugere uma relação de solidariedade entre os movimentos negro e LGBTTIAPN+.

Em contrapartida, o Outro é uma entidade construída relativamente ao complexo EuNós, em conflito ou oposição direta, para estabelecer o oponente argumentativo da voz autoral. Sua concepção equivale às entidades externas ao centro dêitico, conforme definidas por Hart (2014). Esses posicionamentos são construídos a partir de dissensos reais e são desenvolvidos para que a audiência reconheça as divisões do espaço discursivo conforme delimitadas pelas youtubers. Assim como o Nós, o Outro consiste em um objeto do discurso, e não a atores sociais determinados.

Ressaltamos que, embora seja possível propor a identificação entre usuários/audiência com essas entidades discursivas, acreditamos que discussões mais consistentes a esse respeito necessitariam de estudos etnográficos. Assumimos, portanto, que as análises que realizamos aqui não permitam conclusões assertivas a esse respeito, mas não descartamos a possibilidade de a MEA poder contribuir em pesquisas a esse respeito.

Dessa forma, no vídeo “POR QUE VOCÊ É TÃO AGRESSIVA, NÁTALY?”, do canal Nátaly Neri, pudemos delimitar que o Eu corresponde a Nátaly, o Nós, a mulheres negras que compartilham sua postura combativa em relação ao estereótipo da mulher negra raivosa, e o Outro, a comentaristas racistas, que, mesmo que inconscientemente, compartilham a visão de que mulheres negras são naturalmente agressivas.

A cada uma dessas entidades discursivas corresponde um campo epistêmicoaxiológico, depreendido a partir da análise da configuração funcional dos movimentos argumentativos assumidos pelo Eu, pelo complexo Eu-Nós e atribuídos ao Outro. A base desta noção está presente em Hart (2014), mais especificamente nos conceitos de campo (ground) e de eixo avaliativo. $\mathrm{O}$ autor define campo como o "a zona imeadiatamente circundante ao centro dêitico" (HART, 2014, p. 164) ${ }^{122}$. Embora não esteja definido pelo autor (ao menos nos textos aos quais tivemos acesso) em que consiste o campo no eixo avaliativo, aproveitamos a nomenclatura para propor uma definição mais detalhada.

\footnotetext{
${ }^{122}$ No original, "The zone immediately surrounding the deictic centre" (HART, 2014, p. 164). O centro dêitico, por sua vez, corresponde ao ponto de vista atual do falante/ouvinte no 'espaço' social, temporal, epistêmico e axiológico ("The deictic centre 130plica130ntes the speaker/hearer's current point of view in social, temporal, epistemic and axiological 'space"'). 'Espaço' aqui corresponde ao Espaço Discursivo de um determinado texto (HART, 2014, p. 164).
} 
Para nós, os campos epistêmico-axiológicos são compostos, numa perspectiva argumentativa, pelas Alegações e Garantias, Propostas de Ação, Objetivos, Meios-Fins e Valores defendidos por/atribuídos a cada entidade. Denominamos esses campos epistêmicos, na medida em que definem uma determinada posição frente a um problema argumentativo (seja ele epistêmico ou prático), e axiológicos, posto que são orientados por um determinado sistema de valores (delimitado a partir de um discurso e/ou de uma filiação ideológica).

A partir da delimitação desses campos, investigamos de que forma a distância epistêmico-axiológica entre os posicionamentos é negociada, transformada e/ou mantida ao longo de um determinado texto, constituindo relações de complementariedade, alternatividade ou oposição entre as Alegações e Propostas de Ação em pauta, e, consequentemente, sugerindo relações de solidariedade, neutralidade ou antagonismo entre as comunidades discursivas a que as entidades fazem referência.

Isso é verificado a partir da avaliação dos tipos de movimentos epistêmico-axiológicos realizados em um determinado texto. Eles consistem na exploração das intersecções e dos pontos de tensão epistêmico-axiológica entre os campos das entidades mapeadas textualmente.

Enquanto os movimentos de afastamento epistêmico-axiológico consistem em delimitar os princípios e parâmetros que delineiam as fronteiras entre os campos epistêmicoaxiológicos de acordo com a voz autoral, os movimentos de aproximação se voltam para a construção de regiões de proximidade epistêmico-axiológica.

Essas regiões podem ser criadas por meio da apresentação de pressupostos construídos como comuns, por meio da concessão à perspectiva do Outro, ou ainda pela sugestão de acordos entre valores, crenças ou visões de mundo com base nas intersecções entre os campos epistêmico-axiológicos do Eu-Nós e do Outro a respeito do assunto em discussão.

Tais regiões se mostram importantes na construção dos movimentos argumentativos epistêmicos e práticos, possivelmente contribuindo para a orientação da leitura do texto (que pode se tornar mais ou menos resistente ou complacente, por exemplo) e também para o convencimento e/ou persuasão de determinados auditórios. Além disso, elas permitem à analista depreender os pontos de tensão dialógica que favorecem a construção de laços de solidariedade ou antaognismo entre as comunidades discursivas, num primeiro plano, e entre grupos sociais, mais amplamente.

Ademais, a ausência/presença de movimentos de aproximação epistêmico-axiológicos também se mostraram relevantes na avaliação do grau de dissenso entre as posições argumentativas em disputa nos textos, como sugerimos nas seções anteriores. No vídeo 
“HETEROFOBIA E RACISMO REVERSO EXISTEM?”, por exemplo, que trata de uma questão argumentativa de desacordo profundo, não depreendemos regiões de proximidade epistêmico-axiológica ao longo do texto.

Em suma, a partir da análise do mapeamento de entidades discursivas no Espaço Discursivo e de seus respectivos campos epistêmico-axiológicos, podemos depreender as relações entre Alegações e Propostas de Ação defendidas pelas comunidades discursivas representadas e, consequentemente, as diferenças entre suas crenças, seus comportamentos, seus valores e seus pontos de vista.

Em seguida, com a consideração dos movimentos de aproximação/afastamento epistêmico-axiológico, vemos quais são os efeitos discursivos gerados sobre as relações entre essas comunidades (solidariedade/antagonismo/neutralidade) a partir dos efeitos sobre as relações sugeridas entre as Alegações e Propostas de Ação em disputa (em termos de complementariedade/alternatividade/oposição).

Ademais, com a análise sistemática de textos, podemos detectar a criação de "rotas de conceptualização" (GONÇALVES-SEGUNDO, 2017, p. 76), a partir do uso reiterado de certas operações de perspectivação conceptual, ou seja, o uso contínuo de uma forma específica de construção de Espaço Discurso nos canais analisados. No longo prazo, essas rotas criam compreensões consolidadas a respeito de relações de complementariedade, alternatividade e oposição entre determinadas crenças, comportamentos, valores e pontos de vista, e mesmo de relações de solidariedade, neutralidade e antagonismo entre certas comunidades discursivas.

Por esse motivo, hipotetizamos que a Movimentação Epistêmico-Axiológica possa constituir uma estratégia discursiva voltada para a negociação de distâncias epistêmicoaxiológicas intersubjetivas - expandindo a sugestão de Cap (2014) a respeito do rearranjo simbólico do espaço discursivo.

Na seção seguinte, discutiremos as etapas metodológicas necessárias para essas análises e as categorias analíticas recrutadas para a sua realização.

\subsubsection{Movimentação Epistêmico-Axiológica: Metodologia de análise}

De forma ampla, o estudo da Movimentação Epistêmico-Axiológica tem como objetivo investigar os recursos linguístico-discursivos e argumentativos mobilizados para o mapeamento das entidades discursivas construídas ao longo do texto em relação à posição da voz autoral e como/se essa posição relativa é transformada ou mantida ao longo do texto. Em suma, trata-se de investigar o mapeamento das comunidades discursivas representadas nos textos e a forma como são posicionadas em relação à voz autoral em termos de (des)alinhamento epistêmico- 
axiológico (sugerindo relações de solidariedade/neutralidade/antagonismo) e da relação de complementariedade/ alternatividade/oposição entre suas Alegações e Propostas de Ação frente a um determinado problema argumentativo.

Em primeiro plano, portanto, a análise da Movimentação Epistêmico-Axiológica objetiva chegar a um mapeamento da projeção das entidades discursivas no espaço discursivo em relação à voz autoral. Em segundo lugar, pretende-se verificar se esse mapeamento é modificado ao longo do texto. Por fim, procura-se depreender os efeitos da mudança/manutenção desse mapeamento.

Para desenvolver essa investigação, seguimos as seguintes etapas:

\section{Mapeamento das entidades no Espaço Discursivo: Eu, Nós e Outro}

Realizada por meio da análise da Configuração Funcional dos Argumentos para delimitar os campos epistêmico-axiológicos das entidades discursivas e localizá-las em termos de associação com o endogrupo/exogrupo.

2. Mapeamento dos movimentos de aproximação/afastamento epistêmico-axiológico

1.1 Nível macro: Realizado por meio da depreensão das relações de complementariedade/alternatividade/oposição entre Alegações e Propostas de Ação, além de outros elementos argumentativos, como as Garantias e Meio-Fim.

1.2 Nível micro: Realizado por meio da análise da utilização dos recursos do sistema de AvALIATIVIDADE em trechos selecionados com base na diversidade de funções assumidas pela MEA na estrutura dos movimentos argumentativos.

3. Interpretação das funções da Movimentação Epistêmico-Axiológica na constituição de estratégias discursivas

Realizada por meio da análise da Movimentação Epistêmico-Axiológica na constituição das estratégias discursivas em face dos objetivos de cada texto, em especial para a depreensão das relações de solidariedade/neutralidade/antagonismo entre comunidades discursivas.

Nas seções seguintes, descreveremos brevemente os objetivos de cada etapa e resenharemos as principais categorias de análise utilizadas.

\subsubsection{Mapeamento das entidades no Espaço Discursivo: Eu, Nós e Outro}

Em termos de aplicação metodológica, procuramos, em nossas análises, discernir o campo epistêmico-axiológico das comunidades discursivas representados no texto em termos de distância/proximidade em relação ao Eu por meio das estratégias referenciais e predicativas de representação de ambos. Possivelmente por tratar-se de vídeos localizados na esfera do 
ativismo, notamos que os posicionamentos enunciados pelo $\mathrm{Eu}$ constantemente ecoavam e invocavam outras vozes, que também participavam do endogrupo. Isso se mostrou relevante para a compreensão das articulações discursivas entre diferentes vertentes feministas e entre o feminismo e outros movimentos sociais. Por isso, propomos a categoria Nós como objeto de análise, de forma a visibilizar essas dinâmicas.

Para esta etapa, ocorrem as análises da configuração funcional dos argumentos, que nos permitem verificar não apenas como se constitui o campo do complexo Eu-Nós, como também o lugar que o Outro ocupa relativamente a essa posição.

\section{Configuração funcional dos argumentos: argumentação epistêmica e prática}

Nesta seção, descreveremos brevemente os modelos de análise argumentativa propostos por Toulmin (2006) e Fairclough e Fairclough (2012), bem como os desdobramentos dos mesmos efetuados por Sousa (2018) e Gonçalves-Segundo (2016a, 2018a, 2019a, 2020a).

Gonçalves-Segundo (2019a, p. 112-113) define a dimensão da configuração funcional dos argumentos da seguinte forma:

[...] diz respeito aos scripts de operacionalização dos movimentos argumentativos. Tal dimensão está mais diretamente associada ao aspecto justificatório (ou lógico) da argumentação e, portanto, aos modos de organização do raciocínio argumentativo textualizado ou inferível, ainda que seja possível, por meio dela, dar conta do dissenso e do dialogismo inscritos na argumentação, concernentes ao aspecto comunicativo (ou retórico). Pelo estudo dessa dimensão, podemos depreender o papel das distintas proposições - derivadas de enunciados - na defesa de Alegações e de Propostas de Ação, por mais que tenhamos que reduzir, em maior ou menor grau, suas marcas enunciativas para compreendermos o raciocínio efetuado. É no âmbito dessa dimensão que se localizam os layouts de Toulmin ([2006]1958) e Fairclough \& Fairclough (2012).

Os usos do argumento (TOULMIN, 2006 [1958]), um dos textos fundadores da renovação dos estudos argumentativos no ocidente, tinha como objetivo apontar falhas no estado da arte dos estudos da lógica formal britânica para a compreensão da argumentação cotidiana e acabou tendo como subproduto o que veio a se chamar "modelo Toulmin", um esquema de sistematização dos argumentos que consiste, basicamente, na "expansão do constructo básico da lógica (premissas/conclusão) de modo a adaptá-lo à natureza comunicacional da argumentação" (GRÁCIO, 2010, p. 178).

Existem duas linhas interpretativas principais acerca da natureza do modelo Toulmin. A linha proposicional focaliza os raciocínios subjacentes à argumentação, enquanto a dialética privilegia os elementos linguísticos e não-linguísticos que concorrem para a modificação de crenças, atitudes, valores e comportamentos do interlocutor (HARADA, 2009, p. 46-47, 
tradução nossa). Nesta perspectiva, o modelo se constitui não apenas pelo reconhecimento de relações de apoio ou refutação entre proposições, como também prevê também a participação de um interlocutor (Oponente), real ou imaginário, que precisa ser persuadido ou convencido de algo, ou com quem se busca chegar a um acordo (HARADA, 2009, p. 51).

Harada (2009, p. 52) propõe que o modelo possa ser interpretado também a partir do ponto de vista retórico, posto que não apenas inclui um Oponente à sua teorização, como também considera o tipo de dados ou fundamentos, as garantias e os respaldos necessários para convencê-lo, aproximando-se da noção de auditório proposta por Perelman e Olbrechts-Tyteca (2002 [1958]).

Gonçalves-Segundo (2018a) propõe mais uma interpretação para o modelo Toulmin: a dialógica. Um dos elementos centrais do modelo, a Alegação $(\mathbf{A})^{123}$, costuma ser entendida como a "asseveração ou pretensão de que uma crença seja verdadeira, que deve ser aceita ou que constitui uma boa razão para agir de uma determinada maneira" (HARADA, 2009, p. 51, tradução nossa). Para Gonçalves-Segundo (2020a, p. 241, itálico do original), a Alegação consiste em "uma resposta possível a esse problema, em um ponto de tensão dialógica que é focalizado publicamente pelo orador em termos de investimento linguístico, discursivo e cognitivo orientado à sua justificação e - potencialmente, não necessariamente - à adesão do outro".

Essa Alegação pode ser qualificada (Q - Qualificação) ${ }^{124}$, o que consiste na inscrição do grau de comprometimento do Proponente em relação àquilo que enuncia - isso inclui tanto o grau de razoabilidade da Alegação, conforme avaliado por seu Proponente, quanto o grau de abertura crítica a que ele se dispõe (GONÇALVES-SEGUNDO, 2020a).

Quando uma Alegação é questionada, seu Proponente precisa apresentar algum tipo de justificativa - causa, exemplo ou comparação (dentre outros) - que lhe transfira aceitabilidade. Esses elementos consistem no que se chama de Dados (D). Por outro lado, algumas asserções não são polêmicas no âmbito de uma dada prática, ao se considerar um determinado auditório, tornando dispensáveis a apresentação de Dados. Um exemplo de caso em que a apresentação de Dados é dispensável seria uma apresentação em um congresso de Linguística Cognitiva que

123 Ao longo deste capítulo, iremos nos referir aos elementos da configuração funcional do argumentos sempre com a primeira letra maiúscula (Alegação, Proposta de Ação, Garantia etc.) e, no momentos de abreviação, utilizaremos a(s) primeira(s) letra(s) do elemento sempre que possível. No capítulo seguinte, iremos diferenciar os elementos como pertencentes a movimentos argumentativo do Eu-Nós ou do Outro a partir de um sistema de cores - nos layouts, rosa equivalerá ao Eu-Nós, azul ao Outro e roxo aos elementos compartilhados por ambos os discursos - e da adição do sinal ' (assim, Alegação'/A') para indicar o discurso do Outro.

${ }^{124}$ Gonçalves-Segundo (2020a) propõe que a Qualificação possa incidir em qualquer elemento argumentativo: Dados, Bases, Refutações e mesmo Garantias (quando textualizadas). 
aplique em suas análises a noção de metáfora conceptual. Sendo este um dos principais conceitos da área, mostra-se desnecessário justificar a pertinência da noção - a menos que a autora proponha resenhar diversas perspectivas acerca do conceito ou problematizá-lo.

Diversas interações argumentativas se encerram com a apresentação desses elementos, porém algumas se deparam com um obstáculo subjacente à relação estabelecida entre eles e a Alegação defendida. São os casos em que se coloca em dúvida a Garantia (G), a inferência ou acordo prévio (muitas vezes baseada no senso comum e implícita no discurso do Proponente) que estabelece uma relação entre os Dados e a Alegação, garantindo a transferência da força de um para o outro (GONÇALVES-SEGUNDO, 2016, p. 73; HARADA, 2009).

Embora essas Garantias consistam, muitas vezes, em generalizações ou princípios práticos ou morais previamente acordados e aceitos pelo senso comum (TOULMIN, 2006; HARADA, 2009, p. 51), Gonçalves-Segundo (2020a) afirma que este caráter "previamente acordado" deva ser compreendido como uma pré-legitimação discursiva. Nesse sentido, a Garantia deve constituir uma visão circulante, validada por um determinado discurso. Consequentemente, ela pode ser posta em discussão e mesmo rechaçada categoricamente quando confrontada por uma discursividade antagônica ${ }^{125}$.

Ademais, tanto as Garantias quanto os próprios Dados podem ser postos em questão, requisitando que o Proponente ofereça algum tipo de Base (B), isto é, uma informação oriunda do domínio evidencial concernente aos Dados, Garantias ou Refutações apresentadas que permita asseverar a veracidade ou aplicação desses elementos no movimento argumentativo (GONÇALVES-SEGUNDO, 2020a). Assim como os Dados, as Bases são dependentes do campo discursivo no qual o texto está inserido. Outro modo de reforçar ou matizar a força do fluxo argumentativo é por meio do elemento que apresentamos alguns parágrafos acima: a Qualificação (Q), que consiste, grosso modo, no valor modal epistêmico da proposição. Nos casos de Refutação, a força da tríade Dados-Garantia-Alegação determina o valor da Qualificação

Por fim, o elemento que subjaz à tensão dialógica consiste na Refutação $(\mathbf{R})$. Ela pode ser aplicada sobre a Alegação, os Dados, a Base ou mesmo a Garantia e visa a impedir ou enfraquecer o fluxo argumentativo que sustenta a Alegação ou ainda atuar como ressalva (GONÇALVES-SEGUNDO, 2020a).

${ }^{125}$ Veremos, nas análises do vídeo "HETEROFOBIA E RACISMO REVERSO EXISTEM? | LouiePonto feat. Nátaly Neri” em que a refutação da Alegação' (Heterofobia e racismo reverso existem), atribuída ao Outro, é refutada a partir da Garantia - que consiste nas definições de racismo e LGBTfobia que lhe são atribuídas pela voz autoral. 
A diagramação do modelo Toulmin pode ser elaborada conforme a figura abaixo:

Figura 5 - Layout de Argumentação Epistêmica

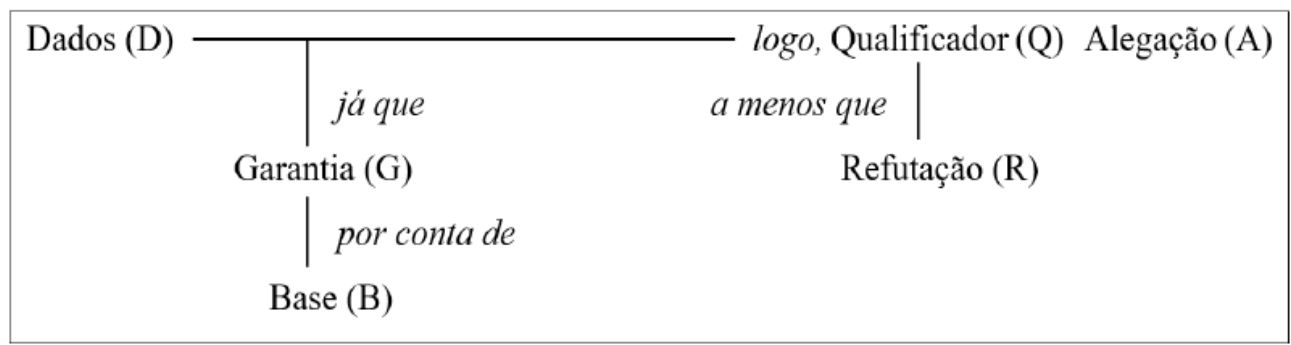

Fonte: retirado de Gonçalves-Segundo (2020a, p. 240).

Enquanto o modelo Toulmin se mostra mais adequado para a análise da argumentação epistêmica, o modelo proposto por Fairclough e Fairclough (2012) se volta para a análise da argumentação prática. Esta proposta foi elaborada para contemplar o debate deliberativo parlamentar, no qual diversas Propostas de Ação são colocadas em disputa e argumenta-se em favor de cada uma. Alguns estudos têm sido realizados a fim de considerar sua aplicação em textos argumentativos monologais, como é o caso de Sousa (2018) e Gonçalves-Segundo (2016, 2019).

O coração deste modelo é a Proposta de Ação, o caminho defendido por um determinado movimento argumentativo para atingir um Objetivo desejado. Este Objetivo, por sua vez, é definido com base em Valores ${ }^{126}$ que determinam o que é (in)desejável, (in)aceitável

\footnotetext{
${ }^{126}$ De modo geral, os Valores envolvem as "preocupações factuais dos atores sociais ou [os] compromissos que eles assumem como parte da ordem do discurso da instituição à qual estão vinculados. Nesse sentido, não devemos igualar Valores a desejos individuais, ainda que eles possam coincidir" (GONÇALVES-SEGUNDO, 2019, p. 119). Para uma perspectiva mais aprofundada a respeito do que está em jogo na constituição desses parâmetros, ver Gonçalves-Segundo (2019).
} 
e aprimorável. Esse Objetivo é contraposto às Circunstâncias (sejam elas Motivadoras ${ }^{127}$, Viabilizadoras $^{128}$, Catalisadoras ${ }^{129}$, Bloqueadoras ${ }^{130}$ ou Adversas ${ }^{131}$ ).

Enquanto as Circunstâncias Motivadoras se referem à leitura negativa de um estadode-coisas presente, que é considerado indesejável, inaceitável ou aprimorável, as demais consistem na avaliação (positiva ou negativa) das Propostas de Ação em disputa. Já a factibilidade e a efetividade da Proposta de Ação ${ }^{132}$ para mudar esse estado-de-coisas e atingir o Objetivo é postulada pelo Meio-Fim.

A Proposta de Ação é, em geral, elaborada em diálogo com outras Contra-Propostas. Assim, cada Proposta pode ser conectada a Consequências. As Consequências Positivas visam a reforçar o beneficiamento da Proposta da voz autoral, enquanto as Negativas costumam enfraquecer a Contra-Proposta ${ }^{133}$. Tendo em vista, no entanto, que os vídeos analisados recuperam o embasamento das Contra-Propostas, assim como os movimentos de refutação à Proposta de Ação apresentada pelo Eu, por vezes veremos Consequências Negativas e Circunstâncias Bloqueadoras, por exemplo, relacionadas aos movimentos argumentativos do $\mathrm{Eu}$.

De forma geral, Gonçalves-Segundo (2019, p. 117) diferencia entre dois grandes tipos de dissenso que embasam a argumentação prática:

\footnotetext{
127 Gonçalves-Segundo (2019, p. 122-123) define as Circunstâncias Motivadoras como aquelas que "dão origem ao problema prático, na medida em que resultam de um enquadramento discursivo que avalia o estado-de-coisas presente de forma negativa, mais especificamente, como indesejável, inaceitável ou, pelo menos, aprimorável”.

${ }^{128}$ Gonçalves-Segundo (2019, p. 123) define as Circunstâncias Viabilizadoras como aquelas que "delimitam a viabilidade da Proposta de Ação, indicando que há, no estado-de-coisas presente, condições para aplicá-la. A análise desse tipo de Circunstância está ligada [...] à avaliação do critério de viabilidade da Proposta".

${ }^{129}$ Gonçalves-Segundo (2019, p. 124) define as Circunstâncias Catalisadoras como aquelas que "delimitam o potencial de o estado-de-coisas presente apresentar condições que garantam o alcance do estado de mundo futuro expresso nos Objetivos, por meio da efetivação da Proposta de Ação. Assim, a análise desse tipo circunstancial consiste em um dos elementos que compõem tanto o critério da eficácia quanto da eficiência da Proposta".

${ }^{130}$ Gonçalves-Segundo (2019, p. 124) define as Circunstâncias Bloqueadoras como aquelas que "delimitam a inviabilidade da Proposta de Ação, indicando que não há, no estado-de-coisas presente, condições para aplicá-la. Nesse sentido, elas podem direcionar a reflexão, em textos monologias (sic), ou a deliberação, em textos dialogais sob contextos pragmaticamente relevantes, para a rejeição da Proposta em foco e para a ponderação de alguma Contra-Proposta de Ação".

131 Gonçalves-Segundo (2019, p. 124) define as Circunstâncias Adversas como “[...] aquelas que delimitam condições que desestimulam a realização da Proposta de Ação. [...] não são construídas como impeditivas; contudo, oferecem obstáculos para a efetivação da Proposta. Em geral, elas tendem a atuar ou como um mecanismo de ponderação que requisitará dos oradores uma reavaliação do projeto ou como um mecanismo de atrição relativo à Proposta, buscando desestimular adesão, dadas as dificuldades de concretização, ainda que seja possível fazê-lo. Por conseguinte, elas também podem direcionar a deliberação para uma possível Contra-Proposta".

132 Gonçalves-Segundo (2019) propõe uma série de parâmetros envolvidos na avaliação das Propostas: eficácia, viabilidade, eficiência inofensividade, beneficiamento e (des)respeito a Valores (GONÇALVES-SEGUNDO, 2019, p. 118).

${ }^{133}$ Esse padrão de associação é semelhante ao que costuma ocorrer com as Circunstâncias Viabilizadoras e Catalisadoras, e com as Circunstâncias Bloqueadoras e Adversas, respectivamente.
} 
i. Problema prático orientado a alternativas de ação.

ii. Problema prático orientado às motivações para ação.

O primeiro tipo envolve um acordo prévio sobre o Objetivo almejado, e a avaliação negativa do estado de coisas presente é compartilhada por todos. Ocorre o embate entre diferentes alternativas e a defesa de uma determinada Proposta de Ação. O ponto de tensão nesses casos é a relação Meio-Fim, ou seja, a eficácia da Proposta de Ação em gerar, de fato, o estado de coisas visado explicitado nos Objetivos $^{134}$ (GONÇALVES-SEGUNDO, 2019).

Um exemplo desse tipo de dissenso será explorado na análise do vídeo "RÓTULOS ME LIMITAM OU ME DEFINEM? | Especial Dia do Orgulho LGBT | Louie Ponto”, no qual há uma discussão entre diferentes Propostas de Ação que visam a um estado de coisas no qual seja possível Viver em uma sociedade na qual a sexualidade não seja motivação para violências físicas e simbólicas, na qual não seja necessário dar satisfação para ninguém (Objetivo compartilhado).

No segundo tipo, não há acordo entre as leituras das Circunstâncias, e a própria necessidade de haver uma Proposta de Ação está em jogo. O vídeo "POR QUE VOCÊ É TÃO AGRESSIVA NÁTALY?" é um exemplo desse tipo de dissenso, tendo em vista que gira em torno de duas leituras diversas da personalidade de Nátaly e de sua atuação no YouTube. Neste caso, a youtuber questiona a necessidade de ela mudar o seu comportamento e a eficácia dessa estratégia para aumentar o alcance de seu canal, apresentando outra leitura do estado de coisas.

Como mencionamos no início da seção, é pela descrição da configuração funcional dos argumentos que iniciamos as análises a respeito do Mapeamento das entidades no espaço discursivo. A partir desse primeiro momento, depreendemos a distância relativa entre as entidades discursivas. As análises se iniciam por meio da depreensão de qual é a filiação discursiva das vozes autorais em relação a campos político-ideológicos (progressismo, conservadorismo, liberalismo, marxismo etc.), por exemplo, por meio da consideração das questões argumentativas, dos Valores, Objetivos, Alegações e Propostas de Ação em jogo no texto. Isso nos permite verificar qual é a dinâmica endogrupo x exogrupo que orientará o texto. Nos textos sob análise, percebemos que, de forma geral, o endogrupo era composto a partir de valores progressistas, e o exogrupo, conservadores. A partir do tópico discutido no vídeo,

${ }^{134}$ De forma análoga ao modelo Toulmin, no qual as análises são voltadas para a delimitação de movimentos argumentativos que concorrem para a defesa de uma Alegação (e para a refutação de Contra-alegações), na argumentação prática os seus elementos constitutivos se articulam para a defesa de uma Proposta de Ação (e para a derrota de Contra-Propostas). 
depreendemos, enfim, as entidades discursivas (Eu, Nós e Outro) e seus respectivos campos epistêmico-axiológicos.

No vídeo “HETEROFOBIA E RACISMO REVERSO EXISTEM?”, por exemplo, o Eu corresponde à representação discursiva de Louie e Nátaly no texto. No vídeo "POR QUE VOCÊ É TÃO AGRESSIVA, NÁTALY”, o Nós corresponde à coletividade de mulheres negras, com o critério do compartilhamento de uma série de experiências com o racismo e o sexismo. Por fim, no vídeo "YOUTUBER SÓ FALA MERDA NA INTERNET", o Outro corresponde a integrantes do campo progressista que discordam das youtubers no que se refere à proeminência, eficácia e mesmo à própria validade dos ativismos digitais. Enquanto, nos dois primeiros vídeos, o Outro se projeta (de acordo com a representação de seu discurso realizada pelas youtubers) no campo do progressismo, esse mapeamento é rejeitado pelas vozes autorais, que o localizam como alinhado ao exogrupo. No último vídeo, por outro lado, o Outro é considerado como parte do endogrupo, e se discute se o ativismo digital é um modo de ação válido para os movimentos sociais progressistas com o objetivo de construir comunidades engajadas.

O layout abaixo foi elaborado para servir de exemplo para a explicação dos critérios de formatação dos elementos da configuração funcional prática e epistêmica. Ao longo da dissertação, nos referimos aos elementos da configuração funcional do argumentos sempre com a primeira letra maiúscula (Alegação, Proposta de Ação, Garantia etc.) e, no momentos de abreviação, utilizaremos a(s) primeira(s) letra(s) do elemento sempre que possível. Para diferenciar os elementos como pertencentes a movimentos argumentativo do Eu ou do Outro, utilizaremos um sistema de cores nos layouts - rosa equivalerá ao Eu, azul, ao Outro e roxo, aos elementos compartilhados por ambos os discursos.

Ademais, a adição do sinal ' (por exemplo, Alegação'/A') indicará a referência a um elemento do discurso do Outro; quando houver mais de uma instância do mesmo elemento em um dado movimento, ou quando à entidade for atribuído mais de um movimento argumentativo, marcaremos a pertença por meio da adição de um numeral e, caso seja necessário, de uma letra (assim, podemos ter uma $\mathrm{A} 1$, sustentada pelos Dados $\mathrm{D} 1^{\mathrm{A}}$ e $\mathrm{D} 1^{\mathrm{B}}$ ). Elementos do layout que estiverem tracejados indicam inferências de elementos não plenamente materializados na materialidade do texto (como nas Circunstâncias bloqueadoras') ou para delimitar um elemento composto por um bloco de outro tipo argumentativo (como é o caso do Meio-Fim apresentado acima). 
Em cada caixa de texto, haverá uma breve paráfrase dos trechos correspondentes àquele elemento (sempre em itálico), ou a recuperação de trechos específicos (sempre entre aspas), quando não for possível ou produtivo parafraseá-los, como ocorre na apresentação de experiências pessoais como argumento de autoridade ou em exemplos concretos, que reproduzem os comentários do Outro. Ressaltamos que a técnica de paráfrase é utilizada apenas para a descrição do raciocínio argumentativo no nível de análises macro. No nível micro, recuperamos os elementos linguísticos tais como foram enunciados, a partir da transcrição dos vídeos de acordo com as regras do NURC (PRETI, 2010).

\section{Figura 6 - Layout de argumentação prática}

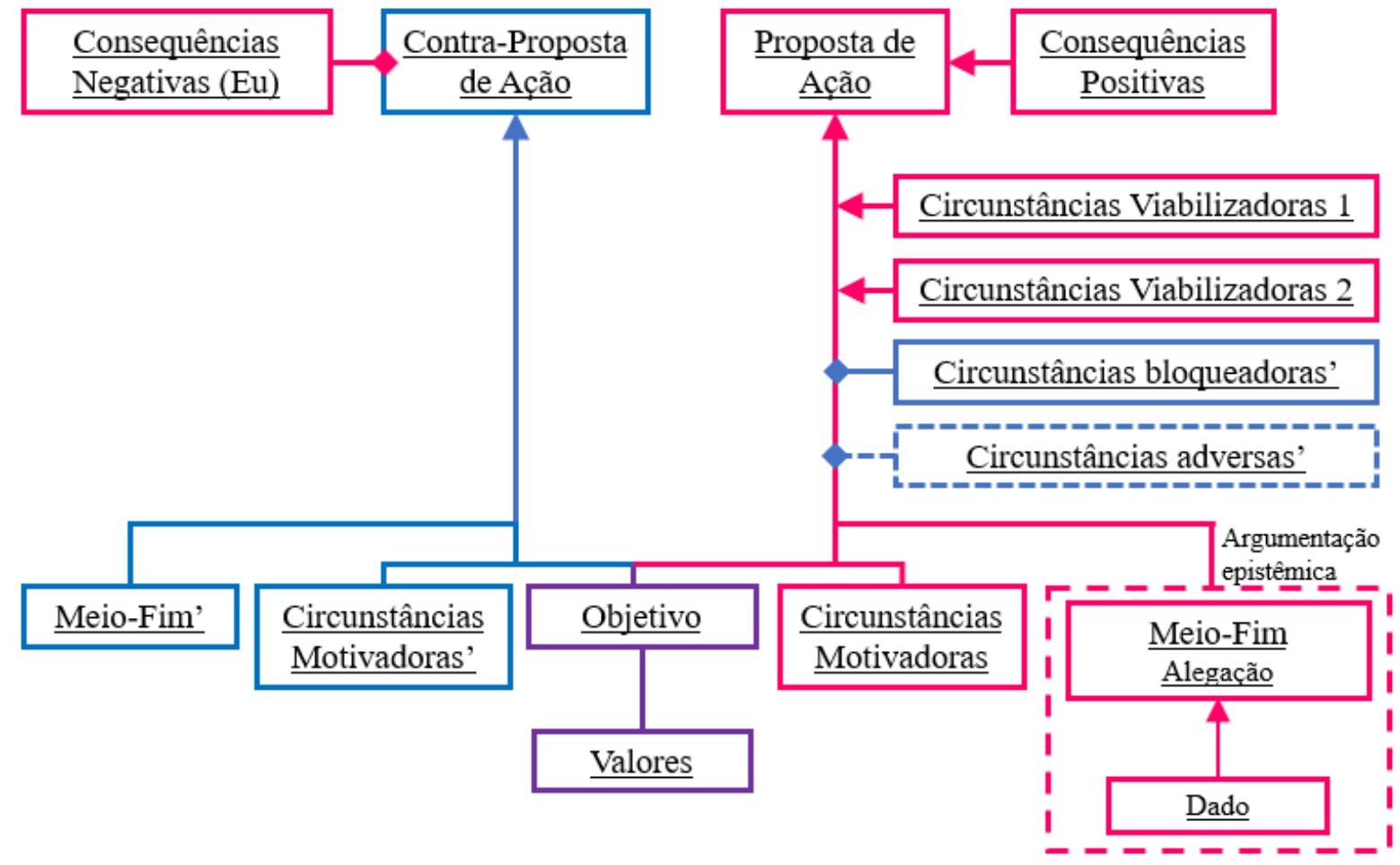

Fonte: elaboração própria a partir de Fairclough; Fairclough (2012); Gonçalves-Segundo (2019, p. 8)

\subsubsection{Mapeamento dos movimentos de aproximação/afastamento epistêmico- axiológico}

A partir do mapeamento das entidades e de seu envolvimento nos movimentos argumentativos, verificamos as regiões de proximidade epistêmico-axiológica (sugeridas por meio de movimentos de aproximação), assim como a analisamos a delimitação de fronteiras entre os mesmos (realizada por meio dos movimentos de afastamento). Para tanto, realizamos a análise dos recursos de ATITUDE e de ENGAJAMENTO em relação aos pontos de tensão dialógica verificados a partir da primeira etapa metodológica. 


\section{Sistema de Avaliatividade}

Martin e White (2005) localizam o sistema de AvALIATIVIDADE na corrente de investigações da metafunção interpessoal da Linguística Sistêmico-Funcional ${ }^{135}$. No que se refere aos níveis de estratificação, a AVALIATIVIDADE se inscreve na semântica discursiva (MARTIN; WHITE, 2005, p. 33), podendo ser realizada por meio de diversas formas léxicogramaticais e fonético-fonológicas. Na presente pesquisa, focalizamos sobretudo as formas léxico-gramaticais da inscrição da AVALIATIVIDADE.

Os recursos utilizados para inscrever a perspectiva intersubjetiva são divididos entre aqueles que ativam posicionamentos avaliativos positivos ou negativos (ATITUDE) e que podem ser graduados em termos de prototipia ou escalaridade (GRADAÇÃO) e aqueles que permitem o posicionamento do enunciado frente a alternativas dialógicas reais ou potenciais, indicando o grau de engajamento da voz autoral com a perspectiva construída no enunciado (ENGAJAMENTO). Para esta pesquisa, voltamo-nos especialmente para os subsistemas da ATITUDE e do ENGAJAMENTO.

Essas estratégias tanto permitem a construção de comunidades de comunhão de sentimentos e valores, quanto participam da construção das imagens das vozes autorais/argumentadoras, além de indicar o alinhamento ou desalinhamento destas em relação a outras vozes e possíveis leitoras/es - o que, por sua vez, permite entrever a construção do auditório do texto (MARTIN; WHITE, 2005, p. 1).

O quadro a seguir contempla alguns dos recursos que realizam o sistema da AvALIATIVIDADE:

\footnotetext{
135 Adotamos esta categoria de análise devido à sua riqueza de detalhes em termos de análise microlinguística e produtividade para a interpretação discursiva, sem paralelos no arcabouço teórico-metodológico da Linguística Cognitiva até então. Tendo em vista as aproximações declaradas entre a Linguística Sistêmico-Funcional e a Análise Crítica do Discurso, e mesmo entre as recentes articulações entre a Linguística Cognitiva e a SistêmicoFuncional, acreditamos que nossa escolha se justifique devido à proficuidade desses diálogos teóricometodológicos.
} 
Quadro 3 - Realização da Avaliatividade de acordo com os estratos linguísticos

\begin{tabular}{|l|l|l|l|}
\hline Registro & Semântica discursiva & Léxico-gramática & Fonética e Fonologia \\
\hline & & Léxico avaliativo & \\
& & Modo & \\
& & Modalização & \\
Relações & Eolaridade & \multirow{2}{*}{ Altura } \\
Campo & Atitude & Numeração & Mudança de tom \\
& Gradação & Intensificação & Qualidade da voz \\
& & Repetição & \\
& & Extensão & \\
& & Lógico-semântica & \\
& & Vocativo & \\
\hline
\end{tabular}

Fonte: Elaboração própria a partir de Martin; White (2005) e Gonçalves-Segundo (2011).

No que se refere à inscrição das subjetividades nos textos, Martin e White (2005, p. 62) distinguem entre dois tipos: a subjetividade individual e a social. Enquanto a primeira consiste em leitoras/es específicos, idiossincráticos, a segunda diz respeito a comunidades de leitoras/es, que se posicionam a partir de configurações específicas de gênero, geração, classe, etnia e competências comunicativas. Essas variáveis se mostram fundamentais para a especificação da hipótese de leitura que se constrói, seja ela complacente, resistente ou tática ${ }^{136}$.

\section{ATITUDE}

A categoria da ATITUDE recobre os campos semânticos tradicionalmente conhecidos como emoção, ética e estética, dentre os quais se destaca o da emoção como recurso expressivo primário (MARTIN; WHITE, 2005, p. 42). Este campo é denominado AFETO, que consiste no registro de sentimentos por meio da linguagem. O campo da ética é sistematizado no subsistema do JULGAMENTO, que trata das atitudes linguageiras referentes à avaliação de comportamentos em termos de admiração e crítica. Por fim, a APRECIAÇÃo trata da codificação de fenômenos semióticos e naturais com base em um campo do saber específico.

${ }^{136}$ Uma leitura tática consiste em "um posicionamento parcial e interessado em relação ao texto, que procura utilizar o texto para alcançar objetivos sociais diferentes daqueles esperados", enquanto leituras resistentes se opõem ao posicionamento "naturalizado pela co-seleção de significados em um texto"; a leitura complacente, por sua vez, consiste na aceitação dessa seleção (MARTIN; WHITE, 2005, p. 62). 
JULGAMENTO e APRECIAÇÃO podem ser entendidos como sentimentos institucionalizados baseados em valores comunitários compartilhados. Mais especificamente, nesta visão, os JULGAMENTOS consistem em avaliações no campo comportamental e podem ser institucionalizados ainda de forma a constituir regras e regulamentos de organizações e de instituições como a Igreja e o Estado. A APRECIAÇÃO ${ }^{137}$, por sua vez, trabalha com os sentimentos enquanto "proposições sobre os valores das coisas" (MARTIN; WHITE, 2005, p. 45) - bons exemplos são as escolas estéticas e a crítica de arte ou literária. Não trataremos, entretanto, deste subsistema nesta pesquisa, voltando-nos apenas para o JULGAMENTO e para o AFETO, dada sua produtividade no corpus.

Nos termos de Halliday (1994), o AFETO enquanto subsistema semântico-discursivo pode ser realizado por meio de processos materiais transformativos, mentais e comportamentais, além de adjuntos modais e de predicações adjetivas e adverbiais. Em outras palavras, o AFETO pode ser representado como qualidade - por meio da descrição de participantes ("um homem triste" - epíteto), da atribuição de características a participantes ("a mulher estava animada" - atributo) e a processos ("o menino saiu cabisbaixo" - circunstância), de processos afetivos mentais e comportamentais ("isso me irrita", "eu chorei horrores") e de comentários desiderativos ("infelizmente, isso ainda acontece"). Além disso, encontramos também realizações nominalizadas de qualidades afetivas e processos ("prazer", "tristeza", "raiva", "luto”, "soluçar”, “nó na garganta”).

Para a descrição e mapeamento das emoções, o subsistema do AFETO (MARTIN; WHITE, 2005; GONÇALVES-SEGUNDO, 2011) propõe seis fatores, a saber:

i. polaridade: os sentimentos são considerados positivos ou negativos no contexto de produção?;

ii. aspectualidade: os sentimentos são representados como experiências internas (processo/estado mental) ou envolvem algum tipo de manifestação paralinguística ou extralinguística (onda comportamental)?;

iii. responsividade: os sentimentos são representados como respostas a algum gatilho ou estímulo emocional específico ou são caracterizados como um humor corrente e não direcionado?;

iv. localização do estímulo no eixo realis-irrealis: os sentimentos estão relacionados a um gatilho já realizado (realis) ou ainda não realizado (irrealis)?;

\footnotetext{
${ }^{137}$ Para uma aplicação da APRECIAÇÃo para análise de outros campos do conhecimento, sugerimos a leitura da dissertação de Sandra Gomes Rasquel (2020).
} 
v. intensidade;

vi. qualidade afetiva: (in)felicidade, (in)satisfação, (in)segurança, inclinação.

Esses recursos são constitutivos das estratégias de Movimentação EpistêmicoAxiológica, posto que permitem à voz autoral construir, por meio da linguagem, suas hipóteses acerca dos estados mentais e emoções do Outro, bem como representar os seus próprios. Além disso, podem indicar também os sentimentos que a voz autoral nutre em relação ao Nós e ao Outro, o que permitiria o reconhecimento de sua proximidade ou distância emocional, assim como a existência de conflitos ou laços prévios de solidariedade, de neutralidade ou de antagonismo.

Outro campo da ATITUDE que se mostrou importante para as nossas análises é o dos JULGAMENTOS. Por meio das opções disponíveis neste subsistema, construímos atitudes em relação a outras pessoas, suas ações, seu comportamento e, enfim, seu caráter. Os autores dividem os julgamentos entre os de estima e os de sanção social. Os primeiros têm como referência normas culturais de aceitabilidade e adequação, sendo subdivididos em julgamentos de capacidade, normalidade e tenacidade. Os segundos têm como referência regras e regulamentos mais ou menos explícitos, em geral codificados em normas morais e legais de uma dada sociedade em termos políticos ou religiosos, por exemplo. São subdivididos em julgamentos de veracidade (honestidade) e de propriedade (ética).

A descrição e a sistematização das realizações dos JULGAMENTOS presentes em um dado texto podem, assim como o estudo dos AFETOS, indicar aproximação e afastamento epistêmicoaxiológico entre o complexo Eu-Nós e o Outro de acordo com a voz autoral. Eles também podem apontar para os discursos que legitimam ou deslegitimam determinados comportamentos e crenças - sobretudo no que se refere ao reconhecimento das Garantias que embasam o fluxo argumentativo em apoio a uma dada Alegação.

Nas análises, seguiremos a seguinte formatação: itálico para indicar o tipo de julgamento realizado e negrito para salientar o elemento linguístico analisado. Por exemplo, "os julgamentos positivos combinados de capacidade: competência ("mobilizam os seus conhecimentos"), tenacidade: obstinação ("e falam de forma interesSAda e decidida")". 
Quadro 4 - Tipos de JULGAMENTo e exemplos de realizações canônicas

\begin{tabular}{|c|c|c|c|}
\hline \multicolumn{3}{|c|}{ Julgamentos de estima social } & Exemplos \\
\hline Normalidade & $\begin{array}{c}\text { Grau de } \\
\text { excepcionalidade }\end{array}$ & comum $\leftrightarrow$ singular & $\begin{array}{l}\text { bizarro, comum, } \\
\text { especial, frequente, } \\
\text { estranho, intrigante }\end{array}$ \\
\hline Capacidade & $\begin{array}{c}\text { Grau de } \\
\text { capacidade ou } \\
\text { competência }\end{array}$ & $\begin{array}{c}\text { competente } \leftrightarrow \text { incompetente } \\
\text { capaz } \leftrightarrow \text { incapaz }\end{array}$ & $\begin{array}{l}\text { forte, poderosa, fraca, } \\
\text { inteligente, sábio }\end{array}$ \\
\hline Tenacidade & $\begin{array}{c}\text { Grau de } \\
\text { obstinaçãa }\end{array}$ & indolente $\leftrightarrow$ obstinado & $\begin{array}{c}\text { determinada, } \\
\text { teimosa, incisiva, } \\
\text { assertiva }\end{array}$ \\
\hline \multicolumn{3}{|c|}{ Julgamentos de sanção social } & Exemplos \\
\hline Veracidade & $\begin{array}{c}\text { Grau de } \\
\text { honestidade }\end{array}$ & honesto $\leftrightarrow$ mentiroso & $\begin{array}{l}\text { duas-caras, falso, } \\
\text { vira-casaca, } \\
\text { confiável, } \\
\text { inconsistente }\end{array}$ \\
\hline Propriedade & $\begin{array}{c}\text { Grau de } \\
\text { transparência ética } \\
\text { ou civismo }\end{array}$ & bom $\leftrightarrow \mathrm{mau}$ & $\begin{array}{c}\text { magnânima, justa, } \\
\text { cruel, maldoso }\end{array}$ \\
\hline
\end{tabular}

Fonte: elaborado a partir de Gonçalves-Segundo (2011, p. 173)

Nesta dissertação, trabalharemos com os subtipos de JULGAMENTO como campos de avaliação úteis para a análise da Movimentação Epistêmico-Axiológica, mas não adotaremos a macrodivisão entre estima social e sanção social, conforme propostas por Martin e White (2005) devido a impasses que surgiram durante as análises dos vídeos. Explicamos: uma série de JULGAMENTOS analisados tensionaram as categorias propostas pela literatura, levando-nos a refletir, por exemplo, sobre a categorização das injúrias raciais no âmbito desse subsistema da AvALIATIVIDADE. Com o objetivo de tratar dessas questões com mais especificidade, propomos duas novas categorias e três subdivisões no sistema, dispostas no Quadro 5 a seguir: 
Quadro 5 - Revisão das categorias de JULGAMENTO

\begin{tabular}{|c|c|c|c|c|}
\hline Normalidade & $\begin{array}{c}\text { Grau de } \\
\text { excepcionalidade }\end{array}$ & \multicolumn{2}{|c|}{ comum $\leftrightarrow$ singular } & $\begin{array}{l}\text { bizarro, comum, } \\
\text { especial, frequente, } \\
\text { estranho, intrigante }\end{array}$ \\
\hline \multirow[t]{2}{*}{ Capacidade } & $\begin{array}{l}\text { Grau de } \\
\text { competência }\end{array}$ & \multicolumn{2}{|c|}{$\begin{array}{c}\text { competente } \leftrightarrow \text { incompetente } \\
\text { capaz } \leftrightarrow \text { incapaz }\end{array}$} & $\begin{array}{l}\text { forte, poderosa, fraca, } \\
\text { inteligente, sábio, } \\
\text { racional, louco, doida, } \\
\text { descompensada }\end{array}$ \\
\hline & $\begin{array}{c}\text { Grau de } \\
\text { subjugação }\end{array}$ & \multicolumn{2}{|c|}{ autônomo $\leftrightarrow$ controlado } & $\begin{array}{l}\text { independente, dócil, } \\
\text { autônomo }\end{array}$ \\
\hline Tenacidade & $\begin{array}{c}\text { Grau de } \\
\text { obstinação }\end{array}$ & \multicolumn{2}{|c|}{ indolente $\leftrightarrow$ obstinado } & $\begin{array}{l}\text { determinada, teimosa, } \\
\text { incisiva, assertiva, pró- } \\
\text { ativa }\end{array}$ \\
\hline Cordialidade & $\begin{array}{l}\text { Grau de } \\
\text { cordialidade }\end{array}$ & \multicolumn{2}{|c|}{ rude $\leftrightarrow$ cordial } & $\begin{array}{l}\text { cruel, gentil, tranquilo, } \\
\text { irônica, humilde, } \\
\text { soberbo, prepotente, } \\
\text { arrogante, doce }\end{array}$ \\
\hline Veracidade & $\begin{array}{c}\text { Grau de } \\
\text { honestidade }\end{array}$ & \multicolumn{2}{|c|}{ honesto $\leftrightarrow$ mentiroso } & $\begin{array}{c}\text { duas-caras, falso, vira- } \\
\text { casaca, confiável, } \\
\text { inconsistente }\end{array}$ \\
\hline \multirow[t]{2}{*}{ Propriedade } & \multirow{2}{*}{$\begin{array}{c}\text { Grau de } \\
\text { transparência } \\
\text { ética ou civismo }\end{array}$} & \multirow{2}{*}{$\begin{array}{c}\text { bom } \leftrightarrow \\
\text { mau }\end{array}$} & $\begin{array}{c}\text { Violência } \\
\text { violento } \leftrightarrow \text { pacífico }\end{array}$ & $\begin{array}{l}\text { violento, pacífico, } \\
\text { agressivo, de boa, } \\
\text { tranquila, calma, raivosa }\end{array}$ \\
\hline & & & $\begin{array}{c}\text { Justiça } \\
\text { justo } \leftrightarrow \text { injusto }\end{array}$ & $\begin{array}{l}\text { magnânima, justa, } \\
\text { maldoso, racista }\end{array}$ \\
\hline Humanidade & $\begin{array}{c}\text { Grau de } \\
\text { humanização } \\
\text { conferido ao } \\
\text { indivíduo }\end{array}$ & \multicolumn{2}{|c|}{ humano $\leftrightarrow$ animal } & adestrado, exótica \\
\hline
\end{tabular}

Fonte: elaboração própria. 


\section{ENGAJAMENTO}

Os enunciados são, para a AVALIATIVIDADE, naturalmente posicionados ou atitudinais (MARTIN; WHITE, 2005, p. 92). O ENGAJAMENTO consiste em um sistema de realização da postura da instância produtora frente aos posicionamentos valorativos referenciados no texto e que ela/ele considera relevantes para suas leitoras/ouvintes (MARTIN; WHITE, 2005, p. 92). Essa concepção se apoia nos conceitos de dialogismo e heteroglossia propostos pelo Círculo de Bakhtin (BAKHTIN, 2016). Nessa perspectiva, a comunicação é entendida como inerentemente dialógica, no sentido de que todo enunciado se encontra numa cadeia de produção de sentido, consistindo em respostas a enunciados anteriores e em antecipação a enunciados futuros. Desse modo, cada enunciado avalia e cria imagens dos participantes da interação, bem como daquelas/es a quem faz referência.

Consequentemente, nenhum enunciado é de fato produzido por uma só "voz". O binômio monoglossia/heteroglossia diz respeito ao "estilo interpessoal" da voz autoral no que se refere à forma de se construir um cenário heteroglóssico envolvendo outras vozes e alternativas dialógicas no âmbito de um texto (MARTIN; WHITE, 2005, p. 93). Dentro do subsistema de ENGAJAMENTO, entende-se a heteroglossia como a assunção dessa pluralidade na constituição do enunciado por parte da voz autoral, enquanto a monoglossia consiste em estratégias para a geração do efeito de que o enunciado não é plural em sua formação nem é dotado de uma tensão dialógica inerente: é construído como fato, não disputado.

A GRADAÇÃO, por sua vez, consiste no sistema responsável por "graduar a força de um enunciado ou o foco da categorização que identifica valores semânticos" (MARTIN; WHITE, 2005, p. 94), representando, assim, o comprometimento da voz autoral em relação a uma determinada tese, bem como a força dos seus laços com determinadas comunidades de valores ou crenças.

O subsistema de ENGAJAMENTO é organizado conforme está exposto na figura a seguir: 


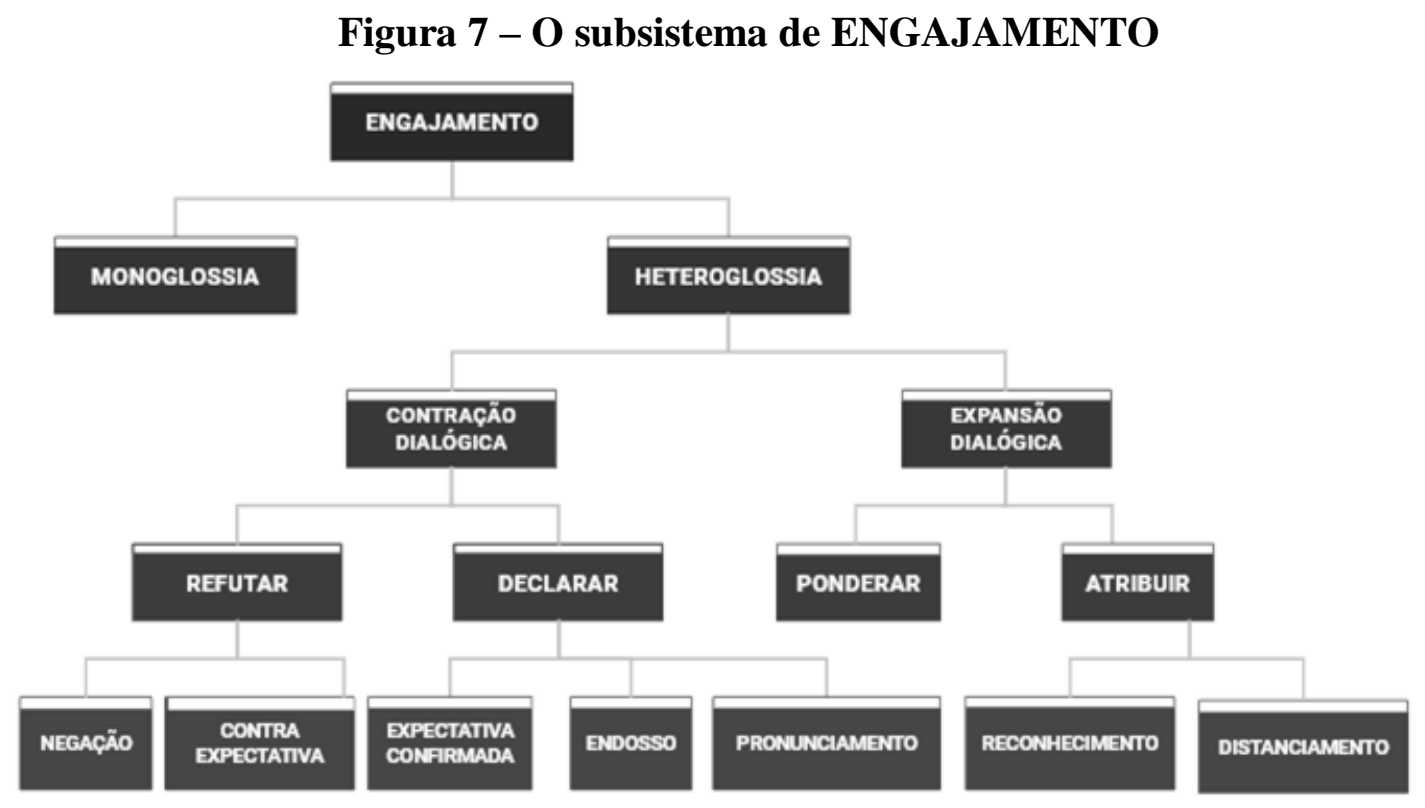

Fonte: elaborado a partir de Martin; White (2005) e Gonçalves-Segundo (2011).

Detalhando as categorias, temos, dentre os tipos de enunciado que visam a deslegitimar/desautorizar as alternativas dialógicas (contração dialógica), aqueles que refutam - procurando rejeitar um ponto de vista ou, ao menos, sua aplicação em um determinado caso - e aqueles que declaram - que visam a restringir o escopo de aplicação de certas alternativas dialógicas, reforçando a alternativa à qual a voz autoral se filia (MARTIN; WHITE, 2005; GONÇALVES-SEGUNDO, 2011).

A refutação pode ser realizada de duas maneiras: por meio da negação, que visa a invalidar completamente uma dada alternativa dialógica ("e a gente pode com um exercício muito simples perceber que essas coisas não existem"138); no caso, a de que essas coisas [racismo reverso e heterofobia] existiriam; e por meio da contraexpectativa, que quebra a expectativa levantada por uma seção anterior do texto (correspondente a uma alternativa dialógica), desautorizando a sua aplicação a um determinado domínio, evento ou entidade ("mas na maioria dos meus vídeos eu tô Nátaly Neri falando sobre as minhas questões mobilizando os meus conhecimentos").

A declaração pode ser realizada de três maneiras diferentes: por meio da expectativa confirmada/concordância, que antecipa uma posição favorável do leitor/ouvinte em relação à perspectiva apresentada ("óbvio que tem negro pessoas negras que não se aceitam que têm dificuldade em se identificar como óbvio que tem pessoas LGBT que também têm dificuldade nesse processo"); por meio do pronunciamento/afirmação, que reconhece a tensão dialógica

\footnotetext{
${ }^{138}$ Os exemplos colocados entre aspas correspondem a instâncias retiradas do corpus.
} 
envolvendo o ponto de vista defendido e confronta abertamente um discurso outro - ao qual o leitor/ouvinte pode estar alinhado inclusive - ("é desonestiDAde na verdade né porque tem muita gente que SAbe o que está falando...”); e, por fim, por meio do endosso, que consiste em recrutar um discurso outro, apresentando-o como legítimo, inegável, válido, correto ou garantido, para sustentar o ponto de vista autoral ("tem pesquisas que afirmam que é um dos países talvez o pior país ou um dos piores países pra... pessoas gays e lésbicas").

A expansão dialógica, por sua vez, visa a construir o texto como um espaço plural, aberto a alternativas dialógicas. Ela se subdivide em dois tipos gerais: a ponderação e a atribuição.

A ponderação reconhece a contingência do próprio enunciado, ancorado em um determinado discurso e/ou numa perspectiva específica, invocando a possibilidade de que outras perspectivas sejam igualmente (ou até mais) válidas (“eu entendo esse discurso”). Já a atribuição assinala a associação de outras perspectivas a determinados atores ou grupos sociais (MARTIN; WHITE, 2005; GONÇALVES-SEGUNDO, 2011).

Enquanto a ponderação não se subdivide, podemos encontrar dois subtipos de atribuição. São eles: o reconhecimento, que diz respeito a uma postura neutra em relação às alternativas dialógicas ("existe essa ideia de que você não deve se rotular porque rótulos te limitam rótulos NÃO foram FEItos pras pessoas que você deve viver fora de caixas e não se enquadrar em nenhum modelo enfim"), e o distanciamento ("infelizmente mulheres já são tidas como histéricas há muito tempo"), que envolve o desalinhamento autoral em relação às vozes/perspectivas que o produtor traz para seu texto.

Consideramos a aplicação do ENGAJAMENTO como categoria de análise para a investigação da construção discursiva da Movimentação Epistêmico-Axiológica porque permite o reconhecimento e a sistematização i) do posicionamento da voz autoral em relação às alternativas dialógicas em termos de oposição/alternatividade/complementariedade; ii) estabelecimento de laços de solidariedade/antagonismo entre as entidades discursivas.

Essas questões se mostram especialmente relevantes para a análise deste corpus porque, conforme indicamos nas Considerações Iniciais, acreditamos que possa existir um padrão linguístico-discursivo emergente entre as práticas de movimentos sociais que consiste em apresentar as necessidades, desejos, crenças e valores de grupos sociais marginalizados em redes sociais como forma de promover a visibilidade de suas demandas na esfera pública. Isso acarretaria a necessidade de lidar com um auditório heterogêneo e, consequentemente, 
desenvolver processos argumentativos capazes de abarcar diversas perspectivas sobre um determinado tópico.

Esses recursos exercem funções fundamentais na negociação de alinhamento e desalinhamento em relação a alternativas dialógicas presentes no texto, bem como no manejo das relações entre as instâncias de produção textual e as comunidades discursivas em um dado texto. Isso se processa por meio do posicionamento discursivo materializado nas avaliações e atitudes sobre crenças e pressuposições no que diz respeito às avaliações normativas sobre o mundo, a natureza da realidade e do passado histórico.

Além disso, quando se apresenta uma perspectiva ou proposta de ação em um texto, muitas vezes isso implica um convite ao interlocutor para que ela/ele reveja suas crenças e valores e se engaje com o ponto de vista apresentado. Consequentemente, essa negociação também envolve a construção da relação entre escritora/falante e leitora/ouvinte, o que implica a construção subterrânea do destinatário presumível, ideal ou visado, assumido pela instância produtora do texto e que estará mais ou menos alinhado com as pressuposições e propostas presentes no texto. Isso é realizado por meio dos recursos que inscrevem a leitora no texto, assumindo, por exemplo, que uma dada perspectiva seja compartilhada pelas participantes da interação ou, pelo contrário, que seja um ponto de discordância que requer estratégias para alcançar o convencimento ou persuasão.

Nesse sentido, a AvaliatividAdE se aproxima da Nova Retórica, na medida em que esta concebe o "conjunto daqueles que o orador que influenciar com a sua argumentação" (PERELMAN; OLBRECHTS-TYTECA, 2002 [1958], p. 22), o auditório, como um construto do próprio orador, que deve se basear em informações psicológicas e sociais sobre o público visado de forma a organizar o seu discurso de forma adequada e eficiente, levando em consideração as opiniões dominantes, as convicções indiscutidas e as premissas aceitas sem hesitação em um determinado meio (PERELMAN; OLBRECHTS-TYTECA, 2002 [1958], p. 23), bem como índices referentes à escolaridade, gênero, raça/etnia, classe social e posição na sociedade (AMOSSY, 2018, p. 55). Essa construção perpassa necessariamente pelo imaginário social do meio em que o próprio orador está inserido, bem como por suas próprias crenças, valores, preconceitos e ideologias. Sendo assim, o auditório não consiste em um reflexo perfeito do público, mas uma imagem construída pelo orador que "não se confunde com a sua realidade empírica" (AMOSSY, 2018, p. 55).

Ademais, as alternativas dialógicas são necessariamente ligadas aos indivíduos ou grupos sociais que as defendem, ainda que isso não esteja explícito no texto. 
Consequentemente, os efeitos de abertura ou fechamento para outras perspectivas podem envolver o estabelecimento de relações de solidariedade ${ }^{139}$ e/ou antagonismo com determinados grupos. Nesse sentido, interessa sobretudo a produção contextualizada de sentido e os efeitos retóricos dos textos, o que envolve a consideração de diversas possibilidades de realização lexical e gramatical, envolvendo questões de modalidade, polaridade, evidencialidade, intensificação, atribuição, concessão e causalidade (MARTIN; WHITE, 2005, p. 94).

A solidariedade é entendida na AVALIATIVIDADE não apenas como o acordo ideacional ou atitudinal entre o Eu e o Outro, mas, sobretudo, como a "tolerância em relação a pontos de vista alternativos" e a "comunalidade na qual o falante/escritor inscreve o leitor/ouvinte" (MARTIN; WHITE, 2005, p. 96). Os laços de solidariedade podem, inclusive, incluir posições completamente discrepantes, oferecendo-se como uma "terceira via".

Nesse sentido, o subsistema de ENGAJAMENTO realiza a construção das vozes autorais no que se refere ao seu (des)alinhamento em relação a alternativas dialógicas, bem como ao grau de comprometimento e validade que é atribuído a elas. Outra consequência do caráter dialógico desta perspectiva é que essas estruturas constroem também o aspecto antecipatório do texto e o estabelecimento de laços de solidariedade/neutralidade/antagonismo em relação a certos discursos, atores e grupos sociais, sinalizando para as/os leitoras/es quais são as resposta esperadas às posições representadas no texto: se elas devem ser apoiadas, questionadas ou rejeitadas (MARTIN; WHITE, 2005, p. 93). Nisso consistem os efeitos dialógicos ou retóricos relacionados aos recursos de posicionamento intersubjetivo (MARTIN; WHITE, 2005, p. 95).

\subsubsection{Análise dos efeitos da Movimentação Epistêmico-Axiológica na constituição de estratégias discursivas}

Nesta última etapa, analisamos os efeitos discursivos dos movimentos realizados no Espaço Discursivo sobre a relação entre as entidades discursivas e como isso se traduz em termos das relações entre as comunidades discursivas. Com isso, verificaremos o uso da Movimentação Epistêmico-Axiológica na constituição de estratégias discursivas voltadas para a formação política de sua audiência.

Para tantos, apresentaremos os tipos de efeitos discursivos previstos pela Movimentação Epistêmico-Axiológica e resenharemos de forma sucinta a tipologia de classes de visada argumentativa proposta por Gonçalves-Segundo (2020c), assim como algumas questões

139 Na perspectiva da Avaliatividade, o estabelecimento de relações de solidariedade não implica necessariamente o alinhamento à tese proposta, mas o reconhecimento desta como uma alternativa dialógica válida. 
essenciais para a discussão das particularidades das estratégias discursivas do ativismo digital no YouTube: os conceitos de colapso do contexto, persistência dos conteúdos e públicos em rede (propostas por boyd, 2011; 2014), bem como as problematizações que eles colocam para a concepção retórica do auditório (PERELMAN; OLBRECHTS-TYTECA, 2002[1958]) de textos publicados em ambientes de sociabilidade online (como, por exemplo, redes sociais).

Salientamos que, embora recrutemos noções retóricas e categorias de análise argumentativas para essa teorização, não afirmamos que a Movimentação EpistêmicoAxiológica leva necessariamente à concretização da adesão. O que buscamos é depreender efeitos discursivos sobre a relação entre as Alegações e Propostas de Ação (entre outros elementos argumentativos) e comunidades discursivas representadas em cada texto.

A partir da análise dos movimentos de aproximação e afastamento epistêmicoaxiológico, foi possível depreender três possíveis efeitos discursivos concernentes à relação dos elementos argumentativos que compõem cada campo. São eles:

\section{Efeitos discursivos sobre a relação entre Alegações e Propostas de Ação}

1. Efeito de Complementariedade: Ambas as Alegações/Propostas de Ação são não apenas válidas, como complementares. Por exemplo, a Proposta de Ação do Outro é reenquadrada como Objetivo comum para o Eu; a leitura das Circunstâncias Motivadoras do Outro é detalhada por informações novas apresentadas pelo Eu.

2. Efeito de Alternatividade: Ambas as Alegações/Propostas de Ação são válidas, o que se busca é a legitimação das próprias Alegações e Propostas. Nesses casos, compartilha-se um Objetivo, mas a leitura do estado de coisas é diferente.

3. Efeito de Oposição: Apenas uma Alegação/Proposta de Ação é válida/legítima; busca-se desqualificar a concorrente. É possível que tanto os Objetivos quanto as Circunstâncias Motivadoras sejam diferentes e irreconciliáveis.

\section{Efeito discursivos sobre a relação entre comunidades discursivas}

1. Efeito de Solidariedade: as comunidades discursivas representadas pelo Nós e pelo Outro podem articular suas Alegações e Propostas de Ação, e o Outro não precisa mudar seu comportamento para ser aceito no endogrupo, podendo inclusive passar a fazer parte do Nós.

2. Efeito de Neutralidade: as comunidades discursivas representadas pelo Nós e pelo Outro podem defender suas Alegações e desenvolver suas Propostas de Ação de 
forma autônoma, e o Outro não precisa mudar seu comportamento para ser aceito no endogrupo.

3. Efeito de Antagonismo: as comunidades discursivas representadas pelo Nós e pelo Outro não podem articular suas Alegações e Propostas de Ação e o Outro precisa mudar seu comportamento para ser aceito no endogrupo.

A interpretação desses efeitos em termos das estratégias discursivas das youtubers, considerando as pautas específicas trabalhadas por cada texto, será efetuada ao final das análises da seção 2 e resumida na seção 3 do capítulo seguinte. Para tanto, consideraremos o seu uso em termos da visada argumentativa da formação política como um tipo particular de visada argumentativa à preservação ideológica. 


\section{Capítulo 3 - A Movimentação Epistêmico-Axiológica como estratégia discursiva no ativismo digital feminista no YouTube}

\section{Introdução}

Neste capítulo, procederemos às análises de movimentos de aproximação e de afastamento epistêmico-axiológico realizados nos vídeos que compõem o corpus desta pesquisa. Organizamos este capítulo em duas seções de análises e uma seção final, na qual executaremos a etapa de explicação em termos da função dos movimentos para o propósito da formação política em ambientes digitais, bem como discutiremos os padrões depreendidos, com vistas a sistematizar os resultados obtidos. As atuais limitações e os potenciais de desenvolvimento da metodologia aqui aplicada serão desenvolvidos nas Considerações Finais.

A primeira seção é dedicada ao mapeamento das entidades (Eu, Nós e Outro) no Espaço Discursivo e à delimitação de seus respectivos campos epistêmico-axiológicos. Em outras palavras, nela discutimos quais são as Alegações e Propostas de Ação defendidas pelo Eu-Nós e quais são atribuídas ao Outro. A partir disso, exploramos a maneira pela qual esses posicionamentos demonstram filiações a determinados discursos e/ou ideologias. Para tanto, recrutamos também algumas referências para a contextualização dos debates em pauta. Dessa forma, descrevemos os campos epistêmico-axiológicos dos grupos (endogrupo; exogrupo) e das entidades (Eu, Nós e Outro) e, assim, depreendemos a projeção das entidades e sua posição relativa no espaço discursivo.

Isso é realizado por meio da análise da Configuração Funcional dos argumentos desenvolvidos nas discussões empreendidas em cada vídeo, sistematizada por meio de uma série de figuras que apresentam o layout dos argumentos apresentados pelo Eu e também daqueles atribuídos ao Outro. Trata-se de um procedimento que visa a organizar a estrutura argumentativa subjacente, isto é, os raciocínios (por vezes inferenciais) realizados ao longo do texto. Nos layouts, realizamos paráfrases para recuperar e salientar o raciocínio argumentativo que se processa ao longo do texto, depreendendo sua estrutura. Consiste, portanto, em uma metodologia que permite uma compreensão "estática" do texto, que nos ajuda a compreender relações de intertextualidade e interdiscursividade, mas que não dá conta de abordá-lo em sua dimensão microlinguística e interacional.

Tal dimensão será explorada na seção seguinte, na qual analisamos os movimentos de afastamento e de aproximação epistêmico-axiológica em si. Nela recuperamos os aspectos argumentativos e discursivos em pauta nos trechos selecionados, lidando mais diretamente com a materialidade linguística para descrever e analisar a maneira como as vozes autorais negociam 
a criação de regiões de proximidade epistêmico-axiológicas e delimitam as fronteiras entre os campos das entidades e dos grupos. Ressaltamos, no entanto, que essa seção não se pretende, de forma alguma, exaustiva em termos das instâncias de Movimentação Epistêmico-Axiológica realizadas nos vídeos. O critério de seleção dos trechos para análise teve como objetivo apresentar a diversidade de possibilidades de aplicação da Movimentação EpistêmicoAxiológica enquanto estratégia discursiva. Assim, selecionamos ao menos um trecho de aproximação e um trecho de afastamento de cada vídeo, e prezamos pela variedade em termos da função exercida na estrutura argumentativa - apresentar Alegações ou Propostas de Ação, realizar a refutação externa ou interna dos movimentos argumentativos atribuídos ao Outro, demonstrar incompatibilidade de Valores, entre outras.

A seção 2 está, então, subdividida em três partes: a primeira é reservada para as análises de afastamento epistêmico-axiológico; a segunda se dedica às análises de aproximação epistêmico-axiológica; por fim, a terceira seção se volta para um caso desafiador, no qual o afastamento e a aproximação se mostraram especialmente intrincados.

Ao longo de e, em especial, ao final de cada análise, realizaremos uma discussão a respeito de possíveis efeitos retórico-discursivos dos recursos empregados nos excertos selecionados, tanto em função das discussões em pauta nos textos, quanto para os propósitos mais amplos do ativismo digital - levando em consideração o estilo, a proposta e o públicoalvo dos canais LouiePonto e Nátaly Neri (Afros e Afins, à época da publicação dos vídeos), discutidos no Capítulo 1.

Ao final do capítulo, na seção 3, empreenderemos uma discussão geral a respeito dos resultados obtidos e dos padrões depreendidos, assim como apontaremos nossas percepções a respeito dos potenciais e as limitações da noção de Movimentação Axiológica e da metodologia aqui utilizada. Objetivos delimitados, passemos, pois, às análises.

\subsection{Mapeamento das entidades no Espaço Discursivo e delimitação dos respectivos campos epistêmico-axiológicos}

As análises aqui efetuadas correspondem à primeira etapa da análise da Movimentação Epistêmico-Axiológica: a depreensão das entidades e de seus respectivos campos epistêmicoaxiológicos, bem como de sua projeção relativa no espaço discursivo do texto. Conforme discutimos no Capítulo 2, devido ao caráter argumentativo dos vídeos analisados, optamos por realizar a delimitação dos campos epistêmico-axiológicos a partir das análises da Configuração Funcional dos argumentos a partir do modelo Toulmin (TOULMIN, 2006; GONÇALVES- 
SEGUNDO, 2016, 2018b, 2020a) para a dimensão epistêmica, e pelo modelo de Fairclough e Fairclough (2012; GONÇALVES-SEGUNDO, 2019) para a dimensão prática. Os vídeos foram transcritos seguindo as regras do NURC (PRETI, 2010), com um acréscimo: nos casos em que há a "projeção" de imagens e frases no vídeo, transcrevemo-las entre colchetes ("[[O ATIVISMO DIGITAL É MUITO IMPORTANTE]]”).

Todos os vídeos que compõem nosso corpus são intitulados a partir de uma das perguntas epistêmicas que integram a discussão em pauta (Por que você é tão agressiva, Nátaly?; Youtuber só fala merda na internet?; Heterofobia e racismo reverso existem?; Rótulos me limitam ou me definem?). Embora não sejam necessariamente elas que definem de fato a divisão do espaço discursivo (em termos de endogrupo x exogrupo), elas dão pistas das tensões dialógicas que o constituem, indicando o grau de dissenso que permeia as questões. Veremos, por exemplo, casos em que o tema em debate, por se configurar como um caso de desacordo profundo (FOGELIN, 2005 [1985]), coloca sérios obstáculos para a construção de uma relação de solidariedade entre o Eu e o Outro.

Por outro lado, há também casos em que a discussão se volta para diferentes Propostas de Ação referentes às práticas e aos discursos do endogrupo. Nesses casos, as Alegações e Propostas de Ação se mostram articuladas, sugerindo uma relação entre teoria e prática e contribuindo para o desenvolvimento ou fortalecimento de relações de solidariedade dentro do campo do endogrupo.

Aqui e no restante do capítulo, a ordem das análises está de acordo com a data de publicação dos vídeos (do mais antigo ao mais recente). Sugerimos às/aos leitoras/es que assistam aos vídeos analisados antes de proceder à leitura das seções. Para tanto, arrolamos o link de cada vídeo ao título das respectivas subseções, no formato de nota-de-rodapé.

\section{“POR QUE VOCÊ É TÃO AGRESSIVA, NÁTALY?"140}

Este vídeo se insere num debate transnacional do Feminismo Negro e dos movimentos de mulheres negras em geral que consiste no desafio aos estereótipos criados para silenciar as mulheres negras que denunciam os efeitos combinados do racismo e do sexismo. Esse debate concebe a criação de estereótipos como uma estratégia de silenciamento, a qual é teorizada por, entre outras autoras ${ }^{141}$, Patricia Hill Collins (2019), a partir dos conceitos de imagens de controle, ponto de vista autodefinido e autovaliação (discutidos no capítulo anterior). Nesse

\footnotetext{
${ }^{140}$ Disponível em: 〈https://www.youtube.com/watch?v=aBF_5w8unyA>.

${ }^{141}$ Ressaltamos aqui a relevância dos trabalhos de Lélia Gonzalez (1984) e Beatriz Nascimento (2019a, 2019b) a esse respeito.
} 
sentido, interessa-nos analisar de que forma Nátaly se opõe a esses estereótipos para construir sua imagem como feminista negra atuando no campo da comunicação e, mais do que isso, de que forma sua voz se articula às vozes de outras ativistas feministas enfrentando discriminações semelhantes, constituindo estratégias discursivas e argumentativas ${ }^{142}$.

De acordo com Huda Hassan $(2015)^{143}$, o estereótipo da mulher negra raivosa serve ao propósito do silenciamento, com a especificidade de se voltar para o policiamento das denúncias das opressões combinadas de racismo e sexismo às quais estão sujeitas. Para a autora, o estereótipo da mulher negra raivosa foi construído nos Estados Unidos para deslegitimar as denúncias desse grupo contra o racismo e o sexismo, reforçando, por meio da cultura pop e das representações negativas de mulheres negras na mídia, que elas são "o alvo perfeito para a violência: loucas demais para serem acreditadas, raivosas o suficiente para justificar retaliação física" ${ }^{144}$.

Parece-me que a Mulher Negra Raivosa serve para silenciar mulheres e, em particular, apagar nossas denúncias sobre o racismo e o sexismo. Embora mulheres negras existam na intersecção desses dois sistemas de opressão, seria impossível que mulheres negras estivessem certas sobre qualquer um deles (ou ambos) com razão. Nós estamos com raiva porque isso faz parte de nossa natureza. Nós estamos com raiva sem motivo. Quando Amandla Stenberg, uma atriz adolescente de 16 anos conhecida por sua atuação em Jogos Vorazes, explicou como as tranças de Kylie Jenner exibiam o roubo e comercialização da cultura negra, usuários do Twitter disseram que ela estava muito brava. O tropo se duplica como uma acusação; nossas opiniões são irracionais porque elas estão embasadas em emoções. ${ }^{145}$

Nos termos de Angelique M. Davis e Rose Ernst (2019 [2017]), o uso do estereótipo da mulher negra raivosa como estratégia de tergiversação em relação às denúncias contra o

\footnotetext{
${ }^{142}$ Embora consideremos um terreno bastante fértil para aprofundar a compreensão a respeito da construção de relações de solidariedade, neutralidade e antagonismo, não nos aprofundaremos, nas relações intertextuais estabelecidas nos vídeos.

${ }^{143}$ Esse texto é citado na matéria arrolada por Nátaly na descrição do vídeo. Além dele, ela também cita uma performance de slam estadunidense de Porsha Olayiwola, "Angry Black Woman”. A performance completa está disponível em: 〈https://www.youtube.com/watch?v=iiPiJ_Ge50s\&ab_channel=MarcosFerreira> .

${ }^{144}$ No original, "engineer the perfect target for violence: too crazy to be believed, angry enough to justify physical retaliation" (HASSAN, 2015, s/p).

145 No original, "It seems to me that the Angry Black Woman serves to silence women, and in particular to erase our identification of racism and sexism. Although black women exist at the intersection of these two systems of oppression, black women couldn't possibly be righteously upset about either (or both). We are angry because it is in our nature. We are angry without cause. When 16-year-old Amandla Stenberg, a teenage actress known for her role in Hunger Games, explained how Kylie Jenner's braids exhibited the theft and commercialization of black culture, Twitter users told her she was too angry. The trope doubles as an accusation; our opinions are irrational because they're rooted in emotion." (HASSAN, 2015, s/p)
} 
racismo e o sexismo se configura como um processo de gaslighting racial. Segundo as autoras (DAVIS; ERNST, 2019, p. 3) ${ }^{146}$, esse fenômeno se caracteriza da seguinte forma

Grupos dominantes utilizam o policiamento de tom ${ }^{147}$ para punir o estilo comunicacional de pessoas marginalizadas que desafiam a sua opressão. Ele foca a emoção por trás de uma mensagem em vez de tratar da mensagem em si. Por meio do foco na maneira pela qual a mensagem é passada, a despeito da legitimidade do conteúdo, o policiamento de tom prioriza o conforto dos privilegiados (HUGS, 2015) e minimiza a importância das experiências de pessoas marginalizadas "ao colocar sanções que determinam como de que forma elas serão ou não ouvidas" (ZEVALLOS, 2017).

Nesse sentido, a denúncia do uso desses estereótipos assume uma relevância especial para o combate à desumanização de mulheres negras e à legitimação de sua dominação física e simbólica. Nos termos de Hassan (2015), isso deve passar pela humanização de mulheres negras, de forma a também salientar que a raiva que muitas delas expressam ao falar sobre a supremacia branca e seus impactos sobre suas vidas nada mais é do que uma emoção humana e uma resposta válida a situações de violência e discriminação racistas. Com isso em mente, ela afirma que

Se os estereótipos e a discriminação racista se reforçam mutuamente, será importante desfazer o tropo da Mulher Negra Raivosa na cultura pop. É dessa forma que a próxima geração ou irá aprender a desumanizar mulheres negras ao tornar a raiva a sua identidade, ou aprender que a raiva é uma emoção que, entre outras, todos os seres humanos experienciam. ${ }^{148}$

Em outras palavras, esse processo de humanização envolve não apenas a criação de representações positivas (que não retratam mulheres negras como pessoas naturalmente agressivas), como também a normalização do fato de que essas mulheres sentem, entre outras coisas, raiva, e que em muitas ocasiões esse sentimento é justificado e nasce como resposta a uma situação de opressão - assim como as críticas que realizam a respeito da sociedade em que vivem ou sobre o modo como são representadas nas mídias.

\footnotetext{
${ }^{146}$ No original, "Dominant groups use tone policing to chastise the communication style of marginalized people who challenge their oppression. It focuses on the emotion behind a message rather than the message itself. Through focusing on the manner in which the message is delivered, no matter the legitimacy of the content, tone policing prioritizes the comfort of the privileged (Hugs 2015) and minimizes marginalized peoples' experiences, "by placing sanctions on how they will or will not be heard" (Zevallos 2017)" (DAVIS; ERNST, 2019, p. 3)

${ }^{147}$ Para mais explicações sobre o termo "policiamento de tom”, ver os seguintes artigos: Angry Black Bitch: "The punishment for being too real" (https://wearyourvoicemag.com/angry-black-bitch-punishment-real/), "Unpacking the Conversations that Matter: 'If you weren't so ANGRY, people would listen,' and the Problem with 'TonePolicing" (http://www.theinclusionsolution.me/unpacking-the-conversations-that-matter-if-you-werent-soangry-people-would-listen-and-the-problem-with-tone-policing/) e "Foda-se o policiamento de tom" (https://www.naomekahlo.com/foda-se-o-policiamento-de-tom/).

${ }^{148}$ No original, "If racial stereotypes and racial discrimination are mutually reinforcing, it will be important to dismantle the Angry Black Woman trope in popular culture. That's where the next generation will either learn to dehumanize black women by making anger their identity, or learn that anger is an emotion that, among others, all humans experience." (HASSAN, 2015, s/p).
} 
No vídeo sob análise, depreendemos dois grandes movimentos argumentativos: (i) a refutação dos ataques ${ }^{149}$ endereçados a Nátaly, embasados no estereótipo da mulher negra raivosa e (ii) a explicitação das relações entre esses comentários e a discursividade racista. A apresentação dessa relação tem como objetivo efetuar um chamado à reflexão (e à ação) para aqueles que reproduzem e sustentam essas representações. Isso é feito por meio de uma mudança de enquadramento: ao apresentar os ataques sobre seus posicionamentos, personalidade e modo de expressão, Nátaly, antes de falar sobre si, questiona o processo avaliativo que a constrói como uma pessoa agressiva. Assim, em vez de discutir por que "é tão agressiva”, Nátaly ataca os pressupostos da pergunta, e, dessa forma, põe em pauta outra questão: "por que você me acha tão agressiva?". Assim, o centro da discussão se modifica e enfoca as diferentes discursividades que estruturam a construção de imagens sobre ela e sobre outras mulheres negras na sociedade brasileira.

Esse reenquadramento se processa pela conexão entre os ataques pessoais e as discussões efetuadas por feministas negras acerca da representação de mulheres negras na mídia e os estereótipos acerca desse grupo social nos imaginários populares. Assim, Nátaly, ao constituir um Eu, mulher negra, se alia, ao longo do texto, a um Nós, mulheres negras, também constituído textualmente. Dessa forma, ao mesmo tempo em que (re)constrói sua imagem, ela combate o policiamento de tom (tone policing ${ }^{150}$ ) como forma de silenciamento de mulheres negras.

Segundo a youtuber, esses ataques aparecem sobretudo nos vídeos em que ela está "falando sobre questões um pouco mais tensas sobre racismo...", sugerindo uma correlação entre a temática e esses comentários ${ }^{151}$. Ao longo dos movimentos de afastamento axiológico, ela colocará em jogo a motivação dessas "críticas", explicitando sua Garantia e, consequentemente, voltando a discussão do vídeo para a imagem dos próprios comentaristas.

\footnotetext{
${ }^{149}$ Para uma discussão mais aprofundada a respeito do assédio misógino e racista que se volta a mulheres negras em ambientes de sociabilidade online, recomendamos a leitura de Trindade (2020), já mencionado no Capítulo 1. ${ }^{150}$ Essa relação entre o estereótipo da Sapphire ou "Angry Black Woman” e o policiamento de tom é discutido com detalhes por Huda Hassan na matéria para o BuzzFeed de 31 de julho de 2015 que citamos anteriormente. Nela, Hassan discute o caso do assassinato de Sandra Bland por forças policiais no Texas e da cobertura midiática da discussão entre Taylor Swift e Nicki Minaj sobre o racismo no VMA, ambos ocorridos mais cedo naquele mês (https://www.buzzfeednews.com/article/hudahassan/the-twilight-of-the-angry-black-woman\#.tkV0Mr5ON).

Essa é matéria é citada por Arthur Francischi em matéria para o Geledés a respeito de um caso de racismo envolvendo Alessandra Stanley, repórter do The New York Times, a roteirista e produtora Shonda Rhimes e a atriz Viola Davis à época do lançamento da série "How To Get Away With Murder" (https://www.geledes.org.br/quase-um-ano-depois-o-que-aprendemos-com-o-episodio-da-negra-raivosaenvolvendo-shonda-rhimes/). Tal matéria é recomendada por Nátaly na descrição do vídeo.

${ }^{151}$ Sugerimos a esse respeito, novamente, o capítulo de Trindade (2020) a respeito dos ataques racistas a mulheres negras em redes sociais.
} 
Em suma, trata-se de um movimento de autodefinição que questiona não só as imagens criadas sobre ela, como também "a credibilidade e as intenções daqueles que possuem o poder de definir" (COLLINS, 2009, p. 24-25 apud BUENO, 2020, p. 143). Não à toa, Nátaly finaliza a discussão dizendo "você não precisa ter medo de mim você não precisa ter medo da minha voz você precisa ter medo de você... e do que você acredita que eu devo ser...".

Esse movimento se constitui por meio de uma primeira divisão do espaço discursivo a partir de duas diferentes Alegações a respeito da imagem de Nátaly.

Uma delas é a avaliação negativa da youtuber, construída por meio de ataques à sua imagem na seção de comentários do canal (atribuídos ao Outro), que a consideram "agressiva" e “arrogante”. A segunda Alegação, por sua vez, é construída por Nátaly (Eu), apresentando uma autoimagem positiva, definida por meio de expressões como "leve" e "sabe do que está falando", sugerindo sensatez, coerência e sabedoria.

A estrutura argumentativa do texto visa a contrapor essas duas representações conflitantes da youtuber, atrelando-as a entidades, grupos e suas respectivas discursividades ao longo de uma série de movimentos argumentativos que visam ao convencimento (adesão às Alegações: Nátaly Neri não é agressiva; Nátaly Neri não é arrogante) e à persuasão (adesão às Propostas de Ação: Deixar de reproduzir o estereótipo da mulher negra raivosa para policiar o tom de mulheres negras; Continuar apoiando o canal e outras mulheres negras ativistas digitais).

Conforme Nátaly atribui ao Outro os ataques a sua imagem, o campo epistêmicoaxiológico do exogrupo se compõe pela discursividade racista, o imaginário social por meio do qual se (re)produzem estereótipos e imagens de controle desses grupos de forma irrefletida ou deliberada. O Outro se encontra projetado neste campo devido ao teor dos comentários a respeito dos modos de expressão de Nátaly. Ao longo do vídeo, Nátaly irá demonstrar que a premissa (Garantia) que embasa a imagem construída pelos comentários é, em si, racista e, portanto, demonstra uma filiação aos valores do exogrupo. Essa relação está resumida no layout da Figura 8, apresentada abaixo. 


\section{Figura 8 - Layout da Configuração Funcional Epistêmica do campo epistêmico- axiológico do Outro no vídeo "POR QUE VOCẾ É TÃO AGRESSIVA, NÁTALY?"}

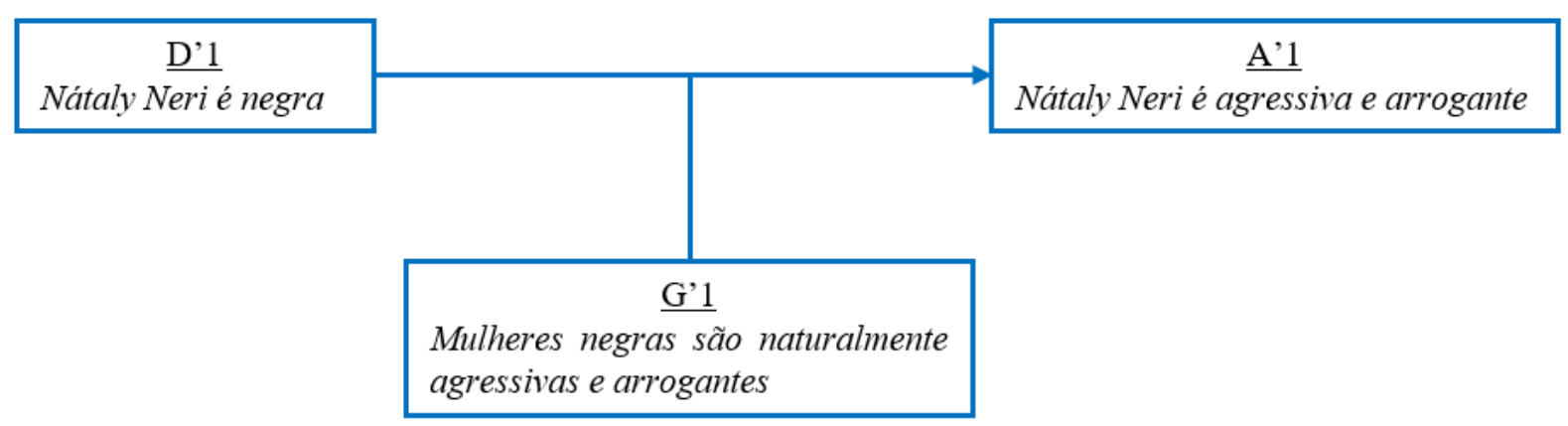

Fonte: elaboração própria.

Nessa configuração, a passagem dos Dados D’1 (Nátaly Neri é negra) à ContraAlegação A'1 (Nátaly Neri é agressiva e arrogante) está embasada pela Garantia G'1 (Mulheres negras são naturalmente agressivas e arrogantes). A Contra-Alegação A'1 é materializada nos comentários reportados por Nátaly no início do vídeo, que a concebem como “agressiva", "brava", "arrogante”, enfim, uma pessoa que "tenta lutar pela igualdade com MAIS Ódio" (linhas 5 a 14 do Anexo 1). A Garantia G'1, por sua vez, é trabalhada por ela em detalhe, de forma a explicitar seu caráter racista e suas origens históricas no Brasil - e, em segundo plano, suas semelhanças com as experiências de mulheres negras em outros territórios, como os Estados Unidos.

Por meio da atribuição do raciocínio esquematizado na Figura 8 ao Outro, ela demonstra que há traços do discurso do exogrupo (racista) no discurso desses comentários e argumenta em favor da mudança de pensamento por parte da parcela do auditório que compactua com essa visão ${ }^{152}$.

Para efetuar a Refutação à posição do Outro, Nátaly realiza uma discussão acerca dos estereótipos da mulher negra (a Tia Anastácia, a mulata exportação e a mulher negra raivosa) e de seus efeitos sobre a percepção da sociedade a respeito desse grupo social ${ }^{153}$. Dessa forma, a voz autoral $(\mathrm{Eu})$ se articula a uma coletividade da qual participam as intelectuais e ativistas

\footnotetext{
152 Conforme discutido no Capítulo 2, hipotetizamos que o Outro, nesses vídeos, corresponda a membros do endogrupo, tendo em vista que, tipicamente, para segui-las, assistir a e/ou comentar seus vídeos, devem apresentar uma certa concordância com seus posicionamentos ou interesse nas temáticas abordadas. Acreditamos que membros do exogrupo possam ter interesse nos vídeos e até cheguem a consumi-los com certa regularidade, embora isso seja menos comum. Não consideramos, no entanto, que a interação realizada por trolls e haters apresente a abertura inicial requerida para o diálogo e para o processamento da empatia, como discutido por Cameron (2012). Nesse sentido, ressaltamos ainda o uso das redes para a realização de ataques racistas como indicado por Trindade (2020), o que configuraria uma interação pautada por antagonismo.

${ }^{153}$ Essa questão será analisada em detalhe na seção seguinte, mais especificamente na discussão sobre o trecho N1.
} 
negras que apontam esses estereótipos como estratégias de silenciamento e, mais amplamente, todas as mulheres negras afetadas por esses estereótipos ${ }^{154}$.

Essa Refutação continua em um movimento que se opera em duas etapas: a primeira contrasta as avaliações negativas presentes nos referidos comentários com a imagem autodefinida de Nátaly ${ }^{155}$, a segunda consiste na avaliação a respeito do Outro.

Na primeira etapa, o contraste entre as imagens criadas sobre ela e as imagens que ela constrói para si gira em torno das mesmas categorias de julgamentos e é subdividida em dois aspectos: a personalidade de Nátaly - o que envolve, principalmente, a contraposição de julgamentos positivos e negativos de cordialidade, tenacidade e propriedade: violência - e seu tom de voz, considerado arrogante - o que será trabalhado sobretudo por meio de julgamentos de capacidade.

Na Figura 9, os julgamentos positivos consistem em Dados (D1 e D2) e contribuem para o objetivo de alterar não apenas a imagem individual de Nátaly (colaborando para embasar as alegações A1 e A2 expostas no layout abaixo: Nátaly Neri não é agressiva nem arrogante), como também gerar efeitos sobre a percepção a respeito do Nós como um todo. A Garantia (G1) que permite a passagem dos Dados à Alegação consiste na definição de um perfil desvinculado da arrogância e da agressividade e se articula à autodescrição de Nátaly, no processo de autoavaliação.

Em suma, participa desse processo de positivação da imagem de Nátaly não apenas a Refutação dos julgamentos negativos que constroem os estereótipos da mulher negra, como também as declarações e julgamentos positivos, as perguntas retóricas e semirretóricas envolvidas na construção da sua imagem autodefinida, explicitamente atrelada à das mulheres negras em termos coletivos ${ }^{156}$.

\footnotetext{
${ }^{154}$ Essa questão será analisada em detalhe na seção seguinte, mais especificamente na discussão sobre o trecho N3.

${ }^{155}$ Essa questão será analisada em detalhe na seção seguinte, mais especificamente na discussão sobre o trecho N4.

${ }^{156}$ Este processo será analisado em detalhe nas discussões dos trechos N1-N4 na seção seguinte.
} 
Figura 9 - Layout da Configuração Funcional Epistêmica do campo epistêmico-axiológico do Eu-Nós no vídeo "POR QUE VOCÊ É TÃO AGRESSIVA, NÁTALY?"

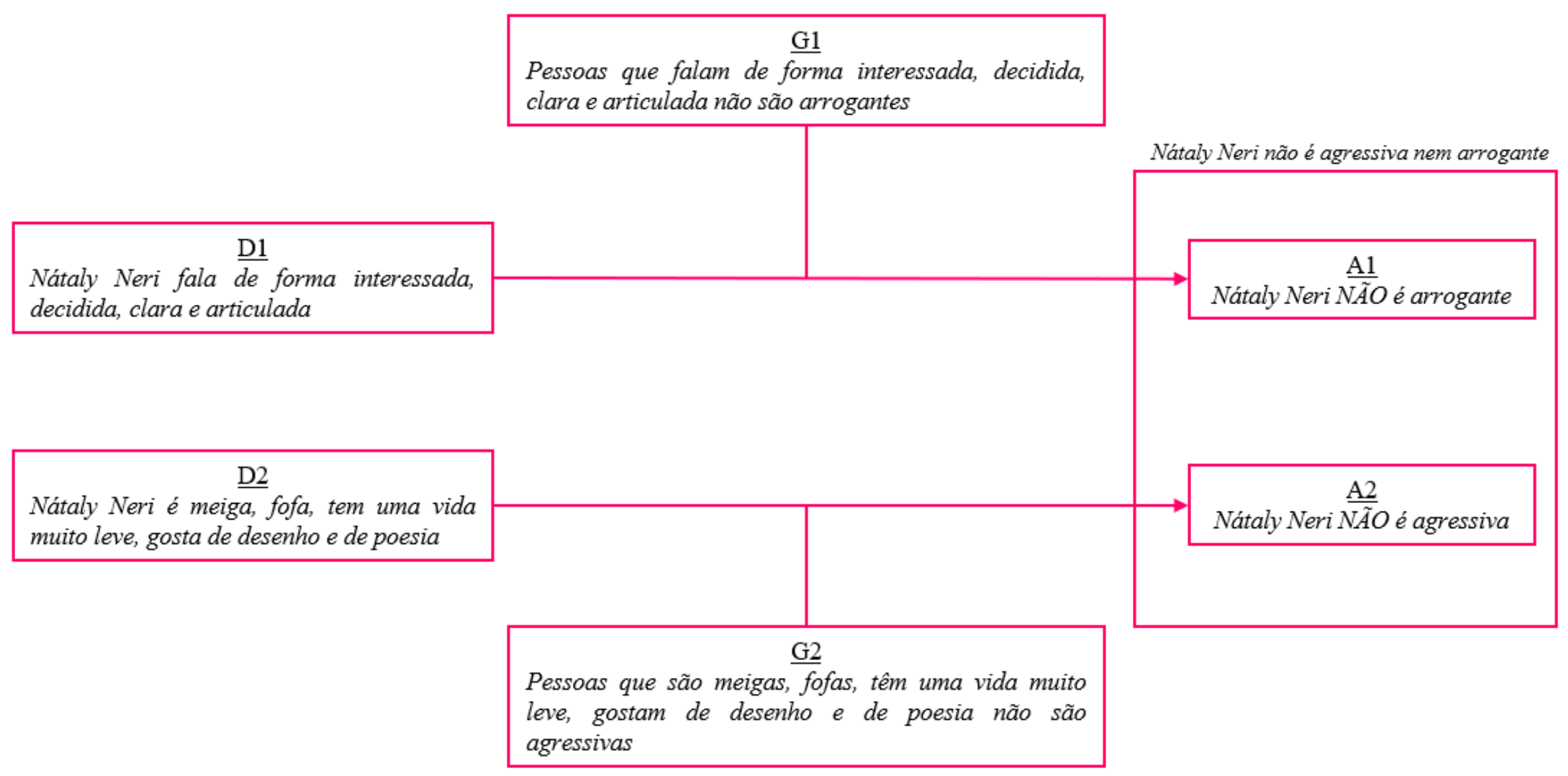

Fonte: elaboração própria. 
Em outras palavras, esse movimento, realizado por meio do contraste entre as representações elaboradas pelo Outro e as representações autodefinidas, exerce a função de valorizar a identidade do Eu-Nós. Com o detalhamento dos campos epistêmico-axiológicos em disputa, vemos que as Alegações apresentadas por Nátaly se constituem por meio da construção de uma imagem autodefinida de si, pautada pelo "direito" de falar em qualquer tom de voz e expressão - o que se aplicará também ao Nós, mulheres negras em geral.

Sabemos, portanto, que a discussão se dá no nível das avaliações e, consequentemente, está intimamente envolvida com a imagem da youtuber e com a elaboração de uma imagem coletiva. Por isso, a imagem de Nátaly constitui-se como uma Alegação, contraposta àquela construída sobre ela em comentários em seu canal.

Essa discussão constitui a dimensão epistêmica da problemática do vídeo, focada em discutir desacordos em relação às Garantias de cada posicionamento. Essas questões serão elaboradas em detalhes nas análises da Movimentação Epistêmico-Axiológica dos trechos N1, N3, N4 e N5 na seção seguinte, por meio das quais veremos de que forma os movimentos de afastamento e de aproximação epistêmico-axiológica contribuem para a desmobilização em relação à Alegação' (Nátaly Neri é agressiva) e para a adesão a uma imagem positiva da youtuber e de mulheres negras em geral.

Por meio desse processo, ela reenquadra a questão argumentativa do texto, que deixa de ser por que Nátaly é tão agressiva?. Refutando essa imagem, a discussão se volta às/aos comentaristas: por que elas/es a consideram agressiva?. Assim, a essa dimensão epistêmica do texto, subjaz outra, intimamente ligada à primeira, que visa à mudança de comportamento no sentido de não apenas constituir um movimento de desmobilização em relação à alegação do Outro, como também efetuar um chamado à reflexão e uma denúncia no que se refere a sia filiação discursiva. Esse processo se constitui por meio da explicitação da estrutura argumentativa desse discurso, que seria composta por um raciocínio sintomático que atribui uma característica negativa a um grupo racializado com base em argumentos biologizantes ${ }^{157}$.

Tendo em vista o modo de expressão dos comentários, muitos deles se pretendem críticas "construtivas" e "bem-intencionadas" 158 , supostamente voltadas para aumentar o alcance do canal de Nátaly. Ao longo do vídeo, no entanto, Nátaly não apenas expõe a filiação discursiva do Outro ao exogrupo, como salienta o fato de que as orientações contidas nos

\footnotetext{
${ }^{157}$ Essa discussão é realizada com mais detalhe nas análises do trecho N1.

158 Considerando o fraseamento dos comentários, que contam com recursos de defesa da face e polidez, entendemos que, de um ponto de vista formal, eles se encaixariam como críticas construtivas e bem-intecionadas a respeito dos vídeos de Nátaly. Analisando o seu conteúdo, no entanto, vemos que constituem estratégias de policiamento de tom. Por isso, as aspas.
} 
comentários não constituem uma Proposta de Ação eficaz para a consecução do objetivo de aumentar o alcance de seu canal. Antes, essa Proposta teria como objetivo silenciar mulheres negras.

A partir disso, desenvolve outro raciocínio de cunho prático, objetivando persuadir o Outro a modificar seu comportamento discursivo (GONÇALVES-SEGUNDO, 2020b): parar de associar Nátaly e outras mulheres negras ao estereótipo da mulher negra raivosa e continuar apoiando o canal e outras mulheres negras ativistas digitais ${ }^{159}$.

Neste caso, compreendemos que o convencimento a respeito das Alegações A1 e A2 consiste em uma etapa prévia à persuasão. Nesse caso, o processo de revisão de crenças efetuado pelo auditório resultaria na adesão à perspectiva de Nátaly - isto é, que o público empreenda uma reflexão acerca das ações e comportamentos (sobretudo discursivos) que tem empreendido até então e abandone sua percepção inicial sobre mulheres negras em favor de outras, autodefinidas por essas mulheres.

Além da estrutura que embasa A1 e A2, a sugestão de revisão de crenças é apoiada por um raciocínio sintomático por sinal (GONÇALVES-SEGUNDO, 2018b) a respeito dos comentários que reproduzem o estereótipo da mulher negra raivosa. Para tanto, Nátaly realiza um outro reenquadramento (linhas 5-13), que se volta para o gatilho dos afetos negativos de insegurança mencionados nos ataques. Esse reenquadramento permite que Nátaly aplique as características a ela atribuídas pelos comentários ao Outro.

O raciocínio sintomático apresentado consiste em: Os comentários são racistas; Comentários racistas são ameaçadores; Quem escreve esses comentários é ameaçador. Esse raciocínio se aproxima daquilo que Perelman e Olbrechts-Tyteca (2002, p. 339) afirmam a respeito da relação de coexistência entre a pessoa e seus atos ${ }^{160}$ :

$\mathrm{O}$ valor que atribuímos ao ato nos incita a atribuir um certo valor à pessoa, mas não se trata de um valor indeterminado. Se por um acaso um ato acarreta uma transferência de valor, esta é correlativa a um remanejamento de nossa concepção da pessoa, à qual atribuiremos, de um modo explícito ou implícito, certas tendências, aptidões, instintos ou sentimentos novos.

Essa transferência de propriedades do ato para a pessoa pode se dar com o objetivo de prever atos futuros, interpretar comportamentos passados, mas, em suma, tem vistas a construir esse ato e/ou essa propriedade como característicos da pessoa que está sendo julgada (PERELMAN; OLBRECHTS-TYTECA, 2002, p. 340). Dessa forma, e ao demonstrar o cunho

${ }^{159}$ Esse processo será analisado em detalhe no trecho N4.

${ }^{160}$ Para a Nova Retórica, ato é "tudo quanto pode ser considerado emanação da pessoa, sejam eles ações, modos de expressão, reações emotivas, cacoetes involuntários ou juízos.” (PERELMAN; OLBRECHTS-TYTECA, 2002, p. 339) 
racista desses comentários, ela afirma que a insegurança que os comentaristas dizem sentir em relação a ela ("nossa eu adoro a Nátaly Neri mas eu acho ela muito brava tenho medo de me aproximar...”) não só é infundada, como se basei numa percepção racista a respeito de mulheres negras, que potencialmente se traduz em percepções ou ações preconceituosas de forma recorrente e generalizada.

Considerando a ambiguidade da filiação discursiva do Outro (que, embora apresente traços do discurso racista em sua fala, se projeta no campo do endogrupo), mostra-se relevante apontar a incoerência em seu comportamento discursivo para apresentar uma forma mais coerente de encarar a questão. Assim, Nátaly argumenta para explicitar o papel do Outro nas práticas de silenciamento dessas mulheres. Como ela mesma coloca: "você não precisa ter medo de mim você não precisa ter medo da minha voz você precisa ter medo de você... e do que você acredita que eu devo ser...”.

Esse estratégia de reenquadramento expõe a tensão dialógica existente entre a Proposta de Ação defendida pelo Eu-Nós e a Contra-Proposta de Ação atribuída ao Outro, cuja relação será analisada em detalhe com o apoio das figuras 10 e 11a seguir.

Na Figura 10, veremos que, ao reportar alguns comentários no início do vídeo (linhas 5 - 13), Nátaly atribui ao Outro um desejo de "ajudá-la", por meio do oferecimento de "conselhos" a respeito de como ela poderia melhorar seu conteúdo e, assim, potencializar o alcance de seu canal (Objetivo). Em suma, esses "conselhos" sugerem uma mudança de tom (Contra-Proposta de Ação), considerando que seu modo de expressão "agressivo" e "arrogante" seria responsável por dificultar a compreensão de suas críticas e análises, afastando possíveis interessados (Circunstâncias Motivadoras). Para contornar esse problema e aumentar o alcance do canal, seria necessário tornar o tom mais apaziguador. Tendo em vista o modo de construção desses comentários, depreendemos os Valores de Cordialidade e Antirracismo como (supostamente) orientadores da proposta, o que sugere uma autoprojeção do Outro no campo epistêmico-axiológico do endogrupo.

No entanto, vimos que, ao longo do vídeo, a youtuber contra-argumenta em relação a esse movimento argumentativo. Além do reenquadramento, veremos que ela realiza uma série de Refutações à Contra-Proposta, mais especificamente ao seu Objetivos e ao seu Meio-Fim, bem como efetua uma Refutação baseada em Valores (MACAGNO; WALTON, 2019) à Contra-Proposta e apresenta Consequências Negativas decorrentes da mesma. 
Figura 10 - Layout da Configuração Funcional Prática do campo epistêmico-axiológico do Outro no vídeo "POR QUE VOCÊ É TÃo AGRESSIVA, NÁTALY?"

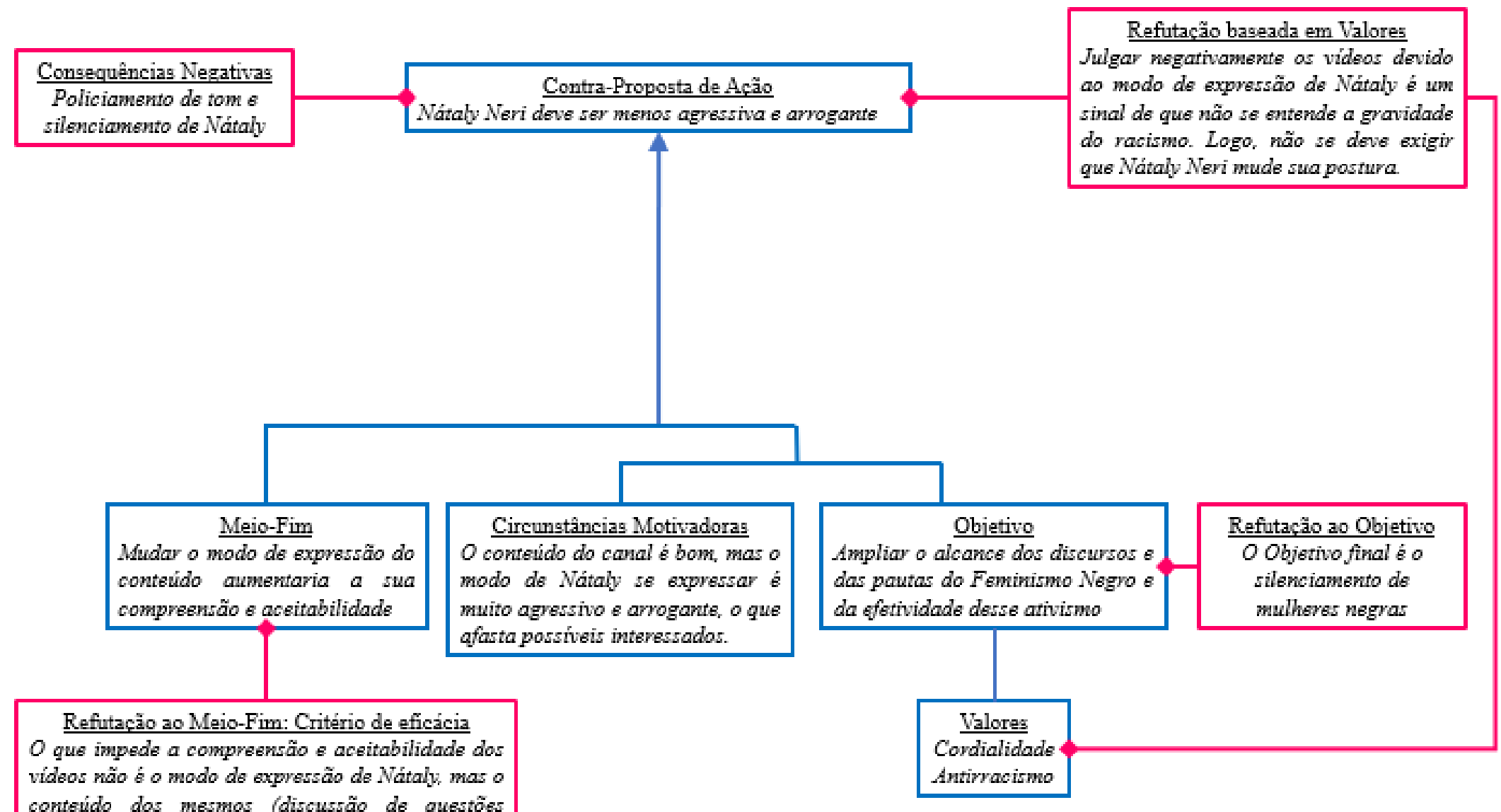

Fonte: elaboração própri 
No que se refere ao Meio-Fim, ataca a sua eficácia - Nátaly defende que mudar sua expressão não seria suficiente para aumentar a aceitabilidade de seus vídeos, posto que o desconforto que eles geram não advém de seu tom, mas sim dos tópicos que são discutidos.

Isso denotaria, então, uma falha na leitura do estado de coisas por parte do Outro (Circunstâncias Motivadoras). Dessa forma, coloca-se em xeque a Contra-Proposta em si, posto que, sendo gestada a partir de uma leitura equivocada, sua aplicação torna-se, no mínimo, questionável.

Ademais, a Contra-Proposta é considerada não apenas ineficaz, como potencialmente prejudicial para os Valores anunciados por seus propositores, posto que consistiria em uma instância de policiamento de tom das denúncias de mulheres negras. Dessa forma, denuncia-se o desrespeito ao Valor Antirracismo anunciado inicialmente (GONÇALVES-SEGUNDO, 2019), e afirma-se que a sua execução estaria enquadrada sob um Objetivo mais amplo, mesmo que não antecipado, de contribuir para o silenciamento sistemático dessas mulheres.

Em suma, Nátaly denuncia a apropriação indevida da retórica antirracista. O Outro, embora demonstre reconhecer a importância de sua produção ativista, ao mesmo tempo tenta controlá-la, apontando falhas percebidas devido a uma visão a respeito da youtuber que é mediada por um estereótipo e, dessa forma, reforça um imaginário racista. Isso seria um sinal de uma compreensão deficitária sobre o funcionamento do racismo e do papel exercido pelos próprios comentários na manutenção de sua estrutura. Essa operação pode ser resumida pelo trecho "você precisa ter medo de você... e do que você acredita que eu devo ser" (linhas 131132), que responsabiliza o Outro pela percepção equivocada e pela Contra-Proposta ineficaz.

Assim, enquanto, na Refutação ao movimento argumentativo do Outro, Nátaly argumenta que não há motivos reais para que seu auditório tema a sua voz, na defesa de sua Proposta de Ação, a youtuber afirma que a fonte do sentimento de desconforto experienciado pelos comentaristas estaria neles mesmos, mais especificamente na internalização e na reprodução de um imaginário racista. Trata-se do raciocínio sintomático por sinal discutido anteriormente neste capítulo: Os comentários são racistas; Comentários racistas são ameaçadores; Quem escreve esses comentários é ameaçador. Assim, o desconforto estaria na própria percepção de que, em seus vídeos, Nátaly denuncia uma estrutura social da qual eles não só fazem parte, como ajudam a manter e da qual se beneficiam. 
Figura 11 - Layout da Configuração Funcional Prática do campo epistêmico-axiológico do Eu no vídeo "POR QUE VOCÊ É TÃO AGRESSIVA, NÁTALY?"

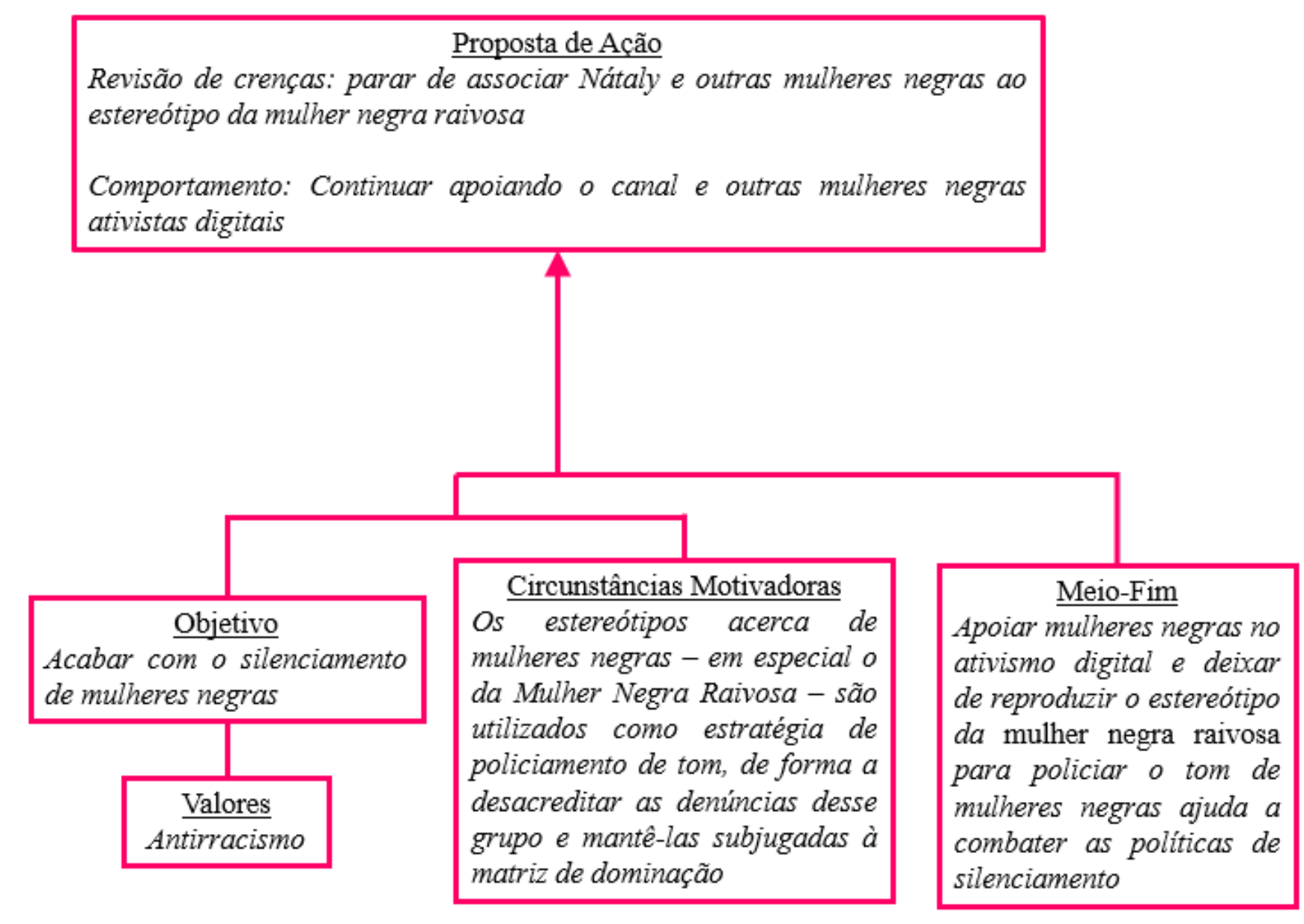

Fonte: elaboração própria. 
Para atacar essa questão, Nátaly reenquadra o problema, apresentando como Objetivo: acabar com o silenciamento de mulheres negras, entendido como o verdadeiro obstáculo para a ampliação do alcance de seu ativismo. O movimento argumentativo que defende a sua Proposta de Ação está resumido na Figura 11 na página anterior.

Nátaly defende uma Proposta de Ação voltada especificamente para os comentaristas, recomendando que realizem um processo de revisão de crenças e mudem seu comportamentoa partir das problematizações efetuadas por ela. Para justificar essa Proposta, Nátaly realiza uma leitura do estado de coisas que localiza o problema na reprodução de estereótipos e na forma como esse imaginário atua sobre a percepção das ações de mulheres negras, muitas vezes consideradas agressivas ou arrogantes a despeito de como se comportam - assim, a real motivação dos comentários reportados seria o desconforto ao terem suas crenças confrontadas por mulheres negras que "ousam falar”, desafiando as políticas de silenciamento e denunciando o racismo e o sexismo, o que ainda é considerado por muitos uma espécie de tabu. Para superar essa questão, Nátaly salienta a necessidade de um comprometimento verdadeiramente antirracista, o que envolveria um processo de autocrítica e o apoio a mulheres negras atuantes em diversas plataformas online são apresentados como ações verdadeiramente antirracistas e eficazes de acordo com a youtuber.

Vemos, portanto, que, enquanto as entidades Eu e Nós são projetadas no campo do endogrupo, o Outro é mapeado por Nátaly no campo do exogrupo. Uma vez que se atribui a essa entidade uma autoprojeção no primeiro campo, sugerindo uma suposta relação de solidariedade, Nátaly se dispõe a argumentar em favor da deslegitimação desse mapeamento, demonstrando as incongruências entre o discurso e os atos dos comentaristas em relação ao Valor antirracista, que seria, segundo o Outro, orientador de suas práticas.

Em suma, vimos que, neste vídeo, a youtuber realiza um reenquadramento do movimento argumentativo, partindo de uma pergunta polêmica e atrativa para realizar uma discussão mais condizente com os propósitos do seu canal. Ao longo do vídeo, ela descreve alguns dos principais estereótipos sobre mulheres negras em uso no Brasil e, sobretudo, como o estereótipo da mulher negra raivosa é recrutado para o silenciamento de mulheres negras.

Nos trechos analisados na seção 2, provenientes deste vídeo, veremos em detalhe de que forma ela delimita as fronteiras entre os campos - descrevendo o conteúdo e o funcionamento dos estereótipos, apresentando narrativas pessoais e traços de sua personalidade como gesto de captação empática e realocando o gatilho do AFETO de insegurança (N1-N4) - e como lida com a sugestão de um laço de solidariedade nos comentários em sua Refutação, construindo uma 
região de proximidade epistêmico-axiológica a partir da apresentação de um acordo epistêmicoaxiológico feminista a respeito do uso de estereótipos para silenciar mulheres em geral (N5).

\section{"YOUTUBER SÓ FALA MERDA NA INTERNET? Feat. Louie Ponto"161}

Como já discutimos 1, em 2017, a discussão sobre a legitimidade do ativismo digital era uma grande polêmica que dividia ativistas e militantes do campo progressista e da esquerda a respeito de táticas e práxis ${ }^{162}$. Este vídeo está voltado justamente para a legitimação das práticas discursivas de ativismo político progressista (ligadas aos movimentos de mulheres - incluindose aí os feminismos -, movimentos negros e LGBT) no YouTube. Essa dimensão epistêmica está atrelada a uma dimensão prática que se traduz em uma Proposta de Ação: Participe das comunidades engajadas na Internet - seja por meio do apoio a produtores de conteúdo, seja pela criação de conteúdo engajado ${ }^{163}$.

Ao contrário dos demais vídeos analisados, este não está orientado à explicitação de traços discursivos do exogrupo ainda presentes em posicionamentos e comportamentos de certos membros do endogrupo. Na verdade, em 2017, já havia uma grande mobilização de grupos conservadores, machistas, homofóbicos e racistas (exogrupo) nas plataformas online, em especial no YouTube - envolvidos no processo de escalada da extrema direita no Brasil. Simultaneamente, apesar de haver diversas mobilizações progressistas nas redes sociais (conforme discutimos no capítulo 1), uma parcela do endogrupo continuava cética em relação à validade e à eficácia dos ativismos e das militâncias online, deslegitimando os grupos e as/os atoras/es sociais que davam atenção a essas práticas - tanto como produtores, quanto como consumidores -, denominando-as/os pejorativamente de "ativistas de sofá"164.

\footnotetext{
${ }_{161}$ Disponível em: <https://www.youtube.com/watch?v=ZCMzbWdEZn4\&ab_channel=N\%C3\%A1talyNeri >.

162 Evidentemente, é impossível ignorar as mudanças que ocorreram em relação a essa questão desde então, sobretudo com as novas percepções acerca das articulações nas redes sociais avindas da eleição de Bolsonaro em 2018 e da necessidade de isolamento social devido à pandemia do coronavírus. Ainda assim, apesar de a polêmica em relação à legitimidade do ativismo digital não mais se conformar nos termos expostos aqui, não deixa de ser importante refletir sobre as divergências que este vídeo apontava dentro do campo progressistas no ano de 2017, o que pode também informar sobre os modos de lidar com as contradições encontradas ao atuar nas redes sociais que essas youtubers e outras/os ativistas desenvolveram ao longo dos anos.

${ }^{163}$ Acerca da defesa do YouTube enquanto plataforma válida para a realização de discussões sociais e divulgação científica em termos de argumentação prática, sugerimos a leitura de Gonçalves-Segundo (2019a), que analisa argumentos algo semelhantes aos discutidos nesse vídeo.

${ }^{164}$ Considerando que Nátaly e Louie também atuam como influenciadoras, divulgando produtos e serviços de algumas marcas - é notável a dificuldade extrema de se manter apenas com os proventos do YouTube e muitos produtores de conteúdo têm adotado a mesma postura -, as críticas também são contra esse tipo de parceria com empresas privadas.
} 
Assim, neste vídeo, o Outro corresponde a esse grupo de céticos, enquanto o Nós consiste nos "canais que falam sobre questões sociais de um modo geral" (linhas 23-24) ou, como temos chamado nesta dissertação, "youtubers ativistas”. O endogrupo, por sua vez, consiste naquelas e naqueles que compartilham ideais progressistas - ativistas e militantes dos movimentos feministas, LGBT $^{165}$ e negros, de mulheres negras e de mulheres lésbicas.

As entidades são mapeadas da seguinte forma no espaço discursivo: o Eu corresponde a Louie e a Nátaly, que, embora tenham suas especificidades, neste vídeo (e no outro em que fazem parceria) podem ser compreendidas como uma só voz autoral ${ }^{166}$. O Nós corresponde aos demais membros de comunidades engajadas do YouTube - produtores de conteúdo e seguidores. Por fim, o Outro faz referência àquelas/es que desmerecem ou são contrárias/os aos "ativismos de internet" como formatos ou facetas legítimas de movimentos sociais.

Como já mencionamos, ao contrário dos outros vídeos, o Espaço Discursivo não se mostra dividido entre exogrupo e endogrupo. Isso se reflete numa argumentação baseada em muitos Valores comuns e que privilegia a criação de regiões de proximidade epistêmicoaxiológica.

Desse modo, os campos epistêmico-axiológicos são definidos com base na adesão a uma das duas Propostas de Ação em resposta ao seguinte problema prático: qual seria a estratégia mais efetivalo ambiente mais adequado ou propício para construir comunidades engajadas capazes de debater questões sociais e levar à transformação social ${ }^{167}$ A tensão dialógica está, portanto, na escolha do curso de ação: será mais proveitoso/efetivo construir comunidades engajadas pautadas pelos meios offline apenas (Contra-Proposta de Ação, defendida pelo Outro), ou incluir o ativismo digital como uma das estratégias dos movimentos sociais (Proposta de Ação do Eu-Nós)?

Em primeiro plano, está a Proposta defendida pelo Eu-Nós, que pode ser resumida em Participar das comunidades engajadas na Internet. Isso abarca desde o reconhecimento da importância do apoio das seguidoras em termos de inscrição, curtidas e compartilhamentos, até o convite para a produção de conteúdo nas comunidades de criadores de conteúdo engajado em plataformas online (tais como o Black Twitter e o Twitter Indígena).

\footnotetext{
${ }^{165}$ Neste capítulo, utilizaremos a sigla "LGBT", posto que foi é o termo utilizado pelas youtubers nos vídeos analisados.

166 Não se trata de uma questão dos vídeos de colaboração em geral, mas sim dos vídeos colaborativos em que ambas as youtubers defendem uma mesma Proposta de Ação ou Alegação.

${ }^{167}$ Depreende-se, portanto, o Objetivo: construir comunidades engajadas capazes de debater questões sociais e levar à transformação social.
} 


\section{Figura 12 - Layout da Configuração Funcional Prática do vídeo "YOUTUBER SÓ FALA MERDA NA INTERNET? Feat. Louie Ponto}

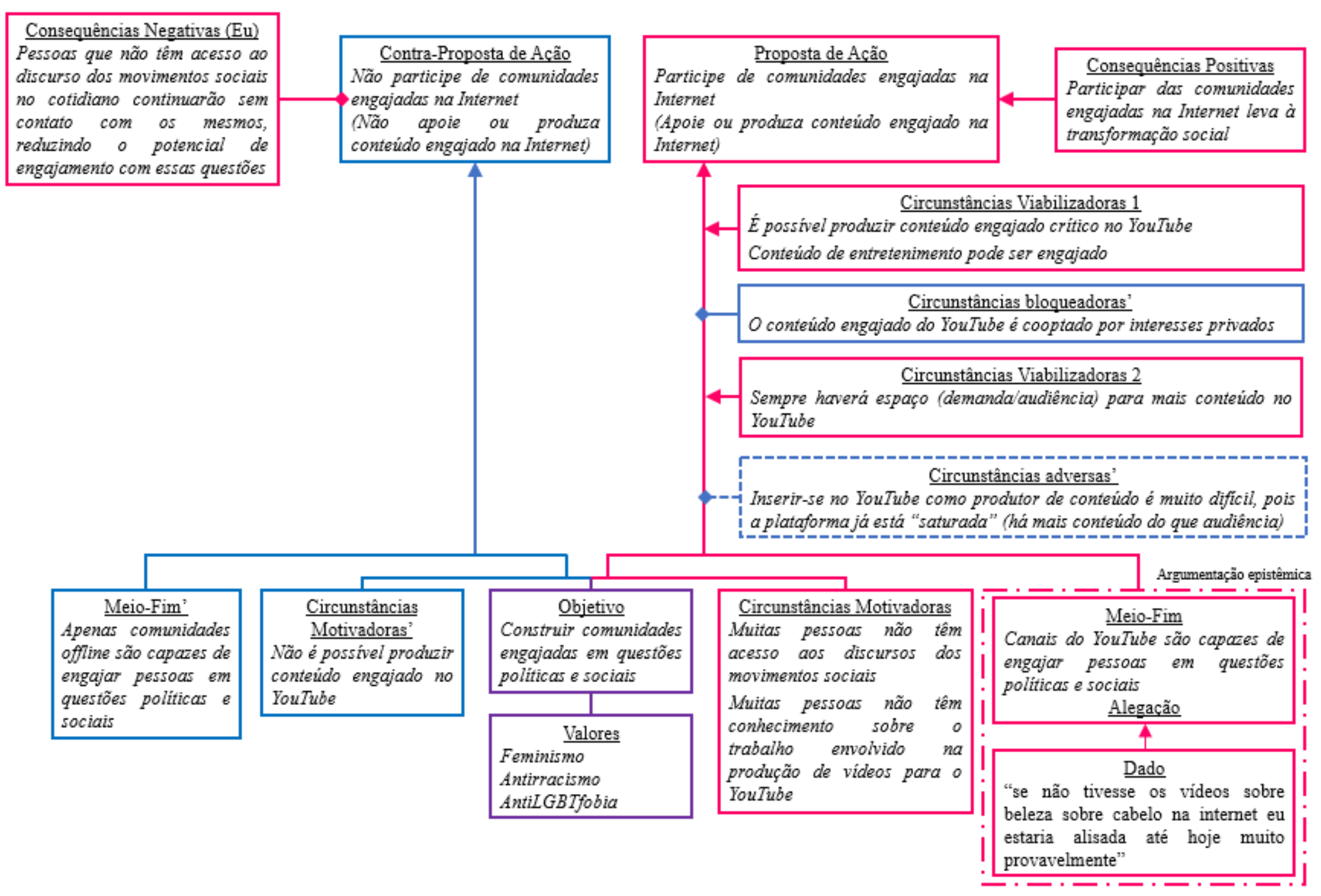

Fonte: elaboração própria. 
A Contra-Proposta de Ação, por sua vez, consiste em Participar apenas de comunidades engajadas fora da Internet, baseada em uma percepção das estratégias de mobilização online como pouco eficazes, despolitizadas e mesmo como casos de cooptação dos discursos progressistas por interesses privados.

Vemos, portanto que, embora na projeção do mapeamento no espaço discursivo do texto as entidades se localizem no mesmo campo epistêmico-axiológico, sua intersecção é limitada. Ela se dá devido a algumas premissas compartilhadas, como seus Valores e Objetivos. Por outro lado, as diferenças entre sua leitura de Circunstâncias, Consequências e Propostas de Ação são fundamentais para a diferenciação de suas fronteiras. Assim, a tensão argumentativa deste vídeo, como pode ser visto na Figura 12 na página anterior, está relacionada a divergências entre leituras de Circunstâncias - mais especificamente no que se refere às Circunstâncias Viabilizadoras do Eu-Nós e às Circunstâncias Motivadoras do Outro -, bem como à compreensão sobre cada Meio-Fim.

A Proposta de Ação encampada pelo Eu-Nós pretende responder à problemática apontada nas Circunstâncias Motivadoras, que definem a falta de acesso aos discursos dos movimentos sociais e o desconhecimento do trabalho envolvido na produção de vídeos para o YouTube, sobretudo os de conteúdo engajado como obstáculos que impedem a consecução do Objetivo (Construir comunidades engajadas em questões políticas e sociais). São esses entendimentos que constroem o estado de coisas presente como negativo, e estabelecem um ponto de partida para a Proposta de Ação defendida (Participe de comunidades engajadas na Internet).

A eficácia da Proposta para atingir o Objetivo desejado deriva, portanto, do entendimento de que Canais do YouTube são capazes de causar mudanças na vida das pessoas (Meio-Fim). Uma vez que, como veremos, a tensão dialógica entre os campos epistêmicoaxiológicos do Eu-Nós e do Outro se refere sobretudo ao potencial político do ativismo digital, mostra-se necessário embasar esse Meio-Fim, o que é feito por meio de uma breve recuperação da narrativa pessoal de Nátaly a respeito de sua própria transição capilar ${ }^{168}$.

A factibilidade dessa Proposta de Ação é apoiada ainda pela apresentação de dois grupos de Circunstâncias Viabilizadoras, que refutam, por sua vez, as Circunstâncias Adversas e Bloqueadoras atribuídas ao Outro, fortalecendo o fluxo em prol da Proposta de Ação. A Circunstância Viabilizadora É possível produzir conteúdo engajado no YouTube/ Conteúdo de entretenimento pode ser engajado faz frente à Circunstância Bloqueadora' O conteúdo

\footnotetext{
${ }^{168}$ Esse embasamento constituirá uma instância de argumentação epistêmica, elaborada mais à frente.
} 
engajado do YouTube é cooptado por interesses privados, enquanto Sempre haverá espaço (demanda/audiência) para mais conteúdo no YouTube opõe-se à Resistência a inserir-se no YouTube como produtor de conteúdo por entender que a plataforma está saturada de conteúdo.

É importante ressaltar ainda que a Circunstância Bloqueadora' O conteúdo engajado do YouTube é cooptado por interesses privados para a Proposta do Eu-Nós ecoa a Circunstância Motivadora' do Outro Não é possível produzir conteúdo engajado no YouTube. Esta nega de saída a possibilidade do ativismo digital, entendendo que Apenas comunidades offline são capazes de engajar pessoas em questões políticas e sociais (Meio-Fim) e, portanto, eficazes para alcançar o Objetivo comum Construir comunidades engajadas em questões políticas e sociais.

Como indicamos acima, a base de ambas as Propostas de Ação depende da resposta ao problema epistêmico da qualidade/eficácia do conteúdo engajado de plataformas online em proporcionar uma formação política de qualidade que possa resultar em transformação social. Por esse motivo, elabora-se uma argumentação em defesa desse potencial, apresentada abaixo por meio dos layouts da configuração funcional epistêmica das Circunstâncias Motivadoras do Outro e das Circunstâncias Viabilizadoras do Eu-Nós. Discutiremos, em primeiro lugar, a defesa das Circunstâncias Motivadoras do Outro'.

As principais questões desse vídeo têm relação com o modelo de negócios da plataforma e com as práticas discursivas nela realizadas- como, por exemplo, os vídeos de publicidade, tanto no espaço comprado pelas marcas, quanto nos conteúdos originais das/os youtubers. Nesse sentido, a tensão dialógica envolve a capacidade de as youtubers produzirem um conteúdo engajado de qualidade mesmo sofrendo as coerções materiais da plataforma, que orientam, ao menos em parte, suas estratégias de comunicação - o que poderia colocar em risco seu potencial crítico.

Conforme mostrado na Figura 12, de acordo com o discurso do Outro, essas questões inviabilizariam a produção de um conteúdo crítico e, consequentemente, a construção de comunidades verdadeiramente engajadas em questões políticas e sociais. Essa visão está esquematizada na Figura 13 a seguir.

Os Dados apresentados para defender o discurso de que o conteúdo engajado produzido para o YouTube não tem potencial crítico apontam, por um lado, a relação entre canais e marcas/empresas privadas (que promoveriam um instantâneo favorecimento econômico aos canais decorrente do aumento de seguidores - D’1), e, por outro, a concepção de que há uma forma homogênea de produzir conteúdo (sempre voltada para o entretenimento acrítico - D’2 ${ }^{\mathrm{A}}$ ), 
Figura 13 - Layout da Configuração Funcional Epistêmica das Circunstâncias Motivadoras do Outro no vídeo "YOUTUBER SÓ FALA MERDA NA INTERNET? Feat. Louie Ponto"

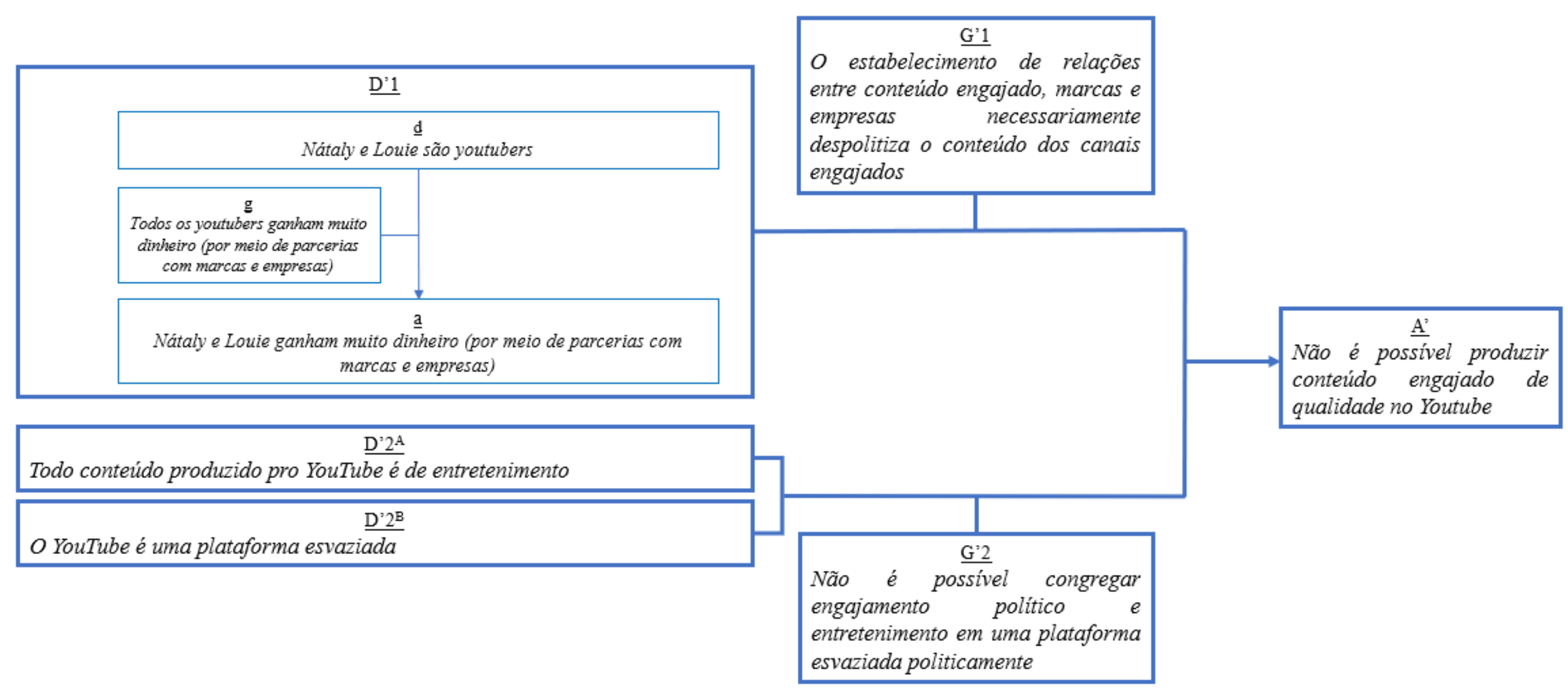

Fonte: elaboração própria. 
além da própria natureza da plataforma (baseada na oferta de audiência para conteúdo publicitário $\left.-\mathrm{D}^{\prime} 2^{\mathrm{B}}\right)$.

No primeiro grupo de Dados (D’1), a passagem à Contra-Alegação é garantida pelo entendimento (G’1) de que $O$ estabelecimento de relações entre conteúdo engajado, marcas $e$ empresas necessariamente despolitiza o conteúdo dos canais engajados. No segundo (D’2), essa relação se justifica pelo entendimento (G’2) de que Não é possível congregar engajamento político e entretenimento em uma plataforma esvaziada politicamente.

Em suma, trata-se de uma estratégia argumentativa que deslegitima as práticas discursivas e as estratégias política adotada pelas youtubers.

Para desmobilizar o fluxo argumentativo do Outro e legitimar o seu, as youtubers constroem para si um lugar intermediário: o lugar da ponte, da porta de entrada. Trata-se da metáfora situada (VEREZA, 2013): ATIVISMO DIGITAL É PONTE/PORTA DE ENTRADA (desenvolvida no Quadro 6) que embasa o entendimento de que o ativismo digital se localiza no intermédio entre o movimento social (feminismo negro, feminismo lésbico) e audiências não engajadas, a partir da qual as youtubers poderiam produzir um conteúdo ativista não só didático, crítico e de qualidade, mas o mais importante: acessível.

O detalhamento dessa suposta "acessibilidade" será parte fundamental do movimento argumentativo de Refutação da posição do Outro ao longo do vídeo. Dessa forma, também são abordadas as discussões sobre o suposto "esvaziamento político" da plataforma e dos conteúdos de beleza e entretenimento, causado por suas coerções materiais e discursivas.

Em sua defesa, as youtubers argumentam que a natureza e os objetivos comerciais do YouTube não exercem coerção suficiente sobre suas práticas a ponto de influenciar os princípios políticos da sua produção de conteúdo. Seu movimento argumentativo age, portanto, tanto para defender as próprias práticas, quanto para defender as potencialidades desse espaço de sociabilidade online (na perspectiva da comunidade de produção de conteúdo). Para tanto, elas enfatizam o potencial emancipatório de pelo menos parte dos conteúdos engajados ali publicados.

No layout abaixo (Figura 14), esquematizamos os Dados e Garantias utilizados para sustentar a Alegação (A1). Separamo-los em dois grandes tipos: aqueles que versam sobre o engajamento político das próprias ativistas (D1) e aqueles que defendem a possibilidade de criar conteúdo engajado de qualidade nas plataformas (D2 $\left.{ }^{\mathrm{A}}-\mathrm{D} 2^{\mathrm{B}}\right)$. 
Figura 14 - Layout da Configuração Funcional Epistêmica das Circunstâncias Viabilizadoras do Eu-Nós no vídeo "YOUTUBER SÓ FALA MERDA NA INTERNET? Feat. Louie Ponto"

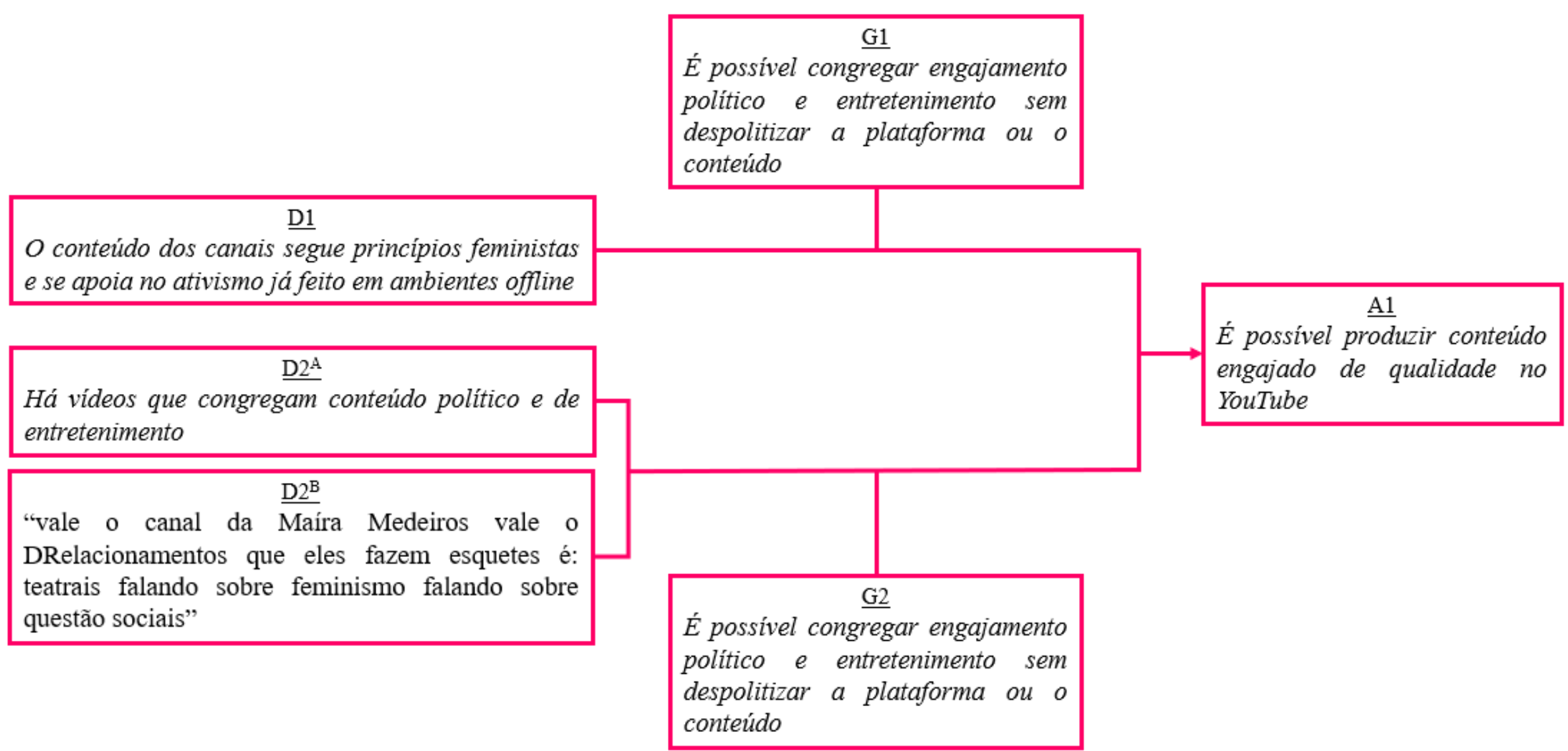

Fonte: elaboração própria. 
Articulando os dois tipos de argumentos, elas condicionam a qualidade do conteúdo ao compromisso político de cada produtor de conteúdo ("o nosso conteúdo ele tá muito ligado nas coisas que a gente acredita então ele não é TÃO flexível asSIM" - linhas 55-56).

Trata-se de um aproveitamento estratégico da plataforma como espaço para produzir conteúdo engajado. Isso não significa, no entanto, encarar política como entretenimento, mas, sim, pautar politicamente assuntos de entretenimento - discutindo a dimensão política da estética negra ${ }^{169}$ e da representação de lésbicas na cultura pop ${ }^{170}$, por exemplo - e de politizar gêneros de entretenimento típicos do YouTube - como as esquetes, o Maquia e Fala e os vídeos de reação, por exemplo.

Em suma, os canais engajados no YouTube (e o ativismo digital como um todo) como espaços de "ponte" ou "porta de entrada" teriam como propósito oferecer uma espécie de formação política básica, preocupada em didatizar e divulgar questões dos ativismos feministas, negros e LGBT, sobretudo para o público adolescente. Isso se justificaria pela baixa capilaridade desses debates em determinados territórios e espaços institucionais, como as escolas e a mídia hegemônica (que elas exemplificam por meio das próprias experiências).

Dessa forma, elas reafirmam o compromisso com os Valores (Feminismo, Antirracismo, AntiLGBTfobia) e os Objetivos em comum com o Outro (Construir comunidades engajadas em questões políticas e sociais), sugerindo uma relação de complementariedade entre as Propostas de Ação, e, consequentemente, a criação de um laço de solidariedade entre as comunidades discursivas.

As discussões realizadas nesta subseção serão aprofundadas na seção seguinte nas análises dos movimentos de afastamento epistêmico-axiológico.No trecho NL1, exploramos as diferenças entre as Circunstâncias Motivadoras do Eu-Nós e do Outro; em NL2, analisamos o recurso da concessão ao discurso Outro para legitimar o espaço da "ponte" ou "porta de entrada". Já os movimentos de aproximação epistêmico-axiológicos serão analisados nos trechos NL3 e NL4, que explicitam as semelhanças e acordos entre as visões de mundo das comunidades, sugerindo as relações de complementariedade e solidariedade indicadas no parágrafo anterior.

\footnotetext{
${ }^{169}$ Como, por exemplo, o vídeo "A IMPORTÂNCIA DA ESTÉTICA E AUTOESTIMA NEGRA: Geração Tombamento é Política?", de Nátaly Neri, disponível em: <https://www.youtube.com/watch?v=srKdoOEbjeg $>$. ${ }^{170}$ Como, por exemplo o vídeo "REPRESENTATIVIDADE LÉSBICA E REFERÊNCIAS POSITIVAS | Louie Ponto", de LouiePonto, disponível em: 〈https://www.youtube.com/watch?v=8yF-Zc-Id6M\&t=736s $>$.
} 


\section{“HETEROFOBIA E RACISMO REVERSO EXISTEM? | LouiePonto feat. Nátaly}

\section{Neri" 171}

Este vídeo se insere na polêmica a respeito das “discriminações inversas” (LUZ, 2017), alegações largamente recrutadas na esfera pública e também em conversas casuais que visam a caracterizar a luta contra as opressões (movimentos feministas, negros e LGBT) como mobilizações e discursos eles mesmos opressores e intolerantes (trata-se das "denúncias" de "racismo reverso"172, "heterofobia" e "femismo", dentre outros).

No vídeo sob análise, o problema epistêmico que orienta a discussão e mapeia o espaço discursivo é da ordem do estabelecimento das noções de racismo reverso e de heterofobia no continuum realis-irrealis, isto é, discutem se elas fazem referência a fenômenos de fato existentes, e estabelecem seu status como noções inválidas. Delineiam-se duas comunidades discursivas com base na adesão a uma das Alegações em resposta à questão exposta no título Heterofobia e racismo reverso existem?: Heterofobia e racismo reverso existem e Heterofobia e racismo reverso não existem.

De acordo com Luz (2017), as alegações de heterofobia e de racismo reverso estão diretamente relacionadas ao perfil cordial das relações cotidianas entre grupos sociais opressores e oprimidos no Brasil. No contexto atual (LUZ, 2017, p. 149),

A acusação de discriminação inversa costuma ser feita contra militantes sociais e defensores dos direitos humanos e espraiou-se em círculos de debates nas redes sociais, entre políticos e organizações conservadoras, até o consenso médio das ideias sociais, a ponto de tornar-se elemento de defesa de posições políticas simpáticas a episódios de agressões a lésbicas, gays, travestis, transexuais, mulheres negras e negros.

Essas táticas defensivas se apoiam na "invisibilização, negação e banalização do racismo e do machismo, estendida à homofobia, à lesbofobia e à transfobia" (LUZ, 2017, p.151). Elas consideram "agressivas, excessivas e radicais" (LUZ, 2017, p. 156, itálico do original) as denúncias realizadas pelos movimentos sociais ${ }^{173}$. Tratam-se de táticas que visam a "desacreditar a interpretação da discriminação" (LUZ, 2017, p.156) - seja a tentativa de deslegitimar a Proposta de Ação ou a relação de causa e efeito apresentada, ou ainda atacar a imagem da ativista/militante/coletivo/organização em questão, desqualificando seu trabalho -

${ }^{171}$ Disponível em: 〈https://www.youtube.com/watch?v=PHwYRDumASg\&lc\&ab_channel=LouiePonto>.

${ }^{172}$ A esse respeito, em específico, recomendamos ainda a leitura de "Racismo reverso é um delírio da branquitude colonial", de Tatiana Nascimento, que apresenta uma outra perspectiva acerca da questão, igualmente instigante, mas que não abordaremos nestas análises. Disponível em: < https://palavrapreta.wordpress.com/2020/05/29/racismoreverso/>. Acesso em 30/10/2020.

173 Trata-se de uma questão semelhante à discutida na seção 1.1 a respeito da mobilização do estereótipo da mulher negra raivosa como estratégia de silenciamento das denúncias de mulheres negras ativistas e militantes a respeito do racismo, do sexismo e, também, da LGBTfobia. 
e, em última instância, defender ou desculpar as agressões racistas, misóginas e LGBTfóbicas. São exemplos desse posicionamento as acusações de que as lutas antirracistas, feministas e pela comunidade LGBT são "mimimi”, vitimismo ou demasiado radicais. Inseridas diretamente nesta polêmica, neste caso - posto que são as tais ativistas acusadas de serem "vitimistas" ou "radicais demais" - estão as youtubers.

Assim, vemos que subjazem à divisão do espaço discursivo duas principais discursividades, respectivamente: o conservadorismo (que corresponde à delimitação do campo epistêmico-axiológico do exogrupo), que afirma a existência da heterofobia e do racismo reverso, e o progressismo ${ }^{174}$ (que corresponde à filiação discursiva do endogrupo), que a refuta. No entanto, embora a questão Heterofobia e racismo reverso existem? seja central para a discussão realizada no vídeo, existe também uma questão subsidiária aberta, subjacente à discussão: “o que é racismo?”. Ela é levantada como forma de desestabilizar a Alegação' (conservadora) e iremos analisá-la com cuidado após a descrição do mapeamento do espaço discursivo.

As entidades discursivas (Eu, Nós e Outro), por sua vez, são mapeadas em termos de proximidade ou distância epistêmico-axiológica em relação à matriz discursiva do endogrupo e do exogrupo. Assim, sua projeção em um ou outro campo depende dos traços discursivos que apresentam - ou que lhes são atribuídos.

O Eu, assim como no vídeo "YOUTUBER SÓ FALA MERDA NA INTERNET? Feat. Louie Ponto", é duplo - corresponde a Louie e a Nátaly como como uma só voz autoral. Já o Nós se refere à coletividade de pessoas negras em geral, mulheres em geral e pessoas LGBT ativistas/militantes, a quem os referidos ataques são comumente direcionados. Quanto ao Outro, este se refere especificamente a atoras/es sociais que se consideram parte do endogrupo progressista, mas, apesar de próximas/os em alguns aspectos ao campo epistêmico-axiológico de Nátaly e Louie - tendo em vista que parecem ter algum contato com os canais e respondem aos vídeos com comentários, demonstrando engajamento com as discussões efetuadas -, reproduzem a Alegação do racismo reverso e da heterofobia e, portanto, apresentam um nível relevante de filiação discursiva ao posicionamento do exogrupo.

Segundo Fogelin (2005), os debates acerca das discriminações inversas nomeadamente, aqueles que se referem a políticas de discriminação positiva (ALMEIDA, 2019), como as ações afirmativas de cotas raciais - são exemplos de desacordos profundos, isto

${ }^{174}$ Consideramos "progressista" aqui, pontualmente e de forma simplificada, como o posicionamento social e político favorável às pautas e demandas dos movimentos sociais feministas, negros e LGBT. 
é, contextos em que as condições normais para a argumentação não existem (FOGELIN, 2005, p. 7). Enquanto, em condições normais, há acordos de fundo a respeito dos compromissos dos participantes envolvidos no processo argumentativo - como um certo grau de conhecimento partilhado a respeito do tema e um conjunto de procedimentos válidos para a discussão das ideias e alcance de objetivos -, os casos de desacordo profundo seriam aqueles em que há um choque entre essas proposições de fundo, o que impediria o estabelecimento de um campo comum de conhecimentos e propósitos partilhados para a resolução do dissenso e até mesmo para a simples discussão de ideias (FOGELIN, 2005, p. 8).

Neste caso, o Eu e o Nós estão projetados no campo epistêmico-axiológico do endogrupo devido ao compartilhamento de valores e pontos de vista progressistas, o que envolve não só compreensões comuns acerca da estruturação da sociedade brasileira, como também valores de defesa e promoção de movimentos sociais antiopressão - considerando vários graus de radicalidade. A projeção do Outro, por sua vez, é ambígua: poderia ser projetado tanto no campo do exogrupo quanto no do endogrupo a partir dos traços discursivos atribuídos à entidade.

Essa ambiguidade se dá porque os comentários relatados pelas youtubers sugerem que haveria uma autoprojeção das/os autoras/es dos comentários no campo do endogrupo. No entanto, essa projeção é disputada ao longo do vídeo sobretudo por meio de movimentos de afastamento epistêmico-axiológico que participam refutação interna da Alegação defendida pelo Outro. Nesse processo, evidencia-se também que se trata de um caso de desacordo profundo, posto que os critérios argumentativos expressados por/atribuídos às entidades se mostram bastante diversos.

Nos parágrafos seguintes, iremos apresentar com mais detalhes como se processa a divisão e o mapeamento do espaço discursivo por meio da análise da Configuração Funcional Epistêmica dos movimentos argumentativos que defendem as duas Alegações em pauta ${ }^{175}$.

Como mencionamos acima, embora a questão argumentativa presente no título do vídeo oriente em grande parte os fluxos argumentativos, há outra pergunta, de caráter aberto, que é fundamental para a estrutura argumentativa do texto: "o que é racismo?".

Enquanto a pergunta do título, nuclear, enfoca a factualidade das noções de racismo reverso e heterofobia, a pergunta subsidiária, por sua vez, permite problematizar a noção de

\footnotetext{
175 Ao contrário dos demais vídeos selecionados para análise, neste não depreendemos uma dimensão prática articulada à dimensão epistêmica.
} 
racismo atribuída ao Outro, que consiste na Garantia de seu movimento argumentativo em defesa da Alegação Heterofobia e racismo reverso existem, considerada insuficiente pelas youtubers. Assim, a resposta do complexo Eu-Nós a "o que é racismo?" consiste tanto em refutação interna da Garantia do Outro (Figura 15) como em Dados para o movimento argumentativo do Eu-Nós em resposta à pergunta nuclear, constituindo uma refutação externa (Figuras 16 e 17).

Na Figura 15 a seguir, apresentamos o layout que define o campo epistêmico-axiológico do Outro em termos da pergunta argumentativa do vídeo e o movimento argumentativo de refutação interna efetuado pelo Eu-Nós.

Para desmobilizar a adesão à Alegação', as youtubers desafiam a Garantia G'1, identificando-a como uma hipergeneralização e denunciando suas raízes ideológicas ao salientar seu aspecto "irracional" - o aspecto irracional da ideologia racista em si, da qual a tese do racismo reverso participa (GONZALEZ, 2011; KILOMBA, 2019; LUZ, 2017). Além disso, a representação do Outro, que no começo está focada em seu aspecto egocêntrico e algo ingênuo ("ficam perdidas", "ai que dor! ai meu deus por que que você tá fazendo isso comigo?" - linhas 42-43), ao longo do vídeo se torna uma crítica ética ("é desonestidade na verdade"). Simultaneamente, as youtubers defendem sua própria definição de racismo e LGBTfobia como questões estruturais de forma a inviabilizar a definição proposta pelo Outro.

Ao longo do vídeo é proposta uma aproximação entre certas características do racismo e da LGBTfobia - especialmente no que se refere ao caráter estrutural desses sistemas de dominação. Embora o foco da argumentação recaia sobre as origens do racismo, também a LGBTfobia tem suas origens num discurso patologizante que visa à normatização dos corpos e apresenta consequências sobre a vida dessa população em termos de saúde, oportunidades e segurança. Essa aproximação se baseia na definição de sistemas de dominação estruturais, que servirá também como Garantia para negar a equiparação entre o racismo e o racismo reverso, a LGBTfobia e a heterofobia.

Conforme reportado pelas youtubers, a Alegação A'1 Heterofobia e racismo reverso são exemplos de práticas de discriminação (em outras palavras, Heterofobia e racismo reverso existem) sustenta-se em episódios de preconceito e/ou discriminação de pessoas brancas e/ou heterossexuais com base em sua raça e/ou sexualidade ("ter que pagar pra ser hétero", "medo de sair na rua", "ser branco agora é crime", "sou chamado de leite azedo", "o meu cabelo é cacheado eu também sofro racismo por isso"), bem como em um suposto posicionamento dis- 
Figura 15 - Layout da Configuração Funcional Epistêmica do Outro e do movimento de refutação interna efetuado pelo Eu-Nós no vídeo "HETEROFOBIA E RACISMO REVERSO EXISTEM? | LouiePonto feat. Nátaly Neri"

"ai agora não pode mais ser hétero... nossa agora vou
ter que pagar pra ser hétero ((risos)) eu tenho medo de
andar na rua que eu sou hétero"
"você quer dividir o mundo [...] eu não tenho culpa do
que os meus antepassados te fiZEram ser branco agora
é CRIme [[SER BRANCO AGORA É CRIME]] eu
tamBÉM sou chamado de leite azedo o meu cabelo é
cacheado eu também sofro racismo por ISso"
"eu conheço um cara gay que bateu num cara hétero
porque ele era heterossexual"

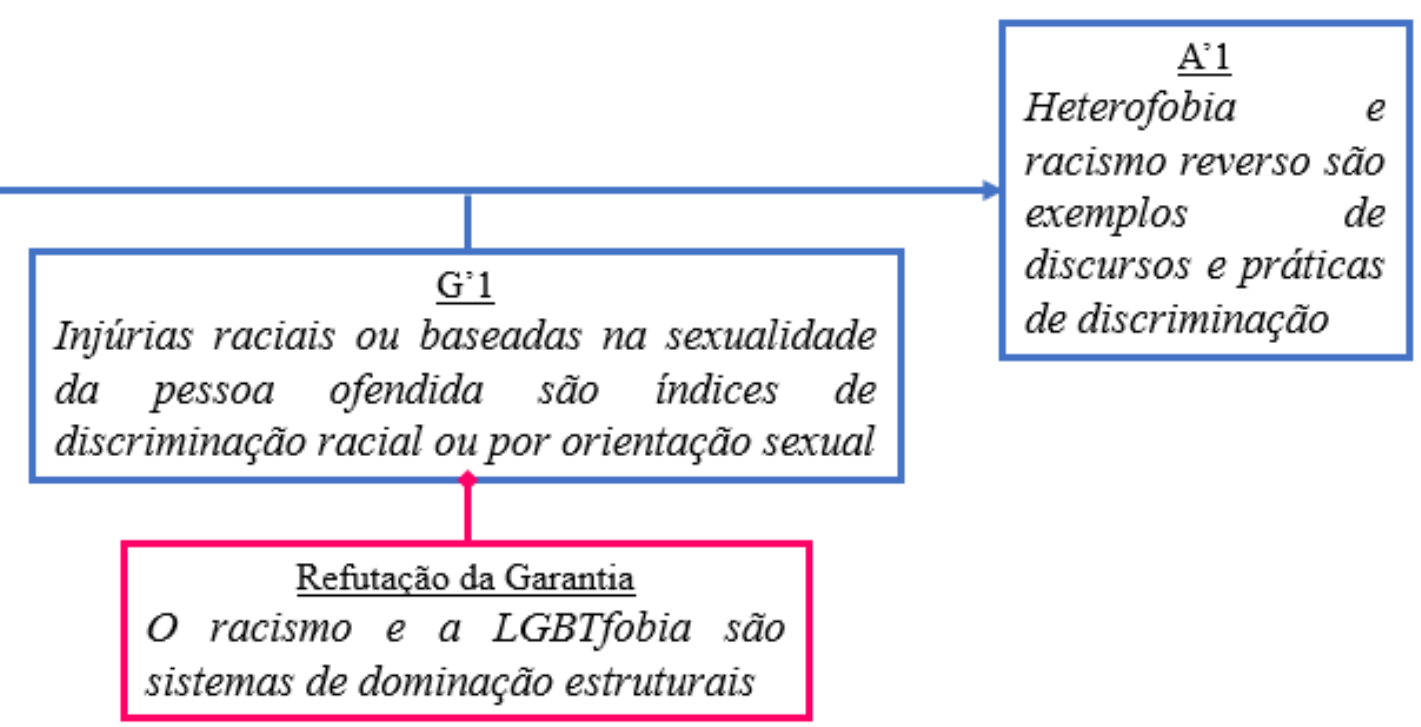

Fonte: elaboração própria 
criminatório dos movimentos negros e LGBT ("não pode mais ser hétero", "você quer dividir o mundo", "eu não tenho culpa do que os meus antepassados te fizeram").

A Garantia (G’1), que permite passar desse conjunto de Dados para a Alegação (A'1), consiste em uma definição de discriminação racial ou por sexualidade que está de acordo com um entendimento do racismo e da LGBTfobia enquanto episódios de discriminação e violência, como eventos ocasionados por crenças e sentimentos pessoais de rejeição ou ódio. Veremos em detalhe na seção seguinte como essa concepção se aproxima de uma visão individualista do racismo, como definido por Almeida (2019).

Essa Garantia (G’1) é refutada por meio de outra definição para o racismo e para a LGBTfobia, que os concebe como sistemas de dominação estruturais. Essa definição aproximase do que Almeida (2019, p. 34) define como racismo enquanto processo, isto é, o racismo se constitui como "um processo em que condições de subalternidade e de privilégio que se distribuem entre grupos raciais se reproduzem nos âmbitos da política, da economia e das relações cotidianas".

Assim, o que é considerado um Dado válido para a categoria racismo, por exemplo, é tensionado, posto que essa definição requisita a consideração da opressão como um fato não apenas episódico ou comportamental, mas que age de forma articulada por meio e através de instituições, como os ambientes educacionais e a polícia, tendo se originado ideologicamente na forma de discursos pseudocientíficos para cumprir objetivos econômicos e políticos.

Essa Refutação da Garantia se mostra central para a estratégia discursiva das youtubers, posto que consiste ela mesma na sua resposta à questão subsidiária "o que é racismo?" e permitirá a elas apresentar sua visão em relação à factualidade das noções de racismo reverso e heterofobia. Ao final do vídeo, Nátaly define o que ela entende como o caráter estrutural do racismo - e, a partir da fala de LouiePonto, infere-se que haveria uma analogia possível entre racismo e LGBTfobia nesse sentido (linhas 95-120). Esse movimento não só embasa a Alegação A1 O racismo e a LGBTfobia são sistemas de dominação estruturais, como também deslegitima a defesa das noções de racismo reverso e heterofobia enquanto opressões comparáveis ao racismo e a LGBTfobia (contribuindo para o fortalecimento do movimento em prol de A2 - A heterofobia e o racismo reverso não são sistemas de dominação estruturais e, consequentemente, não podem ser comparados ao racismo e à LGBTfobia).

Na Figura 16, vemos a estruturação da resposta do Eu-Nós à questão subsidiária “o que é racismo?" e o estabelecimento da analogia entre racismo e LGBTfobia. Trata-se da Alegação (A1) O racismo e a LGBTfobia são sistemas de dominação estruturais, sustentada pelos Dados 
Figura 16 - Layout da Configuração Funcional Epistêmica do Eu no vídeo "HETEROFOBIA E RACISMO REVERSO EXISTEM? | LouiePonto feat. Nátaly Neri”"

Pessoas negras sofrem $\frac{\mathrm{D}^{\mathrm{A}}}{\mathrm{com}}$ perseguição por forças
policiais, discriminação no mercado de trabalho e
em ambientes educacionais por serem reconhecidas
como negras

$\underline{D 1^{\mathrm{B}}}$

Pessoas LGBT sofrem violência física e verbal regularmente por serem reconhecidas como LGBT

\section{$\underline{D 1 C}$}

O racismo e a LGBTfobia são fruto de teorias pseudocientificas que buscavam provar que pessoas brancas e/ou heterossexuais eram superiores a outros pessoas negras e/ou LGBT devido a certas caraterísticas biológicas ou comportamentais

\section{e as}

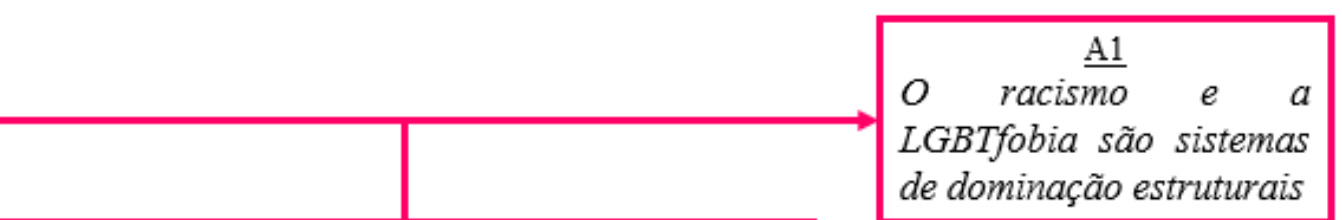

Sistemas de dominação estruturais são caracterizados por discursos oriundos de instituições de poder e se refletem na vida das pessoas dominadas por meio de violências físicas e simbólicas, discriminação direta $e$ indireta, assim como por políticas de genocídio e assassinato em massa

Fonte: elaboração própria. 
D1, que demonstram a recorrência, a pervasividade, o grau e a permanência das violências contra pessoas negras e LGBT. A combinação de tais fatores permite explicar a maior probabilidade de membros dessas populações se encontrarem em uma situação de vulnerabilidade social, por exemplo - o que não é previsto pela outra definição.

Os Dados $\mathrm{D} 1^{\mathrm{A}}$ e $\mathrm{D} 1^{\mathrm{B}}$ apresentados consistem na paráfrase de uma série de estatísticas, títulos de notícias e exemplos utilizados pelas youtubers ao longo do vídeo. D1 ${ }^{\mathrm{c}}$, por sua vez, é uma paráfrase da definição de racismo efetuada por Nátaly, já indicando a analogia em relação à LGBTfobia licenciada por Louie (linhas 95 - 114).

A Garantia (G1), que permite a passagem dos Dados (D1) para a Alegação (A1), é inferida a partir do contraste das noções de racismo/racismo reverso e heterofobia/LGBTfobia realizado pelas youtubers ao longo do vídeo, e atua no sentido de definir o que elas entendem por racismo e LGBTfobia. Ela é instrumentalizada também na defesa de uma segunda Alegação (A2), que consiste, essa sim, na resposta à pergunta-título, como veremos abaixo.

Essa mesma Garantia (agora denominada G2) é o que permite refutar a Alegação’ de que a heterofobia e o racismo reverso constituem um sistema de discriminação comparável à LGBTfobia e ao racismo. Retratamos este movimento na Figura 17, organizando-o em função da Alegação A2. Os Dados D2 (D2 ${ }^{\mathrm{A}}, \mathrm{D} 2^{\mathrm{B}}$ e $\mathrm{D} 2^{\mathrm{C}}$ ) consistem na afirmação de que pessoas brancas/heterossexuais, enquanto grupo, não se encontram em situações comparáveis às expostas pelos exemplos, notícias e estatísticas mencionadas acima. Além disso, a não existência de teorias pseudocientíficas para legitimar sistemas de dominação com base em uma suposta inferioridade de uma raça branca ou na concepção patologizante da heterossexualidade $\left(\mathrm{D} 2^{\mathrm{C}}\right)$ também aparece como sustentação dessa Alegação.

Por fim, ressaltamos que não há, ao longo do vídeo, apresentação de acordos ou concessões de fato à perspectiva do Outro. Por isso, pudemos depreender apenas movimentos de afastamento epistêmico-axiológico. Hipotetizamos que isso se deva ao fato de que se trata de um caso de desacordo profundo. Como não há consenso em relação aos critérios de validação da argumentação, não há possibilidade de intersecção entre os campos epistêmico-axiológicos. Essa questão será explorada com detalhe na análise dos trechos LN1 e LN2 na seção seguinte. 


\section{Figura 17 - Layout da Configuração Funcional Epistêmica do Eu no vídeo "HETEROFOBIA E RACISMO REVERSO EXISTEM? |}

\begin{tabular}{|lrr|}
\hline \multicolumn{4}{|c|}{$\underline{\mathrm{D}}^{\mathrm{A}}$} & & \\
Pessoas brancas & não & sofrem com \\
perseguição por & forças & policiais, \\
discriminação no mercado de trabalho e em \\
ambientes educacionais & por & serem \\
reconhecidas como negras & & \\
\hline
\end{tabular}

$\underline{\mathrm{D} 2^{\mathrm{B}}}$
Pessoas heterossexuais não sofrem violência
fisica e verbal regularmente por serem
reconhecidas como LGBT

\section{$\underline{\mathrm{D} 2}{ }^{\mathrm{C}}$}

Não houve e não há teorias pseudocientíficas que busquem provar que pessoas negras elou LGBT são superiores a pessoas brancas e/ou heterossexuais devido a certas caraterísticas biológicas ou comportamentais
LouiePonto feat. Nátaly Neri" 176

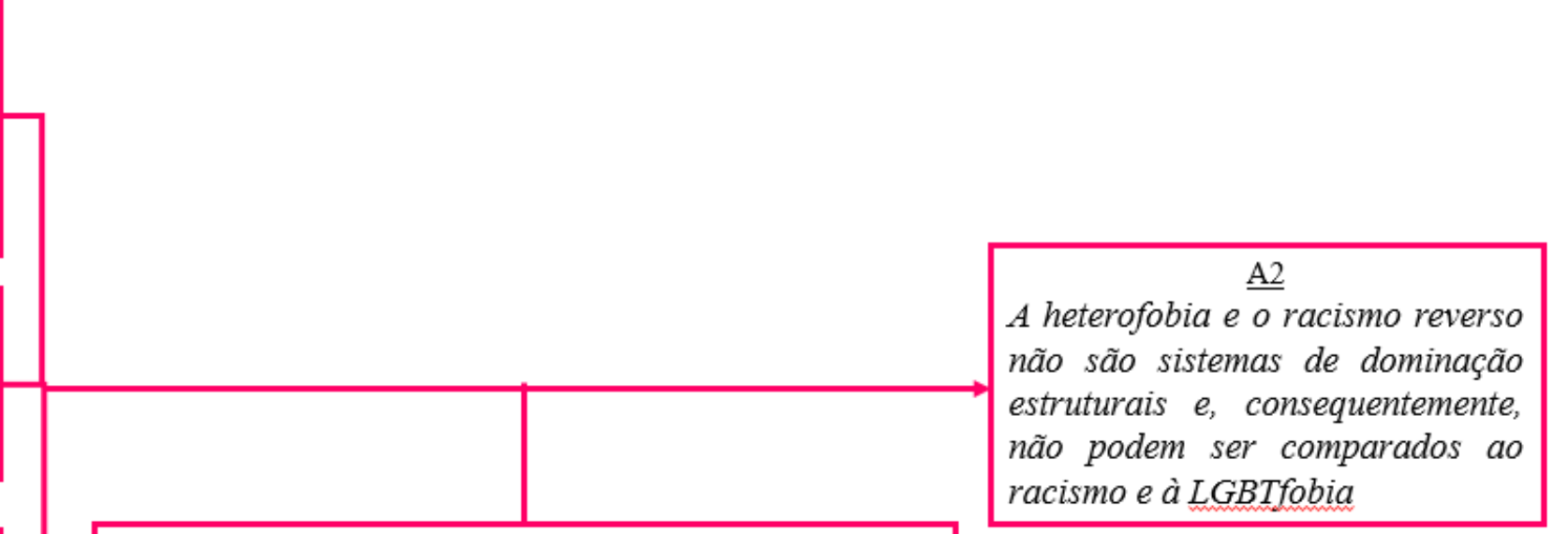

Sistemas de dominação estruturais são caracterizados por discursos oriundos de instituições de poder $e$ se refletem na vida das pessoas dominadas por meio de violências fisicas e simbólicas, discriminação direta $e$ indireta, assim como por políticas de genocídio $e$ assassinato em massa

Fonte: elaboração própria.

${ }^{176}$ A Alegação A2 poderia ser desmembrada em mais um movimento argumentativo, em defesa à Alegação "Heterofobia e racismo reverso não podem ser comparados ao racismo e à LGBTfobia". Entretanto, por essa opção de diagramação não contribuir com os objetivos analíticos do trabalho, optamos por uma versão compacta. 


\section{“RÓTULOS ME LIMITAM OU ME DEFINEM? | Especial Dia do Orgulho}

\section{LGBT $^{177}$ | Louie Ponto"}

O vídeo sob análise nesta seção foi publicado no dia 28 de junho de 2017, data na qual se comemora o Dia do Orgulho LGBT no Brasil e em diversos outros países. Nos dias atuais, a celebração tem se estendido pelo mês de junho, envolvendo eventos como as paradas do orgulho LGBT, realizadas em diversos países ao redor do mundo, além de ações e manifestações de coletivos e organizações em ambientes on e offline ${ }^{178}$.

Nos últimos anos, com o progressivo aumento da presença de figuras públicas LGBT visíveis na política institucional e na mídia, além de publicações e programas voltados para essa parcela da população, têm-se multiplicado as iniciativas de comemoração da data, o que se dá também por meio de campanhas, séries de vídeos, filtros comemorativos etc. Entre essas ações, temos a publicação de conteúdos em plataformas online (blogs, YouTube, Facebook, Instagram, Twitter, dentre outras) voltados para a discussão de diversas temáticas referentes aos movimentos e às culturas LGBT. Em geral, essas postagens compartilham o objetivo de promover discursos de conscientização acerca da das pautas dos movimentos, a celebração de figuras históricas e de produções culturais relevantes, assim como a conscientização a respeito de questões de saúde, segurança e garantia dos direitos humanos a essas populações.

No vídeo analisado, a discussão gira em torno da politização da identidade LGBT, motivada pelo exemplo de uma pesquisa do aplicativo $\operatorname{Her}^{179}$, segundo a qual

[..] o número de mulheres que se definem como lésbicas caiu quase $20 \%$ apenas no ano passado [2014]. Entre as 85 mil mulheres entrevistadas, aumentou de $16 \%$ para $27 \%$ a fatia das que se identificam como "bissexuais". Já o percentual de usuárias que escolhem a classificação 'sem rótulos' pulou de $1 \%$ para $9 \%$. (ÉPOCA, 2015) ${ }^{180}$

A posição assumida por Louie problematiza a posição de muitas mulheres especialmente celebridades e figuras públicas - que se relacionam sexual e afetivamente com

\footnotetext{
${ }^{177}$ Disponível em: 〈https://www.youtube.com/watch?v=p-Dd_ZxH6qI\&ab_channel=LouiePonto〉.

${ }^{178}$ A título de exemplo, citamos as celebrações e manifestações de rua organizadas pelas comunidades LGBT de São Paulo no mês de junho. Dentre elas, destacamos a Parada do Orgulho LGBT de São Paulo, uma das maiores do mundo; a Caminhada de Mulheres Lésbicas e Bissexuais, que se opõe à lesbofobia, à bifobia e à transfobia e que, em 2020, chegaria a sua $18^{a}$ edição (não ocorreu devido à pandemia), e a Marcha do Orgulho Trans, que se iniciou em 2018 e conta com o apoio da Mandata Quilombo de Erica Malunguinho (Deputada Estadual pelo PSOLSP), e a POC CON, feira de quadrinhos e artes gráficas LGBTQ, que se iniciou em 2019.

${ }^{179}$ A pesquisa foi publicada em 2015 com dados referentes a 2014, e o vídeo é de 2017. O aplicativo é intitulado como "Her - Aplicativo para Lésbicas" na Play Store, e se afirma "o maior (e melhor!) app para lésbicas, bissexuais e mulheres gay do mundo". Fonte: <https://play.google.com/store/apps/details?id=com. weareher.her\&hl=pt $>$. Acesso em 14/10/2020.

180 Fonte: https://epoca.globo.com/comportamento/mulheres-que-sentem-atracao-pelo-mesmo-sexo-estaodeixando-de-se-identificar-como-lesbicas-diz-pesquisa-de-aplicativo-17212554. Acesso em: 14/10/2020.
} 
mulheres, mas não assumem uma sexualidade de forma política, isto é, não se reivindicam lésbicas, bissexuais ou pansexuais, por exemplo, e optam por assumir uma identidade "sem rótulos".

Essa questão é abordada por meio de uma argumentação epistêmica, que explora as bases ideológicas deste comportamento, e também por uma argumentação prática, que coloca em pauta a importância da construção de uma identidade LGBT para a conquista de direitos. De forma simplificada, a delimitação das entidades discursivas se coloca da seguinte forma: o Eu corresponde a Louie, mulher cis branca e ativista lésbica; o Nós corresponde ao movimento LGBT em geral ${ }^{181}$, e o Outro consiste em pessoas LGBT "invisíveis", que se reivindicam "sem rótulos". Em termos gerais, o Outro consiste em uma interlocutora lésbica que não é assumida publicamente, não se associa aos territórios e grupos - muito menos é engajada com o movimento. Trata-se de uma mulher que ainda está "no armário" ou que é "discreta".

Nesse sentido, o Outro é parte do Nós, ou melhor, o Outro é instado a fazer parte do Nós. Explicamos: Louie coloca em pauta dois posicionamentos possíveis de pessoas LGBT em relação à expressão de sua sexualidade (ou identidade de gênero). Esses posicionamentos correspondem, no vídeo, a duas Propostas de Ação distintas: "rotule-se" (defendida pelo EuNós) e "não se rotule" (Contra-Proposta de Ação que corresponde ao comportamento atribuído ao Outro). De forma mais ampla, esse posicionamento se traduz em disposições mentais, corporais e sociais mais gerais, que podem ser traduzidas pela noção de "(in)visibilidade" 182 (SANT'ANNA; GUIMARÃES, 2019).

Assim, as Propostas de Ação podem ser descritas de forma mais imediata como "tornese visível" vs. "mantenha-se invisível”, ou "assuma uma identidade LGBT" vs. "mantenha-se sem rótulos" na vida cotidiana. Simultaneamente, está sendo promovida a adesão ao movimento social - que, em termos concretos, poderia traduzir-se na participação em um coletivo lésbico, bissexual, trans ou LGBT, ou ainda em setoriais LGBT de partidos políticos, por exemplo.

De forma mais ampla, essas entidades e seus respectivos posicionamentos estão relacionados à divisão do espaço discursivo entre endogrupo - pessoas LGBT (Eu, Nós e Outro são membros do endogrupo) e aliadas/os de posicionamento progressista, afeitos aos movimentos LGBT e suas manifestações de orgulho (Paradas, manifestações etc.) - e exogrupo - homofóbicos. Assim, embora o Outro compartilhe certas características com o discurso do

181 Tendo em vista o público-alvo do canal de Louie, tomaremos como padrão nesta seção o endereçamento das questões a mulheres lésbicas. Assim, nas análises deste texto, iremos assumir como padrão uma mulher lésbica para exemplificar as discussões e para nos referir ao Outro.

182 Salientamos que essa noção de invisibilidade faz referência às discussões efetuadas no capítulo 1 , e não se resume aos "mecanismos de invisibilização" discutidos por Louie no vídeo. 
Eu-Nós - como a sexualidade e alguns Valores, por exemplo -, Louie irá argumentar que essa entidade está discursivamente afiliada ao exogrupo no que se refere ao tema em debate. Vemos, portanto, que neste caso os campos epistêmico-axiológicos são constituídos tanto pelas Alegações e Propostas de Ação, quanto por traços de identidade. Os diferentes posicionamentos, bem como os pontos de acordo e de tensão dialógica entre a visão de mundo do Eu e do Outro, são sistematizados a seguir por meio da análise da Configuração Funcional Prática que realizaremos nos parágrafos seguintes, com o apoio do layout exposto na Figura 18.

No início do vídeo, Louie se mostra simpática ao desejo por uma sociedade na qual a sexualidade não seja motivação para violências físicas e simbólicas. Veremos que, ao longo do texto, esse desejo se constituirá como um Objetivo comum ao Eu e o Outro, e a discussão a respeito da construção de uma identidade política LGBT se desenvolverá de forma a apresentar a Proposta de Ação de Louie como a estratégia mais eficaz para atingi-lo.

Assim, embora Louie sugira uma percepção comum entre o Eu e o Outro a respeito do preconceito em relação a pessoas LGBT na sociedade brasileira, existe uma diferença na qualificação deste preconceito e de suas consequências em termos subjetivos e sociais. Essa distinção, de caráter central, se deve aos diferentes Valores (Equidade e Igualdade) que orientam cada uma das leituras, posto que cada visão de mundo determinará obstáculos diferentes a serem combatidos para que se atinja o Objetivo comum ${ }^{183}$. Em termos técnicos, são as diferentes leituras do estado de coisas que configuram Circunstâncias Motivadoras diversas.

Iremos, primeiramente, explorar os pontos de tensão dialógica a respeito da leitura do estado de coisas de acordo com o Eu, e, posteriormente, apresentaremos a análise da Configuração Funcional Prática do vídeo como um todo.

Para Louie, as Circunstâncias Motivadoras se relacionam com a estrutura social, o que localiza o debate numa dimensão política - mesmo em seus aspectos subjetivos. Em termos concretos, essa discussão abarca também políticas públicas, os projetos de cura gay e Escola Sem Partido, por exemplo.

\footnotetext{
${ }^{183}$ Essa diferenciação será analisada em detalhe na seção 2.3 nas análises do trecho L3, posto que envolve a consideração dos diferentes entendimentos a respeito do funcionamento da LGBTfobia na sociedade, salientando certas contradições internas ao endogrupo - sobretudo no que se refere à permanência de certos traços discursivocomportamentais homofóbicos, que serão resumidos pela youtuber como "discurso da falsa igualdade", isto é, a crença de que "rotular-se" leva à segregação e, consequentemente, a menos igualdade e integração à sociedade. Trata-se de um caso em que afastamento e aproximação epistêmico-axiológicos estão especialmente imbricados.
} 
Figura 18 - Layout da Configuração Funcional Epistêmica do vídeo "RÓTULOS ME LIMITAM OU ME DEFINEM? | Especial Dia do Orgulho LGBT | Louie Ponto" 184

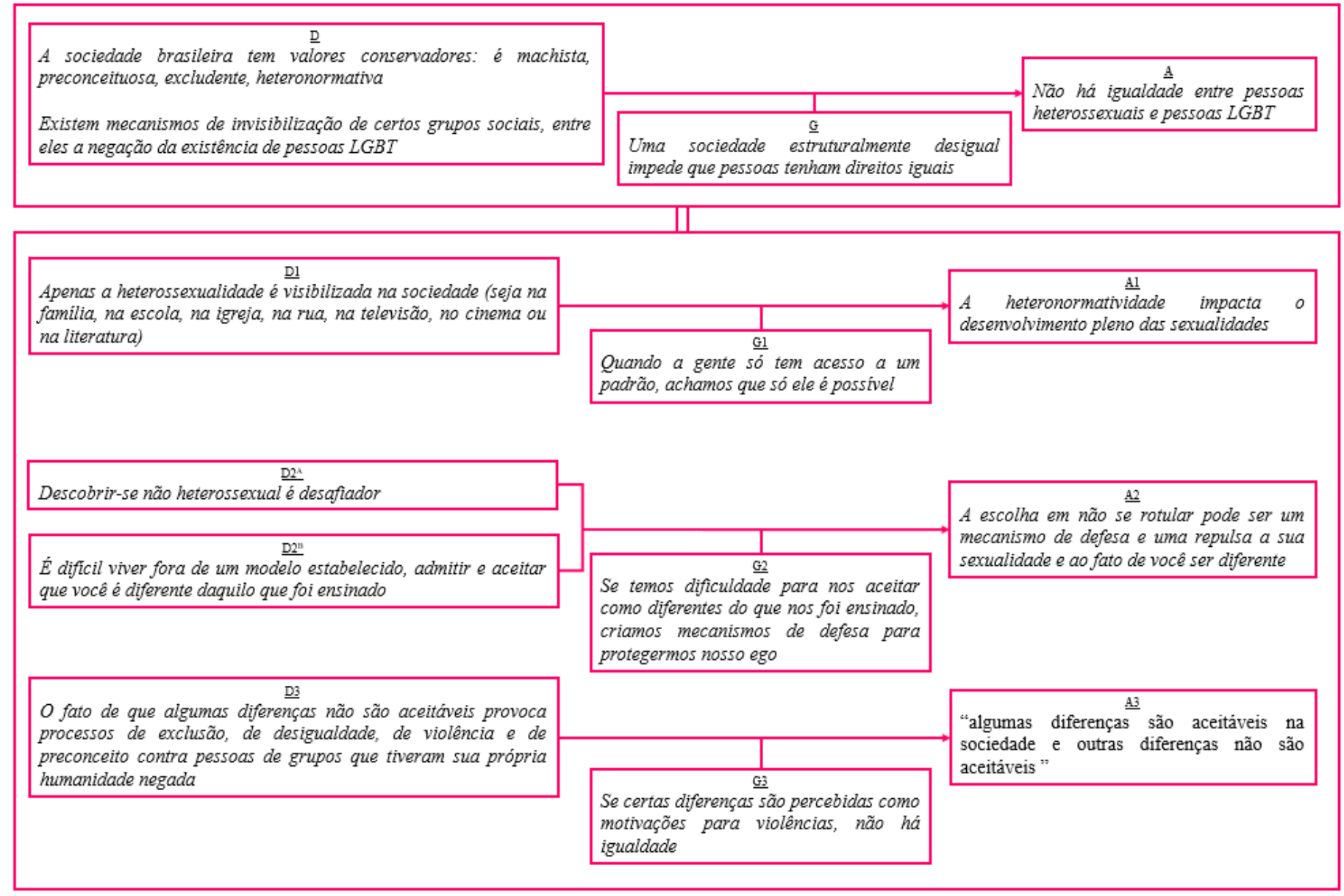

Fonte: elaboração própria.

${ }^{184} \mathrm{O}$ duplo-traço que conecta os conjuntos de layouts marca que o bloco inferior consiste em uma explicação sobre o movimento argumentativo resumido no bloco superior. 
No vídeo, esse movimento argumentativo consiste na explicitação das diferenças entre as leituras do estado de coisas que compõem as Circunstância Motivadoras do Eu e do Outro. Louie parte de um entendimento que projeta como consenso entre ela e o Outro que a sociedade brasileira é machista, preconceituosa e excludente, orientada por valores conservadores. A partir disso, ela explora as diferenças entre a sua leitura e a do Outro, enfocando a origem de cada discurso. Para desenvolver a sua própria perspectiva, ela apresenta as consequências da heteronormatividade e da invisibilização das pessoas LGBT na esfera pública sobre as subjetividades de pessoas não heterossexuais. Assim, enfatiza a dimensão política da invisibilidade como ferramenta de dominação sobre as subjetividades de pessoas não heterossexuais.

Em termos epistêmicos, esses tópicos servirão como Dados ( $\mathrm{D}$ - A sociedade brasileira tem valores conservadores: é machista, preconceituosa, excludente, heteronormativa; Existem mecanismos de invisibilização de certos grupos sociais, entre eles a negação da existência de pessoas $L G B T$ ) para sustentar a Alegação (A - Não há igualdade entre pessoas heterossexuais e pessoas $L G B T$ ) e defender o Valor da Equidade como mais adequado para essa discussão do que o da Igualdade ${ }^{185}$. A Garantia $(\mathrm{G}$ - Uma sociedade estruturalmente desigual impede que pessoas tenham direitos iguais) que permite a passagem de D para A consiste na consideração da heteronormatividade como um modo de organização social que inviabiliza a Igualdade como princípio norteador para interpretar a sociedade brasileira e propor saídas, posto que uma sociedade desigual seria marcada, justamente, pela ausência do valor da Igualdade como fundante das relações sociais e, assim, necessitaria de agendas políticas de reparação para alçar toda a população ao mesmo patamar de direitos ${ }^{186}$.

Nesse sentido, o movimento argumentativo realiza uma refutação externa. Por um lado, colabora para desmobilizar a adesão à Proposta de Ação do Outro (doravante chamada de Contra-Proposta de Ação) - Não se rotular -, posto que visa demonstrar a inadequação dos Valores que a orientam. Por outro, contribui para o fortalecimento de sua própria Proposta, já que apresenta motivações sociais e subjetivas para "sair do armário" e engajar-se no movimento social.

\footnotetext{
185 A Igualdade é compreendida nessa análise como um Valor que preconiza um tratamento igual a todas as pessoas, enquanto a Equidade compreende que seja necessária uma postura que respeite as pessoas considerando as suas diferenças, obtendo, assim, um tratamento capaz de levar a uma situação de fato equânime entre todas as pessoas.

${ }^{186}$ Em última instância, esse Valor é considerado uma marca de cooptação do Outro pelo discurso homofóbico, posto que inviabilizaria a luta contra violências específicas.
} 
No conjunto, há três movimentos argumentativos no segmento explicativo que visa a esclarecer acerca da noção de heteronormatividade e do processo de invisibilização de pessoas LGBT, bem como suas consequências subjetivas para pessoas não heterossexuais. Esses movimentos desenvolvem a relação entre os Dados (D) e a Alegação (A), culminando nas alegações A1 (A socialização é heteronormativa), A2 (A escolha em não se rotular pode ser um mecanismo de defesa e uma repulsa a sua sexualidade e ao fato de você ser diferente) e A3 (“algumas diferenças são aceitáveis na sociedade e outras diferenças não são aceitáveis...”).

$\mathrm{O}$ primeiro movimento explora as consequências da heteronormatividade para o desenvolvimento e compreensão da sexualidade. De acordo com a youtuber, a falta de representatividade LGBT na sociedade se dá tanto por meio do apagamento dessa parcela da população nas narrativas históricas, quanto da sua exclusão ou repressão em diversos espaços ("na família na escola na igreja na rua na televisão no cinema na literatura" - D1). Isso ocasiona a falta de referências para os processos de subjetivação e desenvolvimento das identidades tanto de pessoas heterossexuais quanto não heterossexuais. Dessa forma, pode levá-las a entender que só existe uma forma de expressar sua sexualidade, isto é, relacionando-se com pessoas do gênero oposto (A1 - A heteronormatividade impacta o desenvolvimento pleno das sexualidades) - pressupondo também um binarismo de gênero. A Garantia (G1 - Quando a gente só tem acesso a um padrão, achamos que só ele é possível) deste raciocínio não é explicitada no texto, mas parece estar apoiada numa compreensão de que os processos subjetivos de desenvolvimento da sexualidade também se ancoram na experiência discursiva do ator social.

Nesse contexto, os processos de descoberta da própria sexualidade (D2 ${ }^{\mathrm{A}}$ - Descobrirse não heterossexual é desafiador) e do reconhecimento da mesma como "fora do padrão" (D2 ${ }^{\mathrm{B}}$ - É difícil viver fora de um modelo estabelecido, admitir e aceitar que você é diferente daquilo que foi ensinado) são marcados por dificuldade e sofrimento, o que seria capaz de produzir um sentimento de auto-ódio, comum em situações de trauma e repressão (G2 - Se temos dificuldade para nos aceitar como diferentes do que nos foi ensinado, criamos mecanismos de defesa para protegermos nosso ego), que se manifesta pela negação ou repulsa à própria sexualidade (A2 - A escolha em não se rotular pode ser um mecanismo de defesa e uma repulsa a sua sexualidade e ao fato de você ser diferente).

Esse processo de invisibilização e marginalização também é apontado como causa das violências físicas e simbólicas às quais estes grupos muitas vezes são submetidos', tendo em vista que uma sociedade que hierarquiza as pessoas como base em, entre outras coisas, sua 
sexualidade permite que certas pessoas sejam consideradas "menos humanas" (D3 - O fato de que algumas diferenças não são aceitáveis provoca processos de exclusão, de desigualdade, de violência e de preconceito contra pessoas de grupos que tiveram sua própria humanidade negada), autorizando assim a vigilância constante e a violência contra as mesmas (G3 - Se certas diferenças são percebidas como motivações para violências, não há igualdade). Esse terceiro movimento de fato culmina na Refutação da Alegação' (“a gente é tudo igual”), posto que, em uma sociedade em que a violência contra certos grupos é autorizada, não se pode falar em igualdade de forma abstrata.

Esse movimento será analisado com mais detalhe na seção seguinte no que se refere aos movimentos de afastamento axiológico no trecho L1. Quanto aos movimentos de aproximação epistêmico-axiológica, discutiremos a construção de um Objetivo comum ao Eu-Nós e ao Outro nas análises do trecho L2.

A síntese das relações entre os elementos da argumentação prática empreendida em resposta ao problema prático qual comportamento em relação à sexualidade levaria a uma sociedade na qual a sexualidade não é motivação para violências físicas e simbólicas? é apresentada na página seguinte.

Para superar esse estado de coisas e alcançar o referido Objetivo comum (Viver em uma sociedade na qual a sexualidade não seja motivação para violências físicas e simbólicas, na qual não seja necessário dar satisfação para ninguém), Louie apresenta como Proposta de Ação Rotular-se ( "Sair do armário" e Engajar-se no movimento LGBT). O embasamento desta Proposta, assim como o da Contra-Proposta de Ação atribuída ao Outro e a relação entre elas, está resumido no layout da Figura 18, a seguir.

No discurso do Eu-Nós, "Rotular-se", isto é, "sair do armário" e engajar-se com o movimento seriam maneiras de agir contra a heteronormatividade e a LGBTfobia de forma eficaz. A efetividade dessa Proposta de Ação se apoia no entendimento de que, tanto no passado quanto no presente, Assumir-se LGBT de forma visível (combater a invisibilização) e lutar pelos seus direitos (combater violências físicas e simbólicas) levará a uma sociedade na qual a sexualidade não é motivação para violências físicas e simbólicas (Meio-Fim).

Em contrapartida, a Contra-Proposta de Ação, atribuída ao Outro, consiste em Não se rotular (não "dar satisfação" sobre a sua sexualidade) e está embasada no entendimento de que Não se assumir abertamente retira a motivação para o preconceito, violências físicas e simbólicas (Meio-Fim). Vemos, portanto, que estão em jogo concepções bastante distintas a respeito do funcionamento da LGBTfobia (como já discutido anteriormente). 
Figura 19 - Layout da Configuração Funcional Prática do vídeo "RÓTULOS ME LIMITAM OU ME DEFINEM? | Especial Dia do Orgulho LGBT | Louie Ponto"

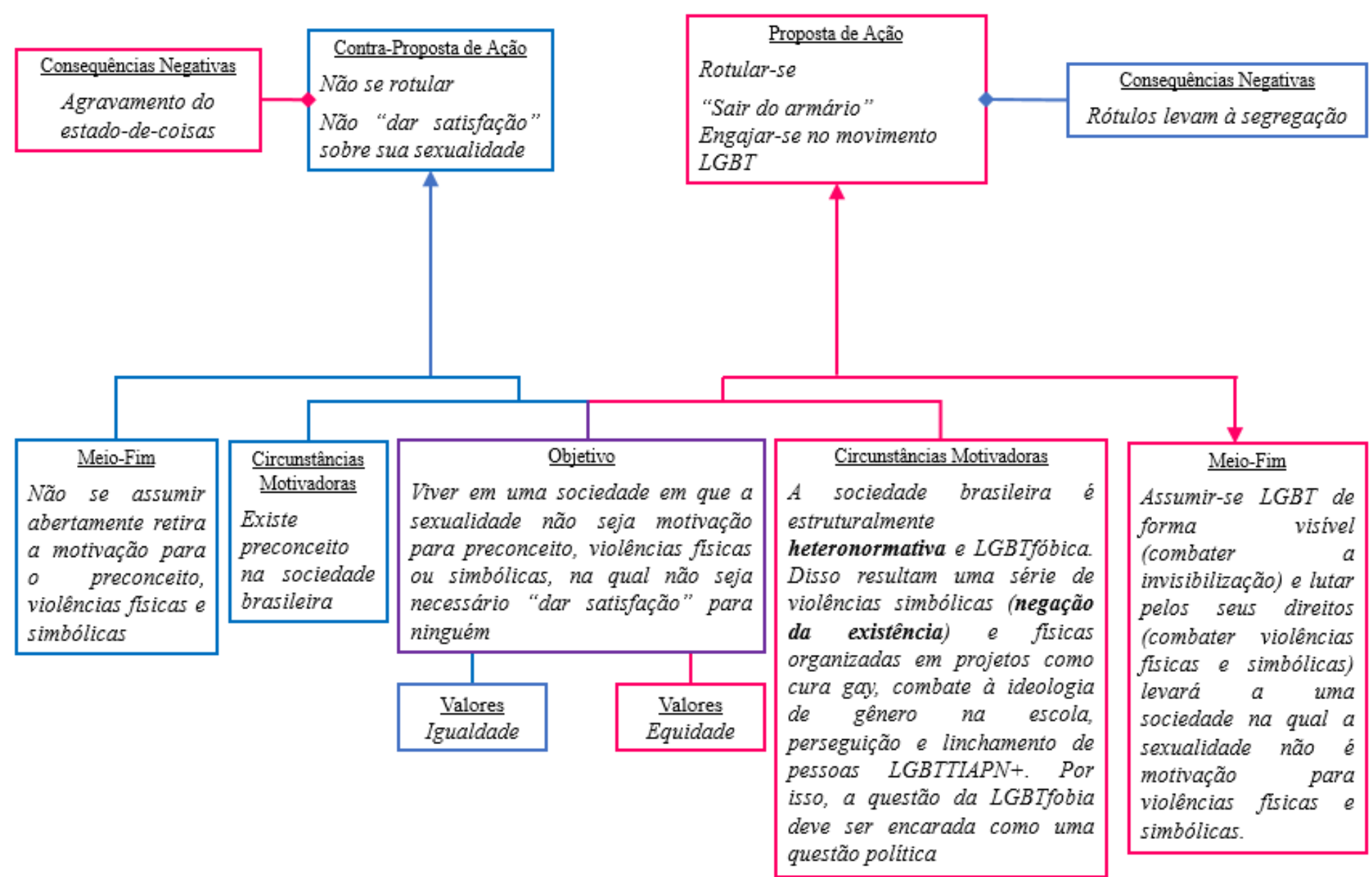

Fonte: elaboração própria. 
Como forma de colocar em jogo o potencial beneficiamento de cada Proposta de Ação, a youtuber apresenta Consequências Negativas relacionadas à sua Proposta quanto à ContraProposta. Ela trata essa Contra-Proposta como decorrente da cooptação do Outro pelo discurso homofóbico. Esta é não apenas considerada ineficaz para solucionar o problema: seria também capaz de agravar a situação atual. Optando pela invisibilidade e incapacitadas de lutar contra violências específicas pela amarra do "discurso da falsa igualdade", ocorreria a manutenção do sistema de exclusão.

Por outro lado, Louie faz referência à possibilidade de os "rótulos" levarem à segregação (talvez isso faça referência à criação de espaços predominantemente ou exclusivamente LGBT, como festas, coletivos e outros espaços de sociabilidade), mas não se aprofunda na refutação deste ponto em específico, considerado pouco relevante frente aos benefícios que adviriam desta Proposta.

Finalizamos aqui a seção 1, na qual discutimos a Movimentação Epistêmico-Axiológica a partir de uma perspectiva macro, estática, dos textos. A seguir, passaremos para as análises de nível micro do mapeamento dos movimentos de aproximação/afastamento epistêmicoaxiológico.

\subsection{Análise dos movimentos de afastamento e aproximação epistêmico-axiológicos}

Nas subseções a seguir, realizaremos as análises de movimentos de aproximação e afastamento epistêmico-axiológicos em trechos selecionados. Os trechos analisados serão apresentados de acordo com a ordem cronológica externa e interna aos vídeos, assim como na seção 1. Ao introduzi-los, realizaremos uma breve contextualização a respeito da divisão do espaço discursivo do vídeo em questão, recuperando as discussões da seção anterior, e de que modo o trecho se insere na respectiva estratégia discursiva.

A isso se seguirão as análises de AVALIATIVIDADE (em especial ENGAJAMENTO, JULGAMENTO e AFETO), que terão como objetivo discutir como os pontos de tensão dialógica são geridos textualmente. A partir disso, depreenderemos os das construções de fronteiras e regiões de proximidade epistêmico-axiológica sobre as relações de complementariedade, alternatividade e oposição entre os elementos argumentativos (sobretudo Alegações e Propostas de Ação), bem como sobre as relações de solidariedade, de neutralidade e de antagonismo sugeridas entre as comunidades discursivas.

Ressaltamos que as análises realizadas nesta seção não se pretendem exaustivas e visam à discussão da variedade de formas linguístico-textuais por meio das quais as operações de 
aproximação e afastamento epistêmico-axiológico se articulam às estratégias discursivas dos vídeos selecionados. Temos certeza de que análises mais abrangentes acerca dessas operações no decorrer da argumentação de cada um dos vídeos seriam uma grande contribuição para o entendimento de sua função na organização textual. No entanto, o interesse desta pesquisa foi investigar a diversidade das formas e efeitos das operações de Movimentação EpistêmicoAxiológica em relação ao mapeamento do Espaço Discursivo. Assim, mostrou-se mais relevante trabalhar com trechos selecionados de uma variedade de textos em vez de nos debruçarmos de forma exaustiva sobre um ou dois vídeos.

\subsubsection{Movimentos de afastamento epistêmico-axiológico}

Como apresentado no capítulo anterior, os movimentos de afastamento epistêmicoaxiológico consistem na explicitação da distância epistêmico-axiológica, isto é, na apresentação daquilo que é entendido pelas vozes autorais como diferenças entre os valores (distância axiológica) e pontos de vista (distância epistêmica) do Eu-Nós e o do Outro. Em suma, consistem em comparações entre visões de mundo e perspectivas em relação a um determinado problema epistêmico ou prático que visam a explicitar as principais diferenças entre determinadas comunidades discursivas a partir do ponto de vista da voz autoral.

Nesse sentido, os objetivos da MEA consistem em delimitar os princípios e parâmetros que delineiam as fronteiras entre campos epistêmico-axiológicos de acordo com as vozes autorais, seja por meio da apresentação dos traços discursivos do exogrupo presentes nos movimentos argumentativos atribuídos ao Outro (estereótipos e mitos sociais, por exemplo), seja por meio da refutação interna ou externa dos movimentos argumentativos endereçados às Alegações e Propostas de Ação do Outro.

Em termos de sua participação na estrutura argumentativa, agem tanto na refutação externa, quanto da refutação interna. Neste caso, participam na explicitação de distinções entre as Garantias concorrentes (como será visto nos trechos N1-N4, LN1 e LN2), e atingem as Alegações que compõem a leitura das Circunstâncias Motivadoras (NL1 e NL2), assim como os Valores que embasam Propostas de Ação (L1).

A partir dessas análises, efetuaremos interpretações a respeito do uso das operações de afastamento axiológico em termos das estratégias discursivas de cada vídeo e de sua função para i) a inserção das youtubers nos debates e polêmicas dos ativismos progressistas a partir de uma perspectiva feminista, e ii) a legitimação dos ativismos digitais como lócus de atuação 
possível. Verificaremos, assim, de que forma essas fronteiras contribuem para o fortalecimento de certas identidades, filiações discursivas e posições epistêmico-axiológicas.

Passemos, agora, à descrição, análise e interpretação dos trechos.

Iniciamos com quatro trechos (N1-N4) retirados do vídeo "POR QUE VOCÊ É TÃO AGRESSIVA, NÁTALY?”. Neste vídeo, Nátaly joga luz sobre a questão do policiamento de tom e das políticas de silenciamento sobre as denúncias de mulheres negras. Isso é realizado por meio de uma complexa estratégia de reenquadramento argumentativo, que parte da pergunta “por que você é tão agressiva, Nátaly?" para desvelar os estereótipos e mitos sociais que subjazem a ela.

Esse reenquadramento é realizado em três etapas, por meio das quais Nátaly refuta o estereótipo da mulher negra raivosa ${ }^{187}$, explicitando seu caráter racista, e apresenta uma imagem autodefinida de si de forma articulada a perspectivas feministas negras (conformando um Nós, mulheres negras). Solucionada a questão superficial, ela se volta para a discussão da questão argumentativa de fundo: "por que você me acha tão agressiva?", por meio da qual apresenta uma Proposta de Ação para o Outro se aliar no combate às políticas de silenciamento.

Neste vídeo, o espaço discursivo é dividido entre endogrupo e exogrupo a partir da filiação a um discurso antirracista ou racista, respectivamente. De acordo com os comentários reproduzidos por Nátaly no início do vídeo ${ }^{188}$ (transcritos entre as linhas 6 e 14 do anexo 1), o Outro se projeta no espaço do endogrupo, identificando-se como antirracista na medida em que "elogia" o conteúdo produzido por Nátaly e demonstra-se "preocupada/o" com o seu alcance. No entanto, seu enunciado é caracterizado por traços discursivos do exogrupo, nomeadamente o estereótipo da mulher negra raivosa, que orienta a sua percepção a respeito de Nátaly.

Em termos da Configuração Funcional Epistêmica ${ }^{189}$, como vimos na seção 1.1, esse estereótipo consiste na Garantia (Mulheres negras são naturalmente agressivas) que embasa a Contra-Alegação do Outro (Nátaly Neri é agressiva). Tais elementos são construídos por meio

\footnotetext{
${ }^{187}$ Para mais informações sobre o estereótipo da "Sapphire" ou "Angry Black Woman, ver a pesquisa de Suzane Jardim e Francisco Izzo a respeito dos estereótipos racistas internacionais, repostada também no Portal Geledés. Fonte: $\quad<$ https://medium.com/@ suzanejardim/alguns-estere\%C3\%B3tipos-racistas-internacionaisc7c7bfe3dbf6\#.t5intpfxa>. Acesso em 01/07/2020

${ }^{188}$ Os comentários referidos estão transcritos a seguir: "Nátaly... desse jeito que você fala você não vai conseguir alcançar ninGUÉM... Nátaly... a discussão até que tá boa mas você podia ter sido menos agresSIva... por que que essa menina é TÃO agressiva? ninguém vai entenDER o que ela fala assim... como que você tenta lutar pela igualdade com MAIS Ódio? NÁtaly o seu tom de voz é muito arroGANte... você podia usar menos ironias isso deixa a sua fala MUIto agresSIva... nossa eu adoro a Nátaly Neri mas eu acho ela muito brava tenho medo de me aproximar... meu DEus aquela menina é Ótima mas ela podia ser um pouquinho menos agressiva... eu acho que ela ia alcançar mais gente assim...”.

${ }^{189} \mathrm{O}$ movimento argumentativo está sintetizado na Figura 8 na página 163.
} 
de representações negativas (ligadas à violência e falta de cordialidade) de um grupo social (mulheres negras) e de uma pessoa (Nátaly Neri), membro deste grupo.

A imagem autodefinida da youtuber, por sua vez, é conformada por meio de uma autoavaliação composta por julgamentos positivos atrelados à cordialidade e à competência, que se constituem como Dados para as suas próprias Alegações (Nátaly Neri não é agressiva; Nátaly Neri não é arrogante) e se contrapõem diretamente às imagens de arrogância e agressividade construídas pelo Outro ${ }^{190}$.

Assim, embora a youtuber reconheça a autoprojeção do Outro no campo epistêmicoaxiológico progressista (endogrupo), ela se opõe a esse mapeamento ao explicitar sua subordinação ao campo epistêmico-axiológico do exogrupo. Isso é realizado por meio da denúncia do caráter racista de seus comentários. Dessa forma, ela joga foco sobre aquilo que considera ser o real problema na polêmica sobre a sua suposta agressividade.

$\mathrm{O}$ trecho N1 apresentado abaixo faz parte da primeira parte do movimento de afastamento epistêmico-axiológico e constitui a apresentação do estereótipo da mulher negra raivosa. Para descrever o estereótipo e o seu funcionamento social, Nátaly constrói uma mulher negra "virtual" e os julgamentos que recaem sobre ela.

De acordo com ela, esse estereótipo tem raízes discursivas na ideologia da supremacia racial, da qual fazem parte outros estereótipos que visam ao controle da representação de mulheres negras: a "mulata exportação" e a "Tia Anastácia”. Neste vídeo, ela realiza uma leitura dos estereótipos voltados à manutenção dos papéis sociais na sociedade hierarquizada por gênero e raça (NASCIMENTO, 2019a [2006]; 2019b), que são utilizados não só para atacar a sua imagem enquanto comunicadora, mas também como uma força de dominação simbólica, uma vez que afetariam mulheres negras brasileiras em geral.

Essa leitura também será utilizada mais à frente para impulsionar uma representação própria, que desafia os estereótipos e os papéis que lhe são impostos, criando, dessa forma, uma imagem autodefinida de si por meio do processo de autoavaliação (COLLINS, 2019; BUENO, 2020). Veremos ainda de que forma esse processo contribui para a criação de laços de solidariedade e de antagonismo em relação a diferentes grupos sociais e comunidades epistêmicas.

Passemos agora à leitura de N1, em que Nátaly descreve os conteúdos do estereótipo.

N1) N o terceiro estereótipo e objeto desse VÍdeo é a mulher negra raivosa... The Angry Black Woman... que é justamente a ideia de uma mulher negra que quando reclama de todos esses outros estereótipos sobre a sua realidade que é racista que é

${ }^{190}$ O movimento argumentativo está sintetizado na Figura 9 na página 165. 
miSÓgina é tida como LOUca... é tida como alguém que... não sabe o que FAla... que fala porque passa muita RAIva porque vive muitas coisas e porque é NAturalmente zangada é NAturalmente brava é NAturalmente descontroLAda e também tá muito próxima à animaliDAde à falta de domínio de SI do seu CORpo da sua fala e dos seus pensamentos... então é aquela mulher negra que fala muito ALto é aquela mulher negra que já chama por barRAco é aquela mulher negra que usa o dedinho nos filmes americanos

Iniciamos as análises pela observação dos mecanismos de ENGAJAMENTO utilizados por Nátaly para estabelecer um laço de solidariedade com uma mulher negra "virtual" (des)construída por meio da análise do estereótipo ${ }^{191}$. Essa (des)construção se realiza por meio da expansão dialógica: atribuição: reconhecimento, que indica não apenas o reconhecimento da tensão dialógica subjacente a respeito da representação dessa mulher e de sua visão de mundo ("uma mulher negra que quando reclama de todos esses outros estereótipos sobre a sua realidade"), como também demonstra o alinhamento da youtuber a uma perspectiva específica: "que é racista que é miSÓgina". Nesse caso, o alinhamento à perspectiva dessa mulher negra é realizado por meio do parentético acerca de sua "realidade", “que é [racista, misógina]", legitimando as "denúncias" dessa mulher virtual.

O laço de solidariedade é, portanto, constituído por meio da exposição de uma concordância discursiva, da projeção de uma região axiológica comum ${ }^{192}$, apresentando o discurso encampado pelo Eu, Nátaly. Dessa forma, ela começa a povoar o espaço discursivo, que anteriormente era composto apenas pelo Eu e pelo Outro, que ocupava um lugar antagônico em relação a ela. Com o estabelecimento do campo epistêmico-axiológico a partir do qual ela irá argumentar - que entende que a realidade é, de fato, racista e misógina -, ela discute a imagem construída da mulher negra raivosa por meio do estereótipo em duas etapas.

A primeira etapa de apresentação da imagem estereotipada da mulher negra raivosa retoma os julgamentos utilizados nas representações estereotipadas por meio do mecanismo de expansão dialógica: atribuição: distanciamento: "é tida como LOUca... é tida como alguém que... não sabe o que FAla... que fala porque passa muita RAIva porque vive muitas coisas". Neste trecho, a expressão "é tida como", pelo contágio avaliativo (MARTIN; WHITE, 2005)

\footnotetext{
191 “(Des)construída", pois ela é, ao mesmo tempo, discursivamente evocada para exemplificar o funcionamento do estereótipo e para apontar as incongruências do mesmo em relação à realidade.

192 Isso não se configura como uma instância de aproximação epistêmico-axiológica, pois nosso foco aqui é verificar as intersecções e divisões construídas entre oos campos do Eu e do Outro construídos textualmente neste vídeo. Entendemos que, aqui, essa "mulher negra "virtual"” está aliada ao Eu-Nós. Seria de grande interesse, no entanto, uma pesquisa que se debruçasse sobre os mecanismos de perspectivação conceptual e de movimentação epistêmico-axiológica, em particular, utilizados para a construção do Eu-Nós e de laços de solidariedade intragrupais.
} 
do trecho anterior, é utilizada para mostrar o contraste entre realidade e a heterorrepresentação (a visão atribuída ao Outro). Dessa heterorrepresentação participam os julgamentos negativos de capacidade ("LOUca", "não sabe o que FAla") e de capacidade/tenacidade ${ }^{193}$ : subjugação (“que fala porque passa muita RAIva porque vive muitas coisas").

O segundo movimento aprofunda esse contraste e começa a discutir o processo de naturalização desses julgamentos: "e porque é NAturalmente zangada é NAturalmente brava" (julgamentos negativos de cordialidade), "é NAturalmente descontrolada" (julgamentos negativos de capacidade: competência), "e também tá muito próxima à animaliDAde à falta de domínio de SI do seu CORpo da sua fala e dos seus pensamentos..." (julgamentos negativos combinados de capacidade: competência e de humanidade). A isso ela conecta uma corporalidade estereotipada: “então é aquela mulher negra que fala muito ALto é aquela mulher negra que já chama por barRAco", que invoca, por sua vez, julgamentos negativos de cordialidade ("que fala muito Alto") e de propriedade: violência ("já chama pro barRAco"). E, por fim, por meio da referência "aquela mulher negra que usa o dedinho nos filmes americanos", orientada para recrutar elementos da experiência compartilhada entre a youtuber e seu público a respeito da representação de mulheres negras na indústria hollywoodiana, traz-se à consciência exemplos de obras baseadas neste estereótipo, comprovando sua existência e pervasividade na cultura pop.

Em ambos os movimentos, a figura da mulher negra é afetivamente construída de forma negativa. Ela é caracterizada pela "raiva", por estar sempre "zangada" e "brava", de forma que isso parece constituir não só sua personalidade, mas sua própria natureza. Trata-se de afetos negativos de insatisfação de ordem interna (estados mentais) que podem motivar manifestações para e extralinguísticas - como "falar muito alto", "falar coisas sem sentido" e "chamar para o barraco". O estímulo emocional, embora esteja localizado no eixo realis como algo que já aconteceu, é tão difuso ("porque vive muitas coisas"), que passa a ser considerado um humor corrente e com direcionamento indistinto de altíssima intensidade e intrínseco ("NAturalmente brava", "NAturalmente descontroLAda", "NAturalmente zangada"). Em suma, trata-se de uma condição mental de descontrole psicológico total que incorre em severa

193 Como indicamos no capítulo anterior, utilizamos nesta dissertação uma grade para a análise dos julgamentos que inclui uma categoria híbrida entre a capacidade e a tenacidade para dar conta do grau de subjugação (autônomo $\leftrightarrow$ controlado) atribuído a uma pessoa. Consideramos que essa categoria seja híbrida, pois implica não apenas uma falta de obstinação (aspecto de personalidade) para reagir a uma opressão, mas também uma falta de capacidade para fazê-lo (seja força física, técnica ou intelectual). Propusemos essa categoria, porque se mostrou necessária para dar conta dos aspectos envolvidos na naturalização da subjugação de seres humanos e grupos sociais com base em supostos atributos físicos ou psíquicos, estratégia bastante pervasiva entre as ideologias misóginas, racistas e heteronormativas. 
desumanização (“tá muito próxima à animaliDAde à falta de domínio de SI do seu CORpo da sua fala e dos seus pensamentos...”).

Vemos, então, que o estereótipo da mulher negra raivosa envolve julgamentos negativos de cordialidade, de capacidade: competência, de capacidade/tenacidade: subjugação, tenacidade: obstinação e de propriedade: violência, culminando nos julgamentos negativos de humanidade. Dessa forma, Nátaly atribui ao exogrupo a construção de uma imagem sobre mulheres negras profundamente desumanizada, incapacitada para a interação social e para o diálogo racional.

Em contrapartida, isso invoca um julgamento negativo de propriedade: justiça (racista) que recai indiretamente sobre o Outro enquanto comunidade discursiva. Em outras palavras, o Outro é considerado racista devido ao seu comportamento discursivo. Esse julgamento será progressivamente explicitado ao longo do texto, e os desdobramentos desse movimento de delimitação de fronteiras entre os campos epistêmico-axiológicos terão um papel importante para o reenquadramento da questão argumentativa.

Ademais, a descrição dos estereótipos atua não apenas para definir o campo epistêmicoaxiológico do Outro, como também para delimitar, por oposição, o campo epistêmicoaxiológico do Eu e as comunidades discursivas ligadas a ele. Essa proximidade será construída, simultaneamente, por meio da explicitação de acordos epistêmicos (pontos de vista, Alegações, Propostas de Ação) e axiológicos (Valores comuns), como também a uma semelhança psicossocial, que se deve às experiências compartilhadas. Todos esses elementos participam da constituição da entidade discursiva Nós, que faz referência à comunidade discursiva de mulheres negras antirracistas, ligada ao combate de políticas de silenciamento a partir de uma perspectiva racial crítica.

Por acordos epistêmicos, entendemos o compartilhamento de pressupostos teóricos (característica comum de comunidades discursivas) e consensos na avaliação da conjuntura, nomeadamente o consenso de que há estereótipos específicos sobre mulheres negras que estão articulados a um discurso racista cujas origens remontam ao projeto político-econômico da invasão dos territórios de África e das Américas.

Quanto às semelhanças psicossociais, Nátaly projeta que ser representada a partir desses estereótipos é uma experiência compartilhada pelas mulheres negras em geral (“e todas nós mulheres negras estamos sujeitas a termos esses estereótipos ou permanentemente em nossas vidas ou passando vez ou outra...”). Dessa forma, o centro dêitico do endogrupo é constituído 
por um Eu-Nós que engloba não apenas Nátaly e as mulheres negras que a seguem, mas, potencialmente, todas as mulheres negras brasileiras.

Assim, ela realiza uma ponte entre a "teoria" e as experiências coletivas/coletivizadas, para então aprofundar a discussão com base em suas próprias experiências pessoais (“o estereótipo da mulata exportação é permanente na minha vida... me persegue desde que eu era uma criança e continua até hoje...") e como ativista ("o outro estereótipo que é o da mulher negra raivosa aparece em momentos muito específicos pra mim... quando por exemplo eu tô falando sobre racismo..."), focalizando a associação entre o estereótipo da mulher negra raivosa e sua experiência como youtuber e ativista. Dessa forma, ela reforça também a atribuição da característica racista ao discurso e à imagem do Outro.

Esse processo é importante para a sedimentação da legitimidade de sua fala enquanto mulher negra intelectual e ativista, que constrói e compartilha conhecimento não apenas sobre si e suas experiências, mas também sobre a vida social brasileira. Essa legitimidade é construída de duas formas: ela se processa tanto pela humanização de Nátaly - o que inclui a apresentação de experiências pessoais e gostos particulares, associados a um universo lúdico e "leve", que podem inclusive gerar uma identificação com o seu público-alvo primário, adolescentes e jovens adultas ${ }^{194}$-, como também pela reivindicação da raiva e da indignação como reações apropriadas em relação à situação de marginalização e opressão da população negra. Isso é efetivado, entre outras estratégias, por meio da referência ao slam "Angry Black Woman", de Porsha Olayiwola, apresentado nas finais do Individual World Poetry Slam de $2014^{195}$ e às referências aos artigos citados na seção de descrição.

Como apontamos anteriormente, ao longo do vídeo, esses aspectos participarão do processo de autoavaliação de si que se contrapõe ao estereótipo descrito no trecho N1. No trecho N2 (linhas 97 - 111), temos um exemplo da construção dessa imagem, que participa da delineação do campo epistêmico-axiológico da youtuber e da explicitação de suas diferenças em relação ao campo epistêmico-axiológico do Outro.

N2) N eu geralmente não estou nervosa galera... geralmente... eu só tô articulando os meus pensamentos... geralmente eu faço os meus vídeos... tem alguns vídeos que me doem mais tem alguns vídeos que eu falo... no alto de algum sentimento de

\footnotetext{
${ }^{194}$ Trata-se da importância do compartilhamento de histórias e perspectivas pessoais têm de gerar identificação e contribuir para a criação de uma identidade coletiva que trabalhamos nos capítulos 1 e 2 .

${ }^{195}$ O slam é mencionado por Nátaly no vídeo (linhas 86-89) e o link para uma gravação legendada da apresentação está relacionada na descrição do vídeo. Reproduzimos o link a seguir e orientamos as/os leitoras/os a assistiremno: https://www.youtube.com/watch?v=iiPiJ_Ge50s. Optamos por não nos aprofundarmos nas relações de intertextualidade entre os vídeos, embora julguemos que uma investigação nesse sentido se mostraria bastante profícua não apenas para a consideração das estratégias utilizadas neste vídeo como um todo, como tambémpara o entendimento acerca da construção de redes e referências entre ativistas e artistas negras na diáspora.
} 
inquietaÇÃO e de... desconforto com alguns temas mas na maioria dos meus vídeos eu tô Nátaly Neri falando sobre as minhas questões mobilizando os meus conhecimentos

Para construir sua imagem, ela realiza uma contração dialógica: refutação: negação “eu geralmente não estou nervosa galera", seguida de uma sequência de dois casos de contração dialógica: declaração: pronunciamento ("eu só tô articulando os meus pensamentos", "tem alguns vídeos que me doem mais tem alguns vídeos que eu falo... no alto de algum sentimento de inquietaÇÃO e de... desconforto com alguns temas") e uma contração dialógica: refutação: contraexpectativa ("mas na maioria dos meus vídeos eu tô Nátaly Neri falando sobre as minhas questões mobilizando os meus conhecimentos").

Por meio da negação, do pronunciamento e dessa contraexpectativa, ela redefine os afetos envolvidos no processo de produção de seus vídeos: ao invés de "estar nervosa", ela estaria tomada por um "sentimento de inquietação" e "desconforto", sobretudo nos "vídeos que me doem mais". Ao invés de um humor corrente, trata-se de afetos negativos de insegurança de ordem interna (sensações e estados mentais) pontuais e de intensidade variável ("tem alguns vídeos que me doem mais", "tem alguns vídeos que eu falo... no alto de algum sentimento de inquietaÇÃO e de... desconforto com alguns temas"). Com isso, ela reconceptualiza possíveis manifestações paralinguísticas, por exemplo o uso de determinado tom de voz ou expressão corporal, como reações naturais aos estímulos, situações e questões que envolvem dor, perda e injustiça - e não como sinais de uma "natureza" irracional e descontrolada. De modo geral, tais estímulos estão localizado no eixo realis como situações que já aconteceram e consistem em temas ou episódios narrados sobre pessoas ou estruturas institucionais racistas que atuam como gatilhos para os sentimentos descritos.

Além disso, como apontado acima, esses afetos não são representados como onipresentes nas produções de Nátaly, o que implica que, em boa parte do tempo, outros sentimentos e sensações estão em jogo, demonstrando sua amplitude emocional - novamente, contrapondo-se à ideia de que mulheres negras apresentam apenas um humor corrente e permanente, que se manifesta não importa o tema em debate ou a situação que estão vivendo.

Pelo contrário, os julgamentos de capacidade positivos, invocados nas expressões "articulando os meus pensamentos", "falando sobre as minhas questões", "mobilizando os meus conhecimentos", constroem-na não apenas como uma pessoa racional, mas também como detentora de saberes e produtora de conhecimento. Em suma, trata-se da apresentação de uma descrição autodefinida de si mesma, por meio da qual ela desafia a imagem de controle e propõe 
outros significados sobre suas ações e seu cotidiano ao centralizar a questão em sua experiência (BUENO, 2020, p.143). Esse processo de autoavaliação continua por meio de uma série de julgamentos positivos realizados sobre sua atuação enquanto comunicadora e ativista, que irá se entremear em considerações a respeito das avaliações realizadas sobre outras profissionais e ativistas negras ${ }^{196}$.

Essas duas imagens são contrastadas no trecho N3 (linhas 94-104). Como ela coloca, "eu particularmente tenho uma vida muito leve mas isso tudo é anulado...". Aqui, Nátaly indica, por meio da contração dialógica: negação: contraexpectativa ("mas"), que a imagem construída nos comentários ignora a realidade. Segundo ela, esse processo de deformação da sua imagem é constante - assim como é a necessidade de refutá-lo de alguma forma - como sugere o uso dos termos "todas as vezes" e "o tempo inteiro", que assinalam aspecto iterativo do fenômeno, como veremos a seguir.

N3) $\mathrm{N}$ e aí tem outro ponto por que todas as vezes que mulheres negras mobilizam os seus conhecimentos e falam de forma interesSAda e decidida sobre um assunto nós somos tidas como loucas... nós somos tidas como arroGANtes?... eu sou chamada o tempo inteiro de arrogante... onde há arrogância em expor as minhas DOres? e expor um conhecimento que EU busQUEI elaborar ao longo da minha vida? o que há de arrogante em mulheres negras que sabem do que estão falando? eu particularmente sou uma pessoa muito DOce... eu particularmente gosto de coisas fofas... eu particularmente... assisto deSEnho até hoje... eu particularmente adoro Padrinhos Mágicos Hora da Aventura eu particularmente gosto de giBIS eu particularmente gosto de deSEnho eu particularmente gosto de poeSIA eu particularmente tenho uma vida muito leve mas isso tudo é anulado...

Neste trecho, a palavra-chave que diferencia os dois posicionamentos é a polaridade dos julgamentos de capacidade e de cordialidade negativos relacionados à agressividade. O termo "arrogância" se refere a um comportamento de "[o]rgulho que se manifesta por atitude de prepotência ou desprezo com relação aos outros; altivez, cachaço, jactância, presunção, soberba", "[f]alta de respeito; liberdade desrespeitosa; atrevimento, insolência, ousadia" (ARROGÂNCIA, 2020) e conota um despreparo, uma capacitação que não está de acordo com a posição ocupada, que pretende ser disfarçada por meio de um comportamento autoritário e, não raro, ofensivo em relação às pessoas em seu redor. É essa característica que define parte das críticas realizadas a Nátaly e, para refutá-las, ela propõe uma conexão entre essa visão e o estereótipo da mulher negra raivosa (N1), além de apresentar uma visão autodefinida de si (N2)

196 Embora não nos aprofundemos nesta discussão aqui, achamos que seria possível empreender uma análise da função de uma versão brasileira do estereótipo da Black Lady (COLLINS, 2019; BUENO, 2020) nos ataques referenciados neste vídeo e enfrentados por outras mulheres negras em ascensão econômica e profissional (TRINDADE, 2020). 
que contradiz essa imagem. No trecho sob análise, ela explora o contraste entre essas duas representações de forma a salientar a incongruência entre as críticas e a realidade.

Esse processo se inicia por meio de perguntas retóricas, ("por que todas as vezes que mulheres negras mobilizam os seus conhecimentos e falam de forma interesSAda e decidida sobre um assunto nós somos tidas como loucas... nós somos tidas como arroGANtes...?”, "onde há arrogância em expor as minhas DOres? e expor um conhecimento que EU busQUEI elaborar ao longo da minha vida? o que há de arrogante em mulheres negras que sabem do que estão falando?") que apontam a incoerência entre a imagem construída nos comentários e o próprio conteúdo dos vídeos de Nátaly e de falas de mulheres negras em geral. Ele continuará em um segundo momento de autoavaliação, no qual ela apresenta diversos detalhes pessoais de forma a instigar um processo de humanização de si (captação da empatia).

As perguntas retóricas citadas acima iniciam o processo de reenquadramento da pergunta argumentativa que mencionamos no início na seção. Elas colocam em xeque as premissas das críticas em uma operação que parte da articulação entre a experiência do Nós e do Eu. As perguntas retóricas enquadram a questão na dimensão social, referindo-se tanto ao $\mathrm{Eu}$, Nátaly, quanto ao Nós, mulheres negras. Isso é realizado por meio do recurso de contração dialógica: declaração: pronunciamento (“e aí tem outro ponto [...]”), que reconhece a tensão dialógica ("por que todas as vezes que mulheres negras mobilizam os seus conhecimentos e falam de forma interesSAda e decidida sobre um assunto nós somos tidas como loucas... nós somos tidas como arroGANtes?”). Assim, os julgamentos positivos combinados de capacidade: competência ("mobilizam os seus conhecimentos") e tenacidade: obstinação ("e falam de forma interesSAda e decidida"), que se coadunam com a autoimagem defendida por Nátaly, são contrastados com os julgamentos negativos de capacidade: competência ("nós somos tidas como loucas") e de cordialidade ("nós somos tidas como arroGANtes") atribuídos ao Outro.

Enquanto os julgamentos positivos são apresentados de forma monoglóssica - e, dessa forma, construídos como reais -, o julgamento negativo é realizado por meio de expansão dialógica: atribuição: distanciamento (“tidas como”) - o que o relaciona a uma visão de mundo específica e não legitimada.

Os julgamentos e as representações positivas sobre a coletividade de mulheres negras são articulados à experiência de Nátaly, que se utiliza dos mesmos tipos de julgamentos para se descrever. Dessa forma, assim como mulheres negras "mobilizam os seus conhecimentos e falam de forma interessada e decidida sobre um assunto", Nátaly também "expõe um 
conhecimento que [buscou] elaborar ao longo da [sua] vida" - invocando julgamentos positivos de capacidade: competência.

Por meio do encapsulamento do conteúdo dos vídeos como "expor as minhas dores" julgamento positivo de veracidade que denota alto grau de honestidade ao falar abertamente acerca de sentimentos, emoções e situações dolorosas - e "expor um conhecimento que eu busquei elaborar ao longo da minha vida" - que, por sua vez, invoca julgamentos positivos de capacidade: competência e tenacidade: obstinação -, coloca-se em pauta a natureza dos ataques à imagem de Nátaly. Essa sugestão se torna explícita na pergunta retórica seguinte (“o que há de arrogante em mulheres negras que sabem do que estão falando?’).

Essa incongruência é construída no eixo temporal como experiências que se repetem ao longo da vida de Nátaly e de outras mulheres mulheres negras ("todas as vezes que mulheres negras [...] eu sou chamada o tempo inteiro de arrogante..."). Dessa forma, ela estabelece uma relação entre uma incessante tentativa de desqualificar o trabalho e a competência de mulheres negras e, em contrapartida, a constante busca por conhecimento e desenvolvimento pessoal dessas mulheres, que, apesar de beneficiarem a sociedade, não são devidamente reconhecidas por determinados setores devido à mediação entre realidade e representação realizada pelas imagens de controle (BUENO, 2020).

Nesse momento - e progressivamente ao longo do texto -, o Eu se amplia, passando a constituir o Eu-Nós. Ao falar sobre si, Nátaly se constrói de forma intimamente articulada a outras vozes, consideradas suas semelhantes - mulheres em geral num primeiro momento, como será explorado no trecho N5, e, em específico, mulheres negras. Assim, estão implicadas na discussão muito mais vozes alinhadas ao Eu e representadas como um consenso, como uma comunidade discursiva, relacionada a uma identidade de gênero e étnico-racial, que valida e legitima esse discurso. Consequentemente, esse campo epistêmico-axiológico é reforçado, enquanto o campo epistêmico-axiológico do Outro é esvaziado de legitimidade.

A autodefinição não se encerra nos julgamentos positivos de capacidade conforme exposto anteriormente, mas também se elabora por meio da apresentação de gostos e de características pessoais, como sua personalidade "doce" e "leve" (julgamentos positivos de cordialidade), bem como o apreço por certas séries de animação populares entre jovens brasileiros nascidos entre os anos 1990 e 2000, como Padrinhos Mágicos e Hora da Aventura, assim como gibis, desenho e poesia. Trata-se de elementos que, além de permitirem uma identificação com seu público-alvo, parecem orientados a criar a imagem de uma pessoa doce, 
sensível e leve, ligada à infância e a um mundo lúdico e artístico - o que se opõe à imagem de agressividade constante criada pela imagem de controle.

De modo geral, em termos argumentativos, os movimentos de afastamento epistêmicoaxiológicos participam tanto da refutação interna quanto da refutação externa das Alegações' (Nátaly Neri é agressiva; Nátaly Neri é arrogante), posto que envolvem a defesa de uma outra imagem de si (refutação externa) e a disputa em relação à Garantia' (Mulheres negras são naturalmente agressivas e arrogantes) - refutação interna. Para tanto, ela se dedica a explicar as formas pelas quais esse estereótipo atua na representação de mulheres negras na sociedade. Dessa forma, promove a deslegitimação do campo epistêmico-axiológico do Outro com base nos valores compartilhados pelo endogrupo.

Em suma, opera-se um processo de humanização de Nátaly, construindo sua imagem por meio de um mosaico de detalhes que constroem uma identidade multifacetada por meio de referências compartilhadas com o auditório, que salienta o valor e as particularidades individuais, oferecendo informações que podem orientar o processo de mudanças a respeito do entendimento sobre si e sobre o outro (CAMERON, 2011).

Trata-se, em suma, de um processo de captação da empatia (GONÇALVESSEGUNDO, 2019b) ${ }^{197}$. Assim, entendemos que o processamento da empatia aqui também varia de acordo com aspectos de identidade e com a filiação discursiva de quem assiste ao vídeo. Dependerá, provavelmente, de questões como raça, gênero e idade, no mínimo, mas também da leitura - resistente, complacente ou tática - que se faz do vídeo e do compartilhamento de referências e gostos culturais

Por outro lado, a representação autodefinida desses conhecimentos e do posicionamento crítico e resiliente de mulheres negras frente à violência simbólica representada pelos estereótipos e imagens de controle também é projetada de forma constante e reiterada ("todas as vezes", "o tempo inteiro", "ao longo da minha vida"), construindo um julgamento positivo de tenacidade: obstinação que as apresenta como decididas, inteligentes e resilientes. Assim, Nátaly faz referência a processos de opressão e resistência contínuos e quase onipresentes, que envolvem constante preparo, ação e recriação.

\footnotetext{
197. Martin e White (2005) diferenciam entre três modos de leitura: tático, resistente e complacente. A leitura tática corresponde um padrão interessado e parcial, que utiliza o texto com objetivos diversos do que aqueles para os quais foi produzido; o padrão resistente consiste numa leitura que assume um posicionamento contrário àquele propagado pelo texto; o modo complacente, por fim, corresponde àquele que compartilha do posicionamento do texto e o aceita sem disputa. Considerações mais aprofundadas a esse respeito dependeriam, portanto, de um tipo de investigação que não realizamos nesta pesquisa, mas que, sem dúvidas, contribuiriam deveras para as análises realizadas e para a compreensão dos processos de consumo e interpretação desses vídeos.
} 
Trata-se de um caso semelhante ao que Hart (2014) descreve como um dos efeitos possíveis da proximização temporal, isto é, a intensificação da proximização espacial e/ou axiológica. Trata-se de um mecanismo de perspectivação conceptual por meio do qual "o cenário apresentado no plano espacial ou axiológico é perspectivado como próximo e estendendo-se em direção a ou como parte do ground temporal do conceptualizador" (HART, 2014, p. 173, grifos nossos). Dessa forma, a situação deixa de se configurar como uma violência episódica e passa a se estabelecer como uma condição recorrente.

Aqui, o Outro é uma entidade ameaçadora, um perigo constante que ativa a necessidade de preparo para combater a ameaça externa, perspectivada como "rotineiramente presente" (CAP, 2013, p. 97). No entanto, não se trata de se antecipar a uma agressão futura, mas sim de uma situação de ataque já presente, na qual, por meio dos comentários, o Outro invade o centro dêitico, atacando o Eu-Nós simbolicamente. Dessa forma, o Outro é conceptualizado como agressivo e ameaçador.

Essa caracterização culmina no trecho N4, no qual Nátaly apresenta a Proposta de Ação capaz de colocar um fim na situação descrita nos parágrafos anteriores. Trata-se de um movimento que instiga a desvinculação do Outro em relação ao discurso do exogrupo.

N4) $\mathrm{N}$ e qualquer um qualquer um que tente poDAR... qualquer um que tente determiNAR a forma como eu devo ou não devo falar está me colocando dentro do estereótipo está sendo raCISta... está dizendo que eu correspondo ou NÃO às suas expectativas sociais... a estereótipos que visam controlar e que nasceram pra justificar violências... que nasceram pra justificar o ódio e a exploração que mulheres negras sofreram ao longo da história... esse é meu tom esses são os meus vídeos essa é a forma que eu me comunico essa é a minha personalidade... e não é porque eu sou uma mulher negra raivosa... é simplesmente porque eu sou eu se eu estiver com raiva eu tenho todo o direito de estar se eu não estiver com raiva tudo bem é o meu jeito se eu quiser ser iRÔnica é o meu jeito se eu não quiser ser irônica é o meu jeito eu espero que vocês parem... que vocês realmente parem de me enxergar como uma mulher negra raiVOsa... porque eu vou continuar falando nesse TOM eu vou continuar falando usando as minhas pausas erguendo as minhas sobrancelhas usando as minhas iroNIas e ninguém vai me parar porque é dessa forma que eu me comunico... pra você que acha eu sou brava você não me conhece... porque na verdade eu sou uma fofinha ((suspiro))... se você julga os meus vídeos se você acha que eu sou uma pessoa intensa deMAIS é porque realmente você não entende a gravidade do que eu tô falando... essa é a forma como eu me comunico... você não precisa ter medo de mim você não precisa ter medo da minha voz você precisa ter medo de você... e do que você acredita que eu devo ser...

Ela aponta os diversos equívocos que subjazem às críticas que a acusam de ser "agressiva" por meio de mecanismos combinados de ENGAJAMENTO e JULGAMENTO que 
responsabilizam os comentaristas diretamente. Os comentários são representados como tentativas de "podar" e "determinar" a forma como Nátaly se expressa, dado que a avaliam a partir de estereótipos racistas que estabelecem expectativas sociais específicas para determinar a aceitabilidade dos discursos de mulheres negras de forma a controlá-las e justificar as violências, o ódio e a exploração de sua força de trabalho.

Tais comentários são parafraseados por meio de mecanismos de expansão dialógica: atribuição: distanciamento, que refutam os julgamentos realizados com novos julgamentos sobre o Outro. Assim, em "pra você que acha eu sou brava você não me conhece" e "se você julga os meus vídeos se você acha que eu sou uma pessoa intensa deMAIS é porque realmente você não entende a gravidade do que eu tô falando", os julgamentos negativos de cordialidade ("brava", "intensa demais") são combatidos com julgamentos negativos de capacidade: competência, que desautorizam a fonte dos ataques ("você não me conhece", "você não entende a gravidade do que eu tô falando"). Essa reconceptualização invoca julgamentos negativos de propriedade: justiça e veracidade que deslegitimam os comentários do Outro.

A partir disso, ela atribui ao Outro um afeto negativo de insegurança cujo gatilho seria ela mesma ("você não precisa ter medo de mim você não precisa ter medo da minha voz"), e afirma que esse gatilho está mal posicionado, posto que deveria ser o próprio comentarista ("você precisa ter medo de você... e do que você acredita que eu devo ser..."), após ter demonstrado quais são as ideias e ações que realmente possuem potencial destrutivo. Esse afeto também invoca um julgamento negativo de propriedade: violência para caracterizar o Outro.

Esses julgamentos apoiam as sugestões de revisão de crenças e mudança de comportamento discursivo ("eu espero que vocês parem... que vocês realmente parem de me enxergar como uma mulher negra raiVOsa..."), ao mesmo tempo em que legitimam sua intenção de manter seus próprios comportamentos e atitudes ("porque eu vou continuar falando nesse TOM eu vou continuar falando usando as minhas pausas erguendo as minhas sobrancelhas usando as minhas iroNIas e ninguém vai me parar porque é dessa forma que eu me comunico...”), estendendo ambas (as recomendações e suas intenções) no eixo temporal em direção ao futuro.

Resumindo, os movimentos de afastamento epistêmico-axiológico analisados em N1N4 contribuem para a estratégia argumentativa de reenquadramento da questão argumentativa, que deixa de ser Por que você é tão agressiva, Nátaly?, para questionar Por que você me acha agressiva?. Isso é realizado por meio da explicitação da filiação ideológica desses comentários, projetando o Outro no campo epistêmico-axiológico do exogrupo. Tendo em vista os projetos 
de formação política do canal, sabemos que, além de ser importante para a preservação da imagem da youtuber, isso também participa da deslegitimação do discurso hegemônico racista e machista. Dessa forma, corrobora as afirmações de discursos antirracistas, em especial dos feminismos negros, o que envolve a discussão detalhada a função de estereótipos e de imagens de controle na construção de imagens de mulheres negras.

A resolução do problema apresentado, portanto, não se daria por meio de um contraataque do Eu-Nós, mas sim por um processo de revisão de crenças a ser efetuado pelo Outro, o que se assemelha ao processo de campo em transformação (shifting ground) descrito por Hart (2014). De acordo com o autor, o campo em transformação consiste na aproximação de um campo epistêmico-axiológico em relação ao outro. No caso sob análise, essa aproximação seria efetuada pelas entidades exteriores ao centro dêitico (no caso, o Outro) em relação ao campo epistêmico-axiológico do Eu-Nós. Trata-se, portanto, de um caso de campo em resistência, devido à apresentação de perspectivas contra-hegemônicas como formas de combater a discursividade e o comportamento do exogrupo, perspectivado como ameaçador.

Em termos da inserção do vídeo nos debates dos feminismos negros, entendemos que a discussão realizada por Nátaly faz referência à problemática do epistemicídio (CARNEIRO, 2005) e da máscara (KILOMBA, 2019), posto que discute formas de silenciamento de mulheres negras e como os estereótipos podem agir no sentido da desumanização. Esse é um tema recorrente no canal de Nátaly: além desse vídeo, encontramos pelo menos mais três que se voltam à questão dos estereótipos desde 2017: "ESTEREÓTIPOS da Mulher NEGRA Brasileira"198, "ORIENTAÇÃO SEXUAL E ESTEREÓTIPOS RACISTAS Uma reflexão confusa mas é isso, vamos conversar" 199 e "Estereótipos negros no mercado de trabalho - Com Magá Moura \#YouTubeNegro"200 - além de outros nos quais a questão dos estereótipos aparece como apoio para a discussão principal.

Vemos, portanto, que o debate se mostra premente nas manifestações dos feminismos negros na Internet, sobretudo na produção de Nátaly. Além disso, ele auxilia uma série de outros debates, como, por exemplo, o da representatividade, posto que mostra as linhas de grade que orientam a construção de personagens negras em produtos audiovisuais e suas consequências

\footnotetext{
198 Disponível em: <https://www.youtube.com/watch?v=cvp3rvYVaDo\&ab_channel=N\%C3\%A1talyNeri>. Publicado em 25/07/2020. Neste vídeo ela comenta o artigo "Racismo e sexismo na cultura brasileira", de Lélia Gonzalez (1984).

199 Disponível em: <https://www.youtube.com/watch?v=iBXv9aV316E\&ab_channel=N\%C3\%A1talyNeri>. Publicado em 31/03/2020.

200 Disponível em: 〈https://www.youtube.com/watch?v=pzR903ALs94\&ab_channel=N\%C3\%A1talyNeri>. Publicado em 12/11/2016.
} 
políticas e subjetivas, por exemplo, e também contribui para a educação em relações étnicoraciais. Ademais, seria possível argumentar também sobre a vulnerabilidade socioeconômica naturalizada por esses estereótipos, tendo em vista que normalizam a divisão do trabalho em linhas de gênero e de raça, desvalorizando também a qualidade e a importância da atuação dessas trabalhadoras.

Nas últimas páginas, exploramos casos de afastamento epistêmico-axiológico que podem contribuir para instigar um processo de revisão de crenças e uma mudança de comportamento discursivo. Hipotetizamos três possíveis padrões de consumo dos vídeos de Nátaly: (i) uma espécie de "guia" para discussões, funcionando como formação política, sugerindo estratégias argumentativas e discursivas para o debate dos estereótipos; (ii) uma forma de empoderamento, instigando em outras mulheres negras o processo de autodefinição; (iii) um ponto de partida para que pessoas que realizam as ações e compartilham os estereótipos denunciados por Nátaly revejam suas crenças.

Assim, a depender de quem estiver assistindo ao vídeo, a reação e o engajamento com a questão será diferente, a depender da entidade (Eu-Nós ou Outro) com quem a consumidora textual se identifica e qual a sua filiação discursiva (endogrupo x exogrupo), entre outros fatores, como a sua participação em comunidades discursivas específicas e seu propósito de consumo $^{201}$. Se a consumidora textual se identificar com o posicionamento da entidade Outro e considera-se filiado à discursividade do exogrupo, possivelmente sua leitura será resistente ou mesmo tática - se assiste ao vídeo para produzir uma contra-argumentação, por exemplo. Por outro lado, se ocorre essa identificação, mas a consumidora se vê como parte do endogrupo, é possível que realize uma leitura complacente, e busque realizar as Propostas de Ação indicadas pela youtuber. Já as hipóteses de leitura decorrentes de uma identificação da consumidora com o Eu-Nós, por sua vez, demonstraram a necessidade de maiores reflexões. Abordaremos essas limitações nas Considerações Finais.

A seguir, debruçamo-nos sobre dois exemplos de afastamento epistêmico-axiológico presentes no vídeo "YOUTUBER SÓ FALA MERDA NA INTERNET? Feat. Louie Ponto". Eles estão transcritos nos trechos NL1 (linhas 25-49) e NL2 (linhas 49-59) e participam da refutação das Alegações que constituem a leitura das Circunstâncias Motivadoras (Não é possível produzir conteúdo engajado no YouTube) para a Contra-Proposta de Ação (Não

\footnotetext{
201 Acreditamos que as análises que realizamos aqui possam contribuir para a verificação dessas hipóteses de leituras. Trata-se, no entanto, de questões complexas que merecem abordagens que não exploramos nesta pesquisa, como a etnografia.
} 
participe de comunidades engajadas na Internet) atribuída ao Outro ${ }^{202}$. Simultaneamente, esse movimento de refutação contribui para o fortalecimento da Proposta de Ação encaminhada pelas youtubers (Participe de comunidades engajadas na Internet).

Conforme discutido na seção 1.2, o entendimento do Outro a respeito de comunidades engajadas na Internet se pauta por uma série de presunções (Garantias), reproduzidas a seguir, que questionavam a legitimidade das estratégias do ativismo digital ${ }^{203}$. São elas: $O$ estabelecimento de relações entre conteúdo engajado, marcas e empresas necessariamente despolitiza o conteúdo dos canais engajados; Não é possível congregar engajamento político e entretenimento em uma plataforma esvaziada politicamente.

Para refutá-las, as youtubers se contrapõem à hipótese de que haveria "esvaziamento político" da plataforma, supostamente causado pelas suas coerções materiais e ideológicas, defendendo que a qualidade e o grau do engajamento do conteúdo dependeria do compromisso político da instância de produção, o que possibilitaria também a abordagem política de conteúdos como beleza e entretenimento.

Nos parágrafos a seguir, iremos nos debruçar sobre os mecanismos de ENGAJAMENTO e JULGAMENTO utilizados pelas vozes autorais para gerir a tensão dialógica a respeito das potencialidades da plataforma no trecho NL1, na discussão sobre as Circunstâncias Motivadoras.

NL1) L por exemplo existe uma ideia de que todo conteúdo produzido pro YouTube é um conteúdo de entretenimento e soMENTte de entretenimento... e não tem problema tem um monte de canais que tem realmente esse objetivo... mas não são todos os youtubers que estão aqui na plataforma com o objetivo de fazer vídeo... de entretenimento... vídeo engraçado... apesar de que a gente pode também fazer esse tipo de vídeo só que a gente tá aqui no YouTube com outro objetivo além desse

$\mathrm{N}$ exatamente... e essa é uma coisa que me pegou muito principalmente agora: depois que meu canal cresceu que as pessoas principalmente nos ambientes acadêmicos me julgam MUIto ironizam o fato de eu ser youtuber... tipo isso também acontece com você

L aham

$\mathrm{N}$ porque você também tá no ambiente acadêmico né? Louie está no mestrado indo para o doutorado estamos conversando aqui com uma mulher muito inteligente mas é uma coisa que acontece muito comigo na universidade de ironizarem o

\footnotetext{
${ }^{202}$ A configuração funcional da argumentação epistêmica em prol dessa leitura das Circunstâncias está resumida por meio do layout apresentado na Figura 13 - Layout da Configuração Funcional Epistêmica das Circunstâncias Motivadoras do Outro (p. 167).

${ }^{203}$ Como discutimos nas Considerações Iniciais e no capítulo I, a compreensão acerca do potencial das plataformas para o ativismo e para a militância se modificou muito nos últimos anos, sobretudo na pandemia, quando os meios digitais se tornaram como os principais palcos para a ação de ativistas, coletivos, ONGs, partidos e movimentos sociais.
} 
fato de eu estar me formando em Ciências Sociais e ser youtuber como se o YouTube fosse uma plataforma esvaziada e que você não consegue desenvolver absolutamente nada com seriedade

L sabe uma coisa engraçada? eu já vi pessoas que tem canal no YouTube e não se dizem youtubers e tem... certo receio tipo ah eu tenho um canal mas eu não sou youtuber eu sou produTOR de conteÚdo digiTAL mas cara você tá no YouTube qual o problema de dizer que você é um youtuber? não tem problema... eu sempre fiquei muito nervosa com o número de inscritos eu sempre fiquei nossa nossa eu preciso ter um milhão eu preciso ter dois milhões três milhões porque era isso que eu VIA de outros canais só que eu preciso entender que a relevância do meu canal não é exatamente um NÚmero que eu alcanço mas é a diferença que eu FAço na vida das pessoas que me acompanham e é por isso que eu estou aqui

exataMENte

Neste excerto, Nátaly e Louie realizam, primeiramente, uma defesa do YouTube enquanto plataforma para o ativismo digital. A apresentação da Alegação' ("todo conteúdo produzido pro YouTube é um conteúdo de entretenimento e soMENTte de entretenimento") é realizada por meio da expansão dialógica: reconhecimento ("existe uma ideia") e da expansão dialógica: ponderação ("não tem problema"). Trata-se de uma concessão (em partes) ao discurso do Outro: as vozes autorais admitem que a Alegação’ se aplica de fato a parte do conteúdo produzido no YouTube ("e não tem problema tem um monte de canais que têm realmente esse objetivo"). Por outro lado, a contração dialógica: refutação: contraexpectativa (“mas não são todos os youtubers que estão aqui na plataforma com o objetivo de fazer vídeo... de entretenimento... vídeo engraçado") apresenta os casos aos quais a Alegação' não se aplica - como seria o caso dos canais de Natály e Louie.

Além disso, vemos que elas enxergam um potencial impacto negativo da Alegação' sobre a construção de suas imagens como ativistas de fato, posto que ela é utilizada para deslegitimar ou, pelo menos, contestar a qualidade acadêmica de seu trabalho ("as pessoas principalmente nos ambientes acadêmicos me julgam MUIto ironizam o fato de eu ser youtuber"; "mas é uma coisa que acontece muito comigo na universidade de ironizarem o fato de eu estar me formando em Ciências Sociais e ser youtuber") por estar apoiada em um entendimento - não compartilhado pelas youtubers (como vemos pelo mecanismo de expansão dialógica: atribuição: distanciamento "como se") de que o YouTube é "uma plataforma esvaziada e que você não consegue desenvolver absolutamente nada com seriedade”.

Vê-se, portanto, que essa concepção invoca julgamentos negativos de capacidade endereçados a todos os ativistas digitais que atuam no YouTube (Nós), tanto no que diz respeito à sua capacidade de avaliar e selecionar seus espaços de atuação ("plataforma esvaziada"), 
quanto no que se refere à sua competência para produzir conteúdos de qualidade ("não consegue desenvolver absolutamente nada com seriedade").

De acordo com elas, essa visão generalizante sobre o conteúdo produzido no YouTube teria duas consequências possíveis para os ativistas digitais. A primeira seria uma espécie de "receio" em se associar às plataformas, especialmente o YouTube ("eu já vi pessoas que têm canal no YouTube e não se dizem youtubers e têm... certo receio tipo ah eu tenho um canal mas eu não sou youtuber eu sou produTOR de conteÚdo digiTAL").

Esse "receio" constitui um afeto negativo de insegurança expressado por outros youtubers, que se processa internamente e é motivado pelos julgamentos negativos relatados pelas youtubers - logo, estão localizados no pólo realis e o afeto é considerado parcialmente legítimo, posto que elas demonstram compreender suas origens, embora discordem do posicionamento (“qual o problema de dizer que você é um youtuber? não tem problema”). Dessa forma, atribui-se a esse discurso a capacidade de inibir a afirmação de uma determinada identidade profissional ou mesmo um determinado tipo de ativismo ou militância, prejudicando a propagação das pautas progressistas.

A segunda consequência consiste na crença de que só haveria um modo de se medir o sucesso dos canais ou a qualidade dos conteúdos: as métricas de visualização ("eu sempre fiquei muito nervosa com o número de inscritos eu sempre fiquei nossa nossa eu preciso ter um milhão eu preciso ter dois milhões três milhões porque era isso que eu VIA de outros canais"). Essa concepção é refutada pela apresentação de um outro parâmetro para aferir o impacto dos conteúdos: o engajamento da audiência, ou "a diferença que eu FAço na vida das pessoas que me acompanham”. Essa experiência pessoal será recuperada posteriormente por Nátaly, que afirma a importância que a produção de conteúdo sobre beleza voltado para mulheres negras mesmo que não necessariamente engajado de forma aberta - teve para o seu processo de transição capilar e para a afirmação de sua identidade.

Esse parâmetro seria capaz de avaliar seu sucesso tanto como youtuber/comunicadora, quanto como ativista, tendo em vista que permitiria analisar o seu conteúdo em termos de qualidade e intensidade das relações criadas com o público, subvertendo os critérios da plataforma. Dessa forma, enfatiza-se o potencial de gerar engajamento e mudanças na vida dos usuários, característica essencial para os ativismos que buscam criar mais comunidades engajadas em torno de questões sociais e políticas - Objetivo comum entre o Eu-Nós e o Outro.

No entanto, as críticas ao ativismo digital no YouTube e aos canais está ligada também a outras visões a respeito da plataforma, que repudiam o envolvimento de influenciadores 
digitais com marcas e empresas privadas e denunciam uma possível despolitização dos conteúdos em virtude dessa associação. Esses receios são discutidos e refutados em NL2 (linhas 49 - 59).

NL2) $\mathrm{N}$ realmente existe essa ideia que nossos canais são riQUÍSsimos porque youtubers são riQUÍSsimos... só que a gente entra no tipo de conteúdo que a gente produz e principalmente nos nossos posicionamentos

L na verdade eu gasto mais dinheiro no YouTube do que recebo e essa é uma coisa muito curiosa porque o meu canal cresceu e as pessoas acham que por ter crescido eu tô rica ou eu tô ganhando muito dinheiro

N o nosso conteúdo ele tá muito ligado nas coisas que a gente acredita então ele não é TÃO flexível asSIM claro que existem várias marcas que a gente consegue se identificar e que é muito importante pra gente conseguir parceria pra conseguir conseguir continuar com um trabalho consistente e de qualidade... mas é muito complicado o nosso tipo de conteúdo tamBÉM... especificamente porque a gente fala sobre feminismo né...

A questão da despolitização é introduzida por meio de uma hipótese a respeito do retorno financeiro dos canais. Ela é introduzida por meio de expansão dialógica: atribuição: reconhecimento ("realmente existe essa ideia que nossos canais são riQUÍSsimos porque youtubers são riQUÍSsimos"), que indica um raciocínio sintomático por sinal (youtubers são riquíssimos; Louie e Nátaly são youtubers; logo, Louie e Nátaly são riquíssimas), invocando julgamentos negativos de capacidade: competência e veracidade. Assim, sugere-se que o conteúdo do canal se sujeita aos interesses da plataforma e das marcas com quem as youtubers estabelecem parceria, tornando-se despolitizado.

Em contrapartida, este raciocínio é refutado por meio da contração dialógica: refutação: contraexpectativa ("na verdade eu gasto mais dinheiro no YouTube do que recebo"), que defende que, apesar de seus canais terem crescido, elas não se encaixam na categoria de "youtubers riquíssimos". O impedimento estaria, segundo elas, nos conteúdos e nos compromissos políticos de seus canais ("o nosso conteúdo ele tá muito ligado nas coisas que a gente acredita então ele não é TÃO flexível asSIM"). Embora elas admitam um relacionamento com marcas, reconhecendo uma tensão a esse respeito por meio da contração dialógica: declaração: expectativa confirmada ("claro que existem várias marcas que a gente consegue se identificar"), elas o justificam por meio da necessidade de fundos para garantir a continuidade do canal ("e que é muito importante pra gente conseguir parceria pra conseguir continuar com um trabalho consistente e de qualidade").

Elas refutam, em específico, o potencial desse relacionamento de despolitizar seu conteúdo por meio da contração dialógica: refutação: contraexpectativa ("mas é muito 
complicado o nosso tipo de conteúdo tamBÉM... especificamente porque a gente fala sobre feminismo né...”). O conteúdo dos canais e o estabelecimento de parcerias seria, portanto, orientado pelos princípios feministas, antirracistas e/ou pró-LGBT das ativistas, o que invoca um julgamento positivo de veracidade, que reforçaria sua credibilidade como ativistas.

Assim, apesar de demarcar uma diferença nos campos epistêmico-axiológico do Eu-Nós e do Outro por explicitar as distintas percepções a respeito do YouTube enquanto plataforma para o ativismo digital, enfatiza-se também a similaridade político-ideológica entre o Eu-Nós e o Outro por meio da referência aos princípios feministas e com a preocupação em relação ao conteúdo do canal, contribuindo para a defesa da eficácia da Proposta de Ação que aposta na criação de comunidades engajadas por meio do YouTube.

É por meio desse jogo de concessão ao discurso do Outro (realizado por meio da expectativa confirmada) e de contraexpectativa que se delimitam as distâncias entre os campos epistêmico-axiológicos em disputa. A tensão que separa Eu-Nós e Outro consiste na visão a respeito das consequências da relação entre canais progressistas e marcas quanto à despolitização de seus conteúdos. No entanto, essas fronteiras parecem ser mais permeáveis do que as estabelecidas nos demais vídeos analisados. Hipotetizamos que isso se deva à combinação entre as concessões ao discurso do Outro e ao constante reforço do compromisso político dos canais, o que estabeleceria pontos de comunhão entre o Eu-Nós e o Outro. Isso é importante, pois, apesar de salientar que há diferenças nas estratégias e nas leituras das Circunstâncias Motivadoras e Bloqueadoras, as ressalvas do Outro (conforme atribuídas pelas youtubers) são ouvidas e levadas em consideração na formulação dos discursos e das práticas do Eu-Nós, sugerindo uma relação de solidariedade. Afinal de contas, na divisão do espaço discursivo ambos são projetados no campo epistêmico-axiológico do endogrupo progressista.

O motivo para considerarmos esse trecho um caso de afastamento e não de aproximação epistêmico-axiológica, mais especificamente, se dá pelo entendimento de que, em última instância, a concessão não leva ao efeito de complementariedade das Alegações em disputa. Pelo contrário, é fundamental refutar a Garantia' O estabelecimento de relações entre conteúdo engajado, marcas e empresas necessariamente despolitiza o conteúdo dos canais engajados para garantir a legitimidade das suas práticas.

Assim, os movimentos de afastamento epistêmico-axiológico se mostram relevantes inclusive para a construção da região de proximidade epistêmico-axiológica no trecho NL3, apresentado na seção seguinte - a qual é conformada por meio da metáfora da "ponte" ou "porta de entrada". Em suma, em termos argumentativos, percebemos, através dos movimentos de 
afastamento e de aproximação axiológicos, que a Proposta de Ação do Eu-Nós não consiste na negação da Contra-Proposta, mas sim em uma complementação às práticas do ativismo offline.

Enquanto os movimentos epistêmico-axiológicos deste vídeo se constituem dentro dos limites do campo do endogrupo, os trechos do vídeo "HETEROFOBIA E RACISMO REVERSO EXISTEM? | LouiePonto feat. Nátaly Neri” analisados a seguir consistem novamente na negociação da autoprojeção do Outro no campo do endogrupo.

Conforme discutimos na seção 1.3, as Alegações de que existiriam racismo reverso e heterofobia constituem uma estratégia de tergiversação no combate às lutas sociais. Para combatê-las, Louie e Nátaly elaboram uma série de movimentos de afastamento epistêmicoaxiológico que contribuem, simultaneamente, para a refutação interna da Garantia' do Outro e para a refutação externa, apoiando a própria Alegação (Racismo reverso e heterofobia não existem).

Em termos da estrutura da argumentação, como vimos na seção 1.3, a tensão dialógica do vídeo se encontra nos diferentes entendimentos de racismo e LGBTfobia que orientam as estruturas argumentativas do Eu-Nós e do Outro. Essas definições consistem nas Garantias responsáveis por apoiar as Alegações opostas (Heterofobia e racismo reverso existem e Heterofobia e racismo reverso não existem) e são decisivas para a definição das distâncias epistêmico-axiológicas entre as entidades discursivas, posto que determinam a legitimidade da autoprojeção do Outro no campo do endogrupo.

A Garantia', que sustenta o movimento argumentativo atribuído ao Outro, pode ser resumida da seguinte forma: Injúrias raciais ou baseadas na sexualidade da pessoa ofendida são índices de discriminação racial ou por orientação sexual. Paralelamente, o entendimento do Eu-Nós a respeito da definição de racismo e LGBTfobia é o de que eles se constituem como sistemas de dominação estruturais, caracterizados por discursos oriundos de instituições de poder e se refletem na vida das pessoas dominadas por meio de violências físicas e simbólicas, discriminação direta e indireta, assim como por políticas de genocídio e assassinato em massa.

Os trechos LN1 e LN2 são dois exemplos que compõem os referidos movimentos de afastamento epistêmico-axiológico. Em LN1, o movimento é realizado por meio da refutação de uma analogia ${ }^{204}$ e, em LN2, por um raciocínio sintomático por definição ${ }^{205}$ (GONÇALVESSEGUNDO, 2018b).

${ }^{204} \mathrm{O}$ movimento argumentativo está sintetizado na Figura 15 na página 186.

${ }^{205}$ Os movimentos argumentativos estão sintetizadso nas Figura 16 e 17 nas páginas 188 e 189. 
O primeiro movimento visa a colocar em questão a definição de racismo reverso como um tipo de racismo. Com esses exemplos, Nátaly e Louie demonstram a unidirecionalidade das práticas de discriminação direta e indireta que constituem o racismo e a LGBTfobia como sistemas de dominação estruturais. Esses exemplos estão transcritos no trecho LN1 (linhas 5360) abaixo.

LN1) L e a gente pode com um exercício muito simples perceber que essas coisas não existem... por exemplo... uma pessoa heterossexual já... sofreu violência física ou verbal por SER heterossexual? [[NÃO]] uma pessoa heterossexual já morreu por ser heterossexual? [[NÃO]] tem MEdo de sair na rua porque é heterossexual? [[NÃO]]

$\mathrm{N}$ uma pessoa BRANca já deixou de concorrer a uma vaga de emprego porque era uma pessoa branca? [[NÃO]] uma pessoa BRANca já foi parada pela polícia porque ela era branca? [[NÃO]] uma pessoa BRANca já deixou de ter acesso a um ensino de qualidade ou já foi julgada como burra ou incapaz intelectualmente por ser branca? [[NÃO]]

Por meio das perguntas semirretóricas ${ }^{206}$, as vozes autorais estabelecem uma série de pontos de tensão dialógica que orientarão, simultaneamente, as estratégias de refutação interna e refutação externa.

Em suma, os exemplos projetam experiências violentas vividas por pessoas LGBT ("sofreu violência física e verbal", "morreu”, "tem MEdo de sair na rua") e pessoas negras (“deixou de concorrer a uma vaga", "foi parada pela polícia”, "deixou de ter acesso a um ensino de qualidade ou já foi julgada como burra ou incapaz") para o campo das experiências de pessoas heterossexuais e brancas (“uma pessoa heterossexual já... [...] por SER heterossexual?", “uma pessoa BRANca já [...] por ser branca?”). Esses exemplos especificam as experiências que permitiriam caracterizar a heterofobia e o racismo reverso como opressões estruturais na sociedade brasileira. No entanto, a cada pergunta, as youtuber respondem prontamente "não", o que é enfatizado pela projeção da resposta esperada (contração dialógica: refutação: negação).

Essa negação inviabiliza a concepção de que racismo reverso e heterofobia sejam comparáveis ao racismo e à LGBTfobia. Assim, esses exemplos trabalham no sentindo de demonstrar a insuficiência das concepções individualistas do racismo ${ }^{207}$ e da LGBTfobia

\footnotetext{
${ }^{206}$ As perguntas aqui analisadas são semirretóricas porque, embora interpelem o auditório, são explicitamente respondidas pelas youtubers - ao contrário das perguntas retóricas de fato, cuja resposta esperada permanece implícita. Para detalhes, ver artigo de Andréia Araujo e Raquel Freitag (2010).

${ }^{207} \mathrm{O}$ autor define a concepção individualista do racismo da seguinte forma: "O racismo, segundo essa concepção, é concebido como uma espécie de "patologia" ou anormalidade. Seria um fenômeno ético ou psicológico de caráter individual ou coletivo, atribuído a grupos isolados; ou, ainda, seria o racismo uma "irracionalidade" a ser combatida no campo jurídico por meio da aplicação de sanções civis - indenizações, por exemplo - ou penais. Por isso, a concepção individualista pode não admitir a existência de "racismo", mas somente de preconceito", a fim
} 
(ALMEIDA, 2019) atribuídas ao Outro. Em outras palavras, os exemplos agem em prol da refutação interna, que se orienta para desmobilizar a adesão à Alegação' Heterofobia e racismo reverso existem, já que contribuem para a desestabilização da equiparação entre racismo reverso e racismo - tal qual entre heterofobia e LGBTfobia - como questões equivalentes, que mereceriam a mesma consideração da opinião pública. Mais especificamente, elas se direcionam ao potencial de aplicação da Garantia' aos Dados’ para sustentar a Alegação' ("Heterofobia e racismo reverso existem").

Quanto à refutação externa, que visa a contribuir para a adesão à Alegação defendida pelo Eu-Nós (Heterofobia e racismo reverso não existem), os exemplos contribuem para a formulação da seguinte Garantia (G2): Sistemas de dominação estruturais são caracterizados por discursos oriundos de instituições de poder e se refletem na vida das pessoas dominadas por meio de violências físicas e simbólicas, discriminação direta e indireta, assim como por políticas de genocídio e assassinato em massa - que será explicitada no trecho seguinte -, tendo em vista que eles se encaixarão na definição de racismo e LGBTfobia proposta pelas youtubers.

Em LN2 (linhas 95-122), Nátaly compara as duas definições para refutar a Garantia’ e apresentar a noção de racismo estrutural. Para tanto, ela desenvolve o significado do termo “estrutural" por meio da explanação das origens do racismo enquanto sistema de dominação e da definição do conceito sociológico de raça (GUIMARÃES, 1999). Essas definições estão apresentadas no trecho a seguir.

LN2) $\mathrm{N} \quad[\ldots]$ racismo o que é racismo afinal? racismo é simplesmente você ofender o outro por causa do tom da sua pele? não necessariamente se fosse assim seria racismo de fato eu falar que alguém é branquelo azedo ou que alguém é cor de leite coalhado mas NÃO... existiram existem ainda mas existiram muito mais no passado teoRIas raCIStas racismo era realmente um campo de pesquisa em que você buscava provar que um grupo era inferior a outro por conta de suas características biológicas daí PEle... quiseram provar de todo modo os negros tinham cérebros menores... que negros... por questões biológicas estavam predispostos ao CRIme... várias dessas questões foram pesquiSAdas estuDAdas e fomenTAdas na sociedade... então racismo quer dizer que existe um grupo que é inferior e um grupo que é superior a gente dizer que racismo reverso... seria ok seria real... seria inverter essa lógica então a gente teria daí que voltar... a história inteira fazer com que esses estudos raciais... NUNca tivessem existido... e aí é uma coisa muito importante quando a gente tá falando de raça porque eu falo sobre RAça eu falo raça negra ah mas raça não existe de fato não existe BIOlogicamente não há nada que diferencie eu e Louie

de ressaltar a natureza psicológica do fenômeno em detrimento de sua natureza política" (ALMEIDA, 2019, p. 36). Nesse sentido, embora a análise do racismo no plano da responsabilização individual possa contribuir para o seu enfrentamento até certo ponto, a concepção individualista apresenta como limitação conceber o racismo apenas como casos de discriminação direta, e não dá conta de depreender, por exemplo, de que forma ele está inscrito em instituições e opera dentro da "legalidade" (ALMEIDA, 2019, p. 37). 
biologicamente sabe? não há nada que me faça ser mais propensa ao crime faça a Louie ser uma pessoa mais inteligente MAS existe raça quando a gente fala socialmente então por isso que a gente levanta a questão da raça MAS as teorias racistas foram feitas pra dizer que o negro no caso... é inferior... ao branco então não tem COmo você branco dizer que sofre racismo... porque essa teoria não foi feita pra dizer que você é inferior entendeu? não sei deu pra entender?

L deu pra entender! eu sou muito sua fã me dá um autógrafo? ((risos)) [[EU NÃO TAVA BRINCANDO]] e acho que resumindo dá pra explicar de uma maneira curta... a sociedade está estruturada de uma forma maCHISta miSógina homoFÓbica lesbofóbica transfóbica raCISta então não tem como a gente reverter a sociedade falar ah não mas a heterofobia existe gente eu sofro com isso porque você não sofre

$\mathrm{N}$ não

L não

A refutação da definição de racismo atribuída ao Outro é iniciada por meio de uma pergunta semirretórica que coloca em questão a definição de racismo como ofensa por injúria racial ("racismo é simplesmente você ofender o outro por causa do tom da sua pele?"), definição essa que se relaciona com a concepção individualista que discutimos anteriormente. Trata-se da questão epistêmica subsidiária ( $o$ que é racismo?) que permitirá às youtubers responder à questão nuclear: heterofobia e racismo reverso existem?

A definição de racismo reverso depreendida a partir dos exemplos fornecidos pelo Outro pressupõe uma comparação entre injúrias proferidas contra pessoas brancas e/ou heterossexuais e aquelas voltadas para pessoas negras e/ou LGBT, colocando-as no mesmo patamar de gravidade. As discursividades se chocam, e a definição do Outro é considerada insuficiente/problemática pelo Eu-Nós.

Por meio da contração dialógica: refutação: negação parcial ("não necessariamente"), Nátaly concede que a ofensa por injúria racial é uma das manifestações do racismo, mas não é a única; e quando se volta para pessoas não brancas, carrega consigo uma carga ideológica que não existe quando se volta para pessoas brancas. Assim, a possibilidade de acordo com o Outro (complementariedade ou alternatividade entre as Alegações) é localizada no pólo irrealis ("se fosse assim seria racismo de fato eu falar que alguém é branquelo azedo ou que alguém é cor de leite coalhado"), o que demonstra não apenas dissenso, mas um desacordo profundo (FOGELIN, 2005), posto que a questão se mostra da ordem da factualidade das Alegações em jogo. Por meio da contração dialógica: refutação: contraexpectativa seguida de negação (“mas não"), anula-se a abertura a essa alternativa dialógica. 
Segundo as youtubers, definir racismo e LGBTfobia como questões comportamentais seria insuficiente para dar conta dos aspectos ideológicos e políticos desses fenômenos de forma completa. Consequentemente, a força da Garantia' para estabelecer a interligação entre os Dados' e a Alegação' (Racismo reverso e heterofobia existem) é afetada, contribuindo para a enfraquecimento do fluxo argumentativo.

Tendo rejeitado abertamente a definição atribuída ao Outro, Nátaly apresenta a sua definição por meio uma explanação histórica sobre as origens do racismo. Essa definição é apresentada em forma de contração dialógica: declaração: pronunciamento, localizando o surgimento da ideologia racista ("racismo era realmente um campo de pesquisa") e seus propósitos ideológicos (“então racismo quer dizer que existe um grupo que é inferior e um grupo que é superior”, "quiseram provar de todo modo os negros tinham cérebros menores... que negros... por questões biológicas estavam predispostos ao CRIme... várias dessas questões foram pesquiSAdas estuDAdas e fomenTAdas na sociedade...”).

Assim, de acordo com a definição do Eu-Nós, os Dados’ não podem ser classificados como um tipo de racismo ou de discriminação contra uma determinada sexualidade posto que não atingem o mesmo grau de "estruturalidade" que as opressões que incidem sobre pessoas negras e/ou LGBT.

Para explicitar a incompatibilidade entre os Dados' e a Garantia 1 do Eu-Nós, Nátaly desenha uma "realidade alternativa" na qual existiram o racismo reverso e a heterofobia. Tratase de outro exemplo de região de projeção do discurso do Outro no pólo irrealis, de forma a criar um efeito de absurdo: "então a gente teria daí que voltar... a história inteira fazer com que esses estudos raciais... NUNca tivessem existido...”. Esse efeito torna a definição atribuída ao Outro inaplicável, o que torna a passagem dos Dados’ à Alegação' implausível.

Por fim, a youtuber realiza uma pequena digressão, na qual explicita a noção de "raça" que embasa o seu discurso. Nátaly parte da definição do senso comum de "raça" como conceito biológico, criado pelas ideologias racistas, para apresentar "raça" como conceito sociológico, desenvolvido ao longo do século XX como mecanismo para identificar as consequências discursivas, econômicas, políticas, entre outras, dos séculos de escravidão, do (neo)colonialismo e do imperialismo (GUIMARÃES, 1999).

Para fazer essa diferenciação, ela realiza uma concessão ao discurso do Outro no que se refere à rejeição da raça como conceito biológico. Isso se dá por meio da contração dialógica: declaração: expectativa confirmada: "de fato não existe BIOlogicamente não há nada que diferencie eu e Louie biologicamente sabe? não há nada que me faça ser mais propensa ao crime 
faça a Louie ser uma pessoa mais inteligente", a qual imputa ao auditório o entendimento de que raça em termos biológicos não seja um conceito válido. Isso possivelmente é realizado para antecipar a resistência ao uso do termo "raça", tendo em vista que seu entendimento no discurso cotidiano brasileiro costuma estar ligado ao seu uso na ideologia racista da democracia racial. Assumindo essa resistência à utilização do termo, ela apresenta sua definição por meio da contração dialógica: refutação: contraexpectativa ("MAS existe raça quando a gente fala socialmente"), justificando a sua utilização ("então por isso que a gente levanta a questão da raça"). Esse jogo de expectativa confirmada seguida de contraexpectativa colabora para o estabelecimento de um conhecimento partilhado que é tirado do campo em disputa, favorecendo o prosseguimento da argumentação.

Conectando essa questão ao fluxo argumentativo principal, segue-se uma nova contração dialógica: refutação: contraexpectativa ("MAS as teorias racistas foram feitas pra dizer que o negro no caso... é inferior... ao branco"), que retoma o conceito de biologizante de "raça". Embora Nátaly não subscreva a essa noção (o que se mostra por meio da expansão dialógica: atribuição: distanciamento "[as teorias racistas] foram feitas para dizer"), é importante discuti-la para explicitar a unidirecionalidade do racismo. Dessa forma, ela desautoriza o fluxo argumentativo em apoio à Alegação' sobre a existência do racismo reverso e da heterofobia por meio da contração dialógica: refutação: negação que interpela a parcela branca do auditório que reproduz a Alegação' ("então não tem COmo você branco dizer que sofre racismo... porque essa teoria não foi feita pra dizer que você é inferior”).

Essa desautorização será retomada posteriormente por Louie. Além de aproximar a noção de racismo estrutural apresentado por Nátaly à LGBTfobia de forma monoglóssica ("a sociedade está estruturada de uma forma maCHISta miSÓgina homoFÓbica lesbofóbica transfóbica raCISta"), ela retoma a conjectura construída por Nátaly ("reverter a sociedade") por meio de contração dialógica: refutação: negação e de um nós inclusivo, que ameniza o modal dinâmico ("então não tem como a gente reverter a sociedade"). Esse movimento culmina não apenas na deslegitimação, como na própria invalidação do afeto negativo de insegurança atribuído ao Outro ("falar ah não mas a heterofobia existe gente eu sofro com isso porque você não sofre"), por meio da localização do seu gatilho no pólo irrealis.

Em suma, vemos que, em LN1 e LN2, os movimentos de afastamento epistêmicoaxiológicos se dedicam à discussão da polêmica do racismo reverso e da heterofobia a partir das noções de racismo e LGBTfobia como sistemas de dominação fundantes das relações sociais (LUZ, 2017, p. 162), demonstrando sobretudo os obstáculos que colocam para pessoas 
negras no acesso ao mercado de trabalho, à escolaridade e ao usufruto do espaço público, bem como à diferenciação dos gatilhos que levam aos afetos de insegurança no espaço público para pessoas LGBT. Dessa forma, os critérios de discussão da polêmica apresentados pelo Outro/exogrupo são considerados insuficientes e reforça-se a legitimidade do discurso do endogrupo.

Como discutimos na seção 1.3, trata-se de um caso em que a autoprojeção no campo epistêmico-axiológico do endogrupo atribuída ao Outro é disputada pelo Eu-Nós. Essa disputa se dá pelo reconhecimento de traços da discursividade do exogrupo presentes no comportamento discursivo do Outro. Não depreendemos nele, ao contrário dos demais vídeos analisados, movimentos de aproximação epistêmico-axiológica. Hipotetizamos que isso se deva à extensão da distância epistêmico-axiológica entre os campos do endogrupo e do exogrupo.

De fato, se refletimos sobre os propósitos ideológicos do discurso das discriminações inversas, conforme exposto por Luz (2017), fica evidente que não há acordo entre os defensores das teses do racismo reverso e da heterofobia e aqueles que se opõem a essas ideias a respeito dos propósitos dessa discussão. Isso se deve, possivelmente, ao fato de que, para os primeiros, o objetivo das Alegações parece ter mais a ver com a tergiversação em relação às questões levantadas pelos movimentos do que com discussões de fato dispostas a explorar o aspecto estrutural da discriminação por sexualidade e raça no Brasil. Seriam esses os casos em que, segundo Fogelin (2005), não há possibilidade de efetuação da argumentação e da resolução do conflito, posto que não há acordo prévio a respeito dos critérios de validação e objetivos da discussão.

Sendo assim, estariam todos os vídeos a respeito da polêmica do racismo reverso e da heterofobia restritos à preservação ideológica ${ }^{208}$ - em outras palavras, "rezar a missa para convertidos"? Acreditamos que não.

Consideramos que o objetivo da inserção das youtubers nesta polêmica seja de promover formação política, estabelecendo critérios para debater questões relativas à discriminação por raça e sexualidade como questões que estruturam a sociedade brasileira, e colocam certas populações em situação de marginalidade e vulnerabilidade. Tendo em vista o

\footnotetext{
${ }^{208}$ Conforme Gonçalves-Segundo (2020b, p. 3), a preservação ideológica consiste no "efeito perlocucionário de confirmar uma certa concepção da realidade - por exemplo, uma determinada postura moral contra o aborto -, apresentando Dados e Alegações que já são compartilhados e acordados pelos membros do endogrupo (nós), bem como contrarrefutando argumentações que já são concebidas como inválidas e inconsistentes pelo mesmo grupo. Esse processo está, portanto, vinculado ao reforço dos sistemas de crença dos oradores, com efeitos positivos em termos da construção de identificação intragrupo e da consolidação de repertório de conhecimento, mas também com efeitos negativos em termos de vieses contra perspectivas outras (eles).”
} 
tom didático e o público-alvo dos canais, as aproximações entre as noções de racismo e LGBTfobia efetuadas ao longo do vídeo servem também para sugerir relações de solidariedade entre os movimentos negros e LGBT - o que é implicado também pela própria parceria entre os canais.

Assim, entendemos que, embora o vídeo esteja voltado primariamente para pessoas que já compartilham, em certo grau, o posicionamento das youtubers - e, portanto, não precisariam ser convencidas de toda a sua visão de mundo, mas talvez desejem conhecer melhor o seu embasamento -, ele também leva em consideração a audiência que, ainda que reproduza a tese do racismo reverso e da heterofobia, ou não tenha uma opinião formada, considera-se filiada às discursividades que embasam os conteúdos dos canais (nomeadamente no que se refere a valores progressistas e a lutas antiopressão).

Em suma, compreendemos que o vídeo faz referência a uma questão que, no debate público, consiste em um desacordo profundo, e seu objetivo não é resolvê-lo por meio do debate com seu antagonista, mas apresentar para o auditório dos canais o que está em jogo para o endogrupo nessa discussão. Definindo as fronteiras epistêmico-axiológicas do posicionamento do endogrupo, a questão se torna ética/moral e remete ao tensionamento da filiação discursiva do Outro enquanto progressista, antirracista e antiLGBTfobia ${ }^{209}$. Dessa forma, os movimentos de afastamento epistêmico-axiológico realizados dão sustentação à disputa das projeções do Outro no espaço discursivo. Em outras palavras, reproduzir as teses do racismo reverso e da heterofobia demonstram um não alinhamento ao discurso do endogrupo e, de todo modo, interessa às youtubers apresentar suas críticas a essas teses por considera-las prejudiciais para o avanço das suas pautas.

Por outro lado, acreditamos que as aproximações entre os sistemas de dominação com base em raça, sexualidade e identidade de gênero efetuadas pelas youtubers no vídeo contribua também para instigar uma relação de solidariedade entre esses grupos e movimentos sociais, considerando que se trata de um vídeo que se apoia na definição de racismo estrutural para debater também o caráter estrutural da heteronormatividade e da LGBTfobia.

Além disso, essa estratégia colabora também para chamar a atenção da audiência de Louie para a questão do racismo estrutural. Tendo em vista que o foco do canal da Louie é sexualidade e não raça, essa é uma discussão que não aparece de forma tão marcada em outros vídeos e, portanto, a colaboração de Nátaly - cujo estilo do canal (em termos de linguagem e

\footnotetext{
${ }^{209}$ Referimo-nos ao turno de Nátaly em que ela define o posicionamento do Outro como "falta de empatia" e “desonestidade (linhas 79-90)
} 
público-alvo) se assemelha bastante ao da Louie, nomeadamente na combinação do discurso intelectual e ativista com um propósito de formação política -, não só respeita uma "etiqueta do lugar de fala" (no sentido convidar uma mulher negra ativista para gravar um vídeo sobre racismo), como também divulga as pautas dos movimentos negros dentro do canal da Louie.

De forma análoga, o fato de ter sido postado no canal de uma youtuber branca com a participação de uma ativista negra, sua configuração temática (que por vezes privilegia a discussão racial) e da articulação dessas vozes (que se complementam e se apoiam mutuamente) colabora para conformar uma imagem de branquitude crítica para Louie (CARDOSO, 2010), posto que assim ela "desaprova o racismo publicamente" (CARDOSO, 2010, p. 611). Esse aspecto é inclusive ironizado pelas youtubers ao final do vídeo, quando elas se referem à fama de "racista reversa" de Nátaly na internet e invertem as infames afirmações "não sou racista/homofóbico, tenho até amigos que são negros/LGBT" nas perguntas: "você não tem amigos brancos/hétero?" (linhas 123-147).

Nos trechos discutidos a seguir, a filiação discursiva do Outro também se mostra ambígua. Por outro lado, neste caso, o Outro é compreendido como parte do endogrupo devido à identidade atribuída à entidade pela própria youtuber. No vídeo "RÓTULOS ME LIMITAM OU ME DEFINEM?”, Louie discute duas Propostas de Ação que se pretendem capazes de atingir o Objetivo comum: Viver em uma sociedade em que a sexualidade não seja motivação para preconceito, violências físicas ou simbólicas, na qual não seja necessário "dar satisfação" para ninguém.

Para tanto, o espaço discursivo é dividido entre a filiação discursiva ao endogrupo (progressista e pró-LGBT) e ao exogrupo (conservador e LGBTfóbico). O Eu-Nós, defendendo a Proposta de Ação Rotule-se ("saia do armário" e Engaje-se no movimento LGBT), está projetado no campo epistêmico-axiológico do endogrupo, enquanto o Outro, a quem é atribuída a Contra-Proposta de Ação Não se rotule, é textualmente projetado no campo do exogrupo. No entanto, o Outro corresponde a pessoas não heterossexuais não assumidas e, por isso, Louie tensiona o seu posicionamento. Ela o faz, entretanto, de forma sutil, elaborando tanto movimentos de afastamento, quanto de aproximação epistêmico-axiológica. Estes sugerem que, apesar de haver diferenças, o compartilhamento de experiências é mais relevante, sugerindo uma relação de solidariedade entre o Eu e o Outro que pode instigá-la/lo a fazer parte do Nós.

Veremos com a análise do trecho L1, exposto a seguir, que o movimento de afastamento epistêmico-axiológico focalizado participa de duas dimensões da Refutação do movimento argumentativo do Outro. A primeira nega a possibilidade de aplicação do Valor da Igualdade 
(no texto, apresentado como "o discurso da falsa igualdade") para orientar as pautas e estratégias do movimento LGBT, enquanto a segunda dimensão defende que apenas o Valor da Equidade - e consequentemente as Proposta de Ação do Eu-Nós - é capaz de lidar com "violências específicas".

L1) L mas peraí Louie a gente é tudo igual a gente é tudo ser humano NÃO a gente não É tudo igual não existe isso de ser tudo igual... a questão é que algumas diferenças são aceitáveis na sociedade e outras diferenças não são aceitáveis... e essas diferenças não aceitáveis provocam processos de exclusão de desigualDAde de vioLÊNcia de preconceito... e pessoas que fazem parte desses grupos inclusive ao longo da história tiveram a sua PRÓpria humanidade neGAda então como é que a gente pode falar que a gente é tudo igual que a gente é tudo humano se na prática as coisas são bem diferentes? esse discurso de que nós somos todos iguais é usado justamente para manter esse sistema de excluSÃO e pra gente não discuTIR pra gente não levantar as nossas pautas porque como é que a gente vai lutar contra violências específicas que a GENte sofre se a GENte reproduz o discurso da falsa igualdade?

A visão de mundo alternativa é apresentada por meio simulação da interpelação do Outro, que introduz na discussão o Valor da Igualdade por meio da contração dialógica: refutação: contraexpectativa ("mas peraí Louie a gente é tudo igual a gente é tudo ser humano"). Por um lado, essa interpelação se configura como uma expansão dialógica: atribuição: reconhecimento, posto que inclui a alternativa dialógica no texto. Por outro, na lógica do discurso do Outro, constitui uma contração dialógica: declaração: pronunciamento, posto que se contrapõe ao discurso de aceitação das diferenças anteriormente apresentada pela youtuber ("a gente tem que pensar se essa escolha em não se rotular na verdade não é um mecanismo de deFEsa e uma rePULsa à sua sexualidade e ao fato de você ser diferente") e à Proposta de Ação Rotule-se (Assuma sua sexualidade abertamente).

Em resposta, Louie realiza uma contração dialógica: refutação: negação categórica (“NÃO a gente não É tudo igual não existe isso de ser tudo igual...”), o que elimina o espaço de aceitabilidade dessa alternativa dialógica no campo epistêmico-axiológico do Eu-Nós. A partir disso, ela avança o próprio entendimento a respeito do assunto com a contração dialógica: declaração: pronunciamento ("a questão é que algumas diferenças são aceitáveis na sociedade e outras diferenças não são aceitáveis") para demonstrar as divergências entre a visão da "falsa igualdade" e o que ela entende como a realidade da estruturação da sociedade.

Para tanto, ela retoma a noção de que "somos todos iguais" por sermos todos "humanos" para salientar o fato de que aquilo que se entende como "humanidade" não é um aspecto 
garantido a todas as pessoas indiscriminadamente ("e essas diferenças não aceitáveis provocam processos de exclusão de desigualDAde de vioLÊNcia de preconceito... e pessoas que fazem parte desses grupos inclusive ao longo da história tiveram a sua PRÓpria humanidade neGAda"). Ser LGBT, por exemplo, seria um indício de que a pessoa é "menos igual" ou "menos humana" (em relação a pessoas heterossexuais) numa sociedade heteronormativa.

A partir do estabelecimento do contraste entre as alternativas dialógicas, a pergunta semirretórica "então como é que a gente pode falar que a gente é tudo igual que a gente é tudo humano se na prática as coisas são bem diferentes?" (contração dialógica: declaração: pronunciamento), por sua vez, assume a forma de contração dialógica: refutação, posto que reforça a incompatibilidade entre o Valor da Igualdade e o campo epistêmico-axiológico do EuNós, apresentando este como factual, localizando-o no pólo realis. Assim, o Valor da Igualdade não apenas é colocado como diferente daquele preconizado pelo Eu-Nós e pelo endogrupo (Equidade) - o que já coloca em questão a filiação discursiva do Outro -, como também é considerado inadequado para orientar Propostas de Ação eficazes e efetivas para o alcance do Objetivo em questão devido à ineficácia do Meio-Fim (Não se assumir abertamente retira a motivação para o preconceito, violências físicas e simbólicas) para solucionar o problema no longo prazo. Consequentemente, também a leitura do estado-de-coisas atribuída ao Outro é tensionada e considerada insuficiente para explicar a LGBTfobia no Brasil.

Esse movimento culmina na apresentação de possíveis Consequências Negativas relacionadas à Contra-Proposta de Ação, que seriam responsáveis não apenas pela manutenção do estado-de-coisas, mas também pelo seu agravamento ("esse discurso de que nós somos todos iguais é usado justamente para manter esse sistema de excluSÃO e pra gente não discuTIR pra gente não levantar as nossas pautas. A Contra-Proposta de Ação seria, portanto, um marcador da cooptação do Outro pelo discurso do exogrupo. ”). Essa incoerência é denunciada na pergunta retórica: "porque como é que a gente vai lutar contra violências específicas que a GENte sofre se a GENte reproduz o discurso da falsa igualdade?".

Dessa forma, o vídeo reflete o propósito indicado no título de propagar o Orgulho LGBT, afirmando essas identidades positivamente e salientando sua importância política e subjetiva. Dessa forma, a youtuber conecta essas duas dimensões, mostrando como

[...] o empoderamento individual e o coletivo são duas faces indissociáveis do mesmo processo, pois o empoderamento individual está fadado ao empoderamento coletivo, uma vez que uma coletividade empoderada não pode ser formada por individualidades e subjetividades que não estejam conscientemente atuantes dentro de processos de empoderamento. (BERTH, 2019, p. 54) 
Ademais, a conexão realizada entre a dimensão subjetiva e estrutural é apoiada também pela menção a projetos como a "cura gay" e o combate à "ideologia de gênero" nas escolas, o que implica a necessidade de participação política nas questões que atingem a comunidade LGBT. Nisso consiste o Meio-Fim do Eu-Nós (Assumir-se LGBT de forma visível (combater a invisibilização) e lutar pelos direitos LGBTTIAPN+ (combater violências físicas e simbólicas) levará a uma sociedade na qual a sexualidade não é motivação para violências físicas e simbólicas) que sustenta a Proposta de Ação Engaje-se no movimento LGBT como um caminho viável para atingir o Objetivo comum.

Assim como no vídeo "YOUTUBER SÓ FALA MERDA NA INTERNET? Feat. Louie Ponto", aqui o Outro é considerado um membro do endogrupo. Entretanto, neste caso, a diferença epistêmico-axiológica se faz mais marcada, posto que as posições das entidades em relação à questão não se mostram complementares, mas diametralmente oposta. No caso, a posição não coloca em xeque apenas a posição da youtuber, mas a razão de ser do movimento LGBT como um todo.

De fato, como veremos na próxima seção, o que é construído como região de proximidade epistêmico-axiológica diz respeito aos Objetivos comuns. Já as leituras do estado de coisas aparentam um acordo - posto que concebem a sociedade brasileira como machista e LGBTfóbica -, mas ele mesmo é matizado num processo complexo de aproximação e afastamento, que será analisado na seção 2.3.

O que é entendido como diferença entre o Eu-Nós e o Outro, então, são as leituras mais aprofundadas do estado de coisas. No caso do complexo Eu-Nós, a leitura se apoia no entendimento da heteronormatividade como uma questão estrutural e da LGBTfobia enquanto sintoma de um sistema de dominação. Ao Outro, é atribuído um entendimento da LGBTfobia como uma questão apenas comportamental.

Em termos da estrutura argumentativa do raciocínio, isso se traduz também nas diferenças entre os Valores que orientam cada fluxo argumentativo, o Meio-Fim que legitima as diferentes Propostas de Ação e as Consequências Positivas/Negativas relacionadas a cada uma, como vimos na seção 1.4. É nesses elementos que está focalizada a tensão dialógica do vídeo e sobre os quais Louie se detém por mais tempo.

Isso se justifica pelo fato de que, sendo um especial do Dia do Orgulho LGBT, o objetivo do vídeo é justamente afirmar positivamente as identidades LGBT, salientando sua importância política e subjetiva. Dessa forma, o acolhimento e a superação das dores subjetivas são entendidos de forma coletivizada, e os movimentos LGBT são representados como o espaço 
político e social capaz de dar conta das demandas subjetivas e políticas. A youtuber reafirma seu compromisso com a comunidade LGBT como um todo e com as/os atoras/es sociais que compõem sua audiência, mostrando-se disposta e interessada em suas questões pessoais. Veremos nas seções seguintes como essa disposição é utilizada como estratégia discursiva para criar regiões de proximidade epistêmico-axiológica e também delimitar as fronteiras entre os campos epistêmico-axiológicos e sustentar a denúncia da cooptação do Outro pelo discurso LGBTfóbico.

Nesta seção, exploramos em detalhe como os movimentos de afastamento epistêmicoaxiológico se processam numa dimensão microlinguística, realizando conexões com os seus efeitos em termos argumentativos e discursivos. Dessa forma, pudemos tecer algumas considerações das consequências da Movimentação Epistêmico-Axiológica para as estratégias elaboradas pelas youtubers no que diz respeito à sua inserção nos debates envolvidos nos vídeos analisados. Percebemos que mecanismos textual-interativos realizados por meio dos recursos da AvALIATIVIDADE se mostraram essenciais tanto para a delimitação de fronteiras epistêmicoaxiológicas, quanto para explicitar o grau de dissenso e, consequentemente, a distância epistêmico-axiológica que separa o Eu-Nós e o Outro.

Vimos que olhar para a linguagem dessa forma nos possibilitou depreender as estratégias utilizadas na apresentação da perspectiva do Eu-Nós e na projeção do campo epistêmico-axiológico do Outro. Assim, pudemos discutir as diferentes formas pelas quais o dissenso foi gerido - seja por meio da negociação de divergências, ou por meio da explicitação da existência de um desacordo profundo.

\subsubsection{Movimentos de aproximação epistêmico-axiológica}

Os movimentos de aproximação epistêmico-axiológica consistem na criação de regiões de proximidade epistêmico-axiológica, isto é, a projeção de pontos de acordo entre as diferentes discursividades e pontos de vista das entidades projetadas no espaço discursivo. Essas regiões podem ser criadas por meio da apresentação de pressupostos construídos como comuns, pela concessão à perspectiva do Outro, ou ainda pela sugestão de acordos entre valores, crenças ou visões de mundo com base nas intersecções entre os campos epistêmico-axiológicos do Eu-Nós e do Outro a respeito do assunto em discussão.

Tais regiões se mostram importantes na construção dos movimentos argumentativos epistêmicos e práticos, possivelmente contribuindo para a orientação da leitura do texto (que pode se tornar mais ou menos resistente ou complacente, por exemplo) e, portanto, também para o convencimento e/ou persuasão de determinados auditórios. Além disso, elas permitem à 
analista depreender os pontos de tensão dialógica que favorecem a construção de laços de solidariedade entre as entidades discursivas, num primeiro plano, e entre comunidades discursivas e grupos sociais, mais amplamente.

Ademais, a ausência/presença de movimentos de aproximação epistêmico-axiológicos também se mostraram relevantes para a percepção acerca do grau de dissenso entre as posições argumentativas em disputa nos textos. No vídeo "HETEROFOBIA E RACISMO REVERSO EXISTEM?", por exemplo, que trata de uma polêmica de desacordo profundo, não depreendemos regiões de proximidade epistêmico-axiológica ao longo do texto.

O vídeo “POR QUE VOCÊ É TÃO AGRESSIVA, NÁTALY?” também consiste em um caso em que os campos epistêmico-axiológicos em disputa se mostram antagônicos, e o tópico em discussão se assemelha a um desacordo profundo. No entanto, neste caso, há uma região de proximidade epistêmico-axiológica, construída a partir de pressupostos feministas supostamente compartilhados pelo Outro para angariar apoio à posição do Eu-Nós.

Nesta seção, os trechos selecionados permitirão discutir uma gama variada de usos argumentativos da aproximação epistêmico-axiológica, tais como a projeção de pressupostos comuns para introduzir a leitura autoral do estado-de-coisas (N5), a apresentação de Objetivos comuns (L2) e a transformação de Propostas de Ação concorrentes em Propostas de Ação complementares (NL3 e NL4).

O primeiro excerto sob análise foi retirado do vídeo "POR QUE VOCÊ É TÃO AGRESSIVA, NÁTALY?”. Conforme indicado nas seções 1.1 e 2.1, o vídeo parte da questão argumentativa do título para realizar um reenquadramento do problema epistêmico, configurando-o também como um problema prático. Para tanto, a youtuber opera uma discussão a respeito dos estereótipos sobre a mulher negra - sobretudo no que se refere à mulher negra raivosa - para refutar os ataques realizados a respeito de sua imagem e colocar em questão os próprios comentários por meio dos quais eles são realizados. Assim, a filiação discursiva das tais críticas "construtivas" e "bem-intencionadas" é colocada em destaque, desvelando a sua função nas práticas de policiamento de tom e silenciamento de mulheres negras.

Para iniciar esse processo, Nátaly constrói uma região de proximidade axiológica como ponto de partida para a discussão. Ela está transcrita em N5 (linhas 20-25)

N5) N infelizmente ser chamada de louca histérica raivosa não é um privilégio meu... infelizmente mulheres já são tidas como histéricas há muito tempo... só que mulheres NEgras especificamente desenvolvem um OUtro tipo de histeria social que é a RAIva o Ódio a descompensaÇÃO... isso faz parte dos estereótipos construídos a respeito de nós de nossa imagem... estereótipos que foram criados 
pro controle social... eu já falei aqui em um vídeo anterior sobre os três principais estereótipos...

A construção desse acordo é realizada por meio da expansão dialógica: atribuição: distanciamento ("infelizmente ser chamada de"), que atribui a uma discursividade hegemônica - nomeadamente, o discurso machista ou sexista, característico do exogrupo - o uso de adjetivos como "louca", "histérica" e "raivosa" para descrever mulheres em geral. Isso é apresentado como um problema para o grupo social mulheres e não apenas para Nátaly individualmente, alçando a questão a um patamar social por meio da contração dialógica: refutação: negação ("não é um privilégio meu").

Além disso, o problema não é considerado episódico nem recente, mas recorrente, estendendo-o no eixo temporal em direção ao passado - sugerindo uma conceptualização semelhante àquela discutida nos exemplos de campo em resistência (N3 e N4) expostos na seção anterior. Isso é realizado por meio de um enunciado construído de forma monoglóssica (“infelizmente mulheres já são tidas como histéricas há muito tempo...”) no que se refere à factualidade do uso desses estereótipos (não há dúvidas de que mulheres de fato são vistas dessa forma). A expansão dialógica: atribuição: distanciamento ("já são tidas como histéricas há muito tempo"), por sua vez, atribui essa concepção sobre as mulheres à discursividade hegemônica do exogrupo.

O estereótipo da mulher histérica age no sentido de descreditar a perspectiva das mulheres críticas em relação à vida social, posto que suas reclamações e denúncias seriam sintomas de uma indisposição nervosa, e não de sua intelectualidade, por exemplo. Marcelo Honório e Luciana Borges (2018, p. 319) afirmam que

A histeria, dada como doença, oprimiu muitas mulheres no decorrer do tempo. Condicionada como patologia feminina, veio a servir como mais uma ferramenta de opressão e controle do corpo feminino, muitos a usaram como justificativa para silenciar mulheres que transgrediam os valores morais impostos a elas. Uma sociedade patriarcal e falocêntrica não quer reconhecer uma mulher de voz ativa, pensante e dona do próprio corpo, transitando em qualquer âmbito.

Por meio desse estereótipo, "De acordo com Simões (2007), a principal característica dada às histéricas é a insatisfação, insatisfeitas com a vida que têm, sem a concretude de seus desejos, estão sempre se queixando, sempre em busca de reconhecimento"; para controlar suas "tristezas mal compreendidas", "elas são criticadas por muitos e medicadas por outros" (HONÓRIO; BORGES, 2018, p. 320-321). 
Esse entendimento, comum não só às diversas vertentes feministas, como também parte do arcabouço de experiências pessoais de muitas mulheres, permite estabelecer um laço de solidariedade com feministas e mulheres em geral que concordam com a percepção de Nátaly. Esse laço é aproveitado para promover a adesão aos movimentos argumentativos de Nátaly em prol de suas Alegações e Proposta de Ação posteriormente, favorecendo leituras menos resistentes - sobretudo no que se refere às críticas sobre os comentários e ao processo de revisão de crenças.

Assim, embora haja uma responsabilização do exogrupo enquanto comunidade epistêmica acerca dos estereótipos sobre mulheres, constrói-se uma região de proximidade epistêmico-axiológica em relação ao Outro ${ }^{210}$, uma vez que o entendimento de que essa representação é inadequada é imputado como factual, pré-legitimado por ambas as comunidades discursivas.

Dentro dessa região de proximidade epistêmico-axiológica, Nátaly desenvolve as especificidades do uso do estereótipo da mulher histérica sobre mulheres negras, as quais serão introduzidas por meio de dois mecanismos: o ENGAJAMENTO e o AFETO. Assim, por meio da contração dialógica: refutação: contraexpectativa "só que" Nátaly salienta o fato de que os estereótipos operam sobre mulheres negras (Nós) de forma diferente do modo como operam com mulheres não negras - sobretudo brancas.

Ressaltamos que a histeria é um tipo de psicose que foi considerada tipicamente feminina (considerando uma corporalidade prototipicamente cis), posto que se supunha que tivesse origem no útero. Esteve ligada, portanto, aos discursos de patologização de mulheres em geral, consideradas emocionalmente instáveis e inferiores intelectualmente. Há que se considerar, no entanto, como esse estereótipo se articulou a outras matrizes de dominação além do sexismo para agir sobre mulheres.

Assim, enquanto o estereótipo da histeria sobre mulheres negras assume a forma de ódio e raiva, que denotam agressividade e ameaça física a outras pessoas, no que se refere a mulheres brancas ele denota uma fragilidade inata e a languidez. Portanto, embora sirva para legitimar violências contra mulheres em geral em termos do controle dos corpos, ele age de formas diferentes de acordo com linhas raciais.

Essa diferença é explicitada também por meio da diferença na escolha lexical, que codifica os afetos que constituem as diferentes representações de "feminilidades desviantes".

\footnotetext{
${ }^{210}$ Essa ambiguidade em relação à posição epistêmico-axiológica dessa entidade se deve à representação dos comentários realizada por Nátaly no início do vídeo (linhas 6 -14), já comentados na nota-de-rodapé anterior.
} 
De acordo com o dicionário Michaelis, a histeria consiste em "falta de controle de atos e emoções", o que leva a sintomas emocionais e físicos (HISTERIA, 2020), enquanto a descompensação pode ser "falha ou colapso no funcionamento do sistema de defesa, que favorece o comportamento psicótico" (DESCOMPENSAÇÃO, 2020). A raiva, por sua vez, é caracterizada como "violento acesso de fúria; cólera, ira", um "estado ou sentimento de rancor causado por irritação, aborrecimento ou rejeição." (RAIVA, 2020), e o ódio é concebido como "aversão ou repugnância que se sente por alguém ou por alguma coisa; antipatia, desprezo, enzona, odiosidade", "rancor profundo e duradouro que se sente por alguém" (ÓDIO, 2020).

Vemos, assim, que a histeria, do mesmo como que a descompensação, consiste em afetos sem gatilho nem direcionamento aparente. No entanto, a descompensação, em específico, denota uma predisposição à psicose, o que sugeriria, de acordo com o discurso relatado por Nátaly, a concepção de que mulheres negras teriam uma predisposição natural à histeria - mais do que mulheres brancas, por exemplo. Já a raiva e o ódio são gerados por um gatilho específico, e são caracterizados por uma alta intensidade e por maior probabilidade de motivarem ataques físicos a outras pessoas do que a simples histeria - que se manifesta por meio de "crises nervosas, catalepsia, paralisias etc., além de distúrbios psíquicos como o onirismo, a amnésia, a mitomania e outros" (HISTERIA, 2020). Assim, a descrição realizada por meio dos termos "descompensação", "raiva" e "ódio" denota um potencial ameaçador, invocando julgamentos negativos combinados de propriedade: violência e veracidade, construindo mulheres negras como intimidadoras, imprevisíveis e não confiáveis, e, assim, legitimam ações preventivas para impedir que essa suposta ameaça se realize.

Entendemos que a recuperação de pressupostos do paradigma feminista ou de experiências comuns possam contribuir para a criação de uma região de proximidade epistêmico-axiológica que facilitaria o processamento de empatia episódica e, consequentemente, estabeleceria um senso de solidariedade entre mulheres potencialmente capaz de orientar a leitura do auditório - sobretudo de mulheres não negras que, pelas razões apresentadas acima, poderiam estar mais propensas a realizar uma leitura (mais) resistente do vídeo.

A estratégia realizada em N5 leva o auditório a refletir sobre o fato de que o estereótipo da mulher histérica age de modos diferentes como forma de silenciamento de mulheres negras e não negras, podendo operar, inclusive, dentro dos próprios movimentos feministas. Assim, a reflexão sobre os estereótipos das mulheres negras é vista não como um "recorte da experiência feminina universal", mas como um modo de articulação discursiva das matrizes de dominação 
racistas e sexistas que diz respeito não só a mulheres negras, mas também (e talvez principalmente) a mulheres e pessoas brancas em geral - posto que são elas que mobilizam esses estereótipos e usufruem de suas consequências como forma de silenciamento de mulheres negras na esfera pública com vistas à manutenção do status quo.

Em suma, o vídeo apresenta as especificidades dos estereótipos sobre mulheres negras e os seus propósitos político-ideológicos a partir do pressuposto de que esse é um tema que diz respeito às mulheres em geral, tendo em vista que se trata de uma das variações dos estereótipos sexistas que visam a policiar o tom de mulheres que denunciam questões sociais. Trata-se de uma estratégia especialmente relevante do ponto de vista dos conteúdos feministas que se voltam para a discussão das consequências do entrecruzamento de opressões.

O debate entre as "vertentes feministas" tem se mostrado uma questão relevante nas práticas discursivas dos ativismos digitais. As diferenças, divergências e conflitos entre o feminismo negro e o que se convencionou chamar "feminismo branco" - tanto enquanto paradigmas teóricos, como enquanto agendas e práticas - colocam em pauta a pergunta levantada por Sueli Carneiro (2019 [2003]): “de que mulheres estamos falando?”. Explanar essas tensões desafia e questiona o feminismo branco hegemônico e suas assunções acerca da universalização da categoria “mulher”, realizadas com base nas experiências, questionamentos, pontos de vista (não raro eurocentrados, ainda que produzidos em territórios não europeus) e posições ocupadas por mulheres brancas de classe média.

Como consequências práticas, poderíamos sugerir, neste caso, uma possível mudança na relação sugerida entre as comunidades discursivas referidas. Embora seja construída como antagônica no decurso dos movimentos de afastamento, Nátaly abre espaço, nesse momento, para um possível laço de solidariedade (a depender da disposição para a Proposta de revisão de crenças e mudança do comportamento discursivo).

Ao contrário do vídeo anterior, o trecho a seguir discute relações de solidariedade dentro do endogrupo progressista. Entretanto, ao contrário de N5, no vídeo "YOUTUBER SÓ FALA MERDA NA INTERNET? Feat. Louie Ponto”, também postado pelo canal Nátaly Neri, não há divisão do espaço discursivo entre endogrupo e exogrupo.

Como discutido na seção 1.2, no ano da publicação deste vídeo, o debate entre o campo político progressista a respeito da atuação de ativistas e militantes em plataformas online era fonte de grandes disputas à época da publicação do vídeo (15 de abril de 2017). Quando os campos epistêmico-axiológicos do Eu-Nós e do Outro foram apresentados nas subseções 1.2 e 2.2, discutimos o papel dos movimentos de afastamento epistêmico-axiológico para a defesa do 
YouTube enquanto plataforma para a criação de comunidades engajadas realizada pelas youtubers. Esse posicionamento se contrapunha ao entendimento de que essa plataforma seria esvaziada politicamente, o que inviabilizaria a produção de conteúdo crítico de qualidade capaz de alcançar uma audiência significativa e, no longo prazo, contribuir para a criação de comunidades engajadas em questões políticas e sociais.

Aqui, analisaremos os trechos NL3 e NL4, que correspondem às linhas 58-90 da transcrição. Neste trecho, as youtubers apresentam sua concepção em relação ao papel de seus canais dentro da esfera de práticas ativistas, o que participa da defesa de sua Proposta de Ação. Como apontamos na seção anterior, as fronteiras epistêmico-axiológicas entre o Eu-Nós e o Outro deste vídeo se mostram mais "permeáveis" do que as dos outros vídeos.

Textualmente, isso se manifesta em traços linguísticos dos próprios movimentos de afastamento epistêmico-axiológicos, que são compostos por concessões, demonstrando que, mesmo no dissenso, as youtubers buscam ressaltar os acordos entre as posições. Hipotetizamos que isso derivaria do fato de que todas as entidades são projetadas no campo mais amplo do endogrupo, e, portanto, não haveria necessidade, por parte das youtubers, de realizar uma disputa em relação à filiação discursiva do Outro nesse caso. Pelo contrário, vimos que, mais do que agir para refutar a posição contrária, o esforço argumentativo estava voltado para o fortalecimento da visão das mesmas a respeito do papel dos ativismos digitais para os movimentos progressistas.

Por esses motivos, as análises de NL3 e NL4 se voltarão para a verificação das formas pelas quais as regiões de proximidade epistêmico-axiológica criadas no trecho contribuem para a explicitação de concordâncias entre as entidades e, consequentemente, para a criação de um laço de solidariedade que legitimaria a posição pretendida pelas ativistas no campo dos ativismos progressistas.

NL3) N mas é muito complicado o nosso tipo de conteúdo tamBÉM... especificamente porque a gente fala sobre feminismo né... a gente tá falando publicamente a gente tá falando sobre algo que não é meu e que não é da Louie a gente tá falando sobre questões que são de movimento obviamente que a gente não consegue abarcar tudo isso... por conta dos nossos limites enquanto pessoas

L sim eu não vou poder falar sobre e POR nenhuma outra lésbica na verdade eu falo sobre a minha experiência mas é claro que com minha experiência eu acabo falando sobre outras pessoas porque é uma questão não é individual é uma questão poLÍtica só que eu tenho certeza que existe um limite também...

$\mathrm{O}$ trecho vem imediatamente em seguida a NL2, no qual as youtubers realizam movimentos de afastamento epistêmico-axiológicos para apresentar as discordâncias entre o 
Eu-Nós e o Outro a respeito da natureza do YouTube enquanto plataforma e de suas consequências para as práticas de ativismos digitais realizadas por meio da mesma. Em NL3, por outro lado, são explicitadas as concordâncias a respeito dos ativismos progressistas em geral - em especial, o feminismo, que afinal é um dos elementos que une os dois canais. Aqui, a região de proximidade epistêmico-axiológica colabora para a legitimação de seu estatuto como ativistas aos olhos do auditório.

Para tanto, Nátaly reafirma a centralidade dos princípios feministas para a orientação dos conteúdos do canal por meio de uma contração dialógica: refutação: contraexpectativa ("mas é muito complicado o nosso tipo de conteúdo tamBÉM... especificamente porque a gente fala sobre feminismo né...”), que se contrapõe à ideia de que o conteúdo dos canais seria orientado pelas marcas e empresas com as quais elas trabalham. Mais do que isso, a contraexpectativa sugere que haveria, na verdade, uma tensão entre as youtubers e esses agentes, tendo em vista que o discurso feminista exposto em seus canais não depende apenas de suas opiniões pessoais, mas envolve estudo, debate e, em certa medida, a consideração de uma espécie de "posicionamento coletivo" ("a gente tá falando publicamente a gente tá falando sobre algo que não é meu e que não é da Louie a gente tá falando sobre questões que são de movimento").

Por outro lado, a contração dialógica: declaração: expectativa confirmada (“obviamente que a gente não consegue abarcar tudo isso... por conta dos nossos limites enquanto pessoas") sugere uma antecipação a possíveis críticas a respeito do enunciado anterior. Em outras palavras, embora a teoria e a prática feministas permitam que elas extrapolem suas experiências pessoais na hora de realizar análises sociais, as youtubers reconhecem que existem limites para a abrangência de seus conteúdos - sejam as suas experiências pessoais, ou seu grau de conhecimento em relação a determinados assuntos. Possivelmente, este trecho invoca um julgamento positivo de veracidade a respeito das youtubers, por salientarem suas falhas e limitações.

Enfatizar que seus conteúdos apresentam certos limites está ligado com dois princípios que orientam grande parte dos modos de ação dos ativismos digitais: a representatividade e o lugar da experiência (que poderiam ser condensados na noção de lugar de fala como estratégia para garantir, por exemplo, o protagonismo de mulheres lésbicas na hora de discutir suas próprias experiências, pautas e pontos de vista). Eles se traduzem, em parte, nas práticas de compartilhamento de narrativas pessoais na internet, seja em posts de grupos fechados de 
discussão, ou por meios públicos ou anônimos em campanhas como \#MeuPrimeiroAssédio e \#EuEmpregadaDoméstica.

Essas práticas colaboram para a construção de um conhecimento comum orientado pela leitura, compartilhamento e discussão a respeito das semelhanças e diferenças a respeito de experiências de vida relacionadas a uma situação de violência ou da posição social ocupada no ambiente de trabalho, por exemplo. Assim, embora as discussões dos canais façam referência a debates acadêmicos e do interior dos movimentos sociais, elas explicitam o caráter localizado das suas interpretações e referências a respeito dessas discussões.

Esse processo de construção de um posicionamento coletivo a partir do compartilhamento de experiências e pontos de vista pessoais é também explorado por Louie. Por meio da contração dialógica: declaração: expectativa confirmada, ela salienta o fato de que não se pretende "porta-voz" das mulheres lésbicas, e que as questões subjetivas que ela trabalham são oriundas das reflexões empreendidas a respeito de suas experiências pessoais ("sim eu não vou poder falar sobre e POR nenhuma outra lésbica na verdade eu falo sobre a minha experiência").

Por outro lado, a contração dialógica: refutação: contraexpectivativa ("mas") combinada com contração dialógica: declaração: expectativa confirmada ("é claro que") articula essa dimensão subjetiva às discussões sociais e políticas realizadas no canal ("com minha experiência eu acabo falando sobre outras pessoas porque é uma questão não é individual é uma questão política"). Em outras palavras, ela defende que, embora haja limites, existem questões que perpassam as experiências de mulheres lésbicas brasileiras em geral.

Essas diversas iterações de contração dialógica: declaração: expectativa confirmada demonstram não apenas sua concordância com Nátaly, mas também imputam ao auditório a mesma percepção. Nesse sentido, a região de proximidade axiológica entre o Eu-Nós e o Outro é construída a partir dos princípios que elas julgam relevantes tanto para a sua produção, quanto para as estratégias de movimentos feministas em geral - em especial aqueles que se identificam com as práticas de pluralização dos "feminismos da diferença", conforme discutimos no capítulo 1 .

Esse processo continua em NL4, no qual as youtubers exploram o seu propósito no ativismo digital e qual a função que elas atribuem a si mesmas dentro do campo progressista.

NL4) L [...] sabe o que eu penso antes de produzir um conteúdo? antes de gravar um vídeo? eu penso assim se eu fosse adolescente como eu me sentiria?

$\mathrm{N}$ eu penso a mesma coisa eu penso a mesma coisa 
L porque eu não tive isso eu não tive representatividade é uma coisa muito importante e quando eu era criança quando eu era adolescente foi muito difícil pra mim porque eu não via representatividade [...]

L existe toda uma vida fora da internet existe um ativismo fora da internet que é MUIto importante e que já tem uma história então de maneira nenhuma a gente pode desmerecer esse tipo de ativismo

$\mathrm{N}$ muito pelo contrário a gente só está aqui porque esse ativismo foi feito

L e nos trouxe até aqui

$\mathrm{N}$ exatamente

L foi muita leitura da minha parte foi muita:... é foi uma conscientização pessoal primeiro que me trouxe até aqui... e/e o meu objetivo e a minha vontade é justamente de compartilhar este conhecimento

$\mathrm{N}$ eXAtamente é muito importante também as pessoas verem a gente não como criadoras de um conhecimento muitas vezes mas como PONte pra que esse conhecimento flua

L e [[O ATIVISMO DIGITAL É MUITO IMPORTANTE]] o ativismo digital é muito importante porque às vezes é a única porta de entrada que algumas pessoas têm

A delimitação das funções do ativismo digital é realizada em dois momentos. Primeiramente, discute-se a relevância da representatividade para o público jovem e adolescente $^{211}$. Em um segundo momento, as youtubers exploram a metáfora situada mista ${ }^{212}$ que explora a imagem da ponte/porta de entrada para salientar o caráter de comunicação e propaganda do seu ativismo, potencializado por plataformas digitais como o YouTube.

A questão da representatividade é introduzida por meio da pergunta semirretórica “[...] sabe o que eu penso antes de produzir um conteúdo? antes de gravar um vídeo?”, que apresenta como resposta os princípios que regem o conteúdo dos canais com a pergunta: "eu penso assim se eu fosse adolescente como eu me sentiria?”. Essa questão não só indica o público-alvo do

211 De acordo com um levantamento do Think With Google (2017b), os nascidos a partir dos anos 2000 representam uma parcela relevante da audiência da plataforma. À época, logo após o lançamento da plataforma YouTube Kids, o Google anunciava o aplicativo como a maior plataforma infantil do mundo. Além disso, outro levantamento, realizado pela consultoria Provokers (THINK WITH GOOGLE, 2016), já indicava que metade das personalidades mais influentes entre os adolescentes eram youtubers.

${ }^{212}$ A metáfora situada mista consiste na combinação de uma ou mais metáforas no discurso. Segundo Gibbs Jr. (2016), ao contrário do que prega o senso comum, metáforas mistas não são sinais de erros ou falhas cognitivas nem necessariamente colocam obstáculos para a interpretação dos textos. De acordo com Lynne Cameron (2016), em textos falados, a metáfora mista não parece ser um "problema", no sentido de que muitas vezes é realizada e aceita pelos interactantes sem causar espanto ou estranhamento. Para Gibbs Jr. (2016, p. VIII), as metáforas mistas dão um sinal da nossa "flexibilidade cognitiva", que nos permite conceptualizar um certo tópico abstrato a partir de diversas possibilidades metafóricas. Parte dessa flexibilidade estaria na nossa capacidade de transferir a atenção rapidamente de um domínio-fonte para outro, e em ativar apenas parcialmente as informações de um dado domínio fonte, o que nos permitiria considerar uma série de outras fontes possíveis ao mesmo tempo (GIBBS, 2016, p. IX). 
canal - e, consequentemente, do seu ativismo -, como participa da legitimação do seu modo de fazer ativismo digital.

Essa legitimidade se constrói de duas formas: por um lado, o compartilhamento de experiências pessoais ("eu não tive isso eu não tive representatividade é uma coisa muito importante e quando eu era criança quando eu era adolescente foi muito difícil pra mim porque

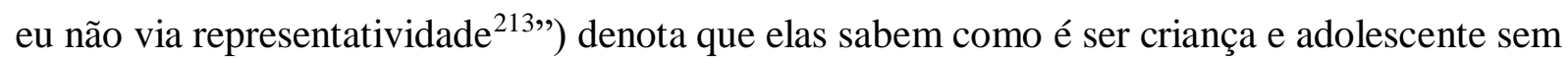
se verem representadas nas mídias e, também, sem ter acesso fácil aos discursos dos movimentos sociais - assim elas mostram ter conhecimento partilhado suficiente com os alvos de seus processos empáticos para de fato entender "como elas se sentem". Por outro lado, sua formação política no ativismo "fora da internet" ("a gente só está aqui porque esse ativismo foi feito") e seus processos de conscientização pessoal ("foi muita leitura da minha parte foi muita:... é foi uma conscientização pessoal primeiro que me trouxe até aqui...”) garantem suas posições enquanto comunicadoras do saber construído pelos movimentos sociais ("o meu objetivo e a minha vontade é justamente de compartilhar este conhecimento"). Essas representações invocam julgamentos positivos de capacidade: competência que as legitimam enquanto ativistas capazes de produzir conteúdo engajado de qualidade, tendo em vista sua capacidade empática de se importar com sua audiência, considerar suas especificidades e agir para amenizar seu sofrimento, num movimento de conscientização e, possivelmente de empoderamento. Trata-se de uma mobilização da projeção empática.

A afirmação monoglóssica sobre a importância do ativismo não digital ("existe toda uma vida fora da internet existe um ativismo fora da internet que é MUIto importante e que já tem uma história") contribui para a atenuação da tensão entre as duas formas de ativismo. A contração dialógica: refutação: negação ("então de maneira nenhuma a gente pode desmerecer esse tipo de ativismo") localiza as youtubers na defesa desse tipo de ativismo também, projetando, dessa forma, uma região epistêmico-axiológica que congrega valores do ativismo de dentro e de fora da internet ("a gente só está aqui porque esse ativismo foi feito").

Busca-se, dessa forma, atenuar as diferenças e projetar uma continuidade entre o EuNós e o Outro. Para tanto, é essencial a metáfora ATIVISMo DIGITAL É PONTE/PORTA DE

\footnotetext{
213 A representatividade é uma questão muito trabalhada nas discussões sobre produção de conteúdo -de entretenimento ou educativo - voltado para adolescentes, jovens e crianças. Não raro alvo de críticas, as políticas de representatividade estão muito ligadas aos feminismos e movimentos negros e LGBT. Essas políticas consistem na reivindicação de políticas de inclusão de certos grupos sociais historicamente marginalizados e excluídos do mercado de trabalho, assim como o reconhecimento de sua importância na esfera pública. No entanto, tratar esse eixo como prioridade do movimento não é ponto pacífico, o que acaba gerando tensões entre ativistas e militantes dessas correntes e os de correntes com outras prioridades.
} 
ENTRADA, que reconhece e legitima os diferentes posicionamentos epistêmico-axiológicos em termos de práticas e estratégias das diversas correntes que participam dos movimentos feministas, LGBT e negros, ao mesmo tempo em que projeta possibilidades de diálogo e de articulação entre essas diferentes posições.

De acordo com essa metáfora, o ativismo digital assumiria uma posição de intermediação entre os movimentos sociais e as pessoas "de fora" desse campo - isto é, considerando o espaço discursivo construído textualmente no vídeo, as pessoas que não têm contato ou não são filiadas ao campo epistêmico-axiológico do endogrupo. Dessa forma, as youtubers seriam responsáveis por interagir com adolescentes e jovens sem acesso a ou com um contato limitado com os discursos antiopressão em outros espaços, colaborando para que "o conhecimento flua", divulgando as visões de mundo, pautas e agendas envolvidas nesses movimentos.

As projeções do domínio-fonte (PONTE/PORTA DE ENTRADA) para o domínio-alvo (ATIVISMO DIGITAL) autorizadas pela metáfora que se mostraram relevantes para essas análises estão resumidas no Quadro 6 a seguir.

\section{Quadro 6 - A metáfora Ativismo digital é ponte/porta de entrada}

DOMÍNIO-FONTE: PONTE/PORTA DE ENTRADA

DOMÍNIO-ALVO: ATIVISMO DIGITAL

\begin{tabular}{ll}
$\begin{array}{l}\text { Está presente em dois ambientes (A e B) } \\
\text { simultaneamente }\end{array}$ & $\begin{array}{l}\text { Dialoga tanto com os movimentos sociais quanto } \\
\text { com o público mais geral }\end{array}$ \\
\hline $\begin{array}{l}\text { É construída para permitir que um agente se desloque } \\
\text { de um ambiente A (origem) a um ambiente B (destino) }\end{array}$ & $\begin{array}{l}\text { É feito para que uma pessoa alheia aos } \\
\text { movimentos sociais possa ter contato com esses } \\
\text { discursos }\end{array}$ \\
\hline
\end{tabular}

Agente que se desloca do ambiente A para o ambiente $\rightarrow$ Jovens alheias aos discursos dos movimentos B

$\rightarrow$ sociais - sobretudo mulheres negras e/ou LGBT

\begin{tabular}{llll}
\hline Passagem pela porta/Travessia pela ponte & $\begin{array}{l}\text { Contato com os conteúdos produzidos pelo } \\
\text { ativismo digital }\end{array}$ \\
\hline $\begin{array}{l}\text { Ambiente A: onde se encontra o Agente antes do } \\
\text { deslocamento (origem) }\end{array}$ & $\rightarrow$ Discursividades conservadoras hegemônicas \\
\hline $\begin{array}{l}\text { Ambiente B: onde se encontra o Agente após o } \\
\text { deslocamento (destino) }\end{array}$ & $\begin{array}{l}\text { Discursividades } \\
\text { hegemônicas }\end{array}$ & progressistas contra-
\end{tabular}

Fonte: elaboração própria.

O principal aspecto do domínio-fonte destacado pela metáfora é a sua capacidade de prover uma estrutura por meio da qual um agente se desloca de um ambiente A (origem) para um ambiente B (destino). Isso é projetado no domínio-alvo para salientar o entendimento de 
que o ativismo digital seria capaz de prover uma estrutura (comunidade engajada na internet) por meio da qual jovens alheias aos movimentos sociais poderiam ter um primeiro contato com esses discursos. O ativismo digital seria, portanto, capaz de promover processos de conscientização pessoais e coletivos a partir do compartilhamento de saberes dos movimentos sociais, o que auxiliaria essas jovens, originalmente filiadas às discursividades hegemônicas (racistas, machistas e heteronormativas), em processos de revisão de crenças e a efetuar mudanças em seu comportamento discursivo e prático - possivelmente se engajando nos ativismos progressistas de outras formas posteriormente.

Dessa forma, as youtubers legitimam suas práticas com base nos Objetivos comuns do endogrupo: criar comunidades engajadas em questões políticas e sociais. Trata-se de localizar um propósito bastante específico para o ativismo digital, com um público-alvo e princípios bem delimitados com vistas a amenizar a tensão entre as Propostas de Ação em disputa. Dessa forma, as Propostas em debate se tornam menos concorrentes e mais complementares. Em outras palavras, as youtubers não sugerem que todo ativismo tenha uma faceta digital, nem que o ativismo deva ser realizado unicamente por meio da Internet. Antes, elas defendem a legitimidade de suas práticas enquanto um dos modos de ação dos movimentos feministas, negros e LGBT.

Por fim, voltamo-nos para o trecho L2 (linhas 10-16), retirado do vídeo "RÓTULOS ME LIMITAM OU ME DEFINEM? | Especial Dia do Orgulho LGBT | Louie Ponto”. Nele vemos um caso em que a delimitação dos Objetivos envolvidos no processo de tomada de decisão se constituiu como uma região de proximidade epistêmico-axiológica, orientando tanto a Proposta de Ação do Eu-Nós, quanto a do Outro.

L2) L existe essa ideia de que você não deve se rotular porque rótulos te limitam rótulos não foram feitos pras pessoas que você deve viver fora de caixas e não se enquadrar em nenhum modelo enfim... eu entendo esse discurso na verdade eu conCORdo com ele porque seria maravilhoso se a gente pudesse viVER sem se definir sem dar satisfação da nossa VIda pras pessoas se a gente pudesse simplesmente SER... e quem faz isso não tá erRAdo eu não estou aqui para dizer que sua postura tá equivocada estou aqui para dizer que às vezes se rotuLAR é uma atitude política

No trecho L2, Louie realiza um complexo de operações de engajamento, combinando recursos de expansão e de contração dialógica de forma a reconhecer uma alternativa dialógica à concepção de mundo que ela defende como válida ao mesmo tempo em que apresenta a sua própria Proposta de Ação. Afirmar a legitimidade de discursos que defendem uma postura de "não se rotular", isto é, não assumir uma identidade abertamente LGBT pode ser inesperada 
para o seu auditório, tendo em vista que Louie é reconhecidamente uma ativista que estimula a "saída do armário".

Esse processo é iniciado pela expansão dialógica: atribuição: reconhecimento ("existe essa ideia de que você não deve se rotular porque rótulos te limitam rótulos não foram feitos pras pessoas que você deve viver fora de caixas e não se enquadrar em nenhum modelo enfim...") que resume a visão atribuída ao Outro, assumindo uma postura neutra em relação à alternativa dialógica (não se rotular). Posteriormente, a expansão dialógica: ponderação: "eu entendo esse discurso" e a contração dialógica: declaração: pronunciamento: "na verdade eu concordo com ele" marcam que ela reconhece a sua legitimidade, e, de certa forma, está de acordo com esse posicionamento. Dessa forma, sugere-se uma possível relação de alternatividade entre as Propostas de Ação, além de uma relação de solidariedade entre a voz autoral e a comunidade discursiva à qual o Outro faz referência, pelo compartilhamento de certos desejos.

Assim, ela constrói uma região epistêmico-axiológica comum, com base nas semelhanças de suas crenças e desejos com as do Outro, apresentando uma possibilidade de conexão (CAMERON, 2013). Após afirmar essa conexão, ela procede à elaboração da sua opinião em relação a essa postura. Primeiramente, ela opera de uma contração dialógica: refutação: negação ("eu não estou aqui para dizer que essa postura tá equivocada") que endereça o fato de que esse posicionamento talvez não fosse o esperado pelo auditório.

Neste momento, com a região epistêmico-axiológica comum já delineada, ela apresenta sua Proposta de Ação: "estou aqui para dizer que às vezes se rotuLAR é uma atitude política", realizada por meio de uma contração dialógica: declaração: pronunciamento, modalizada por meio do advérbio de frequência "às vezes". Dessa forma, ela perspectiva a realidade de forma aberta à alternativa dialógica, já que ambas as possibilidades (rotular-se ou não se rotular) são consideradas possíveis e legítimas. Em outras palavras, ela reconhece que a opção por não assumir a própria sexualidade se justifica em certos casos, do mesmo modo que defende que essa performance seja necessária e urgente em outros.

Assim, o que seria a Contra-Proposta de Ação, atribuída ao Outro, torna-se parte de um Objetivo comum. A divergência está no fato de que, para o Eu-Nós, assumir uma identidade LGBT é entendido como estratégia para que, no futuro, não seja necessário "dar satisfação" sobre a própria sexualidade, enquanto que, para o Outro, esta postura seria em si a melhor estratégia para combater o preconceito. 
Trabalhando a partir do que é consenso para ambas (a vontade de "não dar satisfação"), ela salienta aquilo que aproxima os campos epistêmico-axiológicos. Dessa forma, a questão é retirada do âmbito do individual e colocada no plano coletivo, explorando os aspectos comuns à vida e às experiências de pessoas LGBT em relação a conviver com o preconceito de uma sociedade heteronormativa. O problema será localizado, portanto, no estado de coisas. Dessa forma, por mais que ela discorde do comportamento e do discurso do Outro, ele não é responsabilizado por essa situação. Assim, ao longo do texto, os movimentos argumentativos concorrem para a integração do Outro no campo epistêmico-axiológico do Eu-Nós.

Como apontamos nas análises anteriores, o vídeo celebra os movimentos LGBT como espaços políticos que contribuem para o Objetivo comum de tornar a sociedade um ambiente seguro para essa comunidade, e isso se mostra essencial para garantir a integração. Trata-se, em suma, da construção de um "Nós" que não se mostra homogêneo, mas que busca coesão.

Nesta seção, percebemos que a explicitação de pressupostos comuns e acordos, sobretudo ligados ao campo epistêmico-axiológico do endogrupo, foi uma das estratégias principais para gerir a distância epistêmico-axiológica que separa o Eu-Nós e o Outro. Destacaram-se os recursos de contração dialógica: declaração: expectativa confirmada, que antecipam uma posição favorável do leitor/ouvinte em relação à perspectiva apresentada - seja ela de fato compartilhada ou não - e a monoglossia, que assume como indisputável um determinado posicionamento.

Olhar para a linguagem dessa forma nos auxiliou a compreender de que forma as regiões de proximidade epistêmico-axiológica foram construídas - seja por meio da recuperação de pressupostos comuns, ou por meio pela transformação de um elemento de desacordo (como a utilização da Contra-Proposta de Ação como parte dos Objetivos comuns) -, bem como depreender as estratégias utilizadas na apresentação da perspectiva do Eu-Nós e da projeção do campo epistêmico-axiológico do Outro.

\subsubsection{Articulações entre aproximação e afastamento epistêmicos e axiológicos}

Nesta seção nos debruçaremos sobre um trecho do vídeo "RÓTULOS ME LIMITAM OU ME DEFINEM? | Especial Dia do Orgulho LGBT | Louie Ponto" para discutirmos a articulação entre movimentos de aproximação e afastamento epistêmico-axiológicos.

No trecho L3 (linhas 25-54), apresentado a seguir, Louie discute os aspectos subjetivos envolvidos na Alegação "às vezes se rotuLAR é uma atitude política”. Como discutido na seção 1.4, este trecho apresenta ainda a explicitação das diferenças entre as leituras do estado de coisas 
que compõem as Circunstâncias Motivadoras do Eu e do Outro. Aqui, a youtuber projeta um acordo entre o Eu-Nós e o Outro a respeito do caráter machista, preconceituoso e excludente da sociedade brasileira para explorar as diferenças entre as especificidades das leituras de cada entidade, apresentando as consequências da heteronormatividade e da invisibilização das pessoas LGBT na esfera pública sobre as subjetividades de pessoas não heterossexuais, e a dimensão política da invisibilidade como ferramenta de dominação.

Neste trecho, a youtuber convida o Outro a reconhecer traços subjetivos e experiências comuns. Por meio desse "convite", Louie promove um processo reflexivo a respeito das diferenças e similaridades epistêmicas e axiológicas entre os campos dessas entidades.

L3) L porque a gente vive em uma sociedade com valores conservaDOres maCHISta e preconceituosa excludente heteronormativa e existem mecanismos de INvisibilização de certos grupos sociais... UM desses mecanismos é a negaÇÃO da exisTÊNcia dessas pessoas o que que eu quero dizer com tudo isso? vamos pensar na nossa sociedade... tudo que você olha é heterossexual... na família na escola na igreja na rua na televisão no cinema na literatura... então desde que a gente nasce a gente aprende que a única forma de exisTÊNcia é possível É heterossexual e o impacto disso na nossa subjetiviDAde na nossa VIda é iMENso muitas vezes a gente não consegue nem se perceber uma pessoa não heterossexual... e quando a gente percebe a gente passa por um processo de autoconhecimento e autoaceitação que é bastante complicado... porque é viver fora de um modelo estabelecido é diFÍcil admiTIR e aceiTAR que você é diferente daquilo que sempre te ensinaram a SER por isso a gente tem que pensar se essa escolha em não se rotular na verdade não é um mecanismo de deFEsa e uma rePULsa à sua sexualidade e ao fato de você ser diferente

Trata-se, em suma, de uma projeção empática, por meio da qual a youtuber objetiva criar um laço de solidariedade a partir da projeção de experiências e dores compartilhadas na dificuldade de construir uma identidade não heterossexual. Isso culmina num "você" que focaliza a questão no Outro. Em termos do jogo com o auditório, neste momento o Outro corresponde a uma parcela bastante específica do auditório: pessoas não heterossexuais que não assumem uma identidade LGBT. Louie projeta uma justificativa a respeito desse posicionamento: os traumas subjetivos derivados dos processos de socialização que colocam obstáculos para os processos de autoconhecimento e autoaceitação ("porque é viver fora de um 
modelo estabelecido é diFÍcil admiTIR e aceiTAR que você é diferente daquilo que sempre te ensinaram a SER").

A diferença epistêmica aparece nos diferentes entendimentos a respeito do funcionamento da LGBTfobia na sociedade - como episódios de discriminação ou como sistema de dominação. Já a dimensão axiológica apresenta semelhanças e diferenças. A semelhança estaria na valorização da liberdade sexual e no anseio por uma sociedade que garantisse esse direito. Já a diferença estaria no peso dado ao individual e ao coletivo por cada uma das entidades. Enquanto ao Outro é atribuída a crença de que a defesa do indivíduo LGBT deve ser priorizada (e, portanto, assumir abertamente a sua sexualidade passa a ser uma questão de opção por privacidade e autopreservação), Louie argumenta que esta só é possível a partir da defesa do grupo LGBT, por meio do engajamento nos movimentos (o que requisitaria também assumir abertamente a sua sexualidade).

Em termos da Configuração Funcional Prática, a Alegação "às vezes se rotuLAR é uma atitude política" constitui o Meio-Fim do movimento de argumentação prática que legitima a Proposta de Ação Rotule-se como um caminho válido para transformar o estado de coisas presente de forma a atingir o Objetivo Viver em uma sociedade em que a sexualidade não seja motivação para preconceito, violências físicas ou simbólicas, na qual não seja necessário "dar satisfação" para ninguém.

Esse acordo se realiza em uma série de enunciados monoglóssicos que afirmam que os Valores do exogrupo (LGBTfóbico, conservador) são hegemônicos na sociedade brasileira (“a gente vive em uma sociedade com valores conservaDOres maCHISta e preconceituosa excludente heteronormativa"). Da forma como é construída, essa relação entre tais Valores e o exogrupo é apresentada como algo dado, fora de disputa. Entende-se, portanto, que essa seja uma perspectiva compartilhada com seu auditório. Ademais, o uso do "a gente inclusivo" sugere, mais do que isso, um conjunto de experiências comuns nos processos de socialização aos quais estão sujeitos as/os atoras/es sociais.

As divergências entre as visões de mundo, por sua vez, são introduzidas por meio da discussão sobre o caráter heteronormativo da sociedade brasileira ("e existem mecanismos de INvisibilização de certos grupos sociais... UM desses mecanismos é a negaÇÃO da exisTÊNcia dessas pessoas"). Essas diferenças são exploradas em um tom didático (“o que que eu quero dizer com tudo isso?"), que empreende, por meio da variação entre o uso do sujeito "a gente" e o vocativo "você", uma teorização a respeito das experiências (supostamente) compartilhadas 
pelo Eu e pelo Outro. Essa teorização é apresentada como Dados para justificar a leitura do estado de coisas defendido por Louie como Circunstâncias Motivadoras ${ }^{214}$.

Em outras palavras, as noções de invisibilização e negação da existência das pessoas LGBT são explicadas a partir de uma série de enunciados que projetam um conjunto de experiências partilhadas com o auditório. Isso é realizado por meio do pronome possessivo "nossa" e do pronome "você" genérico, que coletivizam e generalizam tais afirmações, como se elas pudessem ser comprovadas pela simples percepção da realidade (depreendido pelo uso dos verbos "pensar" e "olhar") - "vamos pensar na nossa sociedade... tudo que você olha é heterossexual... na família na escola na igreja na rua na televisão no cinema na literatura...".

Dessa forma, a heteronormatividade (ou a invisibilização e negação da existência das pessoas LGBT) é perspectivada como uma condição inescapável e intrínseca da sociedade brasileira, que determina grande parte das experiências de vida tanto de pessoas heterossexuais quanto não heterossexuais. O marcador discursivo "então" introduz a conclusão do segmento explicativo a respeito dessas noções, apresentando possíveis consequências subjetivas nos processos de descoberta da sexualidade e construção de identidades não heterossexuais ("então desde que a gente nasce a gente aprende que a única forma de exisTÊNcia é possível É heterossexual e o impacto disso na nossa subjetiviDAde na nossa VIda é iMENso").

De forma geral, o uso de pronomes na primeira pessoa do plural assume que o Outro tenha passado pelos mesmos processos ou ao menos semelhantes - mesmo que não os tenha reconhecido dessa forma anteriormente -, construindo um campo de experiências comuns que pretende mostrar que ela/e "não está sozinha/o", criando como que um "espelho" para que o Outro possa se ver "refletido" ali ao reconhecer as consequências das experiências pelas quais passou, o que envolve falar sobre as dores e traumas que possam ter sido causados por elas (“muitas vezes a gente não consegue nem se perceber uma pessoa não heterossexual... e quando a gente percebe a gente passa por um processo de autoconhecimento e autoaceitação que é bastante complicado...”).

Ao final do trecho L3, Louie explicita o convite à reflexão por meio do modal deôntico "tem que" ("por isso a gente tem que pensar") e se "corresponsabiliza" por esse processo, demonstrando disposição para ouvir e compreender o Outro. Trata-se, em suma, da explicitação das condições iniciais para a empatia. Além disso, o uso de "a gente", neste caso, contribui para salientar a identidade comum, atribuída por Louie, e também o convite à inserção do grupo no

\footnotetext{
${ }^{214}$ Não reproduzimos aqui a paráfrase das Circunstâncias Motivadoras devido a sua extensão. Caso a leitora sinta a necessidade de relembrar a leitura do estado de coisas, volte à página 198.
} 
campo do Eu-Nós. Quanto ao conteúdo da reflexão, trata-se de uma alternativa dialógica quanto à fonte da motivação para o Outro decidir não se rotular. Ela é iniciada por meio de uma partícula condicional combinada com um recurso de contração dialógica: declaração: pronunciamento ("se na verdade").

Dessa forma, ela sugere uma nova interpretação acerca das motivações do Outro para não "se rotular", que contraria as justificativas atribuídas ao Outro no início do vídeo. Mais do que ser motivado pela recusa às possíveis limitações impostas pelo 'rótulo LGBT', esse comportamento seria "um mecanismo de deFEsa e uma rePULsa à sua sexualidade e ao fato de você ser diferente", em outras palavras, LGBTfobia internalizada. O uso da condicional ("se"), no entanto, ameniza as tensões entre as alternativas dialógicas, posto que assume a possibilidade de que este não seja o caso para algumas pessoas em específico.

De acordo com o modelo de Ritter e Tendrup (2002), resumido por Frazão e Rosário (2008, p. 31), seria possível distinguir, dentre os modelos existentes para a descrição do processo de saída do armário, três fases comuns, que eles denominam Sensibilização, Tolerância e Integração $o^{215}$. A primeira e a segunda fases correspondem às experiências e aos sentimentos relatados por Louie no trecho L3. Enquanto os sentimentos de inadequação parecem corresponder à fase de Sensibilização ${ }^{216}$, a "escolha em não se rotular" parece ressoar a "vida dupla" da etapa da Tolerância ${ }^{217}$.

Estabelecendo uma relação entre essa perspectiva e a estratégia argumentativa elaborada pela youtuber, o vídeo parece promover, então, uma conscientização sobre esse processo,

\footnotetext{
${ }^{215}$ Ressaltamos que, segundo afirmam Frazão e Rosário (2008), o modelo de Ritter e Tendrup, assim como uma série de outros modelos a respeito das etapas da saída do armário, embora apresentem uma série de benefícios em termos do acompanhamento clínico de gays e lésbicas (o artigo é centrado nessas duas populações), também é marcado por uma série de pontos-cegos, tendo sido elaborado com base em populações clínicas, de maioria branca, estadunidense, de classe média alta, masculina e gay.

${ }^{216}$ De acordo com Frazão e Rosário (2008, p. 32), essa fase seria caracterizada por "uma sensação de diferença e marginalização em relação aos pares do mesmo sexo (principalmente nos rapazes pré-adolescentes), tradicionalmente ligada à não conformidade com os papéis de género estipulados pela sociedade e que, na adolescência, seria associada a uma diferença em termos sexuais. Este facto é, muitas vezes, sentido como inaceitável, levando a várias estratégias defensivas (e.g., procurar terapia reparativa; assumir posições homofóbicas; pensar que se trata apenas de uma fase; imergir numa identidade heterossexual; definir situações e não a orientação sexual como causas do comportamento homossexual; sobrenvolvimento académico ou na carreira; e cruzada contra indivíduos ou actividades do mundo gay) (Ritter \& Tendrup, 2002, cit. por Pachankis \& Goldfried, 2004)".

${ }^{217}$ De acordo com Frazão e Rosário (2008, p. 32), nessa fase "os indivíduos podem não revelar a sua identidade, mas envolvem-se numa vida dupla. De facto, é comum a manutenção de uma identidade heterossexual perante a família e amigos, mas ao mesmo tempo existir um contacto com a comunidade gay para preencher necessidades sexuais, emocionais e sociais. Quando este contacto é recompensador, começa a surgir uma vontade de reduzir a dissonância provocada por uma vida dupla. Em consequência, emerge o orgulho na identidade gay e uma maior procura de relações íntimas com pessoas do mesmo sexo. Muitas vezes, surge também uma sobreidentificação com a identidade homossexual e um desafio a indivíduos heterossexuais com manifestações de comportamentos estereotipados (Ritter \& Tendrup, 2002, cit. por Pachankis \& Goldfried, 2004).”
} 
ressaltando a importância de reconhecer-se nestas etapas e de fazer emergir o "orgulho gay" na concretização da Tolerância. Dessa forma, seria possível partir para a fase seguinte (Integração), na qual "o indivíduo irá integrar a sua identidade homossexual na visão geral do seu si” (FRAZÃO; ROSÁRIO, 2008, p. 32-33). Outros marcadores que se mostram relevantes para a concretização desse processo é a busca por relações íntimas e afetivas, o "desafio à heterossexualidade" e a imersão na cultura gay/lésbica (FRAZÃO; ROSÁRIO, 2008, p. 31-32).

Em termos gerais, como já discutimos, trata-se de um caso diferente não apenas em relação aos vídeos em que os campos epistêmico-axiológicos das entidades discursivas não se interseccionavam, mas também diverso do vídeo "YOUTUBER SÓ FALA MERDA NA INTERNET? Feat. LouiePonto, uma vez que no texto ora sob análise, o Outro é instado a reconhecer-se como parte do Nós devido a uma identidade que lhe é atribuída. Aqui, vemos como o compartilhamento de experiências e sentimentos pessoais de forma coletivizada, e, ao mesmo tempo, a atribuição dessas sensações ao Outro tanto delimita fronteiras, quanto cria uma região de proximidade. As fronteiras são criadas por meio do embate entre discursividades diferentes, enquanto a proximidade é sugerida por meio da projeção empática, na quebra do sigilo e apresentação de experiências comuns entre a comunidade LGBT.

\subsection{Os usos da Movimentação Epistêmico-Axiológica no discurso do ativismo digital}

Nas seções anteriores nos dedicamos a desenvolver análises sobre a construção de efeitos de complementariedade/alternatividade/oposição entre Alegações e Propostas de Ação, assim como a sugestão de relações de solidariedade/neutralidade/antagonismo entre comunidades discursivas, por meio da metodologia que desenvolvemos para o estudo da Movimentação Epistêmico-Axiológica.

Em primeira instância, realizamos a descrição dos espaços discursivos de cada um dos vídeos selecionados como parte do corpus a partir tanto da sua divisão entre endogrupo e exogrupo, quanto do mapeamento das entidades discursivas neste espaço por meio da análise da configuração funcional dos argumentos em sua dimensão epistêmica e prática.

Posteriormente, dispusemos-nos a analisar em detalhes alguns trechos com instâncias variadas de movimentos de aproximação e afastamento epistêmico-axiológico e de que forma eles contribuíram para a gestão das relações de complementariedade, alternatividade e oposição entre elementos argumentativos das estratégias discursivas (sobretudo Alegações e Propostas de Ação, mas também Garantias, Objetivos e Valores), assim como as relações de solidariedade 
ou antagonismo entre as entidades discursivas e, consequentemente, as comunidades discursivas às quais elas fazem referência.

Nesta seção, iremos apresentar os padrões de uso desses movimentos depreendidos a partir da análise das estratégias discursivas de cada vídeo, estabeleceremos paralelos com as estratégias dos feminismos brasileiros contemporâneos (sobretudo os feminismos negros e lésbicos), assim como indicaremos algumas percepções a respeito das especificidades do uso da Movimentação Epistêmico-Axiológica no ativismo digital feminista.

No Quadro 7 a seguir, resumimos os principais resultados obtidos de cada análise.

O vídeo de "POR QUE VOCÊ É TÃO AGRESSIVA, NÁTALY?” recupera as discussões a respeito do silenciamento de mulheres negras, atacando um dos seus mecanismos de reprodução: os estereótipos ou imagens de controle. Por meio do uso de gestos de captação empática (apresentação de narrativas e traços pessoais) e do reenquadramento da questão argumentativa, que deixa de ser “por que você é tão agressiva, Nátaly?" para se tornar “por que você me acha agressiva?”, Nátaly realiza uma autoavaliação a respeito de sua atuação como youtuber, desafiando a imagem de controle mulher negra raivosa mobilizada nos comentários num movimento de autodefinição que deslegitima a competência do Outro para avaliar adequadamente a sua atuação enquanto comunicadora, ressoando as estratégias intelectuais discutidas por Collins (2019), no contexto estadunidense, e Bueno (2020), no contexto brasileiro.

Os efeitos gerados sobre a relação entre as Alegações e Propostas de Ação é de oposição, e sugere-se uma relação de antagonismo entre as comunidades discursivas referenciadas, o que só poderia ser superado a partir de um processo de revisão de crenças e mudança no comportamento discursivo.

Já no vídeo "YOUTUBER SÓ FALA MERDA NA INTERNET? Feat. Louie Ponto", as youtubers discutem as críticas e o ceticismo em relação à efetividade do ativismo digital. Por meio dos movimentos de afastamento epistêmico-axiológico, elas refutam pontos específicos da argumentação atribuída ao Outro e simultaneamente salientam pontos de acordo, de forma a construir um efeito de oposição entre as Alegações e de alternatividade entre as Propostas de Ação. Dessa forma, procuram legitimar sua atuação no campo progressista, sugerindo uma relação de solidariedade com o Outro. 


\begin{tabular}{|c|c|c|c|}
\hline \multicolumn{4}{|c|}{ Quadro 7 - Resultados } \\
\hline & $\begin{array}{l}\text { Posicionamento do } \\
\qquad \text { Outro }\end{array}$ & $\begin{array}{l}\text { Relação entre Alegações e } \\
\text { Propostas de Ação }\end{array}$ & $\begin{array}{l}\text { Relação entre entidades } \\
\text { discursivas }\end{array}$ \\
\hline $\begin{array}{l}\text { YOUTUBER SÓ FALA MERDA NA INTERNET? Feat. } \\
\text { Louie Ponto }\end{array}$ & endogrupo & $\begin{array}{c}\text { Oposição }(\mathrm{A}) \mathrm{e} \\
\text { complementariedade }(\mathrm{P})\end{array}$ & Solidariedade \\
\hline $\begin{array}{l}\text { RÓTULOS ME LIMITAM OU ME DEFINEM? | } \\
\text { Especial Dia do Orgulho LGBT | Louie Ponto }\end{array}$ & $\begin{array}{l}\text { cooptação pelo } \\
\text { exogrupo }\end{array}$ & Alternatividade & Solidariedade \\
\hline
\end{tabular}

**Caso de desacordo profundo

Fonte: elaboração própria. 
A discussão empreendida no vídeo "HETEROFOBIA E RACISMO REVERSO EXISTEM? | LouiePonto feat. Nátaly Neri”, por sua vez, parte do título polêmico para discutir “o que é racismo?”. Dessa forma, elas aproveitam o apelo do desacordo profundo para estabelecer critérios de avaliação das definições e da argumentação em prol de cada uma delas.

Da mesma forma como no primeiro vídeo, os efeitos gerados sobre a relação entre as Alegações e Propostas de Ação é de oposição. Aqui a relação de antagonismo sugerida depende, em última análise, da concepção de cada comunidade discursiva em relação ao racismo e à LGBTfobia. Trata-se, no fundo, da mobilização da estratégia da tergiversão (LUZ, 2017) por parte do Outro, o que impediria o diálogo, por estabelecer objetivos diversos para a comunicação e discussão a respeito das discriminações. Isso só poderia ser superado a partir do reconhecimento dessa distorção, e, novamente, de um processo de revisão de crenças e mudança no comportamento discursivo.

Por fim, no vídeo "RÓTULOS ME LIMITAM OU ME DEFINEM | Especial Dia do Orgulho LGBT | Louie Ponto", Louie ressalta a importância da articulação com o movimento LGBT para combater movimentos, discursos e práticas LGBTfóbicas, assim como para lutar por direitos, ressoando o que Sarmet (2018) afirma a respeito da reinvenção do movimento lésbico nos anos 2010. O efeito gerado sobre a relação entre as Alegações e Propostas de Ação é de complementariedade, e sugere-se uma relação de solidariedade entre as comunidades discursivas referenciadas. Não depreendemos a construção de uma relação de neutralidade entre as comunidades discursivas em nenhum dos vídeos analisados.

Em todos os quatro vídeos, as youtubers estabelecem articulações entre as dimensões social e subjetiva no que diz respeito à construção das identidades, bem como aos efeitos de estruturas sociais sobre aspectos materiais da vida de atoras sociais marginalizadas. Isso é realizado numa linguagem informal, estabelecendo relações de intertextualidade entre os seus vídeos e outras produções audiovisuais (séries, vídeos de slam poetry etc.) voltadas para o seu público-alvo.

Em primeiro lugar, depreendemos duas principais características que contribuíram para determinar a função da MEA como estratégia discursiva em cada vídeo e para a prevalência de um determinado tipo de movimento: o grau de dissenso em relação ao problema prático ou epistêmico e o posicionamento do Outro (em termos da filiação discursiva do posicionamento que lhe é atribuído) no espaço discursivo. Vimos, em suma, que a forma de divisão do espaço 
discursivo do texto entre endogrupo e exogrupo se mostrou essencial para a prevalência de um tipo de efeito discursivo em relação aos elementos argumentativos e às comunidades discursivas referenciadas.

Ressaltamos também a importância dos compromissos compartilhados no ato de argumentar, que Fogelin (2005) indica como essenciais para a ocorrência de uma interação argumentativa. Nos casos de desacordo profundo, em que existe um choque entre as proposições de base (framework propositions), torna-se necessário "trazer à tona essas proposições de base e discuti-las diretamente" (FOGELIN, 2005, p. 8) ${ }^{218}$ para que o debate possa decorrer de forma produtiva, além do apelo ao posicionamento moral ou ético - o segundo aspecto que se mostrou relevante nos casos de afastamento.

Vemos, portanto, a relação com a referência ao compromisso moral ou ético do Outro com as pautas progressistas de transformação social, que também exerce um papel importante nos movimentos de afastamento, posto que as Propostas de Ação apresentadas pelas youtubers são construídas como modos de "colocar em prática" os Valores do endogrupo e, assim, reafirmar sua filiação discursiva ao mesmo. Nessa dinâmica entre o Eu e o Outro, a construção de uma coletividade que corrobora os valores, crenças e posicionamentos do Eu (Nós) se mostrou essencial para a legitimação da voz autoral.

Os fatores que parecem privilegiar a ocorrência do afastamento são: alto grau de dissenso, sobretudo casos em que a discussão é motivada por ataques virtuais cuja motivação se configura como desacordo profundo; não atribuição de um compromisso ético ou político forte do Outro em relação ao Nós ou ao endogrupo. Nestes casos, as Propostas de Ação para o Outro envolvem um processo complexo de revisão de crenças, embasado em conceitos oriundos da academia e do ativismo.

Os fatores que parecem privilegiar a ocorrência da aproximação são: compartilhamento de marcadores sociais entre o Eu-Nós e o Outro (como sexualidade, identidade de gênero e posição política); a pergunta nuclear se referir à tomada de decisão do endogrupo em relação a um problema prático, atribuindo ao Outro um compromisso político e ético forte em relação ao Nós.

Em termos do uso da plataforma, salientamos o aproveitamento de tópicos polêmicos (as questões argumentativas expostas no título dos vídeos muitas vezes se aproximando da estratégia do click bait, isto é, utilizar um título chamativo para conquistar a atenção da

\footnotetext{
${ }^{218}$ No original, "[to] surface these background propositions and then discuss them directly." (FOGELIN, 2005, p.
} 8). 
audiência e "convencê-la" a assistir ao vídeo) e o uso de narrativas pessoais para o desenvolvimento de discussões a respeito de conceitos acadêmicos e/ou oriundos dos ativismos considerados relevantes para a militância on e offline. Em especial, a autoavaliação, os relatos pessoais e a pessoalização da argumentação se mostraram relevantes para o estabelecimento de relações de solidariedade e de projeção da empatia em relação ao Outro - sobretudo quando há identificação com as youtubers, como é o caso do segundo vídeo.

Finalizamos aqui o capítulo de análises. Nas próximas páginas, realizaremos um balanço das discussões empreendidas ao longo da dissertação a partir dos objetivos estabelecidos nas Considerações Iniciais, apresentando nossa percepção a respeito dos potenciais ganhos propiciados pela construção de um modelo de análise centrado na Movimentação EpistêmicoAxiológica, bem como de seus limites, além de indicar searas possíveis para o aprofundamento dessa perspectiva. 


\section{Considerações Finais}

E nos lugares em que as palavras das mulheres clamam para ser ouvidas, cada uma de nós devemos reconhecer a nossa responsabilidade de buscar essas palavras, de lê-las, de compartilhá-las e de analisar a pertinência delas na nossa vida. Que não nos escondamos por detrás das farsas de separação que nos foram impostas e que frequentemente aceitamos como se fossem invenção nossa. (Audre LORDE, 2019a, p. 55)

Nesta dissertação, dedicamo-nos a desenvolver um modelo de análise capaz de dar conta da variabilidade dos mecanismos de projeção e de rearranjo simbólico no Espaço Discursivo em situações em que não há referência direta entre o Outro e o exogrupo nem entre o Outro e um ator social ou co-enunciador com possibilidade de interação simultânea. Hipotetizamos que, para tanto, seria necessária uma abordagem multidisciplinar capaz de fornecer uma metodologia e categorias de análise para a investigação das dimensões cognitiva, retóricoargumentativa e dialógico-atitudinal de tal processo, de modo a viabilizar a depreensão dos modos pelos quais são construídas relações de solidariedade, neutralidade e antagonismo entre comunidades discursivas a partir da disputa entre Alegações e Propostas de Ação.

Partindo, sobretudo, da Teoria da Proximização, dos estudos sobre a empatia e de perspectivas feministas negras sobre as políticas de silenciamento, defendemos que a noção de comunidades discursivas (grupo socialmente reconhecido com base em um determinado comportamento material ou discursivo) e estudo de sua construção como entidades discursivas (objetos do discurso) permitiria aprofundar as reflexões sobre a dinâmica das estratégias discursivas baseadas na distinção entre endogrupo e exogrupo (nós vs. eles). Acreditamos que respostas pré-legitimadas a determinadas questões argumentativas sejam índices importantes para a análise do processo de polarização discursiva que, de alguma forma, perpassa os discursos ativistas na contemporaneidade. Com as análises, depreendemos a relevância dessas respostas para a determinação da filiação ideológica das entidades discursivas em relação ao endo/exogrupo e os critérios para a sugestão de relações de solidariedade, neutralidade ou antagonismo entre as comunidades discursivas.

Para tanto, a Movimentação Epistêmico-Axiológica foi definida como uma estratégia discursiva que opera nas dimensões cognitiva, retórico-argumentativa e dialógico-atitudinal, voltada para o estabelecimento de comunidades de crenças e valores como objetos de discurso e para a construção de relações entre as mesmas ao longo de um determinado texto. Para além disso, ela pode ser utilizada, por meio do contraste entre discursividades distintas, como forma de explorar o dissenso em determinadas práticas sociais e esferas de atividade. 
Para considerar essas três dimensões nos textos, estabelecemos uma metodologia de análise realizada em três etapas, a saber: (i) Mapeamento das entidades no Espaço Discursivo; (ii) Mapeamento dos movimentos de aproximação/afastamento epistêmico-axiológico; (iii) Interpretação das funções da Movimentação Epistêmico-Axiológica na constituição de estratégias discursivas. Essas etapas são realizadas em diálogo com as três dimensões da MEA e partem da definição de três entidades discursivas básicas (Eu, Nós e Outro) para analisar a construção das relações entre as comunidades discursivas nos textos.

Na primeira etapa, considerando a dimensão cognitiva, ancoramos a MEA no sistema cognitivo de Perspectiva (HART, 2014; CHILTON, 2013) como um refinamento da estratégia discursiva de Posicionamento. Nesse primeiro momento, analisamos a participação da MEA na construção de Espaços Discursivos, assim como na delimitação das entidades discursivas.

Essa delimitação é depreendida por meio de categorias de análise e metodologia embasadas na configuração funcional dos argumentos (GONÇALVES-SEGUNDO, 2020a; FAIRCLOUGH; FAIRCLOUGH, 2012; TOULMIN, 2006), que constituem a dimensão retórico-argumentativa. Isso é realizado a partir da depreensão do problema epistêmico/prático central em cada vídeo e como as vozes autorais apresentam os posicionamentos em disputa.

A partir daí, verificamos as variações do grau de abertura dialógica nos pontos de tensão dialógica nos textos, categorizando-as como movimentos de aproximação ou afastamento epistêmico-axiológico. Tal estudo foi realizado por meio da mobilização do sistema de AVALIATIVIDADE (MARTIN; WHITE, 2005) e dos gestos de empatia, dispatia e antagonismo propostos por Gonçalves-Segundo (2019b).

Além dos propósitos teóricos, esperávamos, com esta pesquisa, discernir recursos para análises discursivas a respeito das correlações de forças nos ativismos digitais feministas e da (re)construção de imaginários coletivos. Nesse sentido, interessava-nos refletir sobre os recursos linguístico-discursivos mobilizados pelas youtubers, sobre a natureza argumentativa dos vídeos analisados e sobre sua função no campo do ativismo. Com as análises, percebemos que a MEA se mostrou bastante profícua para a depreensão de variáveis importantes no que se refere à construção de relações entre as entidades discursivas (e, consequentemente, do que isso pode sugerir em termos das relações entre as comunidades discursivas referenciadas). Isso se deve ao fato de que ela nos permitiu perceber a relevância da dos problemas epistêmicos e práticos para a construção de articulações entre movimentos sociais. Essa parece se tratar de uma característica marcante dos ativismos feministas contemporâneos, sobretudo os de inclinação interseccional, constituindo a "gramática política sobre hierarquias e formas de 
opressão" de que falam Rodrigues e Freitas (2019, p. 89) e para a assunção da raça e da sexualidade como categorias de análise sociológicas cruciais para compreender o patriarcalismo, o sexismo e o próprio feminismo no Brasil.

Depreendemos que, dentre os vídeos analisados, as perguntas argumentativas determinantes na projeção do Espaço Discursivo foram, em geral, as de cunho epistêmico fossem elas nucleares ou subsidiárias. O posicionamento do Outro em relação a questões importantes para os ativismos feministas, negros e LGBTTIAPN+ contemporâneos, como a definição de racismo e LGBTfobia, o uso de estereótipos racistas no discurso cotidiano e a (in)visibilidade lésbica, se mostrou determinante no que concerne ao tipo de movimentação realizada e, consequentemente, para a relação entre as comunidades discursivas sugerida pelas youtubers em cada vídeo.

Assim, em vídeos em que (i) o grau de dissenso era maior; (ii) o Outro estava projetado no campo epistêmico-axiológico do exogrupo; (iii) ao Outro não eram atribuídas identidades semelhantes às das youtubers, a distância percebida entre as entidades era maior, e a possibilidade de uma relação de solidariedade estava sujeita à revisão de crenças e à mudança de comportamento discursivo por parte do Outro.

Ressaltamos ainda que, em todos esses casos, as youtubers construíram um Outro (entidade discursiva) que se autoprojetava no campo do endogrupo por meio da atribuição de “críticas bem-intencionadas". Em contrapartida, elas mesmas rejeitavam essa projeção, argumentando em favor da necessidade de que se adequasse aos seus valores, crenças e práticas para que o Outro (comunidade discursiva) pudesse, de fato, ser considerado integrante legítimo do endogrupo. Assim, vemos que a Movimentação Epistêmico-Axiológica atua na validação de pertencimento endogrupal, possibilitando o reconhecimento de critérios para o estabelecimento de alianças e redes de solidariedade.

O eixo epistêmico-axiológico, mais do que as identidades, se mostrou, portanto, fundamental para a construção das entidades discursivas. Assim, enquanto o campo endo/exogrupal é definido por filiações ideológicas, os campos epistêmico-axiológicos das entidades são definidos a partir de sua posição frente a uma questão argumentativa de natureza epistêmica (e não prática) na maioria dos vídeos analisados.

Em “POR QUE VOCÊ É TÃO AGRESSIVA NÁTALY?”, a questão estava na visão dos comentaristas sobre Nátaly e nos estereótipos sobre as mulheres negras. No vídeo "RÓTULOS ME LIMITAM OU ME DEFINEM? | Especial Dia do Orgulho LGBT | Louie Ponto", o problema era a cooptação do Outro pelo discurso da falsa igualdade. Já em 
“HETEROFOBIA E RACISMO REVERSO EXISTEM? | LouiePonto feat. Nátaly Neri”, a discussão corria em torno das definições de racismo e LGBTfobia e da factualidade das noções de racismo reverso e heterofobia.

Isso parece refletir uma tendência dos ativismos feministas contemporâneos que atuam no meio digital de, por um lado, valorizar a conscientização sobre a dimensão política da vida privada ("para o pessoal de casa ficar político", para usar as palavras da poeta Bianca Gonçalves) e, por outro, salientar sua filiação ideológica, em termos da "defesa de uma causa em torno da qual pessoas e instituições são intencionalmente mobilizadas", conforme afirma Zelinda Barros (s/d, p. 7-8). Nesses casos, eram os diferentes posicionamentos frente a uma questão epistêmica que definiam as posições relativas das entidades no Espaço Discursivo.

Em contrapartida, quando olhamos para o vídeo "YOUTUBER SÓ FALA MERDA NA INTERNET? Feat. Louie Ponto", em que não há a projeção do exogrupo no Espaço Discursivo, vemos que a discussão central é de natureza prática. Neste caso, é o modo de fazer ativismo que se mostra mais relevante para a delimitação das entidades.

O que define o eixo principal de distinção entre as entidades parece, então, ser decorrente da natureza da questão do texto. Em textos de visada argumentativa de natureza epistêmica, ainda que haja um raciocínio prático subjacente, é esse o critério que prevalece para a construção das entidades discursivas e para a definição da filiação endo/exogrupal. Por outro lado, nos textos de visada argumentativa de natureza prática, são os modos de ação que definem a distância entre as entidades.

Com isso, comprovamos a produtividade do modelo para a análise de práticas discursivas do ativismo digital, posto que depreendemos os papéis dos movimentos de afastamento e de aproximação epistêmico-axiológica para as práticas de formação política no âmbito do ativismo digital.

Nesse sentido, a contínua aplicação da MEA sobre corpora de práticas discursivas dos movimentos sociais tem o potencial de auxiliar a compreensão a respeito de como a formação política de determinados grupos e organizações é realizada, permitindo também discernir as diferenças entre os modos de (des)construir as diferenças realizados por diferentes filiações ideológicas.

Consideramos que essa abordagem configure um ganho analítico para a consideração de dinâmicas de aproximação e afastamento entre grupos sociais - mais especificamente, de movimentos sociais. No caso da análise de vertentes feministas, por exemplo, seria possível verificar, a partir da construção do Nós, de que forma a categoria "mulheres" é perspectivada 
por uma determinada instância produtora, e como isso demonstra quais são as mulheres com quem essa voz autoral deseja estabelecer laços de solidariedade, neutralidade ou antagonismo.

Ademais, facilita a depreensão de quais traços ideológicos são relevantes quando se trabalha a categoria como protagonista do feminismo lésbico, do feminismo negro, do transfeminism; de que forma feministas brancas criam uma sujeita política feminista universal (aparentemente) desracializada; de que forma um feminismo de classe média e elitista apaga contradições e tensões de classe para estabelecer sua noção de sororidade.

Consideramos que o estado atual da noção de Movimentação Epistêmico-Axiológica seja ainda experimental. Para aprimorá-la, acreditamos que seria necessário realizar análises em mais vídeos de ativismo digital para confirmar os resultados encontrados nesta pesquisa e também aplicá-la a um corpus mais amplo e diversificado, bem como a vídeos de canais filiados a outras discursividades, além de textos de práticas discursivas diversas.

Não exploramos em nossa teorização nem em nossas análises questões como a intertextualidade dos vídeos - tanto em relação a outros vídeos e textos publicados na internet, quanto em relação aos comentários publicados em resposta a outros vídeos -, mas acreditamos que sua investigação seria bastante profícua. Também a multimodalidade e a gestualidade são eixos ignorados neste trabalho que poderiam contribuir sobremaneira para o aprofundamento e descoberta de outros elementos que participam da construção do Espaço Discursivo.

Ademais, consideramos que uma abordagem etnográfica seria bastante benéfica para a compreensão mais aprofundada dos modos de estabelecer relações com a audiência utilizados pelas youtubers e de que forma eles influem (ou não) no estabelecimento de temas e estratégias discursivas.

Essa ampliação permitirá refinar os critérios de construção de entidades discursivas e de delimitação de seus campos epistêmico-axiológicos. Poderemos, assim, discernir com maior detalhe os aspectos envolvidos na negociação da projeção das entidades no campo endo/exogrupal, depreendendo uma lista mais detalhada de mecanismos envolvidos nos movimentos de aproximação e afastamento epistêmico-axiológico e seus efeitos.

Em suma, vimos que, no que se refere aos ativismos que prezam pela construção de visões de mundo radicalmente diferentes - apoiando-se, por exemplo, em epistemes póscoloniais, decoloniais, anticoloniais, contracoloniais e revolucionárias -, a explicitação da filiação ideológica se mostra crucial para a formação política. No feminismo negro, por exemplo, a centralidade da questão racial para o entendimento das relações sociais e da estruturação das sociedades perpassa também pela construção do imaginário coletivo e das 
subjetividades. Relaciona-se, portanto, com a desestabilização dos modos de ver, pensar e representar vigentes, propondo uma reestruturação epistemológica ampla.

Algo semelhante pode ser visto no feminismo lésbico, em que a denúncia da heterossexualidade compulsória aponta para as dinâmicas de poder que afetam a determinam os papéis das mulheres na sociedade heteropatriarcal. Assim, em ambos os processos, colocamse em pauta os processos de construção das identidades e das visões de mundo em geral, e não só a autodefinição de identidades marginalizadas assume um papel essencial, como também se questiona a constituição das identidades e pontos de vista hegemônicos - brancas, masculinas, heterossexuais...

Nesse sentido, vemos a importância do ativismo digital feminista para ampliação da força de vozes não hegemônicas no espaço público (HOLLANDA, 2018) e a disseminação de valores feministas para novas esferas sociais (ALVAREZ, 2014; MARTINEZ, 2019). Sabemos, afinal, os desdobramentos dos ativismos digitais de direita para o cenário político atual. Dessa forma, disputar as narrativas e ampliar as discussões, estabelecendo gênero, raça e sexualidade - e suas intersecções com a classe - como eixos centrais de análise social se apresenta como uma tarefa crucial. Não só fazer isso numa linguagem acessível para o público jovem, como aplicar esses conceitos sobre questões cotidianas se apresentam como estratégias relevantes para desenvolver o senso crítico e construir resistência e projetos de identidade contra-hegemônicos.

Além disso, os vídeos colaborativos demonstram o potencial de certas "etiquetas do lugar de fala" (isto é, uma youtuber branca sem formação na área da segurança pública convidar mulheres negras ativistas e intelectuais para debater racismo nessa área, por exemplo) desestabilizarem a legitimação automática dada a certas atoras/es sociais devido a traços identitários privilegiados. Com isso, começam a se estabelecer também redes plurais e demonstra -se a importância do compromisso ético e político no diálogo entre as vertentes e os modos de fazer ativismo.

Nesse sentido, acreditamos que incentivar os debates e a formação política nesses espaços seja essencial não só para a divulgação das pautas, mas também para o estabelecimento de diálogo com novas/os atoras/es sociais, pois há o potencial de despertar o interesse e capacitar uma série de atoras sociais a compreenderem e se inserirem em certos debates, além de promover um pouco mais de facilidade para acessar e construir espaços seguros dentro e fora das redes. 
Ademais, devido à persistência dos conteúdos, as plataformas se transformam em grandes reservatórios de conhecimento. Se bem organizados e utilizados, estes conteúdos podem ser e de fato são utilizados como forma de repertoriar atoras/es sociais, comunidades discursivas e grupos, colaborando não só para o fortalecimento de uma visão de mundo comum, como também para estabelecer comunicação entre grupos e organizações distantes, organizando redes de esperança e de indignação (CASTELLS, 2013).

Também nesse sentido afirmarmos a necessidade de refletir sobre e questionar a arquitetura das plataformas, pois constituem e determinam muitas das dinâmicas atuais da esfera pública. Nesse âmbito, garantir as condições materiais para o acesso e produção de conteúdo nos ambientes digitais para populações marginalizadas também se caracteriza como uma pauta urgente. Nesse processo, ressaltamos também a importância de se considerar o modo de produção desse conteúdo e os critérios de monetização/desmonetização estabelecidos pelas plataformas. Não se pode deixar de considerar ainda, em um horizonte amplo, a criação de novas plataformas e lógicas para as redes.

Assim, ressaltamos que o ativismo digital está longe, evidentemente, de se bastar em si mesmo. Dessa forma, a discussão de questões práticas a respeito da atuação em pautas locais, como a organização de protestos, a criação de grupos e instituições, além da elaboração de políticas públicas, continuam - e devem continuar sendo - os pontos fulcrais dos movimentos sociais contemporâneos.

O cenário em que nos encontramos em 2021 já é bastante diverso do que vivemos em 2017, e coloca novos desafios e contradições referentes ao uso das plataformas digitais para ações de propaganda e agitação política. O monitoramento de ações nas redes e a coleta de dados, por exemplo, apresentam dilemas cruciais. Não está ao nosso alcance, no entanto, discuti-los ou chegar a conclusões assertivas a respeito do que há de ser feito. Acreditamos que as práxis que se formam em espaços coletivos ofereçam recursos e linhas de ação mais adequados e produtivos para tanto. Ainda assim, esperamos que as discussões realizadas aqui possam, de algum modo, contribuir para a discussão e reflexão a respeito do modo como as relações intersubjetivas são constituídas nas/pelas redes. 


\section{Referências bibliográficas}

AKOTIRENE, Carla. Interseccionalidade. São Paulo: Sueli Carneiro: Pólen, 2019.

ALMEIDA, Silvio. Racismo estrutural. São Paulo: Sueli Carneiro: Pólen, 2019.

ALONSO, Angela. As teorias dos movimentos sociais: um balanço do debate. Lua Nova, São Paulo, 76, p. 49-86, 2009.

ALVAREZ, Sonia. Para além da sociedade civil: reflexões sobre o campo feminista. Cadernos Pagu, n. 43, p. 13-56, jan./jul. 2014.

AMOSSY, Ruth. Argumentação no Discurso. São Paulo: Contexto, 2018.

ARAÚJO, Andréia Silva. FREITAG, Raquel Meister Ko.. Estratégias de interação na fala: funções das perguntas na fala de Itabaiana/SE. Interdisciplinas, Ano 5, v. 10, n. especial, p. 107-120, 2010. Disponível em: <https://seer.ufs.br/index.php/interdisciplinar/article/view/1232>. Acesso em 03/02/2021.

ATLAS DA VIOLÊNCIA 2019. Organizadores: Instituto de Pesquisa Econômica Aplicada; Fórum Brasileiro de Segurança Pública. Brasília: Rio de Janeiro: São Paulo: Instituto de Pesquisa Econômica Aplicada; Fórum Brasileiro de Segurança Pública. Disponível em: <http://www.ipea.gov.br/portal/images/stories/PDFs/relatório_institucional/190605_atlas_da_ violencia_2019.pdf $>$. Acesso em 25/08/2019.

BAIRROS, Luiza. Nossos feminismos revisitados. In: HOLLANDA, Heloisa Buarque de. Pensamento feminista hoje: perspectivas decoloniais. São Paulo: Bazar do Tempo, 2020 [1995], p. 207-214.

BAKHTIN, Mikhail. Os gêneros do discurso. São Paulo: Editora 34, 2016 [1979].

BARROS, Thiane Neves. Estamos em marcha! Escrevivendo, agindo e quebrando códigos. In: SILVA, Tarcízio. Comunidades, Algoritmos e Ativismos Digitais: olhares afrodiaspóricos. São Paulo: Editora LiteraRUA, 2020, p. 184-199. Disponível em: < https://www.researchgate.net/publication/339954112 Comunidades Algoritmos e Ativismo s_Digitais_olhares_afrodiasporicos $>$. Acesso em 31/10/2020.

BARROS, Zelinda. Feminismo Negro e Internet. Disponível em: <https://www.academia.edu/1497162/Feminismo_negro_na_Internet $>$. Acesso em 28/08/2020.

BENTO, Berenice. "Pinkwashing à brasileira": do racismo cordial à LGBTTTfobia cordial. Revista Cult, 2015. Disponível em: <https://revistacult.uol.com.br/home/pinkwashingbrasileira-do-racismo-cordial-lgbtttfobia-cordial/>. Acesso em 08/11/2020. 
BENTO, Maria Aparecida Silva. Pactos narcísicos no racismo: branquitude e poder nas organizações empresariais e no poder público. 169f. Tese (Doutorado) - Universidade de São Paulo, São Paulo, 2002.

BERTH, Joice. Empoderamento. São Paulo: Sueli Carneiro: Pólen, 2019.

BERTHO, Helena. Não são loucos. É um projeto de poder que violenta meninas. Revista AzMina, 17 de agosto de 2020. Disponível em: <https://azmina.com.br/colunas/nao-saoloucos-e-um-projeto-de-poder-que-violenta-meninas/>. Acesso em 12/01/2021.

BLAY, Eva; AVELAR, Lúcia. Breve cronologia do movimento feminista no Brasil. In: BLAY, Eva; AVELAR, Lúcia. 50 anos de Feminismo: Argentina, Brasil e Chile: A Constituição das Mulheres como Atores Políticos e Democráticos. São Paulo: Edusp/Fapesp, p.329-337, 2017.

BOAKARI. Francis Musa. SOUZA, Emanuella Geovana Magalhães de. Mulheres afrodescendentes e espaços virtuais: para visibilizar aberturas epistemológicas. REVISTA FÓRUM IDENTIDADES, v. 29, n. 01, p. 231-246, jan.-jun. de 2019.

boyd, danah. Social Network Sites as Networked Publics Affordances, Dynamics, and Implications In: PAPACHARISSI, Zizi A. A networked self: identity, community and culture on social network sites. New York/Oxon: Routledge, p. 39-58, 2011.

boyd, danah. It's complicated: the social lives of networked teens. New Haven; London: Yale Universit Press, 2014.

BUENO, Winnie. Imagens de controle: um conceito do pensamento de Patricia Hill Collins. Porto Alegre: Editora Zouk, 2020.

BURGESS, Jean; GREEN, Joshua. YouTube: Online Video and Participatory Culture. Cambridge: Polity Press, 2009.

CAMERON, Lynne. Empathy: A review. Living with Uncertainty, 2011. Disponível em: $<$ http://www.open.ac.uk/researchprojects/livingwithuncertainty/sites/www.open.ac.uk.researc hprojects.livingwithuncertainty/files/pics/d115149.pdf>. Acesso em: 03/08/2017.

CAMERON, Lynne. Dyspathy: The dynamic complement of empathy. Living with Uncertainty, 2012. Disponível em: <http://www.open.ac.uk/researchprojects/livingwithuncertainty/sites/www.open.ac.uk.researc hprojects.livingwithuncertainty/files/pics/d134491.pdf>. Acesso em: 03/08/2017.

CAMERON, Lynne. A dynamic model of empathy and dyspathy. Living with Uncertainty, 2013.

Disponível em: 
<http://www.open.ac.uk/researchprojects/livingwithuncertainty/sites/www.open.ac.uk.researc hprojects.livingwithuncertainty/files/files/6\%20Empathy\%20model.pdf $>$. Acesso em: 03/08/2017.

CAMERON, Lynne. Mixed metaphors from a discourse dynamics perspective: A non-issue?. In: GIBBS, Raymond W., Jr.. Mixing metaphor. Amsterdam/Philadelphia: John Benjamins, 2016, p. 17-30.

CAP, Piotr. Axiological aspects of proximization. Journal of Pragmatics, n. 42, p. 392-407, 2010.

CAP, Piotr. Proximization: The pragmatics of symbolic distance crossing. Amsterdam/Philadelphia: John Benjamins Publishing Company, 2013.

CAP, Piotr. Expanding CDS Methodology by Cognitive-Pragmatic Tools: Proximization Theory and Public Space Discourses. In: CAP, Piotr. HART, Christopher. Contemporary Critical Discourse Studies. London/New York: Bloomsbury Academic, 2014a, p. 189-210.

CAP, Piotr. Applying cognitive pragmatics to Critical Discourse Studies: A proximization analysis of three public space discourses. Journal of Pragmatics, n. 70, p. 16-30, 2014b.

CAP, Piotr. Crossing symbolic distances in political discourse space. Critical Discourse Studies, n. 12, v. 3, p. 313-329, 2015. DOI: 10.1080/17405904.2015.1013481.

CARDOSO, Lourenço. Branquitude acrítica e crítica: a supremacia racial e o branco antiracista. Revista Latinoamericana de Ciencias Sociales, Niñez y Juventud, v. 8, n. 1, jan./jun., 2010, p. 607-630. Disponível em: <http://www.scielo.org.co/scielo.php?pid=S1692715X2010000100028\&script=sci_abstract\&tlng=pt $>$. Acesso em: $\langle 30 / 10 / 2020\rangle$.

CARDOSO, Lourenço. A branquitude acrítica revisitada e a branquidade. Revista da ABPN, n. 13, v. 6, mar./jun. 2014, p. 88-106. Disponível em: $<$ http://biblioteca.clacso.edu.ar/Colombia/alianza-cindeumz/20131216065611/art.LourencoCardoso.pdf>. Acesso em: $<30 / 10 / 2020>$.

CARNEIRO, Sueli. A Construção do Outro como Não-Ser como fundamento do Ser. 339f. Tese (Doutorado em Educação) - Universidade de São Paulo, São Paulo, 2005.

CARNEIRO, Sueli. Enegrecer o feminismo: a situação da mulher negra na América Latina a partir de uma perspectiva de gênero. In: HOLLANDA, Heloisa Buarque. (Org.). Pensamento feminista: conceitos fundamentais. Rio de Janeiro: Bazar do Tempo, 2019a, p.313-321 [2003].

CARNEIRO, Sueli. Mulheres em movimento: contribuições do feminismo negro. In: HOLlANDA, Heloisa Buarque (Org.). Pensamento feminista brasileiro: formação e contexto. Rio de Janeiro: Bazar do Tempo, 2019b [2003], p.271-289. 
CARRARA, Sergio; VIANNA, Adriana. Os direitos sexuais e reprodutivos no Brasil a partir da "Constituição Cidadã". In: OLIVEN, R.; RIDENTIM, M; BRANDÃO, G.M (orgs). A Constituição de 1988 na vida brasileira. São Paulo: Editora Hucitec; 2008. p. 334-59.

CASTELLS, Manuel. Redes de indignação e esperança: Movimentos Sociais na Era da Internet. Tradução: Carlos Alberto Medeiros. Rio de Janeiro: Zahar, 2013.

CESTARI, Mariana Jafet. Vozes-mulheres negras ou feministas e antirracistas graças às Yabás. 264f. Tese (Doutorado em Linguística) - Universidade Estadual de Campinas, Campinas, 2015.

CESTARI, Mariana Jafet. Por uma tomada de posição feminista e antirracista na Análise do Discurso. In: ZOPPI FONTANA, Mónica G.; FERRARI, Ana Josefina. Mulheres em Discurso: identificações de gênero e práticas de resistência. Volume 2. Campinas: Pontes Editores, p. 183-203, 2017.

CHILTON, Paul. Analysing Political Discourse: Theory and Practice. London: Routledge, 2004.

CHILTON, Paul. Discourse Space Theory: Geometry, Brain and Shifting Viewpoints. Annual Review of Cognitive Linguistics, v. 3, p. 78-116, 2005.

CLOHESY, Anthony. Politics of Empathy: Ethics, solidarity, recognition. Oxon: Routledge, 2013.

CRENSHAW, Kimberlè. Documento para o encontro de especialistas em aspectos da discriminação racial relativos ao gênero. Estudos Feministas, v. 7, n. 12, p. 171-188, jan. 2002.

COLLINS, Patricia Hill. Se perdeu na tradução? Feminismo negro, interseccionalidade e política emancipatória. PARÁGRAFO, v.5, n.1, p. 6-17. jan./jun., 2017.

COLLINS, Patricia Hill. Pensamento feminista negro. Tradução de Jamille Pinheiro Dias. São Paulo: Boitempo, 2019 [2000].

CYPRIANO, Breno. Feminismo negro e interseccionalidade: práxis política e a consolidação de um pensamento sociopolítico para além das margens. In: MARQUES, Danusa. REZENDE, Daniela. MANO, Maíra Kubík. SARMENTO, Rayza. FREITAS, Viviane Gonçalves. (Orgs.) Feminismos em rede. Porto Alegre: Editora Zouk, 2019, p. 93-128.

DAVIS, Angelique M. ERNST, Rose. Racial gaslighting. Politics, Groups, and Identities, p. 1-14, 2019 [2017]. Disponível em: <https://www.researchgate.net/publication/321253827 Racial gaslighting>. Acesso em: 23/08/2020. DOI: 10.1080/21565503.2017.1403934 
DESCOMPENSAÇÃO. In: MICHAELIS On-line. São Paulo: Editora Melhoramentos, 2015. Disponível em: $\quad$ https://michaelis.uol.com.br/moderno-portugues/busca/portuguesbrasileiro/\%C3\%B3dio/>. Acesso em: 01/08/2020.

ERRÁZURIZ, Valentina. A digital room of their own: Chilean students struggling against patriarchy in digital sites. Feminist Media Studies, p. 1-16, 2019. DOI: 10.1080/14680777.2019.1668451.

FACCHINI, Regina. RODRIGUES, Julian. "Que onda é essa?": "guerras culturais" e movimento LGBT no cenário brasileiro contemporâneo In: A diversidade e a livre expressão sexual entre as ruas, as redes $\mathrm{e}$ as políticas públicas. $1^{\mathrm{a}}$ ed. Porto Alegre: Rede Unida/Nuances, p. 35-60, 2017.

FAGERJORD, Anders. After Convergence: YouTube and Remix Culture. In: HUNSINGER, Jeremy. KLASTRUP, Lisbeth; ALLEN, Matthew. (Eds.). International Handbook of Internet Research. Blacksburg/Copenhagen: Springer, 2010, p. 187-200.

FAIRCLOUGH, Isabela. FAIRCLOUGH, Norman. Political Discourse Analysis. Londres/Nova York: Routledge, 2012.

FAIRCLOUGH, Norman. Analysing Discourse. London: Routledge, 2003.

FAIRCLOUGH, Norman. Semiosis, ideology and mediation: A dialectical view. In: LASSEN, Inger. STRUNCK, Jeanne. VESTERGAARD, Torben. (Eds.). Mediating Ideology in Text and Image: Ten critical studies. Amsterdam/Philadelphia: John Benjamins Publishing Company, 2006, p. 19-36.

FAIRCLOUGH, Norman. Análise Crítica do Discurso como método em pesquisa social científica. Tradução: Iran Ferreira de Melo. Linha D’água, n. 25 (2), p. 307-329, 2012.

FALQUET, Jules. Breve reseña de algunas teorías lésbicas. 2004. Disponível em: $<$ https://apoiamutua.milharal.org/files/2014/04/breve-resenha-teorias-lesbicas.pdf $>$. Acesso em: 31/01/2021.

FERRO'S BAR. Disponível em: <http://outrosurbanismos.fau.usp.br/lugares-memoria-lgbtsao-paulo/ferros-bar/>. Acesso em: 08/11/2020.

FREITAS, Viviane Gonçalves. Vozes das mulheres negras na imprensa feminista brasileira: interseccionalidade, pluralidade e cidadania. In: MARQUES, Danusa. REZENDE, Daniela. MANO, Maíra Kubík. SARMENTO, Rayza. FREITAS, Viviane Gonçalves.(Orgs.). Feminismos em rede. Porto Alegre: Zouk, p. 111-128, 2019.

FIRMIANO, Thayná Colares. RODRIGUES, Bárbara de Oliveira Lima. PINHEIRO, Larissa Souza. Racismo, LGBTfobia e criminalização no Brasil: educação na moção das estruturas. VI 
JOINBR - Encontro Internacional de Jovens Investigadores, 2019. Disponível em: $<$ http://editorarealize.com.br/editora/anais/join/2019/TRABALHO_EV124_MD1_SA70_ID1 881_23082019180322.pdf>. Acesso em 23/08/2020.

FOGELIN, Robert J. The Logic of Deep Disagreements. Informal Logic, vol. 25, n.1, p. 3-11, 2005 [1985].

GGB - Grupo Gay Da Bahia. Assassinatos de LGBT no Brasil. Relatório 2016. Salvador: GGB, 2017. Disponível em: <http://bancariospa.org.br/wp3/wpcontent/uploads/2017/01/relatc3b3rio-20162.pdf >. Acesso em: 13/08/2018.

GOFFMAN, E. A representação do eu na vida cotidiana. 3.ed. Petrópolis: Vozes, 1985 [1956].

GONÇALVES SEGUNDO, Paulo Roberto. Tradição, dinamicidade e estabilidade nas práticas discursivas: um estudo da negociação intersubjetiva na imprensa paulistana. 2011. 447f. Tese (Doutorado em Filologia e Língua Portuguesa) - Universidade de São Paulo, São Paulo, 2011.

GONÇALVES-SEGUNDO, Paulo Roberto. Linguística Sistêmico-Funcional e Análise Crítica do Discurso: explorando convergências e explicitando especificidades. Revista do GEL s v. 43, n. 3, p. 1282-1297, set./dez. 2014.

GONÇALVES-SEGUNDO, Paulo Roberto. Argumentação e falácias em entrevistas televisivas: por um diálogo entre o modelo Toulmin e a perspectiva textual-interativa. Revista Linha D'Água, v.29, n.2, p. 69-96, 2016a. DOI: http://dx.doi.org/10.11606/issn.22364242.v29i2p69-96.

GONÇALVES-SEGUNDO, Paulo Roberto. Exclusão e inclusão na mídia paulista: uma análise cognitivo-retórica da construção dos rolezinhos na Folha de S. Paulo In: AQUINO, Zilda Gaspar de Oliveira; GONÇALVES-SEGUNDO, Paulo Roberto (org.). Estudos do discurso: caminhos e tendências.1 ed. São Paulo: Paulistana, 2016b, p. 134-158. Disponível em: <http://cied.fflch.usp.br/node/42>. Acesso em: 10/11/2020.

GONÇALVES-SEGUNDO, Paulo Roberto. A relevância da noção de perspectivação conceptual (construal) no âmbito dos estudos do texto e do discurso: teoria e análise. Letras, Santa Maria, v. 27, n. 54, p. 69-100, jan./jun. 2017.

GONÇALVES SEGUNDO, Paulo Roberto. A configuração funcional da argumentação: relendo o modelo Toulmin em perspectiva cognitivo-discursiva. XXXIII ENANPOLL. Cuiabá: UFMT, 2018a (Comunicação oral).

GONÇALVES-SEGUNDO, Paulo Roberto. Argumentação e perspectivação conceptual: possibilidades teórico-analíticas. In: VITALE, Maria Alejandra et al (Orgs.). Anais do IV 
Seminário Internacional de Estudos Sobre Discurso e Argumentação (IV SEDiAr). Ilhéus: Editus- Editora da Universidade Estadual de Santa Cruz, p. 922-934, 2018 b.

GONÇALVES-SEGUNDO, Paulo Roberto. Discurso e Prática Social. In: BATISTA Jr., José Ribamar Lopes; SATO, Denise Tomaê Borges; MELO, Iran Ferreira de (Orgs.). Análise do Discurso Crítica para linguistas e não linguistas. São Paulo: Parábola, p. 79-103, 2018c.

GONÇALVES-SEGUNDO, PAULO ROBERTO. A configuração funcional da argumentação prática: uma releitura do layout de Fairclough \& Fairclough (2012). EID\&A - Revista Eletrônica de Estudos Integrados em Discurso e Argumentação, v. 19, p. 109-137, 2019a.

GONÇALVES-SEGUNDO, Paulo Roberto. A projeção e a captação da empatia, da dispatia e do antagonismo: em busca de uma perspectiva centrada na linguagem. In: Paulo Roberto Gonçalves-Segundo; Adriana Moreira Pedro; Agildo Santos Silva de Oliveira; Alexandre Marques Silva; Gabriel Isola-Lanzoni; Sergio Mikio Kobayashi; Winola Weiss. (Org.). Trajetórias teórico-metodológicas nos estudos do discurso. $1^{a}$ ed. São Paulo: FFLCH/USP, v. 1, p. 309-322, 2019 b.

GONÇALVES-SEGUNDO, Paulo Roberto. A configuração funcional da argumentação epistêmica: uma releitura do layout de Toulmin em perspectiva multidisciplinar. BAKHTINIANA - REVISTA DE ESTUDOS DO DISCURSO, v. 15, p. 236-266, 2020a.

GONÇALVES-SEGUNDO, Paulo Roberto. Multimodal metaphors and practical argumentation: discussing rhetorical effects and modes of articulation between modalities. Rev. Estudos Linguísticos, Belo Horizonte, v. 28, n. 2, p. 801-844, 2020b. Disponível em: <http://www.periodicos.letras.ufmg.br/index.php/relin/article/view/16451/pdf >. Acesso em: $31 / 01 / 2021$.

GONÇALVES-SEGUNDO, Paulo Roberto. O modelo multidimensional de análise argumentativa: uma introdução. ALFA: Revista de Linguística (UNESP. ONLINE), v. 64, p. 1-30, 2020c. DOI: http://dx.doi.org/10.1590/2176-457347130.

GONÇALVES-SEGUNDO, Paulo Roberto; RIBEIRO, Rafaela Baracat. Envolvimento e empatia: a solidariedade construída nas colunas de aconselhamento em revistas. Revista do GEL, v. 13, n. 2, p. 211-236, 2016. DOI: http://dx.doi.org/10.21165/gel.v13i2.835

GONZALEZ, Lélia. A categoria político-cultural da Amefricanidade. In: HOLLANDA, Heloisa Buarque. Pensamento feminista: conceitos fundamentais. Rio de Janeiro: Bazar do Tempo, 2019 [1992], p. 341-352.

GONZALEZ, Lélia. Por um feminismo afro-latino-americano. Paper escrito em 1988. In: Caderno de Formação Política do Círculo Palmarino, n.1 - Batalha de Ideias. Afrolatinoamérica, Brasil, p. 12-20, 2011. Disponível em < https://edisciplinas.usp.br/pluginfile.php/271077/mod_resource/content/1/Por\%20um\%20fem inismo\%20Afro-latino-americano.pdf>. Acesso em 28/08/2020. 
GONZALEZ, Lélia. Racismo e Sexismo na cultura brasileira. Paper apresentado na Reunião do Grupo de Trabalho "Temas e Problemas da População Negra no Brasil”, IV Encontro Anual da Associação Brasileira de Pós-graduação e Pesquisa nas Ciências Sociais, Rio de Janeiro, 31 de outubro de 1980. In: Revista Ciências Sociais Hoje, Anpocs, 1984, p. 223-244. Disponível em <https://edisciplinas.usp.br/pluginfile.php/4584956/mod_resource/content $/ 1 / 06 \% 20$ \%20GONZALES\%2C\%20L\%C3\%A9lia\%20-

\%20Racismo_e_Sexismo_na_Cultura_Brasileira\%20\%281\%29.pdf>. Acesso em 28/08/2020.

GRÁCIO, Rui Alexandre Lalanda Martins. Para uma teoria geral da argumentação: questões teóricas e aplicações didácticas. Tese (Doutorado em Ciências da Comunicação) Universidade do Minho, 2010.

GUIMARÃES, Antônio Sérgio. Racismo e anti-racismo no Brasil. São Paulo: Edições 34, 1999.

HALLIDAY, Michael A. K. An Introduction to Functional Grammar. Baltimore: Edward Arnold, 1994.

HALLIDAY, Michael A. K. Introduction to Functional Grammar. London/New York: Routledge, 2014.

HARADA, Eduardo. Algunas aclaraciones sobre el "modelo" argumentativo de Toulmin. Contactos, México, n. 73, p. 45-56, 2009.

HART, Christopher. Discourse, Grammar and Ideology: functional and cognitive perspectives. London/New York, Bloomsbury, 2014.

HASSAN, Huda. The Angry Black Woman Must Die. Buzzfeed News. 2015, s/p. Disponível em: $\quad\langle$ https://www.buzzfeednews.com/article/hudahassan/the-twilight-of-the-angry-blackwoman\#.tkV0Mr5ON>. Acesso em: 30/10/2020.

HETEROPHOBIA. Merriam-Webster. Disponível em: <https://www.merriamwebster.com/dictionary/heterophobia>. Acesso em 08/09/2018.

HISTERIA. In: MICHAELIS On-line. São Paulo: Editora Melhoramentos, 2015. Disponível em: <https://michaelis.uol.com.br/moderno-portugues/busca/portugues-brasileiro/histeria> Acesso em: 01/08/2020.

HOLLAN, Douglas. Empathy across cultures. In: MAIBOM, Heidi L. The Routledge handbook of philosophy of empathy. New York: Routledge, p. 341-352, 2017. 
HOLLANDA, Heloisa Buarque de. Introdução: O grifo é meu. In: HOLLANDA, Heloisa Buarque de. (Org.) Explosão feminista: arte, cultura, política e universidade. São Paulo: Companhia das Letras, 2018, p. 11-19.

HOLlANDA, Heloisa Buarque de. COSTA, Cristiane. Rede. In: HOLLANDA, Heloisa Buarque de. (Org.) Explosão feminista: arte, cultura, política e universidade. São Paulo: Companhia das Letras, 2018, p. 43-60.

hooks, bell. Mulheres negras revolucionárias: nos transformamos em sujeitas. In: bell, hooks. Olhares negros: raça e representação. Tradução de Stephanie Borges. São Paulo: Editora Elefante, p. 96-126, 2019a.

hooks, bell. O olhar opositor: mulheres negras espectadoras. In: bell, hooks. Olhares negros: raça e representação. Tradução de Stephanie Borges. São Paulo: Editora Elefante, p. 216-240, $2019 b$.

HONÓRIO, Marcelo Júnior de Souza. BORGES, Luciana. A OBSCENA SENHORA D.: POR DEUS ESQUECIDA, POR HOMENS OPRIMIDA, PELAS LOUCAS E HISTÉRICAS MUITO BEM-VINDA. Revista de Estudos Acadêmicos em Letras, v. 11, n. 02, p. 304-322, dez., 2018. Disponível em: <https://periodicos.unemat.br/index.php/reacl/article/view/2513 >. Acesso em 31/01/2021.

ISOLA-LANZONI, Gabriel. Articulação multimodal na construção da argumentação: produções vidiáticas de youtubers. In: VITALE, Maria Alejandra et al (Orgs.). Anais do IV Seminário Internacional de Estudos Sobre Discurso e Argumentação (IV SEDiAr). Ilhéus: Editus- Editora da Universidade Estadual de Santa Cruz, p. 922-934, 2018.

JUNQUEIRA, Rogério Diniz. "Ideologia de gênero": a gênese de uma categoria política reacionária - ou: a promoção dos direitos humanos se tornou uma "ameaça à família natural"? In: RIBEIRO, Paula Regina. MAGALHÃES, Joanalira Corpes. (Org). Debates contemporâneos sobre educação para a sexualidade. Rio Grande, RS, Ed. da FURG, 2017. Disponível em: <http://repositorio.furg.br/handle/1/7097>. Acesso em: 28 abr. 2019.

KILOMBA, Grada. Memórias da plantação: episódios de racismo cotidiano. Tradução de Jess Oliveira. Rio de Janeiro: Editora de Livros Cobogó, 2019.

KOCH, Ingedore Villaça. As tramas do texto. São Paulo: Editora Contexto, 2014.

KUMPERA, Julia. Lesbianidade e Branquitude. REBEH - Revista Brasileira de Estudos sobre a Homocultura, v. 02, n. 04, out./dez., p. 136-145, 2019. Disponível em: $<$ https://periodicoscientificos.ufmt.br/ojs/index.php/rebeh/article/view/10172>. Acesso em $30 / 10 / 2020$. 
LORDE, Audre. A transformação do silêncio em linguagem e ação. In: LORDE, Audre. Irmã outsider. Tradução de Stephanie Borges. São Paulo: Autêntica Editora, 2019a, p. 51-56.

LORDE, Audre. Para começo de conversa: alguns apontamentos sobre as barreiras entre as mulheres e o amor. In: LORDE, Audre. Irmã outsider. Tradução de Stephanie Borges. São Paulo: Autêntica Editora, 2019b, p. 57-66.

LUZ, Nilton. Discriminação às avessas: um argumento de defesa de violências. In: GIVIGI, Ana Cristina Nascimento. DORNELLES, Priscila Gomes (Orgs.). Babado acadêmico do Recôncavo Baiano: universidade, gênero e sexualidade. Salvador: Editora da UFBA, 2017, p.149-173.

MAIBOM, Heidi L. Affective empathy. In: MAIBOM, Heidi L. The Routledge handbook of philosophy of empathy. New York: Routledge, 2017a, p. 22-32.

MAIBOM, Heidi L. Introduction to philosophy of empathy. In: MAIBOM, Heidi L. The Routledge handbook of philosophy of empathy. New York: Routledge, 2017b, p. 1-9.

MALUNGUINHO, Érica. [Pronunciamento proferido no Plenário da Assembleia Legislativa do Estado de São Paulo, na 015 a SESSÃO SOLENE DE ENTREGA DA MEDALHA THEODOSINA ROSÁRIO RIBEIRO em 23/03/2018, ocasião da entrega da medalha a Marilândia Frazão de Espinosa, Rita de Cássia Silva Mesquita, Fabiana Dal'Mas Rocha Paes, Joana Aparecida Barros, Magali Mendes, Débora Garcia, Jenny Teixeira Francisco, Lais Moreira, Maria Pulqueria Albuquerque Lima, Amanda Cristina Silva dos Santos, Érica Malunguinho, Joana D’Arc Félix de Sousa, Edna Maria Andrade, Maria Bernadete Raimundo e Maria Cícera Mineiro da Silva]. São Paulo, Assembleia Legislativa do Estado de São Paulo, 2018. Disponível em: <https://www.al.sp.gov.br/repositorio/ementario/anexos/20180418150053-ID_SESSAO=13133.htm>. Acesso em 30/10/2020.

MANOVICH, Lev. The Interface. In: MANOVICH. The Language of New Media. Cambridge: MIT Press, 2000, p. 75-114

MANOVICH, Lev. The Practice of Everyday (Media) Life: From Mass Consumption to Mass Cultural Production? Critical Inquiry, Chicago, Winter 2009.

MARCHA DAS MULHERES NEGRAS. O Bem Viver como nova Utopia. Disponível em: $<$ https://www.geledes.org.br/wp-content/uploads/2015/11/Carta-das-Mulheres-Negras2015.pdf $>$. Acesso em 04/10/2020.

MARTELOTTA, Mário Eduardo. KENEDY, Eduardo. A visão funcionalista da linguagem no século XX. In: CUNHA, Maria Angélica Furtado da. OLIVEIRA, Mariangela Rios de. MARTELOTTA, Mário Eduardo. Linguística funcional: teoria e prática. Parábola Editorial, 2015, p. 11-20. 
MARTIN, J. R.; WHITE, Peter R. R. The language of evaluation: appraisal in English. New York/Hampshire: Palgrave Macmillan, 2005.

MARTINEZ, Fabiana. Feminismos em movimento no ciberespaço. Cadernos Pagu, Campinas, n. 56, p. 1-34, 2019. DOI: http://dx.doi.org/10.1590/18094449201900560012.

MARIANO, Lília Dias. Feminismo protestante. In: HOLLANDA, Heloisa Buarque de. (Org.). Explosão feminista: arte, cultura, política e universidade. São Paulo: Companhia das Letras, 2018, p. 414-442.

MARTINS, Larissa Pinto. Quebrando o Tabu: Visibilidade lésbica através dos boletins Chanacomchana. Revista Latinoamericana de Estudios en Cultura y Sociedad | Latin American Journal of Studies in Culture and Society, v. 05, ed. especial, abr., p. 1-11, 2019.

MATEUS, Elaine; REZENDE, Viviane de Melo. O sistema posição-prática como categoria epistemológica: contribuições para a Análise de Discurso Crítica. Alfa, São Paulo, v. 59, n.3, p. 445-469, 2015. Disponível em: <https://periodicos.fclar.unesp.br/alfa/article/view/6944>. Acesso em: 31/01/2021.

MATOS, Marlise; SIMÕES, Solange. Emergence of Intersectional Activist Feminism in Brazil: The Interplay of Local and Global Contexts. In: BONIFACIO, G. T. Global currents in gender and feminisms: Canadian and International Perspectives. Bingley: Emerald Publishing Limited, 2018. p. 35-47.

MELO, Sergio. ABIBE, Antonio. Creators Connect: o poder dos YouTubers. Disponível em: $<$ https://www.thinkwithgoogle.com/intl/pt-br/advertising-channels/v\%C3\%ADdeo/creatorsconnect-o-poder-dos-youtubers/>. Acesso em: 31/08/2020.

MILLER, D.; SLATER, Don. Etnografia on e off-line: cybercafés em Trinidad. Horizontes Antropológicos, Porto Alegre, ano 10, n. 21, p. 41-65, jan/jun., 2004.

MILLER, Daniel. HORST, Heather. Digital Anthropology. London/New York, 2012.

MOLEK-KOZAKOWSKA, Katarzyna. Distance crossing and alignment in online humanitarian discourse. Journal of Pragmatics, n. 124, p. 1 -13, 2018.

MOMBAÇA, Jota. Notas estratégicas quanto ao uso político do conceito de lugar de fala. Disponível em: <https://www.buala.org/pt/corpo/notas-estrategicas-quanto-aos-usos-politicosdo-conceito-de-lugar-de-fala>. Acesso em: 16/10/2020.

MORAES, Alana. TIBLE, Jean. Quando novos personagens entram em cena?. In: MORAES, Alana. TARIN, Bruno. TIBLE, Jean. (Org.). Cartografias da Emergência: novas lutas no Brasil. 1ed. São Paulo: Friedrich Ebert Stiftung, 2015. 
MOREIRA, Matheus. DIAS, Tatiana. O que é 'lugar de fala' e como ele é aplicado no debate público. Nexo Jornal, 15 jun. 2017. Disponível em: < https://www.nexojornal.com.br/expresso/2017/01/15/O-que-\%C3\%A9-\%E2\%80\%98lugarde-fala\%E2\% $80 \% 99$-e-como-ele-\%C3\%A9-aplicado-no-debate-p\%C3\%BAblico>. Acesso em $24 / 01 / 2020$.

MOURA, Erick. Kit gay nunca foi distribuído em escola; veja verdades e mentiras. Congresso em Foco, 11 jan. 2020. Disponível em: <https://congressoemfoco.uol.com.br/educacao/kitgay-nunca-foi-distribuido-em-escola-veja-verdades-e-mentiras/>. Acesso em 10/11/2020.

MOURA, Bernardo. CYPRESTE, Judite. É falso que Haddad criou 'kit gay' para crianças de seis anos. Aos fatos, 10 out. 2018. Disponível em: <https://www.aosfatos.org/noticias/e-falsoque-haddad-criou-kit-gay-para-criancas-de-seis-anos/>. Acesso em: 10/11/2020.

NASCIMENTO, Beatriz. A mulher negra e o amor. In: HOLLANDA, Heloisa Buarque. (Org.). Pensamento feminista brasileiro: formação e contexto. Rio de Janeiro: Bazar do Tempo, 2019a [2006], p. 265-268.

NASCIMENTO, Beatriz. A mulher negra e o mercado de trabalho. In: HOLLANDA, Heloisa Buarque. (Org.). Pensamento feminista brasileiro: formação e contexto. Rio de Janeiro: Bazar do Tempo, 2019b [2006], p. 206-263.

NASCIMENTO, Tatiana. Racismo reverso é um delírio da branquitude colonial, 2020. Disponível em: <https://palavrapreta.wordpress.com/2020/05/29/racismoreverso/>. Acesso em 30/10/2020.

NEVES, Maria Helena de Moura. A gramática funcional. São Paulo: Martins Fontes, 1997.

NOVELLINO, Maria Salet Ferreira. As Organizações Não-Governamentais (ONGs) Feministas Brasileiras. In: SEMINÁRIO INTERNACIONAL FAZENDO GÊNERO 7, Anais. Florianópolis, 2006.2 Disponível em: <https://repositorio.ufsc.br/bitstream/handle/123456789/90380/241321.pdf?sequence=1\&isAl lowed=y>. Acesso em 23/08/2020.

ÓDIO. In: MICHAELIS On-line. São Paulo: Editora Melhoramentos, 2015. Disponível em: < https://michaelis.uol.com.br/moderno-portugues/busca/portugues-brasileiro/ODIO>. Acesso em 23/08/2020.

OLIVEIRA, Laila Thaíse Batista de. Narrativas em rede: o Feminismo Negro nas redes sociais. In: Anais do I Seminário Nacional de Sociologia da UFS, 27 a 29 de abril de 2016, Programa de Pós-Graduação em Sociologia - PPGS Universidade Federal de Sergipe - UFS, p. 810-823, 2016. 
OYĚWÙMÍ, Oyèrónkẹ. Conceituando o gênero: os fundamentos eurocêntricos dos conceitos feministas e o desafio das epistemologias africanas. In: HOLLANDA, Heloisa Buarque de. (Org.). Pensamento feminista hoje: perspectivas decoloniais. São Paulo: Bazar do Tempo, 2018 [2004], p. 84-95.

PENTEADO, Claudio Luis de Camargo. SANTOS, Marcelo Burgos Pimentel. ARAÚJO, Rafael de Paulo Aguiar. Democracia, Sociedade Civil Organizada e internet: estratégias de articulação online da Rede Nossa São Paulo. Sociologias, ano 16, n. 36, p. 206-235, mai./ago. 2014.

PENTEADO, Claudio L.; LERNER, Celina. "Direita volver: estudo do uso das redes sociais de internet por movimentos sociais de direita no Brasil". Paper apresentado no XXX Congreso Latino Americano de Sociologia - ALAS, Costa Rica, 2015. Disponível em: <http://sociologia-alas.org/congreso-xxx/ponencias/>. Acesso em: 31/01/2021.

PERELMAN, Chaim; OLBRECHTS-TYTECA, Lucie. Tratado da argumentação: A Nova Retórica. São Paulo: WMF Martins Fontes, 2002 [1958].

PERES, Milena Cristina Carneiro. SOARES, Suane Felippe. DIAS, Maria Clara. Dossiê sobre lesbocídio no Brasil: de 2014 até 2017. Rio de Janeiro: Livros Ilimitados, 2018. Disponível em: $\quad<$ https://dossies.agenciapatriciagalvao.org.br/fontes-e-pesquisas/wpcontent/uploads/sites/3/2018/04/Dossi\%C3\%AA-sobre-lesboc\%C3\%ADdio-no-Brasil.pdf>. Acesso em 08/11/2020.

PEZATTI, Erotilde Goretti. O funcionalismo em linguística. In: MUSSALIM, Fernanda; BENTES, Anna Christina (Orgs.). Introdução à Linguística: fundamentos epistemológicos. São Paulo: Cortez Editora, 2004, p. 165-218.

PIEDADE, Vilma. Dororidade. São Paulo: Editora Nós, 2018.

PITANGUY, Jacqueline. Jacqueline Pitanguy. In: HOLLANDA, Heloisa Buarque de (Org.). Explosão feminista: arte, cultura, política e universidade. São Paulo: Companhia das Letras, 2018, p.461-479.

PREECE, Jennifer; GHOZATI, Kambiz. Observations and Explorations of Empathy Online. In: RICE, R. R; KATZ, J. E. The Internet and Health Communication: Experience and Expectations. Thousand Oaks: Sage Publications Inc., 2001, p. 237-260. Disponível em: <https://pdfs.semanticscholar.org/548d/bc3abc68f146c32c54fc03e4f60f52f458e2.pdf >. Acesso em 24/11/2018.

PRETI, Dino (Org). Análise de textos orais. São Paulo: Humanitas, 2010. 
PUAR, Jasbir K. Homonacionalismo como mosaico: viagens virais, sexualidades afetivas. Revista Lusófona de Estudos Culturais, vol. 3, n. 1, 2015, p. 297-318. Disponível em: < https://rlec.pt/index.php/rlec/article/view/1788>. Acesso em 08/11/2020.

RAIVA. In: MICHAELIS On-line. São Paulo: Editora Melhoramentos, 2015. Disponível em: <https://michaelis.uol.com.br/moderno-portugues/busca/portugues-brasileiro/RAIVA/>. Acesso em: 01/08/2020.

RAMOS, Jair de Souza. Subjetivação e poder no ciberespaço: da experimentação à convergência identitária na era das redes sociais. Vivência: Revista de Antropologia, v. 1, p. 57-76, 2015.

RASQUEL, Sandra Gomes. Um estudo crítico discursivo e das marcas avaliativas da responsividade nas cartas do leitor relativas à reforma da previdência em jornais paulistas. Dissertação (Mestrado) - Universidade de São Paulo, São Paulo, 2020. Disponível em: $\quad$ https://www.teses.usp.br/teses/disponiveis/8/8142/tde-12012021-151436/fr.php>. Acesso em 31/01/2021.

RIBEIRO, Djamila. O que é lugar de fala?. Belo Horizonte: Letramento, 2017.

RICH, Adrienne. Compulsory Heterosexuality and Lesbian Existence. Signs, v. 5, n. 4, Women: Sex and Sexuality, p. 631-660, 1980. Disponível em: $<$ https://transasdocorpo.org.br/wp-content/uploads/2017/01/Compulsory-heterosexuality-andlesbian-existence-2.pdf $>$. Acesso em 30/10/2020.

RODRIGUES, Cristiano. FREITAS, Viviane Gonçalves. As vozes de mulheres negras em três tempos. In: CORRÊA, Laura Guimarães (Orgs.). Vozes negras em comunicação: mídias, racismos, resistências. Belo Horizonte: Autêntica, p. 75-92, 2019.

RODRIGUES, Rafaela Baracat Ribeiro. Relações interpessoais na interação midiática: recursos de envolvimento na constituição de práticas discursivas de conselho em revistas de nicho. 2016. Tese (Doutorado em Filologia e Língua Portuguesa) - Universidade de São Paulo, São Paulo, 2016. DOI:10.11606/T.8.2016.tde-24112016-132206. Acesso em: 01/04/2019.

REVERSE RACISM. Oxford Living Dictionaries. English. Disponível em: <https://en.oxforddictionaries.com/definition/reverse_racism>. Acesso em: 08/09/2018.

RIBEIRO, Stephanie. Quem somos: mulheres negras no plural, nossa existência é pedagógica. In: HOLLANDA, Heloisa Buarque de (Org.). Explosão feminista: arte, cultura, política e universidade. São Paulo: Companhia das Letras, p. 261-286, 2018.

SANT'ANNA, Camila Luiz. GUIMARÃES, Cristian Fabiano. Experiências sobre a (in)visibilidade lésbica no ambiente universitário. Saúde em Redes, n. 5, vol. 1, p. 9-23, 2019. DOI: http://dx.doi.org/10.18310/2446-4813.2019v5n1p09-23. 
SARMET, Érica. Feminismo lésbico. In: HOLLANDA, Heloisa Buarque de (Org). Explosão feminista: arte, cultura, política e universidade. São Paulo: Companhia das Letras, 2018, p. 379-399.

SILVA, Cidinha da. De onde viemos: aproximações de uma memória. In: HOLLANDA, Heloisa Buarque de. (Org.) Explosão feminista: arte, cultura, política e universidade. São Paulo: Companhia das Letras, p. 252-260, 2018.

SILVA, Maria Claudia Ferreira da. Marcha das Margaridas. Rio de Janeiro: Aeroplano, 2014.

SILVA, Natália Pereira da. Feminicídio: Uma Análise Constitucional dos Fatores Sociais da Violência Contra Mulheres Negras no Brasil. Conteúdo Jurídico, Brasília-DF, 2019. Disponível em: <https://conteudojuridico.com.br/consulta/artigos/53720/feminicdio-umaanlise-constitucional-dos-fatores-sociais-da-violncia-contra-mulheres-negras-no-brasil> .

Acesso em: 23/08/2020.

SILVA, Tarcízio. Racismo algorítmico em plataformas digitais: microagressões e discriminação em código. In: SILVA, Tarcízio. Comunidades, Algoritmos e Ativismos Digitais: olhares afrodiaspóricos. São Paulo: Editora LiteraRUA, 2020, p. 120-137. Disponível em: $<$ https://www.researchgate.net/publication/339954112 Comunidades Algoritmos e Ativ ismos_Digitais_olhares_afrodiasporicos>. Acesso em 31/10/2020.

SILVEIRA-BARBOSA, Paula. Trajetória da Imprensa Lésbica brasileira, uma história possível. Aedos, v. 11, n. 24, p. 142-163, 2019.

SOARES, Gilberta Santos. COSTA, Jussara Carneiro. Movimento lésbico e Movimento feminista no Brasil: recuperando encontros e desencontros. Estudos Feministas, julho/dezembro 2011, janeiro/junho 2012, p. 1-64.

SPAULDING, Shannon. Cognitive empathy. In: MAIBOM, Heidi L. The Routledge Handbook of Philosophy of Empathy. New York: Routledge, 2017, p. 13-21.

TA, Vivian P.; ICKES, William. Empathic accuracy. In: MAIBOM, Heidi L. The Routledge handbook of philosophy of empathy. New York: Routledge, 2017, p. 353-363.

THINK WITH GOOGLE. Introdução. 2017a. Disponível em: <https://www.thinkwithgoogle.com/intl/pt-br/youtubeinsights/2017/introducao/>. Acesso em 01/04/2019.

THINK WITH GOOGLE; ORBERG, Clarissa. YouTube Kids: um ano de diversão para os pequenos, tranquilidade para os pais e oportunidade para as marcas. 2017b. Disponível em: $<$ https://www.thinkwithgoogle.com/intl/pt-br/estrategias-de-marketing/video/youtube-kidsum-ano-de-divers\%C3\%A3o-para-os-pequenos/>. Acesso em 17/09/2020. 
THINK WITH GOOGLE. YouTubers fazem a cabeça dos jovens. 2016. Disponível em: <https://www.thinkwithgoogle.com/intl/pt-br/estrategias-de-marketing/video/youtube-teens/>. Acesso em 17/09/2020.

TOULMIN, Stephen. Os usos do argumento. São Paulo: Martins Fontes, 2006 [1958].

TSE. Facebook e YouTube têm $\mathbf{4 8 h}$ para retirar do ar vídeos com inverdades sobre livro de educação sexual. Tribunal Superior Eleitoral. 16 out. 2018. Disponível em: < https://www.tse.jus.br/imprensa/noticias-tse/2018/Outubro/facebook-e-youtube-tem-48-horaspara-retirar-do-ar-videos-com-inverdades-sobre-livro-de-educacao-sexual>. Acesso em: 10/11/2020.

TROLAR. In: Dicionário Priberam da Língua Portuguesa, 2008-2020. Disponível em: < https://dicionario.priberam.org/trolar>. Acesso em: 20/01/2021.

van Dijk, T. A., Medeiros, B. W. L., \& Andrade, M. L. C. V. O. (2013). Análise crítica do discurso multidisciplinar: um apelo em favor da diversidade. Linha D'Água, 26(2), 351-381. DOI: https://doi.org/10.11606/issn.2236-4242.v26i2p351-381. Acesso em 17/11/2020.

VEREZA, Solange. "Metáfora é que nem...": cognição e discurso na metáfora situada. Signo, Santa Cruz do Sul, v. 38, n. 65, p. 2-21, jul. 2013. ISSN 1982-2014. Disponível em: $<$ https://online.unisc.br/seer/index.php/signo/article/view/4543>. Acesso em: 01/04/2019.

VIEIRA, Josenia Antunes; MACEDO, Denise Silva. Conceitos-chave em análise de discurso crítica. In: BATISTA Jr., José Ribamar Lopes; SATO, Denise Tomaê Borges; MELO, Iran Ferreira de (Orgs.). Análise do Discurso Crítica para linguistas e não linguistas. São Paulo: Parábola, 2018, p. 48-77.

WEISS, Winola. Proximização e discurso de ódio: homofobia em Casos de Família. In: GONÇALVES-SEGUNDO, P. R.; MODOLO, A. D. R.; SOUSA, D. R. de; FERREIRA, F. M.; COAN, G. I.; BRITTO-COSTA, L. F.. (Org.). Texto, discurso e multimodalidade: perspectivas atuais. 1ed.São Paulo: Editora Paulistana, 2017, p. 370-382.

WHITE, Peter R. R. Valoração - a linguagem da avaliação e da perspectiva. Tradução: Débora de Carvalho Figueiredo. Linguagem em (Dis)curso - LemD, v.4, n.especial, p. 177-205, 2004.

YOUTUBE. Creators for Change: Criadores de conteúdo inspiradores. s/d. Disponível em: https://www.youtube.com/int1/pt-BR/creators-for-change/role-models/>.

\section{Fontes}

\#AutonomiaIntelectual. Playlist publicada no canal Nátaly Neri. 66 vídeos. Última atualização: 01 de agosto de 2020. Disponível em: 〈https://www.youtube.com/playlist?list=PL7TPlcav5cfby8Jm8rQTRRS8r6Ws-wz1t $>$. Acesso em $30 / 10 / 2020$. 
AUTOESTIMA, Identidade e Feminismo Negro. Publicado pelo canal Nátaly Neri. 2015a, 16 min. 46 s., $\quad$ son., color. Disponível em: <https://www.youtube.com/watch?v=BoXsNfC1WMw\&list=PL7TPlcav5cfby8Jm8rQTRRS8 r6Ws-wz1t\&index=66\&ab_channel=N\%C3\%A1talyNeri>. Acesso em: 30/10/2020.

BOLSONARO prova que Haddad é o pai do Kit Gay. Publicado pelo canal Silas Malafaia Oficial. 2018, 2 min. 14 s., son., color. Disponível em: < https://www.youtube.com/watch?v=DfzoQ_bkRII>. Acesso em 12/03/2020.

HETEROFOBIA e racismo reverso existem? | Louie Ponto e Nátaly Neri. Publicado pelo canal LouiePonto. 2017a, 8 min. 10s., son, color. Disponível em: <https://www.youtube.com/watch?v=PHwYRDumASg>. Acesso em 06/09/2018.

HOMONACIONALISMO e pinkwashing: o mal liberal (Exemplo EUA e Israel). Publicado pelo canal Doutora Drag - Dimitra Vulcana. 2019, 18 min. 37 s., son., color. Disponível em:

https://www.youtube.com/watch?v=m4XKcdwd0r0\&ab_channel=TeseOnze>. Acesso em $08 / 11 / 2020$.

NEGRITUDES Brasileiras. Publicado pelo canal Nátaly Neri. 2015, 58min. 44s., son., color. Disponível em: 〈https://www.youtube.com/watch?v=SMIRaztcAwQ>.

PINK money e a diversidade de mercado feat. Dimitra Vulcana | feat 010. Publicado pelo canal Tese Onze. 2019, 15 min. 53 s., son., color. Disponível em: < https://www.youtube.com/watch?v=m4XKcdwd0r0\&ab_channel=TeseOnze>. Acesso em 08/11/2020.

PINKWASHING, Harassment, and the YouTube Hate Machine. Publicado pelo canal rantasmo. 2019, 9 min., 47 s., son., color. Disponível em: $<$ https://www.youtube.com/watch?v=Pzd4NhcqbRg\&ab_channel=rantasmo>. Acesso em 08/11/2020.

POR QUE VOCÊ É TÃo AGRESSIVA, NÁTALY?. Publicado pelo canal Nátaly Neri. 2017a, 11 min. 36 s., son., color. Disponível em: <https://www.youtube.com/watch?v=aBF_5w8unyA\&t\&ab_channel=N\%C3\%A1talyNeri $>$. Acesso em: 01/04/2019.

PRIMEIRO Vídeo do Canal!. Publicado pelo canal Nátaly Neri. 2015b, 5 min. 31 s., son., color. Disponível em: <https://www.youtube.com/watch?v=CRWeayN1AHk\&ab_channel=N\%C3\%A1talyNeri $>$. 


\section{RÓTULOS ME LIMITAM OU ME DEFINEM? | Especial Dia do Orgulho LGBT | Louie}

Ponto. LouiePonto. 2017b, 4 min. 16s., son., color., Disponível em: <https://www.youtube.com/watch?v=p-Dd_ZxH6qI >. Acesso em 22/08/2020.

YOUTUBER Só FALA MERDA NA INTERNET? Feat. Louie Ponto. Publicado pelo canal Nátaly Neri. 2017a, 8 min. 1 s., son., color. Disponível em: <https://www.youtube.com/watch?v=ZCMzbWdEZn4>. Acesso em 01/04/2019. 


\section{Glossário}

\section{Movimentação Epistêmico-Axiológica}

Estratégia discursivo multidimensional realizada para definir, negociar, subverter e manter as distâncias epistêmico-axiológicas entre as entidades discursivas projetadas no espaço discursivo de um determinado texto.

\section{Afastamento epistêmico-axiológico}

Os movimentos de afastamento epistêmico-axiológico se processam por meio da apresentação dos traços discursivos do exogrupo compartilhados pelo Outro (estereótipos e mitos sociais, por exemplo), seja por meio da refutação interna ou externa dos movimentos argumentativos endereçados às Alegações e Propostas de Ação do Outro. Em suma, consistem em movimentos de delimitação de fronteiras entre os campos epistêmico-axiológicos por meio da comparação entre visões de mundo e perspectivas em relação a um determinado problema epistêmico ou prático.

A delimitação de fronteiras se mostra importantes não apenas para a construção dos movimentos argumentativos - dessa forma possivelmente contribuindo para o convencimento e para a persuasão -, como também para o fortalecimento de certas identidades, filiações discursivas e posições epistêmico-axiológicas.

\section{Aproximação epistêmico-axiológica}

Os movimentos de aproximação epistêmico-axiológica consistem na criação de regiões de proximidade epistêmico-axiológica, isto é, a projeção de pontos de acordo entre as diferentes discursividades e pontos de vista. Essas regiões podem ser criadas por meio da apresentação de pressupostos construídos como comuns, por meio da concessão à perspectiva do Outro, ou ainda pela sugestão de acordos entre valores, crenças ou visões de mundo com base nas intersecções entre os campos epistêmico-axiológicos do Eu-Nós e do Outro a respeito do assunto em discussão.

Tais regiões se mostram importantes na construção dos movimentos argumentativos epistêmicos e práticos, possivelmente contribuindo para a orientação da leitura do texto (que pode se tornar mais ou menos resistente ou complacente, por exemplo) e também para o convencimento e/ou persuasão de determinados auditórios. Além disso, elas permitem à analista depreender os pontos de tensão dialógica que favorecem a construção de laços de solidariedade entre as comunidades discursivas, num primeiro plano, e entre grupos sociais, mais amplamente. 


\section{Comunidade discursiva}

As comunidades discursivas correspondem a grupo socialmente reconhecido com base em um determinado comportamento material ou discursivo. Em outras palavras, um grupo social que se define não apenas a partir de sua visão de mundo comum, e sim, mais especificamente, por sua adesão a uma determinada Alegação ou Proposta de Ação a respeito de um certo problema prático ou epistêmico. Essa noção não se confunde, entretanto, com as categorias de endogrupo e exogrupo.

As comunidades discursivas podem ser definidas com graus diversos de especificidade, a depender do problema em pauta. Assim, podemos concluir que, embora feministas negras brasileiras possam ser encaradas como uma comunidade discursiva por apresentarem uma agenda coesa de enfrentamento ao racismo e o sexismo, ainda assim, poderíamos delinear diversas outras comunidades discursivas mais específicas em meio a elas, a depender de seus posicionamentos frente a certo problema, de aspectos identitários (mulheres negras lésbicas, mulheres negras quilombolas etc.) ou ideológicos (mulheres negras liberais, mulheres negras comunistas, mulheres negras anarquistas etc.). Ressaltamos, portanto, que as diferenças entre as comunidades discursivas não significam necessariamente antagonismo, posto que podem consistir apenas em diferentes modos de ação.

\section{Endogrupo e exogrupo}

Categorias que fazem referência a divergências discursivas mais abrangentes, determinadas não apenas pela questão em discussão, mas por filiações ideológicas - feministas, liberais, comunistas, antirracistas etc. Essas divergências podem incluir a questão em pauta, mas não necessariamente. Trata-se de filiações ideológicas, o que inclui a questão em pauta, mas diz respeito a posicionamentos mais amplos (por exemplo, feministas e machistas, progressistas e conservadores, esquerda e direita, racistas e antirracistas, socialistas e liberais, pró-LGBTTIA+ e LGBTfóbicos).

A construção do endogrupo é constitutiva da Movimentação Epistêmico-Axiológica, mas a do exogrupo não. Elas são fundamentais para a projeção do Espaço Discursivo em termos das filiações ideológicas consideradas relevantes pela voz autoral. Em outras palavras, o endogrupo e o exogrupo são definidos "localmente" e determinam os valores do eixo epistêmico-axiológico a partir do qual as entidades discursivas (Eu, Nós e Outro), por sua vez, serão mapeadas no Espaço Discursivo. São eles, portanto, que definem a métrica das distâncias entre as entidades discursivas.

\section{Entidades discursivas}


As entidades discursivas consistem em objetos do discurso construídos textualmente para estabilizar a referência a determinado posicionamento argumentativo com o qual se dialoga no texto. Depreendidas a partir do levantamento das Alegações e Propostas de Ação colocadas em questão no texto, elas são manipuladas ao longo do texto para construir, subverter ou manter relações de solidariedade/neutralidade/antagonismo entre as comunidades discursivas representadas no texto, bem como sugerir relações de complementariedade/alternatividade/ oposição entre certas Alegações ou Propostas de Ação.

$E u$

Entidade discursiva textualmente constituída a partir da voz autoral. Essa noção é desenvolvida a partir das noções de Self trabalhadas por Cameron (2013), de centro dêitico de Chilton (2004), e entidade interna ao centro dêitico, de Cap (2013) e Hart (2014), ainda que elas não sejam plenamente correspondentes. Apoiamo-nos também na noção de voz autoral trabalhada por Martin e White (2005).

$\mathrm{Na}$ perspectiva aqui apresentada, entendemos o Eu como uma projeção discursiva da instância de produção que toma forma a partir da defesa de certos posicionamentos no texto. Em outras palavras, o Eu se constitui na projeção da instância produtora no Espaço Discursivo. É esta a entidade que define o centro dêitico do texto e em torno da qual se constrói o Nós. O Eu não se refere a uma comunidade discursiva propriamente, mas se constitui em referência a uma comunidade por meio da defesa de determinadas Alegações e Propostas de Ação.

Nós

Entidade discursiva textualmente construída a partir das relações intertextuais e interdiscursivas elaboradas pelo Eu como forma de coletivizar sua posição argumentativa. $\mathrm{O}$ Nós se constitui como uma constante (re)articulação entre vozes com propósitos mais ou menos comuns a cada texto. Em outras palavras, não se trata como uma entidade fixa, mas uma entidade que é atualizada ao longo do texto e em diferentes textos a depender da comunidade discursiva que a voz autoral decide estabelecer como centro dêitico. Em suma, essa entidade se refere ao efeito discursivo de uma voz coletivizada, à qual as vozes autorais vez ou outra aderem ou mencionam ao longo dos textos. Reiteramos que essa categoria não é fixa; ela se constitui de maneiras diversas a depender do tema, da Alegação e da Proposta de Ação em foco. Ao longo do texto, conforme o Eu se articula ao Nós e estabelece sua relação de solidariedade, essas entidades passam a configurar um "complexo de vozes" (complexo Eu-Nós), responsável pelo efeito discursivo da coletivização, isto é, o efeito de que a posição argumentativa do Eu 
frente ao problema não é defendida por apenas um ator social, mas corresponde a um posicionamento de grupo.

\section{Outro}

Entidade discursiva que referência a uma determinada comunidade epistêmica cujo fator de coesão é a adesão a uma Alegação ou Proposta de Ação. O posicionamento discursivo atribuído a essa entidade consiste numa divergência localizada em relação a uma pergunta ou questão argumentativa. Sua construção discursiva pode ter como objetivo enfatizar tanto as divergências quanto as semelhanças epistêmico-axiológicas entre a comunidade discursiva a que a entidade faz referência e a comunidade discursiva à qual a entidade Nós faz referência. $\mathrm{O}$ que é enfatizando (se as semelhanças ou as diferenças) dependerá de fatores como: o grau de dissenso/consenso que é atribuído à pergunta ou questão em debate; se o Outro é localizado no espaço discursivo do endogrupo ou do exogrupo; se a relação construída entre as entidades (e sugerida às comunidades que elas representam) é, em última instância, de solidariedade ou antagonismo.

\section{Campo epistêmico-axiológico}

A cada uma das entidades discursivas corresponde um campo epistêmico-axiológico, depreendido a partir da análise da configuração funcional dos movimentos argumentativos assumidos pelo Eu ou pelo complexo Eu-Nós e dos movimentos atribuídos ao Outro.

Para nós, os campos epistêmico-axiológicos são compostos, numa perspectiva argumentativa, pelas Alegações e Garantias, Propostas de Ação, Objetivos, Meios-Fins e Valores defendidos por/atribuídos a cada entidade. Denominamos esses campos epistêmicos, na medida em que definem uma determinada posição frente a um problema argumentativo (seja ele epistêmico ou prático), e axiológicos, posto que são orientados por um determinado sistema de valores (delimitado a partir de um discurso e/ou de uma filiação ideológica).

\section{Efeitos discursivos}

Efeitos discursivos sobre a relação entre Alegações e Propostas de Ação

Efeito de Complementariedade: Ambas as Alegações/Propostas de Ação são não apenas válidas, como complementares. Por exemplo, a Proposta de Ação do Outro é reenquadrada como Objetivo comum para o Eu; a leitura das Circunstâncias Motivadoras do Outro é detalhada por informações novas apresentadas pelo Eu. 
Efeito de Alternatividade: Ambas as Alegações/Propostas de Ação são válidas, o que se busca é a legitimação das próprias Alegações e Propostas. Nesses casos, compartilha-se um Objetivo, mas a leitura do estado de coisas é diferente.

Efeito de Oposição: Apenas uma Alegação/Proposta de Ação é válida/legítima; buscase desqualificar a concorrente. É possível que tanto os Objetivos quanto as Circunstâncias Motivadoras sejam diferentes e irreconciliáveis.

Efeito discursivos sobre a relação entre comunidades discursivas

Efeito de Solidariedade: as comunidades discursivas representadas pelo Nós e pelo Outro podem articular suas Alegações e Propostas de Ação, e o Outro não precisa mudar seu comportamento para ser aceito no endogrupo, podendo inclusive passar a fazer parte do Nós.

Efeito de Neutralidade: as comunidades discursivas representadas pelo Nós e pelo Outro podem defender suas Alegações e desenvolver suas Propostas de Ação de forma autônoma, e o Outro não precisa mudar seu comportamento para ser aceito no endogrupo.

Efeito de Antagonismo: as comunidades discursivas representadas pelo Nós e pelo Outro não podem articular suas Alegações e Propostas de Ação e o Outro precisa mudar seu comportamento para ser aceito no endogrupo. 


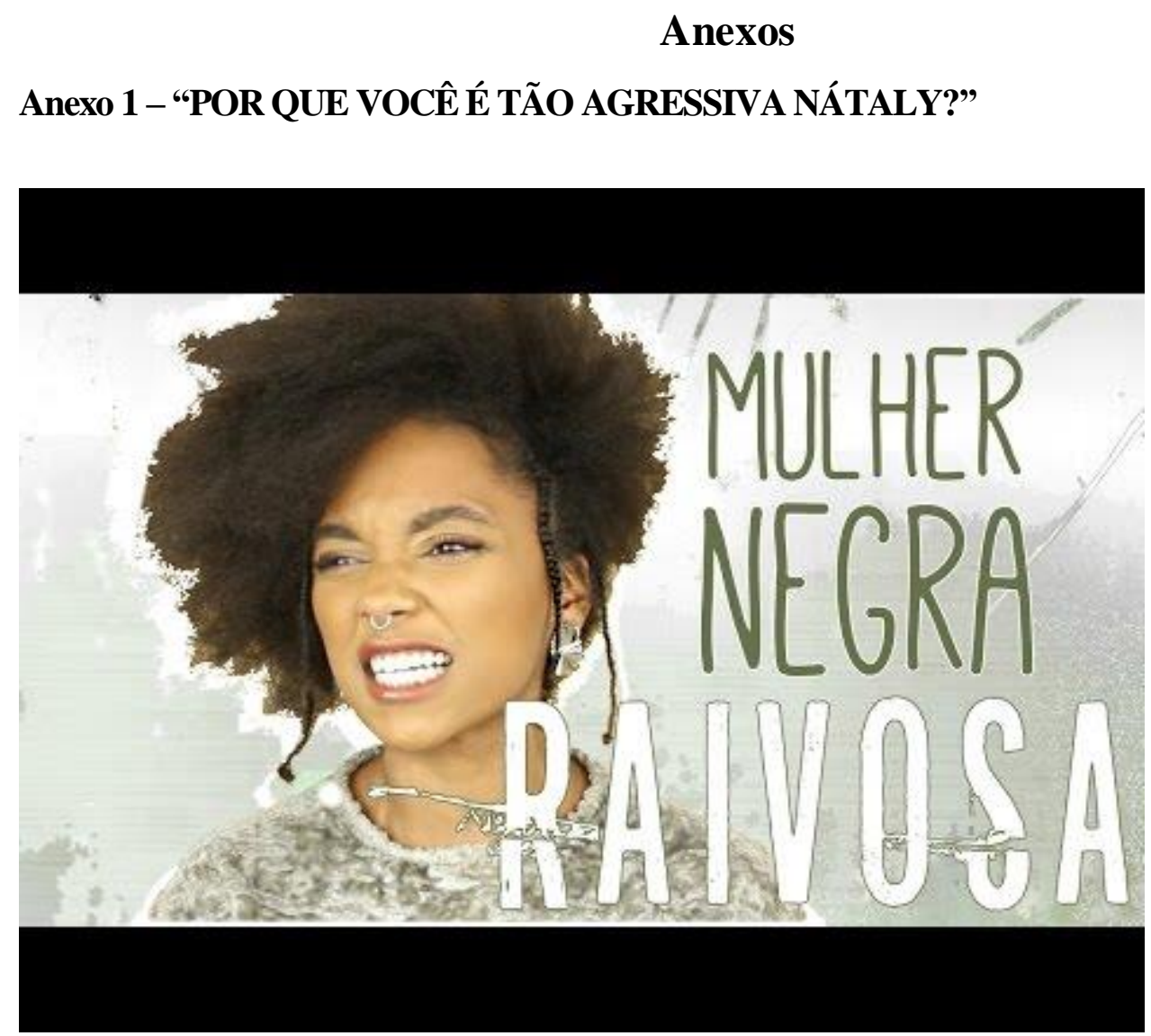

Canal: Nátaly Neri (à época, Afros e Afins por Nátaly Neri)

Postado em: 5 de abril de 2017

Disponível em: https://www.youtube.com/watch?v=aBF 5w8unyA

Acesso em: 23 de janeiro de 2020 às 12:15

Número de visualizações na data do acesso: 67.141 visualizações

Número de curtidas na data do acesso: 12 mil curtidas

Número de dislikes na data do acesso: 227 dislikes

Número de comentários na data do acesso: 1.207 comentários 
MEU NOME É NÁtAly NeRI ESSE É MEU CANAL AFROS E AFINS... SEJAM MUITO BEM VINDOS HOJE A GENTE VAI FALAR SOBRE AGRESSIVIDADE DA MULHER NEGRA PORQUE AS MULHERES NEGRAS SÃO AGRESSIVAS PRA CARAM-BA PORQUE AS MULHERES NEGRAS FALAM GRITANDO PORQUE MULHERES NEGRAS SÃO DESCOMPENSADAS LOUCAS (ufa) um dos comentários mais frequentes nesse canal são coisas como... Nátaly... desse jeito que você fala você não vai conseguir alcançar ninGUÉM... Nátaly... a discussão até que tá boa mas você podia ter sido menos agresSIva... por que que essa menina é TÃO agressiva? ninguém vai entenDER o que ela fala assim... como que você tenta lutar pela igualdade com MAIS Ódio? NÁtaly o seu tom de voz é muito arroGANte... você podia usar menos ironias isso deixa a sua fala MUIto agresSIva... nossa eu adoro a Nátaly Neri mas eu acho ela muito brava tenho medo de me aproximar... meu DEus aquela menina é Ótima mas ela podia ser um pouquinho menos agressiva... eu acho que ela ia alcançar mais gente assim... logo eu gente logo eu taurina TÃO meiGA olha minha carinha... olha a minha voz... eu me acho a pessoa mais fofa do mundo e de verdade isso até me irrita um pouco... mas eu realmente fico muito curiosa quando eu escuto esse tipo de argumento e geralmente presentes nos vídeos em que eu estou falando sobre questões um pouco mais tensas sobre racismo... e hoje nós vamos conversar exatamente sobre isso... sobre estereótipos a respeito da mulher negra... mais especificamente sobre a ideia de mulher negra RAIvosa... infelizmente ser chamada de louca histérica raivosa não é um privilégio meu... infelizmente mulheres já são tidas como histéricas há muito tempo... só que mulheres NEgras especificamente desenvolvem um OUtro tipo de histeria social que é a RAIva o Ódio a descompensaÇÃO... isso faz parte dos estereótipos construídos a respeito de nós de nossa imagem... estereótipos que foram criados pro controle social... eu já falei aqui em um vídeo anterior sobre os três principais estereótipos... eu vou falar de novo só pra gente recordar um dos primeiros principais estereótipos à respeito da mulher negra que foi construído no período de escravidão e continua sendo reiterado E atualizado pela cultura pop.. novelas filmes músicas etc... é o estereótipo da mulher negra Tia Anastácia... que é aquela figura da Tia Anastácia... muito meiga muito dócil e servil que cuida das crianças brancas e da casa como ninguém... que geralmente é GORda geralmente é esCUra e que é extremamente dócil extremamente adesTRAda... é a ideia da pessoa negra que NASce pra servidão... o segundo estereótipo mais recorRENte e reiterado pela cultura pop é à respeito da mulher negra... é a mulata exportação... que é a mulher negra ligada a objetificação no sentido mais radical... que é a da exploração sexual... mulheres negras tipo mulata exportação têm o seu corpo feito pro prazer e que nasceu pra servir outros homens e a mulata exportação tá diretamente ligada a mulheres muito mais curvilíneas que são magras e geralmente mais claras frutos da miscigenação... esses estereótipos surgiram no período da escravidão pra justificar atitudes racistas... pra justificar no primeiro da Tia Anastácia a exploração... SEres negros corpos NEgros nasceram para serem explorados... mulheres negras lidam com isso porque nasceram pra ser dóceis e para servir os nossos FIlhos e o segundo estereótipo da mulata tipo exportação surgiu principalmente pra justifiCAR os estupros aos quais as mulheres negras eram submeTIdas no período 
escravocrata... afiNAL era culpa delas elas eram sexuais demais... os corpos eram FEItos pra isso... o terceiro estereótipo e objeto desse VÍdeo é mulher negra raivosa... The Angry Black Woman... que é justamente a ideia de uma mulher negra que quando reclama de todos esses outros estereótipos sobre a sua realidade que é racista que é miSÓgina é tida como LOUca... é tida como alguém que... não sabe o que FAla... que fala porque passa muita RAIva porque vive muitas coisas e porque é NAturalmente zangada é NAturalmente brava é NAturalmente descontroLAda e também tá muito próxima à animaliDAde à falta de domínio de SI do seu CORpo da sua fala e dos seus pensamentos... então é aquela mulher negra que fala muito ALto é aquela mulher negra que já chama por barRAco é aquela mulher negra que usa o dedinho nos filmes americanos e todas nós mulheres NEgras estamos sujeitas a termos esses estereótipos OU permanentemente em nossas vidas OU passando vez ou outra... o estereótipo da mulata exportação é permanente na minha vida... me persegue desde que eu era uma criança e continua até hoje... o outro estereótipo que é o da mulher negra raivosa aparece em momentos muito específicos pra mim... quando por exemplo eu tô falando sobre racismo... SEMpre que eu vou falar sobre racismo por mais leve e mais doce que seja a minha voz por mais CULtas e por mais bem escolhidas que sejam as minhas palavras alguém sempre vai dizer que eu fui agressiva demais alguém sempre vai dizer eu fui inciSIva demais que eu não precisava ter falado com aquele tom que eu não precisava ter sido TÃO iRÔnica que eu não precisava ter feito isso ((arregala os olhos)) com meus olhos ou que eu não precisava gesticular tanto com a minha boca ((aponta pra a boca)) porque isso é extremaMENte agresSIvo e as pessoas não vão entender e eu vou afastar outras pessoas quando eu uso... esse conjunto ((aponta pra o rosto)) de elementos de fala e de expressão corporal... como vocês veem é um caminho sem volta... eu posso falar sorrindo sobre raCISmo sobre como o povo negro MORre no Brasil sobre como mulheres negras são objetificadas desvalorizadas... posso falar sorrindo eu posso falar brincando eu posso falar de uniCÓRnios e flores e sobre MORte e sobre como as pessoas negras MORrem o tempo inteiro que ainda assim eu vou ser tida como LOUca... ainda assim eu vou ser tida como agresSIva independente da forma como eu uso a minha VOZ independente de quão ROsa seja o meu batom independente de quão brilhante seja o meu sorRIso e os meus Olhos eu sempre vou ser agresSIva... eu SEMpre vou ser LOUca... porque estes são os estereótipos que me cabem toda vez que eu TENto falar sobre as minhas dores... eu quero entender basicaMENte como vocês Acham que a gente deveria falar sobre racismo... como vocês Acham que eu devia construir a minha FAla sobre racismo... é um DOM conseguir falar dessas questões com leveza... é um DOM que eu definitivamente não TEnho... eu não sei se vocês sabem pessoas não negras pessoas que me acusam de agressividade... que acusam OUtras mulheres negras de serem agressivas demais de serem inTENsas demais de serem inciSIvas demais eu não sei se quando vocês fazem isso vocês têm dimenSÃO do que nós estamos falando... eu não sei vocês têm dimenSÃO das DOres das lemBRANças e das experiências que nós temos que mobilizar pra falar sobre tudo isso... me digam COmo eu devo falar dISso sem usar ESte olhar? sem falar de forma CLAra e articuLAda? sem conseguir sorrir? me descCULpem se eu não consigo sorrir me desCULpem se eu uso a minha voz num 
tom que não te agrada... mas é dessa forma que eu vou falar e é dessa forma e de outras formas que QUAISquer mulheres negras vão falar sobre suas dores... eu acho muito engraÇAdo quando vocês tentam me uSAR pra acusar outras mulheres negras pelas suas formas de falar... Nátaly você não acha que mulheres negras que GRItam ou que fazem esCÂNdalo são uma coisa ruim pro movimento negro? Nátaly você não acha que a postura de tal mulher negra é ruim? eu não sou bode expiratório não existe quem possa julgar a forma como a mulher negra fala sobre as suas dores porque ninguém VIve o quê aquela mulher negra viveu porque ninguém SAbe sobre o que nós vivemos... tem um vídeo incrível que fala exatamente sobre isso... chama The Angry Black Woman e eu vou deixar aqui pra vocês assistirem também... que ele expressa basicamente porque que as mulheres negras estão tão nerVOsas pra além dos estereótipos sobre mulheres negras... eu geralmente não estou nervosa galera... geralmente... eu só tô articulando os meus pensamentos... geralmente eu faço os meus vídeos... tem alguns vídeos que me doem mais tem alguns vídeos que eu falo... no alto de algum sentimento de inquietaÇÃo e de... desconforto com alguns temas mas na maioria dos meus vídeos eu tô Nátaly Neri falando sobre as minhas questões mobilizando os meus conhecimentos e aí tem outro ponto por que todas as vezes que mulheres negras mobilizam os seus conhecimentos e falam de forma interesSAda e decidida sobre um assunto nós somos tidas como loucas... nós somos tidas como arroGANtes... eu sou chamada o tempo inteiro de arrogante... onde há arrogância em expor as minhas DOres? e expor um conhecimento que EU busQUEI elaborar ao longo da minha vida? o que há de arrogante em mulheres negras que sabem do que estão falando? eu particularmente sou uma pessoa muito DOce... eu particularmente gosto de coisas fofas... eu particularmente... assisto deSEnho até hoje... eu particularmente adoro Padrinhos Mágicos Hora da Aventura eu particularmente gosto de giBIS eu particularmente gosto de deSEnho eu particularmente gosto de poeSIA eu particularmente tenho uma vida muito leve mas isso tudo é anulado... e eu sou jogada num bolo que diz que eu sou irritada demais... que diz que eu falo de maneira intensa demais... que dizem eu falo de maneira RÍSpida demais que o tom da minha voz é inadequado que a forma como eu falo é inadequada... que as palavras que eu uso são inadequadas... não há inadequação... a gente tem que rePENsar muitas vezes a forma como a gente enxerga o outro... às vezes eu falo mesmo eu utilizo de ironia... eu adoro ser irônica faz parte de quem eu sou faz parte da minha personalidade... não tem NAda a ver com o tom da minha pele... não tem NAda a ver com a minha raça... se uma mulher negra quiser gritar não é porque ela é negra é porque ela quis griTAR porque ela tá raiva e com toda razão ter raiva... se eu quiser griTAR se eu quiser falar ALto se eu quiser ser incisiva se eu quiser falar sobre racismo rindo me divertindo eu posso porque a forma como nós nos comunicamos é individual... eu falo como me cabe... eu falo como as minhas experiências me perMItem e qualquer um qualquer um que tente poDAR... qualquer um que tente determiNAR a forma como eu devo ou não devo falar está me colocando dentro do estereótipo está sendo raCISta... está dizendo que eu correspondo ou NÃO às suas expectativas sociais... a estereótipos que visam controlar e que nasceram pra justificar violências... que nasceram pra justificar o ódio e a exploração que mulheres negras sofreram ao longo da história... esse é meu tom esses são os meus 
vídeos essa é a forma que eu me comunico essa é a minha personalidade... e não é porque eu sou uma mulher negra raivosa... é simplesmente porque eu sou eu se eu estiver com raiva eu tenho todo o direito de estar se eu não estiver com raiva tudo bem é o meu jeito se eu quiser ser iRÔnica é o meu jeito se eu não quiser ser irônica é o meu jeito eu espero que vocês parem... que vocês realmente parem de me enxergar como uma mulher negra raiVOsa... porque eu vou continuar falando nesse TOM eu vou continuar falando usando as minhas pausas erguendo as minhas sobrancelhas usando as minhas iroNIas e ninguém vai me parar porque é dessa forma que eu me comunico... pra você que acha eu sou brava você não me conhece... porque na verdade eu sou uma fofinha ((suspiro))... se você julga os meus vídeos se você acha que eu sou uma pessoa intensa deMAIS é porque realmente você não entende a gravidade do que eu tô falando... essa é a forma como eu me comunico... você não precisa ter medo de mim você não precisa ter medo da minha voz você precisa ter medo de você... e do que você acredita que eu devo ser... se você gostou desse vídeo eu digo que você deixe um LIKE você se inscreva porque eu sou uma pessoa muito FOFA e eu peço LIKES eu peço INSCRIÇÃO e... eu quero que você continue nesse canal me apoiando e apoiando outras mulheres negras em várias outras plataformas e pensando duas vezes antes de dizer que somos arrogantes e agressivas demais... um beijo (manda beijo) e até o próximo vídeo tchau olha que fofa gente eu sou muito fofa pelo amor de deus eu fico incrédula gente eu sou muito fofa para eu queria ser menos fofa queria ser mais sexy assim sei lá... enfim galera é isso tchau 


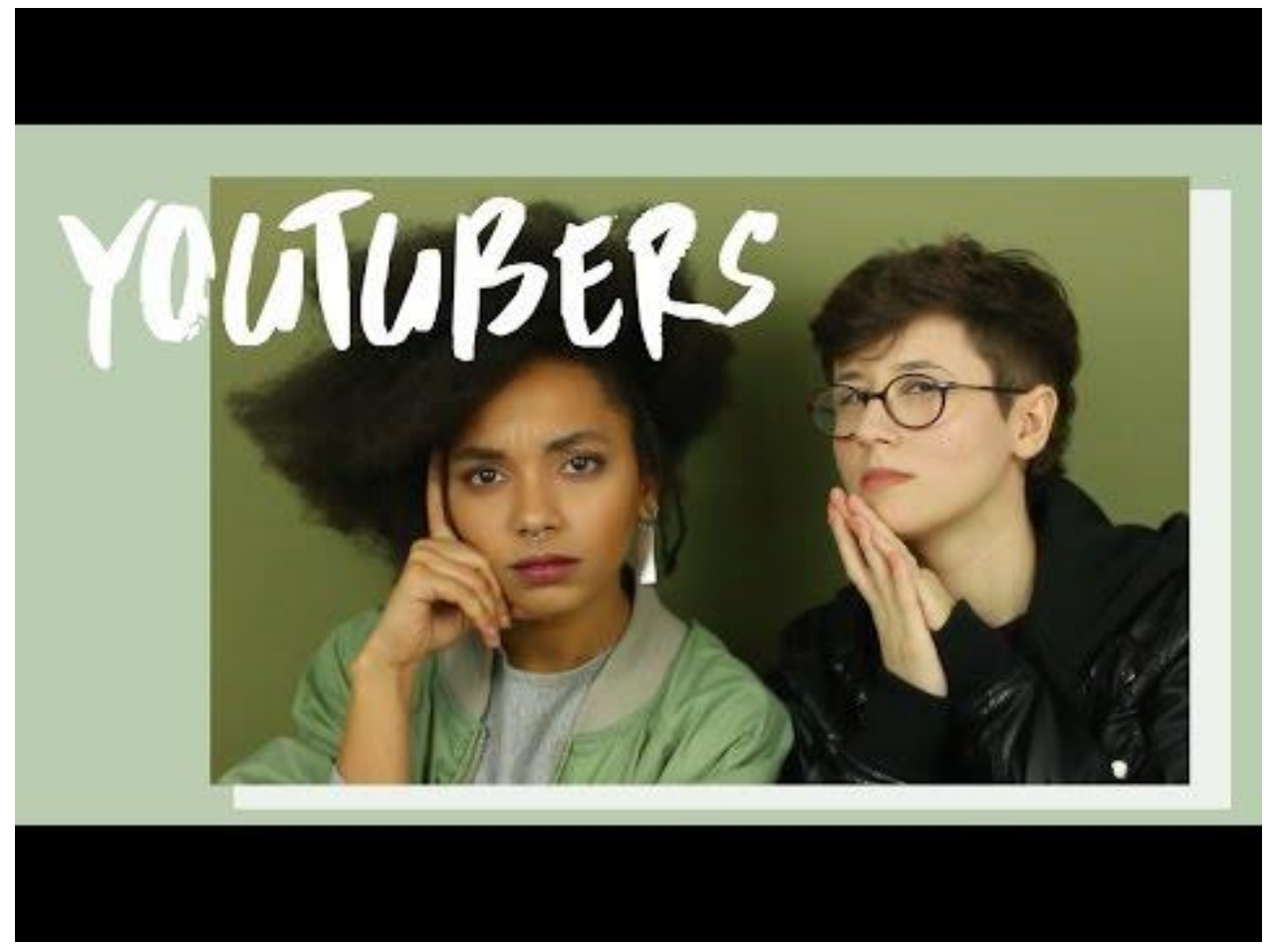

Canal: Nátaly Neri (à época, Afros e Afins por Nátaly Neri)

Postado em: 15 de abril de 2017

Disponível em: https://www.youtube.com/watch?v=ZCMzbWdEZn4

Acesso em: 23 de janeiro de 2020, às 11:45

Número de visualizações na data do acesso: 85.646 visualizações

Número de curtidas na data do acesso: 15 mil curtidas

Número de dislikes na data do acesso: 81 dislikes

Número de comentários na data do acesso: 464 comentários 
1 L ativismo digital é muito importante porque algumas pessoas só tem essa porta de entrada

$2 \mathrm{~N}$ pode mandar essa ((risos)) manda... manda agora...

3 [[INTRO]]

4 N meu nome é Nátaly Neri e esse é meu canal Afro e Afins sejam muito bem vindos... hoje

$7 \quad \mathrm{~N}$ eu descobri que não é esse o nome dela

8 L ai polêmicas

9 N polêmicas hoje... fiquei chocada... mas não vou dizer pra você saber... um pouco mais

10 sobre Louie você tem que ir no canal dela e se inscrever... fala um pouco sobre o seu 11 canal... rapidão

12 L nossa eu não tava preparada pra isso ((risos))

$13 \mathrm{~N}$ aqui é assim tchutchutchutchutchu é rápido ela fala sobre vivências da mulher lésbica ela fala sobre feminismo ela fala sobre atualidades ela fala sobre vegetarianismo... e: sempre tomando chazinho de uma forma muito querida

L é verdade não tô tomando chá hoje será que vai sair o vídeo? ((risos))

$\mathrm{N}$ ah meu deus eu dei um café pra ela antes só deus sabe o que vai acontecer ((risos)) hoje a gente vai falar basicamente sobre nós ((risos)) sobre o trabalho que a gente faz no YouTube... eu já fiz um vídeo sobre isso um vídeo que eu vou deixar aqui que é muito importante \#suporteyoutubersnegros só que nele eu falei sobre as dificuldades sobre as potencialidades dos canais negros voltados pros criadores de conteúdo engajado que falam sobre negritude sobre questões raciais... só que essas dificuldades não moram só nos canais negros mas moram nos canais que falam sobre questões sociais de um modo geral

L por exemplo existe uma ideia de que todo conteúdo produzido pro YouTube é um conteúdo de entretenimento e soMENTte de entretenimento... e não tem problema tem um monte de canais que tem realmente esse objetivo... mas não são todos os youtubers que estão aqui na plataforma com o objetivo de fazer vídeo... de entretenimento... vídeo engraçado... apesar de que a gente pode também fazer esse tipo de vídeo só que a gente tá aqui no YouTube com outro objetivo além desse

$\mathrm{N}$ exatamente... e essa é uma coisa que me pegou muito principalmente agora: depois que meu canal cresceu que as pessoas principalmente nos ambientes acadêmicos me julgam MUIto ironizam o fato de eu ser Youtuber... tipo isso também acontece com você

L aham

$\mathrm{N}$ porque você também tá no ambiente acadêmico né? Louie está no mestrado indo para o doutorado estamos conversando aqui com uma mulher muito inteligente mas é uma coisa que acontece muito comigo na universidade de ironizarem o fato de eu estar me formando em Ciências Sociais e ser youtuber como se o YouTube fosse uma plataforma esvaziada e que você não consegue desenvolver absolutamente nada com seriedade

L sabe uma coisa engraçada? eu já vi pessoas que tem canal no YouTube e não se dizem youtubers e tem... certo receio tipo ah eu tenho um canal mas eu não sou youtuber eu sou produTOR de conteÚdo digiTAL mas cara você tá no YouTube qual o problema de dizer que você é um youtuber? não tem problema... eu sempre fiquei muito nervosa com o 
número de inscritos eu sempre fiquei nossa nossa eu preciso ter um milhão eu preciso ter dois milhões três milhões porque era isso que eu VIA de outros canais só que eu preciso entender que a relevância do meu canal não é exatamente um NÚmero que eu alcanço mas é a diferença que eu FAço na vida das pessoas que me acompanham e é por isso que eu estou aqui

N exataMENte realmente existe essa ideia que nossos canais são riQUíSsimos porque youtubers são riQUÍSsimos... só que a gente entra no tipo de conteúdo que a gente produz e principalmente nos nossos posicionamentos

L na verdade eu gasto mais dinheiro no YouTube do que recebo e essa é uma coisa muito curiosa porque o meu canal cresceu e as pessoas acham que por ter crescido eu tô rica ou eu tô ganhando muito dinheiro

$\mathrm{N}$ o nosso conteúdo ele tá muito ligado nas coisas que a gente acredita então ele não é TÃO flexível asSIM claro que existem várias marcas que a gente consegue se identificar e que é muito importante pra gente conseguir parceria pra conseguir conseguir continuar com um trabalho consistente e de qualidade... mas é muito complicado o nosso tipo de conteúdo tamBÉM... especificamente porque a gente fala sobre feminismo né... a gente tá falando publicamente a gente tá falando sobre algo que não é meu e que não é da Louie a gente tá falando sobre questões que são de movimento obviamente que a gente não consegue abarcar tudo isso... por conta dos nossos limites enquanto pessoas

L sim eu não vou poder falar sobre e POR nenhuma outra lésbica na verdade eu falo sobre a minha experiência mas é claro que com minha experiência eu acabo falando sobre outras pessoas porque é uma questão não é individual é uma questão poLÍtica só que eu tenho certeza que existe um limite também... sabe o que eu penso antes de produzir um conteúdo? antes de gravar um vídeo? eu penso assim se eu fosse adolescente como eu me sentiria?

$\mathrm{N} \quad$ eu penso a mesma coisa eu penso a mesma coisa [

L porque eu não tive isso eu não tive representatividade é uma coisa muito importante e quando eu era criança quando eu era adolescente foi muito difícil pra mim porque eu não via representatividade existe toda uma (buzina de caminhão) que ódio... será que eu posso?

$\mathrm{N}$ agora vai

L existe toda uma vida fora da internet existe um ativismo fora da internet que é MUIto importante e que já tem uma história então de maneira nenhuma a gente pode desmerecer esse tipo de ativismo

$\mathrm{N}$ muito pelo contrário a gente só está aqui porque esse ativismo foi feito

$\mathrm{L} \quad$ e nos trouxe até aqui

$\mathrm{N}$ exatamente

L foi muita leitura da minha parte foi muita:... é foi uma conscientização pessoal primeiro que me trouxe até aqui... e/e o meu objetivo e a minha vontade é justamente de compartilhar este conhecimento

$\mathrm{N}$ eXAtamente é muito importante também as pessoas verem a gente não como criadoras de um conhecimento muitas vezes mas como PONte pra que esse conhecimento flua 
L e [[O ATIVISMO DIGITAL É MUITO IMPORTANTE]] o ativismo digital é muito importante porque às vezes é a única porta de entrada que algumas pessoas têm

$\mathrm{N}$ eXAtamente ((risos)) é exatamente isso gente é basicamente isso mesmo é que uma coisa que também sempre acontece comigo é que como eu falo também de beleza as pessoas tentam reduzir o meu conteúdo em absoluto a beleza... e não que seja um problema falar sobre beleza de forma alguma se eu não ti/se não tivesse os vídeos sobre beleza sobre cabelo na internet eu estaria alisada até hoje muito provavelmente só que como as pessoas estão desacostumadas com o conteúdo que a gente FAZ realmente não enxergam que eu possa falar de beleza e posso também falar de política e de questões sociais

L mas você falou um negócio que eu achei muito interessante que como as vezes um conteúdo de beleza pode ser um conteúdo de beleza engajado porque você disse.... ((buzina do trem)) porque você disse... ((buzina do trem novamente)) o/eu to com um ódio desse trem agora você estão entendendo o que que eu passo ser youtuber não é fácil não ainda mais morando do lado do trem aqui ((buzina do trem)) ((risos)) porque você disse que se não fosse esse tipo de conteúdo você ainda estaria alisando o cabelo por exemplo

N eXAtaMENte então todos os conteúdos são extremamente importantes

L a gente não precisa separar conteúdo de entretenimento... conteúdo engajado cara você pode fazer um conteúdo engajado de uma forma engraçada por exemplo.

N vale o canal da Maíra Medeiros vale o DRelacionamentos que eles fazem esquetes é: teatrais falando sobre feminismo falando sobre questão sociais isso é... nossa eu acho isso poderosíssimo

L então eu acho que resumindo tudo o que a gente falou agora foi pra passar passar uma mensagem MUIto imporTANte apoiem os produtores de conteúdo que vocês gostem $\mathrm{N}$ (uhum)

L e porque eu acho também que as vezes as pessoas não tem muita noção do que tá por trás do nosso trabalho

$\mathrm{N}$ eXAtamente e aí a gente vem aqui abrir as portas da nossa casa pra vocês contar dos nossos processos... eu peço pra você que se você também produz conteúdo na internet que você comece abrir essas discussões

L e se você não produz conteúdo mas tem vontade de produzir conteúdo por faVOR comece aGOra

$\mathrm{N}$ exatamente o YouTube nunca vai tá cheio demais é muito legal a gente conseguir engajar cada vez mais uma comunidade interessada em questões políticas e sociais... pra mostrar que o YouTube é um lugar foda e eu não tenho vergonha de de dizer que sou youtuber

L arrasou... e não se esqueçam de passar no meu canal e ver o vídeo que gravei com Nátaly porque ficou um amorzinho adorei

\section{$\mathrm{N} \quad$ ficou mesmo ficou legal demais}

$$
\text { [ }
$$

L adorei me dá um abraço aqui.

$\mathrm{N}$ muito obrigada por ter vindo no meu canal gente espero que vocês tenham gostado da Louie conheça o canal dela o trabalho dela é muito muito importante muito gostoso de assistir também é isso grande beijo e até o próximo vídeo tchau ah e deixa o like e se 
inscreve também aqui vai gente eu sei que um monte de gente assiste e não é inscrito mancada heim!

132 L tem gente que assiste e não dá like gente por favor né ajudamos ai no entretenimento 133 aquelas ((risos)) 


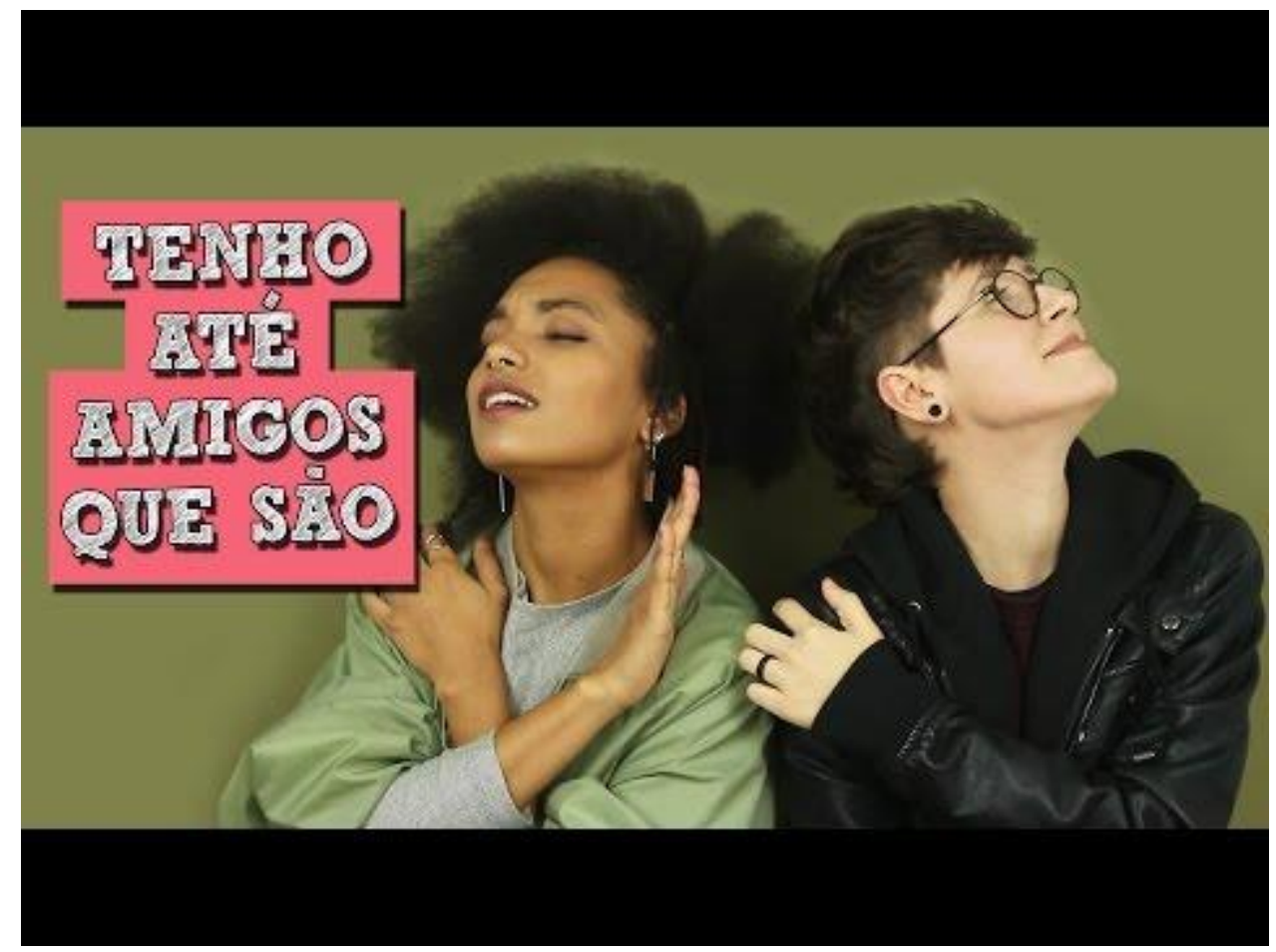

Canal: LouiePonto

Postado em: 15 de maio de 2017

Disponível em: https://www.youtube.com/watch?v=PHwYRDumASg

Acesso em: 23 de janeiro de 2020, às 11:52

Número de visualizações na data do acesso: 317.398 visualizações

Número de curtidas na data do acesso: 47 mil curtidas

Número de dislikes na data do acesso: 1,3 mil dislikes

Número de comentários na data do acesso: 2.056 comentários 
1 L você quer ensaiar o alô gente? um dois três

$2 \mathrm{~N}$ mas eu falo tudo/tudo bom também?

3 L é tipo alô gente tudo bem com você?

4 N tá... não é só alô gente né?

5 L sinta-se à vontade tá?

6 N sou a pior pessoa... é porque eu gosto do seu canal aí eu tô me sentindo tipo ((risos))

7 L sério? mentira né?

$8 \mathrm{~N}$ é óbvio que é sério eu tô nervosa

$9 \quad$ [[MEME:eu tô nervosa]]

10 L/N alô gente tudo bem com você?

11 L hoje é um dia muito especial pra mim e pro meu canal porque eu estou aqui com ela... Nátaly Nery... do Afros e Afins... eu tô emocionada Nátaly

huito prazer em estar aquil

14 L se você não conhece a Nátaly por favor entre no canal dela porque é incrível e tem um vídeo nosso lá também mas só entrem lá depois porque a gente tem um recado MUIto importante pra dar aqui... a gente vai falar uma coisa MUIto séria que atinge milhares de pessoas todos os anos no Brasil uma questão de saúde pública que realmente... violenta cada vez mais brasileiros heterofobia e racismo reverso ((risos)) só que não... eu acho bizarro porque é muito óbvio pra gente que essas coisas não existem mas eu sempre recebo um monte de mensagens no meu canal do tipo ai agora não pode mais ser hétero... nossa agora vou ter que pagar pra ser hétero ((risos)) eu tenho medo de andar na rua que eu sou hétero hétero hétero hétero [[HÉTERO HÉTERO HÉTERO HÉTERO HÉTERO HÉTERO HÉTERO HÉTERO]]

$\mathrm{N}$ no meu é tipo meu deus mas você quer dividir o mundo o que os brancos fizeram contra vocês? [[O QUE OS BRANCOS FIZERAM CONTRA VOCÊS]] eu não tenho culpa do que os meus antepassados te fiZEram ser branco agora é CRIme [[SER BRANCO AGORA É CRIME]] eu tamBÉM sou chamado de leite azedo o meu cabelo é cacheado eu também sofro racismo por ISso

L um outro comentário que eu acho bizarro que eu recebo que é assim quando eu falo sobre preconceito contra pessoas LGBT tem alguém que fala ah mas tem um monte de gay que é babaca tem um monte de lésbica que é idiota eu fico pensando tá então você acha que pessoas heterossexuais deveriam sofrer violência porque tem heterossexuais babacas? ou então você acha que uma pessoa que por algum motivo não é legal merece sofrer violência? não entendo

$\mathrm{N}$ eu acho que a galera fica muito perdida porque eles realmente acham que você falar sobre heterofobia ou falar sobre racismo reverso realmente é algo palpável faz senTIdo quando não faz eles querem meio que equiparar você falar sob/de homofobia e falar de racismo a tipo dores individuais quando a gente tá falando de homofobia quando a gente tá falando de racismo a gente tá falando de uma/de uma discussão que não é minha que não é da Louie mas que é social entendeu? é MUito maior que a gente e essas pessoas quando elas levantam esses questionamentos é tipo ai que dor! ai meu deus por que que você tá fazendo isso comigo? a frase clássica os mais racistas são os próprios negros 
que tem negro pessoas negras que não se aceitam que têm dificuldade em se identificar como óbvio que tem pessoas LGBT que também têm dificuldade nesse processo mas por quê? porque a gente tá falando em estrutura porque a gente tá falando de algo MUIto maiOR do que as minhas dores por ser xingada de alguma coisa a gente tá falando de violências que REalmente MOvem a sociedade realmente fazem sentido para além das minhas dores individuais... ou das dores da Louie

L e a gente pode com um exercício muito simples perceber que essas coisas não existem... por exemplo... uma pessoa heterossexual já... sofreu violência física/verbal por SER heterossexual? [[NÃO]] uma pessoa heterossexual já morreu por ser heterossexual? [[não]] tem MEdo de sair na rua porque é heterossexual? [[NÃO]]

$\mathrm{N}$ uma pessoa BRANca já deixou de concorrer a uma vaga de emprego porque era uma pessoa branca? [[NÃO]] uma pessoa BRANca já foi parada pela polícia porque ela era branca? [[NÃO]] uma pessoa BRANca já deixou de ter acesso a um ensino de qualidade ou já foi julgada como burra ou incapaz intelectualmente por ser branca? [[NÃO]] mas sempre vai aparecer alguém vai dizer sim já!

$\mathrm{L}$

uhum eu ia falar isso! eu conheço um cara gay que bateu num cara hétero porque ele era heterossexual eu acredito que pode existir um caso aí que você conheça não duvido só que é um caso no meio de milhares de casos que acontecem todos os dias o Brasil é o país que mais mata pessoas transexuais no MUNdo...[[NOTÍCIAS]] tem pesquisas que afirmam que é um dos países talvez o pior país ou um dos piores países pra... pessoas gays e lésbicas

N assim como é né o segundo maior país negro do mundo e é o país em que os negros estão [[NOTÍCIAS]] em situação de maior vulnerabilidade socioecoNÔmica quando você olha pra TV nós somos o quê? 3\% do empresariado brasileiro em posições de lideRANça isso é um número assustador sem contar negros na universidade então a gente o Brasil na verdade é uma grande merda [[NÁTALY CHEGOU TRAZENDO VERDADES]] porque a gente é um país que se diz super diverso que se diz super aberto super carnaVAL

L E existe essa fantasia ainda de que o Brasil é um lugar sem preconCEItos o país é super tranquilo pra todas as pessoas igualdade

$\mathrm{N}$ gente não:::

L não a gente não vive nesse país

$\mathrm{N}$ eu acho que quando a pessoa tenta mobilizar o discurso da heterofobia... ou do racismo reverso é realmente uma/uma falta de empatia e uma falta de... capacidade de se colocar no lugar do outro e não no outro Nátaly não no outro Louie no outro... pessoas que sofrem com essas violências todos os dias... é desonestiDAde na verdade né porque tem muita gente que SAbe o que está falando... mas é aquela necessidade de ah mas eu também sofro alguma coisa tudo bem todo mundo sofre alguma coisa em algum nível mas existem coisas que são muito maiores do que a gente... você comparar ser chamado de leite azedo o/ONde isso é uma violência para você? ONde ser chamado de leite azedo vai transformar 
L você pode se ofender de ser chamado de branquelo só que... você está individualizando uma coisa que é estrutural... não sei se as pessoas sabem o que significa ser estrutural

$\mathrm{N}$ por exemplo

$\mathrm{L} \quad$ a gente pode explicar

$\mathrm{N}$ pode... racismo o que é racismo afinal? racismo é simplesmente você ofender o outro por causa do tom da sua pele? não necessariamente se fosse assim seria racismo de fato eu falar que alguém é branquelo azedo ou que alguém é cor de leite coalhado mas NÃO... existiram existem ainda mas existiram muito mais no passado teoRIas raCIStas racismo era realmente um campo de pesquisa em que você buscava provar que um grupo era inferior a outro por conta de suas características biológicas daí PEle... quiseram provar de todo modo os negros tinham cérebros menores que negros... por questões biológicas estavam predispostos ao CRIme... várias dessas questões foram pesquiSAdas estuDAdas e fomenTAdas na sociedade... então racismo quer dizer que existe um grupo que é inferior e um grupo que é superior a gente dizer que racismo reverso... seria ok seria real... seria inverter essa lógica então a gente teria daí que voltar... a história inteira fazer com que esses estudos raciais... NUNca tivessem existido... e aí é uma coisa muito importante quando a gente tá falando de raça porque eu falo sobre RAça eu falo raça negra ah mas raça não existe de fato não existe BIOlogicamente não há nada que diferencie eu e Louie biologicamente sabe? não há nada que me faça ser mais propensa ao crime faça a Louie ser uma pessoa mais inteligente MAS existe raça quando a gente fala socialmente então por isso que a gente levanta a questão da raça MAS as teorias racistas foram feitas pra dizer que o negro no caso... é inferior... ao branco então não tem COmo você branco dizer que sofre racismo... porque essa teoria não foi feita pra dizer que você é inferior entendeu? não sei deu pra entender?

L deu pra entender!

L eu sou muito sua fã me dá um autógrafo? ((risos)) [[EU NÃO TAVA BRINCANDO]] e acho que resumindo dá pra explicar de uma maneira curta... a sociedade está estruturada de uma forma maCHISta miSÓgina homoFÓbica lesbofóbica transfóbica raCISta então não tem como a gente reverter a sociedade falar ah não mas a heterofobia existe gente eu sofro com isso porque você não sofre

$\mathrm{N}$ não

L não

$\mathrm{N}$ ah eu sou uma grande racista reversa na internet é uma grande FAma aí que se espalha sobre mim

L é você tá querendo me bater desde a hora que eu cheguei ((risos))

$\mathrm{N}$ racismo reverso é intenso

$\mathrm{L} \quad$ ah eu to querendo ir embora viu Nátaly prazer

$\mathrm{N}$ não é melhor você ir mesmo porque eu sou bem violenta as pessoas já acham isso de mim gente mas a gente não é amiga Louie? ((risos)) 
130 L a gente é:: um amorZInho

131 N a gente é é amiga por favor não pensem isso da gente porque isso também reproduzir

132 ideias super erRAdas sobre negritude... sobre: discutir questões sociais que inclusive é

133 sobre isso o nosso vídeo no canal ((risos))

134 L passa lá no canal da Nátaly não se esqueçam de curtir esse vídeo de se inscrever no canal

135 de se inscrever no Afros e Afins

$136 \mathrm{~N}$ ah posso falar do que o meu canal fala?

137 L pode sinta-se à vontade

138 [

$139 \mathrm{~N}$ é verdade gente o meu canal fala sobre negritude sobre feminismo e sobre consumo

140 consciente então eu dou dicas de brechó de costura fala sobre racismo fala sobre o

141 feminismo e não sou uma racista reversa apesar de essa ser uma das minhas maiores famas

142 na internet ((risos)) é menTIra gente mentira... eu tenho namorado branco pai branco

$143 \mathrm{~L}$ tenho até amigos que são né?

$144 \mathrm{~N}$ tenho vários amigos brancos você não tem vários amigos héteros também?

$145 \mathrm{~L}$ não ((risos))

$146 \mathrm{~N}$ meLHOR pessoa!

147 [[MENTIRA! EU TENHO AMIGOS QUE SÃO]]

148 L dá o abracinho em você tá? tá bom? você quer dar comigo o abracinho? ((Nátaly abraça

149 Louie)) ah abracinho... abracinho em você beijo tchau

$150 \quad$ [[FILTRO DE CHUVA]]

$151 \mathrm{~N}$ ah achei que era abracinho em mim ((risos))

152 L a:::i abracinho em você também 


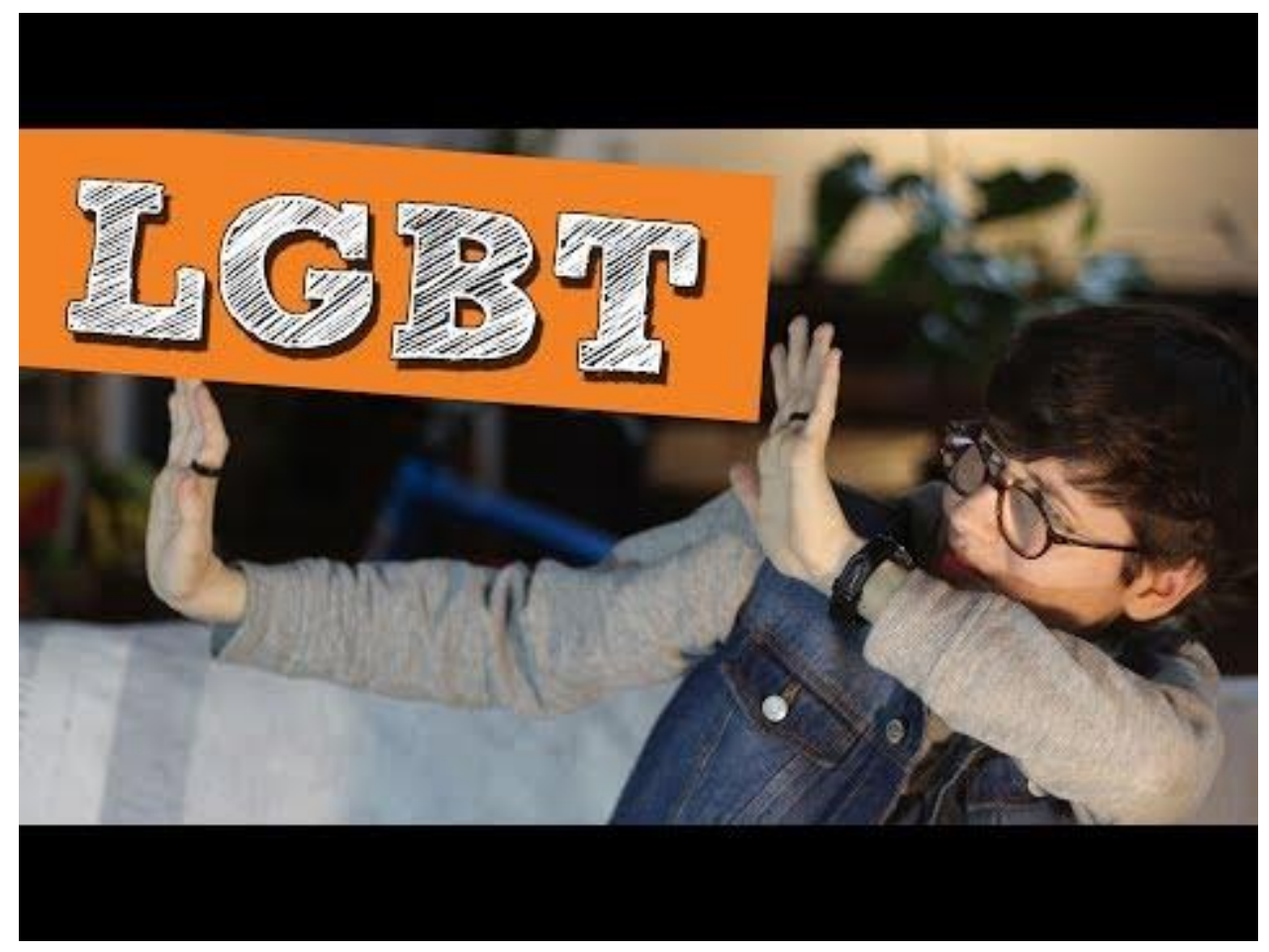

Canal: LouiePonto

Postado em: 28 de junho de 2017

Disponível em: https://www.youtube.com/watch?v=p-Dd ZxH6qI

Acesso em: 23 de janeiro de 2020, às 12:12

Número de visualizações na data do acesso: 106.915 visualizações

Número de curtidas na data do acesso: 21 mil curtidas

Número de dislikes na data do acesso: 73 dislikes

Número de comentários na data do acesso: 630 comentários 
L alô gente tudo bem com vocês? junho já tá acabando mas foi o mês do Orgulho LGBT e hoje eu quero falar sobre rótulos... mas como assim rótulos Louie? eu vejo e escuto alguns comentários do tipo pra que se rotular eu não sou L-G-B-T eu sou humano rótulos me limitam nós somos todos iguais pra que ficar separando as pessoas? e aí eu me lembrei de uma matéria que saiu ano passado em aGOSto ou seja no mês da Visibilidade Lésbica que dizia o seguinte... mulheres que sentem atração pelo mesmo SExo estão deixando de se identificar como lésbicas... diz pesquisa de aplicativo

[[MULHERES QUE SENTEM ATRAÇÃO PELO MESMO SEXO ESTÃO DEIXANDO DE SE IDENTIFICAR COMO LÉSBICAS]]

L o número de mulheres que se definem como lésbicas caiu quase $20 \%$ aPEnas no ano passado...

[[LONDRES- SEGUNDO UMA PESQUISA DO APLICATIVO DE NAMOROS HER, O NÚMERO DE MULHERES QUE SE DEFINEM COMO LÉSBICAS CAIU 20\% APENAS NO ANO PASSADO]] [[CHATEADA]]

L é possível que você esteja se perguntando qual é o problema disso tudo então pega seu chá seu café sua água... e senta aí pra gente conversar... existe essa ideia de que você não deve se rotular porque rótulos te limitam rótulos não foram feitos pras pessoas que você deve viver fora de caixas e não se enquadrar em nenhum modelo enfim... eu entendo esse discurso na verdade eu conCORdo com ele porque seria maravilhoso se a gente pudesse viVER sem se definir sem dar satisfação da nossa VIda pras pessoas se a gente pudesse simplesmente SER... e quem faz isso não tá erRAdo eu não estou aqui para dizer que sua postura tá equivocada estou aqui para dizer que às vezes se rotuLAR é uma atitude política

TF I understand not wanting to check a box or whatever but there's power in labels too you know

$\mathrm{L}$ porque a gente vive em uma sociedade com valores conservaDOres maCHISta e preconceituosa excludente heteronormativa e existem mecanismos de INvisibilização de certos grupos sociais... UM desses mecanismos é a negaÇÃO da exisTÊNcia dessas pessoas o que que eu quero dizer com tudo isso? vamos pensar na nossa sociedade... tudo que você olha é heterossexual... na família na escola na igreja na rua na televisão no cinema na literatura... então desde que a gente nasce a gente aprende que a única forma de exisTÊNcia é possível É heterossexual e o impacto disso na nossa subjetiviDAde na nossa VIda é iMENso muitas vezes a gente não consegue nem se perceber uma pessoa não heterossexual... e quando a gente percebe a gente passa por um processo de autoconhecimento e autoaceitação que é bastante complicado... porque é viver fora de um modelo estabelecido é diFÍcil admiTIR e aceiTAR que você é diferente daquilo que sempre te ensinaram a SER por isso a gente tem que pensar se essa escolha em não se rotular na verdade não é um mecanismo de deFEsa e uma rePULsa à sua sexualidade e ao fato de você ser diferente mas peraí Louie a gente tudo igual a gente é tudo ser humano NÃO a gente não É tudo igual não existe isso de ser tudo igual... a questão é que algumas diferenças são aceitáveis na sociedade e outras diferenças não são aceitáveis... e essas diferenças não aceitáveis provocam processos de exclusão de desigualDAde de vioLÊNcia de preconceito... e pessoas que fazem parte desses grupos inclusive ao longo da história tiveram a sua PRÓpria humanidade neGAda então como é que a gente pode 
falar que a gente é tudo igual que a gente é tudo humano se na prática as coisas são bem diferentes? esse discurso de que nós somos todos iguais é usado justamente para manter esse sistema de excluSÃO e pra gente não discuTIR pra gente não levantar as nossas pautas porque como é que a gente vai lutar contra violências específicas que a GENte sofre se a GENte reproduz o discurso da falsa igualdade? mas ok talvez você esteja completamente tranquilo em relação à sua sexualidade que você simplesmente prefere não se rotular em algum problema nisso? não tem nenhum problema nisso não vim aqui dizer para você mudar de postura... mas vamos pensar uma coisa... quando você não FAla sobre sua sexualidade o mundo inteiro presume que você é heterossexual... porque ele não adMIte a existência de uma outra forma de sexualidade e se as pessoas ao longo da história não tivessem luTAdo pelo diREIto a esses rótulos a nossa situação seria muito pior... e infelizMENte a gente ainda precisa lutar por esses rótulos... enquanto se falar sobre cura gay sobre ideologia de gênero na escola... enquanto a gente tiver medo de sair na rua enquanto o Brasil foi um dos países mais violentos pras pessoas LGBT se rotular vai ser uma atitude poLítica... para quem sabe um dia isso realmente não ser mais necessário e um vídeo como esse não ser mais necessário mas para isso acontecer a gente precisa avançar muito e falar muito então vamos falar abracinho em você beijo tchau 